PNNL-16395

DTS-RPT-090

Rev. 0

\section{Pacific Northwest}

National Laboratory

Operated by Battelle for the

U.S. Department of Energy

\title{
Summary Report of Geophysical Logging for the Seismic Boreholes Project at the Hanford Site Waste Treatment Plant
}

\author{
M. G. Gardner \\ R. K. Price
}

February 2007

Prepared by EnergySolutions, Inc. and Pacific Northwest Geophysics for the Pacific Northwest National Laboratory under Contract DE-AC05-76RL01830 with the U.S. Department of Energy 


\title{
DISCLAIMER
}

This report was prepared as an account of work sponsored by an agency of the United States Government. Neither the United States Government nor any agency thereof, nor Battelle Memorial Institute, nor any of their employees, makes any warranty, express or implied, or assumes any legal liability or responsibility for the accuracy, completeness, or usefulness of any information, apparatus, product, or process disclosed, or represents that its use would not infringe privately owned rights. Reference herein to any specific commercial product, process, or service by trade name, trademark, manufacturer, or otherwise does not necessarily constitute or imply its endorsement, recommendation, or favoring by the United States Government or any agency thereof, or Battelle Memorial Institute. The views and opinions of authors expressed herein do not necessarily state or reflect those of the United States Government or any agency thereof.

\author{
PACIFIC NORTHWEST NATIONAL LABORATORY \\ operated by \\ BATTELLE \\ for the \\ UNITED STATES DEPARTMENT OF ENERGY \\ under Contract DE-AC05-76RL01830
}

Printed in the United States of America
Available to DOE and DOE contractors from the
Office of Scientific and Technical Information,
P.O. Box 62, Oak Ridge, TN 37831-0062;
ph: (865) 576-8401
fax: (865) 576-5728
email: reports@adonis.osti.gov

\author{
Available to the public from the National Technical Information Service, \\ U.S. Department of Commerce, 5285 Port Royal Rd., Springfield, VA 22161 \\ ph: (800) 553-6847 \\ fax: (703) 605-6900 \\ email: orders@ntis.fedworld.gov \\ online ordering: http://www.ntis.gov/ordering.htm
}


DTS-RPT-090

Revision 0

\title{
SUMMARY REPORT OF GEOPHYSICAL LOGGING FOR THE SEISMIC BOREHOLES PROJECT AT THE HANFORD SITE WASTE TREATMENT PLANT
}

\author{
M. G. Gardner \\ R. K. Price
}

February 2007

Prepared for

Pacific Northwest National Laboratory

Richland, Washington 99354

by

EnergySolutions, Inc.

2345 Stevens Drive, Suite 240

Richland, Washington 99354
Pacific Northwest Geophysics $4200 \mathrm{~W} 19^{\text {th }}$ Avenue

Kennewick, Washington 99338 
DTS-RPT-090, Rev. 0

\section{CONTENTS}

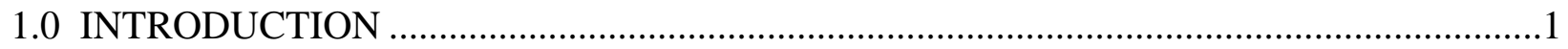

1.1 WASTE TREATMENT PLANT AND THE SEISMIC BOREHOLES PROJECT .............1

1.2 ORGANIZATION AND RESPONSIBILITY ………………..........................................

1.3 PROCEDURE REQUIREMENTS AND QUALITY ASSURANCE ..................................2

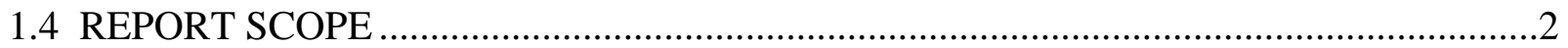

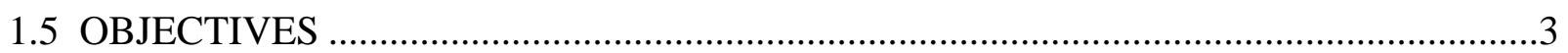

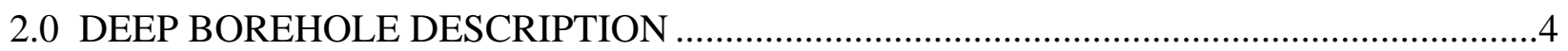

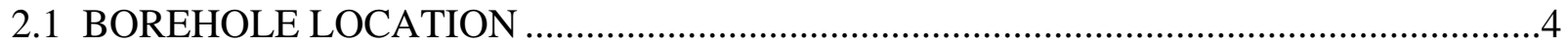

2.2 AS-BUILT DRAWINGS AT COMPLETION OF DRILLING ……..................................

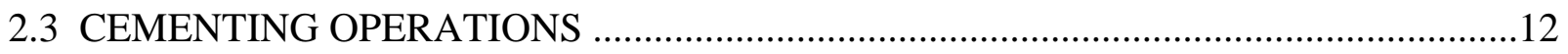

2.3.1 Entry Hole Cementing .............................................................................................12

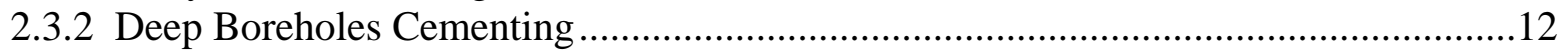

2.3.3 Borehole C4993 .............................................................................................13

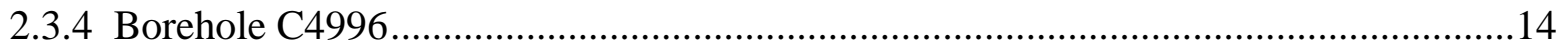

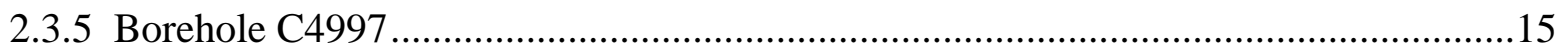

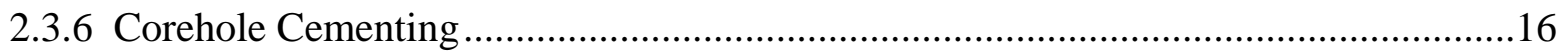

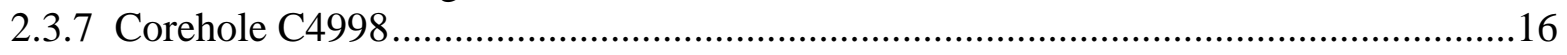

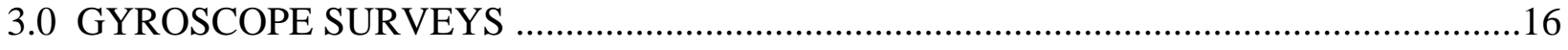

3.1 EQUIPMENT CHARACTERISTICS .......................................................................

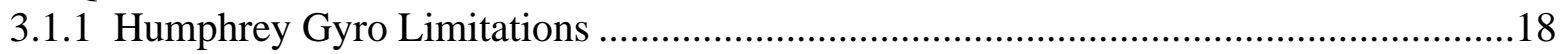

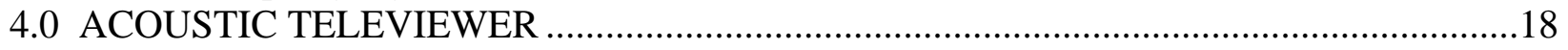

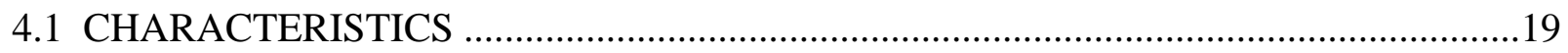

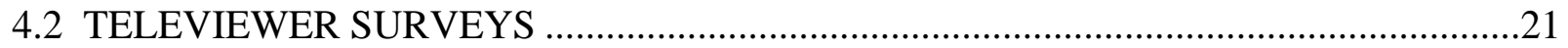

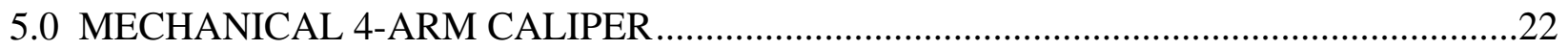

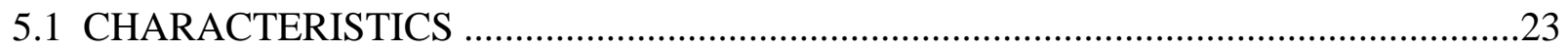

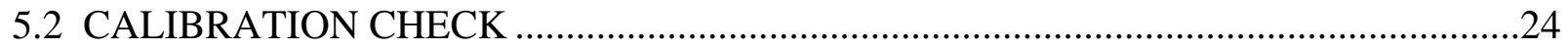

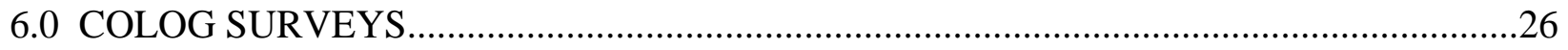

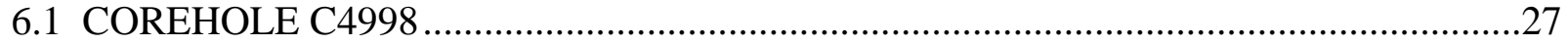

6.2 OPEN-HOLE LOG SUITES (C4993, C4996 AND C4997) ………………….................27

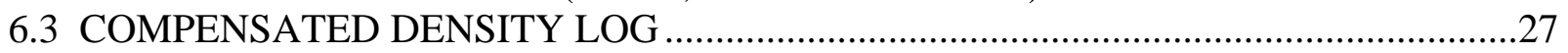

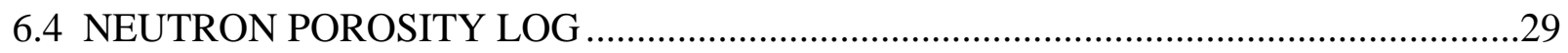

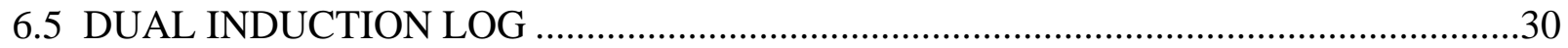

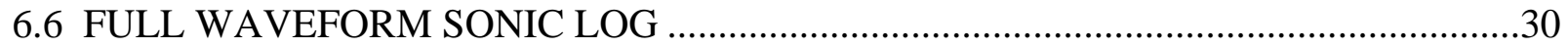

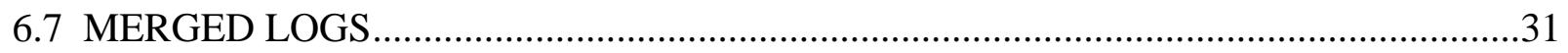

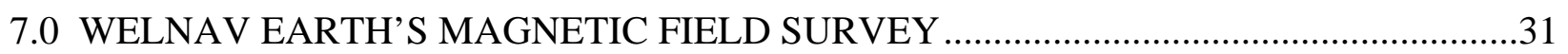

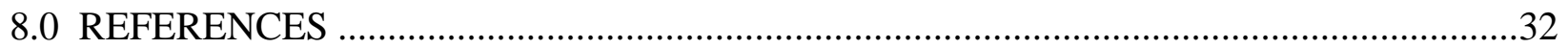

\section{APPENDICES}

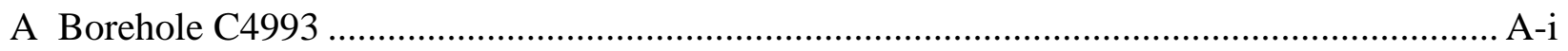

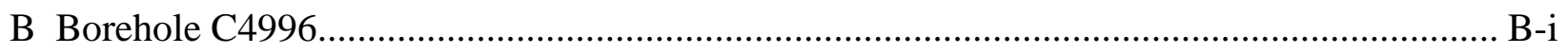

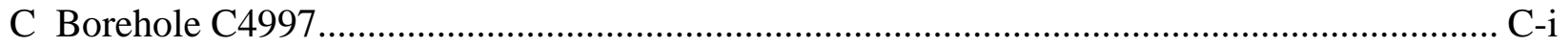

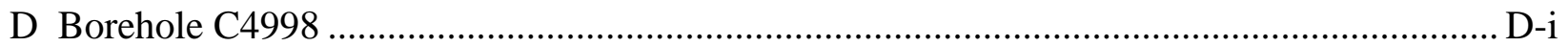




\section{FIGURES}

Figure 1. Hanford Site.................................................................................................. 5

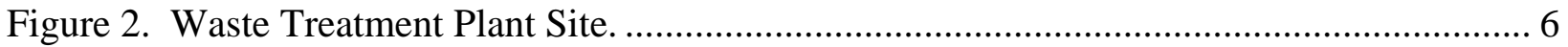

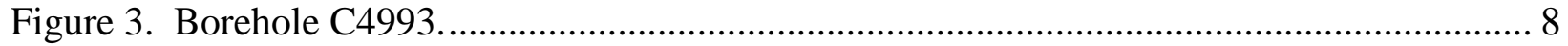

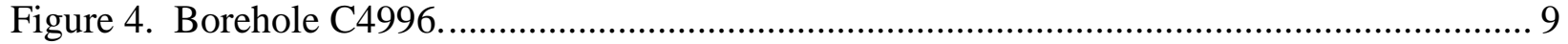

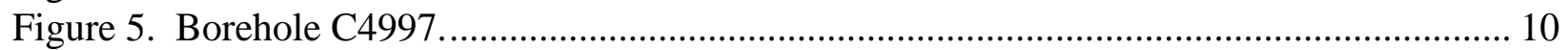

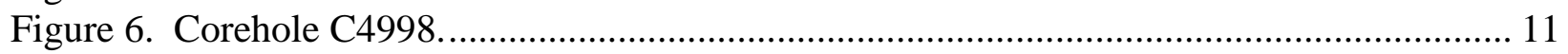

Figure 7. Calibration Check of 4-Arm Caliper. ................................................................. 25

\section{TABLES}

Table 1. Cementing Operations in Borehole C4993............................................................. 13

Table 2. Cementing Operations in Borehole C4996........................................................... 14

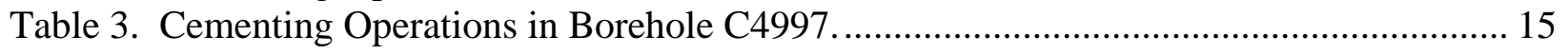

Table 4. Cementing Operations in Corehole C4998............................................................. 16

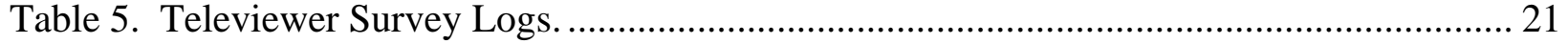

Table 6. Gearhart Owens International 4-Arm Caliper Calibration Coefficients........................ 24

Table 7. Calibration Check of 4-Arm Caliper. .................................................................... 25

Table 8. Caliper Survey Logs and Calibration Check. ...................................................... 26 
DTS-RPT-090, Rev. 0

\section{TERMS}

ASTM

bgs

BNI

DOE

HWT

NQA-1

PC-3

PNNL

QAPjP

SBP

$\mathrm{Vp}$

Vs

WELNAV

WTP
American Society for Testing and Materials

below ground surface

Bechtel National, Inc.

U.S. Department of Energy

standard designation for wireline drill bits and drill rods of nominally 3.782 in. and 3.5 in., respectively.

ASME NQA1-1, 1989 edition, Quality Assurance Program

Requirements for Nuclear Facilities

Performance Category 3

Pacific Northwest National Laboratory

Quality Assurance Project Plan

Seismic Boreholes Project

compressional wave velocity

shear wave velocity

Wellbore Navigation, Inc.

Waste Treatment Plant 
DTS-RPT-090, Rev. 0

This page intentionally left blank. 
DTS-RPT-090, Rev. 0

\section{SUMMARY REPORT OF GEOPHYSICAL LOGGING FOR THE SEISMIC BOREHOLES PROJECT AT THE HANFORD SITE WASTE TREATMENT PLANT}

\subsection{INTRODUCTION}

During the period of June through October 2006, three deep boreholes and one corehole were drilled beneath the site of the Waste Treatment Plant (WTP) at the U.S. Department of Energy (DOE) Hanford Site near Richland, Washington. The boreholes were drilled to provide information on ground-motion attenuation in the basalt and interbedded sediments underlying the WTP site. This report describes the geophysical logging of the deep boreholes that was conducted in support of the Seismic Boreholes Project, defined below. The detailed drilling and geological descriptions of the boreholes and seismic data collected and analysis of that data are reported elsewhere.

\subsection{WASTE TREATMENT PLANT AND THE SEISMIC BOREHOLES PROJECT}

The seismic design basis for the WTP was reevaluated in 2005, resulting in an increase by up to $40 \%$ in the seismic design basis. In 1999, the original seismic design basis for the WTP was based on a probabilistic seismic hazard analysis completed in 1996. The 2005 analysis was performed to address questions raised by the Defense Nuclear Facilities Safety Board about the assumptions used in developing the original seismic criteria and about the adequacy of the site geotechnical surveys. The updated seismic response analysis used existing and newly acquired seismic velocity data, statistical analysis, expert elicitation, and ground-motion simulation to develop interim design ground-motion response spectra that enveloped the remaining uncertainties. The uncertainties in these response spectra were enveloped at approximately the 84th percentile to produce conservative design spectra, which contributed significantly to the increase in the seismic design basis.

A key uncertainty identified in the 2005 analysis was the velocity contrasts between the basalt flows and the sedimentary interbeds beneath the WTP. The velocity structure of the upper four basalt flows (Saddle Mountains Basalt) and that of the interlayered sedimentary interbeds (Ellensburg Formation) produce strong reductions in modeled earthquake ground motions propagating through them. Uncertainty in the strength of velocity contrasts between these basalts and interbeds resulted primarily from an absence of measured shear wave velocities (Vs) in the interbeds. For the 2005 analysis, Vs in the interbeds was estimated from older, limited compressional wave $(\mathrm{Vp})$ data using estimated ranges for the ratio of the two velocities ( $\mathrm{Vp} / \mathrm{Vs}$ ) based on analogues in similar materials. A range of possible Vs for the interbeds and basalts was used and produced additional uncertainty in the resulting response spectra. 
Because of the sensitivity of the calculated response spectra to the velocity contrasts between the basalts and interbedded sediments, DOE initiated the Seismic Boreholes Project (SBP) to emplace additional boreholes at the WTP site and obtain direct Vs measurements and other physical property measurements in these layers. One corehole and three boreholes were installed at the WTP site to a maximum depth of $447.45 \mathrm{~m}(1,468 \mathrm{ft}$ ) below ground surface (bgs). The

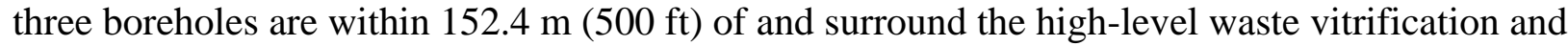
pretreatment facilities of the WTP, the Performance Category 3 (PC-3) structures affected by the interim design spectra. The corehole is co-located with the borehole closest to the two PC-3 structures. The new measurements from the seismic boreholes are expected to reduce the uncertainty in the modeled site response that has been caused by the lack of direct knowledge of the Vs contrasts within these basalt and interbed layers.

\subsection{ORGANIZATION AND RESPONSIBILITY}

Work described in this report was conducted by Pacific Northwest National Laboratory (PNNL) and subcontractors for the U.S. Department of Energy. Bechtel National, Inc. (BNI) is responsible for WTP construction and all WTP site control. Drilling was subcontracted by PNNL, and drill site supervisory and logistical services were provided by EnergySolutions, Inc. (formerly Duratek Federal Services, Inc.) and subcontractors. Additional site personnel were provided by Fluor Hanford, Inc. Drilling of the entry holes for the deep boreholes was performed by Blue Star Enterprises Northwest, Inc., of Richland, Washington. The cored portion (basalt and interbeds) of the C4998 corehole was drilled by Layne Christensen Company of Salt Lake City, Utah. The remaining three deep boreholes were drilled by WDC Exploration and Wells of Woodland, California.

\subsection{PROCEDURE REQUIREMENTS AND QUALITY ASSURANCE}

PNNL has primary responsibility for quality assurance and quality control, with recognition of BNI requirements for NQA-1 standards. The Sampling and Analysis Plan (PNNL-15848) and Quality Assurance Project Plan (QAPjP ${ }^{1}$ ) were used to guide the procedure development and data collection activities needed to support borehole drilling, geophysical measurements, and sampling. The Sampling and Analysis Plan identifies standards (e.g., American Society for Testing and Materials [ASTM]), Hanford Site procedures, and other guidance documents for data collection activities.

\subsection{REPORT SCOPE}

This report provides and describes the data collected during geophysical logging of the three deep boreholes and the corehole. Other logging results are reported elsewhere.

\footnotetext{
${ }^{1}$ Waste Treatment Plant (WTP) Seismic Boreholes Project Quality Assurance Project Plan, Rev. 0, March 2006, Pacific Northwest National Laboratory, Richland, Washington.
} 
Borehole completion, geologic formations and drilling operations are summarized, where necessary, to help in understanding the geophysical logging operations.

A detailed discussion of data processing of logging is beyond the scope of this report. There is no analysis or interpretation of the log results, either, since these are discussed in other reports yet to be completed at the time of this document. The other types of logging, such as suspension logging, seismic logging, and gravity/density logging will be reported in documents to be released by PNNL.

\subsection{OBJECTIVES}

The objective of this report is to present the results of the geophysical logging activities. The overall objectives for conducting geophysical logging in the boreholes and corehole were to acquire subsurface data to support the progression of the drilling activities and to supplement the geologic and seismic data collection. The depth unit (feet) for this project was selected as dominant over the metric unit (meter) for the following reasons.

- Drilling equipment depth is in feet (drill stem and drill collar lengths are $20 \mathrm{ft}$. Drilling recorder depths are in feet).

- Logging equipment (logging cable measuring wheel) depth is calibrated in feet.

The borehole/corehole deviation and orientation as well as the borehole gauge (diameter) were tracked throughout the drilling process as the holes were advanced. The borehole size (diameter) unit (inch) for this project was selected as dominant over the metric unit (centimeter) for the following reasons.

- $\quad$ The drill bit size is in inches (7-7/8 in.)

- The logging equipment caliper calibration jig is in inches. The two calibration sizes for this project were 6 in. and 12 in.

- $\quad$ Casing diameter is manufactured in inches.

The caliper logs collected during the boreholes advancement were used to support the borehole cementing activities as well as the collection of seismic data (to orient the down-hole data collection instruments). The suite of geophysical logs conducted once the boreholes and corehole reached total depth provided additional data to support the geologic interpretation. 
DTS-RPT-090, Rev. 0

\subsection{DEEP BOREHOLE DESCRIPTION}

\subsection{BOREHOLE LOCATION}

The three deep boreholes and corehole were drilled at the WTP at the DOE Hanford Site near Richland, Washington. Figure 1 is a map of the Hanford Site showing the location of the WTP. Figure 2 is a schematic of the WTP providing borehole locations and survey coordinates. The boreholes were located to surround the Pretreatment Facility and the High-Level Vitrification Facility. The corehole was paired with one of the deep boreholes at the center of the WTP site. 
DTS-RPT-090, Rev. 0

Figure 1. Hanford Site.

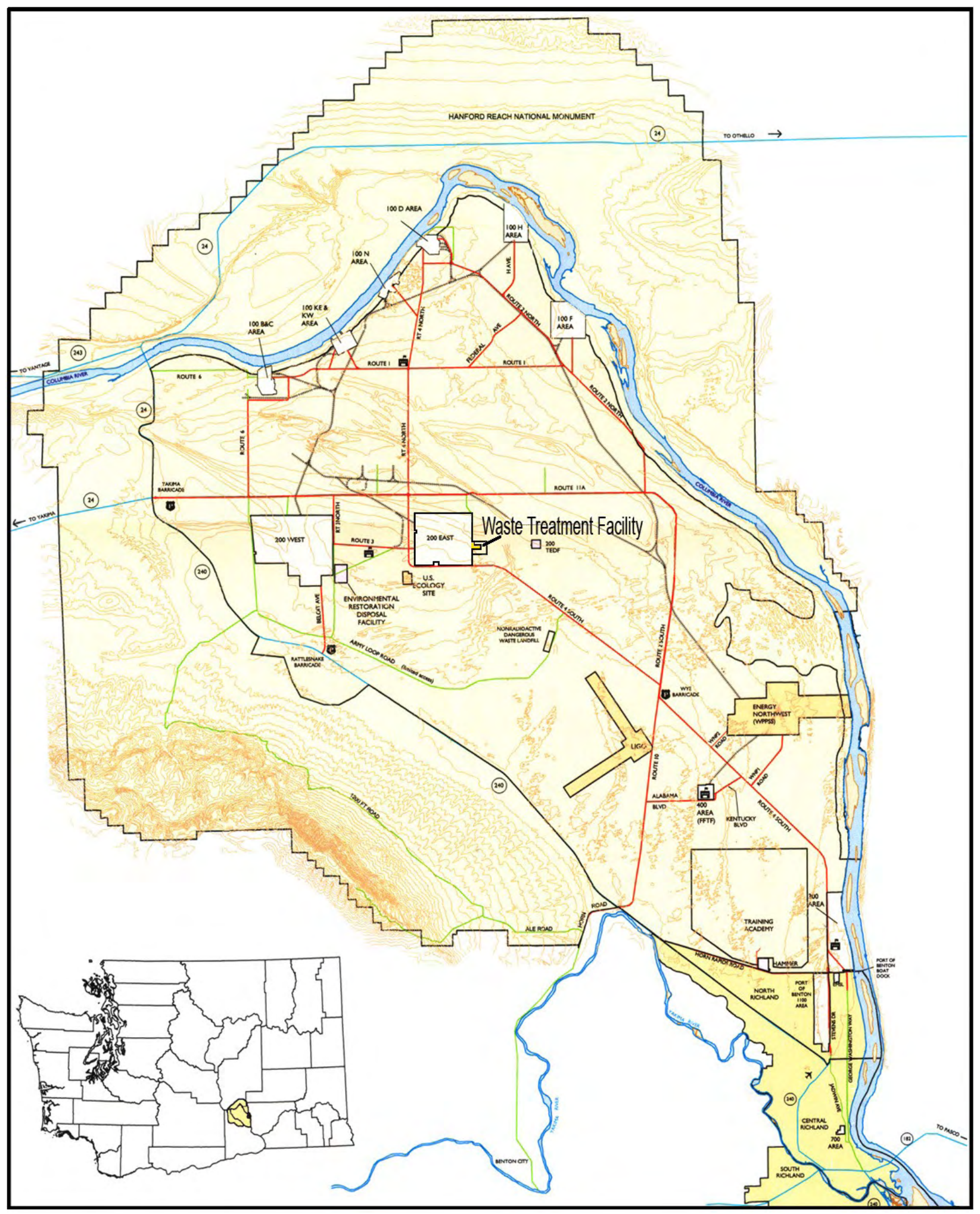


DTS-RPT-090, Rev. 0

Figure 2. Waste Treatment Plant Site.

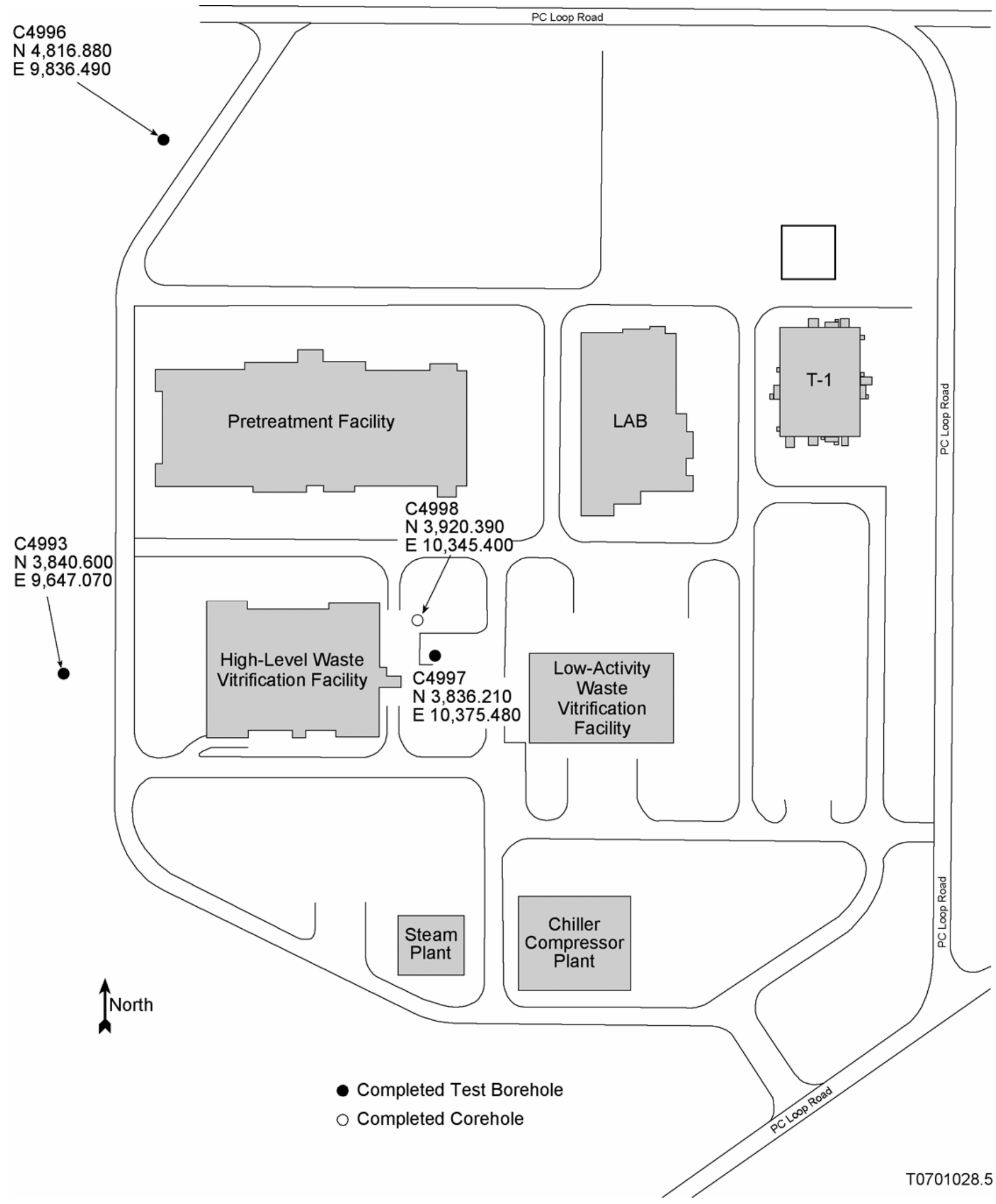




\subsection{AS-BUILT DRAWINGS AT COMPLETION OF DRILLING}

The main geologic units of interest at the WTP are the Saddle Mountains Basalt and the interbedded sediments of the Ellensburg Formation. The seismic boreholes at the WTP penetrated the upper part of the Wanapum Basalt and provide information on the upper Wanapum Basalt and a local sedimentary interbed, the Byron Interbed. Borehole C4996 penetrated the deepest, reaching the upper part of the Roza Member, Wanapum Basalt (C4996). The as-built drawings are provided in Figures 3, 4, 5 and 6.

The as-built design of each borehole at the completion of drilling activities is summarized in this section. The depths of the geologic units were pulled from the final geology report (reference to be inserted later) where detailed descriptions of the geology are found. This report does not attempt to describe the borehole geology. All cementing is not shown in the figures. Please see Section 2.3 for details of the cementing activities during drilling operations. 
Figure 3 shows the as-built for C4993 with the depths of formation interfaces. Details of drilling the upper section of the borehole are in WMP-32119, Entry Boreholes Summary Report for the Waste Treatment Plant Seismic Boreholes Project, and the details of the mud rotary section are given in PNNL-16303, Borehole Summary Report for Core Hole C4998-Waste Treatment Plant Seismic Boreholes Project.

Figure 3. Borehole C4993.

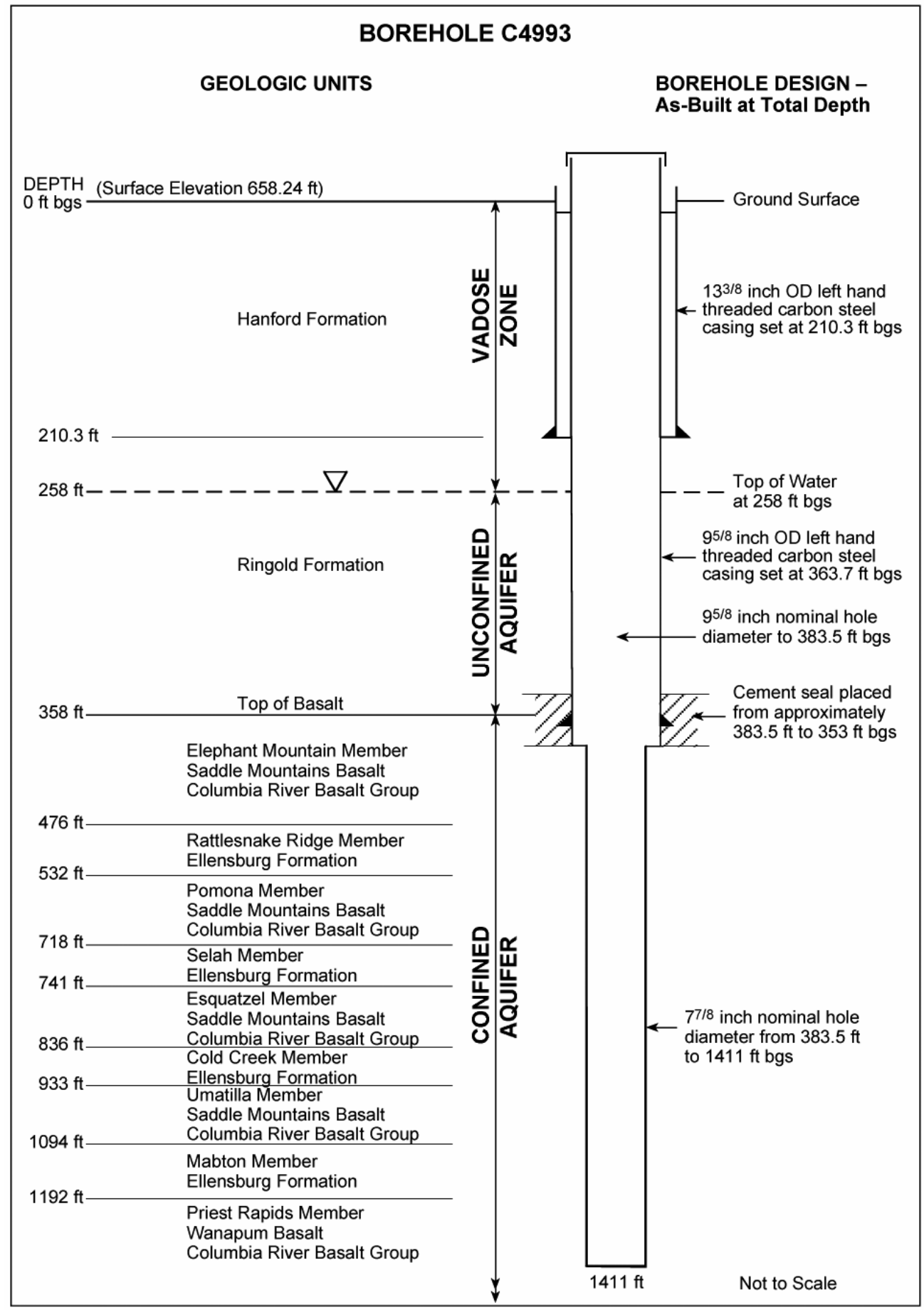

T0701033.4 
Figure 4 shows the as-built for C4996 with the depths of formation interfaces. Details of drilling the upper section of the borehole are in WMP-32119, and the details of the mud rotary section are given in WMP-32076, Borehole Summary Report for Waste Treatment Plant Seismic Borehole C4996.

Figure 4. Borehole C4996.

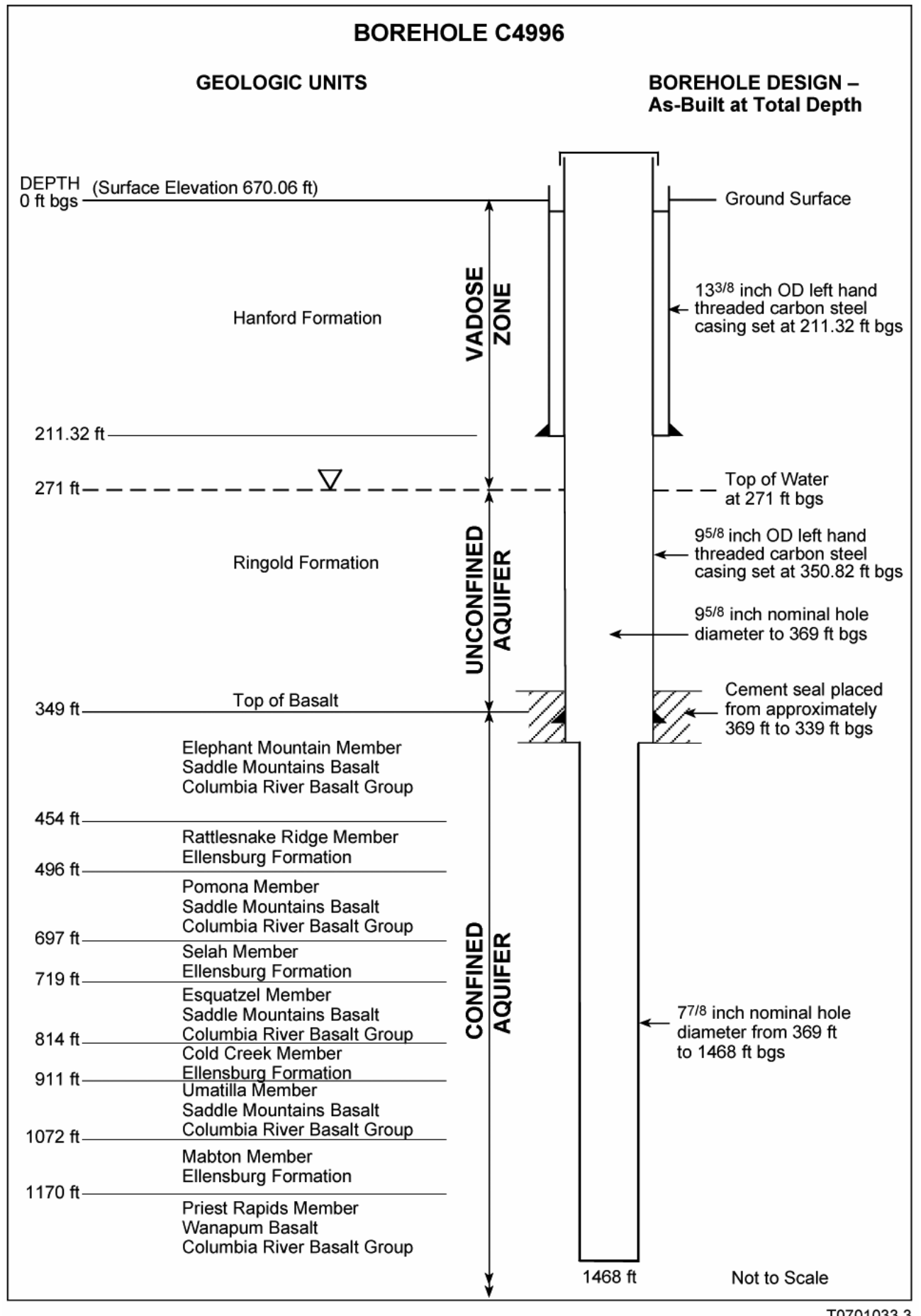


Figure 5 shows the as-built for C4997 with the depths of formation interfaces. Details of drilling the upper section of the borehole are in WMP-32119, and the details of the mud rotary section are given in Landau and Groundwater Associates (Fluor).

Figure 5. Borehole C4997.

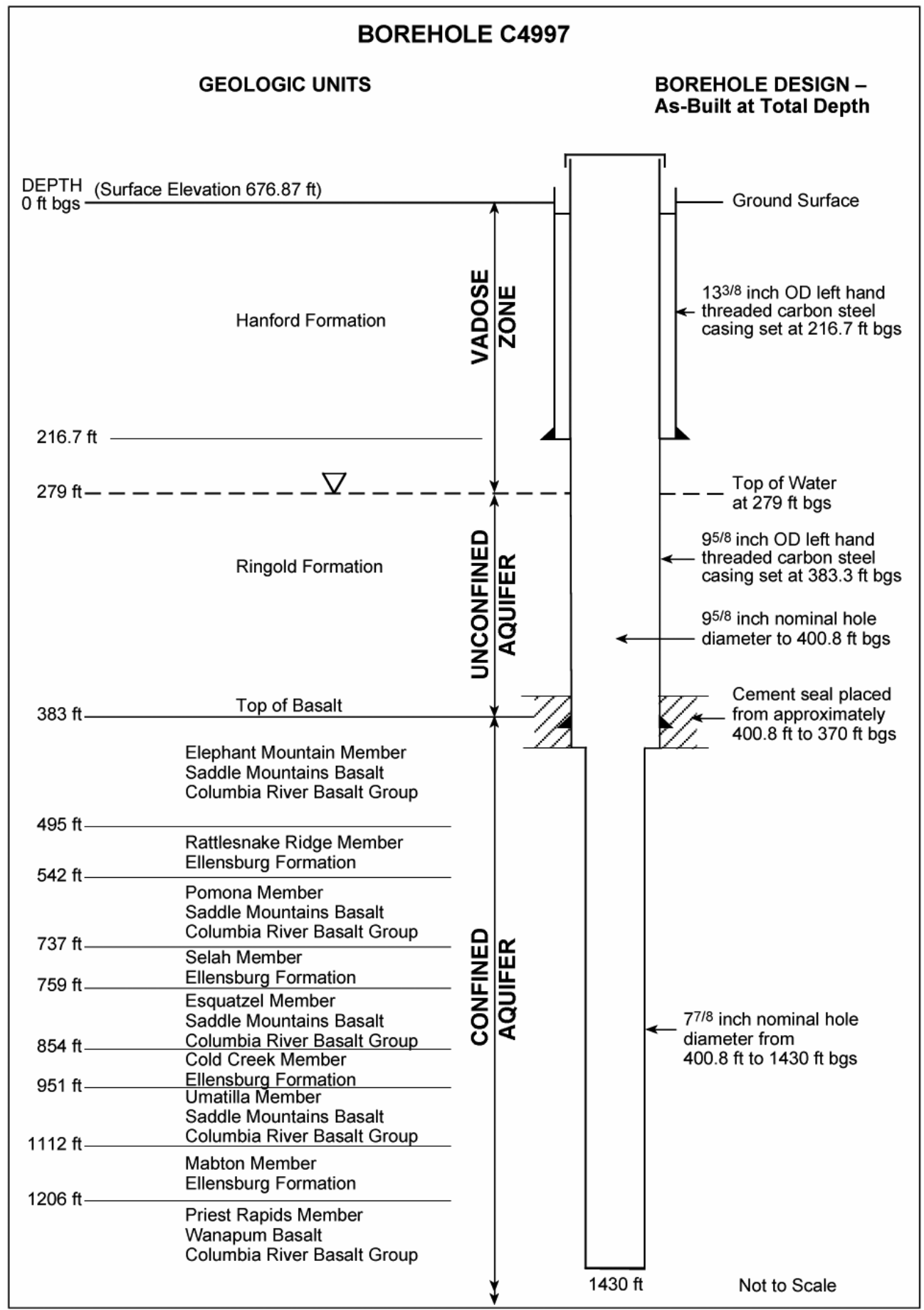

T0701033.2 
Figure 6 shows the as-built for C4998 with the depths of formation interfaces. Details of drilling the upper section of the borehole are in WMP-32119 and the details of the core section are given by PNNL-16303.

Figure 6. Corehole C4998.

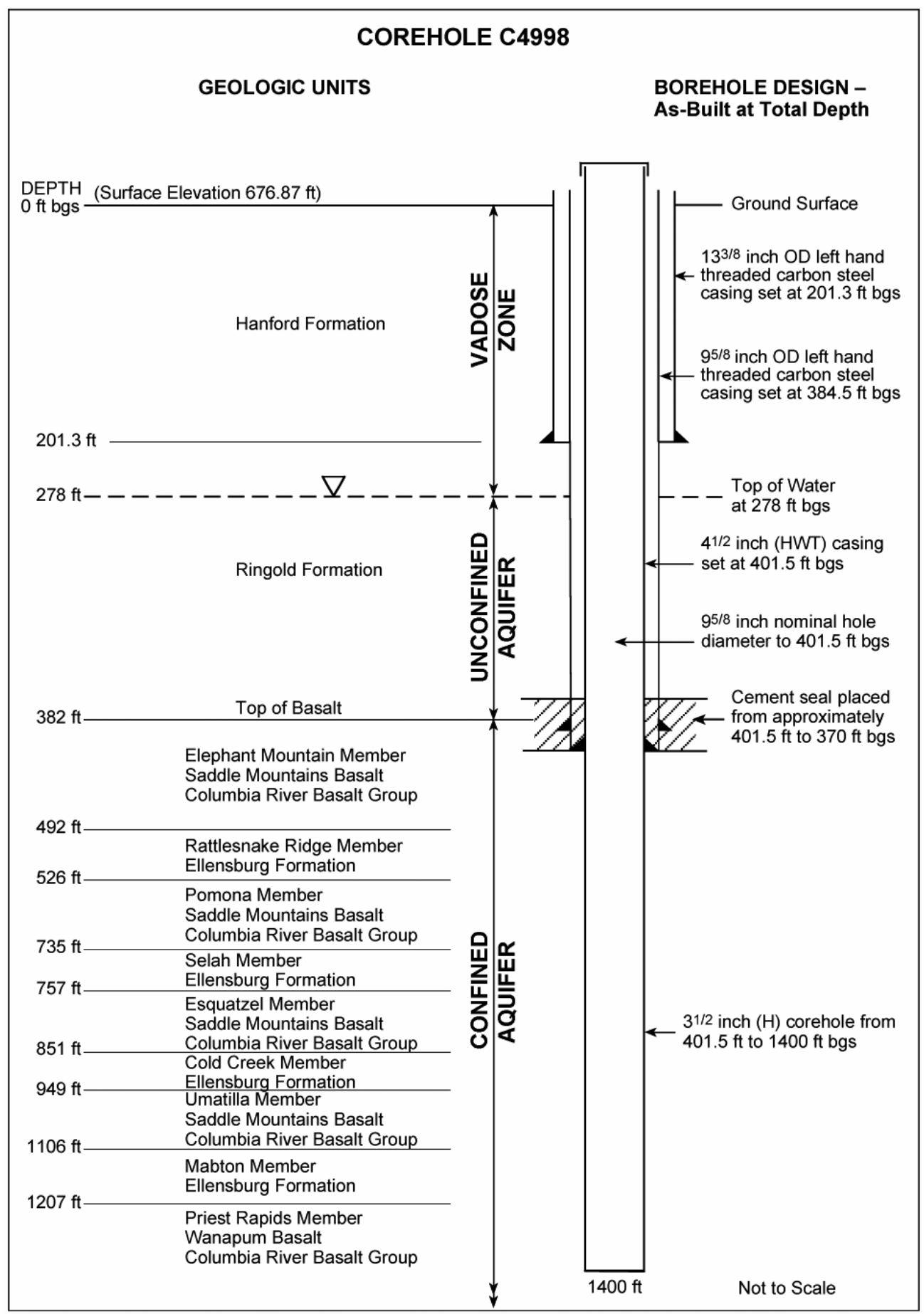




\subsection{CEMENTING OPERATIONS}

During the drilling of the boreholes and corehole, cement grout was placed at predetermined intervals and as needed to maintain control of the borehole. The two types of cementing operations are discussed in the following sections.

\subsubsection{Entry Hole Cementing}

All the boreholes and the corehole were started in preconstructed entry holes. These entry holes were drilled using a cable tool rig to drill through the Ringold and Hanford formations. These suprabasalt formations were lined with casing and sealed to the upper Elephant Mountain basalt with the placement of a small cement interval. This is the first cement operation in each table. The temporary casing sealed to the formation was $24.448 \mathrm{~cm}$ (9.625 in.) outside diameter on P-110 carbon steel casing for the boreholes and $11.43 \mathrm{~cm}$ (4.5 in.) outside diameter HWT carbon steel casing for the corehole.

This cement placement was designed to provide a seal at the bottom of the casing to isolate the unconfined aquifer (in the Ringold) from the confined aquifers in the Wanapum basalts.

\subsubsection{Deep Boreholes Cementing}

Cementing operations during drilling of the deep boreholes were intended to help provide a hard, uniform diameter surface in the interbeds and basalt to assist the seismic logging operations that were scheduled after drilling was completed. In addition, the cement placement provided for hole control to prevent the formation from spalling and reduce/eliminate fluid loss to the interbeds. The whole borehole below the casing was cemented at least once, unless noted below.

Normal operations consisted of drilling through the interbed and into the underlying basalt for $9.14 \mathrm{~m}$ (30 ft) to advance past the flow top and allow room for suspension logging operations. After Televiewer and suspension logging in the open borehole, cement was placed up through the interbed and into the overlying basalt until reaching the previously placed cement level. This cement was drilled out and deepening of the borehole continued.

After the boreholes were completed, a second phase of cementing began in order to re-cement the Mabton and Cold Creek interbeds. Plugs were placed to leave open borehole intervals where possible. This saved cement and the time it would take to drill it back out. The plug intervals are in the comments columns of Tables 1 through 3.

Tables 1 through 3 show the date cement was placed, interval cemented, and approximate volumes of cement mix used for the three deep boreholes. 
DTS-RPT-090, Rev. 0

\subsubsection{Borehole C4993}

Table 1. Cementing Operations in Borehole C4993.

\begin{tabular}{|l|l|l|l|}
\hline \multicolumn{1}{|c|}{ Date } & \multicolumn{1}{|c|}{ Interval } & \multicolumn{1}{c|}{$\begin{array}{c}\text { Estimated } \\
\text { Volume }\end{array}$} & \multicolumn{1}{|c|}{ Comments } \\
\hline $9 / 6 / 06$ & $355^{\prime}-383.5^{\prime}$ bgs & 108 gal & Seal casing to Elephant Mt \\
\hline $9 / 11 / 06$ & $332^{\prime}-562^{\prime}$ bgs & 625 gal & $\begin{array}{l}\text { Pomona, Rattlesnake Ridge } \\
\text { and Elephant Mt. }\end{array}$ \\
\hline $9 / 18 / 06$ & $488^{\prime}-775^{\prime}$ bgs & 760 gal & $\begin{array}{l}\text { Esquatzel, Selah, Pomona } \\
\text { and Rattlesnake Ridge }\end{array}$ \\
\hline $9 / 23 / 06$ & $742^{\prime}-965^{\prime}$ bgs & 570 gal & $\begin{array}{l}\text { Umatilla, Cold Creek and } \\
\text { Esquatzel }\end{array}$ \\
\hline $10 / 1-2 / 06$ & $918^{\prime}-1,222^{\prime}$ bgs & 840 gal & $\begin{array}{l}\text { Priest Rapids, Mabton, } \\
\text { Umatilla and Cold Creek }\end{array}$ \\
\hline $10 / 8-9 / 06$ & $1,190^{\prime}-1,411^{\prime}$ bgs & 690 gal & $\begin{array}{l}\text { Priest Rapids-borehole } \\
\text { bottom- and Mabton }\end{array}$ \\
\hline $11 / 2-3 / 06$ & $1,203^{\prime}-1,255^{\prime}$ bgs & 90 gal & Plug attempt failed \\
\hline $11 / 3 / 06$ & $1,200^{\prime}-\sim 1,255^{\prime}$ bgs & 80 gal & Plug set \\
\hline $11 / 4 / 06$ & $1,065^{\prime}-\sim 1,255^{\prime}$ bgs & 400 gal & $\begin{array}{l}\text { Priest Rapids, Mabton and } \\
\text { Umatilla }\end{array}$ \\
\hline $11 / 4-5 / 06$ & $775^{\prime}-1,065^{\prime}$ bgs & 750 gal & $\begin{array}{l}\text { Umatilla, Cold Creek, } \\
\text { Esquatzel }\end{array}$ \\
\hline
\end{tabular}


DTS-RPT-090, Rev. 0

\subsubsection{Borehole C4996}

Table 2. Cementing Operations in Borehole C4996.

\begin{tabular}{|c|c|c|c|}
\hline Date & Interval & Estimated Volume & Comments \\
\hline $7 / 27 / 06$ & $340^{\prime}-369^{\prime}$ bgs & 90 gal & $\begin{array}{l}\text { Seal casing to Elephant } \\
\text { Mt }\end{array}$ \\
\hline 8/3/06 & $413^{\prime}-532$ ' bgs & 330 gal & $\begin{array}{l}\text { Pomona, Rattlesnake } \\
\text { Ridge and Elephant } \\
\text { Mt. }\end{array}$ \\
\hline $8 / 11 / 06$ & $680^{\prime}-747.1^{\prime}$ bgs & 420 gal & $\begin{array}{l}\text { Esquatzel, Selah, and } \\
\text { Pomona-but not high } \\
\text { enough }\end{array}$ \\
\hline $8 / 12 / 06$ & $620^{\prime}-680^{\prime}$ bgs & 100 gal & Pomona \\
\hline $8 / 17 / 06$ & 702 - 941' bgs & 585 gal & $\begin{array}{l}\text { Umatilla, Cold Creek, } \\
\text { Esquatzel and Selah }\end{array}$ \\
\hline $8 / 23 / 06$ & $910^{\prime}-1,198$ ' bgs & 990 gal & $\begin{array}{l}\text { Priest Rapids, Mabton, } \\
\text { Umatilla and Cold } \\
\text { Creek }\end{array}$ \\
\hline $8 / 29 / 06$ & $896^{\prime}-1,368^{\prime}$ bgs & 1200 gal & $\begin{array}{l}\text { Priest Rapids, Mabton, } \\
\text { Umatilla and Cold } \\
\text { Creek }\end{array}$ \\
\hline 9/6/06 & $1,340 '-1,468$ ' bgs & 310 gal & $\begin{array}{l}\text { Priest Rapids - } \\
\text { borehole bottom }\end{array}$ \\
\hline $10 / 27 / 06$ & $1,166^{\prime}-\sim 1,200^{\prime}$ bgs & 90 gal & Plug set \\
\hline $10 / 28 / 06$ & $1,020^{\prime}-1,166^{\prime}$ bgs & 420 gal & Mabton and Umatilla \\
\hline $10 / 29 / 06$ & 1,008 ' - 1,020' bgs & 90 gal & $\begin{array}{l}\text { Plug failed and slid } \\
\text { down onto previous lift } \\
\text { in Umatilla }\end{array}$ \\
\hline $10 / 30 / 06$ & $815^{\prime}-1,008$ ' bgs & 620 gal & $\begin{array}{l}\text { Umatilla and Cold } \\
\text { Creek }\end{array}$ \\
\hline
\end{tabular}


DTS-RPT-090, Rev. 0

\subsubsection{Borehole C4997}

Table 3. Cementing Operations in Borehole C4997.

\begin{tabular}{|c|c|c|c|}
\hline Date & Interval & $\begin{array}{l}\text { Estimated } \\
\text { Volume }\end{array}$ & Comments \\
\hline $8 / 18 / 06$ & $343^{\prime}-400.8^{\prime}$ bgs & 120 gal & Seal casing to Elephant Mt \\
\hline $8 / 27 / 06$ & $244^{\prime}-567^{\prime}$ bgs & 800 gal & $\begin{array}{l}\text { Pomona, Rattlesnake Ridge and } \\
\text { Elephant Mt. }\end{array}$ \\
\hline 8/29-30/06 & $487^{\prime}-582$ ' bgs & 260 gal & $\begin{array}{l}\text { Pomona, Rattlesnake Ridge and } \\
\text { Elephant Mt., re-cement }\end{array}$ \\
\hline $9 / 6 / 06$ & 519' - 791' bgs & 900 gal & $\begin{array}{l}\text { Esquatzel, Selah, Pomona and } \\
\text { Rattlesnake Ridge }\end{array}$ \\
\hline $9 / 13 / 06$ & 774' - 955' bgs & 670 gal & $\begin{array}{l}\text { Umatilla, Cold Creek and } \\
\text { Esquatzel - Failed }\end{array}$ \\
\hline $9 / 14 / 06$ & 893 ' - 955' bgs & 385 gal & $\begin{array}{l}\text { Umatilla and Cold Creek - } \\
\text { added another lift }\end{array}$ \\
\hline 9/14/06 & 860 ' - 893' bgs & 184 gal & Cold Creek \\
\hline $9 / 25 / 06$ & 918' - 1,137' bgs & 580 gal & Mabton (partial) and Umatilla \\
\hline $10 / 2 / 06$ & $1,120^{\prime}-1,248.7^{\prime}$ bgs & 340 gal & $\begin{array}{l}\text { Priest Rapids and Mabton } \\
\text { (partial) - added another lift; } \\
\text { suspect the 1,120' might be a } \\
\text { bad tag }\end{array}$ \\
\hline $10 / 3 / 06$ & $1,170^{\prime}-1,248.7^{\prime}$ bgs & 140 gal & $\begin{array}{l}\text { Priest Rapids and Mabton } \\
\text { (partial) - after adding cement } \\
\text { tag is 50' lower than previous } \\
\text { day; however, drilling log notes } \\
\text { starting drilling at 1,109' bgs - } \\
\text { gave up cementing interval }\end{array}$ \\
\hline $10 / 25 / 06$ & $\sim 760 '-\sim 780$ ' bgs & 90 gal & Plug failed in the Esquatzel \\
\hline $10 / 28 / 06$ & $1,187^{\prime}-\sim 1,240^{\prime}$ bgs & 148 gal & $\begin{array}{l}\text { Plug in Priest Rapids and } \\
\text { Mabton (across interface) }\end{array}$ \\
\hline $10 / 29 / 06$ & 1,094'-1,187' bgs & 440 gal & Mabton and Umatilla \\
\hline $10 / 29 / 06$ & 978 '-990' bgs & $100 \mathrm{gal}$ & Plug in Umatilla \\
\hline $10 / 30 / 06$ & $900^{\prime}-978$ ' bgs & 444 gal & $\begin{array}{l}\text { Umatilla and Cold Creek } \\
\text { (partial) }\end{array}$ \\
\hline $10 / 31 / 06$ & 830 '-900' bgs & 610 gal & $\begin{array}{l}\text { Cold Creek and Esquatzel (void } \\
\text { between } 870^{\prime}-895^{\prime} \text { bgs) }\end{array}$ \\
\hline $11 / 1 / 06$ & $843^{\prime}-900$ ' bgs & 336 gal & $\begin{array}{l}\text { Cold Creek and Esquatzel - re- } \\
\text { cement }\end{array}$ \\
\hline
\end{tabular}


DTS-RPT-090, Rev. 0

\subsubsection{Corehole Cementing}

The corehole was only cemented when it was judged advantageous to the coring operation itself (for control of mud loss and spalling formations).

Table 4 shows the date cement was placed, interval cemented, and approximate volumes of cement mix used for the corehole.

\subsubsection{Corehole C4998}

Table 4. Cementing Operations in Corehole C4998.

\begin{tabular}{|l|l|l|l|}
\hline \multicolumn{1}{|c|}{ Date } & \multicolumn{1}{|c|}{ Interval } & $\begin{array}{c}\text { Estimated } \\
\text { Volume }\end{array}$ & \multicolumn{1}{c|}{ Comments } \\
\hline $7 / 12 / 06$ & $348.5^{\prime}-401.5^{\prime}$ bgs & 100 gal & Seal casing to Elephant Mt \\
\hline $7 / 27 / 06$ & $495^{\prime}-595^{\prime}$ bgs & 110 gal & $\begin{array}{l}\text { Pomona, Rattlesnake Ridge } \\
\text { (partial) }\end{array}$ \\
\hline $8 / 1 / 06$ & $400^{\prime}-613^{\prime}$ bgs & 110 gal & $\begin{array}{l}\text { Pomona, Rattlesnake Ridge } \\
\text { and Elephant Mt. - done with } \\
\text { a packer }\end{array}$ \\
\hline $8 / 17 / 06$ & $934^{\prime}-994^{\prime}$ bgs & 90 gal & $\begin{array}{l}\text { Umatilla and Cold Creek - } \\
\text { interface }\end{array}$ \\
\hline $8 / 29 / 06$ & $1,088^{\prime}-1,188^{\prime}$ bgs & 145 gal & $\begin{array}{l}\text { Mabton and Umatilla - } \\
\text { interface, Failed }\end{array}$ \\
\hline $8 / 31 / 06$ & $1,061^{\prime}-1,188^{\prime}$ bgs & 145 gal & $\begin{array}{l}\text { Mabton and Umatilla - } \\
\text { interface, Failed }\end{array}$ \\
\hline
\end{tabular}

\subsection{GYROSCOPE SURVEYS}

Gyroscope surveys were acquired to track the inclination of the boreholes at periodic times as drilling progressed. The surveys were recorded approximately each $15 \mathrm{~m}$ (50-ft) during installation of the entry holes, and each $30 \mathrm{~m}(100-\mathrm{ft})$ as the rotary rig was drilling the basalt and interbed formations. Gyroscopic surveys were not performed below the cased interval of the corehole. Two stainless steel centralizers were used to centralize the gyroscope when logging the entry hole casing path. During rotary rig drilling, gyro surveys were performed without centralizers through the drill pipe.

The Humphrey gyroscope used for this project is owned by the DOE. The gyroscope sonde and up-hole electronics control box was recently examined by the equipment vendor (Wellbore Navigation, Inc. [WELNAV]). New gimble bearings were installed and a performance check performed. 
The gyro surveys were acquired at stationary measure points along the borehole and the survey results are presented in this report or in the appendices. Examination of the initial survey of the first two boreholes, i.e. C4998 and C4996, revealed that the precision (repeatability) of the system should be investigated. In the initial gyro runs, it was noticed that successive gyro surveys in the same borehole were generally following the same path; however, the XYZ coordinates did not overlay (i.e., the numbers agreed to the first significant digit, sometimes to the second digit, but rarely to third digit). The equipment vendor (WELNAV) was contacted and the results discussed. The procedure for initial drift check, duration for tool warm-up, and data processing was clarified. Equipment operation is described in the following section. Final results are presented in this document in Appendices A through D.

\subsection{EQUIPMENT CHARACTERISTICS}

The gyroscope survey probe contains three key components: (1) x-axis accelerometer, (2) y-axis accelerometer (also called inclinometers), and (3) the uncaged gyro. These components are delicate (very susceptible to vibrations and shock) and the corresponding sensor responses are susceptible to incorrect readings resulting from shock and vibrations. The gyro is powered by a dynamic motor. The gyro is supported in two-gimble yokes by four small sealed bearings.

Due to the sensitivity of the gyro sensors, extra measures were taken during operation. One or more drift checks were recorded during each survey. A drift check is a set of up to 20 measurements, 15 seconds apart, with the probe at a stationary location in the borehole. Generally, during a drift check, there is no change in the inclinometer reading, and negligible change in the gyro orientation readings. However, occasionally non-linear changes were observed and the logging operators began to recognize that small actions by people in the area of the drill rig (such as a member of the drilling staff opening the door of the cab on the drill rig and stepping on to the running board) could cause a change in the gyro drift rate, during a drift check.

There were several conditions managed in order to minimize errors in the gyroscope surveys.

- Drift of the gyro during the survey was minimized through the following activities. When the gyro was uncaged, the tool drift readings were observed for at least three minutes to verify that the drift rate was low (near zero). If the drift rate was high, then the tool would be moved into position at the hole, the gyro would be oriented to 0 degrees and re-caged. After five minutes, the gyro would be uncaged. This action would reduce the gyro drift to less than 5 degrees during the survey. When the drift exceeded 10 degrees between the start and final reference point, the survey would be rerun.

- The gyro tool was run centralized in the casing. During rotary rig drilling, the gyro tool was run inside the drill stem. Close tolerance between tool outside diameter and drill pipe inside diameter prevented the use of centralizers.

- The gyroscope probe was powered up for at least 30 minutes for the equipment to warm up to operating temperature before conducting the survey. The gyro wheel requires seven minutes to come up to speed, which is $30,000 \mathrm{rpm}$. 
The purpose of a gyroscope probe survey is to track the path of a borehole from its starting location at the top of the borehole into the subsurface (XYZ coordinates). The initial starting orientation (azimuth, compass bearing) is required at the beginning of a borehole survey.

Azimuth (true north compass bearing): Analysis software needs as input the compass direction that the tool face is pointing. The azimuth is determined by the following: (1) A rifle scope is attached to the probe and is sighted to a "survey reference point" object, (2) it is the "magnetic compass reading" of the survey reference point, and (3) it is "local magnetic declination" (16.5 degrees east at the WTP site).

\subsubsection{Humphrey Gyro Limitations}

Following are the limitations of the Humphrey gyro system.

- 2-axis accelerometers (inclinometers) with maximum inclination of 30 degrees from vertical (accelerometer range limit). Must use 3-axis tool for improved precision.

- Accelerometers are not accurate if dip is less than 0.5 degrees. The precision (repeatability) of response is 0.25 degrees at inclination angles from 0 to 30 degrees. Half (0.50) a degree error in inclination translates to $2.74 \mathrm{~m}$ (9-ft) error in a $304.8 \mathrm{~m}$ (1000-ft) hole.

- In vertical (near vertical) boreholes, the direction (azimuth) will appear to have a large error. But remember that at deviation angles of 0 degrees, the azimuth becomes undefined (i.e., at vertical position, even though the tool can face any direction, it is still at the same location.)

- Maximum precision of inclination readings is 0.1 degree (if calibrated).

\subsection{ACOUSTIC TELEVIEWER}

The Acoustic Televiewer logging sonde is designed to generate an image of the borehole wall by transmitting ultrasonic pulses from a rotating sensor and then recording the amplitude and travel time of the signal that reflects at the interface between the borehole fluid and formation (i.e., borehole wall).

The Televiewer logging probe used for this project is owned by the DOE (purchased for this project). It was purchased from Mount Sopris Instruments, located in Golden, Colorado. The logging sonde (Model ABI40) was manufactured by Advanced Logic Technology (ALT), located in Luxembourg, Belgium.

The Televiewer was selected to provide information on the condition of the borehole wall and caliper measurements during drilling. The sensor performance is best when the borehole fluid is clear water. Unfortunately, the equipment performance was degraded by drilling conditions that 
prevented reliable caliper measurements when the borehole diameter exceeded about $24.13 \mathrm{~cm}$ (9.5 in.). Also, the measurements were adversely affected by the high viscosity of the drilling mud, which significantly attenuated the acoustic signal. Additionally, measurements were possibly affected by debris suspended in the mud that reflected the acoustic signal back to the sensor (i.e., shortened travel time).

\subsection{CHARACTERISTICS}

The operational properties of the Televiewer logging sonde are as follows.

- Centralizer. The probe should be centered in the borehole for best operation. Eccentered (i.e., side walled) operation will produce unusable results. Two centralizers were attached to the $1.5 \mathrm{~m}$ (5-ft) long probe, one at the top and one above the mirror window (near the bottom). Each centralizer had six non-metallic bow-rods. The centralizer diameter of $19 \mathrm{~cm}$ (7.5-in.) was generally appropriate to permit the $5.9 \mathrm{~kg}$ (13-lb) probe to travel to the bottom of the borehole (nominal hole diameter of $20 \mathrm{~cm}$ [7.875 in.]). Occasionally, the centralizer diameter had to be reduced to permit the probe to travel through tight-hole conditions of the interbeds between basalt flows. The smallest was $13.97 \mathrm{~cm}$ (5.5 in.) in C4996 on September 5, 2006, for maximum log depth of $446.84 \mathrm{~m}$ (1,466 ft) (see Table 5).

- Acoustic sensor. This is a fixed transducer and a rotating focusing mirror. The rotating mirror is attached to a stepper motor and has a focal radius of $15.24 \mathrm{~cm}$ (6 in.). The rotating mirror and acoustic transducer acquire 72, 144, or 288 measurements per revolution (turn). The mirror rotation rate is 10 turns per second for settings of 72 and 144, and the mirror rotates eight turns per second for the 288 setting.

- Logging Parameters. The acoustic resolution setting for this project was 144 pulses per turn (i.e., 2.5 degrees per pulse) and 10 turns per second (automatic). The minimum depth resolution was $0.28 \mathrm{~cm}(0.0092 \mathrm{ft})$ per revolution (turn). The maximum logging speed to prevent data loss was $2.53 \mathrm{~m}(8.3 \mathrm{ft})$ per minute.

- Recorded Data. The sonde records two values for each acoustic pulse: (1) the two-way travel time (microsecond $[\mu \mathrm{s}]$ ) and (2) amplitude of the first arrival. The travel time is expressed in $1 / 10^{\text {th }}$ of a $\mu \mathrm{s}$. Travel time values range from about 720 to 4200 ( $x 1 / 10^{\text {th }}$ of $\mu \mathrm{s}$ ) or (72 to $420 \mu \mathrm{s})$.

- WellCAD. The Televiewer data is processed and displayed with the WellCAD software program using the module for Image Logs.

o Time Window (acoustic travel time inside the tool) $=75 \mu \mathrm{s}$.

o Borehole Fluid $=1477 \mathrm{~m} / \mathrm{sec}$ (This value was derived from WellCAD computation using travel time scans at specific depth and known hole size.) 
Televiewer Scan: The scan to the right is an example of a good Televiewer scan. The red line (larger circle) is the travel time response and is slightly offset around the black line (smaller circle), which is the external limit of the acoustical window. The scan is from survey file C4996-1466A near $4.43 \mathrm{~m}$ (1,458 ft). In this example the Minimum, Average, and Maximum computed caliper are essentially the same. Acoustic scans with this clarity are rare for the Televiewer surveys of this project.

The next scan shows an example of a Televiewer scan (acoustic response) for tool centralizers that are reduced from $19 \mathrm{~cm}$ (7.5 in.) to $16.5 \mathrm{~cm}$ (6.5 in.). This scan is from survey file C4997-1280. The red line (travel time response) is noticeably askew around the black circle (external limit of the acoustic window). Also this scan is typical with several travel time response values significantly less than the correct response (from the borehole wall). The detector is responding to either debris suspended in the drilling mud or is triggering on residual signal from the previous transmission of the transducer. (Remember, since both centralizers are above the acoustic window, they may be dislodging materials from the borehole wall as the tool is pulled up during the survey). This scan also shows
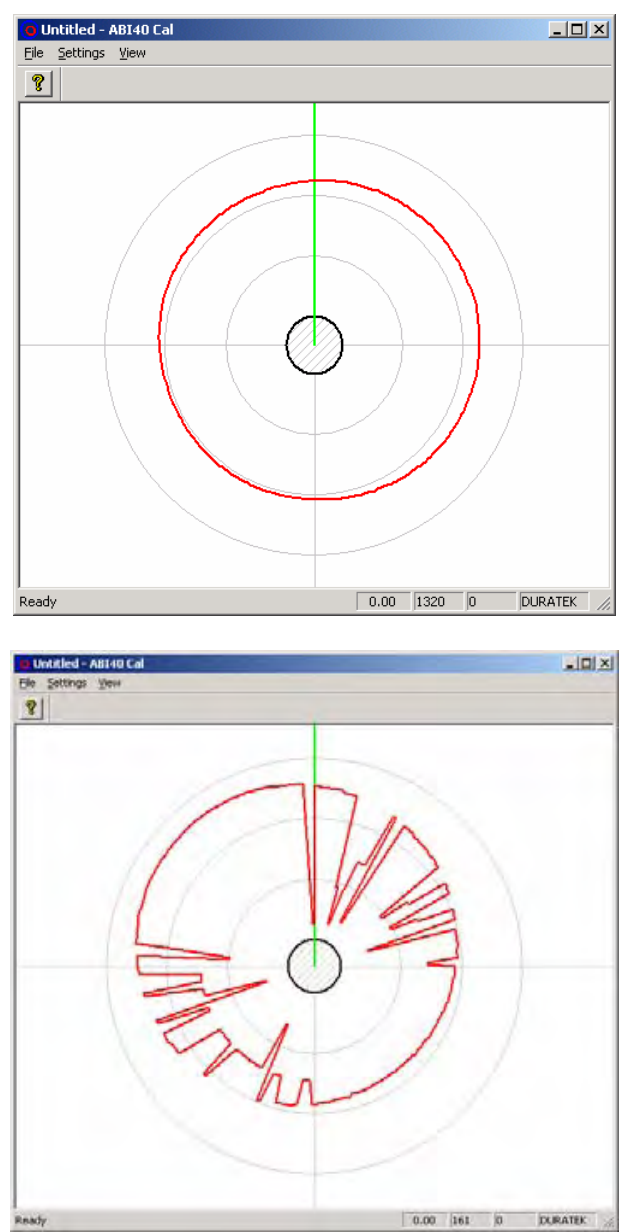
why the best caliper of the Televiewer log survey is from the maximum caliper based on travel time. The computed minimum is obviously incorrect, and the average is significantly influenced by the number of truncated travel time responses in the scan.

The third Televiewer scan is almost completely dominated by travel time response values that are significantly less than the correct response from the borehole wall. These scans frequently occur in the interbed formation layers, and the interbeds are where the washouts occur. Merged logs that compare the maximum Televiewer caliper with the 4-arm mechanical caliper show that the computed caliper from the travel time is often incorrect at hole size greater than $24 \mathrm{~cm}(9.5 \mathrm{in}$.). This scan is from survey file C4996-1360.

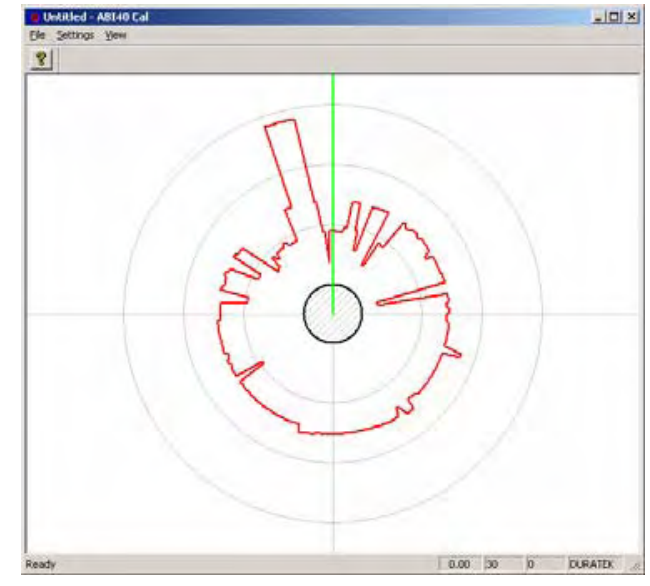

The equipment vendor (Jim LoCoco of Mount Sopris) was contacted about the equipment performance, and we transmitted data samples for his review. The conclusion was that the amplitudes of the acoustic signal were very low, which is the result of the high viscosity of the drilling mud. The amount of polymer in the drilling mud is significantly higher than 
normal and is the source of most of the problems. Since it was not possible during drilling to change out the borehole fluid for the Televiewer surveys, steps were initiated to prepare a mechanical caliper for logging the holes. The 4-arm caliper, discussed later, became available on October 12, 2006.

\subsection{TELEVIEWER SURVEYS}

The Televiewer surveys are summarized in Table 5. The table contains the date of the Televiewer survey, Depth Range (ft), Raw data file name, Centralizer size (in.), Mud Viscosity (sec/qt), and Comment. The table is organized by borehole identification number.

Table 5. Televiewer Survey Logs.

\begin{tabular}{|l|c|c|c|c|c|c|}
\hline $\begin{array}{c}\text { Hole } \\
\text { ID }\end{array}$ & $\begin{array}{c}\text { Televiewer } \\
\text { Survey } \\
\text { Date }\end{array}$ & $\begin{array}{c}\text { Depth } \\
\text { Range } \\
\text { (ft) }\end{array}$ & Raw Data File & Comment & $\begin{array}{c}\text { Centralizer } \\
\text { Size } \\
\text { (in) }\end{array}$ & $\begin{array}{c}\text { Mud } \\
\text { Vis. } \\
\text { sec/qt }\end{array}$ \\
\hline C4993 & $9 / 11 / 2006$ & $349-562$ & C4993-563ft & & 7.5 & \\
\hline C4993 & $9 / 18 / 2006$ & $310-770$ & C4993-772ft & & 7.5 & 28 \\
\hline C4993 & $9 / 23 / 2006$ & $460-957$ & C4993-965ft & & 7.5 & 46 \\
\hline C4993 & $9 / 30 / 2006$ & $725-1182$ & C4993-1185ft & & 6.5 & 40 \\
\hline C4993 & $10 / 1 / 2006$ & $725-1220$ & C4993-1222fft & & 7.5 & 42 \\
\hline C4993 & $10 / 8 / 2006$ & $900-1411$ & C4993-1411ft & & 7.5 & 52 \\
\hline C4993 & $10 / 11 / 2006$ & $370-1411$ & C4993-1411ft & & 7.5 & 42 \\
\hline & & & & & & \\
\hline C4996 & & $346-535$ & No Raw Data File & Colog Televiewer & & \\
\hline C4996 & $8 / 11 / 2006$ & $345-725$ & C4996-745ft & & 7.5 & \\
\hline C4996 & $8 / 16 / 2006$ & $575-940$ & C4996-941ft & Tight hole: $750,818 f t$ & 7.5 & \\
\hline C4996 & $8 / 22 / 2006$ & $700-1196$ & C4996-1196ft & & 7.5 & 36 \\
\hline C4996 & $8 / 28 / 2006$ & $885-1362$ & C4996-1360ft & & 7.5 & 55 \\
\hline C4996 & $9 / 5 / 2006$ & $1000-1466$ & C4997-1460ft & Tight spots: 1130,1166, & & \\
\hline C4996 & $9 / 14 / 2006$ & $350-1465$ & C4996-1466ft & & 7.5 & \\
\hline & & & & & 7.5 & 38 \\
\hline C4997 & $8 / 26 / 2006$ & $355-566$ & C4997-566ft & & & \\
\hline C4997 & $9 / 6 / 2006$ & $380-790$ & C4997-790ft & & 7.5 & 35 \\
\hline C4997 & $9 / 12 / 2006$ & $500-975$ & C4997-976ft & & 7.5 & 39 \\
\hline C4997 & $9 / 24 / 2006$ & $370-1137$ & C4997-1137ft & excess cuttings in mud & 7.5 & 35 \\
\hline C4997 & $10 / 2 / 2006$ & $775-1245$ & C4997-1248ft & & 7.5 & 55 \\
\hline C4997 & $10 / 9 / 2006$ & $1102-1427$ & C4997-1417ft & & 7.5 & 46 \\
\hline C4997 & $10 / 13 / 2006$ & $370-1436$ & C4997-1411ft & & 7.5 & 46 \\
\hline C4997 & $11 / 5 / 2006$ & $798-1280$ & C4997-Nov05-1280ft & & 7.5 & 46 \\
\hline C4997 & $11 / 17 / 2006$ & $845-1432$ & C4997-1430ft & & & \\
\hline & & & & & & \\
\hline
\end{tabular}

A sample Televiewer survey is shown in order to discuss the type of results that were encountered on this project (see Appendix C, "Borehole C4996"). The borehole conditions for the project are believed to be the cause of the difficulties that were encountered. These conditions (discussed above) should be avoided when the Televiewer is deployed on future projects. 
The Televiewer survey results are presented as the standard 3-track plot. The Televiewer survey for C4996, Run 7, Date September 14, 2006, Depth range 350 to $1466 \mathrm{ft}$ is shown as a typical survey for this project.

Track 1. Acoustic travel time of first arrival from ultrasonic pulse is presented with color to show the range of values measured in the travel time sensor responses for each of the 144 pulses per scan revolution (360-degree turn). The color palette grades from low (Blue $=865$ ) to high (Yellow $=2083$ ). The reddish shades represent mid-range values. Unit is $\mu$ s $* 10$ (or $1 / 10^{\text {th }}$ of $\mu \mathrm{s})$

Track 2. Three curves are presented in the center track with the same scale for all, 7 to 13 in: (1) Black Solid curve-4-arm mechanical caliper, the average of the two x-axis and two y-axis arms. (2) Red Dash curve-Maximum caliper computed from Televiewer travel time response. (3) Blue Dot curve-Average caliper computed from Televiewer travel time response.

Track 3. Amplitude of first arrival from the ultrasonic pulse of the sensor scans (corresponds to the travel time). The color palette grades from low (Blue $=1)$ to high $($ Yellow $=70) \mathrm{dB}$. The amplitude response provides a better image of borehole wall conditions.

NOTE 1: Notice that the maximum travel time caliper is generally tracking the 4-arm mechanical caliper through most of the hole. Significant deviations occur when the 4-arm caliper exceeds about $24 \mathrm{~cm}$ (9.5 in.) (which occurs in the depth intervals with the lowest [dark] response values of the travel time and amplitude).

NOTE 2: There is good agreement between the 4-arm mechanical caliper, maximum caliper from travel time, and average caliper from travel time when amplitudes are high (Yellow) and travel times are long (Yellow). This condition can be seen at depths of 767 and $806 \mathrm{ft}$.

NOTE 3: The amplitude and travel time scan results show significant change at the interface between the basalt and interbed formations. The light color representing long travel time and high amplitude is common in basalt intervals, while the dark color representing truncated travel time and low amplitude is common in the interbeds. Notice the dark (low amplitude and truncated travel time) response character between depth intervals of: (695 to $725 \mathrm{ft}$-the Selah Interbed), (814 to $913 \mathrm{ft}$ - the Cold Creek Interbed), and (1,059 to 1,164 ft-the Mabton Interbed).

\subsection{MECHANICAL 4-ARM CALIPER}

The 4-arm mechanical caliper used for this project is owned by DOE. The probe manufacturer is Gearhart Owens International. However, no up-hole electronics control module was available that would record the sonde response data in a digital computer format for integration with the Televiewer, Colog, and other borehole surveys. 
When concerns about suitability arose with the Televiewer survey results, a reliable caliper sensor, the 4-arm caliper, was retrieved and shipped to Mount Sopris where its output signals were integrated into a modern up-hole electronics control module. The 4-arm caliper was returned to Hanford with a tool configuration control file for use with the control box or Matrix control box. The tool control file also contained probe-specific calibration coefficients. The first 4-arm caliper survey was performed on October 12, 2006, in borehole C4993.

Caliper surveys identified depth intervals of tight hole and wash-outs. Multiple caliper logs were run in each borehole. The example below for C4997 shows the type of activities that occurred between logging runs, which could change the caliper measurements. See Section 2.0 for cementing details. Example C4997:

- 10/13/2006 —Caliper survey identified extent of washout of interbeds.

- 10/28/2006 - Cement Bridge Plug installed (1,187-1,240 ft).

- 10/29/2006 —Cement rugose (washout) section of hole (1,094-1,187 ft).

- 10/31/2006 —Cement Bridge Plug installed (990 ft).

- 11/1/2006-Cement rugose section of hole (870-990 ft).

- $11 / 2 / 2006$ - Continued to add cement to fill washout at $860 \mathrm{ft}$ (finally got cement to $843 \mathrm{ft}$ ).

- 11/5/2006 - Caliper survey (drill bit side-tracked original cement-filled hole and began drilling uncemented formation).

\subsection{CHARACTERISTICS}

The operational properties of the 4-arm mechanical caliper are as follows.

- Calibration Check. Calibration of the two x-axis arms and two y-axis arms was checked before and after each borehole log. Two calibration points are used by the electronics control module to convert the caliper arm response values to borehole diameter. Linearity of the sensor response values for the $\mathrm{x}$-axis and $\mathrm{y}$-axis caliper arms is discussed in Section 5.2. The calibration jig has multiple (eight) stops to hold the caliper arms. The stop positions are in inches (from 8 to 24 in.). The 6-in. and 12-in. positions were used for logs during this project.

- Deploy Logging Probe to Bottom of Borehole. After the pre-survey calibration check, the caliper arms are retracted and the tool power is turned off. The probe is deployed to the bottom of the borehole with tool power off and the caliper arm retracted. When the probe reaches the bottom of the hole, the tool power is turned on, and the caliper arms are deployed. After 30 seconds (to deploy the caliper arms) the recording mode is activated, and the $\mathrm{x}$-axis and $\mathrm{y}$-axis caliper responses are recorded in a data file. 
- Logging Speed. The caliper log survey speed is $30 \mathrm{ft} / \mathrm{min}$.

- Post-Caliper Calibration Check. The caliper arms cannot be retracted while tool power is on. Therefore, only the main log survey interval is recorded, from the maximum borehole depth to the surface. No repeat log interval is recorded. When the caliper is removed from the borehole (with caliper arms deployed) a post-survey calibration check is performed. The results are presented in Appendices A through D.

- WellCAD. Processing of the 4-arm caliper survey data is simple: (1) Read survey data values, no calculations are performed, and (2) format presentation plot and output. The presentation plot contents are as follows. Track 1 -Average caliper, Track 2-X-axis caliper, and Track 3-Y-axis caliper.

\subsection{CALIBRATION CHECK}

Calibration of the caliper was performed by Mount Sopris when the tool was integrated with the up-hole control module and the initial calibration coefficients were provided. During installation of the probe onto the Logging truck, the calibration coefficients were checked (see Table 6).

Table 6. Gearhart Owens International 4-Arm Caliper

Calibration Coefficients.

\begin{tabular}{|c|c|c|}
\hline $\begin{array}{c}\text { Calibration Jig } \\
\text { (inch) }\end{array}$ & $\begin{array}{c}\text { X-Axis } \\
\text { Response }\end{array}$ & $\begin{array}{c}\text { Y-Axis } \\
\text { Response }\end{array}$ \\
\hline 6 -in & 352.5 & 303.5 \\
\hline 12 -in & 500 & 431.5 \\
\hline
\end{tabular}

During the initial calibration check, a small degree of non-linearity was noticed. Therefore, the initial calibration coefficients provided by Mount Sopris were used until a later time when further investigation could be performed. During the next caliper log (October 13, 2006), the caliper response was checked with each location of the calibration jig. The data are shown numerically in Table 7 and graphically in Figure 7, (X-axis is black curve, Y-axis is red curve, and average is green curve). The caliper tool was checked for hysteresis during the calibration check by progressively reducing the caliper arms then progressively releasing the caliper arms. No significant hysteresis was identified.

The post-survey calibration check (after the tool has warmed up) is much closer to the actual calibration jig sizes than the pre-survey calibration check. 
DTS-RPT-090, Rev. 0

Table 7. Calibration Check of 4-Arm Caliper.

\begin{tabular}{|c|c|c|c|}
\hline $\begin{array}{c}\text { Jig Size } \\
\text { (in) }\end{array}$ & $\begin{array}{c}\text { X } \\
\text { (in) }\end{array}$ & $\begin{array}{c}\text { Y } \\
\text { (in) }\end{array}$ & $\begin{array}{c}\text { Average } \\
\text { (in) }\end{array}$ \\
\hline 24 & 33.1 & 34 & 33.48 \\
\hline 20 & 24.5 & 25.3 & 24.92 \\
\hline 16 & 18.3 & 18.6 & 18.4 \\
\hline 12 & 13.1 & 13.5 & 13.3 \\
\hline 10 & 10.7 & 11.1 & 10.91 \\
\hline 8 & 8.7 & 9.2 & 8.97 \\
\hline 6 & 6.9 & 7.4 & 7.14 \\
\hline 4 & 5.7 & 6.3 & 6.02 \\
\hline 6 & 7 & 7.3 & 7.15 \\
\hline 8 & 8.7 & 9.1 & 8.88 \\
\hline 10 & 10.7 & 11 & 10.86 \\
\hline 12 & 13 & 13.3 & 13.15 \\
\hline 16 & 18.1 & 18.7 & 18.46 \\
\hline 20 & 24.5 & 25.3 & 24.92 \\
\hline 24 & 32.9 & 33.9 & 33.43 \\
\hline \multicolumn{5}{|r|}{ Post-Survey Calibration } & Check \\
\hline 12 & 12.1 & 12.4 & 12.3 \\
\hline 6 & 6.2 & 6.4 & 6.28 \\
\hline \multicolumn{4}{|r|}{}
\end{tabular}

Figure 7. Calibration Check of 4-Arm Caliper.

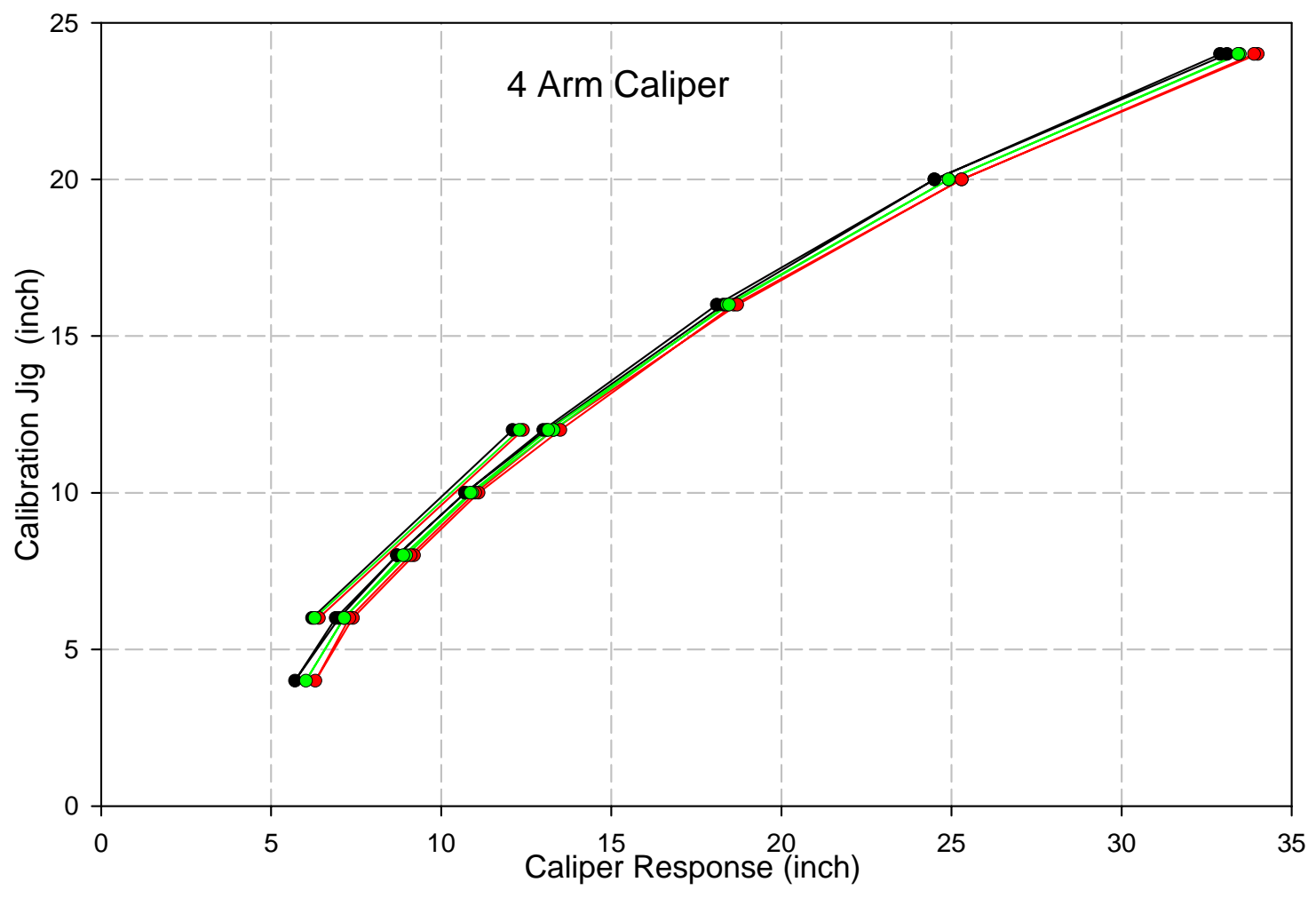


Pre-survey and Post-survey caliper calibration checks were performed for each borehole survey. The 4-arm caliper surveys and calibration checks are presented in Table 8.

Table 8. Caliper Survey Logs and Calibration Check.

\begin{tabular}{|c|c|c|c|c|c|c|c|c|c|c|}
\hline \multirow[t]{2}{*}{$\begin{array}{l}\text { Hole } \\
\text { ID }\end{array}$} & \multirow[t]{2}{*}{$\begin{array}{l}\text { Survey } \\
\text { Date }\end{array}$} & \multirow{2}{*}{$\begin{array}{l}\text { Total } \\
\text { Depth } \\
\text { (ft) }\end{array}$} & \multicolumn{2}{|c|}{$\begin{array}{l}\text { Pre-Survey } \\
\text { 6-in }\end{array}$} & \multicolumn{2}{|c|}{$\begin{array}{c}\text { Pre-Survey } \\
12 \text {-in }\end{array}$} & \multicolumn{2}{|c|}{$\begin{array}{c}\text { Post-Survey } \\
6 \mathrm{In}\end{array}$} & \multicolumn{2}{|c|}{$\begin{array}{c}\text { Post-Survey } \\
12 \text {-in }\end{array}$} \\
\hline & & & & $\mathrm{Y}$ & $\mathrm{X}$ & $\mathrm{Y}$ & $\mathrm{x}$ & $Y$ & $\mathrm{X}$ & $\mathrm{Y}$ \\
\hline C4993 & $10 / 12 / 2006$ & 1411 & $352.5 \mathrm{cnts}$ & $303.5 \mathrm{cnts}$ & $500 \mathrm{cnts}$ & $431.5 \mathrm{cnts}$ & & & & \\
\hline C4993 & $11 / 8 / 2006$ & 1411 & $a v g=7.3$ & & $\operatorname{avg}=13.3$ & & & & & \\
\hline C4993 & $11 / 28 / 2006$ & 1405 & 6.6 & 7.1 & 12.4 & 13.1 & 6.2 & 6.6 & 12.1 & 12.3 \\
\hline C4996 & $10 / 17 / 2006$ & 1457 & 6.6 & 7.3 & 12.6 & 13.0 & 6.2 & 6.6 & 12.3 & 12.4 \\
\hline C4996 & $11 / 2 / 2006$ & 1467 & 6.2 & 7.2 & 12.9 & 13.1 & & & & \\
\hline C4996 & $11 / 8 / 2006$ & 1466 & 6.8 & 7.3 & 12.7 & 13.5 & 6.1 & 6.5 & 12.2 & 12.4 \\
\hline C4997 & $10 / 13 / 2006$ & 1437 & 6.9 & 7.4 & 13.1 & 13.5 & 6.2 & 6.4 & 12.1 & 12.4 \\
\hline C4997 & $11 / 5 / 2006$ & 1124 & 6.3 & 7.1 & 12.5 & 13.0 & & & & \\
\hline C4997 & $11 / 17 / 2006$ & 1435 & 6.9 & 7.6 & 12.8 & 13.6 & 6.3 & 7.6 & 12.8 & 13.6 \\
\hline
\end{tabular}

The caliper logs for each borehole and each survey date are presented in Appendices A through $\mathrm{D}$ as separate logs. Also, a merged caliper of all caliper logs for each of the boreholes is also presented at the beginning of the appendix.

\subsection{COLOG SURVEYS}

The geophysical logging services were provided by Colog, a geophysical logging company based in Colorado. Colog was deployed on five occasions throughout the drilling phase of the project as follows.

- June 22-A gamma-density log was conducted from 200-0 ft bgs in the 13-3/8-in. cased entry hole for C4998.

- July 10-A gamma-density log was conducted from 401.5-200 ft bgs in the 9-5/8-in. cased entry hole for C4998.

- August 2-A Televiewer survey was conducted from 532-401.5 ft bgs in the open hole of borehole C4996.

- September 15-18-Open-hole, gamma-density log was conducted in the C4998 corehole from 1,400-401 ft bgs.

- October 26-Open hole log suites were conducted in boreholes C4993, C4996 and C4997 from total depth to bottom of surface casings. The log suite consisted of gamma-density, caliper, neutron porosity, full wave sonic, and dual induction resistivity. 


\subsection{COREHOLE C4998}

The logging conducted in corehole C4998 on September 15 and 18 was in open hole tubing and in core tubing. The original plan was to conduct the log survey in the core tubing, but due to the stability of the corehole it was decided to conduct open-hole logging. However, due to swelling clays in the interval from 1,174 to $1,215 \mathrm{ft}$, a portion of the corehole was logged within the core tubing. The log plot (see Appendix D for C4998) was prepared by splicing the data collected from the log runs as described below.

- $\quad$ Run 1-Logged within the surface casing from $2 \mathrm{ft}$ then in open hole from 401.5 to 1,174 ft bgs. Encountered obstruction. Conducted cleanout run made with core tubing.

- Run 2-Obstruction encountered at 1,138 ft. No data collected. Conducted cleanout run with core tubing.

- $\quad$ Run 3-Tripped core tubing to 1,195 ft. Logged open hole to 1,217 ft. Encountered obstruction.

- $\quad$ Run 4-Tripped core tubing and washed to 1,400 ft. Pulled tubing back to 1,213 ft. Logged open hole from 1,396 ft to bottom of core tubing at 1,213 ft. Due to problems with caliper arm entering the tubing, no data collected from approximately 1,213 to 1,215 ft. Logged within the core tubing from approximately 1,213 ft to $1,100 \mathrm{ft}$.

\subsection{OPEN-HOLE LOG SUITES (C4993, C4996 AND C4997)}

The open-hole log suites required a log run with each of the four geophysical probes (Compensated Density, Neutron Porosity, Dual Induction Resistivity, and Full Waveform Sonic). The logs were conducted on October 26, 2006, at well completion for the three boreholes (C4993, C4996, and C4997). The log surveys are presented in the Appendix specific for each borehole. The logs are plotted at a depth scale of 1:240 ft.

During the log survey, data values (sensor responses) were recorded at sample increments of $0.1 \mathrm{ft}$ for most surveys, or at increment of $0.2 \mathrm{ft}$ for few surveys. The data values for each $\log$ survey and each borehole are stored as electronic computer files (one file per survey). The electronic files are in WellCAD format. The file names are composed of the borehole number (5 characters) and a single character to designate the logging probe type (i.e., $\mathrm{D}=\mathrm{Density}$, $\mathrm{N}=$ Neutron, $\mathrm{E}=$ Electric, $\mathrm{S}=$ Sonic).

The following topics provide detail information for each of the four logging probe types.

\subsection{COMPENSATED DENSITY LOG}

The density log tool contains a radioactive source (cesium-137) and two gamma detectors (near at $20 \mathrm{~cm}$ and far at $35 \mathrm{~cm}$ ). The source and detectors are heavily shielded to prevent direct 
detection of gamma rays from the source. The principle is to focus gamma rays from the source into the formation, where they collide with electrons in the formation (Compton-scattering) and are reflected back to one of the CsI detectors. The response of the Density tool is determined essentially by the electron density (number of electrons per cubic centimeter) of the formation. Electron density is related to the true bulk density (in grams/cc) of the formation rock matrix material and formation porosity.

In order to minimize the influence from the borehole fluid (drilling mud), the source and detectors are pushed against the wall of the borehole by means of an eccentering arm (caliper). The force exerted is substantial, allowing the probe to cut through most mud cakes. Any mud remaining between the tool and the formation is "seen" as part of the formation and must be accounted for. The two-detector configuration is used to substantially reduce the influence of borehole rugosity and mud cake.

When borehole conditions are ideal, both the long and short spaced density measurements are reading the formation bulk density. Mud cake, rugose hole size and washouts are the main reason for invalid measurements. Since density measurements are also needed when borehole conditions are a problem, the Compensated Density log is used. The Compensated Density log response is derived from the long spaced and short spaced density detector responses. During the development period of the Compensated Density tool (1950s) a spine-and-rib correction chart was developed from testing measurements that showed how the detector response changes with varying thicknesses of drilling mud (and hole size rugosity). The spine-and-rib algorithm is derived during the development phase of each manufacturer's tool and is programmed into the tool processing software. Laboratory analysis of core samples is generally used to correlate density probe measurements with physical properties.

The logging speed is $15 \mathrm{ft} /$ minute for the density log. The results file has five data curves (Natural Gamma, Caliper, Long Spaced Density, Short Spaced Density, and Compensated Density).

The borehole probe (sonde) has two sections. The top section, designated as RAB contains a communications modem and a natural gamma detector (1 in. x 2-in. NaI crystal). The serial number of the RAB section is 2020. The bottom section, designated as HPF, serial number 1516, contains the density detector, diameter $48 \mathrm{~mm}$ (1.9 in.), length $1.89 \mathrm{~m}$ (74.4 in.), weight $21.5 \mathrm{~kg}(47.3 \mathrm{lb})$.

1. The natural gamma detector is scaled $0-100$ cps and the count rate does not change when the tool comes out of the borehole fluid, which confirms that a side-wall logging configuration is better for measuring gamma activity of the formation.

2. The density tool is a pad-type device that must maintain contact with the formation wall. The plot scale is 1 to $4 \mathrm{~g} / \mathrm{cc}$.

3. The caliper records the amount that the pressure arm must be extended to press the logging probe against the borehole wall. A 1-arm caliper will generally locate the largest axis of a borehole. 


\subsection{NEUTRON POROSITY LOG}

Neutron logs respond primarily to the amount of hydrogen present in the formation (i.e., water, $\mathrm{H}_{2} \mathrm{O}$ ). High-energy (fast) neutrons from an americium-beryllium (AmBe) source collide with nuclei of the formation materials as elastic "billiard-ball" collisions. With each collision a neutron loses some of its energy. The greatest energy loss occurs in collisions with the hydrogen nucleus. Collisions with heavy nuclei do not slow the neutron down very much. Thus, the slowing-down of neutrons depends largely on the amount of hydrogen in the formation.

Within a few microseconds the neutrons have been slowed down by successive collisions to thermal velocities, corresponding to energies of around 0.025 electron volts. They then diffuse randomly, without losing any more energy until they are captured by the nuclei of atoms such as hydrogen, silicon, or a thermal neutron detector (HE-3).

When the hydrogen concentration of the material surrounding the neutron source is large, most of the neutrons are slowed down and captured within a short distance of the source. On the contrary, if the hydrogen concentrations are low (i.e., low porosity), the neutrons travel further from the source before being captured. Accordingly, the count rate at the detector increases for decreased hydrogen concentration, and vice versa. This source-detector spacing is $20 \mathrm{~cm}$.

The logging speed is $20 \mathrm{ft} / \mathrm{min}$. The results file has four data curves (Natural Gamma, Caliper from Density, Neutron, and Density Porosity). The neutron tool has two sections. The top section is an RAB component (serial number 2171) and contains a communications modem and a natural gamma detector. The bottom section is designated as OPF, serial number 1387, and contains the neutron detector. The probe is free-floating in the borehole (i.e., no centralization).

1. The natural gamma detector response is different from the natural gamma of the density probe. The count-rate response increases when the probe extends above the borehole fluid. Since the neutron probe is free-floating in the borehole, the natural gamma measurements are significantly influenced by the location of the probe within the borehole (i.e., centered or side-walled). The plot scale is 0-100 cps.

2. The caliper is duplicated from the Compensated Density Log (there is no caliper on the neutron probe).

3. The neutron detector indicated formation porosity when the pores of the formation are water saturated.

4. The density porosity is computed from the Compensated Density Log, and the assumed matrix density (3.15 g/cc) is documented in the plot scale. The porosity calculation is a linear relationship between the formation matrix density, the measured bulk density, and formation fluid density (i.e., $1 \mathrm{~g} / \mathrm{cc}$ ). 


\subsection{DUAL INDUCTION LOG}

Induction logging devices are focused in order to minimize the influence of the borehole and surrounding formations on the measurements. The logging tool has multiple transmitter and receiver coils. However, the measurement principle can be understood by considering a sonde with only one transmitter coil and one receiver coil.

High-frequency alternating current of constant intensity is sent through the transmitter coil. The alternating magnetic field induces secondary currents in the formation. These currents flow in circular ground-loop paths coaxial with the transmitter coil. The ground-loop currents, in turn, create magnetic fields, which induce signals in the receiver coil. The receiver signals are essentially proportional to the conductivity of the formation. Any signal produced by direct coupling of transmitter and receiver coils is balanced out by the measuring circuits.

The logging speed is $40 \mathrm{ft} / \mathrm{minute}$. The results file has four curves (Natural Gamma from Density, Caliper from Density, Medium EM Conductivity, and Deep EM Conductivity). The probe sensor curve is EM (Electro-Magnetic) and the units are millisiemens per meter, which is the same as milli-MHOs per meter. The serial number of the DIL probe is 2599 . The probe is free-floating in the borehole.

1. The natural gamma curve is duplicated from the Compensated Density Log.

2. The caliper is duplicated from the Compensated Density Log.

3. Medium and deep EM conductivity are only valid in open-hole conditions. The reading inside the steel casing does not represent changes in formation properties.

\subsection{FULL WAVEFORM SONIC LOG}

The Full Waveform Sonic log produces one omni-directional click each second. The probe has two receivers ( $3 \mathrm{ft}$ and $4 \mathrm{ft}$ from the transmitter). They record the full waveform for 1,024 milliseconds at an interval of one microsecond. The recording begins at a delay of 56 milliseconds after the transmitted pulse.

Borehole fluid is required for the tool to function properly. The first arrival (shortest travel time) of the acoustic pulse is through the shortest distance to the borehole wall, then through the formation rock matrix to the receiver. 
The logging speed is $12 \mathrm{ft} / \mathrm{min}$. The results file has three data curves (Caliper, Near Receiver, and Far Receiver). The sonic probe identification is CLP and its serial number is 1075. The probe is free-floating in the borehole.

1. The caliper is duplicated from the Compensated Density Log.

2. The near and far receivers show changes in the acoustic properties of the formation matrix and are also affected by hole size conditions (washed-out zones).

\subsection{MERGED LOGS}

A merged log was constructed from the key sensor(s) of each logging probe and assembled into a single presentation plot for each borehole. The merged log has four tracks:

- Track 1: Gamma (Density), Caliper (Density), Gamma (Neutron)

- Track 2: Compensated Density, Neutron

- Track 3: Deep Electro-magnetic (EM) Conductivity

- Track 4: Near Receiver (Full Waveform Sonic).

\subsection{WELNAV EARTH'S MAGNETIC FIELD SURVEY}

After borehole completion, Wellbore Navigation, Inc., of Tustin, California, surveyed the local earth's magnetic field within the basalt flows penetrated. The purpose of the surveys was to acquire magnetic north orientation specific to each basalt flow. The data is used to support the oriented velocity logging method.

The magnetometer tool used has three flux gates that acquire data from the $\mathrm{X}, \mathrm{Y}$, and $\mathrm{Z}$ axes. This data is reported as horizontal field strength and is raw $(\mathrm{X}, \mathrm{Y}, \mathrm{Z})$ readings. This data is then computed to provide the following results.

- $\quad$ Earth’s magnetic declination (degrees).

- $\quad$ Earth’s magnetic dip (degrees).

NOTE: The magnetic field dip is 0 degrees at the equator and 90 degrees at the North Pole.

- Earth’s magnetic field intensity (Oerstands).

Measurements were collected in a Move-Stop-Acquire logging mode. The probe had one centralizer at its top to dampen tool movement. The bottom of the probe had electronics for 
magnetic survey. To prevent metal interference with the magnetic survey, a centralizer was not installed at the bottom. Although the probe was equipped with a gyroscope for deviation measurements, no measurements were acquired.

\subsection{REFERENCES}

PNNL-16303, 2006, Borehole Summary Report for Core Hole C4998-Waste Treatment Plant Seismic Boreholes Project, Rev. 0, Pacific Northwest National Laboratory, Richland, Washington.

PNNL-15848, 2006, Sampling and Analysis Plan Waste Treatment Plant Seismic Boreholes Project, Rev. 2, ICN 1, 2, 3, Pacific Northwest National Laboratory, Richland, Washington.

PNNL-16343, 2007, Borehole Summary Report for Waste Treatment Plant Seismic Borehole C4993, Rev. 0, Pacific Northwest National Laboratory, Richland, Washington.

PNNL-16407, 2007, Geology of the Waste Treatment Plant Seismic Boreholes, Rev. 0, Pacific Northwest National Laboratory, Richland, Washington.

WMP-31815, 2007, Borehole Summary Report for C4997 Rotary Drilling, WTP Seismic Boreholes Project, Rev. 0 Reissue, Environmental Quality Management, Richland, Washington.

WMP-32076, 2007, Borehole Summary Report for Waste Treatment Plant Seismic Borehole C4996, Rev. 0, Freestone Environmental Services, Inc., Richland, Washington.

WMP-32119, 2007, Entry Boreholes Summary Report for the Waste Treatment Plant Seismic Boreholes Project, Rev. 0, Reissue, Gram, Inc., Richland, Washington. 
DTS-RPT-090, Rev. 0

APPENDIX A

BOREHOLE C4993 
DTS-RPT-090, Rev. 0

This page intentionally left blank. 
DTS-RPT-090, Rev. 0

\section{A1.0 BOREHOLE C4993}

\section{A1.1 ENERGYSOLUTIONS AND PACIFIC NORTHWEST GEOPHYSICS GYROSCOPIC LOGS}

Hole: $\mathbf{C 4 9 9 3}$

$\begin{gathered}\text { Survey } \\ \text { Date }\end{gathered}$
10/8/2006
10/6/2006
$9 / 30 / 2006$
$9 / 28 / 2006$
$9 / 26 / 2006$
$9 / 22 / 2006$
$9 / 21 / 2006$
$9 / 17 / 2006$
$9 / 15 / 2006$
$9 / 11 / 2006$
Casing
9/4/2006
$9 / 1 / 2006$
8/30/2006
8/29/2006
8/25/2006
8/23/2006
8/22/2006

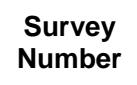

$17^{*}$

$16^{*}$

$15^{*}$

$14^{*}$

$13^{*}$

$12^{*}$

$11^{*}$

$10^{*}$

9*

$8^{*}$

Cable-Tool

7

6

5

4

$3 *$

2

1 *

Maximum
Depth
(feet)

1400

1320

1218

1136

1036

935

815

716

635

536

368

343

311

285

204

146

82
Inclination
From Vertical
(deg)

1.7

1.1

1.3

1.2

1.7

0.6

1.8

0.9

0.5

1

0.8

1.4

1.4

1.7

1.6

1.6

1.1

$\begin{gathered}\text { Closure } \\ \text { Distance } \\ \text { (feet) }\end{gathered}$

25
23
19
20
16
13
12
10
9
10

9
8
7.1
8.3
5.1
3.7
1.2

* = Gyro data includes Out-Run survey check-stations. 
DTS-RPT-090, Rev. 0

\section{Hole: C4993}

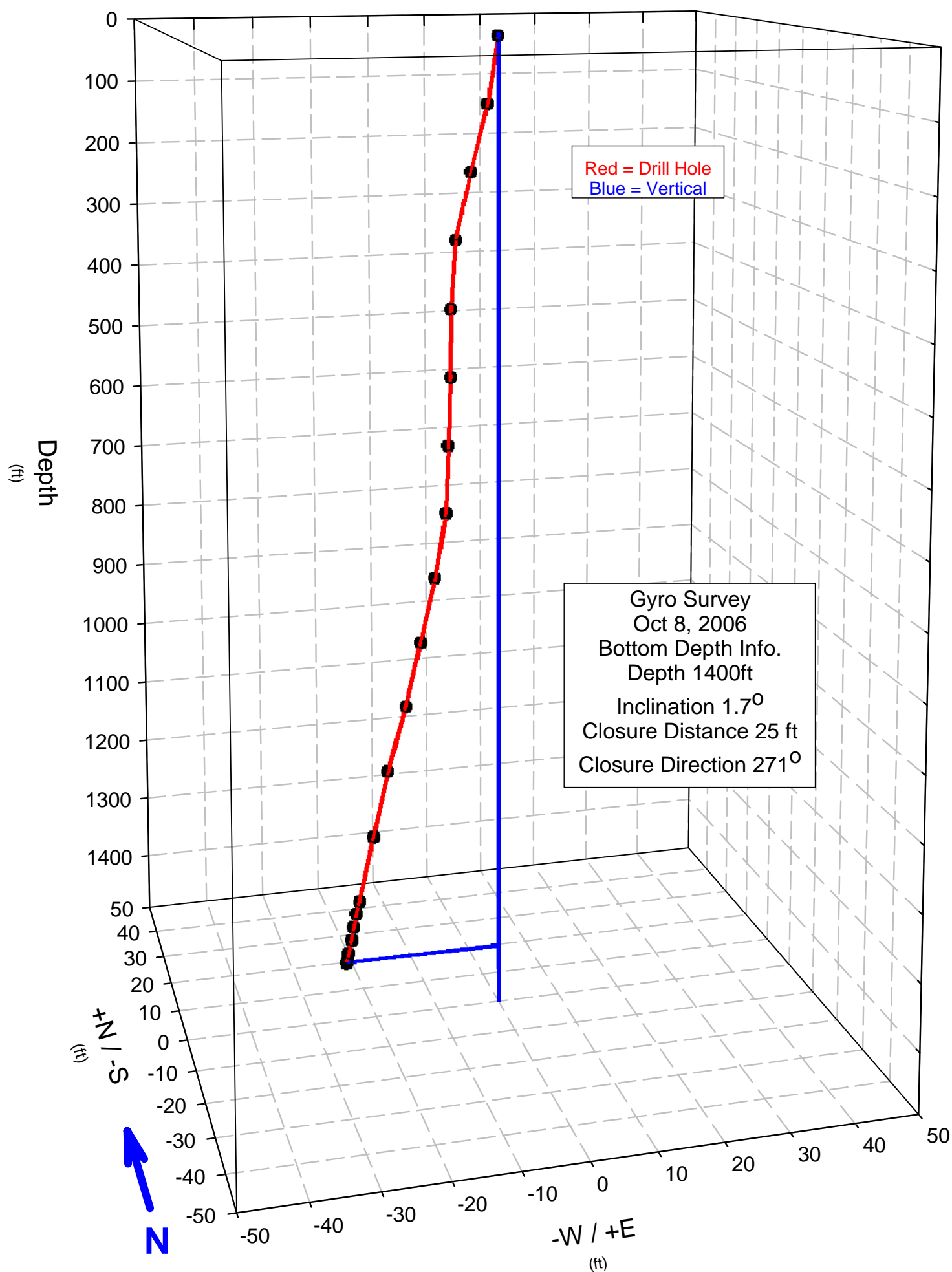


DTS-RPT-090, Rev. 0

Hole: C4993 Survey Date: 10/8/2006

\begin{tabular}{|c|c|c|c|c|c|c|c|}
\hline Measure & TrueVer & $\begin{array}{c}\text { Inclinatio } \\
n \\
\text { from }\end{array}$ & Closure & Closure & $\begin{array}{l}\text { Rectangul } \\
\text { ar }\end{array}$ & $\begin{array}{l}\text { Rectangul } \\
\text { ar }\end{array}$ & \\
\hline$d$ & t. & from & Directio & Distanc & Coordinat & Coordinat & Dog-Leg \\
\hline $\begin{array}{l}\text { Depth } \\
\text { (feet) }\end{array}$ & $\begin{array}{l}\text { Depth } \\
\text { (feet) }\end{array}$ & $\begin{array}{l}\text { Vert. } \\
\text { (deg) }\end{array}$ & $\begin{array}{c}n \\
\text { (deg) }\end{array}$ & $\begin{array}{c}\mathrm{e} \\
\text { (feet) }\end{array}$ & $\begin{array}{c}\text { es } \\
+\mathrm{N} / \mathrm{S}\end{array}$ & $\begin{array}{c}\text { es } \\
+E /-W\end{array}$ & $\begin{array}{l}\text { Severity } \\
0 / 100-f t\end{array}$ \\
\hline 5 & 5 & 0.68 & 345.7 & 0.06 & 0.06 & -0.01 & 5.3 \\
\hline 105 & 104.98 & 1.62 & 279.04 & 1.67 & 0.26 & -1.64 & 1.6 \\
\hline 205 & 204.94 & 1.58 & 269.14 & 4.4 & -0.07 & -4.4 & 0.4 \\
\hline 305 & 304.91 & 1.35 & 266.33 & 6.91 & -0.44 & -6.9 & 0.5 \\
\hline 405 & 404.9 & 0.75 & 259.45 & 8.07 & -1.48 & -7.94 & 1.4 \\
\hline 505 & 504.89 & 0.61 & 253.72 & 8.65 & -2.42 & -8.3 & 0.7 \\
\hline 605 & 604.89 & 0.78 & 249.16 & 9.52 & -3.39 & -8.89 & 0.6 \\
\hline 705 & 704.88 & 0.44 & 247.43 & 10.17 & -3.9 & -9.4 & 1 \\
\hline 805 & 804.87 & 1.56 & 253.79 & 11.44 & -3.19 & -10.99 & 1.1 \\
\hline 905 & 904.84 & 1.12 & 260.88 & 13.2 & -2.09 & -13.04 & 0.5 \\
\hline 1005 & 1004.81 & 1.67 & 265.98 & 15.27 & -1.07 & -15.23 & 0.6 \\
\hline 1105 & 1104.77 & 1.61 & 268.8 & 18 & -0.38 & -18 & 0.3 \\
\hline 1205 & 1204.74 & 1.1 & 269.36 & 20.34 & -0.23 & -20.34 & 0.6 \\
\hline 1305 & 1304.71 & 1.55 & 270.43 & 22.57 & 0.17 & -22.57 & 0.7 \\
\hline 1325 & 1324.71 & 1.13 & 270.77 & 23.02 & 0.31 & -23.02 & 2.2 \\
\hline 1345 & 1344.7 & 1.19 & 270.87 & 23.42 & 0.36 & -23.42 & 1.4 \\
\hline 1365 & 1364.7 & 1.29 & 270.77 & 23.85 & 0.32 & -23.85 & 1.1 \\
\hline 1385 & 1384.69 & 1.46 & 270.58 & 24.33 & 0.24 & -24.32 & 0.9 \\
\hline 1395 & 1394.69 & 1.66 & 270.57 & 24.6 & 0.24 & -24.59 & 4.7 \\
\hline 1399 & 1398.69 & 1.72 & 270.56 & 24.71 & 0.24 & -24.71 & 10.9 \\
\hline 1399.5 & 1399.19 & 1.69 & 270.56 & 24.73 & 0.24 & -24.73 & 6.1 \\
\hline 1400 & 1399.69 & 1.71 & 270.55 & 24.74 & 0.24 & -24.74 & 4 \\
\hline
\end{tabular}


DTS-RPT-090, Rev. 0

Hole: C4993

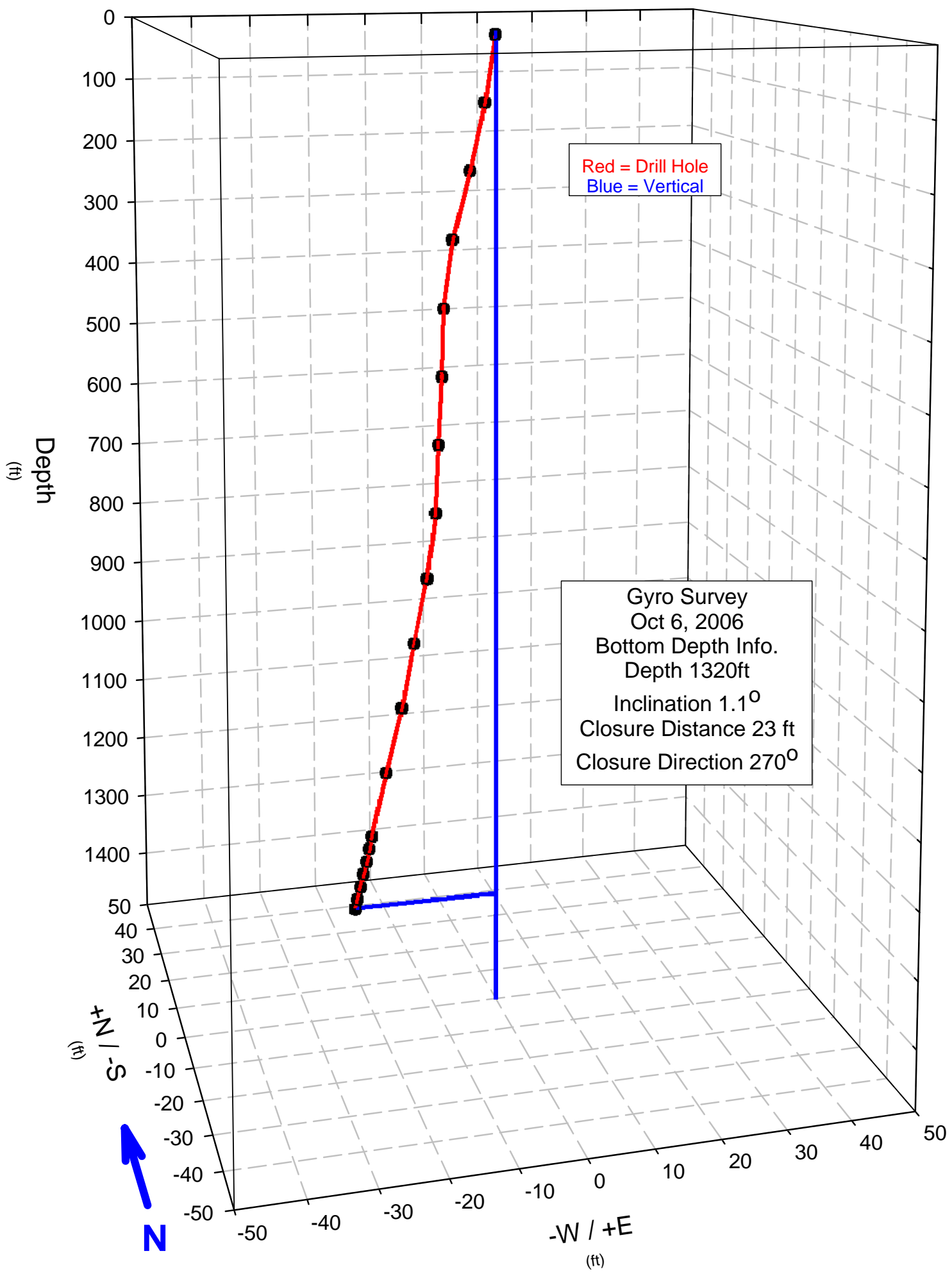


DTS-RPT-090, Rev. 0

Hole: C4993 Survey Date: 10/6/2006

\begin{tabular}{|c|c|c|c|c|c|c|c|}
\hline Measure & TrueVer & $\begin{array}{c}\text { Inclinatio } \\
n \\
\text { from }\end{array}$ & Closure & $\begin{array}{l}\text { Closure } \\
\text { Distanc }\end{array}$ & $\begin{array}{c}\text { Rectangul } \\
\text { ar } \\
\text { Coordinat }\end{array}$ & $\begin{array}{c}\text { Rectangul } \\
\text { ar } \\
\text { Coordinat }\end{array}$ & \\
\hline $\begin{array}{c}\text { d } \\
\text { Depth } \\
\text { (feet) }\end{array}$ & $\begin{array}{c}\text { t. } \\
\text { Depth } \\
\text { (feet) }\end{array}$ & $\begin{array}{l}\text { from } \\
\text { Vert. } \\
\text { (dea) }\end{array}$ & $\begin{array}{c}\text { Directio } \\
n \\
(\text { dea })\end{array}$ & $\begin{array}{c}\text { Distanc } \\
\text { e } \\
\text { (feet) }\end{array}$ & $\begin{array}{c}\text { Coordinat } \\
\text { es } \\
+\mathrm{N} / \mathrm{S}\end{array}$ & $\begin{array}{c}\text { Coordinat } \\
\text { es } \\
+E /-W\end{array}$ & $\begin{array}{l}\text { Dog-Leg } \\
\text { Severity } \\
0 / 100-f t\end{array}$ \\
\hline 5 & 5 & 0.58 & 305.26 & 0.06 & 0.03 & -0.05 & 9 \\
\hline 105 & 104.99 & 1.28 & 279.38 & 1.68 & 0.27 & -1.65 & 0.7 \\
\hline 205 & 204.95 & 1.69 & 266.61 & 4.11 & -0.24 & -4.1 & 0.9 \\
\hline 305 & 304.9 & 1.92 & 261.63 & 7.18 & -1.05 & -7.11 & 0.6 \\
\hline 405 & 404.88 & 0.88 & 257.34 & 9.05 & -1.98 & -8.83 & 2 \\
\hline 505 & 504.87 & 0.75 & 251.37 & 9.91 & -3.16 & -9.39 & 0.7 \\
\hline 605 & 604.86 & 0.78 & 247.87 & 11.05 & -4.16 & -10.24 & 0.3 \\
\hline 705 & 704.86 & 0.31 & 246.09 & 11.87 & -4.81 & -10.85 & 0.6 \\
\hline 805 & 804.85 & 1.36 & 250.72 & 12.83 & -4.24 & -12.11 & 1.2 \\
\hline 905 & 904.82 & 1.14 & 257.78 & 14.24 & -3.01 & -13.92 & 0.2 \\
\hline 1005 & 1004.8 & 1.15 & 262 & 15.85 & -2.21 & -15.7 & 0.5 \\
\hline 1105 & 1104.77 & 1.7 & 264.95 & 18.18 & -1.6 & -18.11 & 0.5 \\
\hline 1205 & 1204.75 & 0.97 & 267.53 & 20.34 & -0.88 & -20.32 & 0.7 \\
\hline 1225 & 1224.74 & 1.21 & 268.01 & 20.68 & -0.72 & -20.67 & 1.2 \\
\hline 1245 & 1244.74 & 1.34 & 268.56 & 21.08 & -0.53 & -21.07 & 0.6 \\
\hline 1265 & 1264.73 & 1.6 & 269.1 & 21.55 & -0.34 & -21.55 & 1.6 \\
\hline 1285 & 1284.72 & 1.45 & 269.57 & 22.05 & -0.17 & -22.05 & 0.8 \\
\hline 1305 & 1304.72 & 1.51 & 270.03 & 22.53 & 0.01 & -22.53 & 0.3 \\
\hline 1320 & 1319.71 & 1.04 & 270.24 & 22.85 & 0.09 & -22.85 & 3.7 \\
\hline
\end{tabular}


DTS-RPT-090, Rev. 0

\section{Hole: C4993}

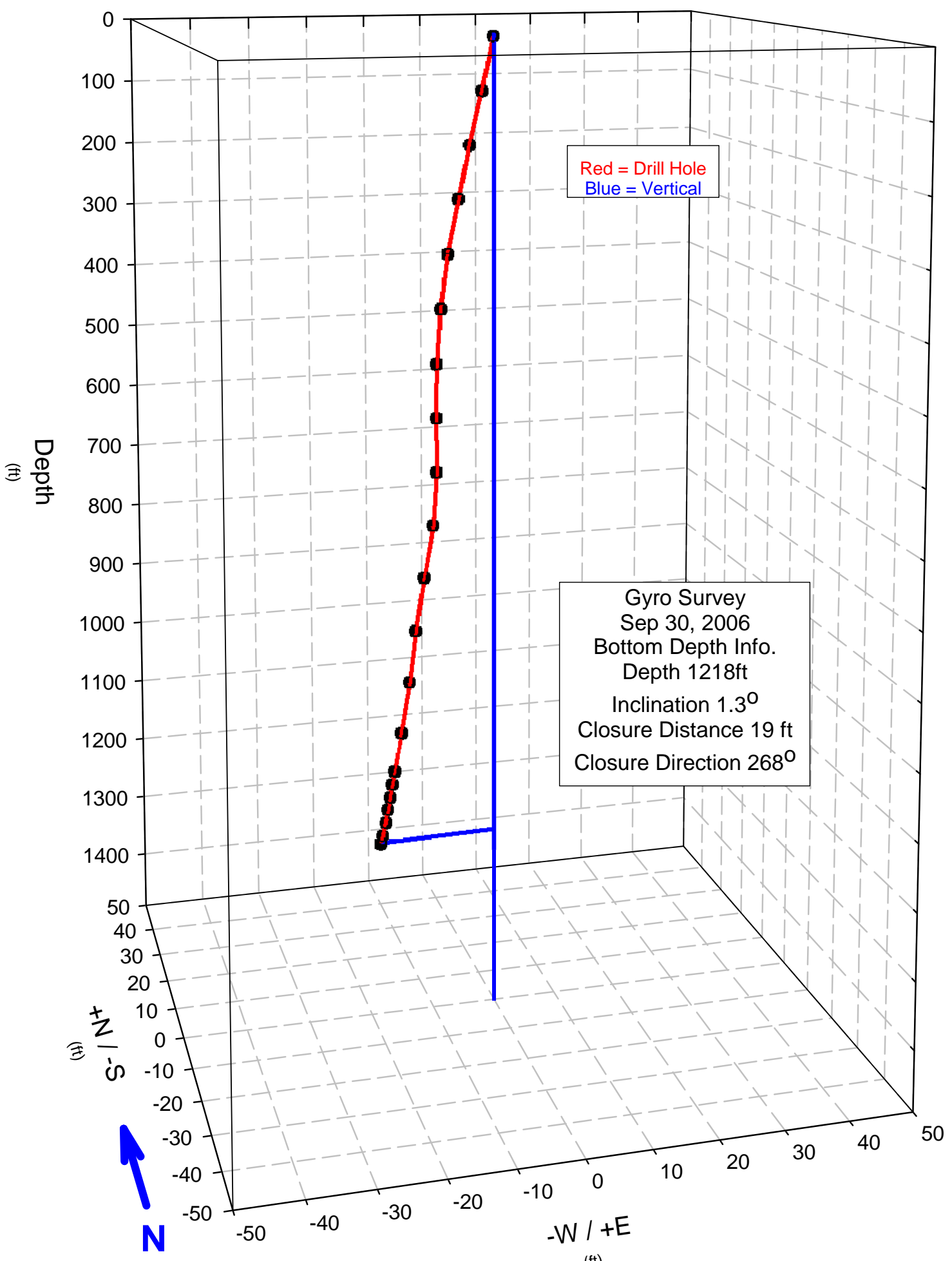

(ft) 
DTS-RPT-090, Rev. 0

Hole: C4993 Survey Date: 9/30/2006

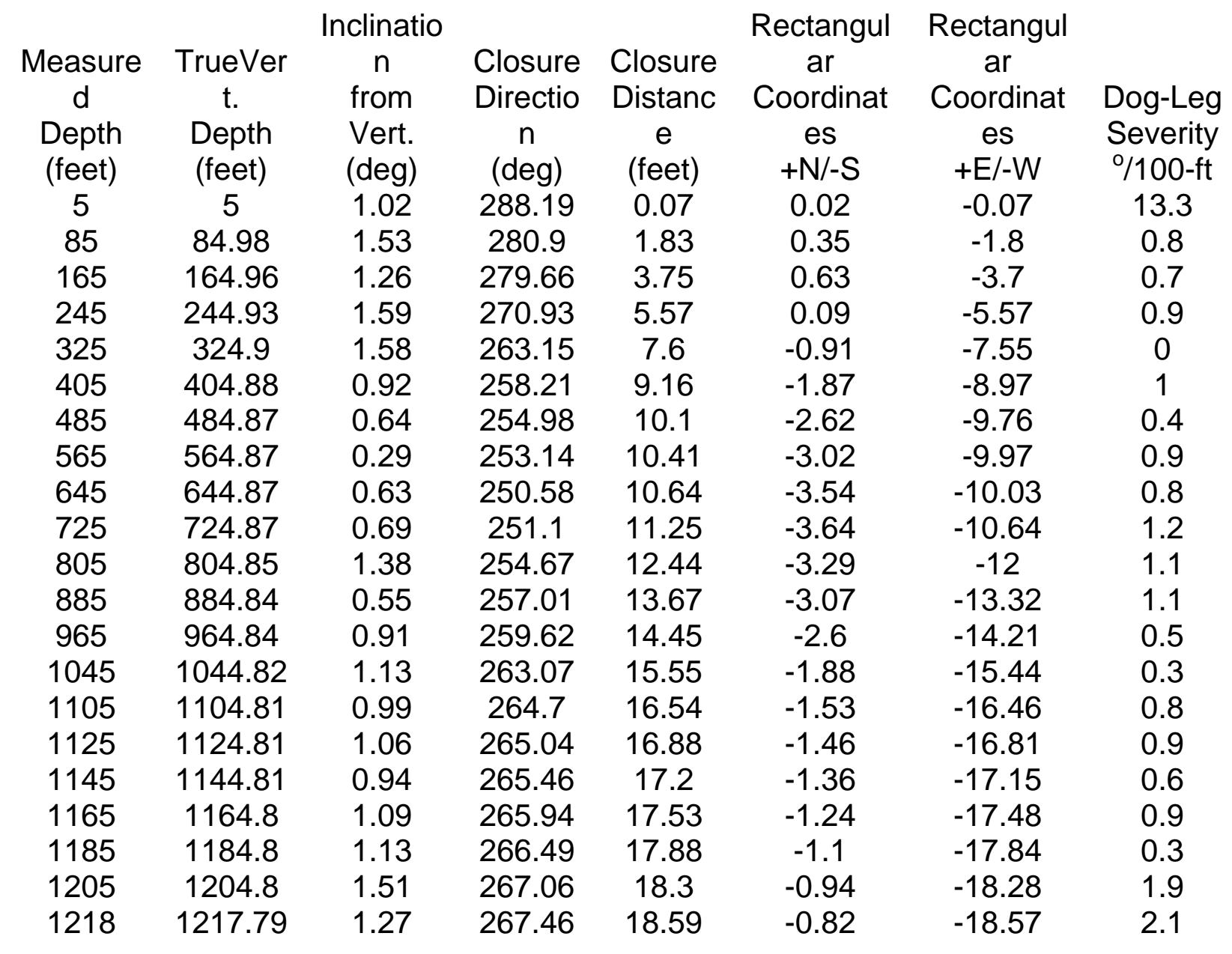


DTS-RPT-090, Rev. 0

Hole: C4993

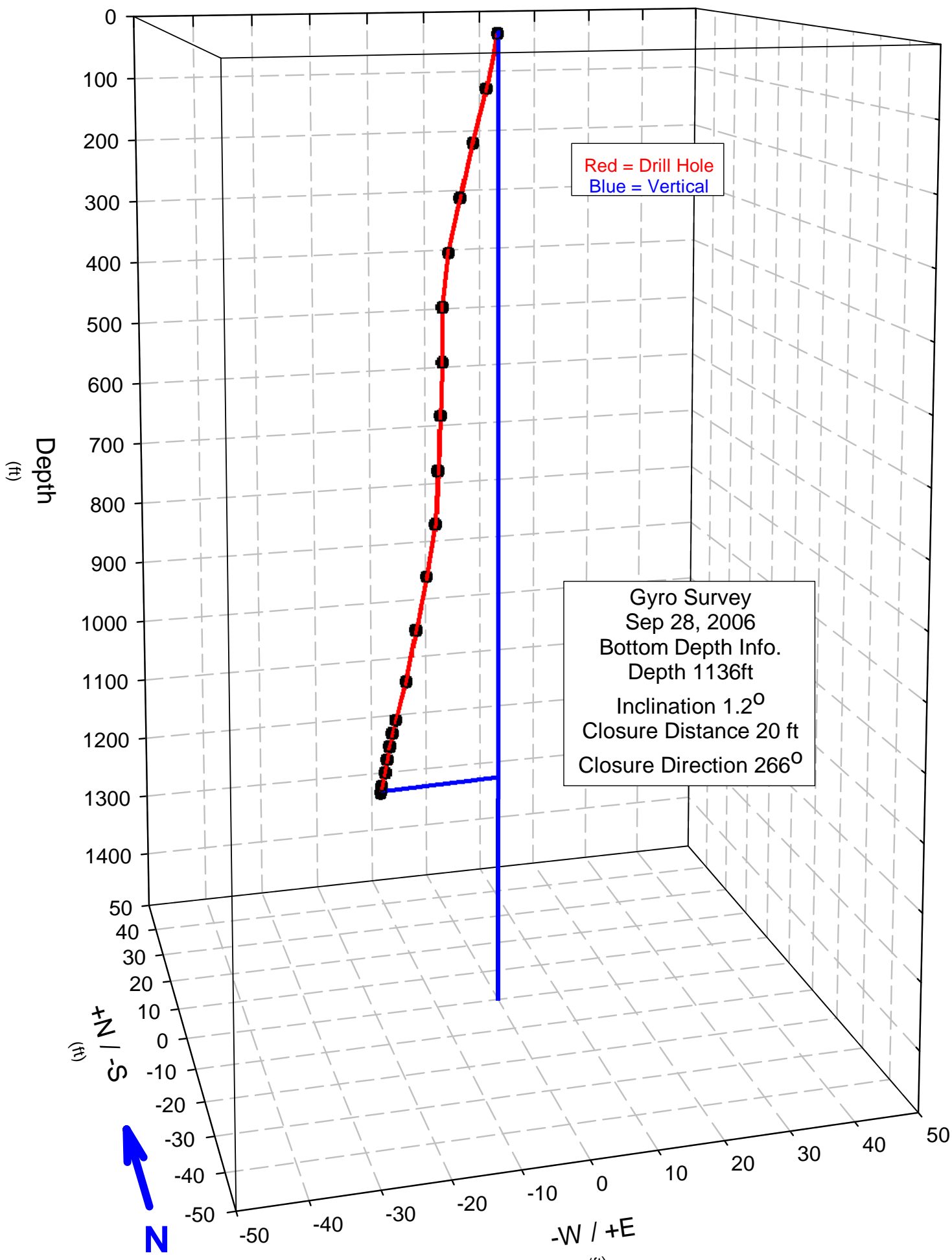

(ft) 
DTS-RPT-090, Rev. 0

Hole: C4993 Survey Date: 9/28/2006

\begin{tabular}{|c|c|c|c|c|c|c|c|}
\hline $\begin{array}{c}\text { Measure } \\
\mathrm{d}\end{array}$ & $\begin{array}{c}\text { TrueVer } \\
\text { t. }\end{array}$ & $\begin{array}{c}\text { Inclinatio } \\
n \\
\text { from }\end{array}$ & $\begin{array}{l}\text { Closure } \\
\text { Directio }\end{array}$ & $\begin{array}{l}\text { Closure } \\
\text { Distanc }\end{array}$ & $\begin{array}{c}\text { Rectangul } \\
\text { ar } \\
\text { Coordinat }\end{array}$ & $\begin{array}{c}\text { Rectangul } \\
\text { ar } \\
\text { Coordinat }\end{array}$ & Dog-Leg \\
\hline Depth & Depth & Vert. & $\mathrm{n}$ & & es & es & Severity \\
\hline (feet) & (feet) & (deg) & (deg) & (feet) & $+\mathrm{N} /-\mathrm{S}$ & $+E /-W$ & $\% / 100-\mathrm{ft}$ \\
\hline 5 & 5 & 1.23 & 310.4 & 0.09 & 0.06 & -0.07 & 13.5 \\
\hline 85 & 84.98 & 1.32 & 282.16 & 1.8 & 0.38 & -1.75 & 0.9 \\
\hline 165 & 164.95 & 1.85 & 271.77 & 3.95 & 0.12 & -3.95 & 0.7 \\
\hline 245 & 244.92 & 1.35 & 266.42 & 6.13 & -0.38 & -6.12 & 0.7 \\
\hline 325 & 324.89 & 1.61 & 263.69 & 8.16 & -0.9 & -8.11 & 0.5 \\
\hline 405 & 404.88 & 0.83 & 259.85 & 9.44 & -1.66 & -9.29 & 2 \\
\hline 485 & 484.87 & 0.21 & 256.03 & 9.75 & -2.35 & -9.46 & 0.8 \\
\hline 565 & 564.87 & 0.61 & 254.8 & 10.27 & -2.69 & -9.91 & 0.5 \\
\hline 645 & 644.87 & 0.62 & 252.33 & 10.95 & -3.32 & -10.43 & 0.5 \\
\hline 725 & 724.86 & 0.49 & 251.76 & 11.47 & -3.59 & -10.9 & 1 \\
\hline 805 & 804.85 & 1.52 & 255.23 & 12.66 & -3.23 & -12.24 & 1.3 \\
\hline 885 & 884.83 & 0.84 & 257.89 & 14.18 & -2.98 & -13.86 & 0.9 \\
\hline 965 & 964.82 & 1.54 & 261.33 & 15.52 & -2.34 & -15.34 & 1.2 \\
\hline 1025 & 1024.79 & 1.71 & 264.06 & 16.98 & -1.76 & -16.89 & 1.2 \\
\hline 1045 & 1044.79 & 1.44 & 264.39 & 17.52 & -1.71 & -17.44 & 1.7 \\
\hline 1065 & 1064.78 & 1.12 & 264.7 & 17.95 & -1.66 & -17.88 & 2.3 \\
\hline 1085 & 1084.78 & 1.09 & 265.09 & 18.32 & -1.57 & -18.25 & 0.3 \\
\hline 1105 & 1104.77 & 0.95 & 265.42 & 18.66 & -1.49 & -18.6 & 0.7 \\
\hline 1125 & 1124.77 & 1.63 & 265.8 & 19.09 & -1.4 & -19.04 & 3.4 \\
\hline 1136 & 1135.77 & 1.2 & 266.04 & 19.35 & -1.34 & -19.3 & 4 \\
\hline
\end{tabular}


DTS-RPT-090, Rev. 0

Hole: C4993

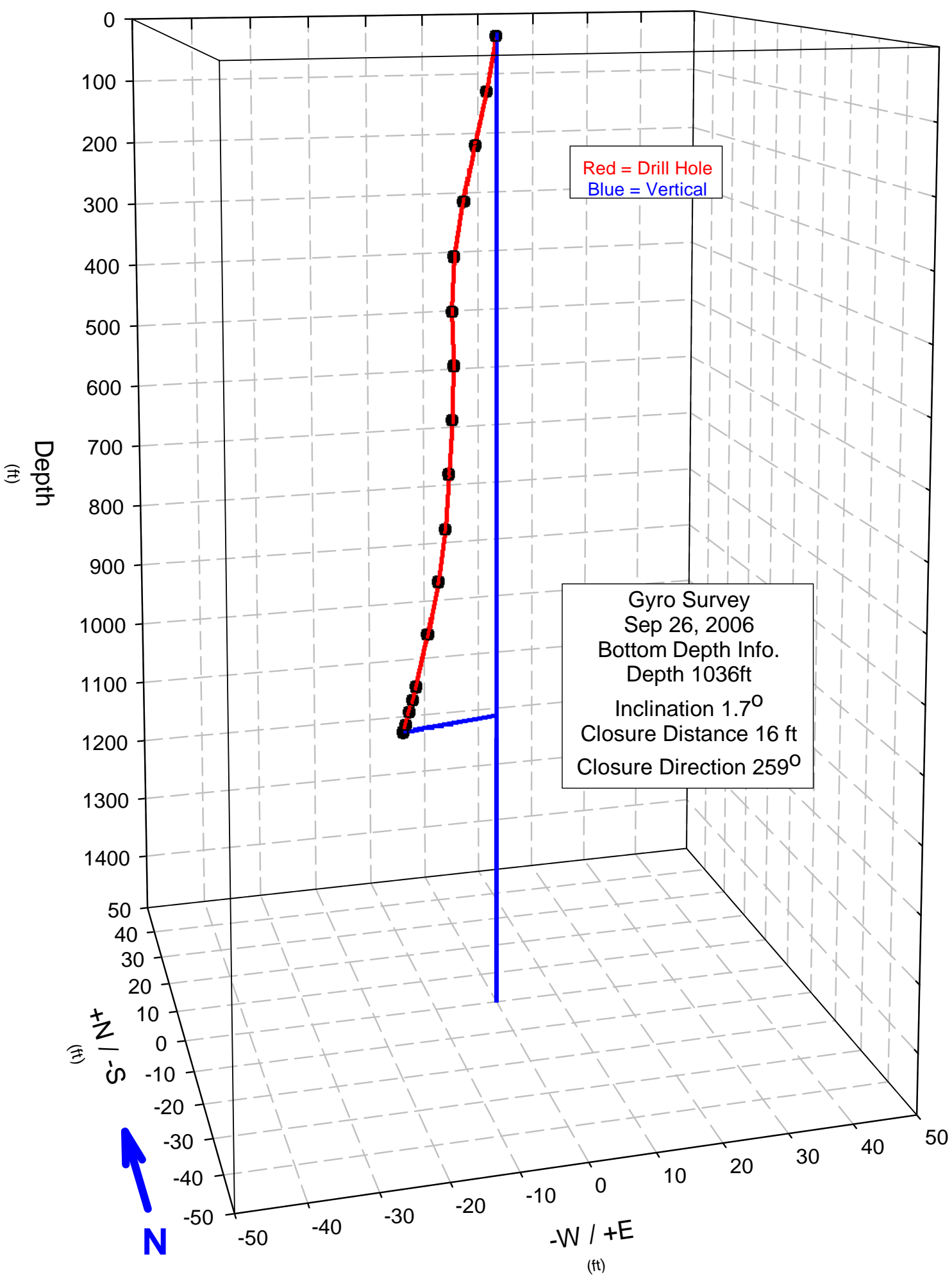


DTS-RPT-090, Rev. 0

Hole: C4993 Survey Date: 9/26/2006

\begin{tabular}{|c|c|c|c|c|c|c|c|}
\hline & & Inclinatio & & & Rectangul & Rectangul & \\
\hline Measure & TrueVer & $\mathrm{n}$ & Closure & Closure & ar & ar & \\
\hline d & & from & Directio & Distanc & Coordinat & Coordinat & Dog-Leg \\
\hline Depth & Depth & Vert. & & $\mathrm{e}$ & es & es & Severity \\
\hline (feet) & (feet) & (deg) & (deg) & (feet) & $+\mathrm{N} /-\mathrm{S}$ & $+\mathrm{E} /-\mathrm{W}$ & $\% / 100-f t$ \\
\hline 5 & 5 & 0.9 & 340.34 & 0.04 & 0.04 & -0.01 & 20.4 \\
\hline 85 & 84.98 & 1.51 & 281.14 & 1.53 & 0.3 & -1.5 & 1.5 \\
\hline 165 & 164.95 & 1.62 & 263.51 & 3.57 & -0.4 & -3.54 & 0.6 \\
\hline 245 & 244.92 & 1.59 & 256.59 & 5.74 & -1.33 & -5.58 & 0.2 \\
\hline 325 & 324.9 & 1.14 & 253.09 & 7.59 & -2.21 & -7.26 & 0.7 \\
\hline 405 & 404.89 & 0.61 & 248.49 & 8.42 & -3.09 & -7.83 & 1.3 \\
\hline 485 & 484.89 & 0.22 & 244.66 & 8.54 & -3.65 & -7.72 & 0.5 \\
\hline 565 & 564.89 & 0.68 & 243.27 & 9.03 & -4.06 & -8.07 & 0.8 \\
\hline 645 & 644.88 & 0.74 & 241.71 & 9.98 & -4.73 & -8.79 & 0.3 \\
\hline 725 & 724.88 & 0.67 & 240.61 & 10.93 & -5.36 & -9.52 & 0.4 \\
\hline 805 & 804.87 & 1.18 & 243.99 & 11.86 & -5.2 & -10.66 & 1.2 \\
\hline 885 & 884.85 & 1.14 & 249.36 & 12.99 & -4.58 & -12.15 & 0.3 \\
\hline 965 & 964.83 & 1.52 & 254.02 & 14.48 & -3.99 & -13.92 & 0.5 \\
\hline 985 & 984.82 & 1.59 & 255.31 & 14.91 & -3.78 & -14.42 & 0.8 \\
\hline 1005 & 1004.81 & 1.7 & 256.68 & 15.35 & -3.54 & -14.94 & 0.5 \\
\hline 1025 & 1024.8 & 1.72 & 258.01 & 15.82 & -3.29 & -15.48 & 0.3 \\
\hline 1036.5 & 1036.3 & 1.71 & 258.72 & 16.11 & -3.15 & -15.8 & 0.3 \\
\hline
\end{tabular}


DTS-RPT-090, Rev. 0

Hole: C4993

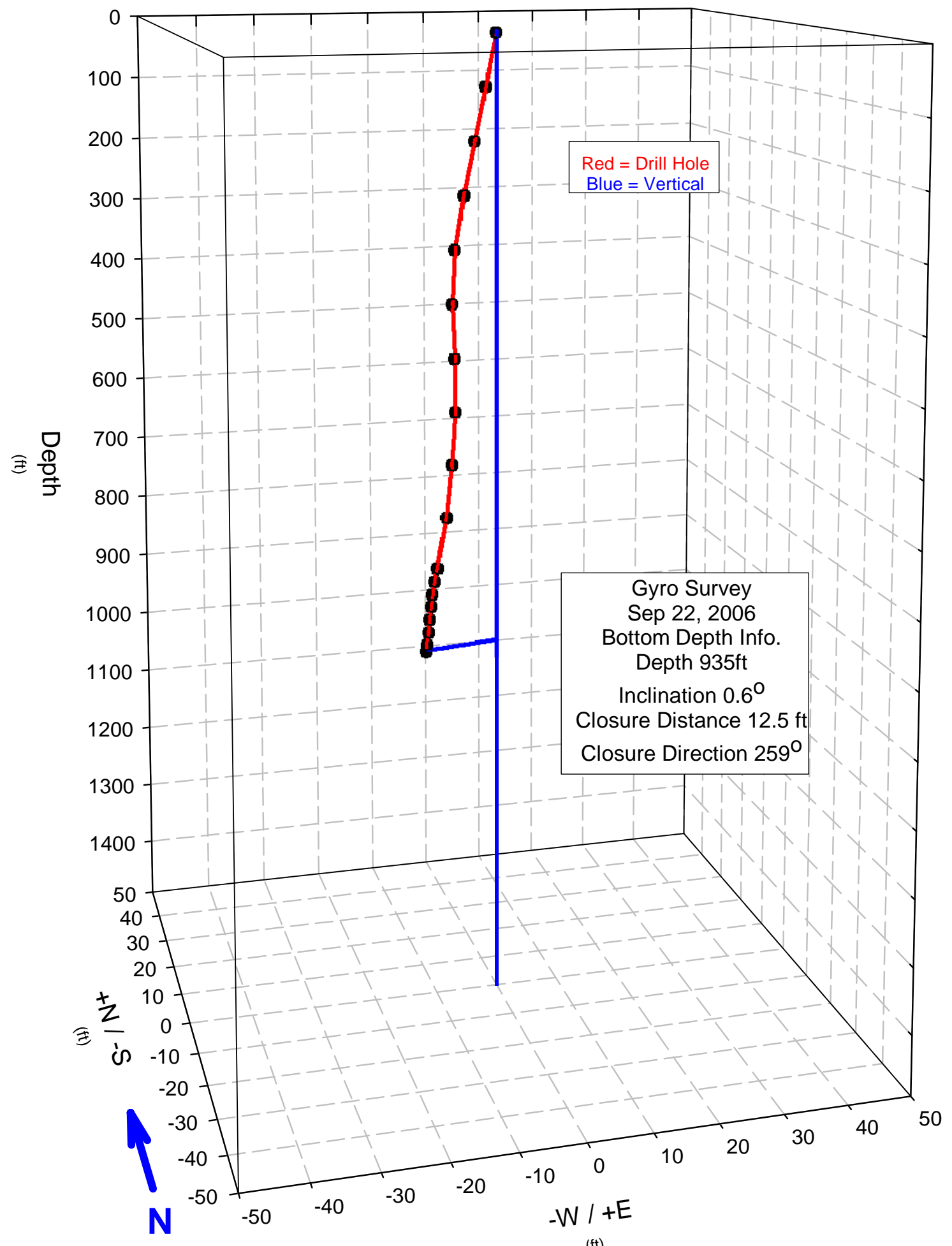

(ft) 
DTS-RPT-090, Rev. 0

Hole: C4993 Survey Date: 9/22/2006

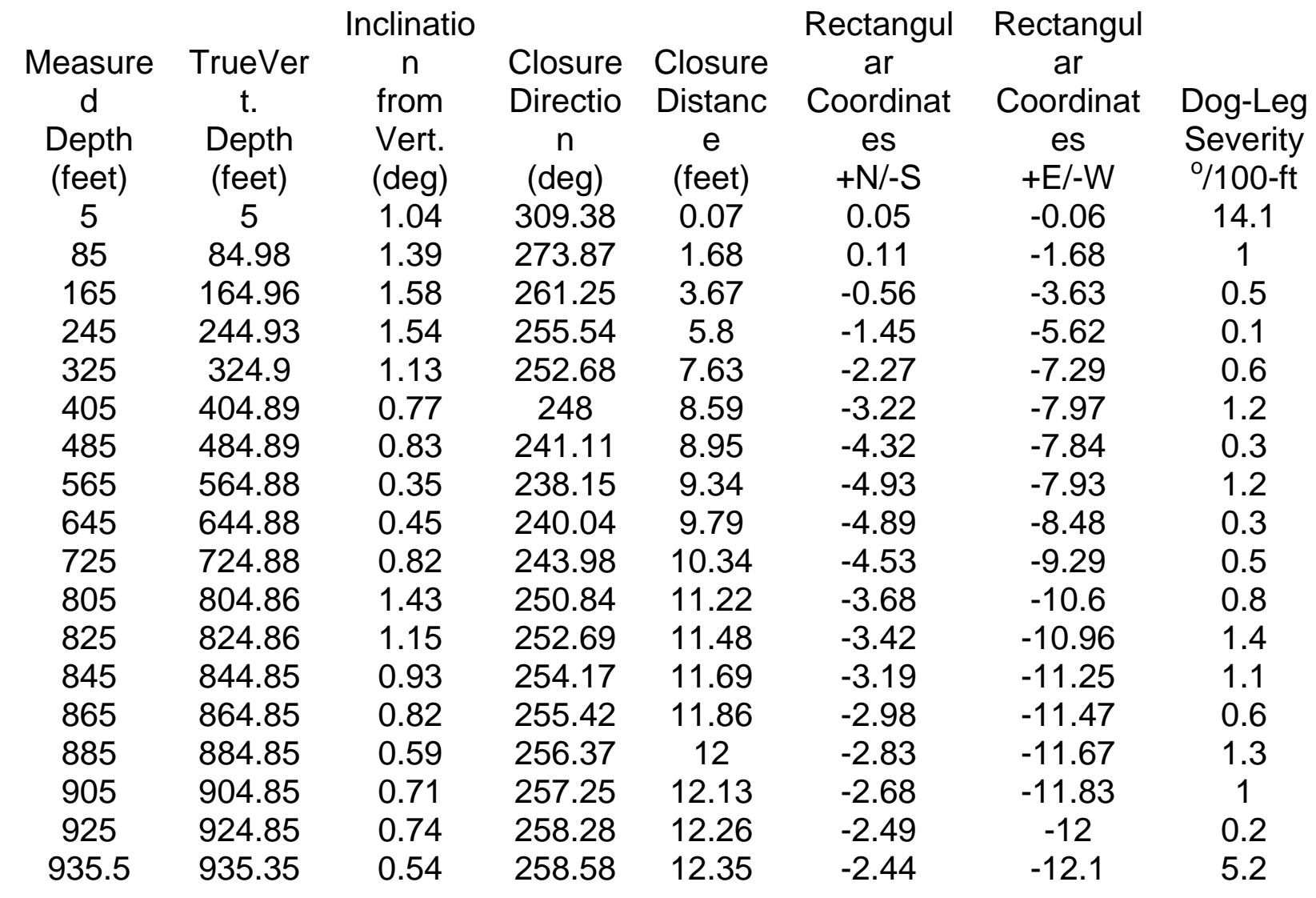


DTS-RPT-090, Rev. 0

Hole: C4993

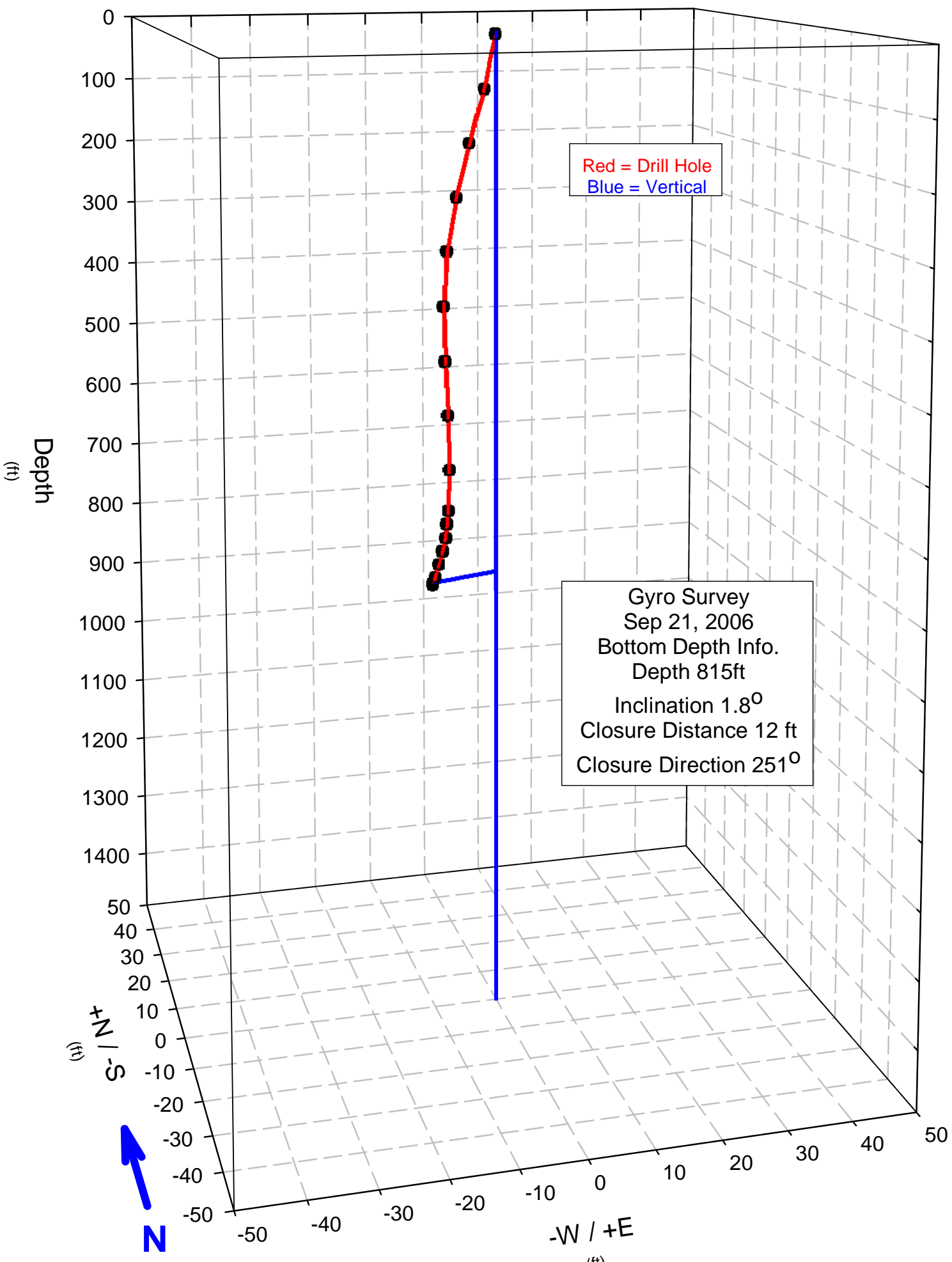

(ft) 
DTS-RPT-090, Rev. 0

Hole: C4993 Survey Date: 8/21/2006

\begin{tabular}{|c|c|c|c|c|c|c|c|}
\hline & & Inclinatio & & & Rectangul & Rectangul & \\
\hline Measure & TrueVer & $\mathrm{n}$ & Closure & Closure & ar & ar & \\
\hline d & & from & Directio & Distanc & Coordinat & Coordinat & Dog-Leg \\
\hline Depth & Depth & Vert. & & $\mathrm{e}$ & es & es & Severity \\
\hline (feet) & (feet) & (deg) & (deg) & (feet) & $+\mathrm{N} /-\mathrm{S}$ & $+\mathrm{E} /-\mathrm{W}$ & $\% / 100-f t$ \\
\hline 5 & 5 & 0.82 & 260.64 & 0.06 & -0.01 & -0.06 & 13.3 \\
\hline 85 & 84.98 & 1.68 & 278.38 & 1.8 & 0.26 & -1.78 & 1.1 \\
\hline 165 & 164.95 & 1.6 & 277.04 & 4.09 & 0.5 & -4.06 & 0.1 \\
\hline 245 & 244.92 & 1.41 & 274.62 & 6.17 & 0.5 & -6.15 & 0.5 \\
\hline 325 & 324.9 & 1.2 & 269.96 & 7.87 & -0.01 & -7.87 & 0.7 \\
\hline 405 & 404.89 & 1.01 & 262.81 & 8.77 & -1.1 & -8.7 & 1.3 \\
\hline 485 & 484.88 & 0.71 & 255.28 & 9 & -2.29 & -8.7 & 0.5 \\
\hline 565 & 564.87 & 0.4 & 250.39 & 9 & -3.02 & -8.47 & 0.4 \\
\hline 645 & 644.87 & 0.71 & 246.2 & 9.27 & -3.74 & -8.48 & 0.6 \\
\hline 705 & 704.87 & 0.49 & 244.18 & 9.77 & -4.25 & -8.79 & 0.7 \\
\hline 725 & 724.87 & 0.62 & 244.2 & 9.96 & -4.33 & -8.97 & 1.2 \\
\hline 745 & 744.86 & 1.02 & 244.73 & 10.23 & -4.36 & -9.25 & 2.2 \\
\hline 765 & 764.86 & 1.65 & 246.22 & 10.6 & -4.27 & -9.7 & 3.9 \\
\hline 785 & 784.85 & 1.71 & 248.19 & 11.05 & -4.1 & -10.26 & 0.8 \\
\hline 805 & 804.84 & 1.7 & 249.96 & 11.53 & -3.95 & -10.83 & 0.3 \\
\hline 815.5 & 815.34 & 1.76 & 250.89 & 11.79 & -3.86 & -11.14 & 1.1 \\
\hline
\end{tabular}


DTS-RPT-090, Rev. 0

Hole: C4993

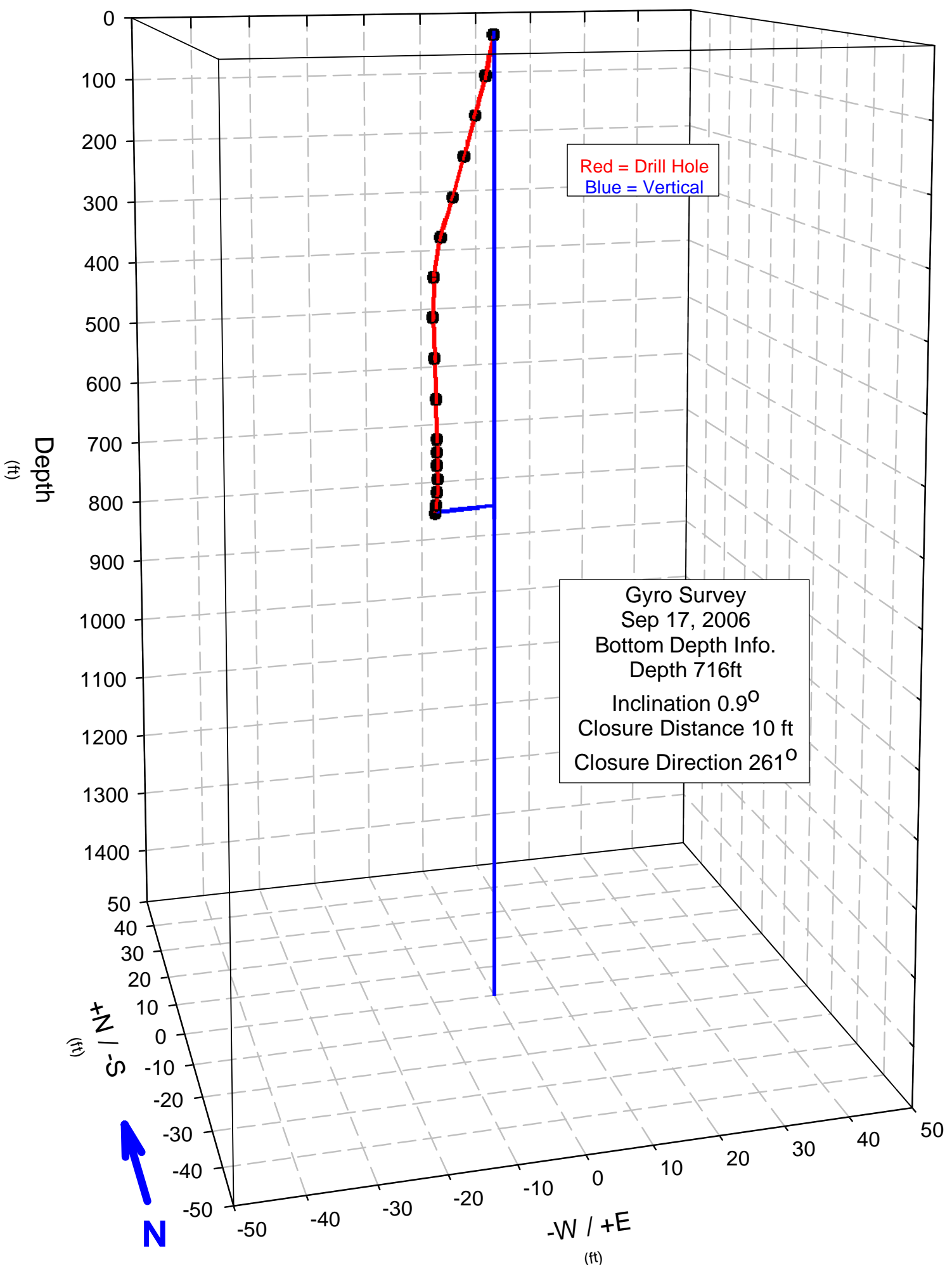


DTS-RPT-090, Rev. 0

\section{Hole: C4993 Survey Date: 9/17/2006}

\begin{tabular}{|c|c|c|c|c|c|c|c|}
\hline & & Inclinatio & & & Rectangul & Rectangul & \\
\hline Measure & TrueVer & $\mathrm{n}$ & Closure & Closure & ar & ar & \\
\hline & & from & Directio & Distanc & Coordinat & Coordinat & Dog-Leg \\
\hline Depth & Depth & Vert. & $\mathrm{n}$ & & es & es & Severity \\
\hline (feet) & (feet) & (deg) & (deg) & (feet) & $+\mathrm{N} /-\mathrm{S}$ & $+\mathrm{E} /-\mathrm{W}$ & $\% / 100-f t$ \\
\hline 5 & 5 & 1.12 & 317.57 & 0.07 & 0.05 & -0.04 & 15.2 \\
\hline 65 & 64.99 & 1.44 & 299.7 & 1.3 & 0.64 & -1.13 & 1.7 \\
\hline 125 & 124.96 & 1.79 & 286.69 & 2.93 & 0.84 & -2.81 & 0.6 \\
\hline 185 & 184.94 & 1.53 & 281.68 & 4.64 & 0.94 & -4.55 & 0.5 \\
\hline 245 & 244.91 & 1.95 & 279.16 & 6.45 & 1.03 & -6.36 & 0.7 \\
\hline 305 & 304.88 & 1.74 & 278.03 & 8.37 & 1.17 & -8.29 & 0.4 \\
\hline 365 & 364.87 & 0.34 & 277.37 & 9.46 & 1.21 & -9.38 & 2.3 \\
\hline 425 & 424.87 & 0.54 & 275.4 & 9.61 & 0.9 & -9.57 & 1 \\
\hline 485 & 484.86 & 0.83 & 271.14 & 9.53 & 0.19 & -9.53 & 0.5 \\
\hline 545 & 544.86 & 0.6 & 266.65 & 9.49 & -0.55 & -9.48 & 0.4 \\
\hline 605 & 604.85 & 0.36 & 263.65 & 9.52 & -1.05 & -9.47 & 0.4 \\
\hline 625 & 624.85 & 0.26 & 263.01 & 9.53 & -1.16 & -9.46 & 0.5 \\
\hline 645 & 644.85 & 0.28 & 262.44 & 9.53 & -1.25 & -9.45 & 0.2 \\
\hline 665 & 664.85 & 0.38 & 261.79 & 9.56 & -1.36 & -9.46 & 0.7 \\
\hline 685 & 684.85 & 0.39 & 261.36 & 9.66 & -1.45 & -9.55 & 1.7 \\
\hline 705 & 704.85 & 0.72 & 261.26 & 9.85 & -1.5 & -9.74 & 1.7 \\
\hline 716 & 715.85 & 0.93 & 261.27 & 10.01 & -1.52 & -9.89 & 2 \\
\hline
\end{tabular}


DTS-RPT-090, Rev. 0

Hole: C4993

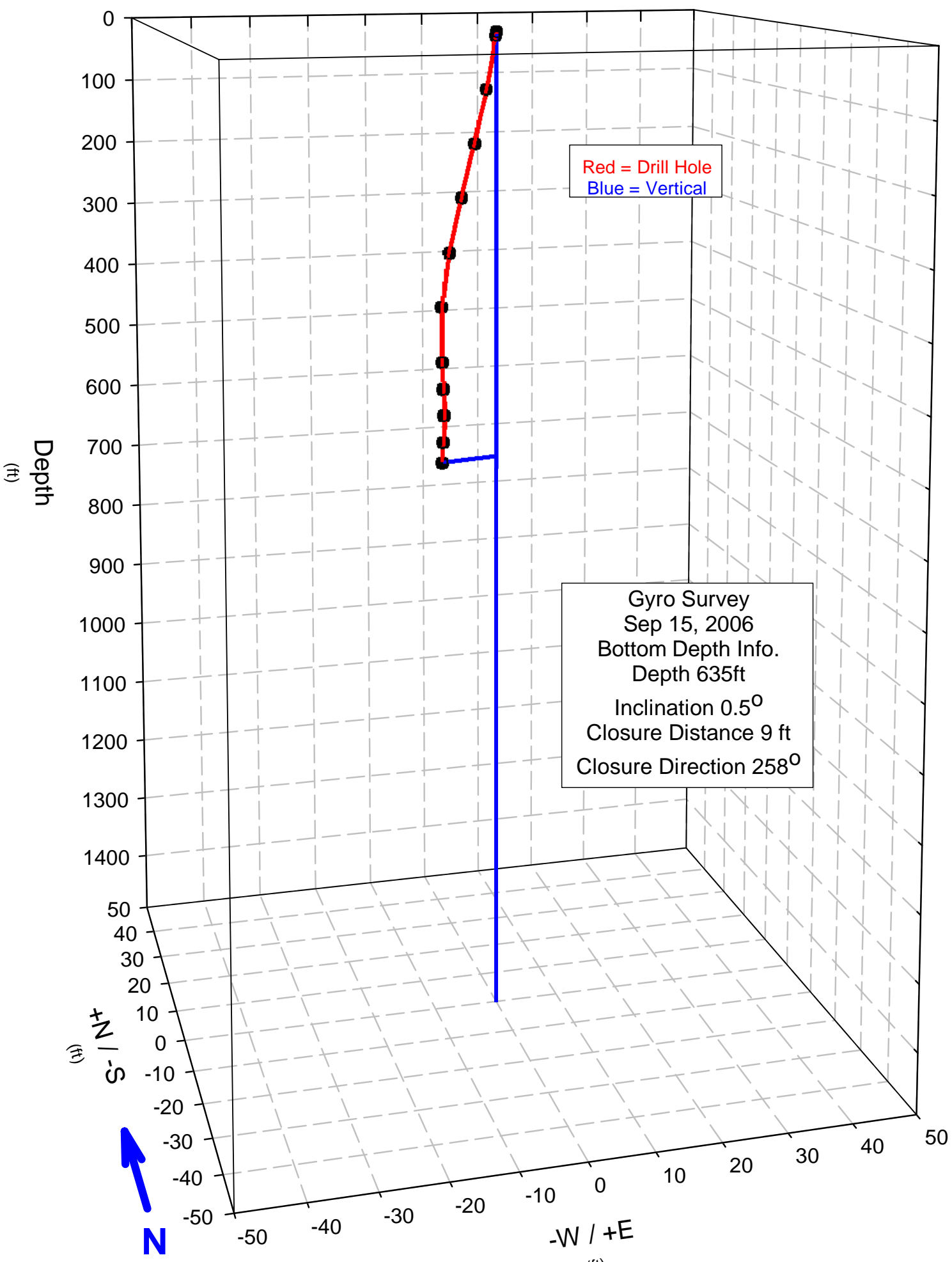

(ft) 
DTS-RPT-090, Rev. 0

\section{Hole: C4993 Survey Date: 9/15/2006}

\begin{tabular}{|c|c|c|c|c|c|c|c|}
\hline & & Inclinatio & & & Rectangul & & \\
\hline Measure & TrueVer & $\mathrm{n}$ & Closure & Closure & ar & $a r$ & \\
\hline d & & from & Directio & Distanc & Coordinat & Coordinat & Dog-Leg \\
\hline Depth & Depth & Vert. & $\mathrm{n}$ & & es & es & Severity \\
\hline (feet) & (feet) & (deg) & (deg) & (feet) & $+\mathrm{N} /-\mathrm{S}$ & $+E /-W$ & $\% / 100-f t$ \\
\hline 0 & 0 & 1.02 & 0 & 0 & 0 & 0 & 0 \\
\hline 5 & 5 & 1.07 & 315.93 & 0.09 & 0.07 & -0.06 & 1.2 \\
\hline 85 & 84.98 & 1.17 & 302.96 & 1.6 & 0.87 & -1.34 & 0.7 \\
\hline 165 & 164.96 & 1.51 & 288.76 & 3.35 & 1.08 & -3.17 & 0.8 \\
\hline 245 & 244.93 & 1.57 & 279.43 & 5.38 & 0.88 & -5.3 & 0.2 \\
\hline 325 & 324.91 & 1.35 & 275.14 & 7.36 & 0.66 & -7.33 & 0.3 \\
\hline 405 & 404.89 & 0.93 & 270.41 & 8.66 & 0.06 & -8.66 & 1.2 \\
\hline 485 & 484.89 & 0.81 & 263.58 & 8.98 & -1 & -8.92 & 1 \\
\hline 525 & 524.88 & 0.57 & 260.51 & 8.92 & -1.47 & -8.8 & 0.6 \\
\hline 565 & 564.88 & 0.29 & 258.65 & 8.94 & -1.76 & -8.77 & 0.9 \\
\hline 605 & 604.88 & 0.41 & 257.94 & 9.13 & -1.91 & -8.92 & 0.9 \\
\hline 635 & 634.88 & 0.44 & 257.85 & 9.35 & -1.97 & -9.14 & 0.2 \\
\hline
\end{tabular}


DTS-RPT-090, Rev. 0

Hole: C4993

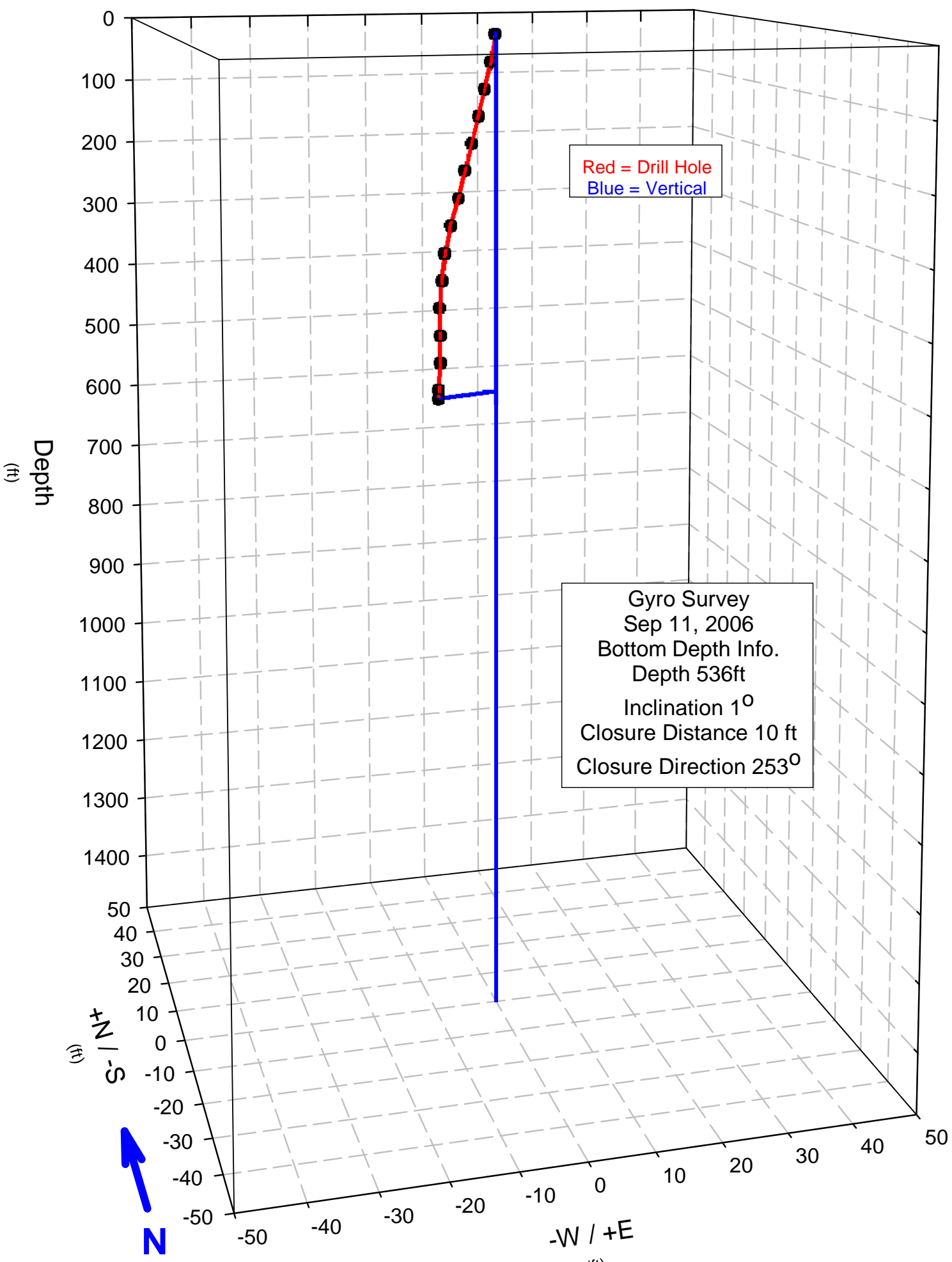

(ft) 
DTS-RPT-090, Rev. 0

\section{Hole: C4993 Survey Date: 9/11/2006}

\begin{tabular}{|c|c|c|c|c|c|c|c|}
\hline & & Inclinatio & & & Rectangul & Rectangul & \\
\hline Measure & TrueVer & $\mathrm{n}$ & Closure & Closure & ar & ar & \\
\hline & & from & Directio & Distanc & Coordinat & Coordinat & Dog-Leg \\
\hline Depth & Depth & Vert. & $\mathrm{n}$ & $\mathrm{e}$ & es & es & Severity \\
\hline (feet) & (feet) & (deg) & (deg) & (feet) & $+\mathrm{N} /-\mathrm{S}$ & $+E /-W$ & $\% / 100-\mathrm{ft}$ \\
\hline 4 & 4 & 0.91 & 292.6 & 0.05 & 0.02 & -0.05 & 21 \\
\hline 44 & 43.99 & 1.13 & 289.12 & 0.71 & 0.23 & -0.67 & 1.9 \\
\hline 84 & 83.98 & 1.78 & 287.1 & 1.68 & 0.49 & -1.61 & 2.7 \\
\hline 124 & 123.97 & 1.15 & 280.32 & 2.67 & 0.48 & -2.63 & 1.6 \\
\hline 164 & 163.95 & 1.98 & 276.08 & 3.74 & 0.4 & -3.72 & 2.1 \\
\hline 204 & 203.94 & 1.36 & 272.06 & 4.85 & 0.17 & -4.85 & 2 \\
\hline 244 & 243.92 & 2.04 & 268.54 & 5.99 & -0.15 & -5.98 & 1.8 \\
\hline 284 & 283.89 & 2 & 265.61 & 7.35 & -0.56 & -7.33 & 0.8 \\
\hline 324 & 323.88 & 1.05 & 263.68 & 8.38 & -0.92 & -8.33 & 2.4 \\
\hline 364 & 363.87 & 0.63 & 263.19 & 8.96 & -1.06 & -8.9 & 1.1 \\
\hline 404 & 403.87 & 1.02 & 261.33 & 9.39 & -1.42 & -9.28 & 2 \\
\hline 444 & 443.87 & 0.68 & 258.2 & 9.61 & -1.96 & -9.4 & 1.6 \\
\hline 484 & 483.86 & 0.68 & 255.99 & 9.81 & -2.37 & -9.52 & 1.5 \\
\hline 524 & 523.86 & 0.96 & 253.9 & 10.25 & -2.84 & -9.84 & 0.8 \\
\hline 536 & 535.86 & 0.95 & 253.2 & 10.4 & -3.01 & -9.96 & 1 \\
\hline
\end{tabular}


DTS-RPT-090, Rev. 0

Hole: C4993

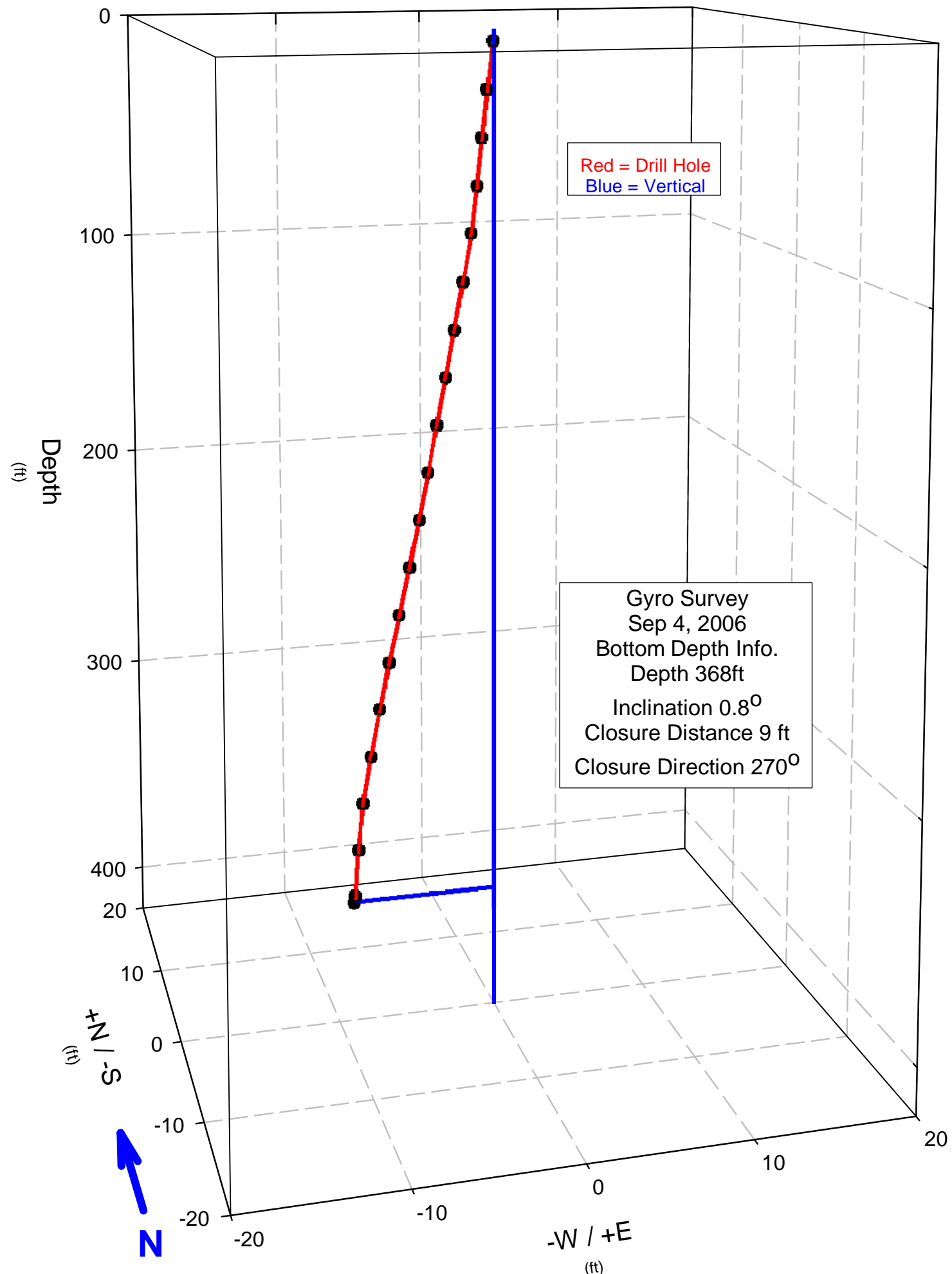


DTS-RPT-090, Rev. 0

Hole: C4993 Survey Date: 9/4/2006

\begin{tabular}{|c|c|c|c|c|c|c|c|}
\hline $\begin{array}{c}\text { Measure } \\
\text { d }\end{array}$ & $\begin{array}{c}\text { TrueVer } \\
\text { t. }\end{array}$ & $\begin{array}{c}\text { Inclinatio } \\
n \\
\text { from }\end{array}$ & $\begin{array}{l}\text { Closure } \\
\text { Directio }\end{array}$ & $\begin{array}{l}\text { Closure } \\
\text { Distanc }\end{array}$ & $\begin{array}{c}\text { Rectangul } \\
\text { ar } \\
\text { Coordinat }\end{array}$ & $\begin{array}{c}\text { Rectangul } \\
\text { ar } \\
\text { Coordinat }\end{array}$ & Dog-Leg \\
\hline Depth & Depth & Vert. & $\mathrm{n}$ & $\mathrm{e}$ & es & es & Severity \\
\hline (feet) & (feet) & (deg) & (deg) & (feet) & $+\mathrm{N} /-\mathrm{S}$ & $+E /-W$ & $\% / 100-\mathrm{ft}$ \\
\hline 5 & 5 & 1.02 & 323.58 & 0.04 & 0.04 & -0.03 & 21.7 \\
\hline 25 & 25 & 1.05 & 297.78 & 0.39 & 0.18 & -0.35 & 2.3 \\
\hline 45 & 44.99 & 0.89 & 287.81 & 0.72 & 0.22 & -0.68 & 1.3 \\
\hline 65 & 64.99 & 0.79 & 284.21 & 1 & 0.25 & -0.97 & 1 \\
\hline 85 & 84.99 & 1.32 & 283.28 & 1.37 & 0.31 & -1.33 & 2.6 \\
\hline 105 & 104.98 & 1.77 & 279.58 & 1.89 & 0.31 & -1.87 & 3.2 \\
\hline 125 & 124.97 & 1.58 & 275.96 & 2.46 & 0.26 & -2.45 & 1.1 \\
\hline 145 & 144.96 & 1.62 & 274.79 & 3.01 & 0.25 & -3 & 1 \\
\hline 165 & 164.96 & 1.6 & 273.98 & 3.57 & 0.25 & -3.57 & 1 \\
\hline 185 & 184.95 & 1.61 & 272.99 & 4.13 & 0.22 & -4.12 & 0.2 \\
\hline 205 & 204.94 & 1.83 & 272.32 & 4.73 & 0.19 & -4.72 & 1.1 \\
\hline 225 & 224.93 & 1.87 & 271.82 & 5.37 & 0.17 & -5.37 & 0.2 \\
\hline 245 & 244.92 & 1.91 & 271.45 & 6.03 & 0.15 & -6.03 & 0.2 \\
\hline 265 & 264.91 & 1.8 & 271.29 & 6.68 & 0.15 & -6.68 & 0.7 \\
\hline 285 & 284.9 & 1.72 & 271.29 & 7.29 & 0.16 & -7.29 & 0.4 \\
\hline 305 & 304.89 & 1.71 & 271.02 & 7.89 & 0.14 & -7.89 & 1.1 \\
\hline 325 & 324.88 & 1.34 & 270.5 & 8.42 & 0.07 & -8.41 & 1.9 \\
\hline 345 & 344.88 & 0.51 & 270.6 & 8.72 & 0.09 & -8.72 & 5.2 \\
\hline 365 & 364.88 & 0.92 & 270.59 & 8.94 & 0.09 & -8.94 & 3.8 \\
\hline 368 & 367.88 & 0.8 & 270.51 & 8.99 & 0.08 & -8.99 & 5.8 \\
\hline
\end{tabular}


DTS-RPT-090, Rev. 0

Hole: C4993

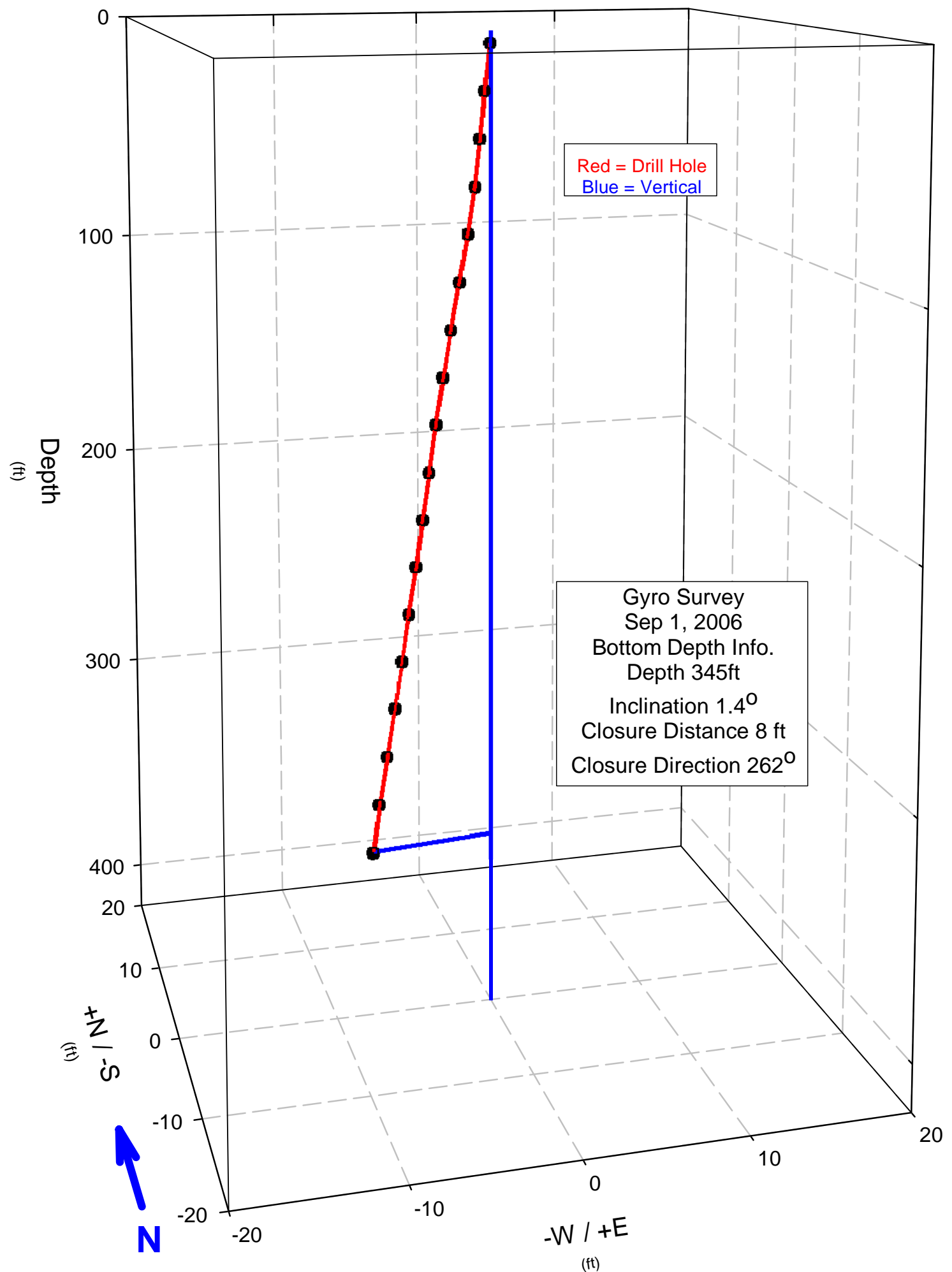


DTS-RPT-090, Rev. 0

Hole: C4993 Survey Date: 9/1/2006

\begin{tabular}{|c|c|c|c|c|c|c|c|}
\hline & & Inclinatio & & & Rectangul & Rectangul & \\
\hline Measure & TrueVer & $\mathrm{n}$ & Closure & Closure & ar & ar & \\
\hline & & from & Directio & Distanc & Coordinat & Coordinat & Dog-Leg \\
\hline Depth & Depth & Vert. & & & es & es & Severity \\
\hline (feet) & (feet) & (deg) & (deg) & (feet) & $+\mathrm{N} /-\mathrm{S}$ & $+\mathrm{E} /-\mathrm{W}$ & $\% / 100-f t$ \\
\hline 5 & 5 & 1.09 & 331.83 & 0.05 & 0.05 & -0.02 & 20.8 \\
\hline 25 & 25 & 1.03 & 306.32 & 0.39 & 0.23 & -0.31 & 4 \\
\hline 45 & 44.99 & 0.66 & 294.96 & 0.66 & 0.28 & -0.6 & 1.8 \\
\hline 65 & 64.99 & 1.1 & 289.63 & 0.96 & 0.32 & -0.91 & 2.2 \\
\hline 85 & 84.99 & 1.6 & 282.92 & 1.41 & 0.31 & -1.37 & 2.9 \\
\hline 105 & 104.98 & 1.62 & 278.14 & 1.95 & 0.28 & -1.93 & 0.7 \\
\hline 125 & 124.97 & 1.54 & 276.1 & 2.5 & 0.27 & -2.48 & 0.4 \\
\hline 145 & 144.96 & 1.48 & 274.05 & 3.01 & 0.21 & -3 & 1.4 \\
\hline 165 & 164.96 & 1.35 & 272.13 & 3.49 & 0.13 & -3.49 & 0.7 \\
\hline 185 & 184.95 & 1.28 & 270.97 & 3.95 & 0.07 & -3.95 & 0.4 \\
\hline 205 & 204.95 & 1.28 & 269.85 & 4.38 & -0.01 & -4.38 & 0.6 \\
\hline 225 & 224.94 & 1.4 & 268.74 & 4.84 & -0.11 & -4.84 & 0.7 \\
\hline 245 & 244.94 & 1.42 & 267.98 & 5.33 & -0.19 & -5.33 & 0.3 \\
\hline 265 & 264.93 & 1.4 & 267.16 & 5.82 & -0.29 & -5.81 & 0.9 \\
\hline 285 & 284.92 & 1.62 & 265.85 & 6.33 & -0.46 & -6.31 & 1.4 \\
\hline 305 & 304.91 & 1.85 & 264.33 & 6.91 & -0.68 & -6.87 & 1.2 \\
\hline 325 & 324.9 & 1.59 & 262.92 & 7.48 & -0.92 & -7.42 & 1.4 \\
\hline 345 & 344.9 & 1.37 & 261.69 & 7.97 & -1.15 & -7.89 & 1.2 \\
\hline
\end{tabular}


DTS-RPT-090, Rev. 0

Hole: C4993

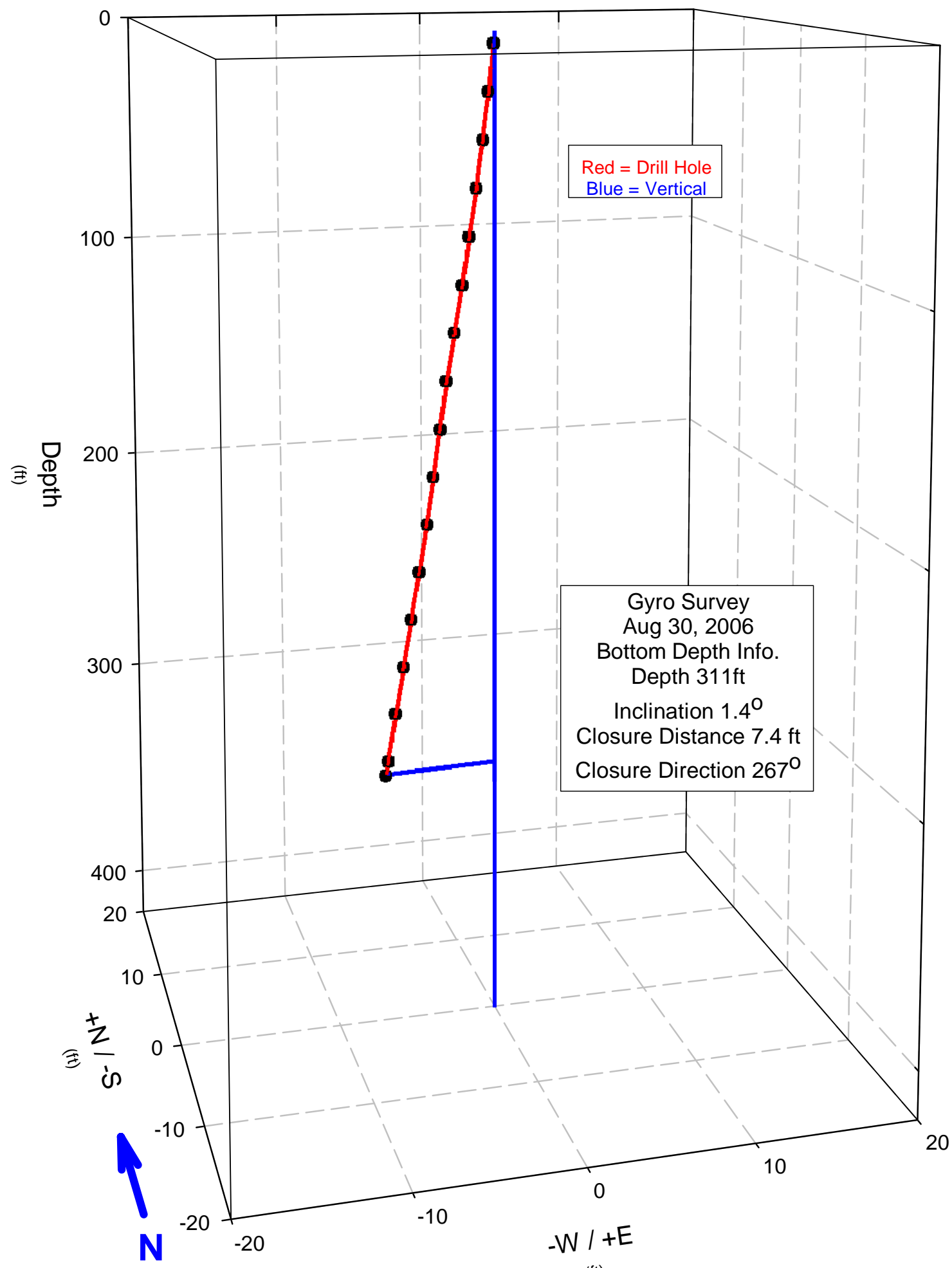

(ft) 
DTS-RPT-090, Rev. 0

Hole: C4993 Survey Date: 8/30/2006

\begin{tabular}{|c|c|c|c|c|c|c|c|}
\hline & & Inclinatio & & & Rectangul & Rectangul & \\
\hline Measure & TrueVer & $\mathrm{n}$ & Closure & Closure & ar & ar & \\
\hline & & from & Directio & Distanc & Coordinat & Coordinat & Dog-Leg \\
\hline Depth & Depth & Vert. & $\mathrm{n}$ & & es & es & Severity \\
\hline (feet) & (feet) & (deg) & (deg) & (feet) & $+\mathrm{N} /-\mathrm{S}$ & $+\mathrm{E} /-\mathrm{W}$ & $\% / 100-f t$ \\
\hline 5 & 5 & 0.89 & 315.66 & 0.06 & 0.04 & -0.04 & 12.4 \\
\hline 25 & 25 & 0.88 & 294.33 & 0.35 & 0.15 & -0.32 & 1.7 \\
\hline 45 & 44.99 & 1.13 & 286.2 & 0.7 & 0.19 & -0.67 & 1.3 \\
\hline 65 & 64.99 & 1.29 & 280.6 & 1.11 & 0.2 & -1.09 & 1.3 \\
\hline 85 & 84.98 & 1.32 & 275.37 & 1.55 & 0.14 & -1.54 & 0.9 \\
\hline 105 & 104.98 & 1.39 & 272.3 & 2.01 & 0.08 & -2.01 & 0.9 \\
\hline 125 & 124.97 & 1.58 & 270.67 & 2.52 & 0.03 & -2.52 & 1 \\
\hline 145 & 144.97 & 1.46 & 268.91 & 3.05 & -0.06 & -3.05 & 1 \\
\hline 165 & 164.96 & 1.32 & 267.36 & 3.52 & -0.16 & -3.52 & 0.7 \\
\hline 185 & 184.95 & 1.22 & 266.4 & 3.96 & -0.25 & -3.96 & 0.5 \\
\hline 205 & 204.95 & 1.4 & 266.07 & 4.42 & -0.3 & -4.41 & 1.2 \\
\hline 225 & 224.94 & 1.43 & 266.09 & 4.91 & -0.33 & -4.9 & 0.2 \\
\hline 245 & 244.94 & 1.49 & 266.27 & 5.42 & -0.35 & -5.41 & 0.5 \\
\hline 265 & 264.93 & 1.47 & 266.47 & 5.94 & -0.37 & -5.93 & 0.3 \\
\hline 285 & 284.92 & 1.48 & 266.46 & 6.46 & -0.4 & -6.45 & 0.3 \\
\hline 305 & 304.92 & 1.33 & 266.63 & 6.95 & -0.41 & -6.94 & 1.2 \\
\hline 311 & 310.92 & 1.43 & 266.72 & 7.09 & -0.41 & -7.08 & 2.1 \\
\hline
\end{tabular}


DTS-RPT-090, Rev. 0

Hole: C4993

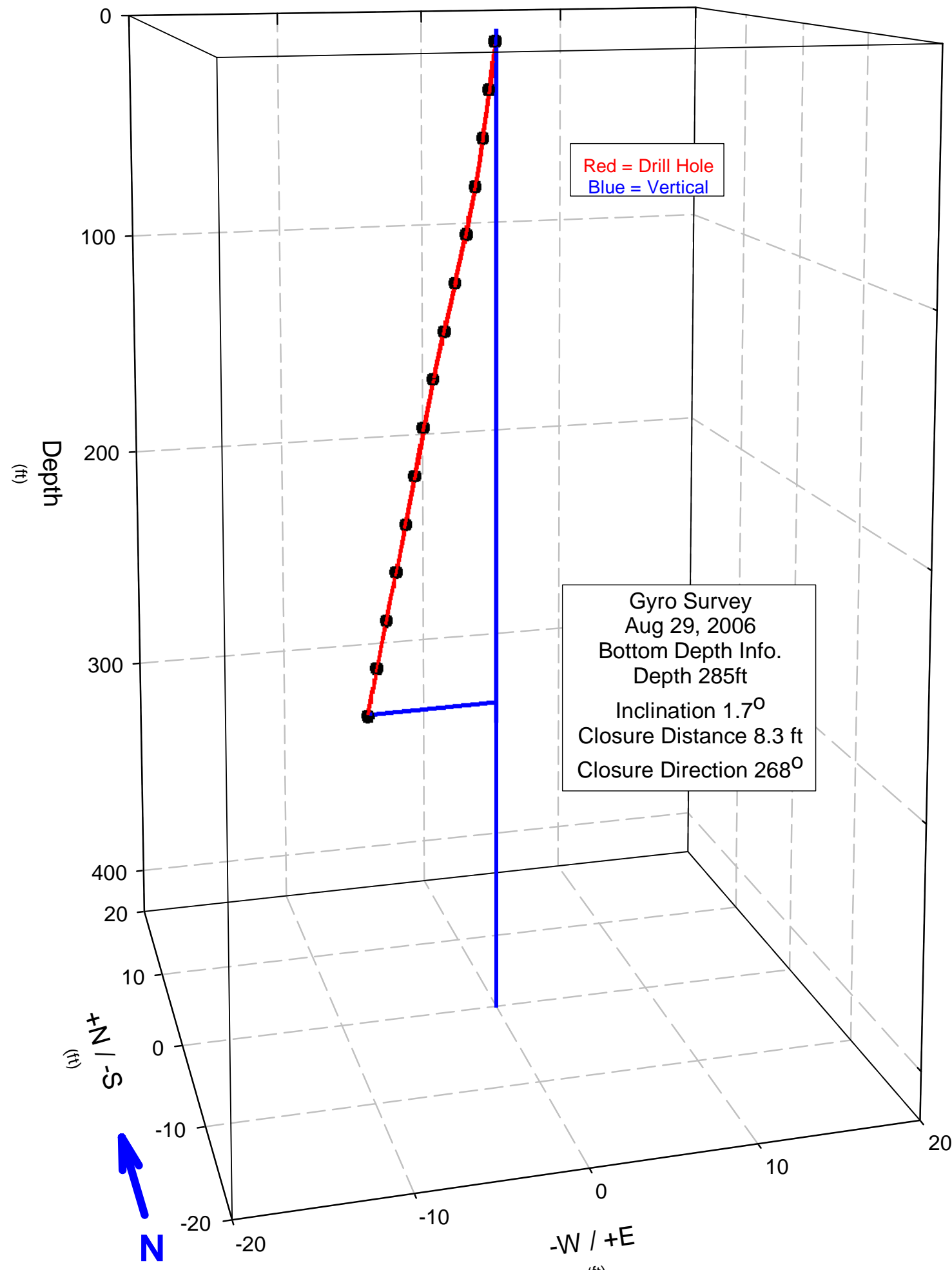

(ft) 
DTS-RPT-090, Rev. 0

\section{Hole: C4993 Survey Date: 8/29/2006}

\begin{tabular}{|c|c|c|c|c|c|c|c|}
\hline & & & & & Rectangul & & \\
\hline Measure & TrueVer & $\mathrm{n}$ & Closure & Closure & ar & ar & \\
\hline & & from & Directio & Distanc & Coordinat & Coordinat & Dog-Leg \\
\hline Depth & Depth & Vert. & $\mathrm{n}$ & & es & es & Severity \\
\hline (feet) & (feet) & (deg) & (deg) & (feet) & $+\mathrm{N} /-\mathrm{S}$ & $+\mathrm{E} /-\mathrm{W}$ & $/ 100-\mathrm{ft}$ \\
\hline 5 & 5 & 1.03 & 268.35 & 0.03 & 0 & -0.03 & 32.5 \\
\hline 25 & 25 & 1.15 & 295.66 & 0.4 & 0.17 & -0.36 & 1.2 \\
\hline 45 & 44.99 & 1.14 & 292.34 & 0.8 & 0.3 & -0.74 & 0.7 \\
\hline 65 & 64.99 & 1.49 & 289.52 & 1.26 & 0.42 & -1.18 & 1.8 \\
\hline 85 & 84.98 & 1.89 & 285.6 & 1.83 & 0.49 & -1.77 & 2.6 \\
\hline 105 & 104.97 & 2.1 & 281.22 & 2.51 & 0.49 & -2.46 & 1.3 \\
\hline 125 & 124.95 & 2.1 & 277.77 & 3.22 & 0.44 & -3.19 & 0.6 \\
\hline 145 & 144.94 & 1.99 & 275.08 & 3.91 & 0.35 & -3.9 & 0.8 \\
\hline 165 & 164.93 & 1.81 & 272.93 & 4.56 & 0.23 & -4.55 & 0.9 \\
\hline 185 & 184.92 & 1.75 & 271.21 & 5.16 & 0.11 & -5.16 & 0.4 \\
\hline 205 & 204.91 & 1.86 & 269.72 & 5.78 & -0.03 & -5.78 & 0.6 \\
\hline 225 & 224.9 & 1.9 & 268.76 & 6.42 & -0.14 & -6.42 & 1 \\
\hline 245 & 244.89 & 1.87 & 268.48 & 7.08 & -0.19 & -7.08 & 0.8 \\
\hline 265 & 264.88 & 1.68 & 268.33 & 7.7 & -0.22 & -7.69 & 1.1 \\
\hline 285 & 284.87 & 1.66 & 268.11 & 8.28 & -0.27 & -8.28 & 0.2 \\
\hline
\end{tabular}


DTS-RPT-090, Rev. 0

Hole: C4993

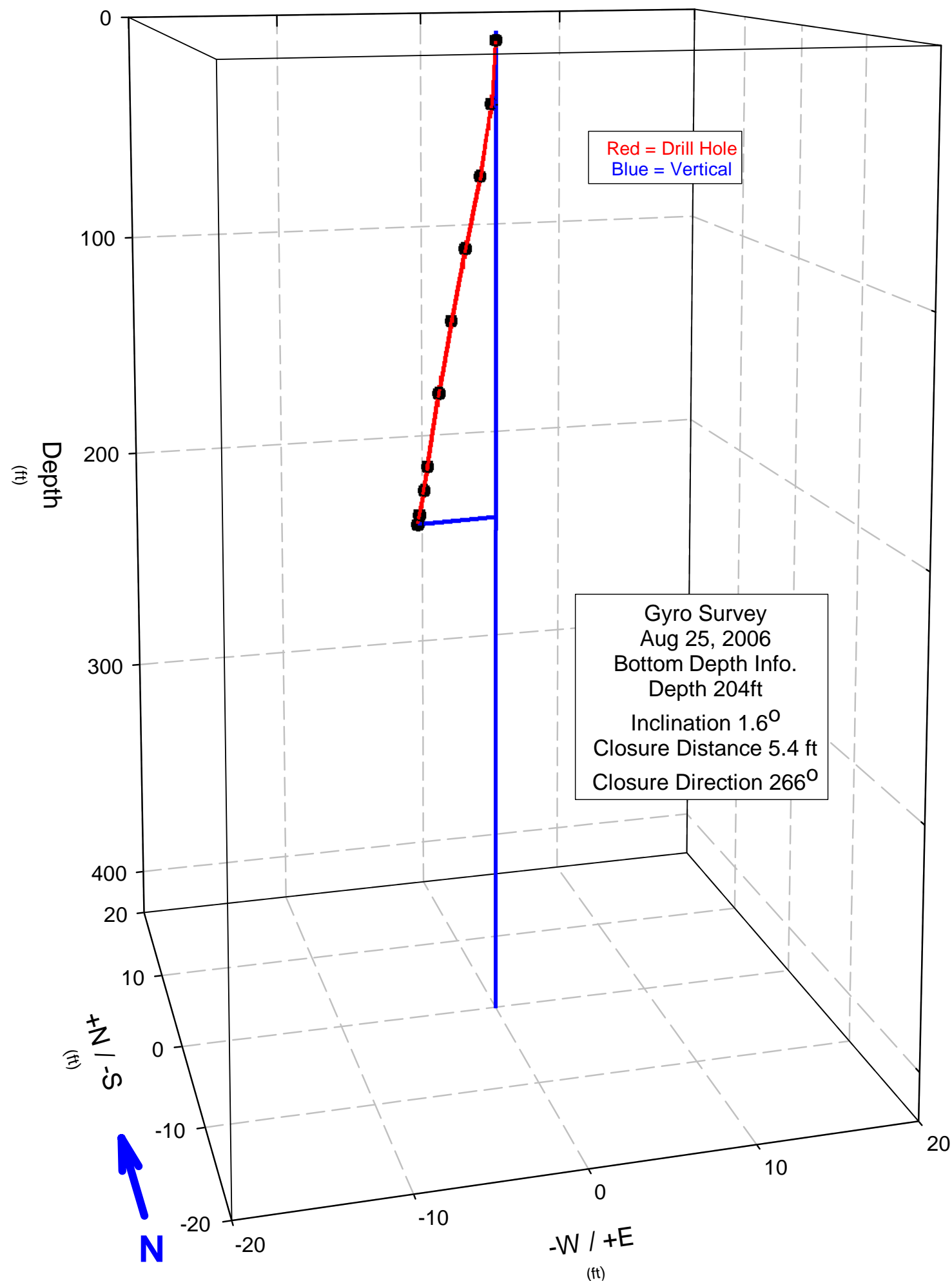


DTS-RPT-090, Rev. 0

\section{Hole: C4993 Survey Date: 8/25/2006}

\begin{tabular}{|c|c|c|c|c|c|c|c|}
\hline & & Inclinatio & & & Rectangul & Rectangul & \\
\hline Measure & TrueVer & $\mathrm{n}$ & Closure & Closure & ar & ar & \\
\hline d & & from & Directio & Distanc & Coordinat & Coordinat & Dog-Leg \\
\hline Depth & Depth & Vert. & $\mathrm{n}$ & e & es & es & Severity \\
\hline (feet) & (feet) & (deg) & (deg) & (feet) & $+\mathrm{N} /-\mathrm{S}$ & $+E /-W$ & $\% / 100-f t$ \\
\hline 4 & 4 & 0.15 & 253.18 & 0 & 0 & 0 & 4.7 \\
\hline 30 & 30 & 1 & 303.51 & 0.26 & 0.14 & -0.21 & 3.4 \\
\hline 60 & 59.99 & 1.72 & 297.01 & 0.95 & 0.43 & -0.85 & 3 \\
\hline 90 & 89.98 & 1.85 & 287.23 & 1.85 & 0.55 & -1.77 & 1.8 \\
\hline 120 & 119.96 & 1.85 & 278.41 & 2.74 & 0.4 & -2.71 & 1.6 \\
\hline 150 & 149.95 & 1.73 & 271.7 & 3.6 & 0.11 & -3.6 & 0.6 \\
\hline 180 & 179.93 & 1.57 & 267.62 & 4.42 & -0.18 & -4.41 & 0.5 \\
\hline 190 & 189.93 & 1.6 & 266.59 & 4.68 & -0.28 & -4.67 & 0.8 \\
\hline 200 & 199.93 & 1.8 & 265.9 & 4.97 & -0.35 & -4.96 & 3.9 \\
\hline 204 & 203.92 & 1.63 & 265.78 & 5.09 & -0.37 & -5.08 & 4.2 \\
\hline
\end{tabular}


DTS-RPT-090, Rev. 0

Hole: C4993

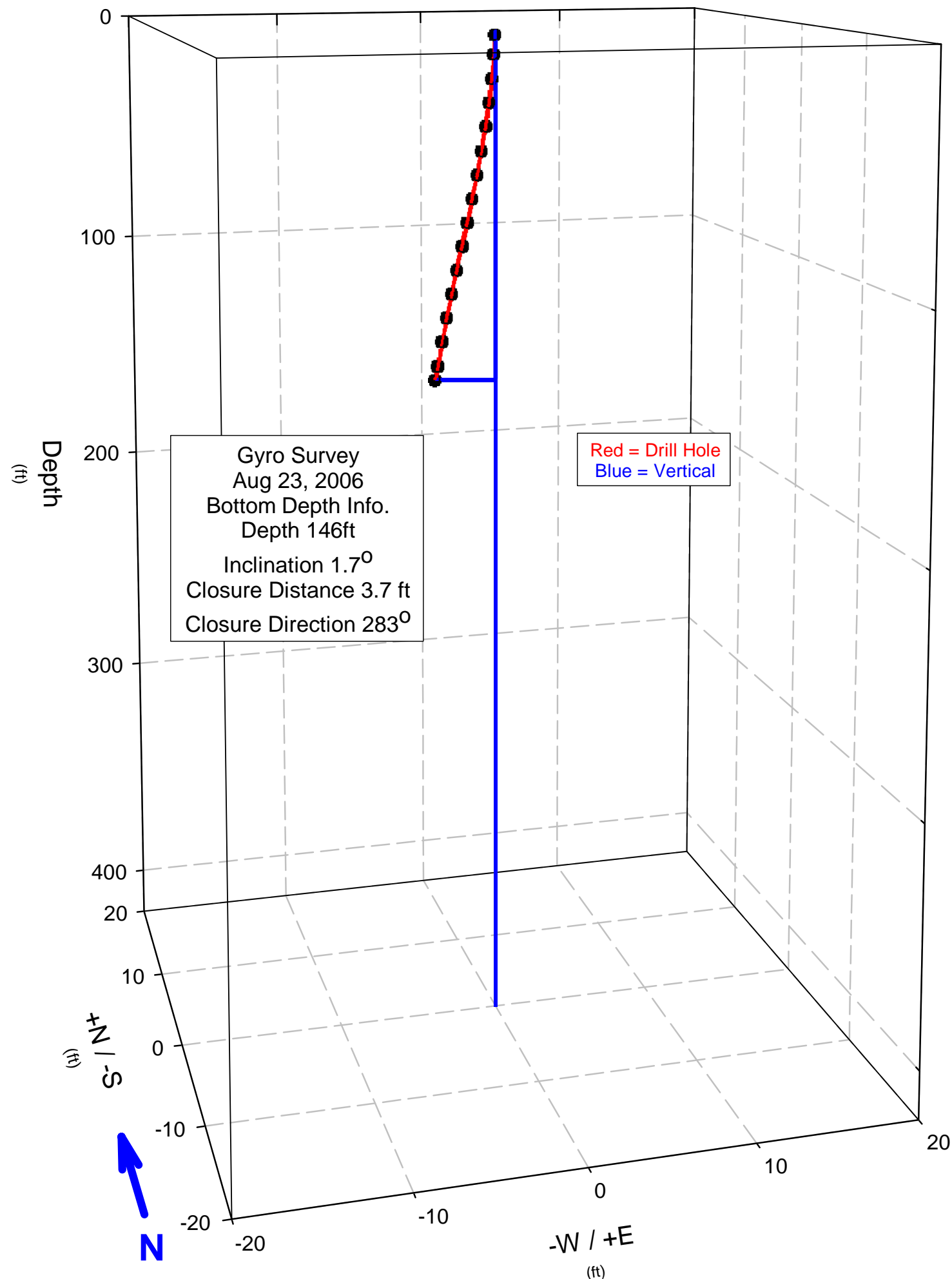


DTS-RPT-090, Rev. 0

Hole: C4993 Survey Date: 8/23/2006

\begin{tabular}{|c|c|c|c|c|c|c|c|}
\hline Measure & TrueVer & $\begin{array}{c}\text { Inclinatio } \\
n \\
\text { from }\end{array}$ & $\begin{array}{l}\text { Closure } \\
\text { Directio }\end{array}$ & $\begin{array}{l}\text { Closure } \\
\text { Distanc }\end{array}$ & $\begin{array}{c}\text { Rectangul } \\
\text { ar } \\
\text { Coordinat }\end{array}$ & $\begin{array}{c}\text { Rectangul } \\
\text { ar } \\
\text { Coordinat }\end{array}$ & \\
\hline $\begin{array}{c}\text { d } \\
\text { Depth } \\
\text { (feet) }\end{array}$ & $\begin{array}{l}\text { t. } \\
\text { Depth } \\
\text { (feet) }\end{array}$ & $\begin{array}{l}\text { from } \\
\text { Vert. } \\
\text { (dea) }\end{array}$ & $\begin{array}{c}\text { Directio } \\
n \\
(\text { dea })\end{array}$ & $\begin{array}{c}\text { Distanc } \\
\text { e } \\
\text { (feet) }\end{array}$ & $\begin{array}{c}\text { Coordinat } \\
\text { es } \\
+\mathrm{N} / \mathrm{S} \text { S }\end{array}$ & $\begin{array}{c}\text { Coordinat } \\
\text { es } \\
+E /-W\end{array}$ & $\begin{array}{l}\text { Dog-Leg } \\
\text { Severity } \\
0 / 100-f t\end{array}$ \\
\hline 2 & 2 & 0.24 & 266.37 & 0.01 & 0 & -0.01 & 15.1 \\
\hline 10 & 10 & 0.61 & 302.38 & 0.07 & 0.04 & -0.06 & 4.6 \\
\hline 20 & 20 & 1 & 305.32 & 0.21 & 0.12 & -0.17 & 3.9 \\
\hline 30 & 30 & 1.08 & 302.61 & 0.39 & 0.21 & -0.32 & 2.5 \\
\hline 40 & 39.99 & 1.39 & 299.16 & 0.6 & 0.29 & -0.52 & 3 \\
\hline 50 & 49.99 & 1.6 & 298.12 & 0.86 & 0.4 & -0.76 & 2.6 \\
\hline 60 & 59.99 & 1.61 & 297.38 & 1.14 & 0.52 & -1.01 & 1.8 \\
\hline 70 & 69.98 & 1.84 & 296.2 & 1.44 & 0.63 & -1.29 & 2.3 \\
\hline 80 & 79.98 & 1.89 & 295.28 & 1.76 & 0.75 & -1.59 & 0.6 \\
\hline 90 & 89.97 & 1.83 & 293.8 & 2.08 & 0.84 & -1.9 & 3.3 \\
\hline 100 & 99.97 & 1.88 & 291.85 & 2.39 & 0.89 & -2.22 & 1 \\
\hline 110 & 109.96 & 1.77 & 289.99 & 2.7 & 0.92 & -2.54 & 1.7 \\
\hline 120 & 119.96 & 1.89 & 288.13 & 3.01 & 0.94 & -2.86 & 1.6 \\
\hline 130 & 129.95 & 1.56 & 286.29 & 3.29 & 0.92 & -3.16 & 3.8 \\
\hline 140 & 139.95 & 1.68 & 284.51 & 3.55 & 0.89 & -3.44 & 1.3 \\
\hline 146 & 145.95 & 1.64 & 283.49 & 3.71 & 0.87 & -3.61 & 0.8 \\
\hline
\end{tabular}


DTS-RPT-090, Rev. 0

\section{Hole: C4993}

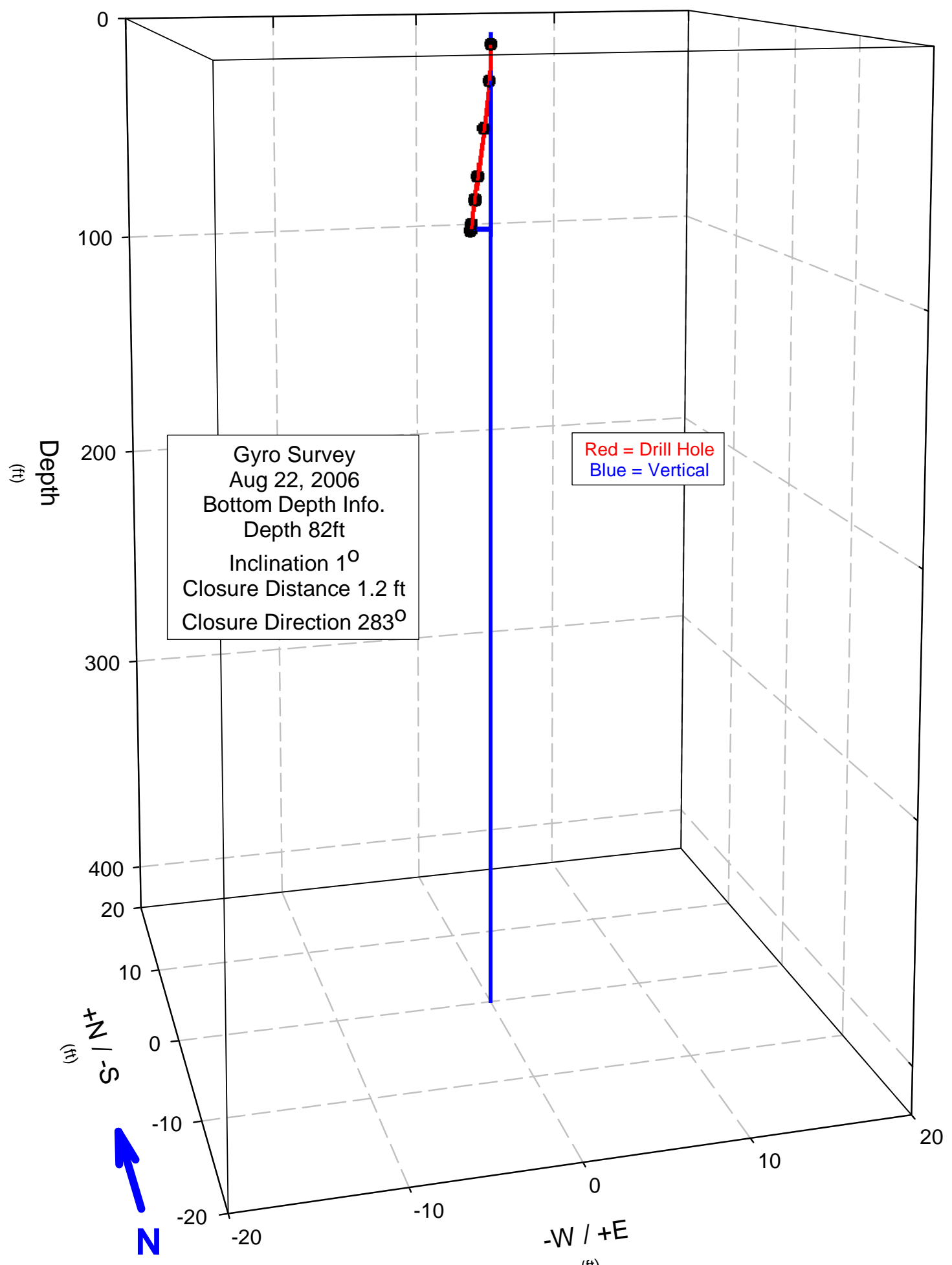


DTS-RPT-090, Rev. 0

\section{Hole: C4993 Survey Date: 8/22/2006}

\begin{tabular}{|c|c|c|c|c|c|c|c|}
\hline & & Inclinatio & & & Rectangul & Rectangul & \\
\hline Measure & TrueVer & $\mathrm{n}$ & Closure & Closure & ar & ar & \\
\hline & & from & Directio & Distanc & Coordinat & Coordinat & Dog-Leg \\
\hline Depth & Depth & Vert. & $\mathrm{n}$ & & es & es & Severity \\
\hline (feet) & (feet) & (deg) & (deg) & (feet) & $+\mathrm{N} /-\mathrm{S}$ & $+E /-W$ & $\% / 100-f t$ \\
\hline 5 & 5 & 0.27 & 52.54 & 0.03 & 0.02 & 0.03 & 23.6 \\
\hline 20 & 20 & 0.9 & 326.3 & 0.09 & 0.08 & -0.05 & 7.4 \\
\hline 40 & 40 & 1.1 & 305.74 & 0.41 & 0.24 & -0.34 & 3.3 \\
\hline 60 & 59.99 & 1.14 & 291.85 & 0.78 & 0.29 & -0.72 & 1.3 \\
\hline 70 & 69.99 & 1.16 & 286.64 & 0.96 & 0.27 & -0.92 & 1.8 \\
\hline 80 & 79.99 & 1.13 & 283.42 & 1.15 & 0.27 & -1.12 & 2.5 \\
\hline 82.5 & 82.49 & 1.1 & 283.06 & 1.2 & 0.27 & -1.17 & 1.8 \\
\hline
\end{tabular}


DTS-RPT-090, Rev. 0

\section{A1.2 ENERGYSOLUTIONS AND PACIFIC NORTHWEST GEOPHYSICS CALIPER LOGS}
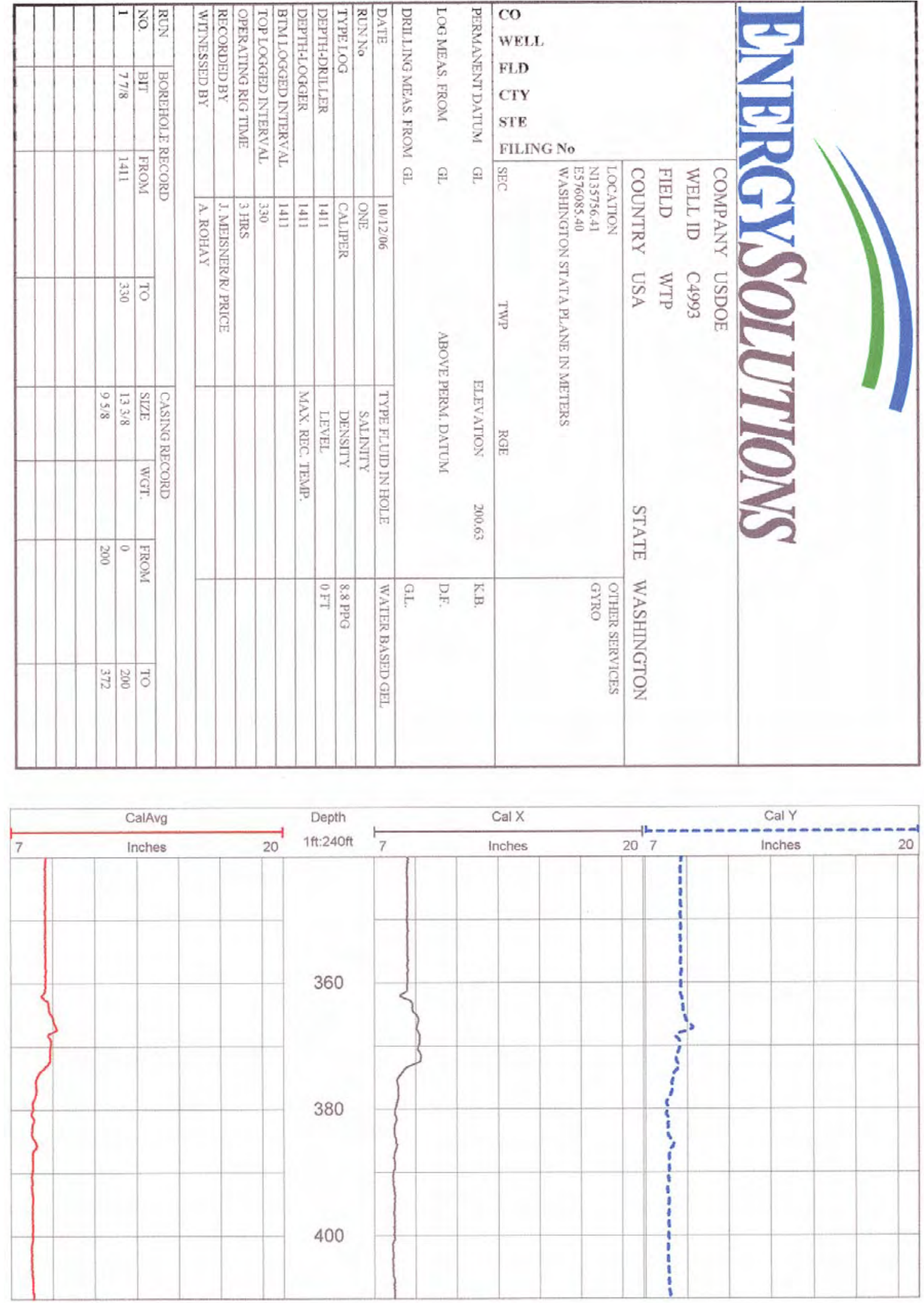
DTS-RPT-090, Rev. 0

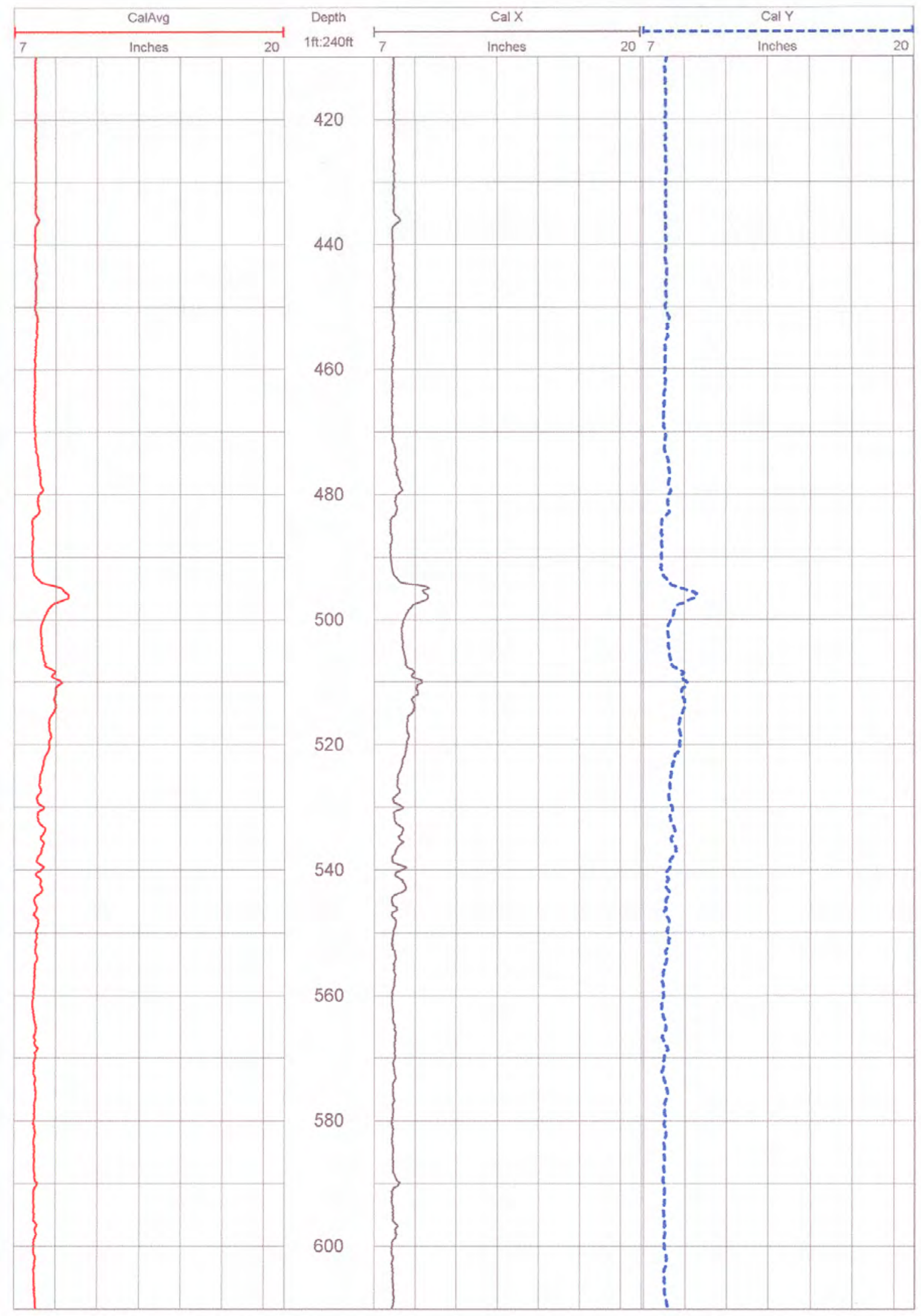


DTS-RPT-090, Rev. 0

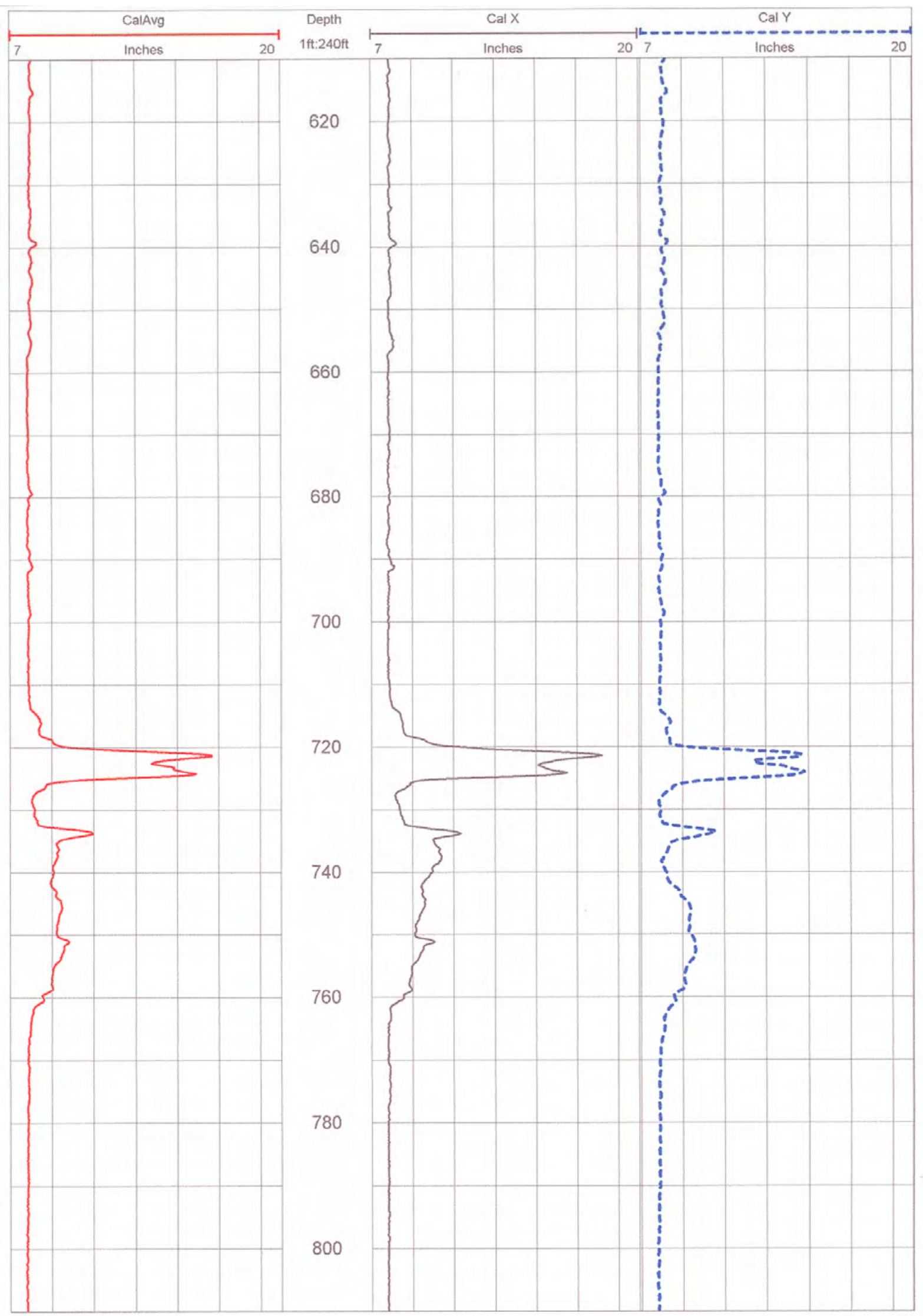


DTS-RPT-090, Rev. 0

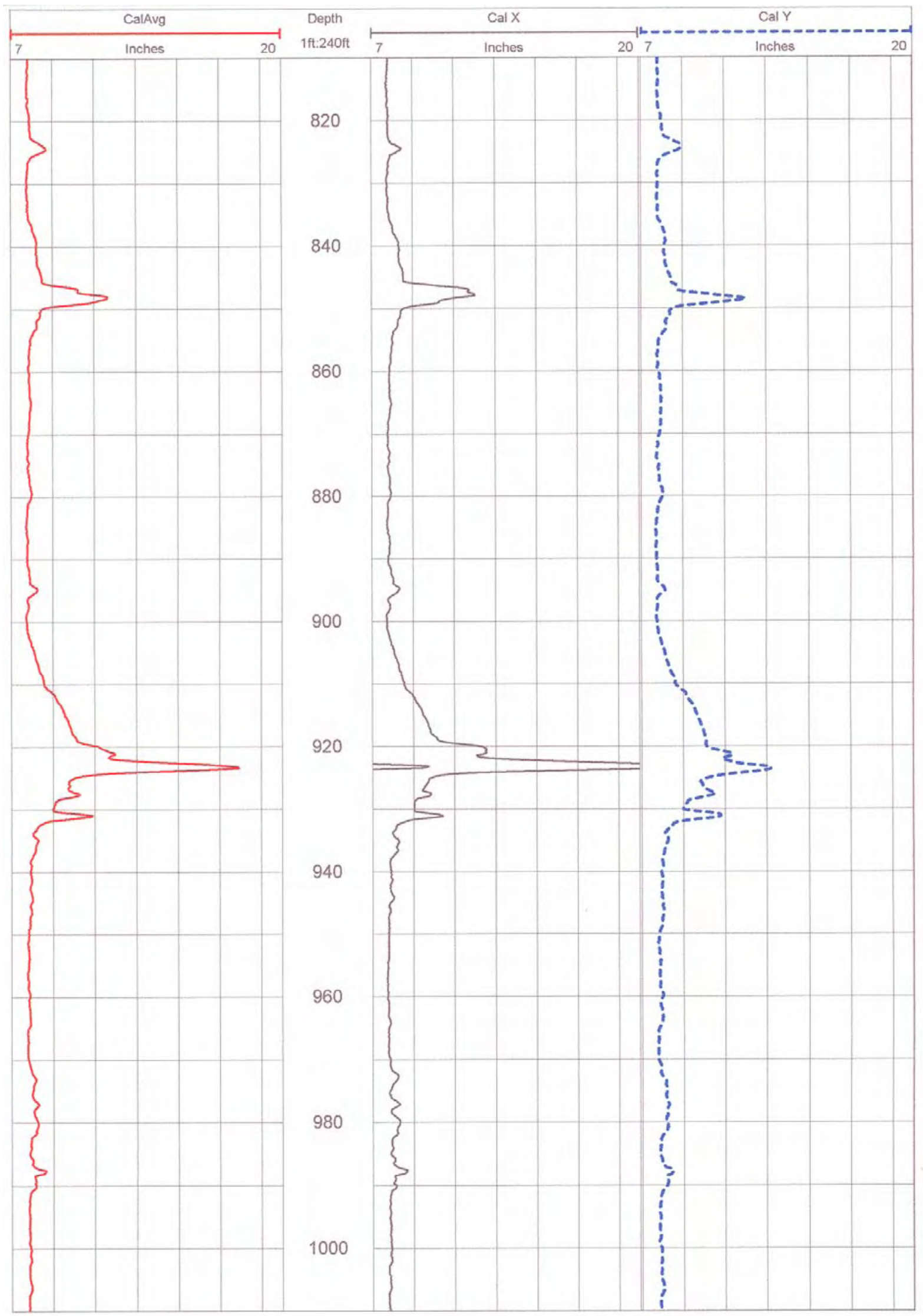


DTS-RPT-090, Rev. 0

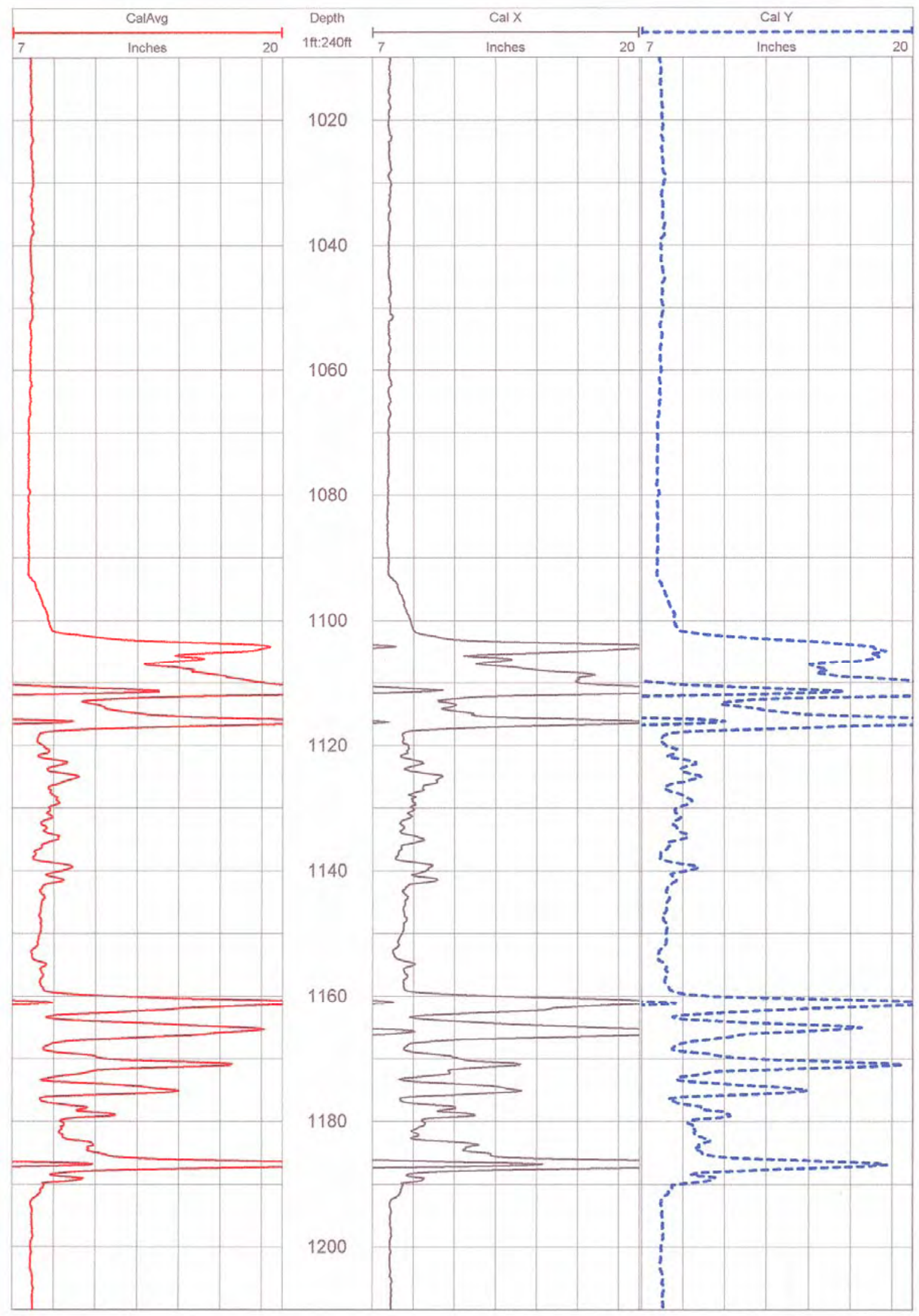


DTS-RPT-090, Rev. 0

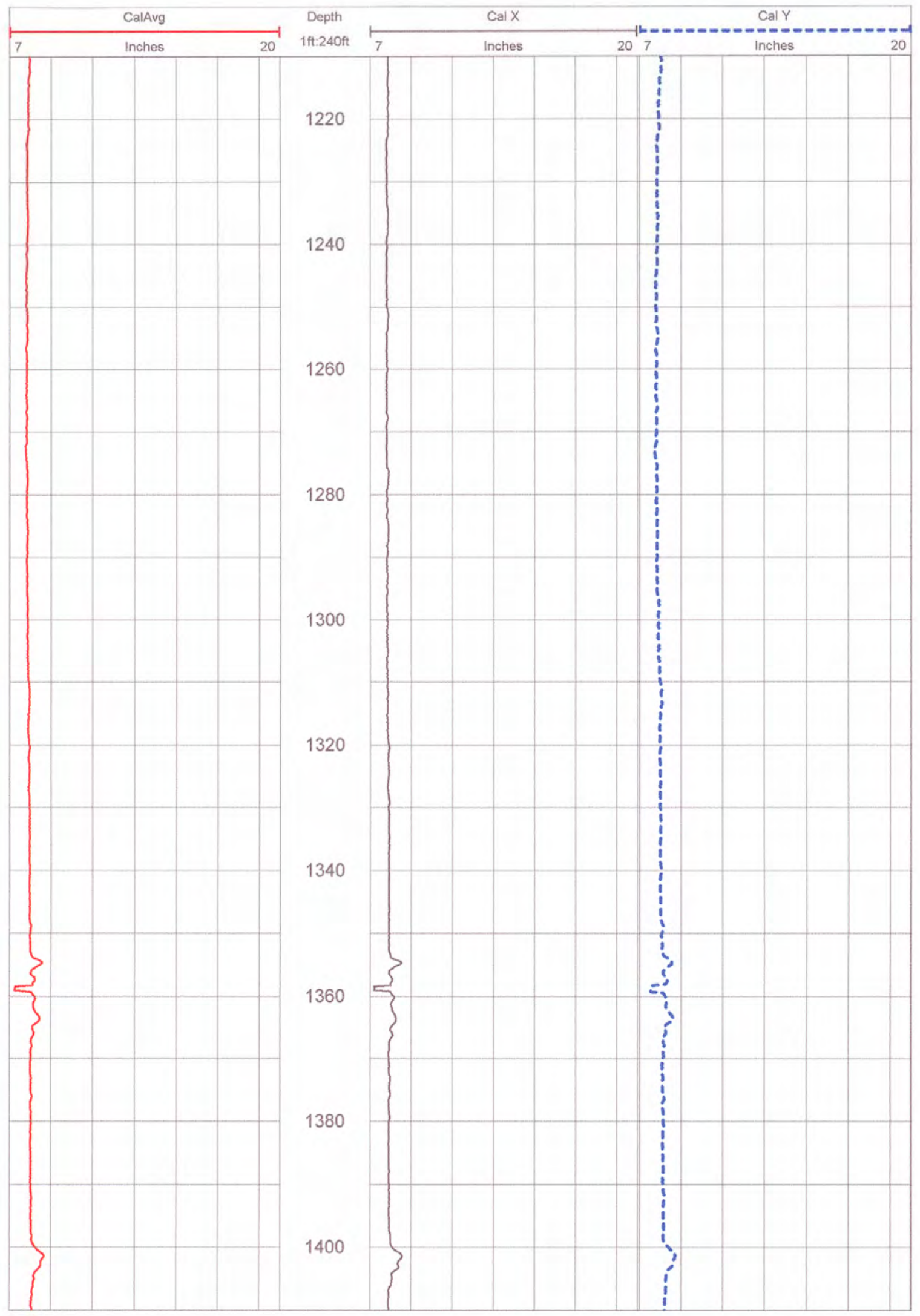


DTS-RPT-090, Rev. 0

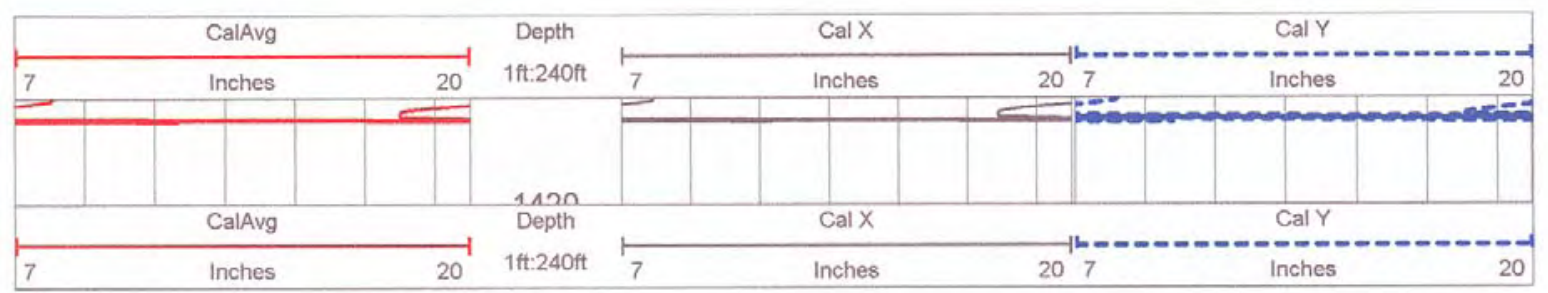


DTS-RPT-090, Rev. 0
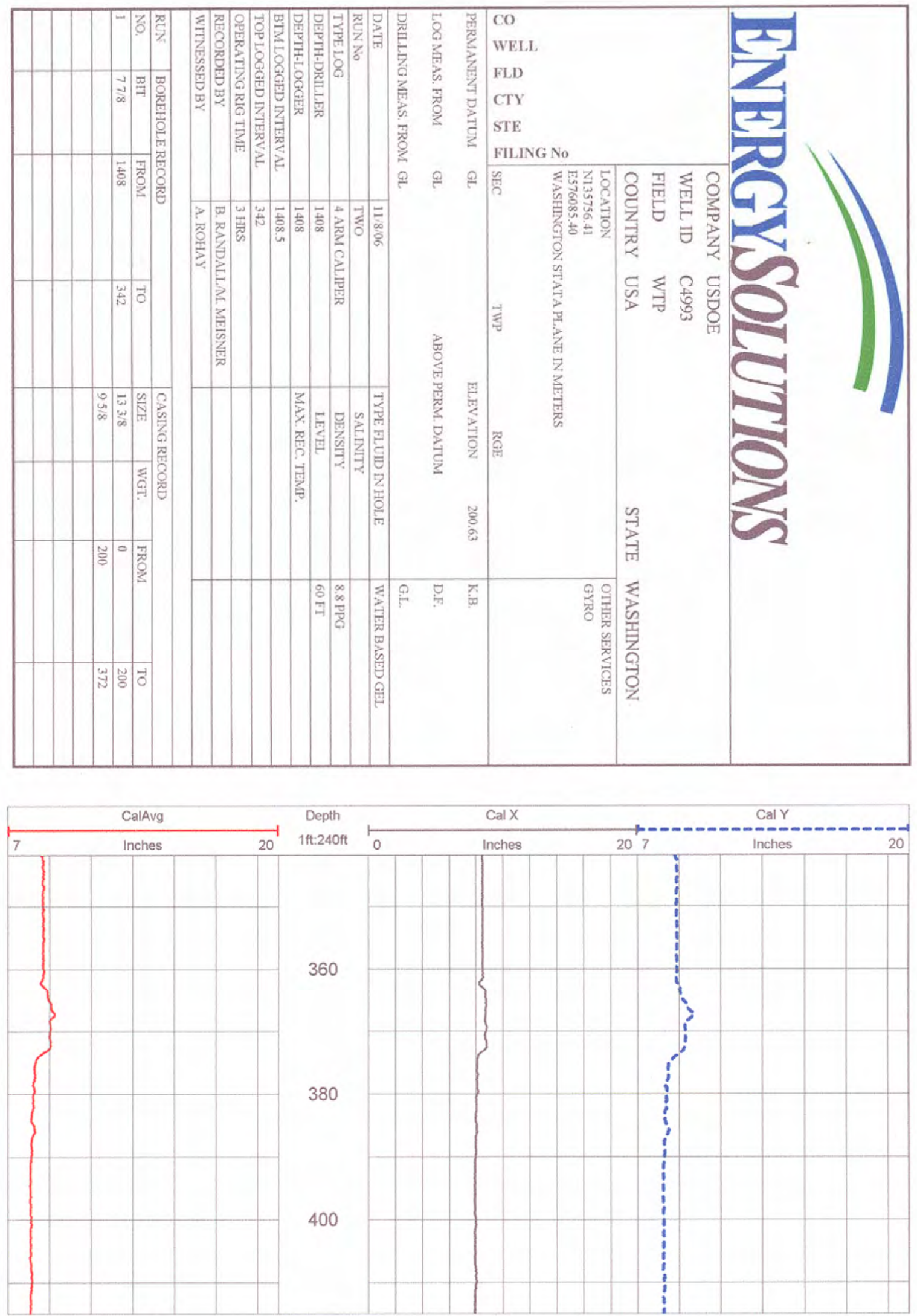
DTS-RPT-090, Rev. 0

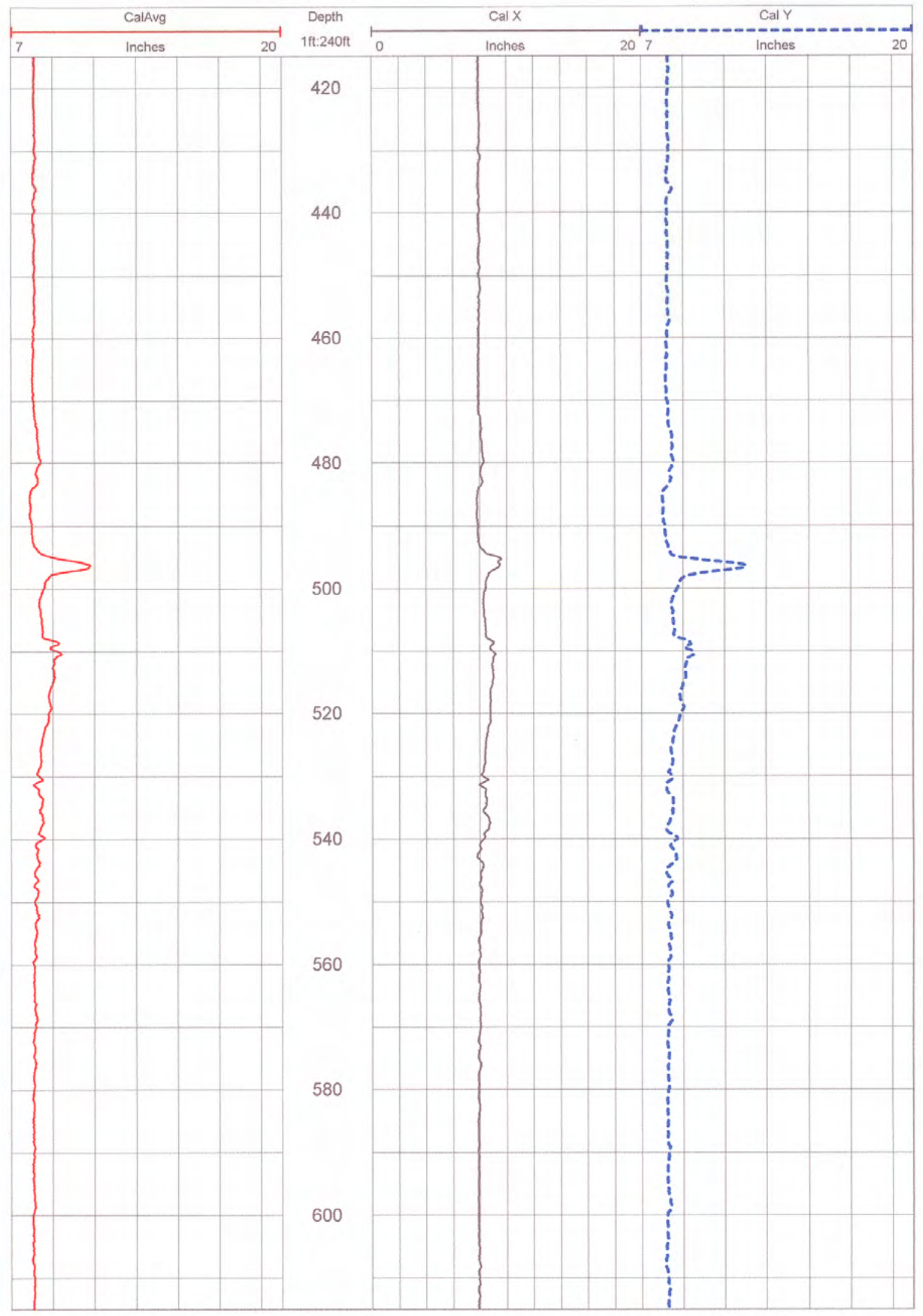


DTS-RPT-090, Rev. 0

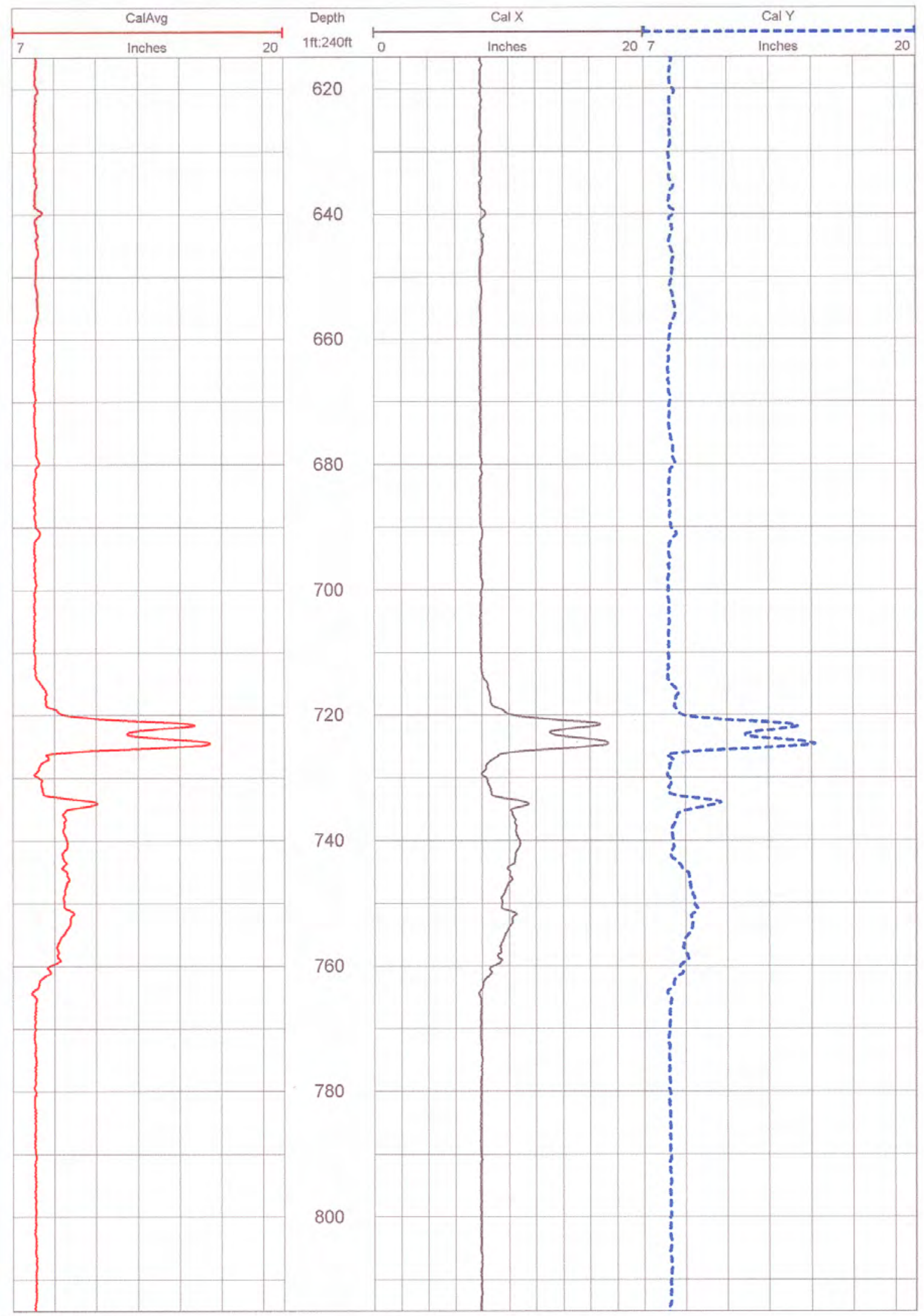


DTS-RPT-090, Rev. 0

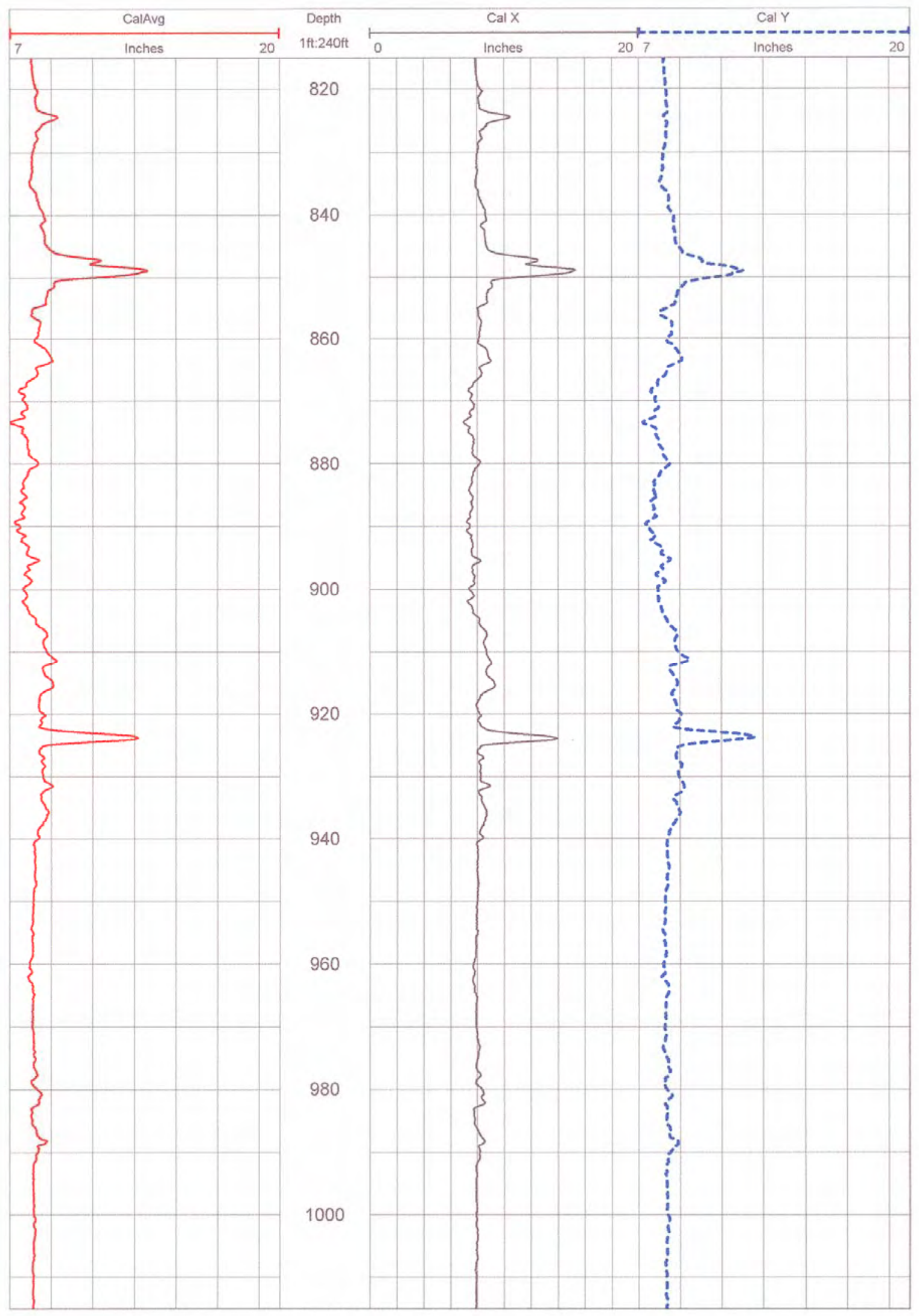


DTS-RPT-090, Rev. 0

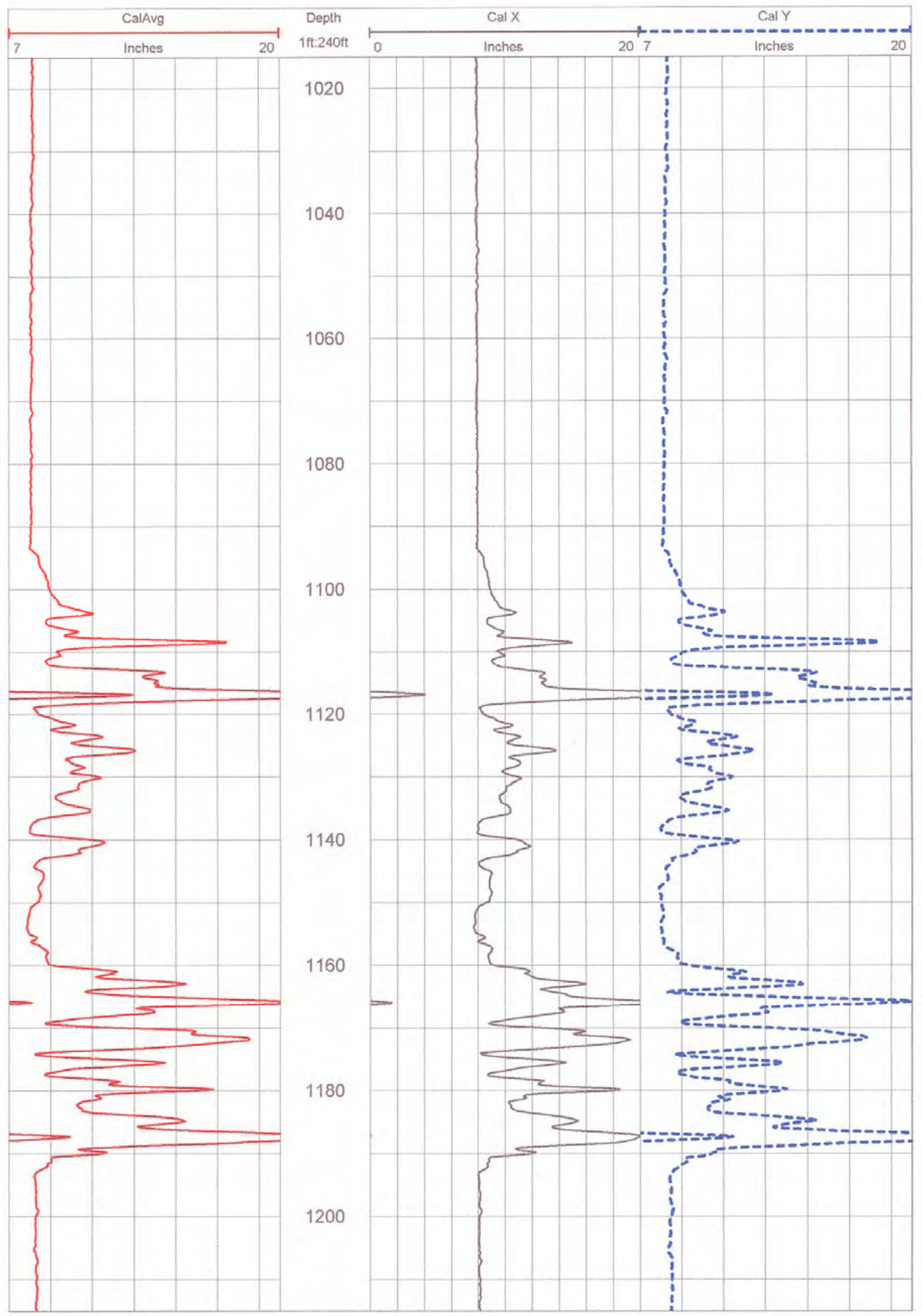


DTS-RPT-090, Rev. 0

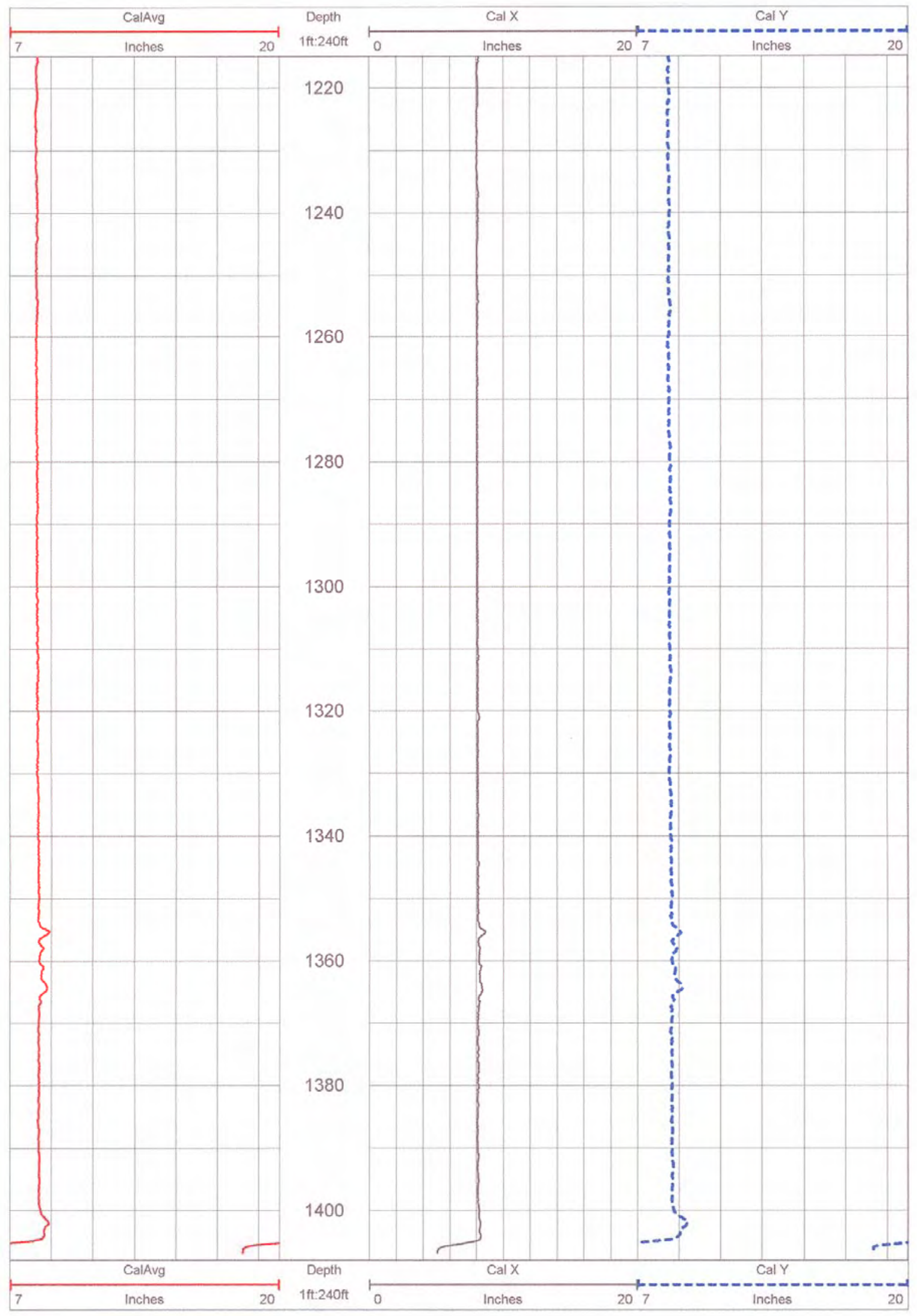


DTS-RPT-090, Rev. 0
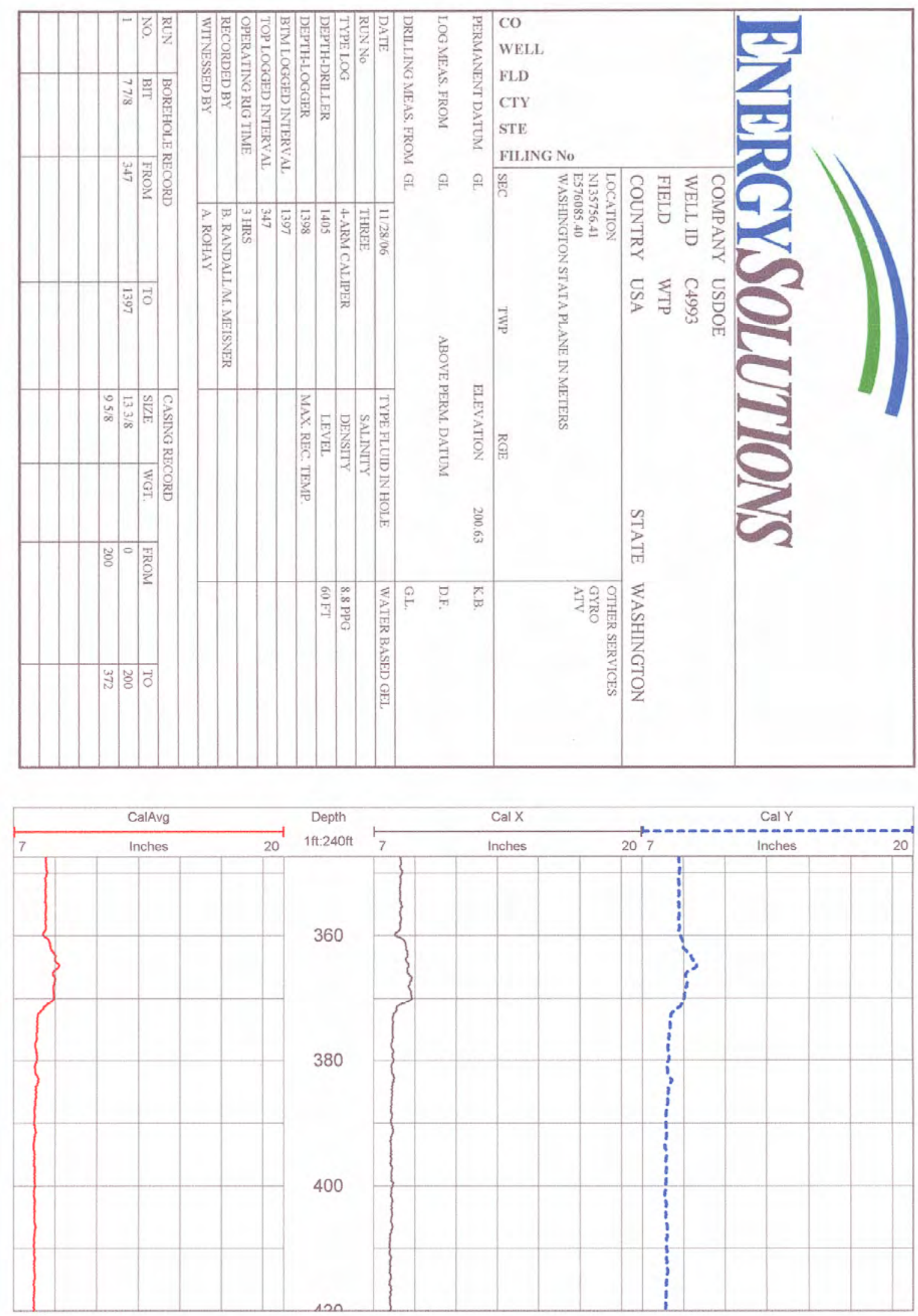
DTS-RPT-090, Rev. 0

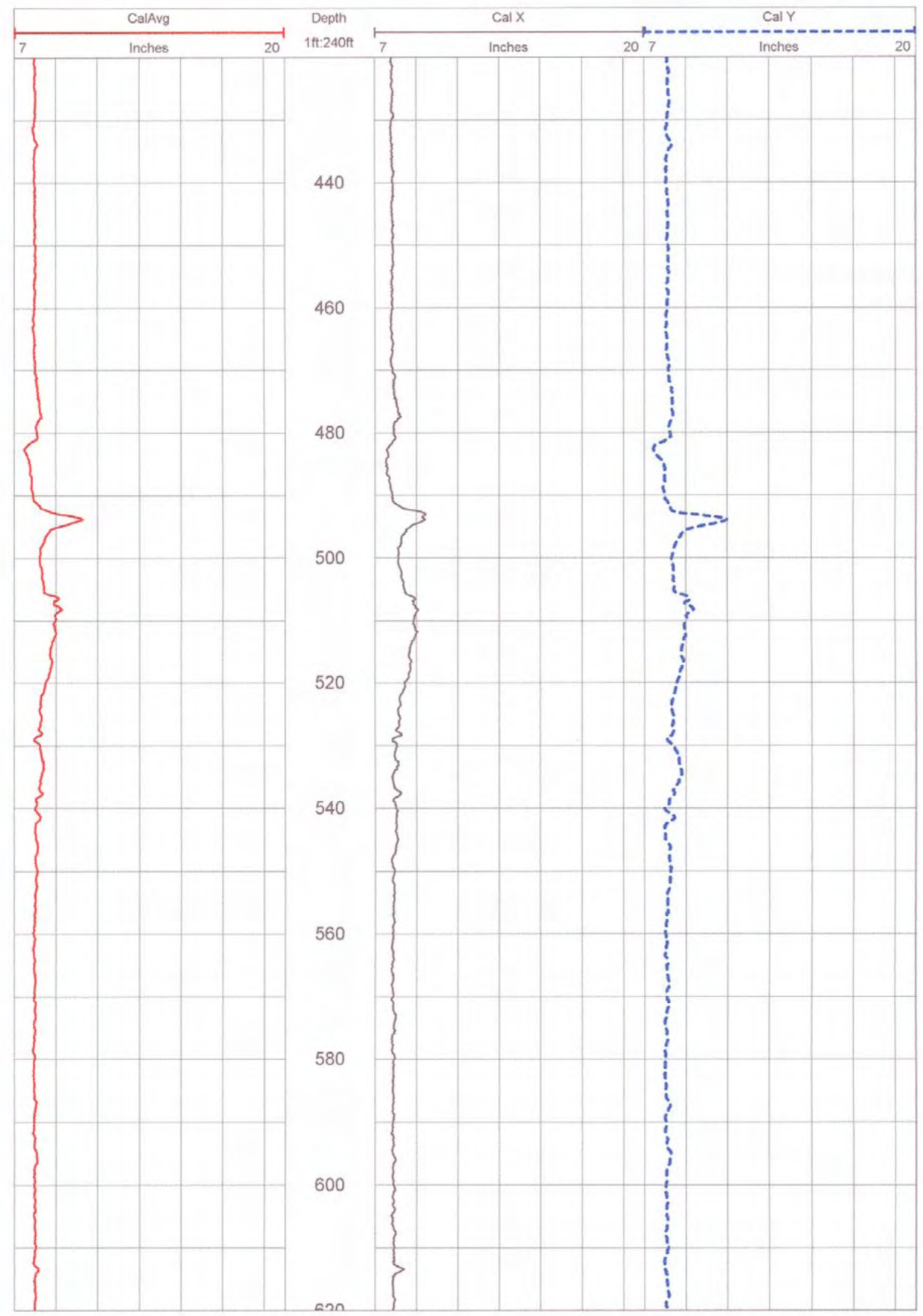


DTS-RPT-090, Rev. 0

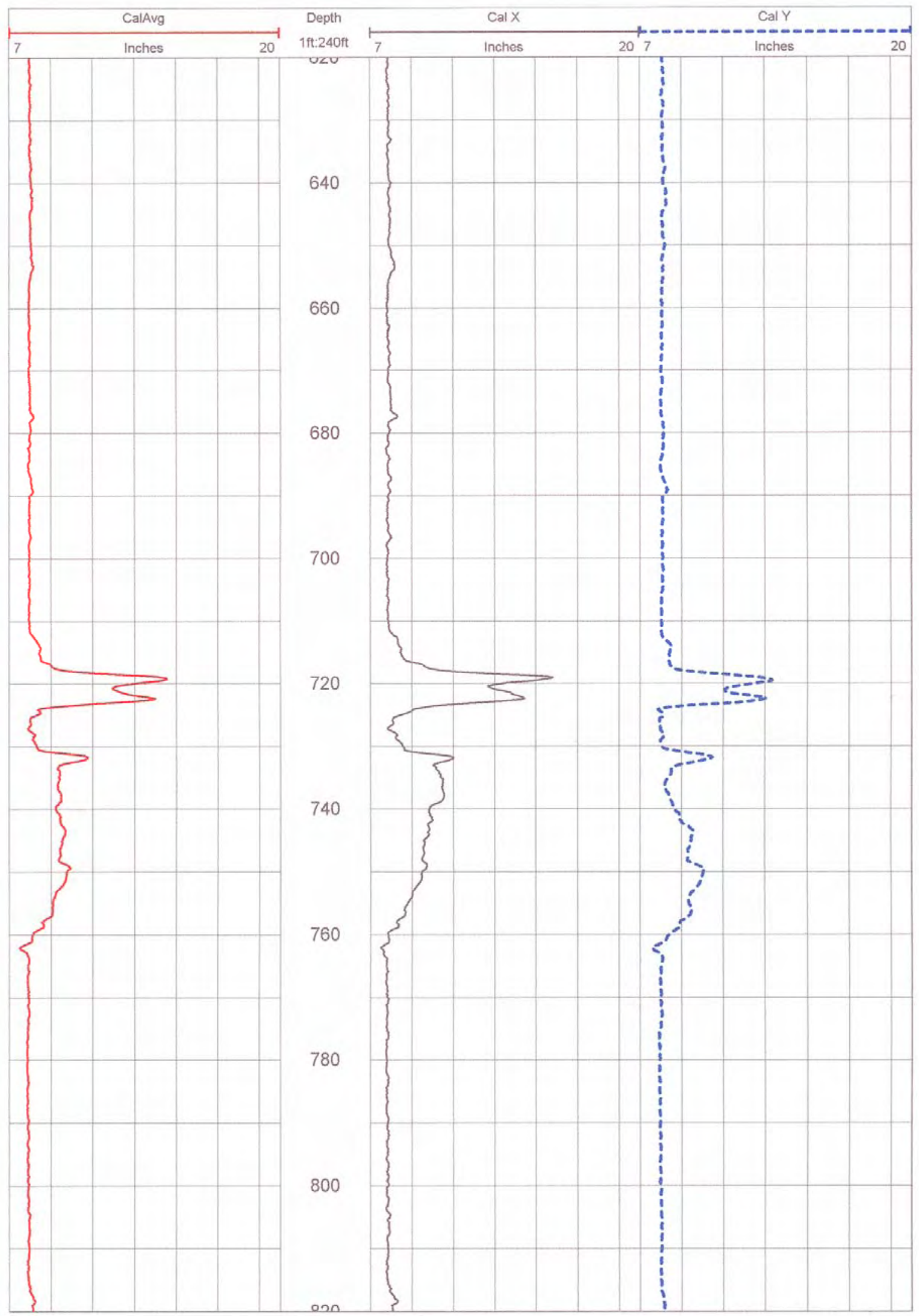


DTS-RPT-090, Rev. 0

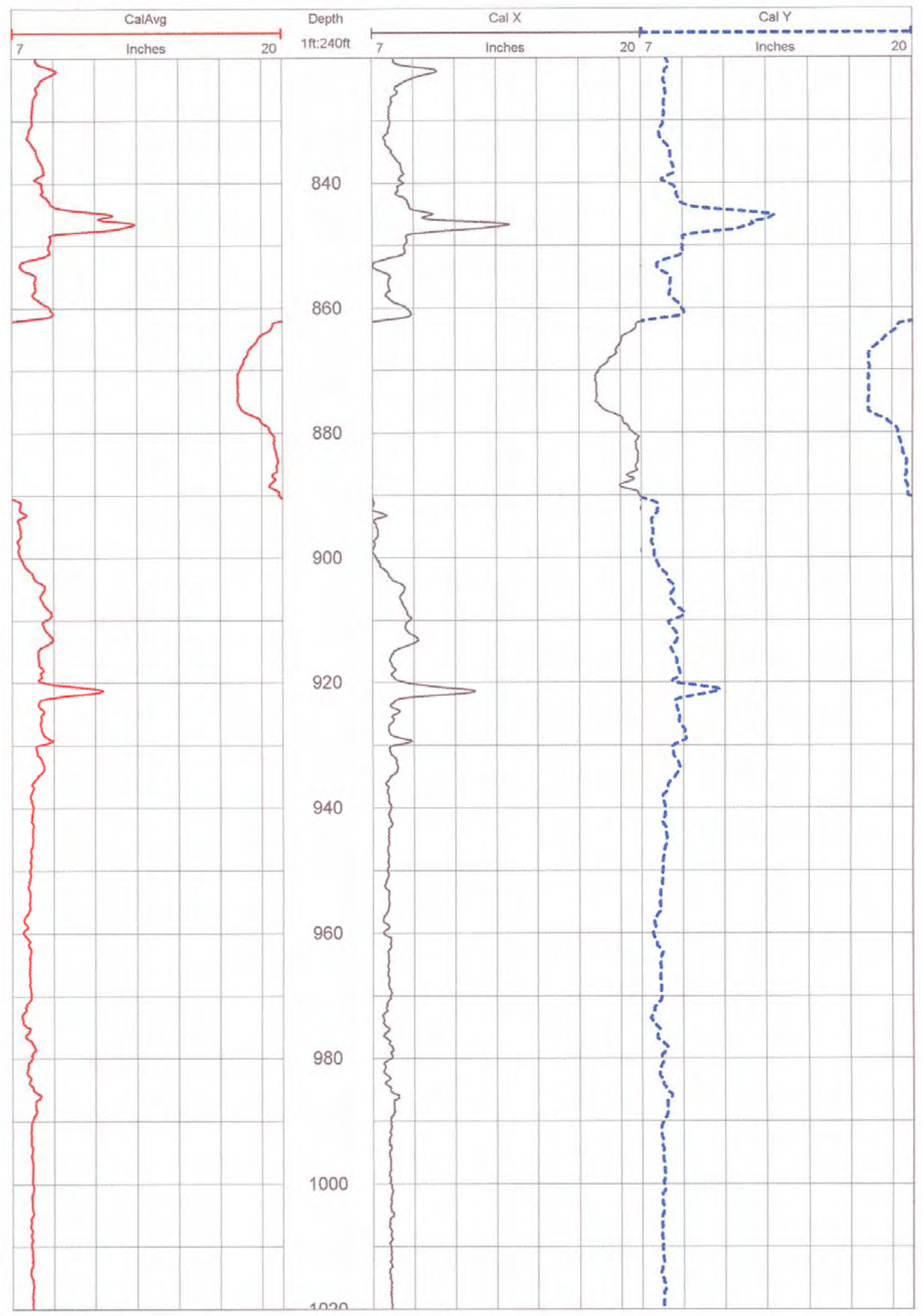


DTS-RPT-090, Rev. 0

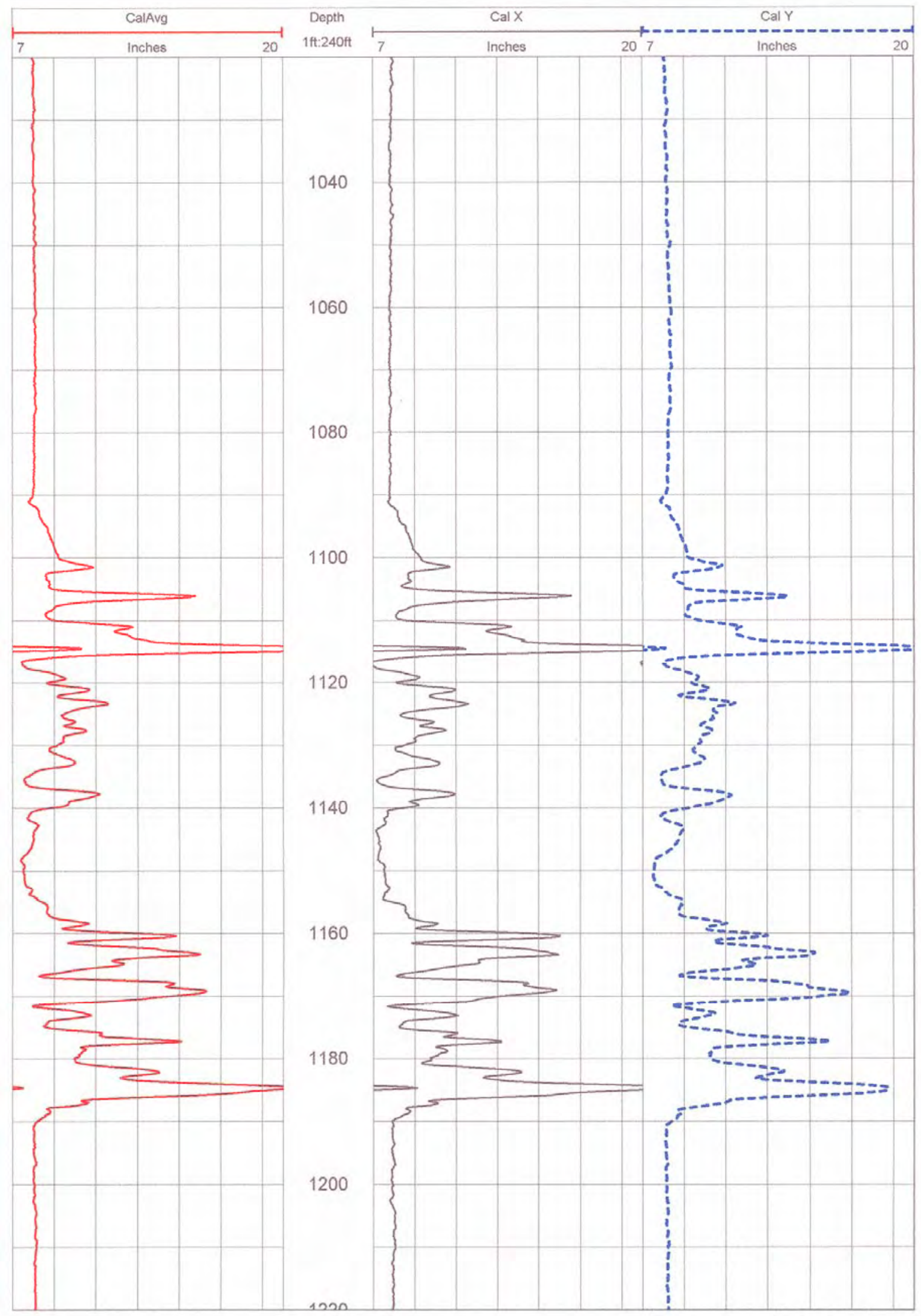


DTS-RPT-090, Rev. 0

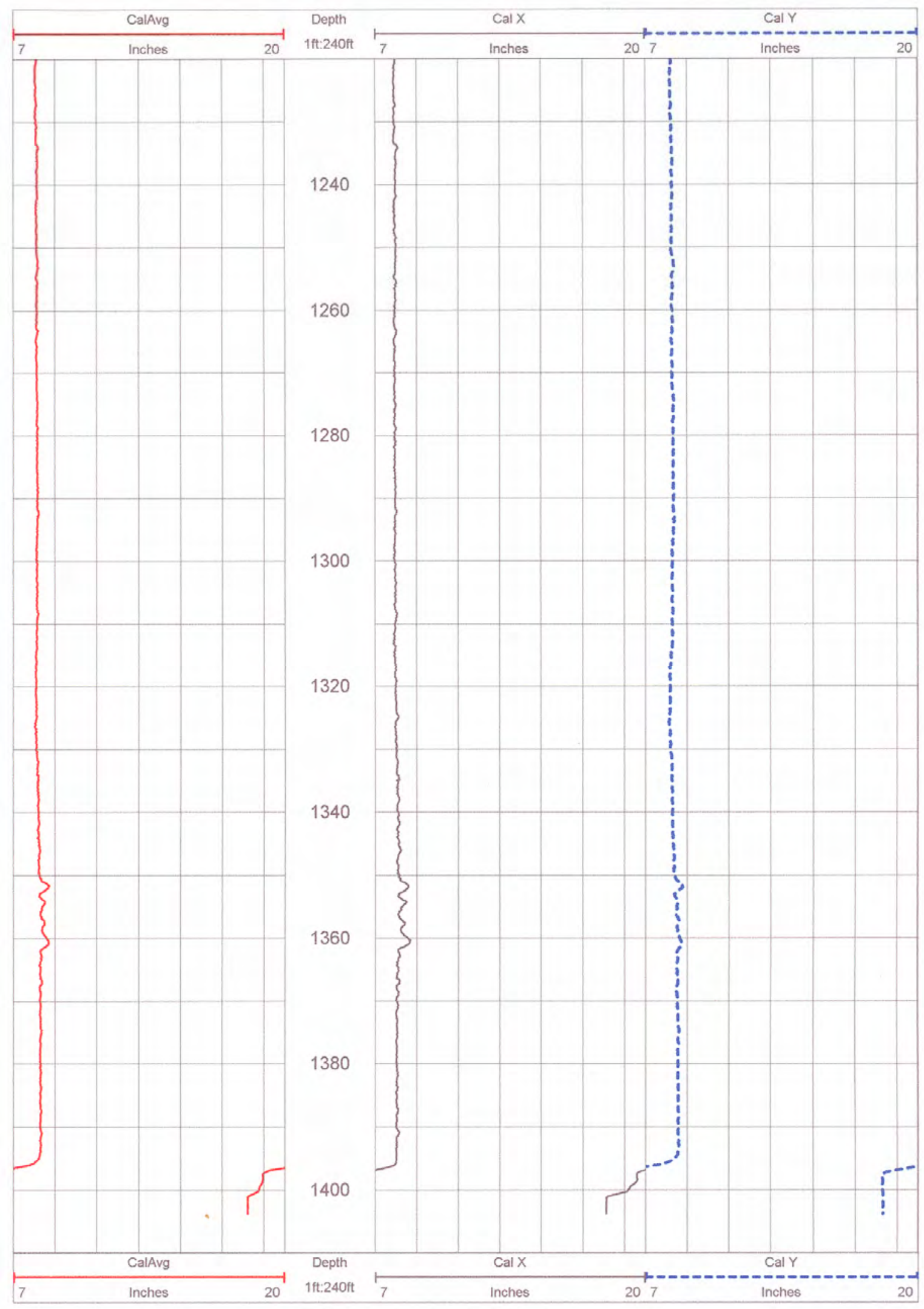


DTS-RPT-090, Rev. 0

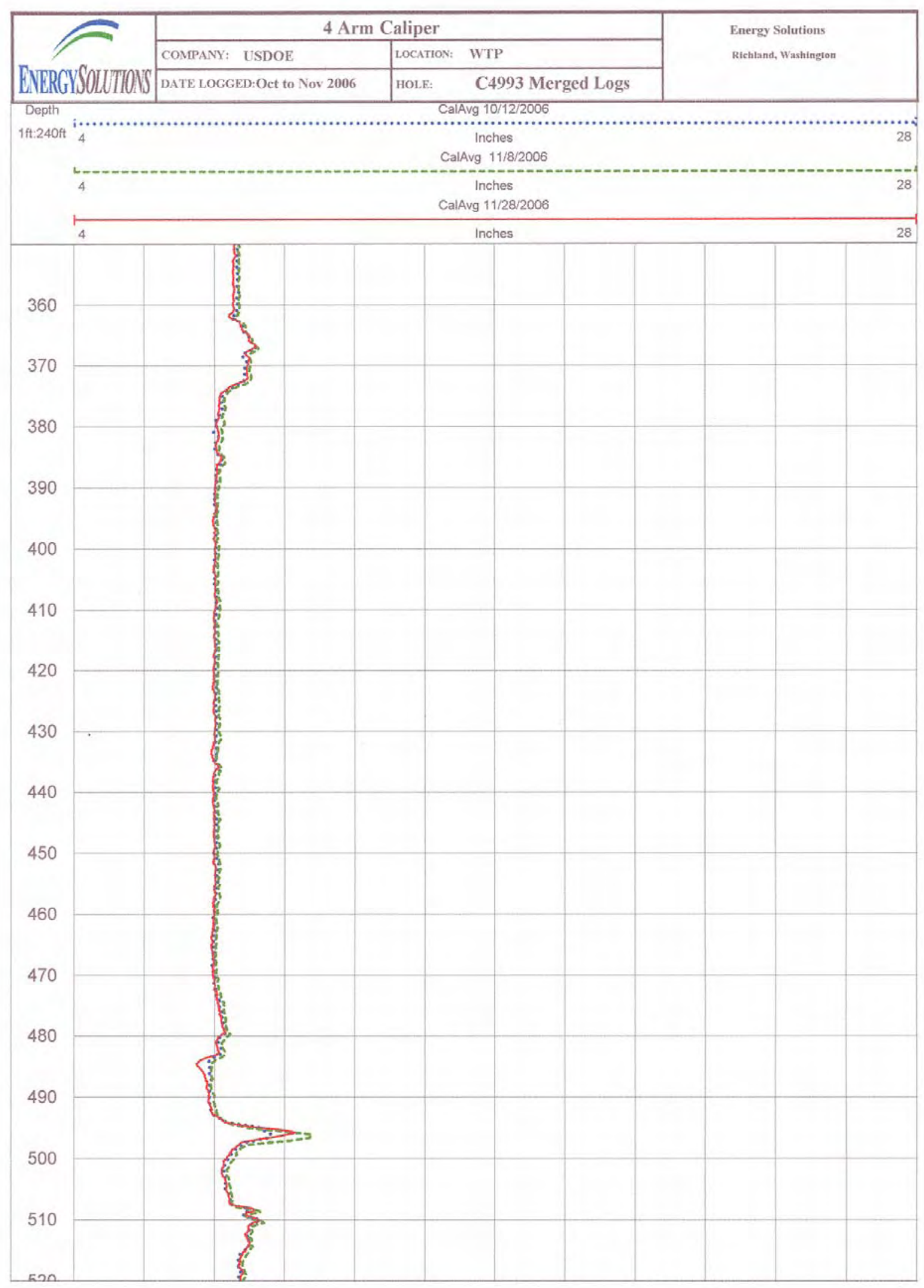


DTS-RPT-090, Rev. 0

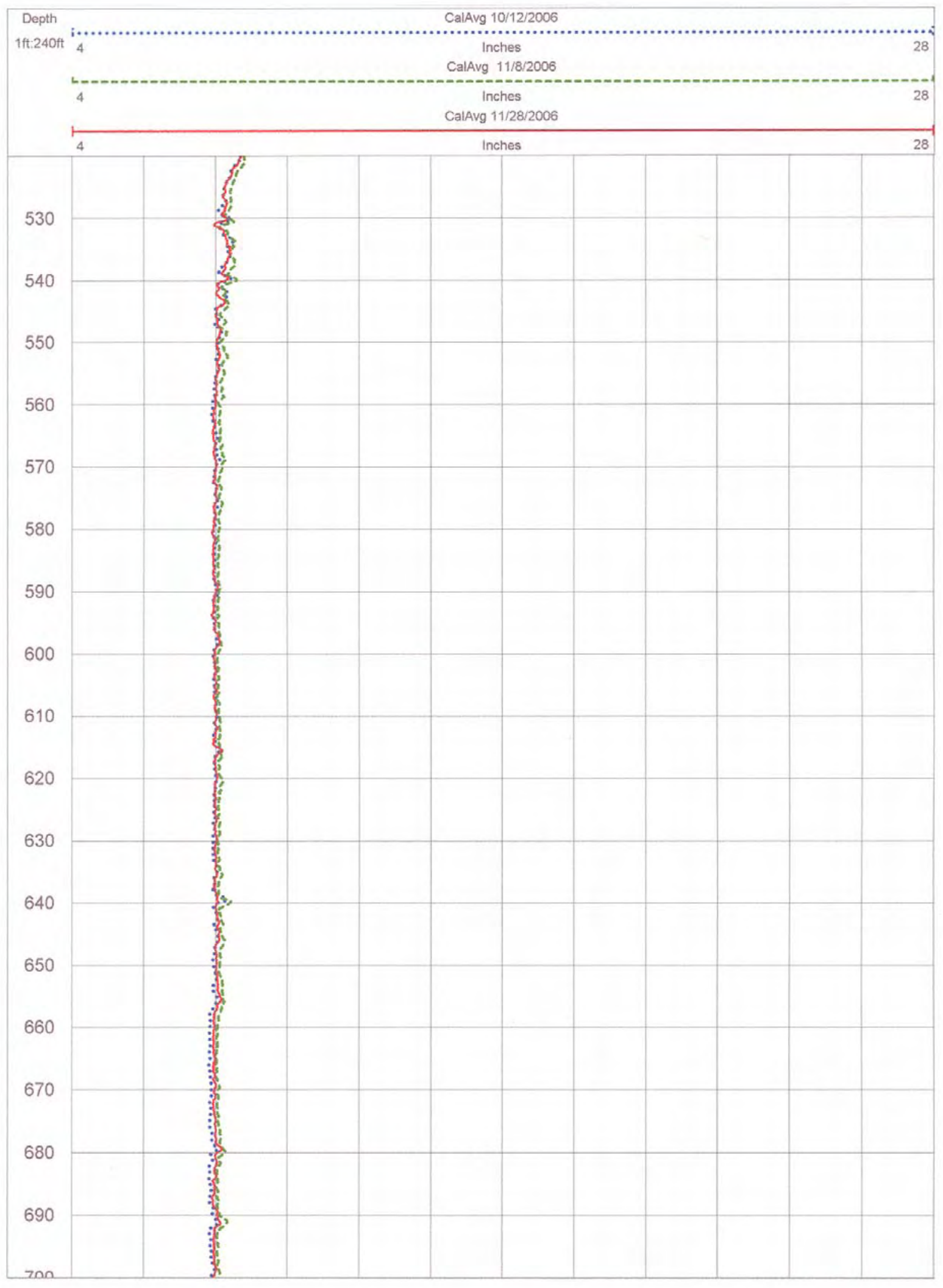


DTS-RPT-090, Rev. 0

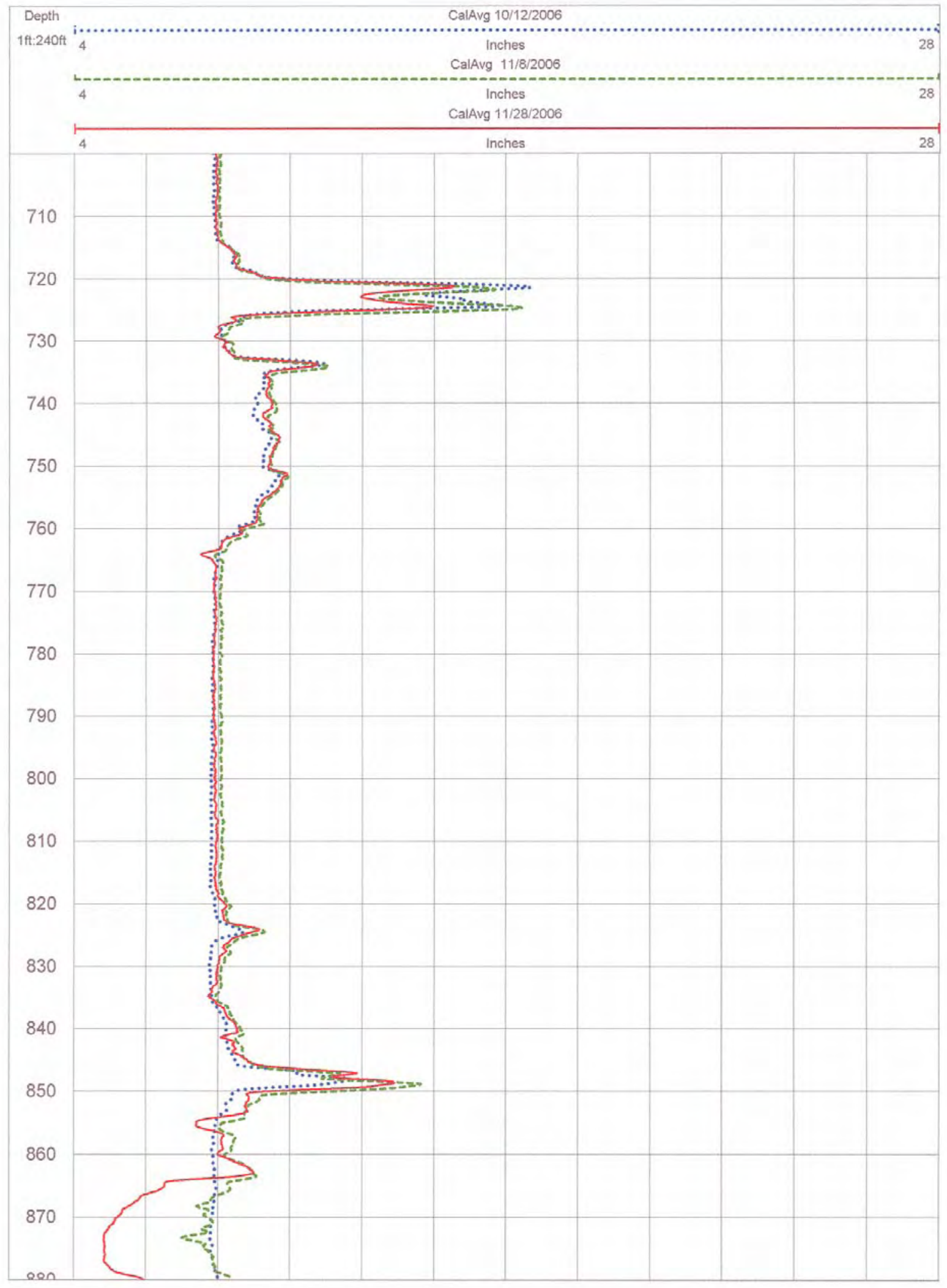


DTS-RPT-090, Rev. 0

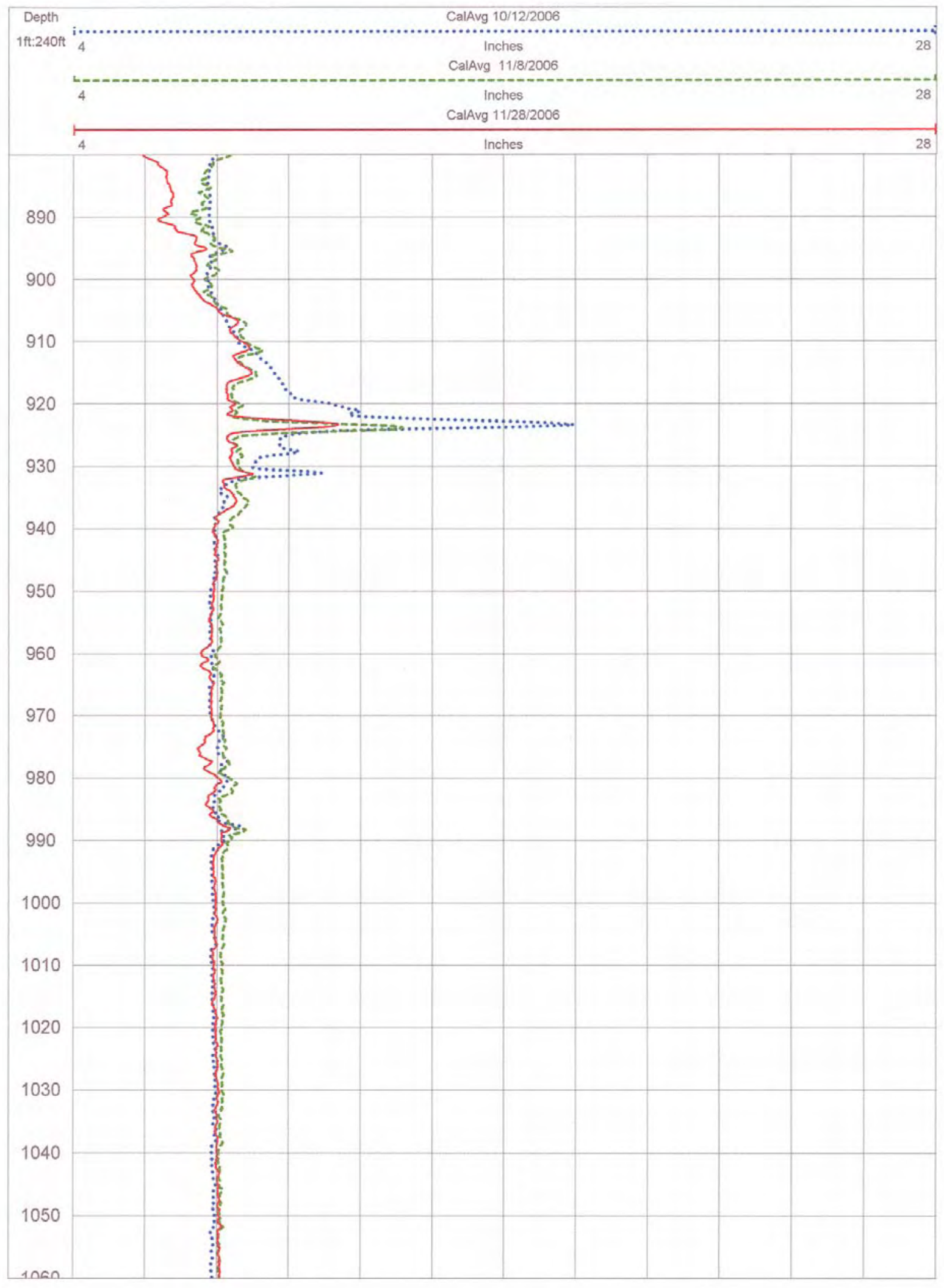


DTS-RPT-090, Rev. 0

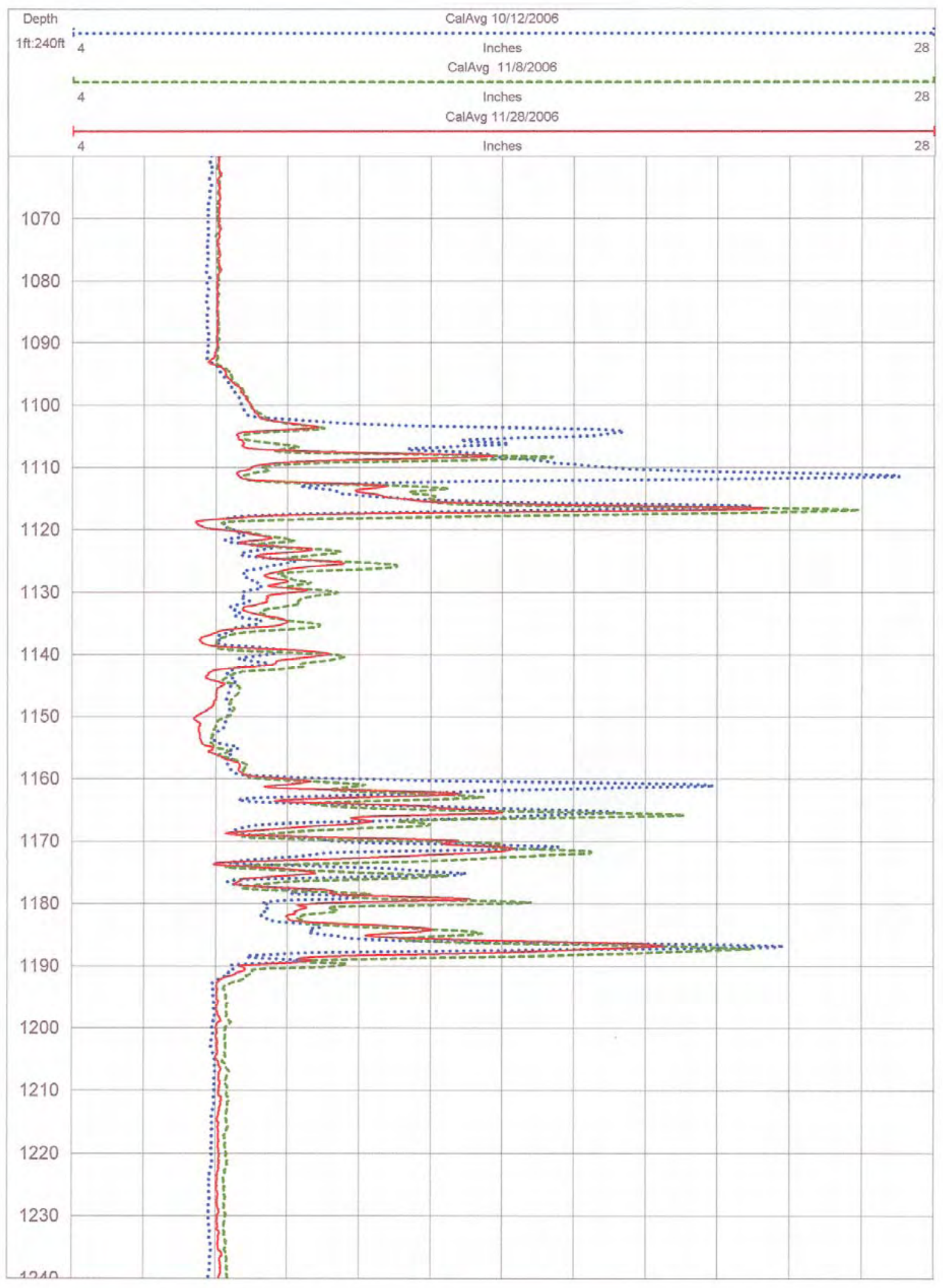


DTS-RPT-090, Rev. 0

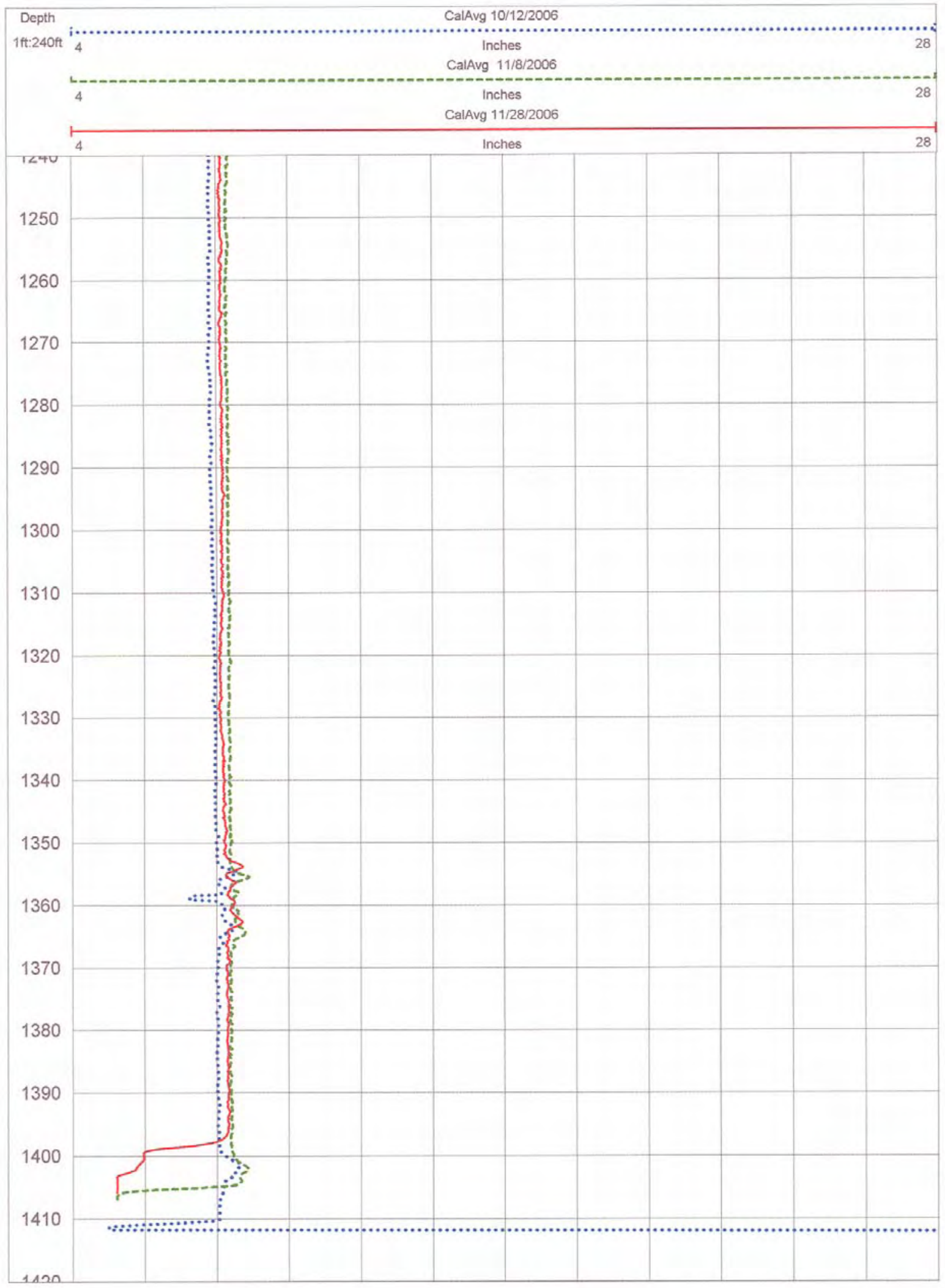


DTS-RPT-090, Rev. 0

\section{A1.3 COLOG MERGED LOGS}

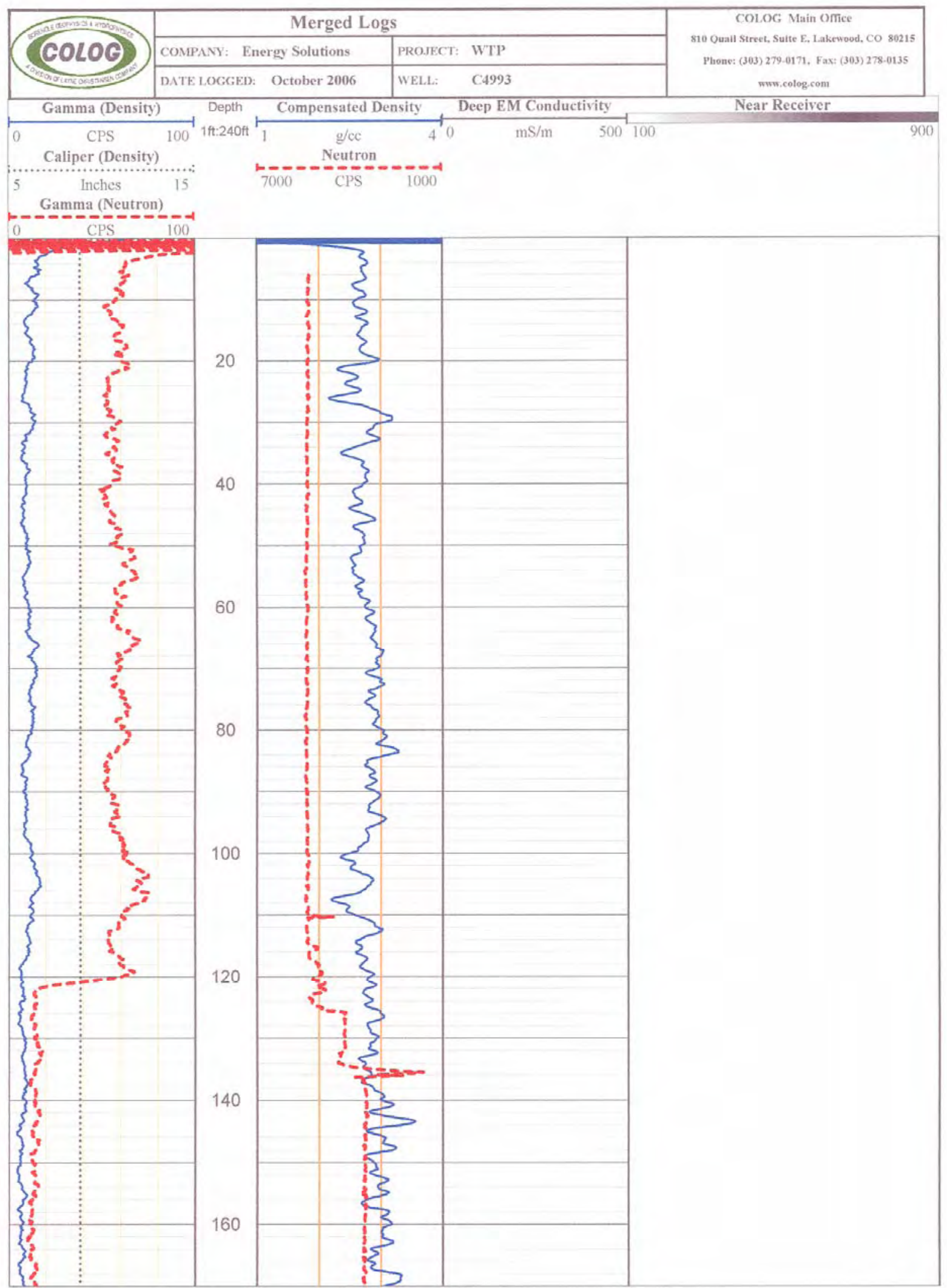


DTS-RPT-090, Rev. 0

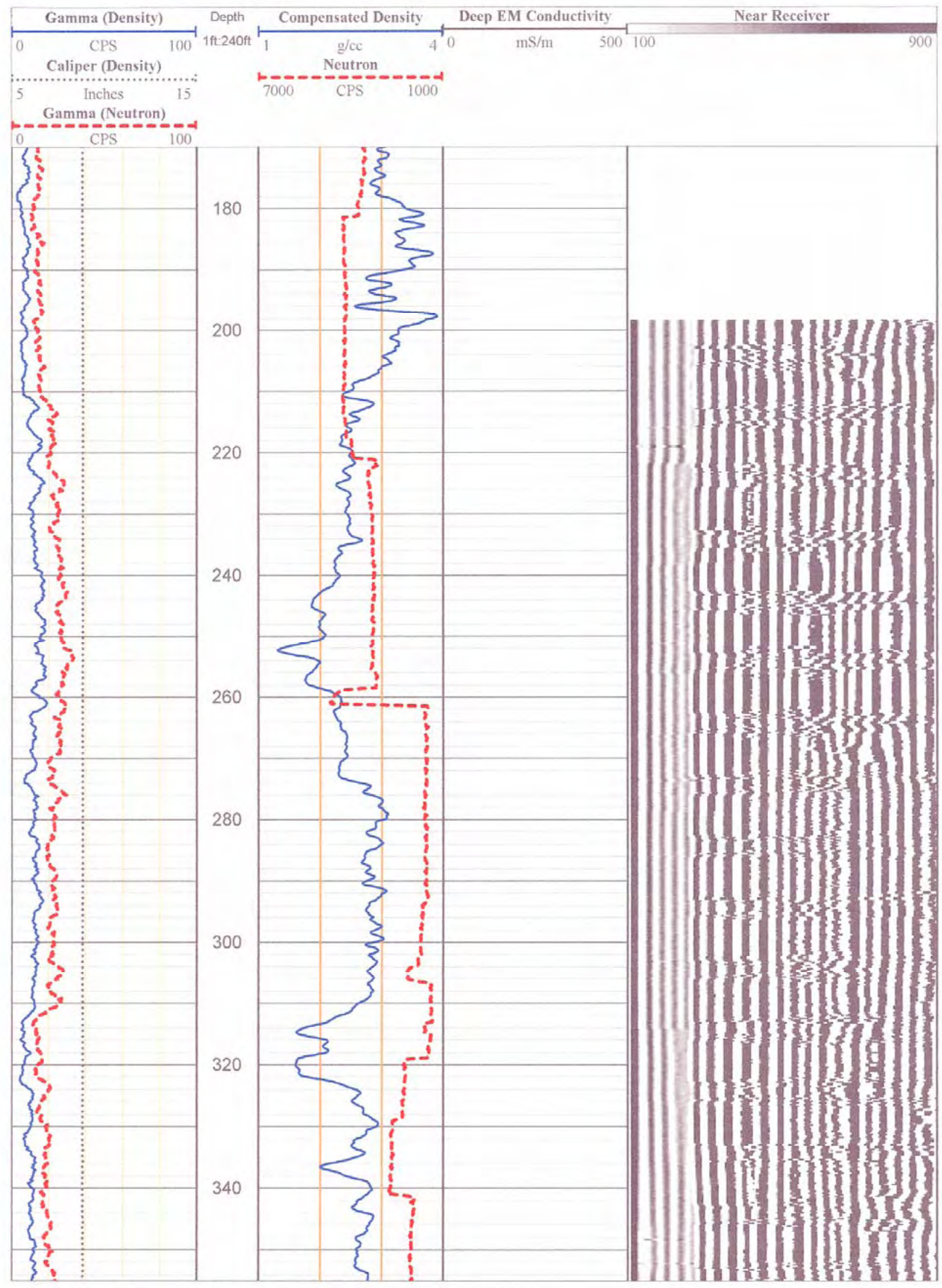


DTS-RPT-090, Rev. 0

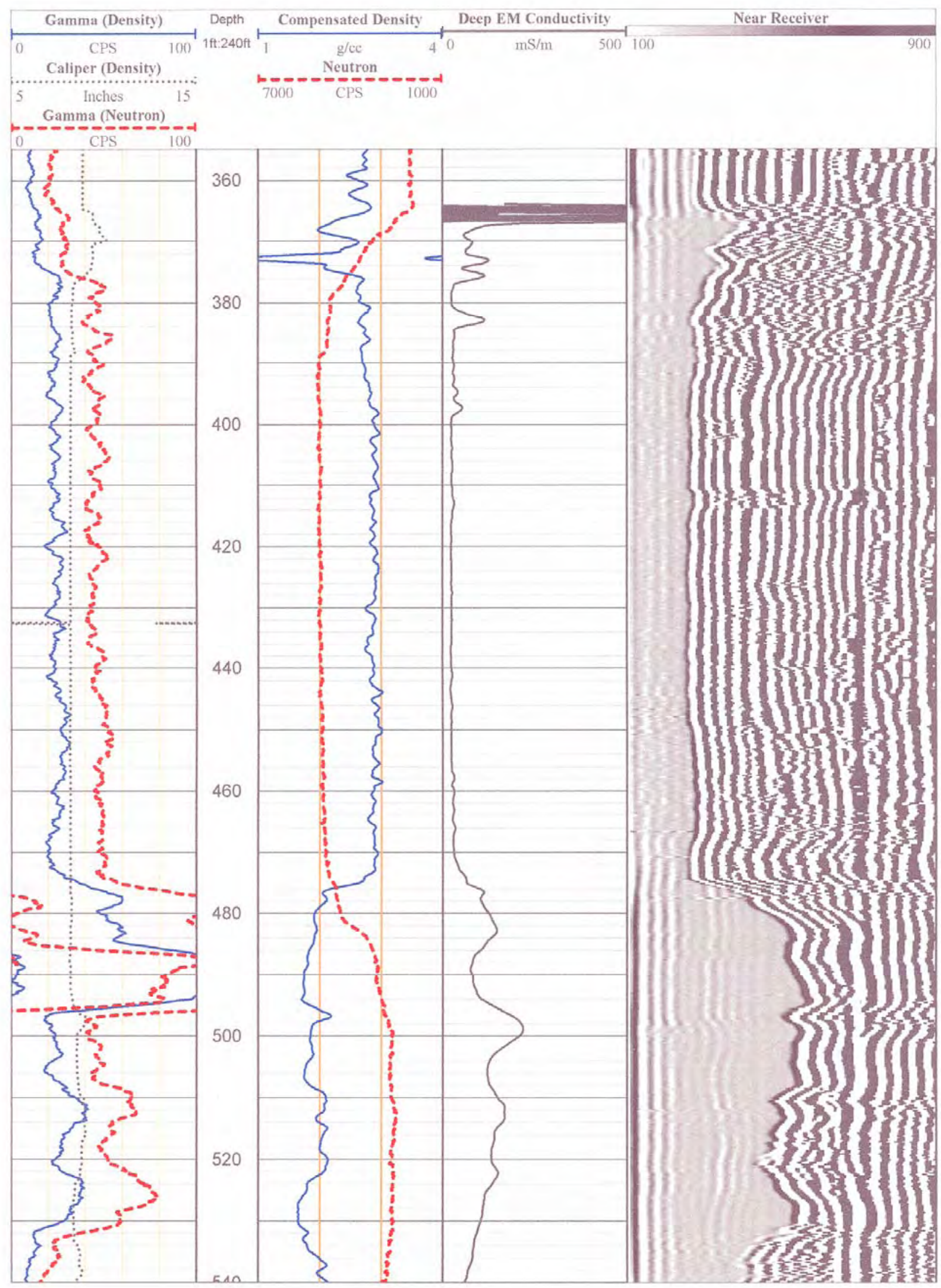


DTS-RPT-090, Rev. 0

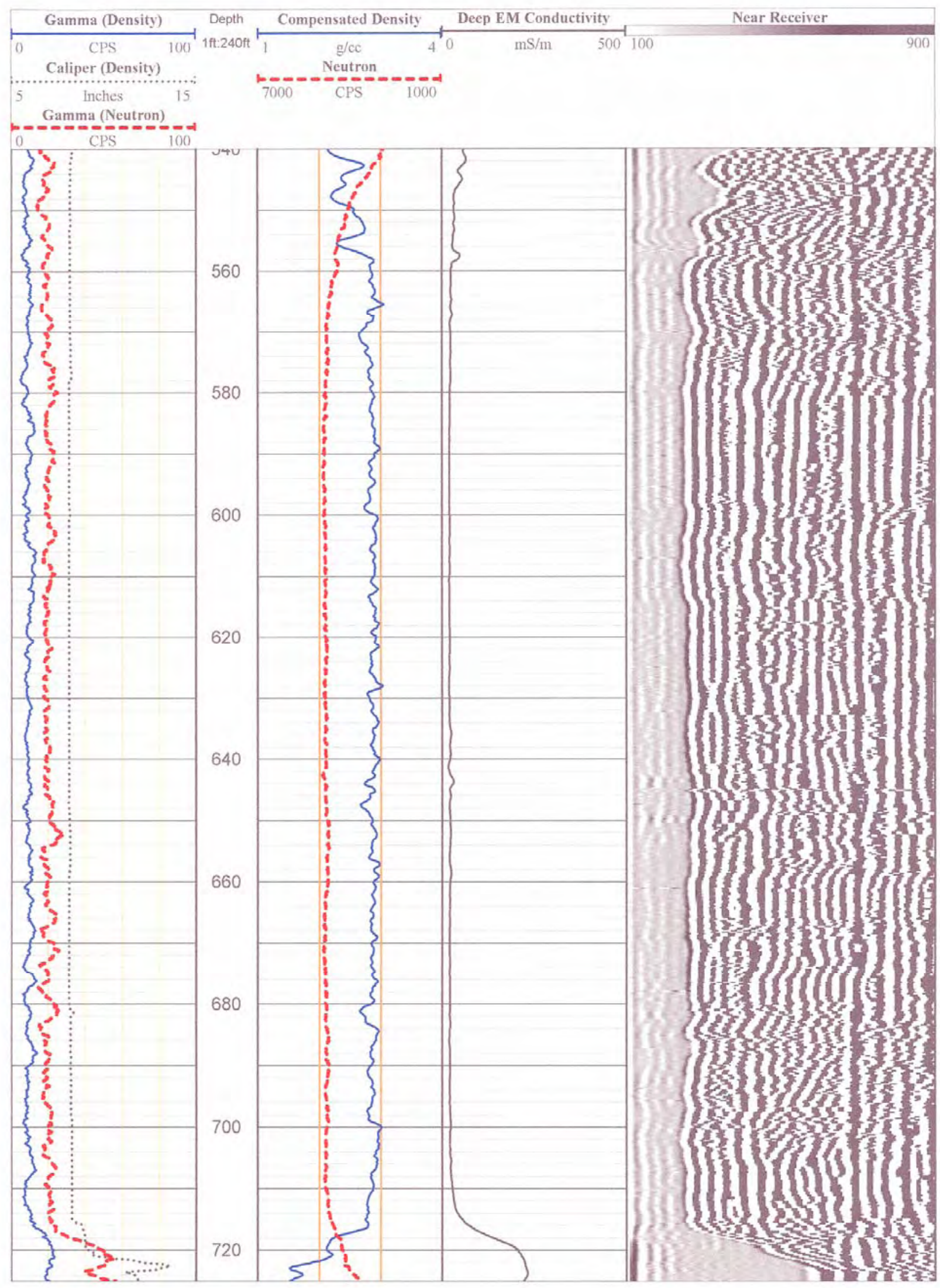


DTS-RPT-090, Rev. 0

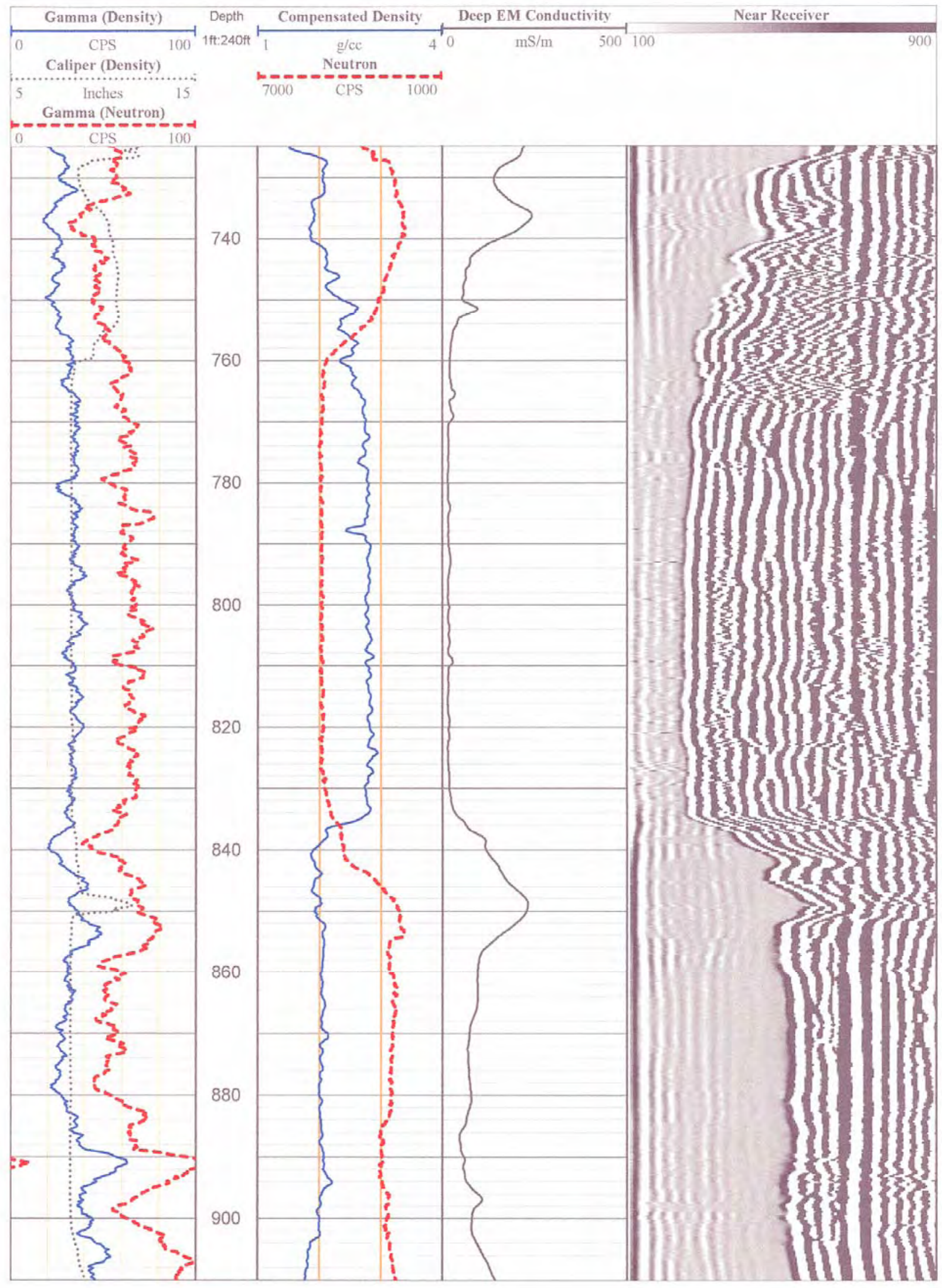


DTS-RPT-090, Rev. 0

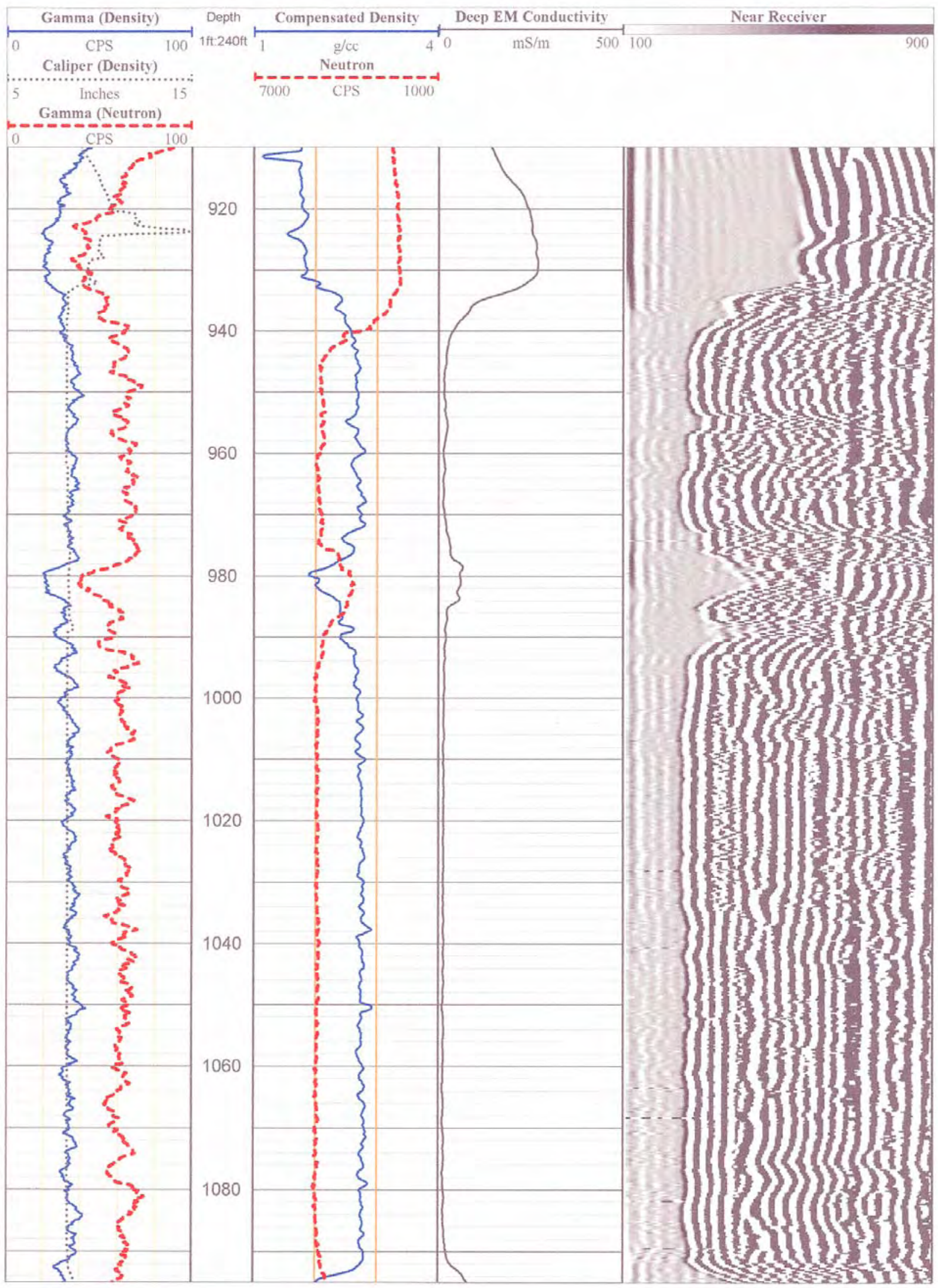


DTS-RPT-090, Rev. 0

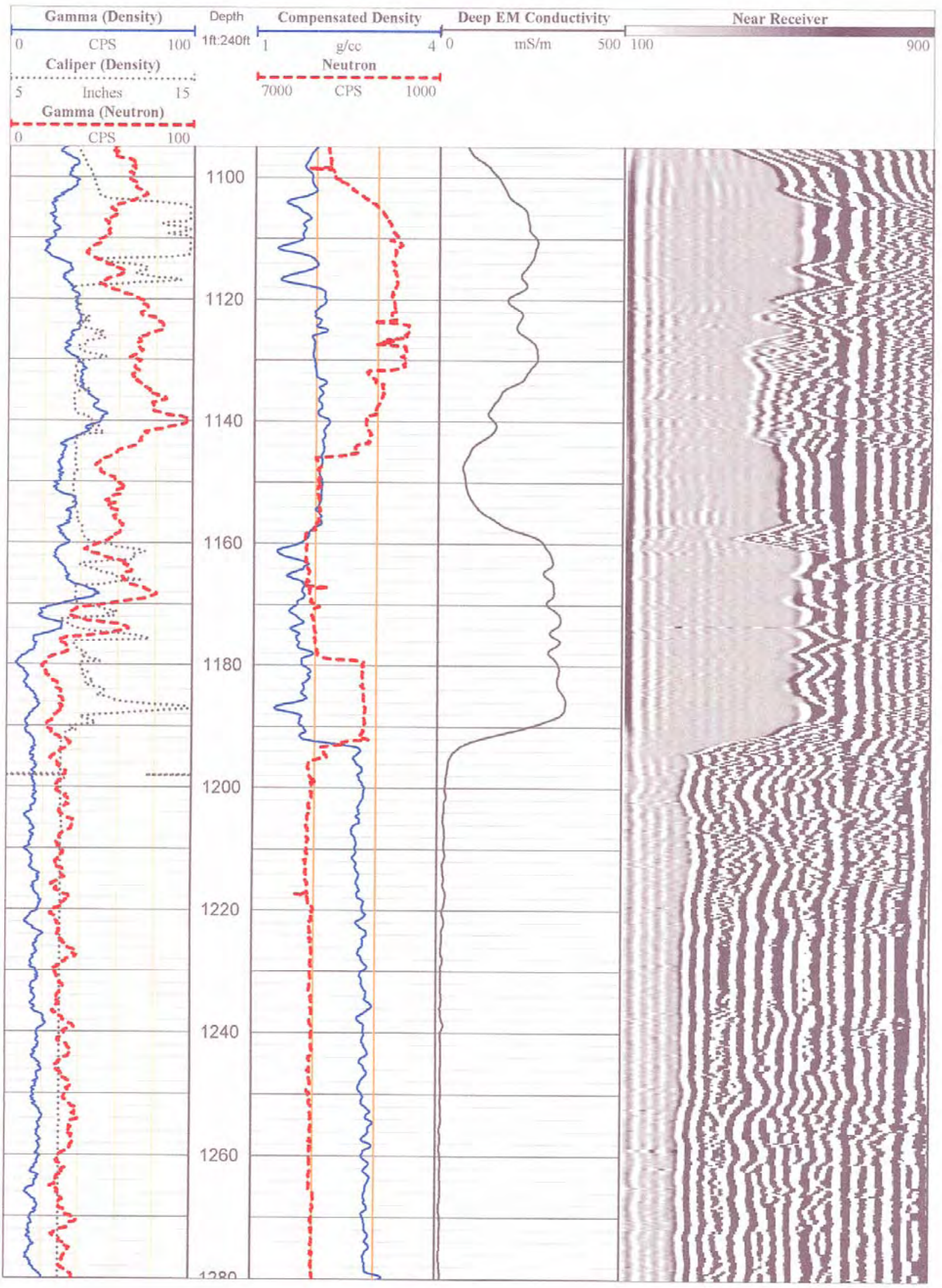




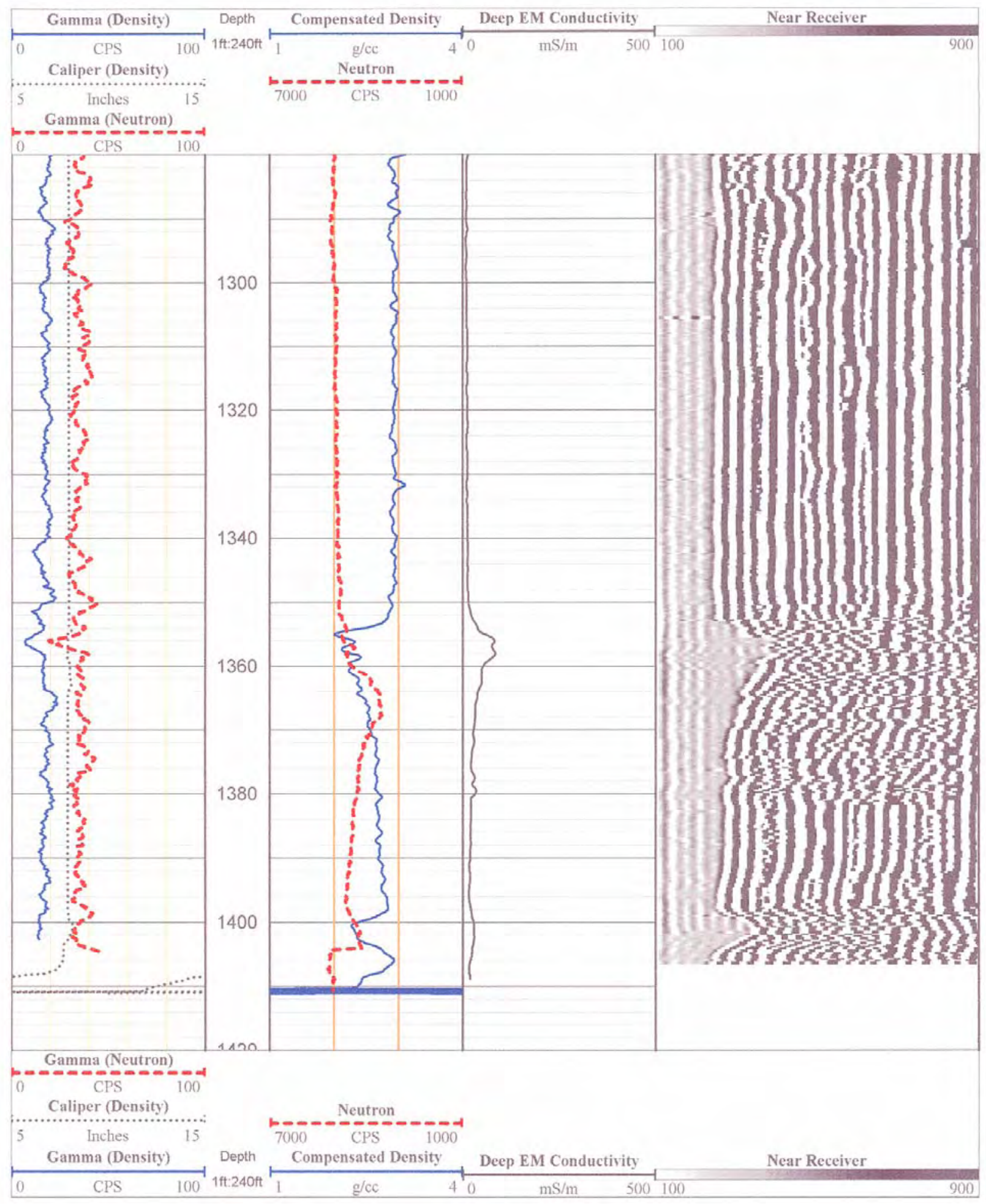


DTS-RPT-090, Rev. 0

\section{A1.4 COLOG COMPENSATED DENSITY LOG}

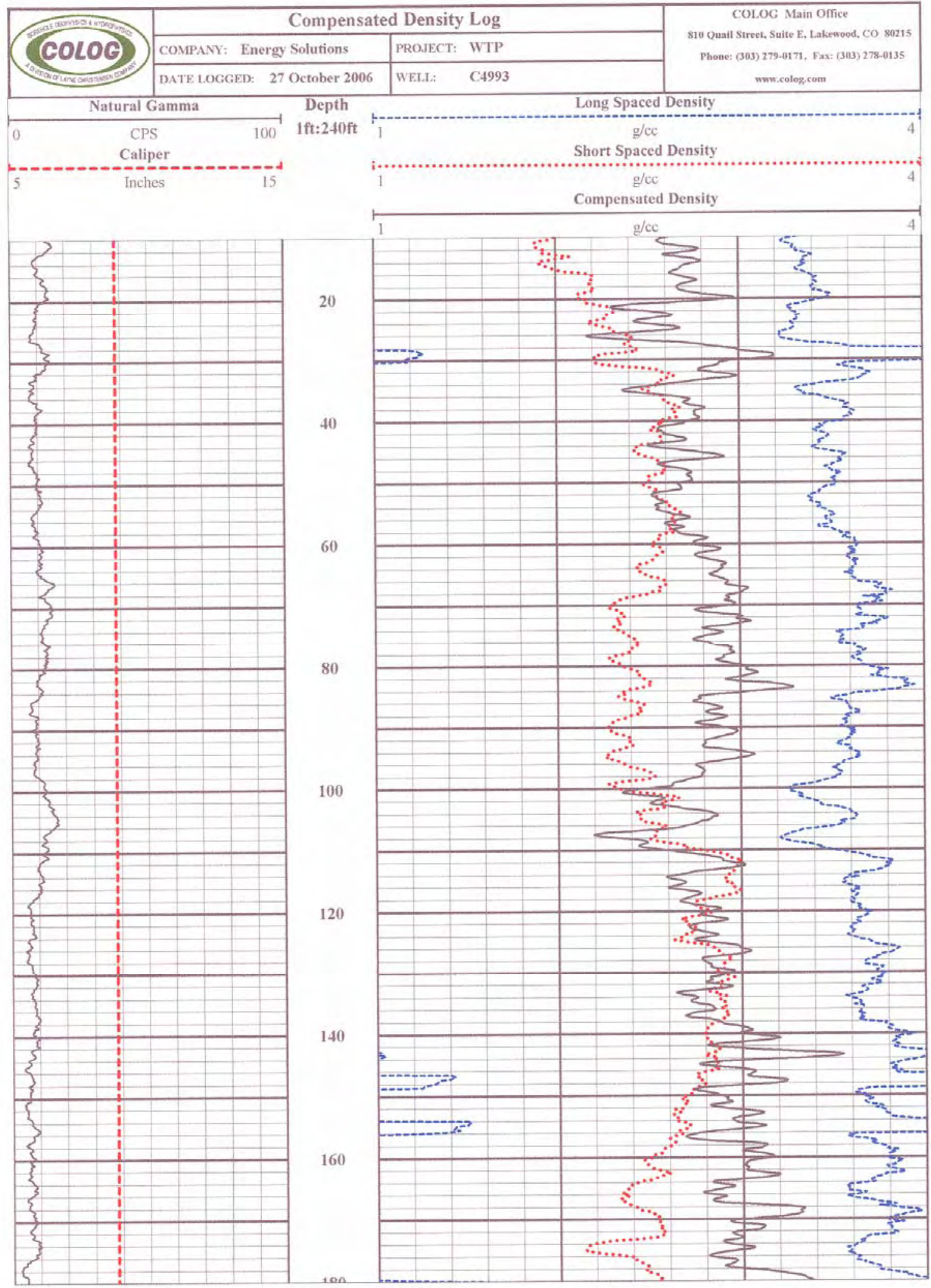


DTS-RPT-090, Rev. 0

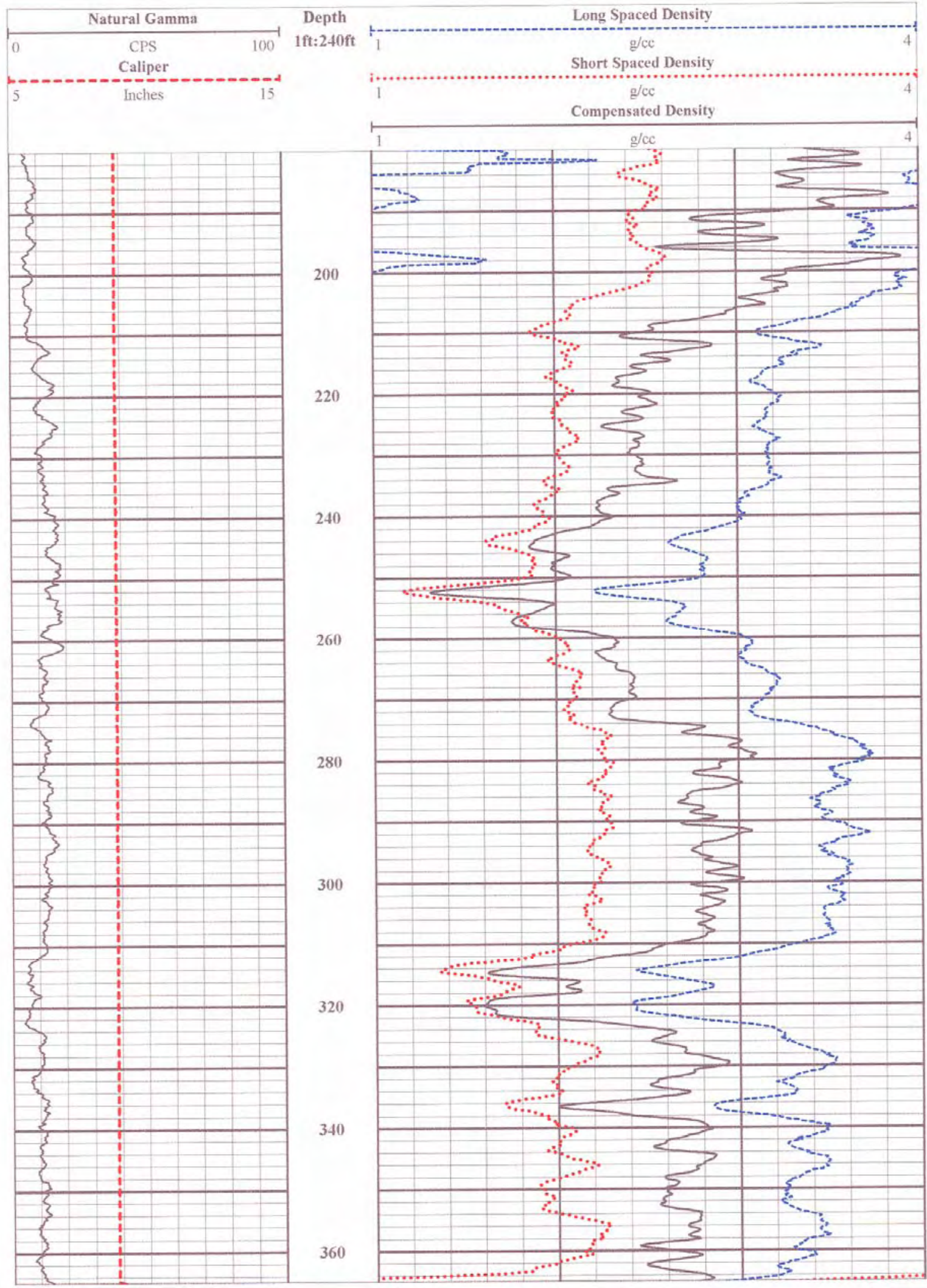


DTS-RPT-090, Rev. 0

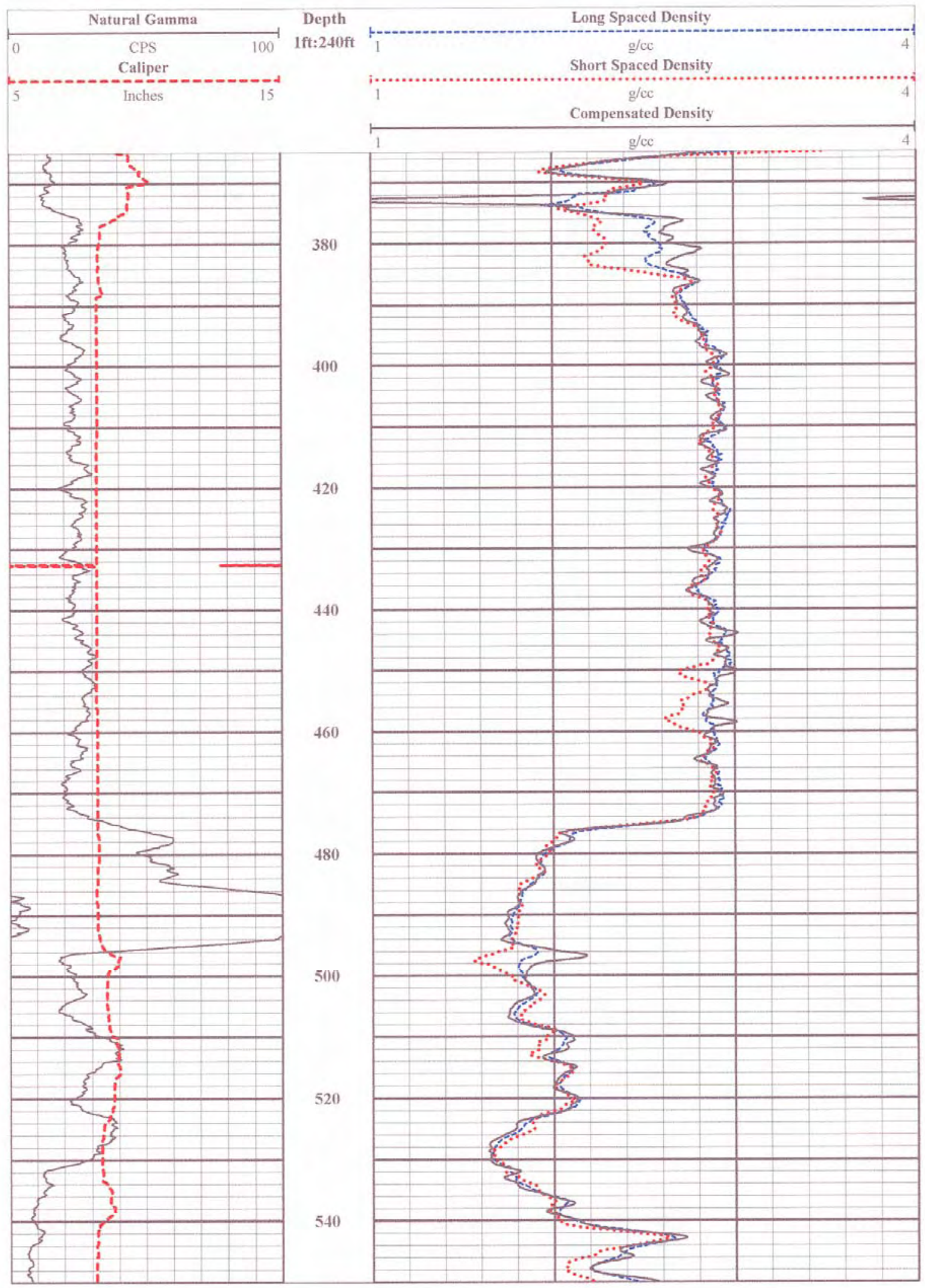


DTS-RPT-090, Rev. 0

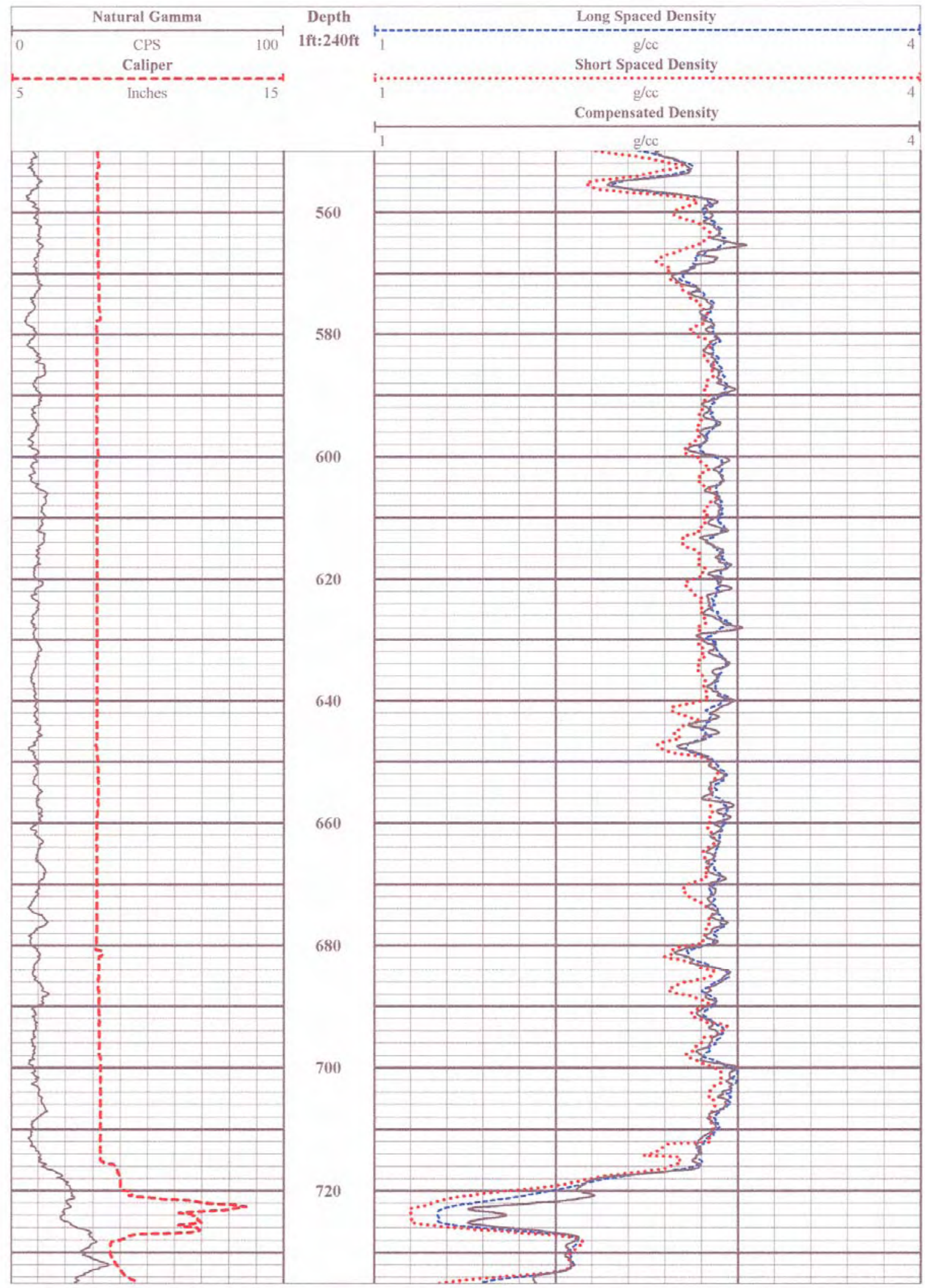


DTS-RPT-090, Rev. 0

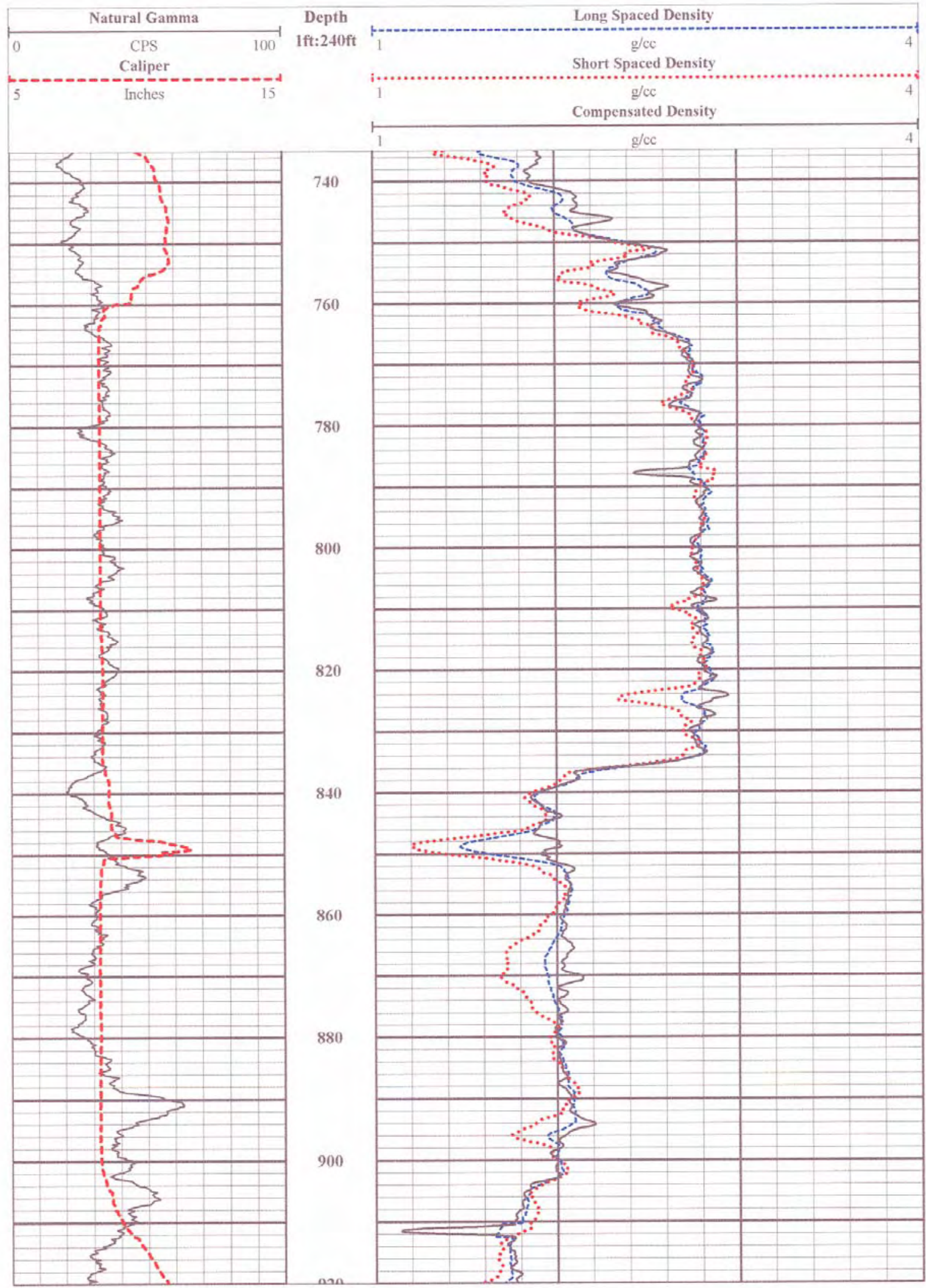


DTS-RPT-090, Rev. 0

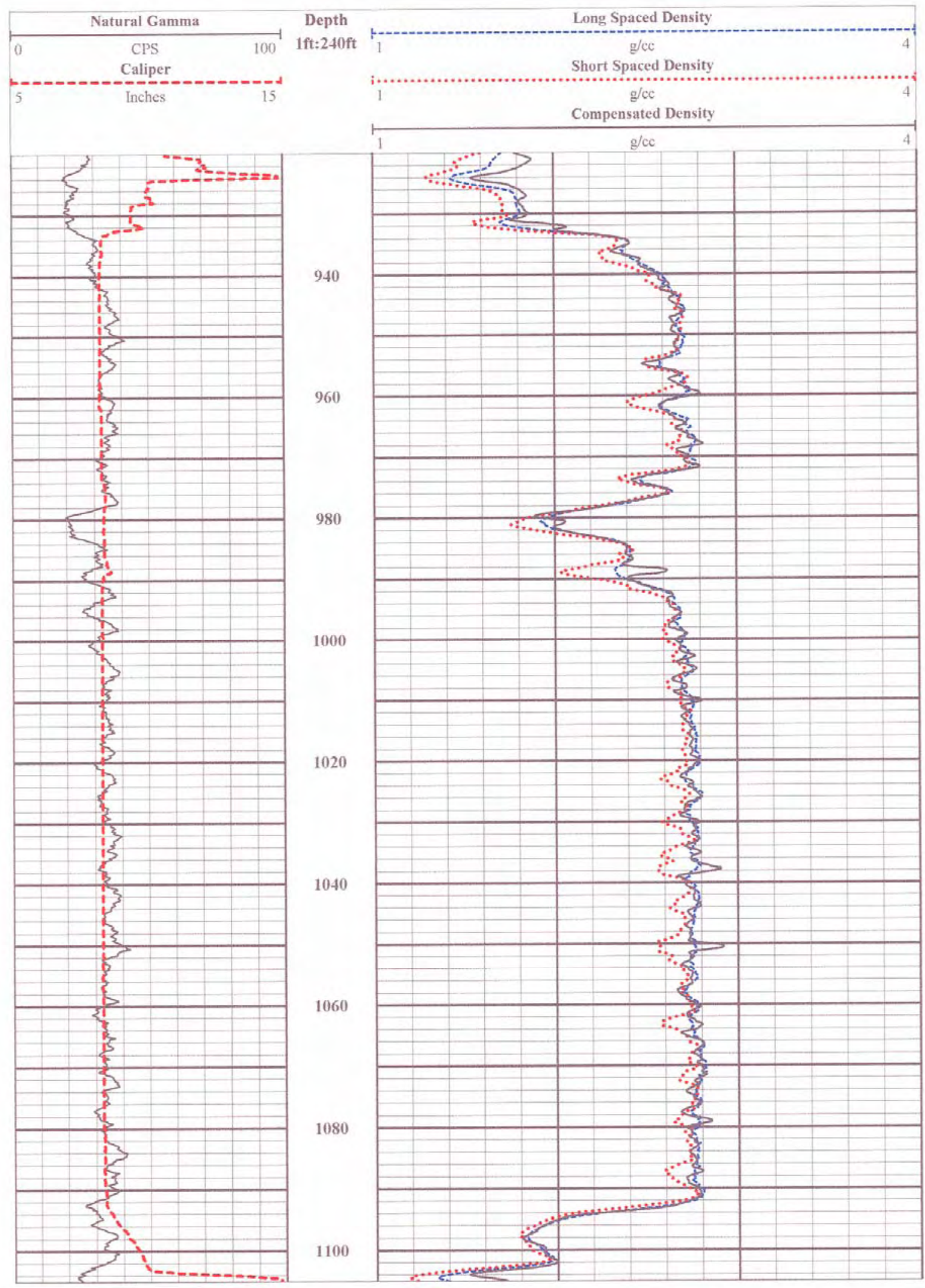


DTS-RPT-090, Rev. 0

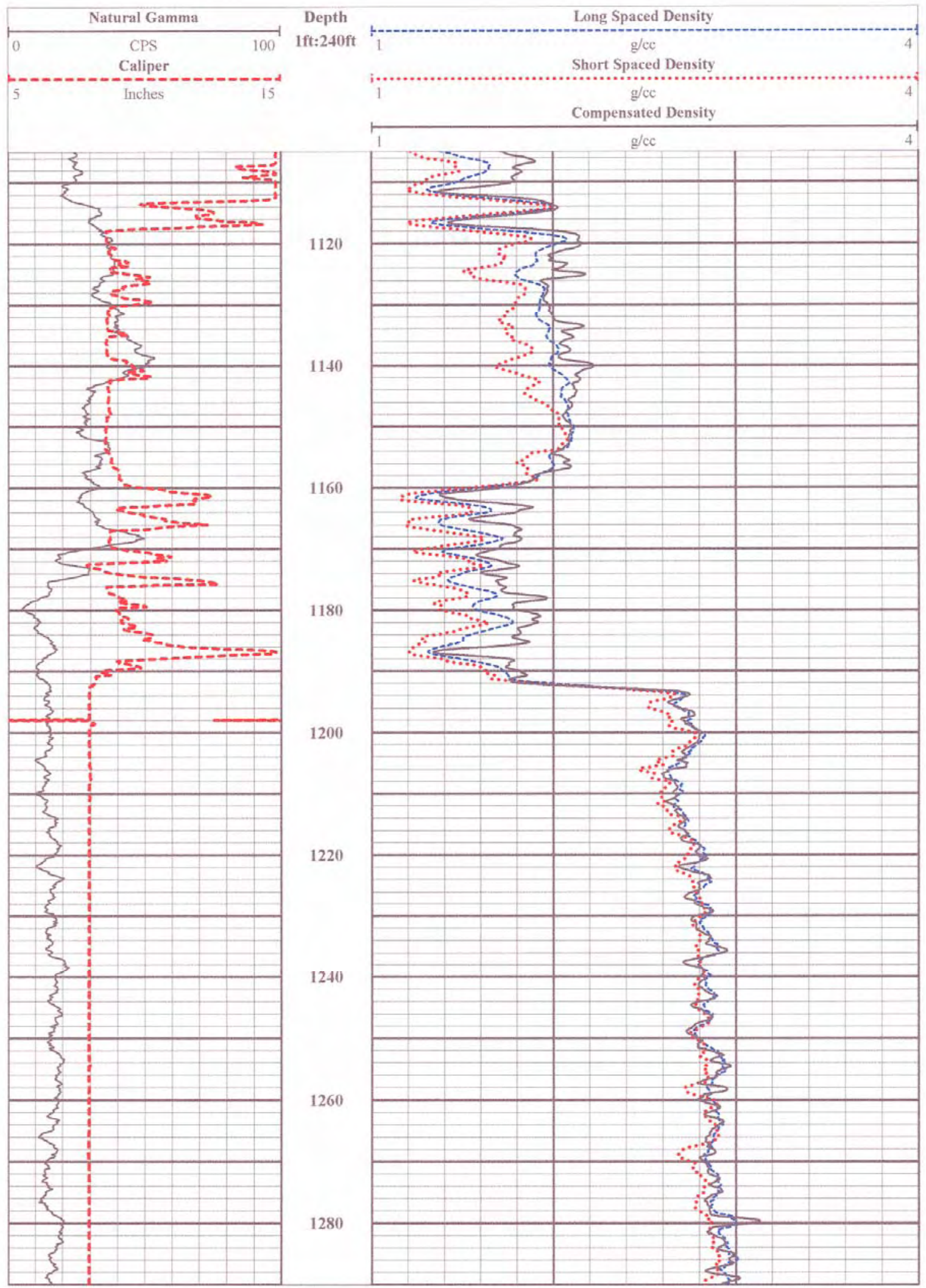


DTS-RPT-090, Rev. 0

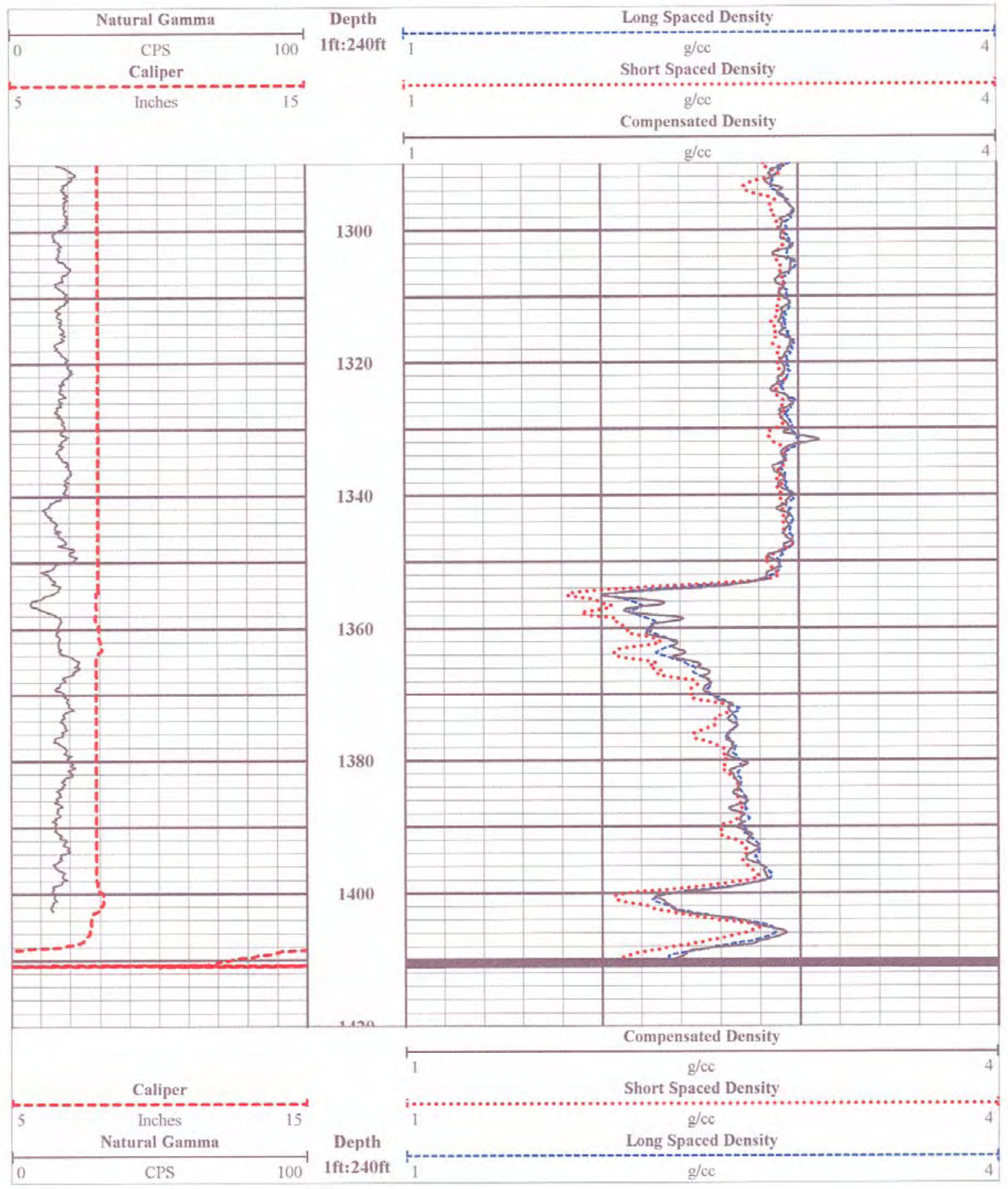


DTS-RPT-090, Rev. 0

\section{A1.5 COLOG NEUTRON/POROSITY LOG}

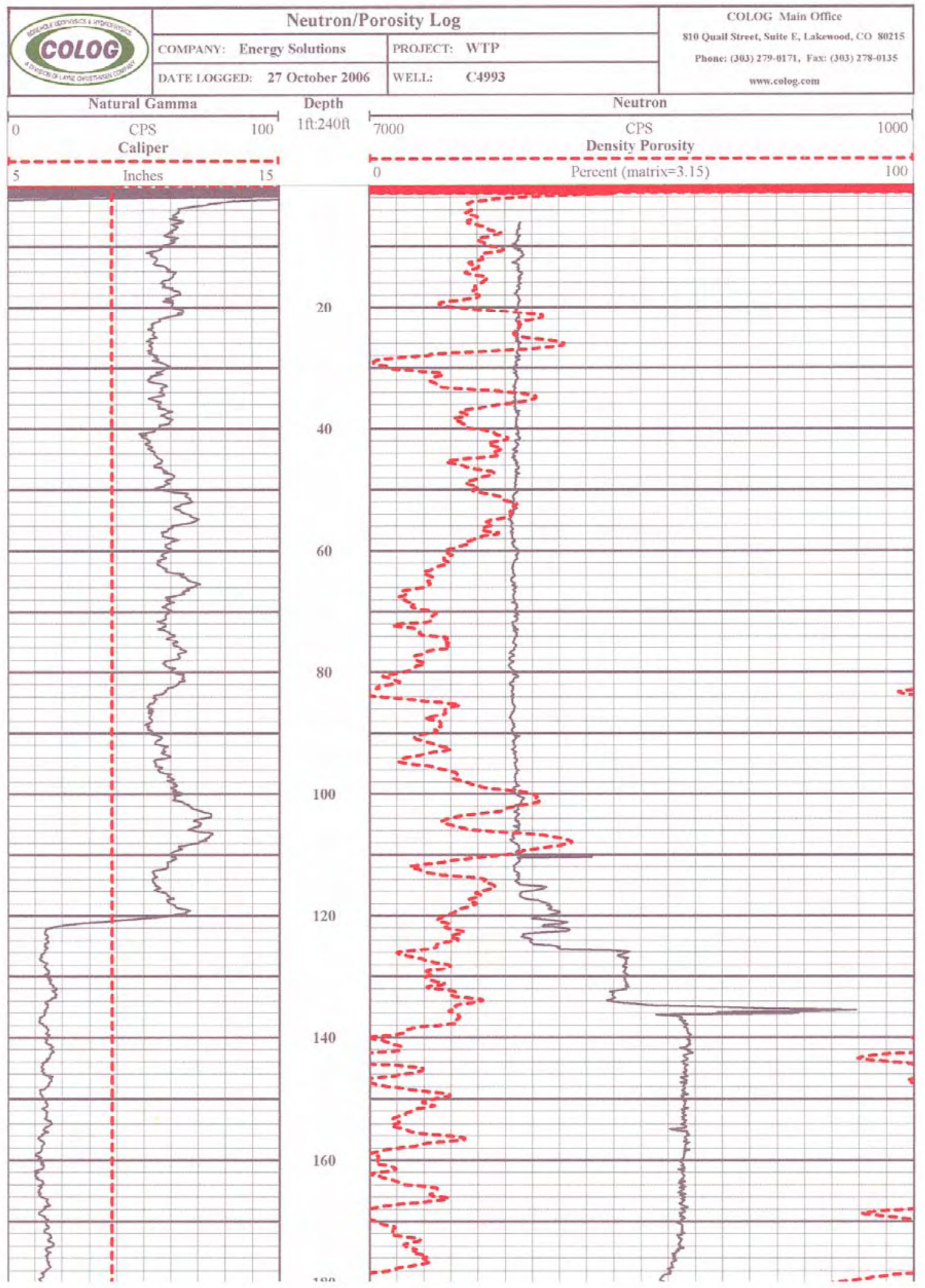


DTS-RPT-090, Rev. 0

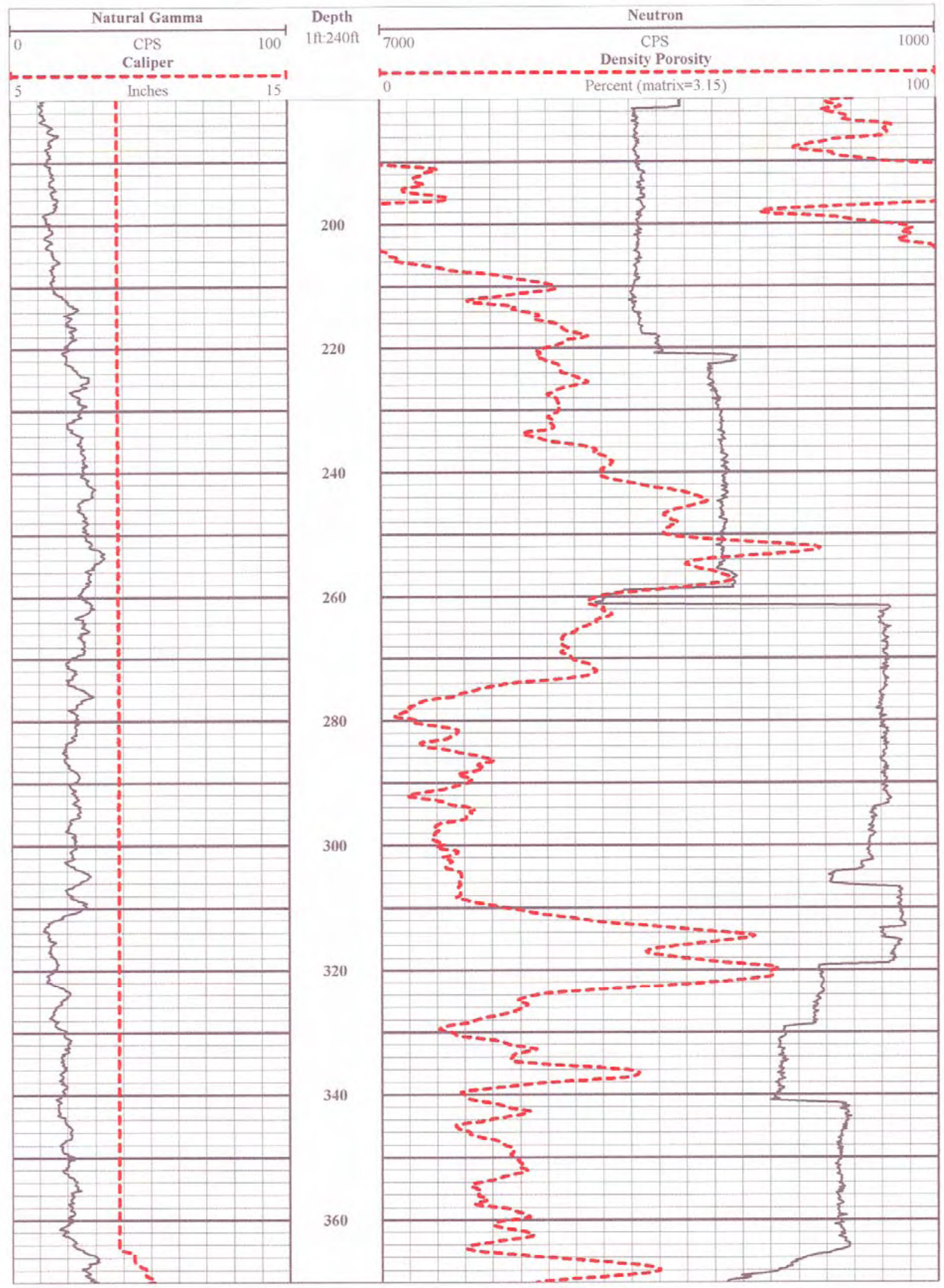


DTS-RPT-090, Rev. 0

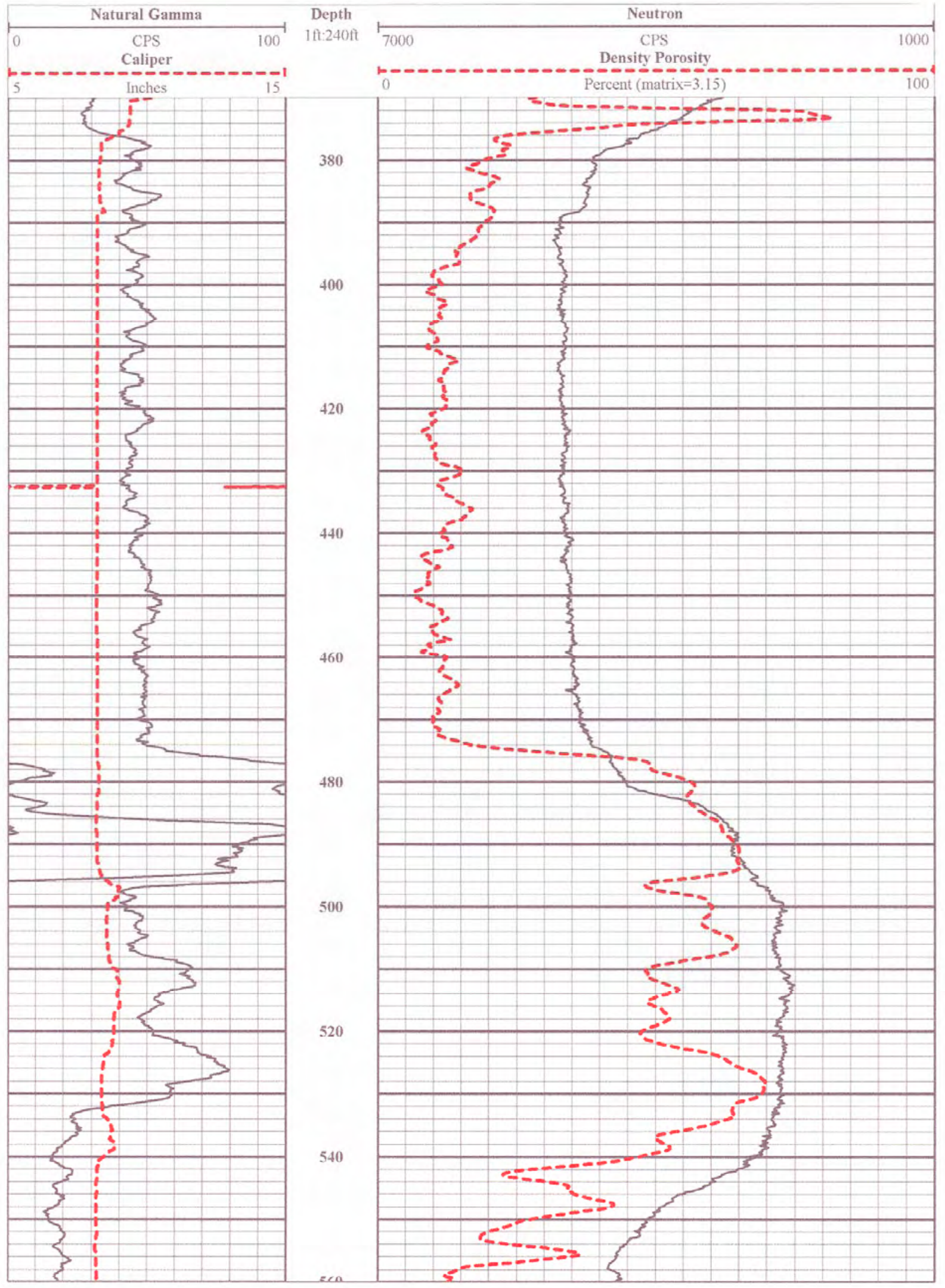


DTS-RPT-090, Rev. 0

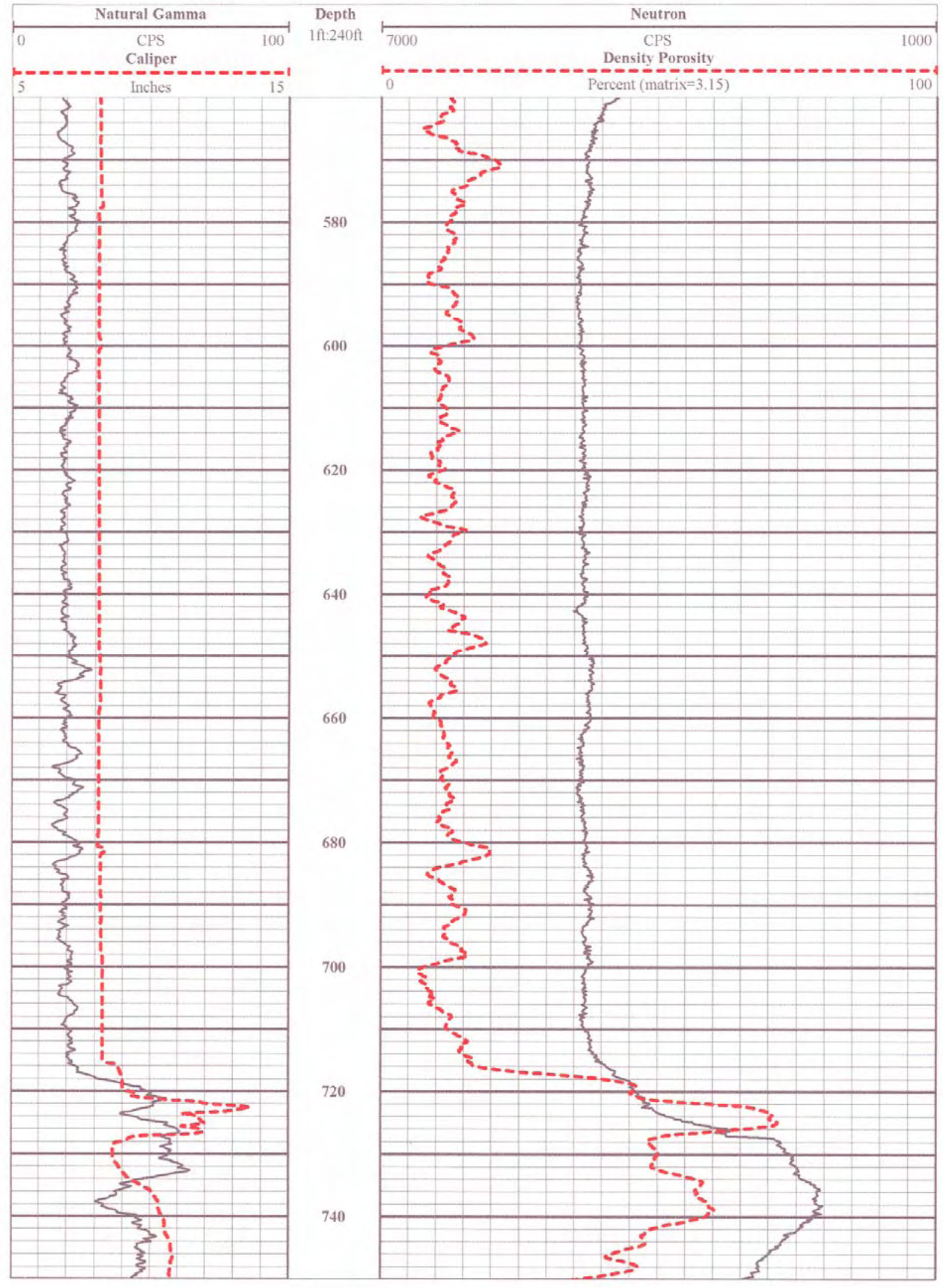


DTS-RPT-090, Rev. 0

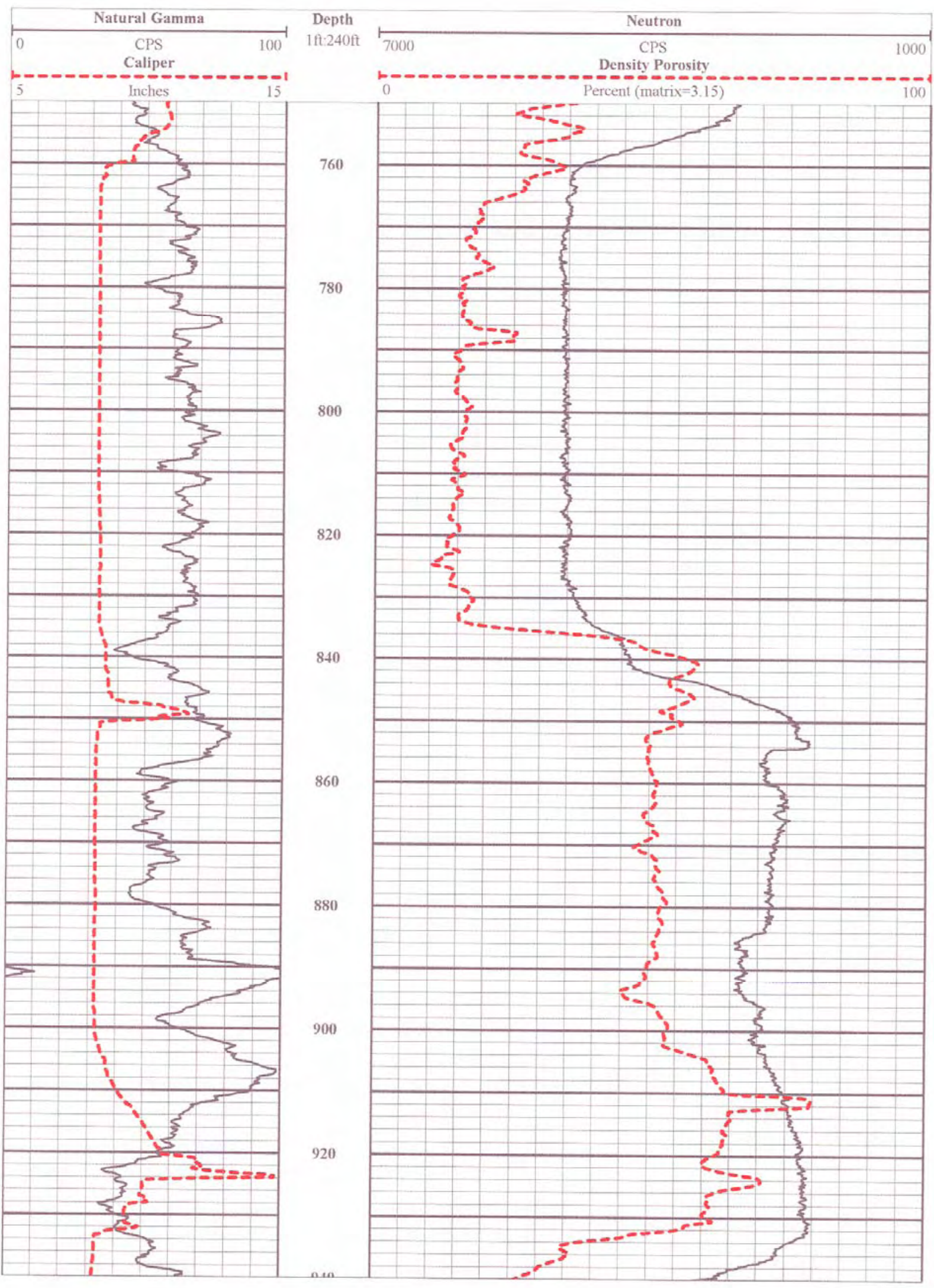


DTS-RPT-090, Rev. 0

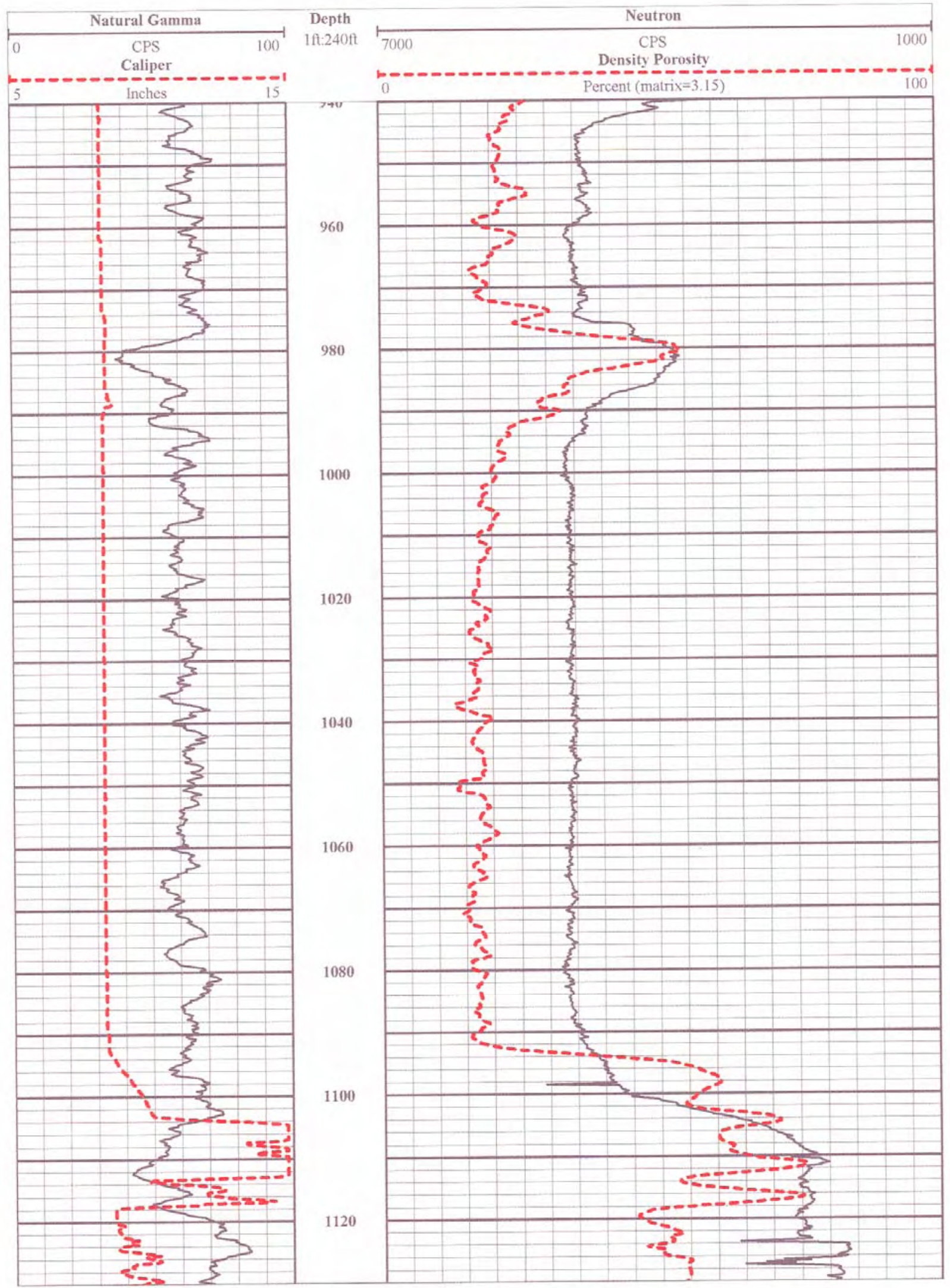


DTS-RPT-090, Rev. 0

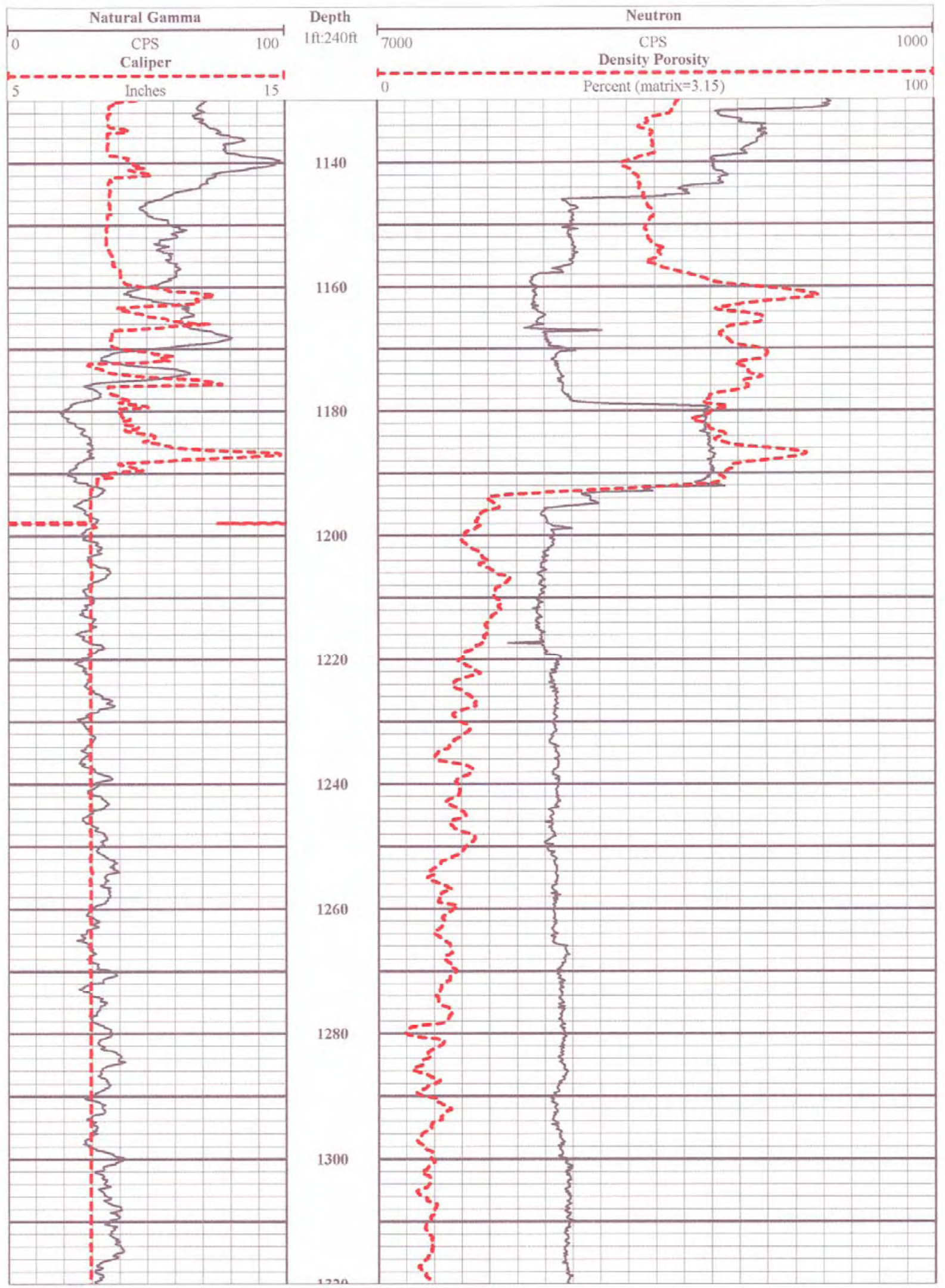


DTS-RPT-090, Rev. 0

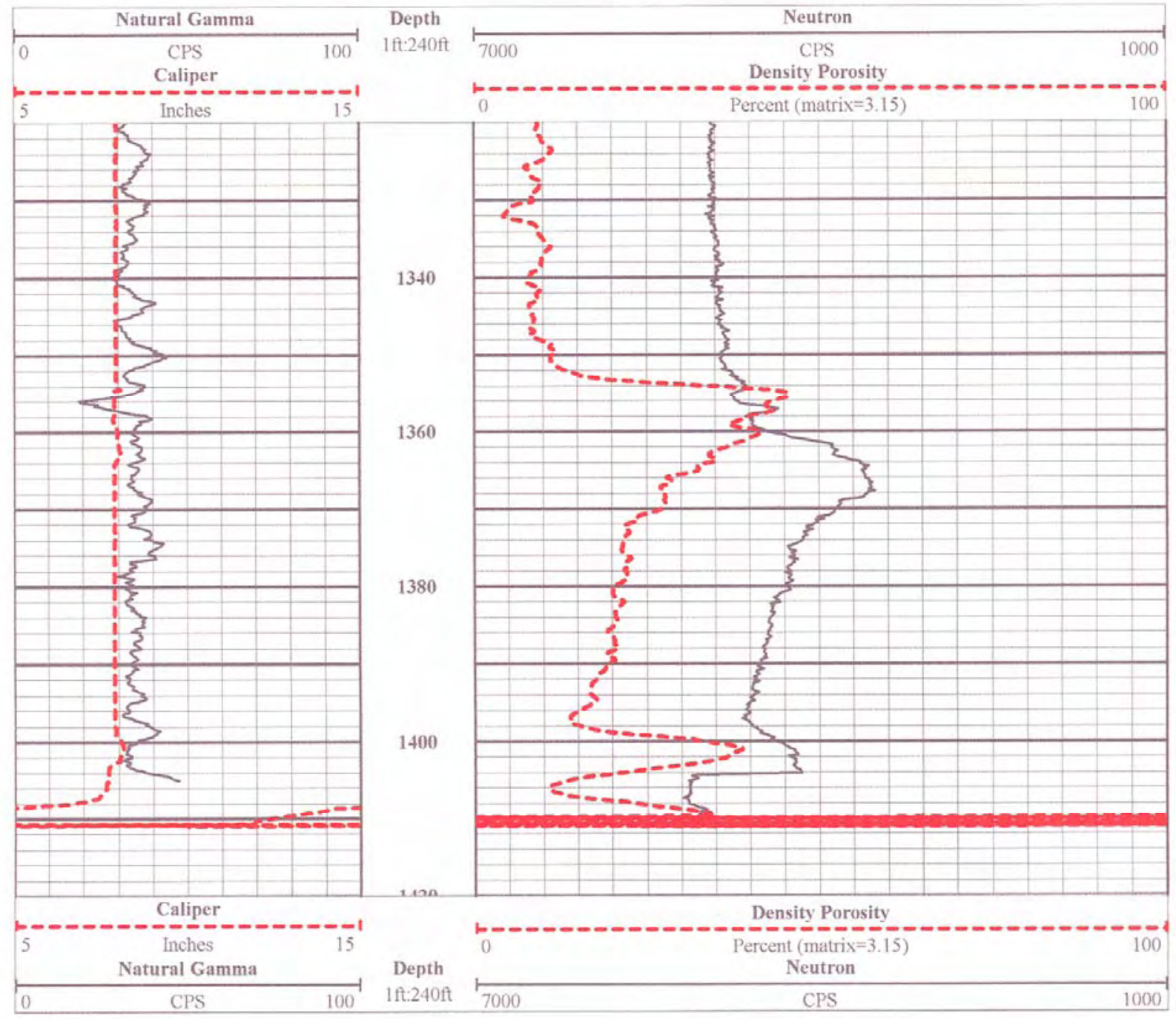


DTS-RPT-090, Rev. 0

\section{A1.6 COLOG DUAL INDUCTION LOG}

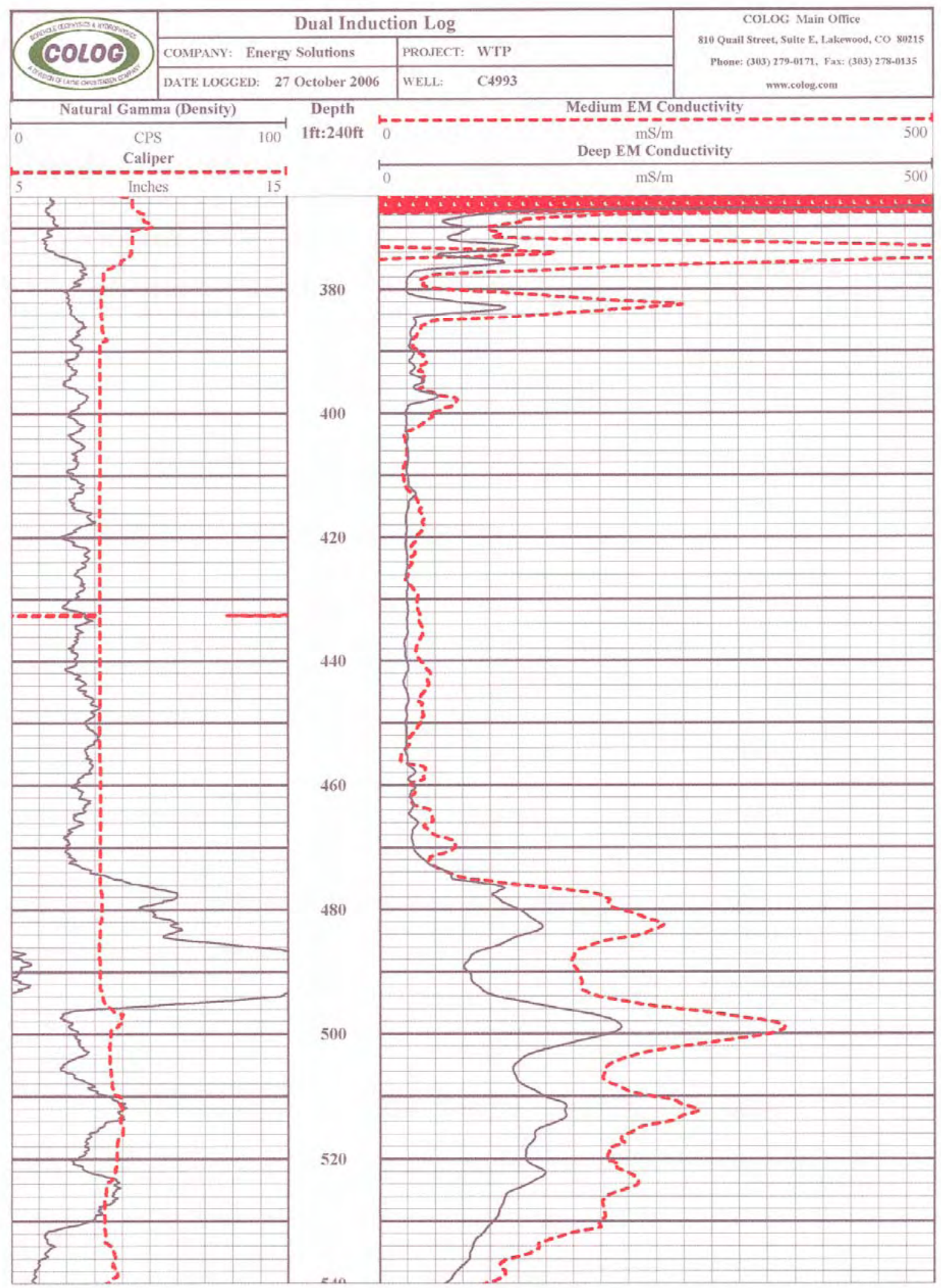


DTS-RPT-090, Rev. 0

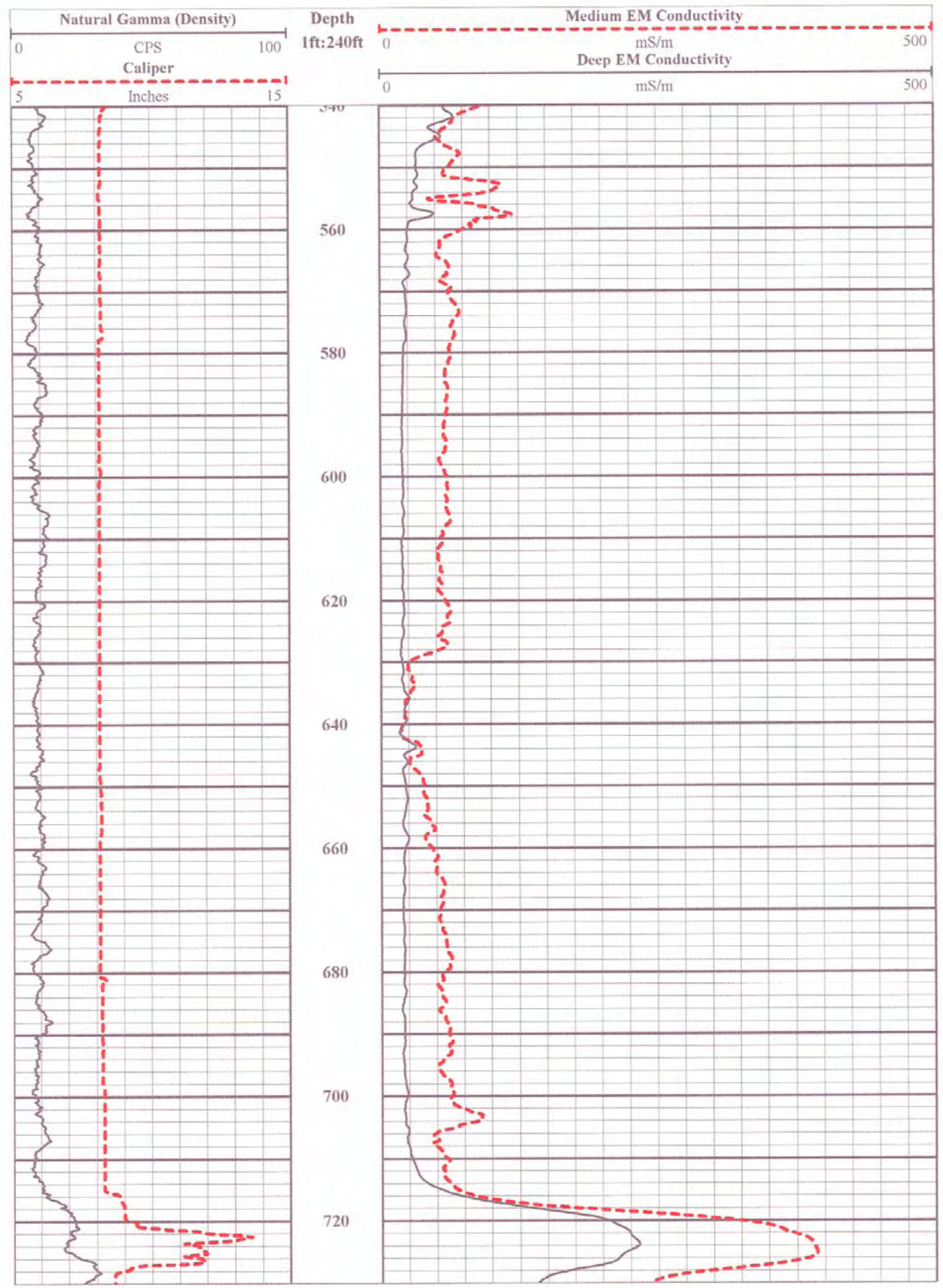


DTS-RPT-090, Rev. 0

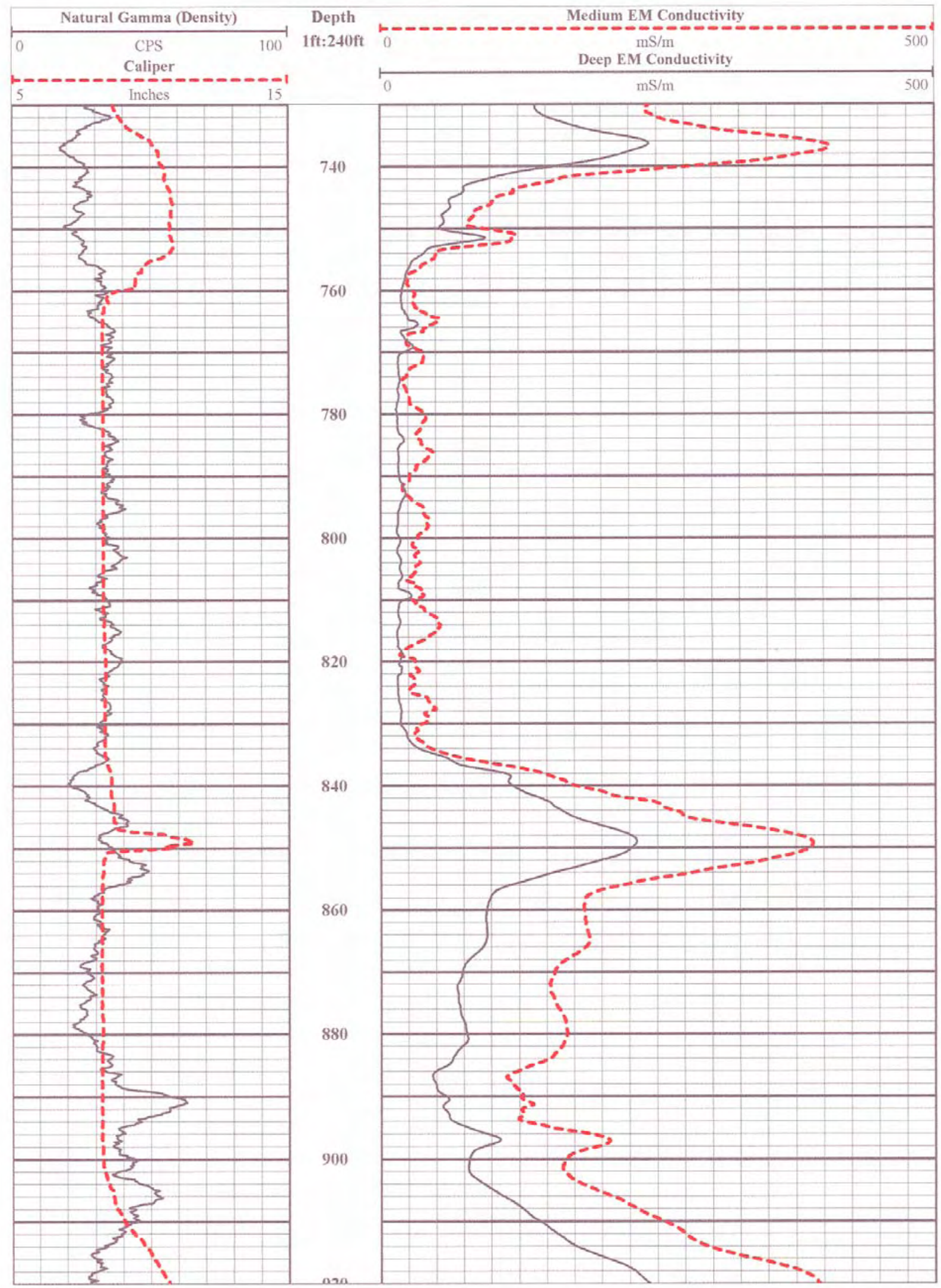


DTS-RPT-090, Rev. 0

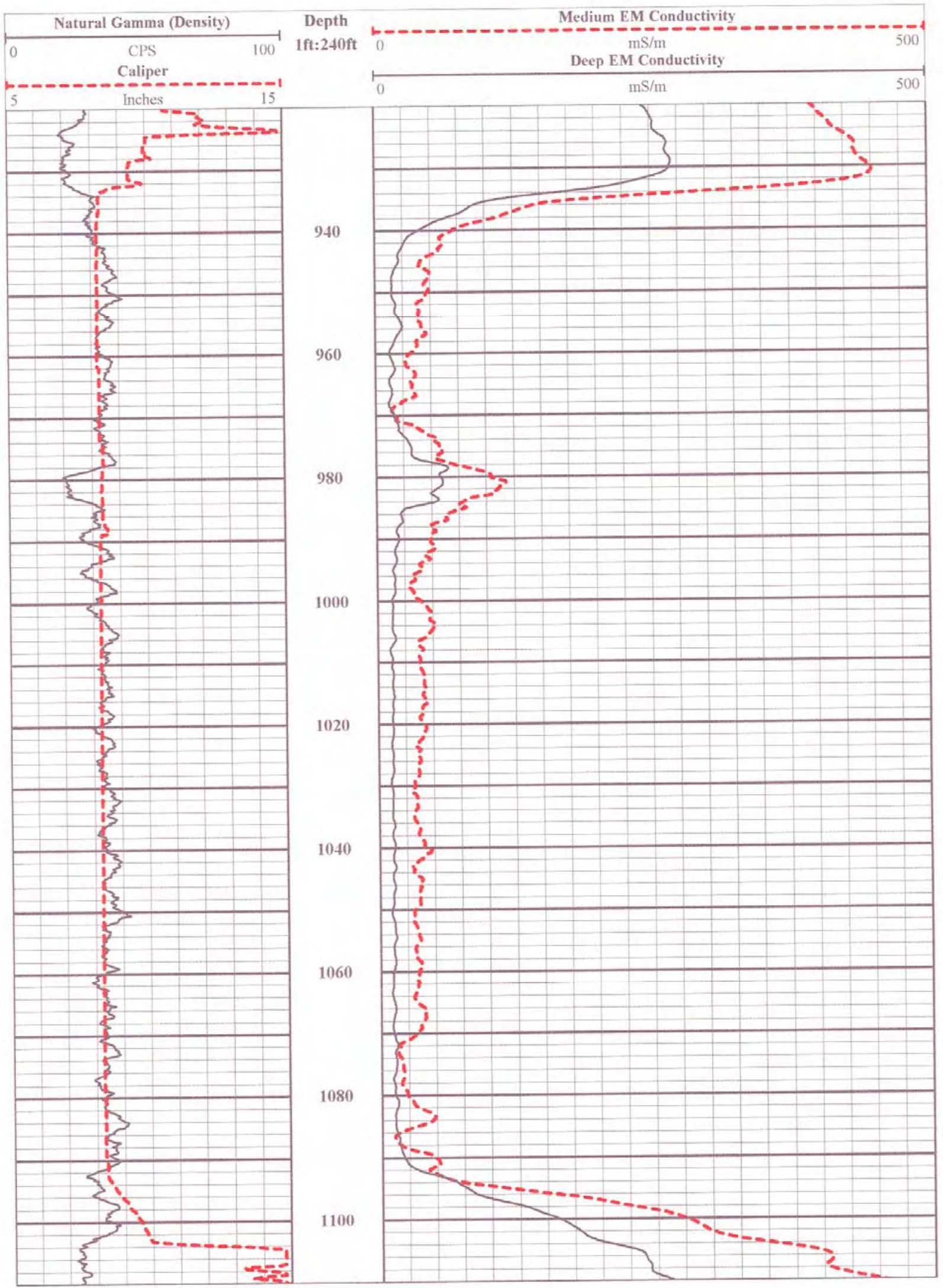


DTS-RPT-090, Rev. 0

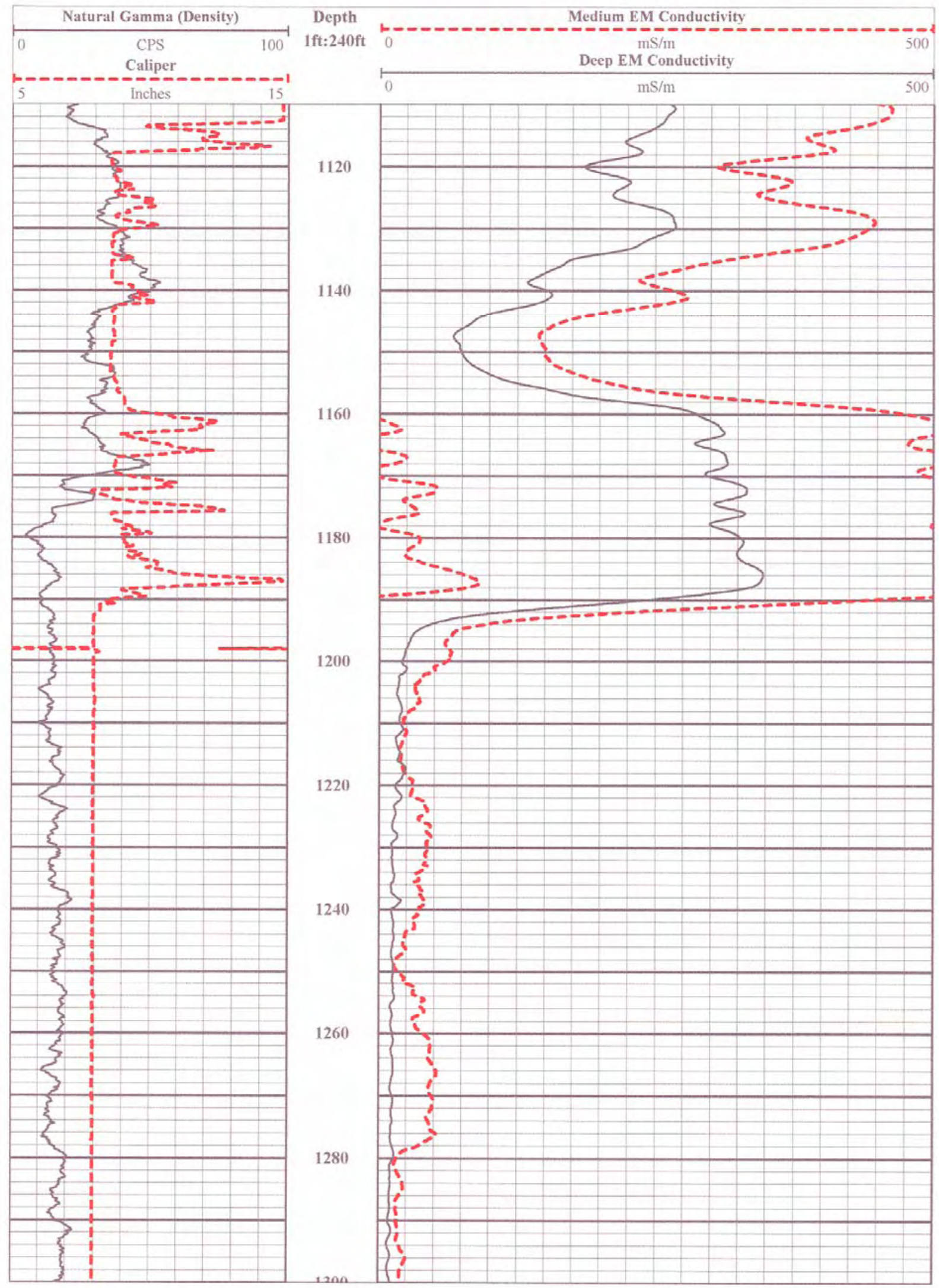


DTS-RPT-090, Rev. 0

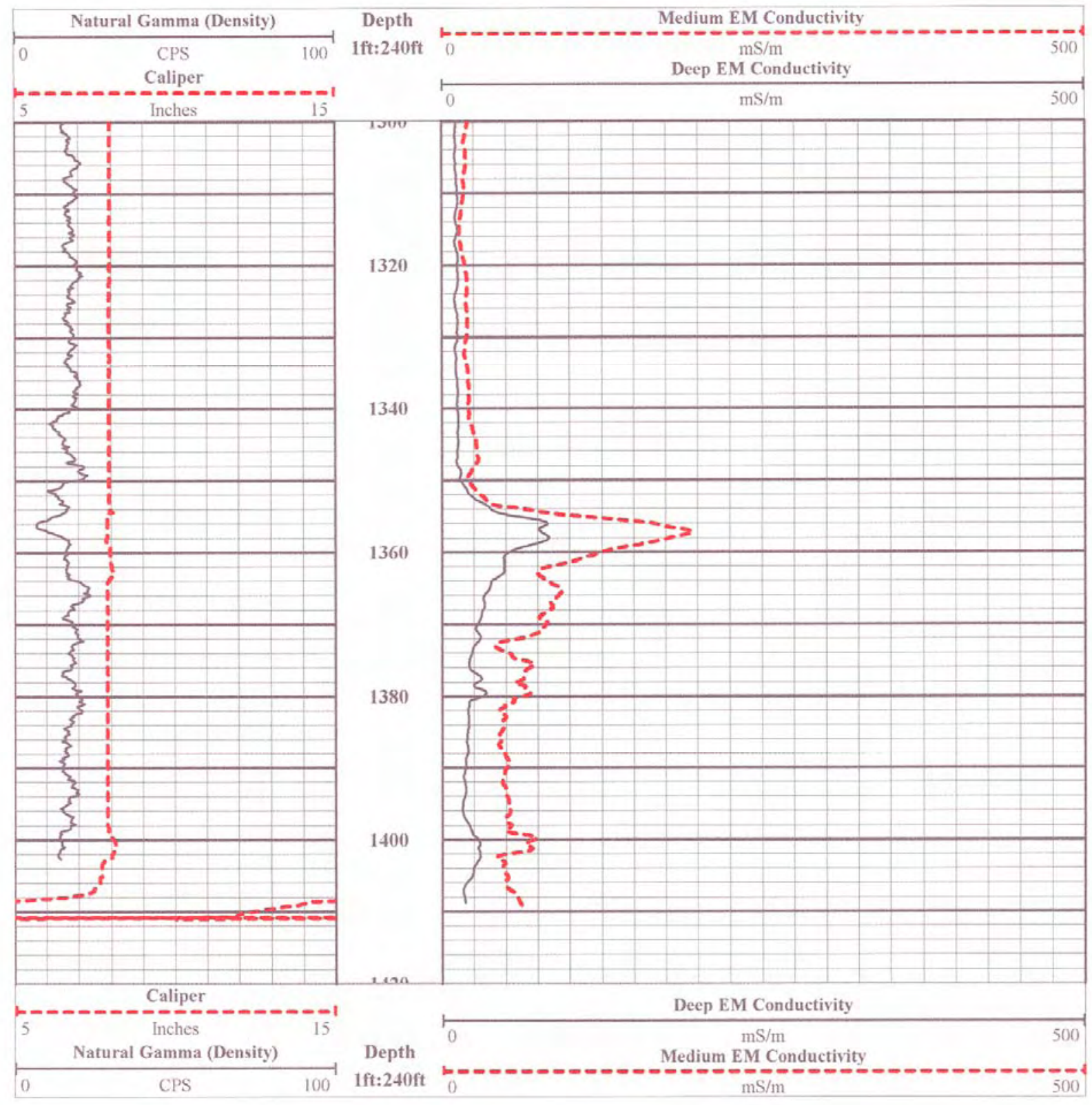


DTS-RPT-090, Rev. 0

\section{A1.7 COLOG FULL WAVEFORM SONIC LOG}

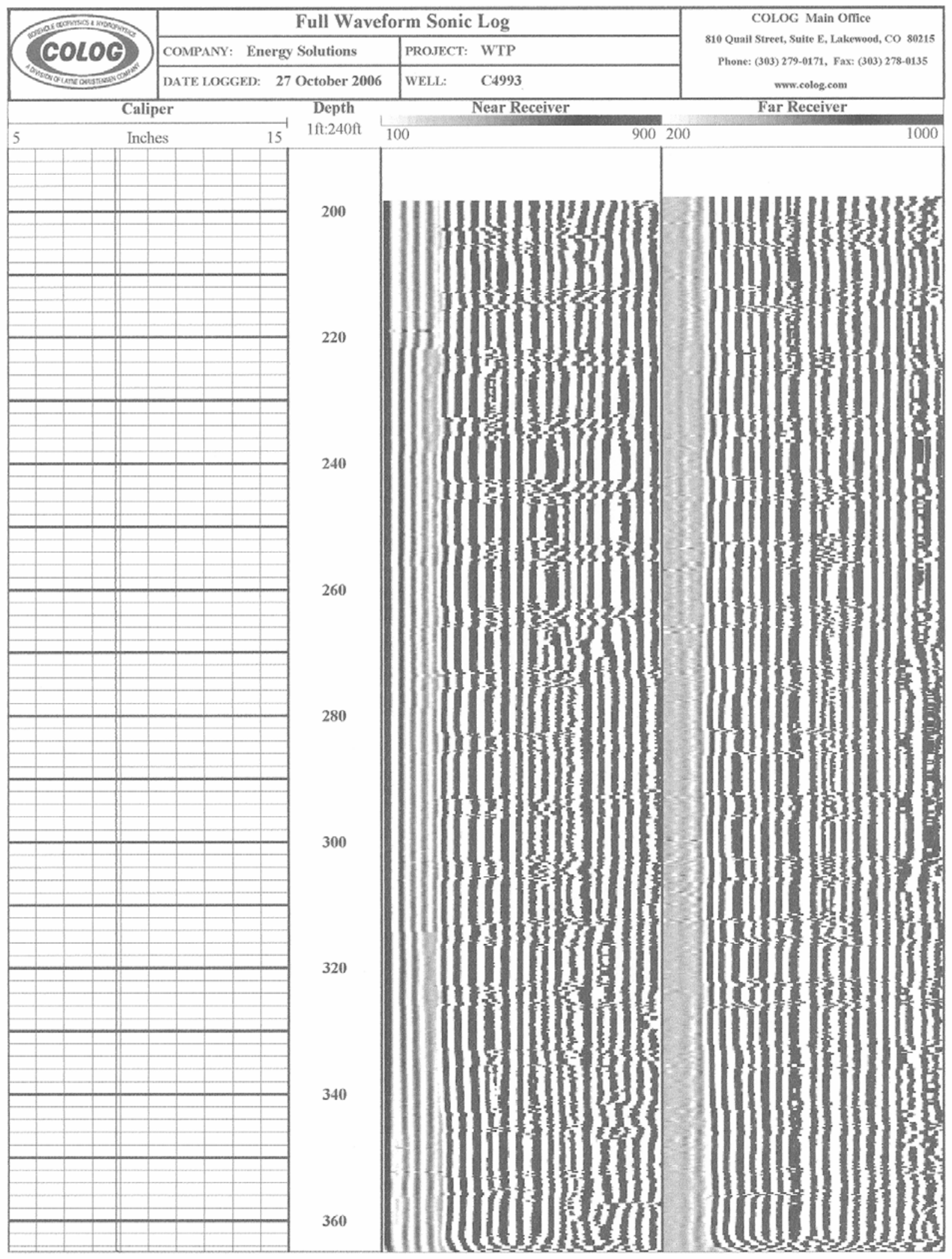


DTS-RPT-090, Rev. 0

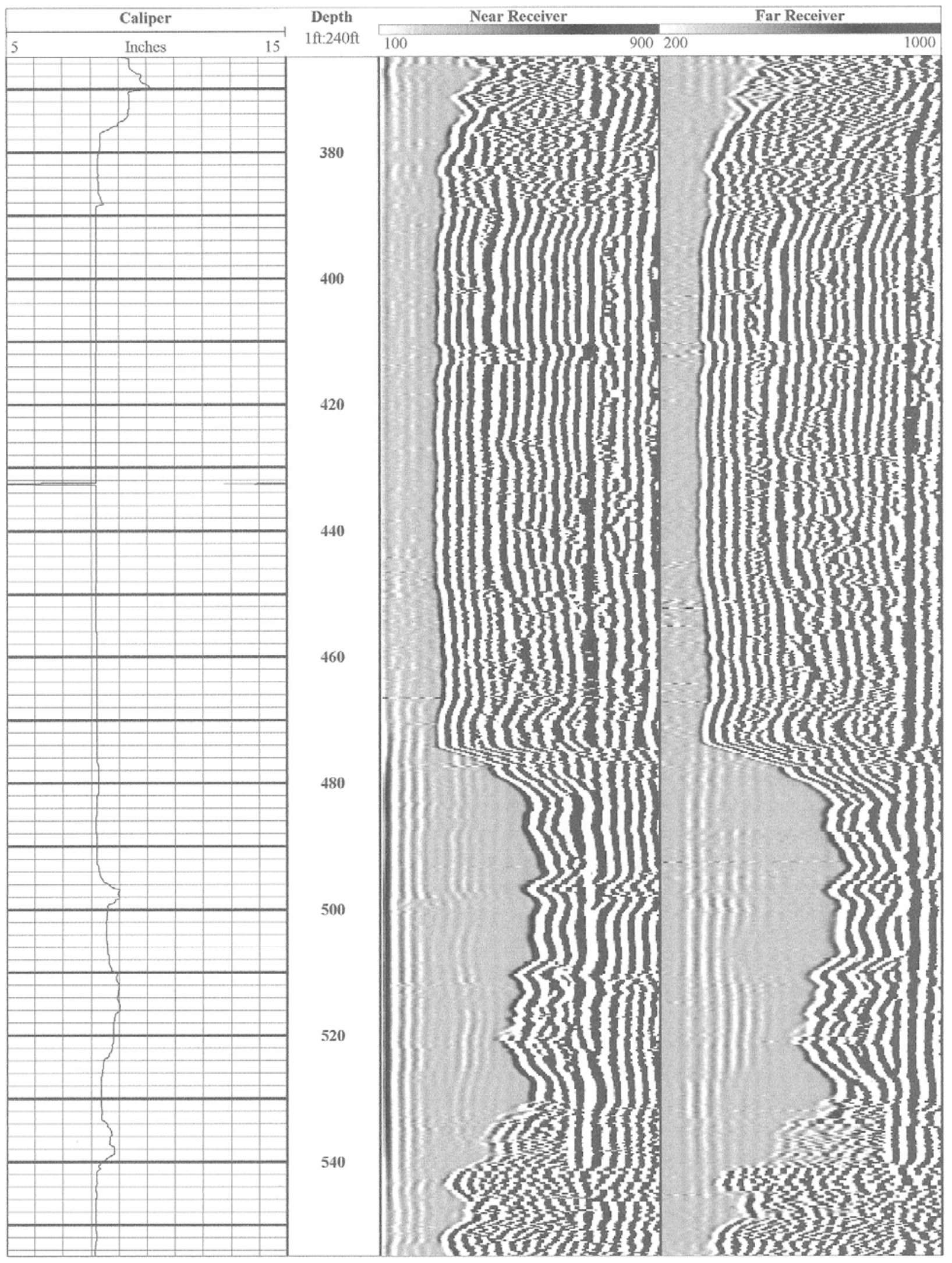


DTS-RPT-090, Rev. 0

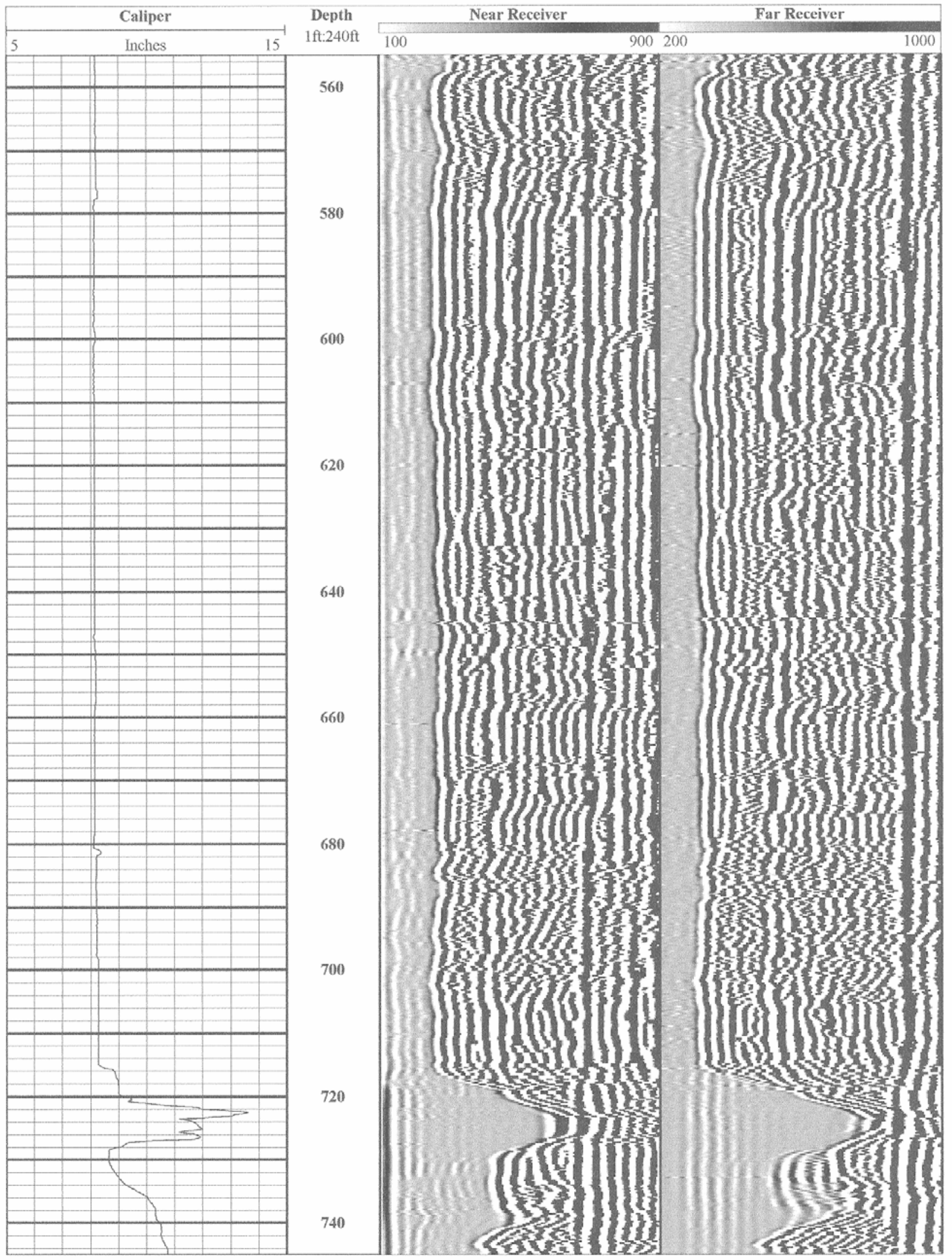


DTS-RPT-090, Rev. 0

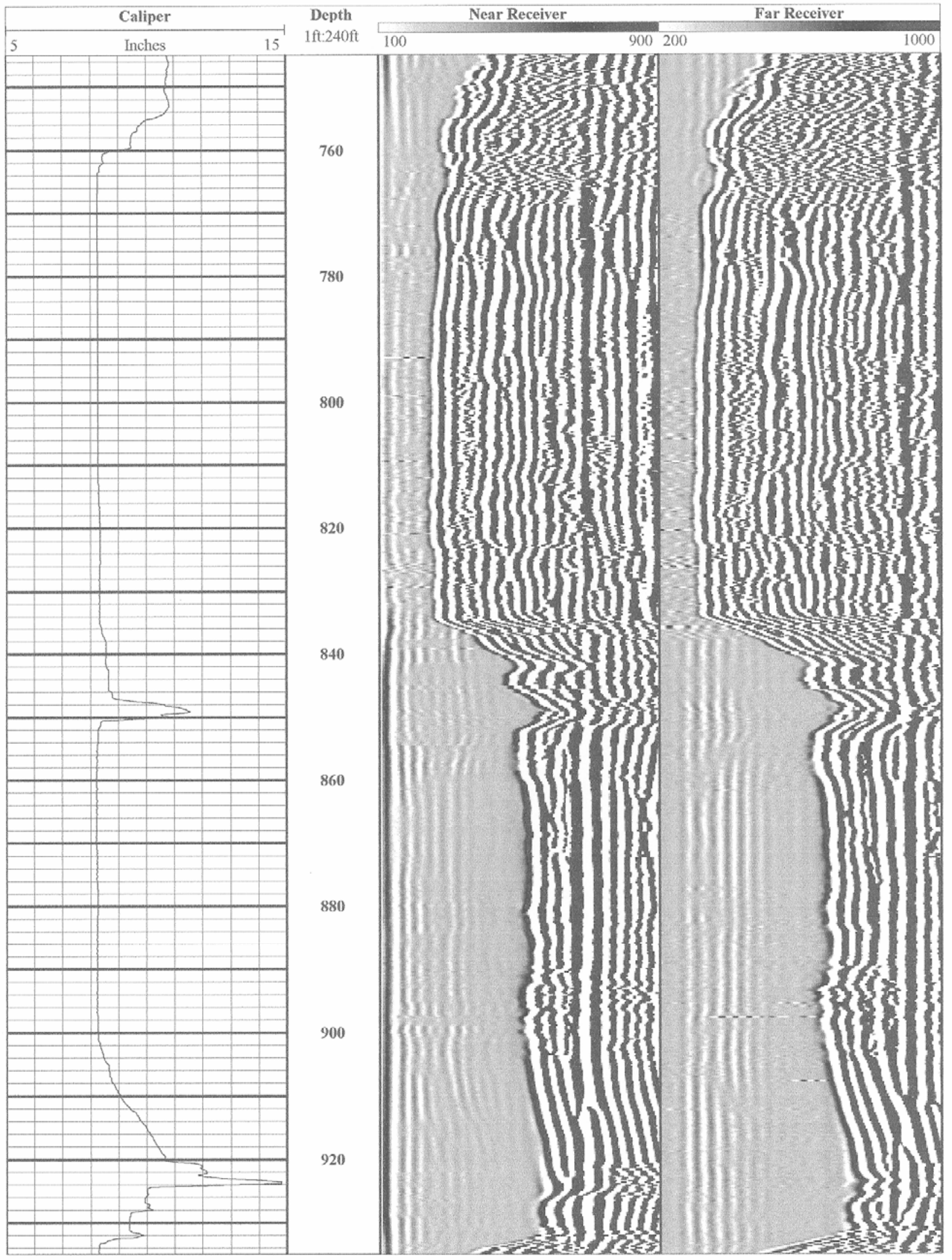


DTS-RPT-090, Rev. 0

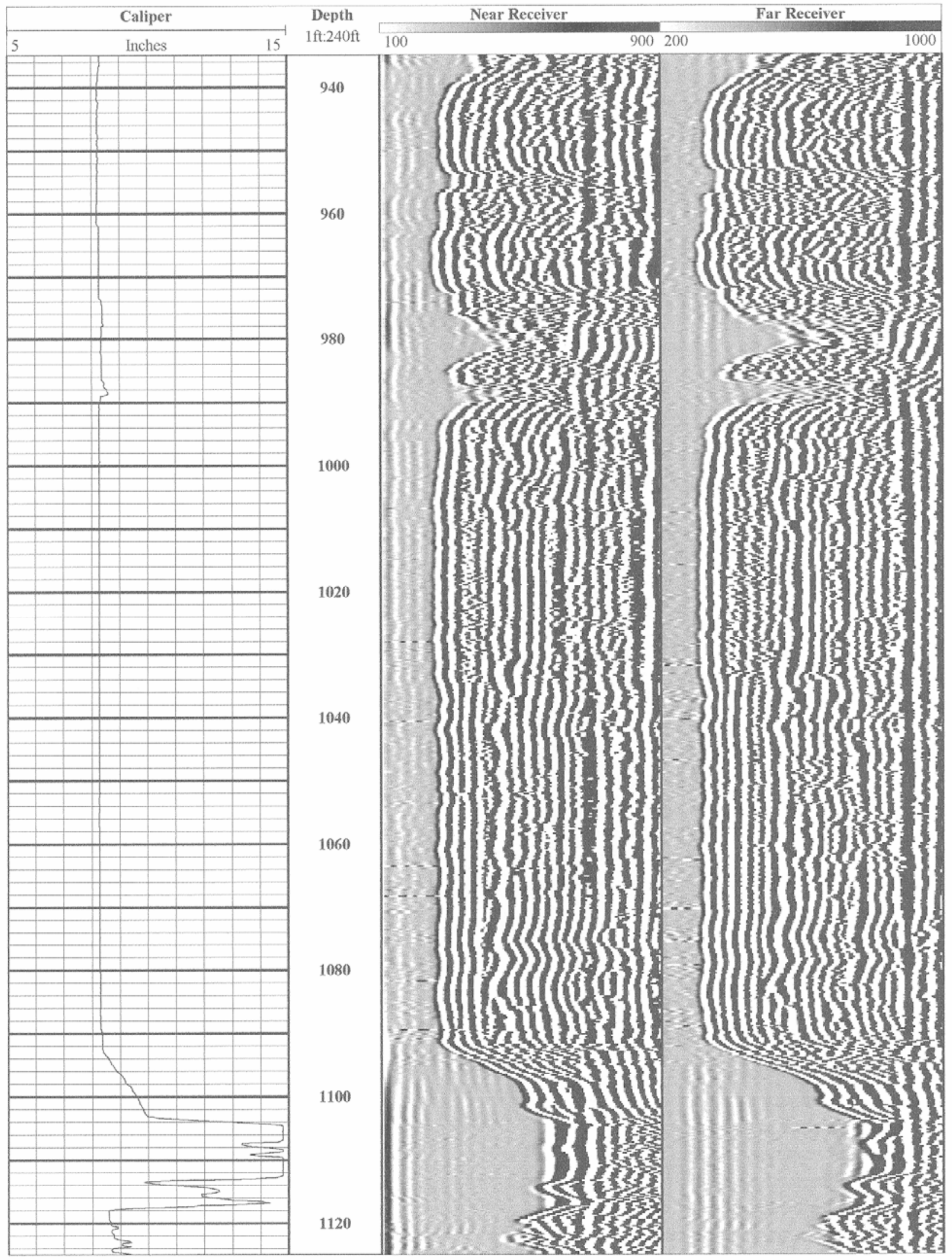


DTS-RPT-090, Rev. 0

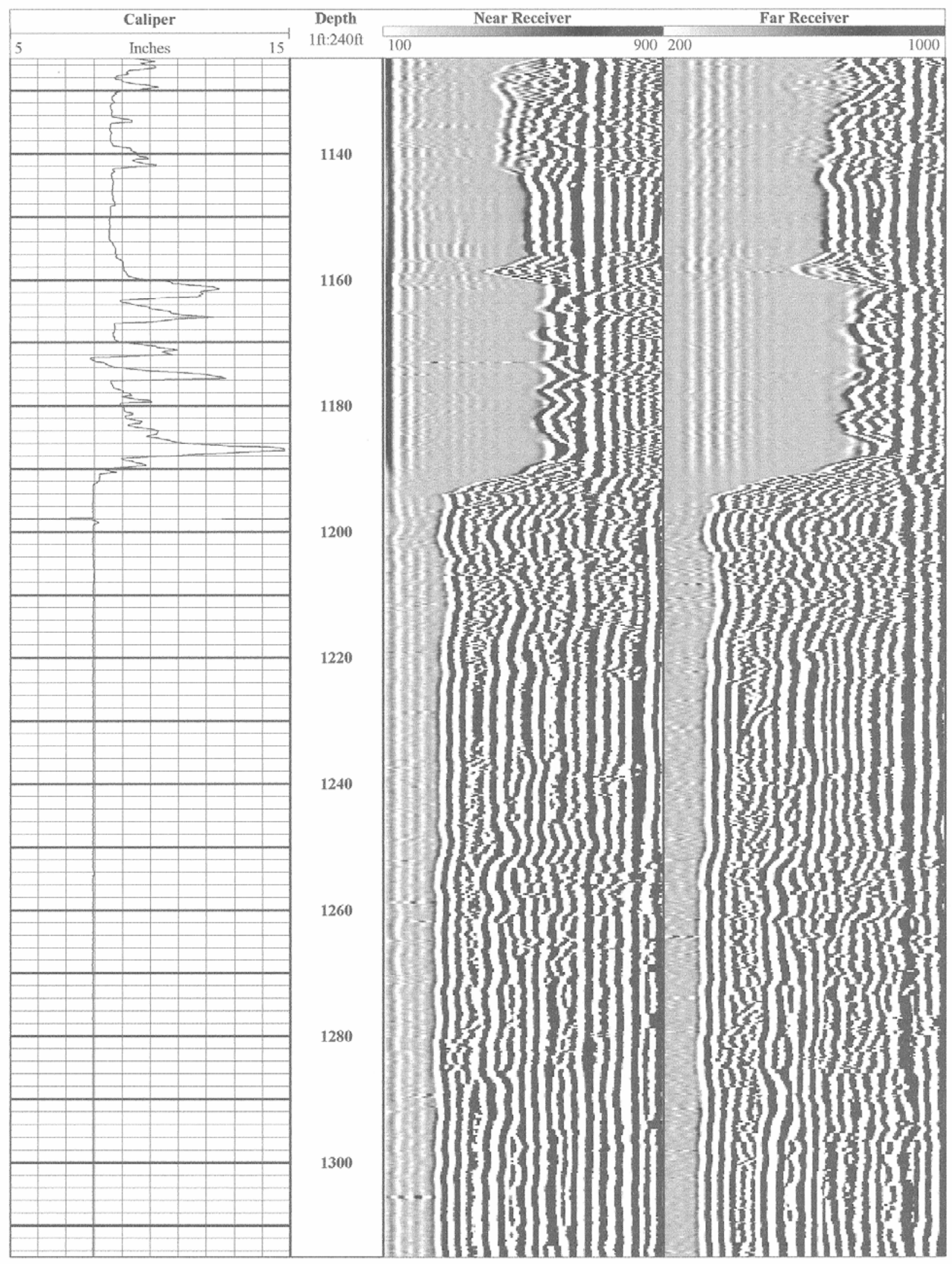


DTS-RPT-090, Rev. 0

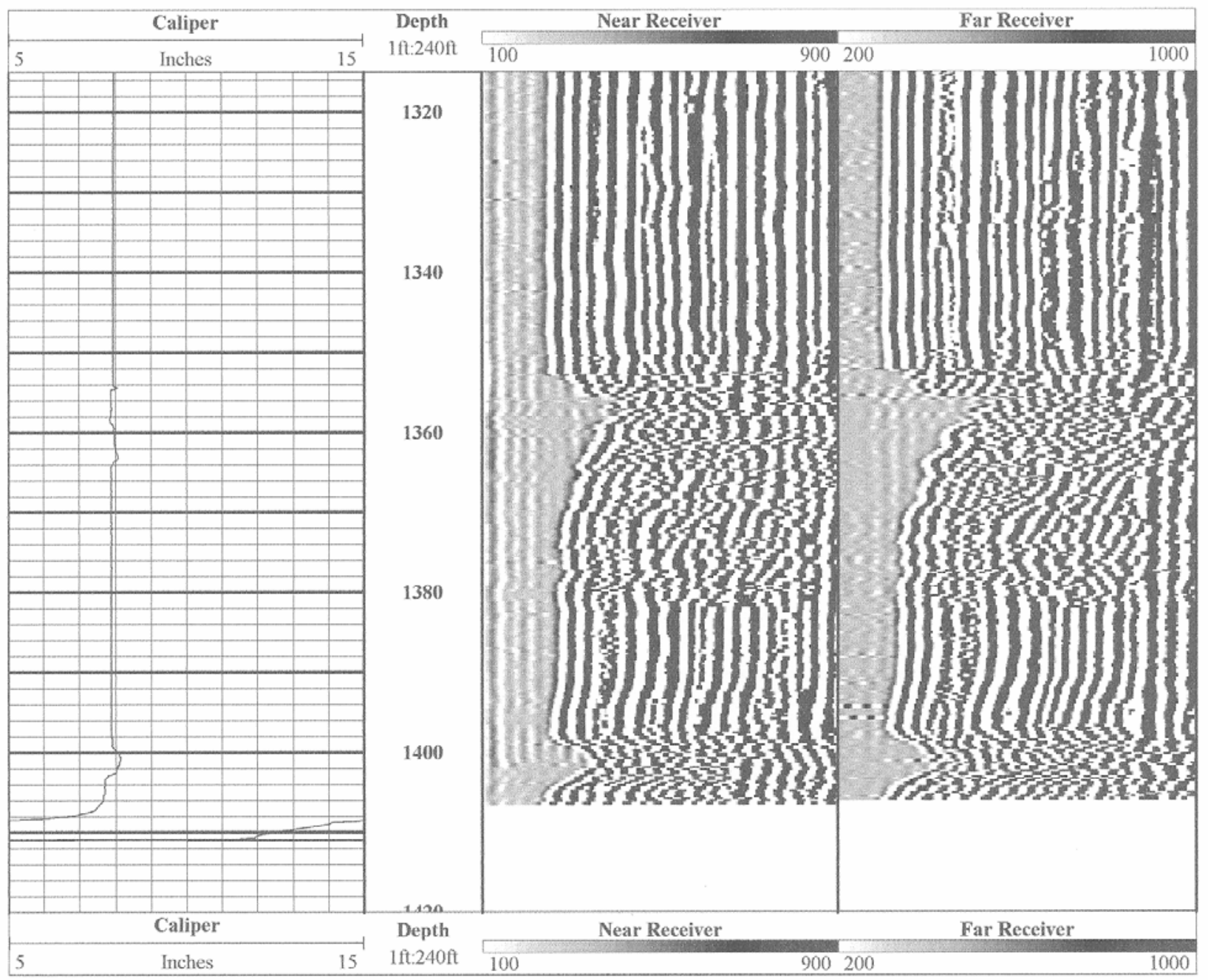


Wellbore Navigation, Inc.

Tustin, California

Earth's Magnetic Field Survey

For

Energy Solutions

Job Number: $\quad 48-0350-312$

Well Name: $\quad$ C4993

Location: Hanford Site

Survey Date: $\quad$ October 24, 2006

Survey Engineer: Dawson/Adams

Magnetic Declination: 00.00E True North

Surface Y-Coordinate: $\quad 135756.41$

Surface X-Coordinate: $\quad \mathbf{5 7 6 0 8 5 . 4 0}$

Surface Elevation: $\quad 200.63$

\section{Depth Measured in FEET}

Comments: $\quad$ Surface Casing Depth $372 \mathrm{ft}$.

USGS: Dip=69.08 Degrees

Intensity $=0.54600$ Oerstads

Declination= 16.60 Degrees 
DTS-RPT-090, Rev. 0

\begin{tabular}{|c|c|c|c|c|c|c|c|c|}
\hline $\begin{array}{c}\text { Hole } \\
\text { ID }\end{array}$ & $\begin{array}{l}\text { Measured } \\
\text { Depth }\end{array}$ & $\begin{array}{c}\text { Magnetic } \\
\text { Declination }\end{array}$ & $\begin{array}{l}\text { Magnetic } \\
\text { Intensity }\end{array}$ & $\begin{array}{l}\text { Magnetic } \\
\text { Dip }\end{array}$ & HFS & X-HFS & Y-HFS & Z-HFS \\
\hline C4993 & 360 & 2.574844 & 0.83065 & 78.57 & 0.16461 & 0.0074 & 0.16444 & 0.81418 \\
\hline C4993 & 380 & 29.01386 & 0.59893 & 69.33 & 0.21141 & 0.10254 & 0.18488 & 0.56038 \\
\hline C4993 & 400 & 20.01509 & 0.56175 & 68.68 & 0.20424 & 0.0699 & 0.1919 & 0.52331 \\
\hline C4993 & 420 & 24.14086 & 0.53992 & 69.18 & 0.19191 & 0.07849 & 0.17512 & 0.50466 \\
\hline C4993 & 440 & 20.12787 & 0.53727 & 68.67 & 0.19543 & 0.06725 & 0.18349 & 0.50047 \\
\hline C4993 & 460 & 15.88112 & 0.52887 & 66.81 & 0.20826 & 0.05699 & 0.20031 & 0.48614 \\
\hline C4993 & 480 & 18.45747 & 0.55066 & 70.2 & 0.18653 & 0.05906 & 0.17693 & 0.51811 \\
\hline C4993 & 500 & 17.67757 & 0.55126 & 70.25 & 0.18628 & 0.05657 & 0.17748 & 0.51883 \\
\hline C4993 & 520 & 18.50511 & 0.54959 & 70.06 & 0.18743 & 0.05949 & 0.17774 & 0.51664 \\
\hline C4993 & 540 & 28.64401 & 0.58986 & 75.77 & 0.145 & 0.06951 & 0.12725 & 0.57176 \\
\hline C4993 & 560 & 17.62399 & 0.56664 & 71.81 & 0.17689 & 0.05356 & 0.16859 & 0.53832 \\
\hline C4993 & 580 & 14.11453 & 0.59806 & 74.42 & 0.16063 & 0.03917 & 0.15578 & 0.57609 \\
\hline C4993 & 600 & 13.59198 & 0.60536 & 73.45 & 0.17244 & 0.04052 & 0.16761 & 0.58028 \\
\hline C4993 & 620 & 9.797577 & 0.59618 & 72.35 & 0.18076 & 0.03076 & 0.17813 & 0.56812 \\
\hline C4993 & 640 & 12.66144 & 0.63068 & 74.32 & 0.17045 & 0.03736 & 0.16631 & 0.60721 \\
\hline C4993 & 660 & 13.20889 & 0.55105 & 69.64 & 0.19172 & 0.04381 & 0.18665 & 0.51662 \\
\hline C4993 & 680 & 9.519836 & 0.55824 & 69.78 & 0.19294 & 0.03191 & 0.19029 & 0.52384 \\
\hline C4993 & 700 & 10.70804 & 0.55652 & 69.5 & 0.1949 & 0.03621 & 0.1915 & 0.52128 \\
\hline C4993 & 720 & 11.11749 & 0.56963 & 71.12 & 0.18432 & 0.03554 & 0.18087 & 0.53898 \\
\hline C4993 & 740 & 10.13504 & 0.53593 & 69.26 & 0.18979 & 0.0334 & 0.18683 & 0.5012 \\
\hline C4993 & 760 & 13.23935 & 0.48509 & 63.19 & 0.21879 & 0.05011 & 0.21298 & 0.43295 \\
\hline C4993 & 780 & 10.12079 & 0.36219 & 47.26 & 0.24581 & 0.04319 & 0.24198 & 0.26601 \\
\hline C4993 & 800 & 11.66327 & 0.44787 & 60.2 & 0.22258 & 0.045 & 0.21798 & 0.38865 \\
\hline C4993 & 820 & 15.82974 & 0.52062 & 64.31 & 0.22569 & 0.06156 & 0.21713 & 0.46916 \\
\hline C4993 & 840 & 4.724335 & 0.46765 & 61.55 & 0.22278 & 0.01835 & 0.22203 & 0.41117 \\
\hline C4993 & 860 & 9.855774 & 0.55031 & 69.08 & 0.1965 & 0.03363 & 0.1936 & 0.51403 \\
\hline C4993 & 880 & 9.326294 & 0.55021 & 69.09 & 0.19637 & 0.03182 & 0.19377 & 0.51397 \\
\hline C4993 & 900 & 9.166382 & 0.54959 & 69.05 & 0.19651 & 0.0313 & 0.194 & 0.51326 \\
\hline C4993 & 920 & 9.400784 & 0.54962 & 68.8 & 0.19876 & 0.03246 & 0.19609 & 0.51242 \\
\hline C4993 & 940 & 7.878433 & 0.49844 & 63.3 & 0.22396 & 0.0307 & 0.22184 & 0.44529 \\
\hline C4993 & 960 & 15.32608 & 0.50888 & 62.73 & 0.23316 & 0.06163 & 0.22487 & 0.45232 \\
\hline C4993 & 980 & 6.921921 & 0.51423 & 63.22 & 0.23169 & 0.02792 & 0.23001 & 0.45908 \\
\hline C4993 & 1000 & 14.51632 & 0.51534 & 66.31 & 0.20706 & 0.0519 & 0.20045 & 0.47191 \\
\hline C4993 & 1020 & 6.828202 & 0.47544 & 58.23 & 0.25032 & 0.02976 & 0.24855 & 0.4042 \\
\hline C4993 & 1040 & 2.836022 & 0.46574 & 55.45 & 0.26413 & 0.01307 & 0.26381 & 0.3836 \\
\hline C4993 & 1060 & 2.307987 & 0.46698 & 55.14 & 0.26691 & 0.01075 & 0.2667 & 0.38318 \\
\hline C4993 & 1080 & 3.908508 & 0.47944 & 61.24 & 0.23068 & 0.01572 & 0.23014 & 0.4203 \\
\hline C4993 & 1100 & 8.04048 & 0.55472 & 68.83 & 0.20033 & 0.02802 & 0.19836 & 0.51728 \\
\hline C4993 & 1120 & 8.388569 & 0.55446 & 68.79 & 0.2006 & 0.02926 & 0.19845 & 0.5169 \\
\hline C4993 & 1140 & 9.129448 & 0.55605 & 68.71 & 0.2019 & 0.03203 & 0.19934 & 0.5181 \\
\hline C4993 & 1160 & 10.09096 & 0.55617 & 69.23 & 0.19723 & 0.03456 & 0.19418 & 0.52003 \\
\hline C4993 & 1180 & 8.921036 & 0.55677 & 68.49 & 0.20415 & 0.03166 & 0.20168 & 0.51799 \\
\hline C4993 & 1200 & 7.065529 & 0.62664 & 73.21 & 0.18101 & 0.02227 & 0.17964 & 0.59993 \\
\hline C4993 & 1220 & 13.33696 & 0.56405 & 70.64 & 0.18698 & 0.04313 & 0.18194 & 0.53216 \\
\hline C4993 & 1240 & 14.28964 & 0.55164 & 69.83 & 0.19021 & 0.04695 & 0.18432 & 0.51781 \\
\hline C4993 & 1260 & 20.29974 & 0.58131 & 70.29 & 0.19605 & 0.06802 & 0.18388 & 0.54725 \\
\hline C4993 & 1280 & 11.93675 & 0.56603 & 71.03 & 0.184 & 0.03806 & 0.18002 & 0.53529 \\
\hline C4993 & 1300 & 9.363754 & 0.55402 & 70.54 & 0.18457 & 0.03003 & 0.18211 & 0.52237 \\
\hline C4993 & 1320 & 11.57204 & 0.5562 & 68.88 & 0.20041 & 0.0402 & 0.19634 & 0.51884 \\
\hline C4993 & 1340 & 12.86716 & 0.55425 & 69.29 & 0.196 & 0.04365 & 0.19108 & 0.51844 \\
\hline C4993 & 1360 & 9.464157 & 0.58397 & 70.16 & 0.1982 & 0.03259 & 0.1955 & 0.54931 \\
\hline C4993 & 1380 & 16.38838 & 0.61768 & 75.83 & 0.15121 & 0.04266 & 0.14506 & 0.59889 \\
\hline C4993 & 1400 & 11.62325 & 0.59671 & 76.07 & 0.14365 & 0.02894 & 0.1407 & 0.57916 \\
\hline
\end{tabular}


DTS-RPT-090, Rev. 0

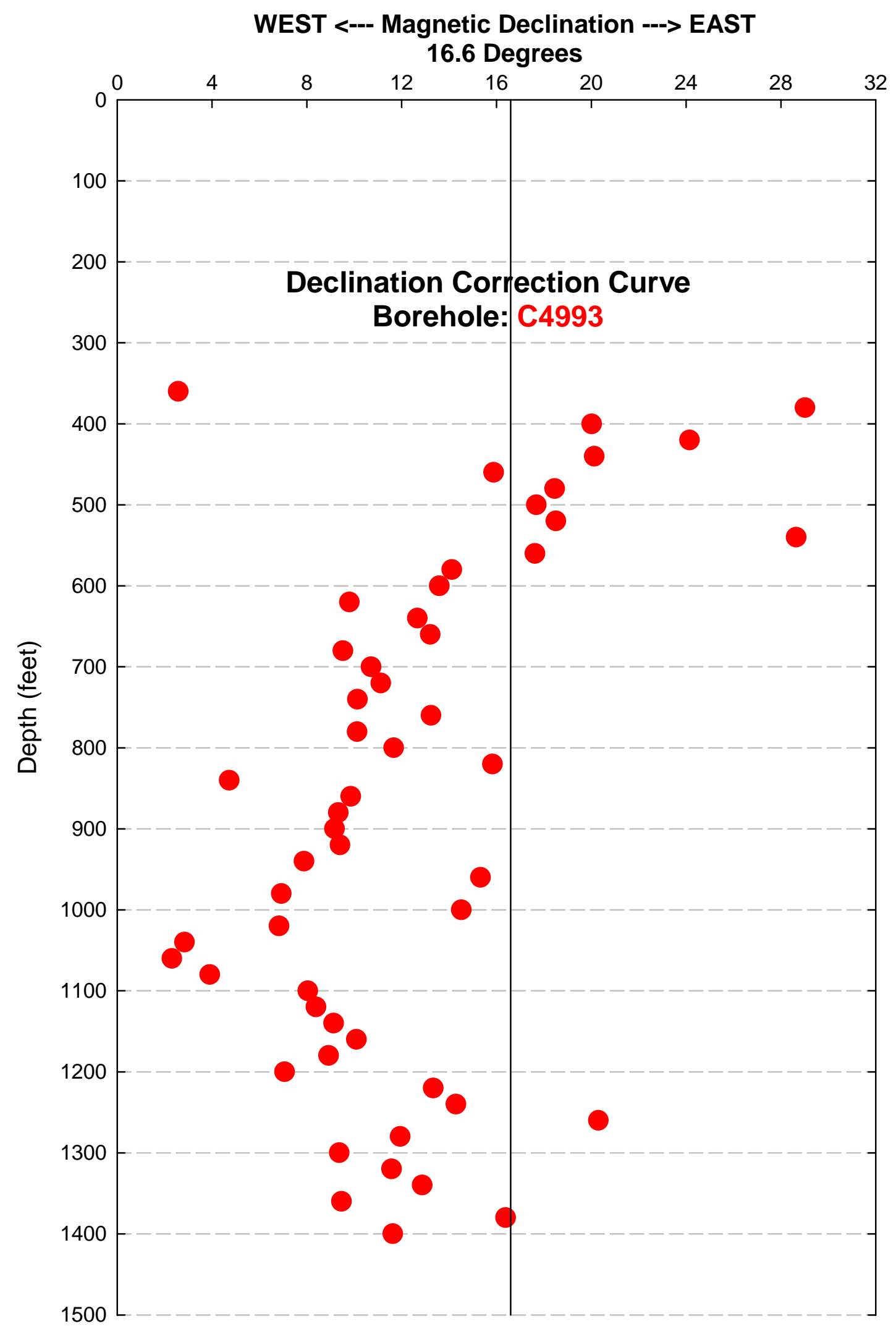


DTS-RPT-090, Rev. 0

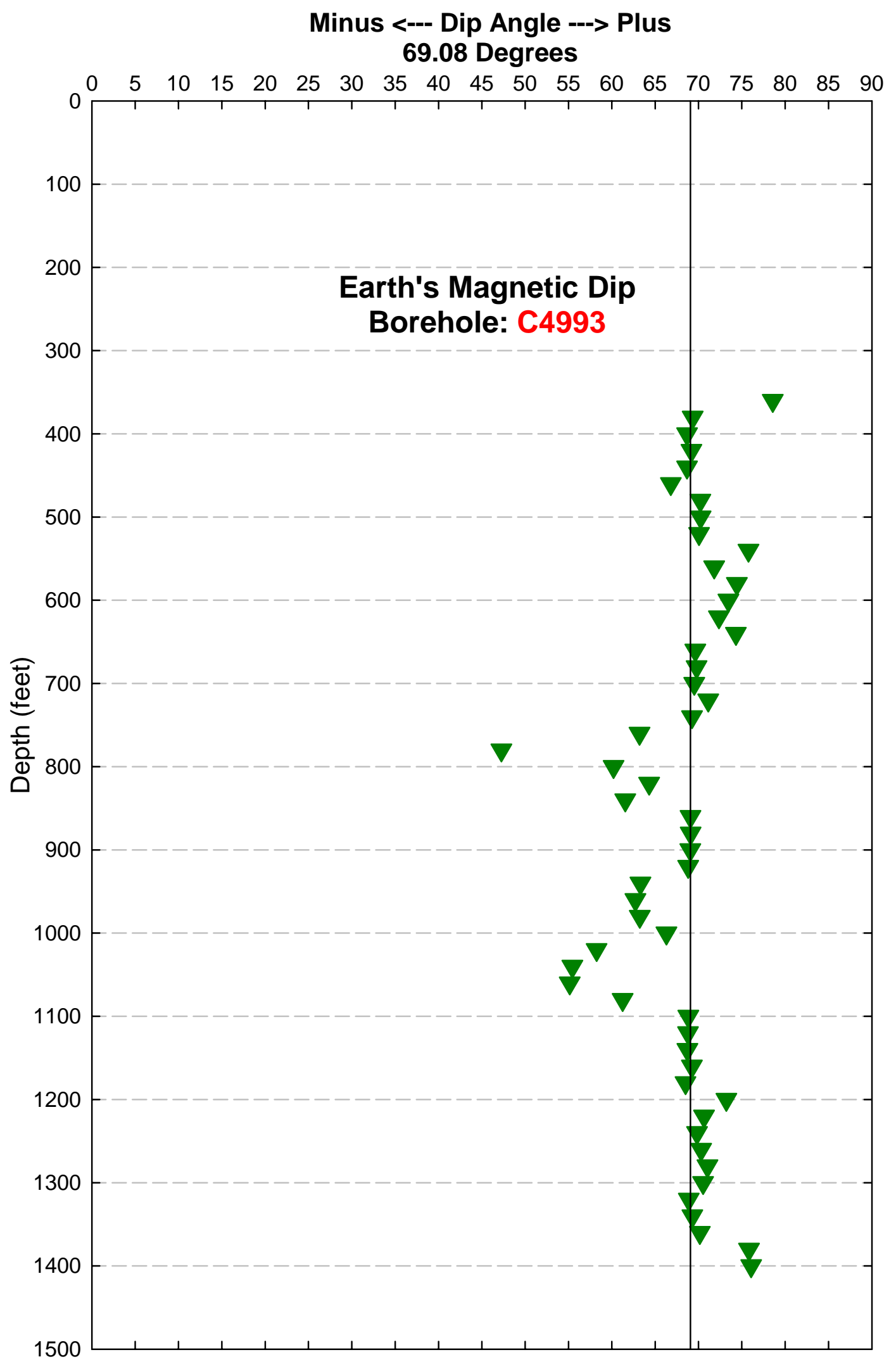


DTS-RPT-090, Rev. 0

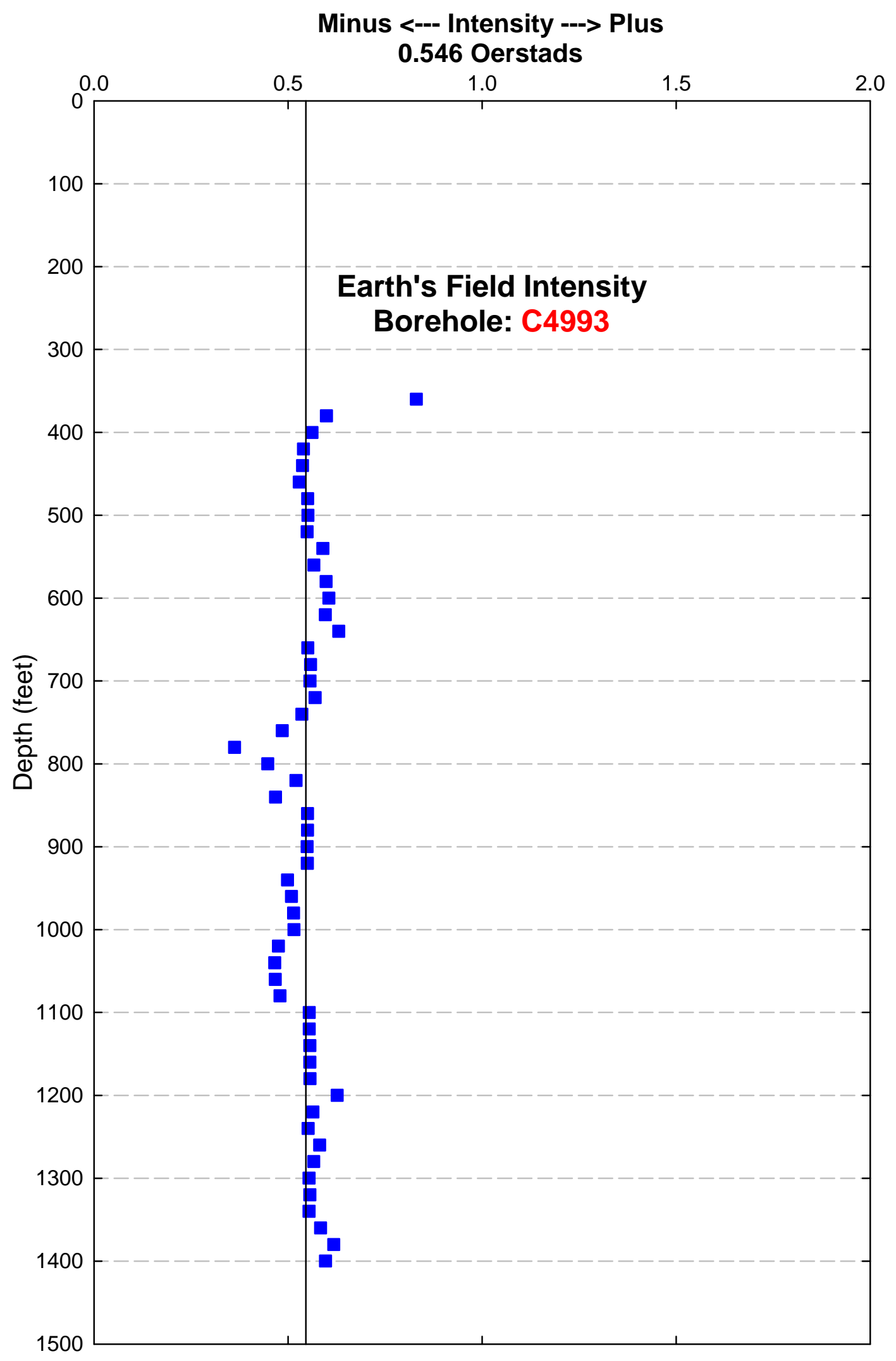


DTS-RPT-090, Rev. 0

APPENDIX B

BOREHOLE C4996 
DTS-RPT-090, Rev. 0

This page intentionally left blank. 
DTS-RPT-090, Rev. 0

\section{B1.0 BOREHOLE C4996}

\section{B1.1 ENERGYSOLUTIONS AND PACIFIC NORTHWEST GEOPHYSICS GYROSCOPIC LOGS}

$\begin{array}{ccccc}\text { Survey } & \text { Hole: C4996 } & & \\ \text { Date } & \begin{array}{c}\text { Survey } \\ \text { Number }\end{array} & \begin{array}{c}\text { Maximum } \\ \text { Depth } \\ \text { (feet) }\end{array} & \begin{array}{c}\text { Inclination } \\ \text { From Vertical } \\ \text { (deg) }\end{array} & \begin{array}{c}\text { Closure } \\ \text { Distance } \\ \text { (feet) }\end{array} \\ \text { 9/1/2006 } & 18^{*} & 1457 & 0.3 & 26 \\ 8 / 26 / 2006 & 17^{*} & 1356 & 0.8 & 27 \\ 8 / 25 / 2006 & 16^{*} & 1257 & 0.6 & 27 \\ 8 / 21 / 2006 & 15^{*} & 1158 & 1.1 & 25 \\ 8 / 20 / 2006 & 14^{*} & 1055 & 0.7 & 25 \\ 8 / 19 / 2006 & 13 & 965 & 1.2 & 21 \\ 8 / 16 / 2006 & 12^{*} & 861 & 1.0 & 19 \\ 8 / 14 / 2006 & 11 & 785 & 1.2 & 18 \\ 8 / 10 / 2006 & 10^{*} & 676 & 1.3 & 13 \\ 8 / 4 / 2006 & 9 & 576 & 1.7 & 13.5 \\ 8 / 2 / 2006 & 8 & 477 & 1.1 & 9.2 \\ \text { Casing } & \text { Cable-Tool } & & & 7.3 \\ 7 / 26 / 2006 & 7 & 351 & 2.7 & 0.7 \\ 7 / 24 / 2006 & 6 & 294 & 2.9 & 0.3 \\ 7 / 20 / 2006 & 5 & 244 & 3.5 & 1.1 \\ 7 / 14 / 2006 & 3 & 94 & 0.9 & \\ 7 / 13 / 2006 & 2 & 37 & & \end{array}$


DTS-RPT-090, Rev. 0

Hole: C4996

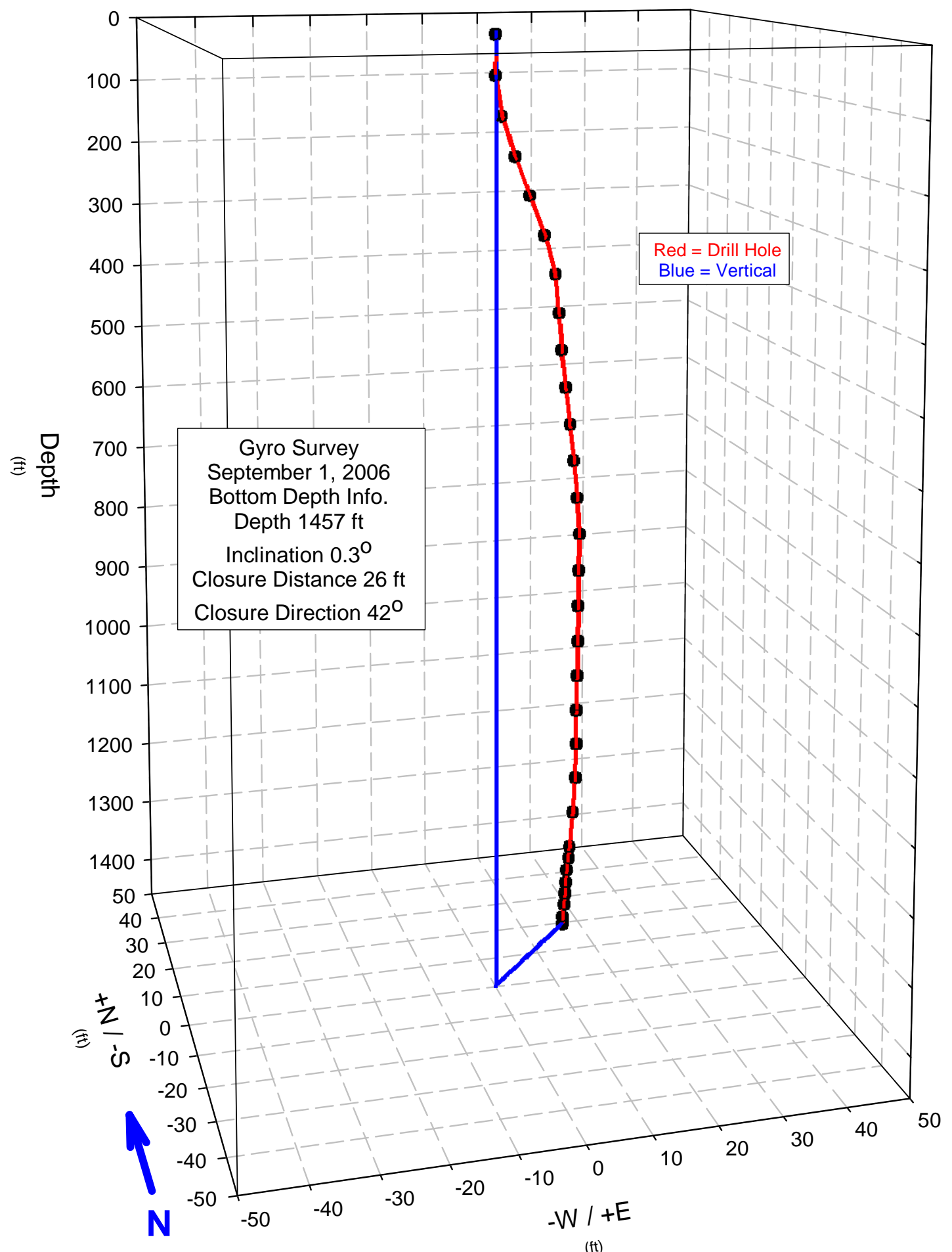


Hole: C4996 Survey Date: 9/1/2006

$\begin{array}{cccccccc}\begin{array}{c}\text { Measured } \\ \text { Depth } \\ \text { (feet) }\end{array} & \begin{array}{c}\text { TrueVert. } \\ \text { Depth } \\ \text { (feet) }\end{array} & \begin{array}{c}\text { Inclination } \\ \text { from Vert. } \\ \text { (deg) }\end{array} & \begin{array}{c}\text { Closure } \\ \text { Direction } \\ \text { (deg) }\end{array} & \begin{array}{c}\text { Closure } \\ \text { Distance } \\ \text { (feet) }\end{array} & \begin{array}{c}\text { Rectangular } \\ \text { Coordinates } \\ + \text { N/-S }\end{array} & \begin{array}{c}\text { Rectangular } \\ \text { Coordinates } \\ + \text { E/-W }\end{array} & \begin{array}{c}\text { Dog-Leg } \\ \text { Severity } \\ \text { O/100-ft }\end{array} \\ 65 & 5 & 0.47 & 317.98 & 0.05 & 0.03 & -0.03 & 5 \\ 125 & 65 & 0.43 & 357.11 & 0.23 & 0.23 & -0.01 & 1.4 \\ 185 & 124.99 & 1.54 & 82.61 & 1.01 & 0.13 & 1 & 1.9 \\ 245 & 244.95 & 2.81 & 83.75 & 3.24 & 0.35 & 3.22 & 2.6 \\ 305 & 304.83 & 2.39 & 79.68 & 5.94 & 1.06 & 5.85 & 0.7 \\ 365 & 364.79 & 1.14 & 80.16 & 8.55 & 1.46 & 8.43 & 1 \\ 425 & 424.78 & 1.31 & 76.52 & 10.49 & 1.8 & 10.33 & 2.8 \\ 485 & 484.76 & 1.71 & 71.64 & 12.71 & 2.68 & 11.19 & 1.2 \\ 545 & 544.73 & 1.7 & 67.66 & 14.23 & 5.41 & 12.06 & 0.7 \\ 605 & 604.71 & 1.4 & 65.22 & 15.72 & 6.59 & 13.17 & 0.2 \\ 665 & 664.7 & 1.19 & 63.83 & 17.02 & 7.5 & 15.27 & 0.6 \\ 725 & 724.68 & 1.02 & 62.83 & 18.13 & 8.28 & 16.13 & 0.3 \\ 785 & 784.68 & 0.79 & 61.64 & 18.97 & 9.01 & 16.7 & 0.7 \\ 845 & 844.67 & 1.04 & 59.59 & 19.62 & 9.93 & 16.92 & 0.6 \\ 905 & 904.66 & 1.24 & 57.18 & 20.45 & 11.09 & 17.19 & 0.6 \\ 965 & 964.65 & 1.02 & 55.11 & 21.36 & 12.22 & 17.52 & 0.4 \\ 1025 & 1024.64 & 0.95 & 53.25 & 22.12 & 13.23 & 17.72 & 0.2 \\ 1085 & 1084.62 & 1.4 & 51.2 & 23.04 & 14.44 & 17.96 & 0.8 \\ 1145 & 1144.61 & 1.27 & 49.27 & 24.19 & 15.78 & 18.33 & 0.3 \\ 1205 & 1204.6 & 0.8 & 47.72 & 25.02 & 16.83 & 18.51 & 1 \\ 1265 & 1264.59 & 0.97 & 46.1 & 25.61 & 17.76 & 18.45 & 0.3 \\ 1325 & 1324.59 & 0.74 & 44.39 & 25.95 & 18.55 & 18.15 & 1 \\ 1345 & 1344.58 & 0.64 & 43.87 & 25.92 & 18.69 & 17.96 & 1.4 \\ 1365 & 1364.58 & 0.75 & 43.37 & 25.83 & 18.78 & 17.74 & 0.7 \\ 1385 & 1384.58 & 0.44 & 42.94 & 25.81 & 18.89 & 17.58 & 2.8 \\ 1405 & 1404.58 & 0.78 & 42.52 & 25.91 & 19.09 & 17.51 & 1.7 \\ 1425 & 1424.58 & 0.8 & 41.98 & 25.91 & 19.26 & 17.33 & 3.6 \\ 1445 & 1444.58 & 0.4 & 41.59 & 25.9 & 19.37 & 17.19 & 3.8 \\ 1457.5 & 1457.08 & 0.25 & 41.47 & 25.95 & 19.45 & 17.19 & 1.2 \\ & & & & & & & \end{array}$


DTS-RPT-090, Rev. 0

Hole: C4996

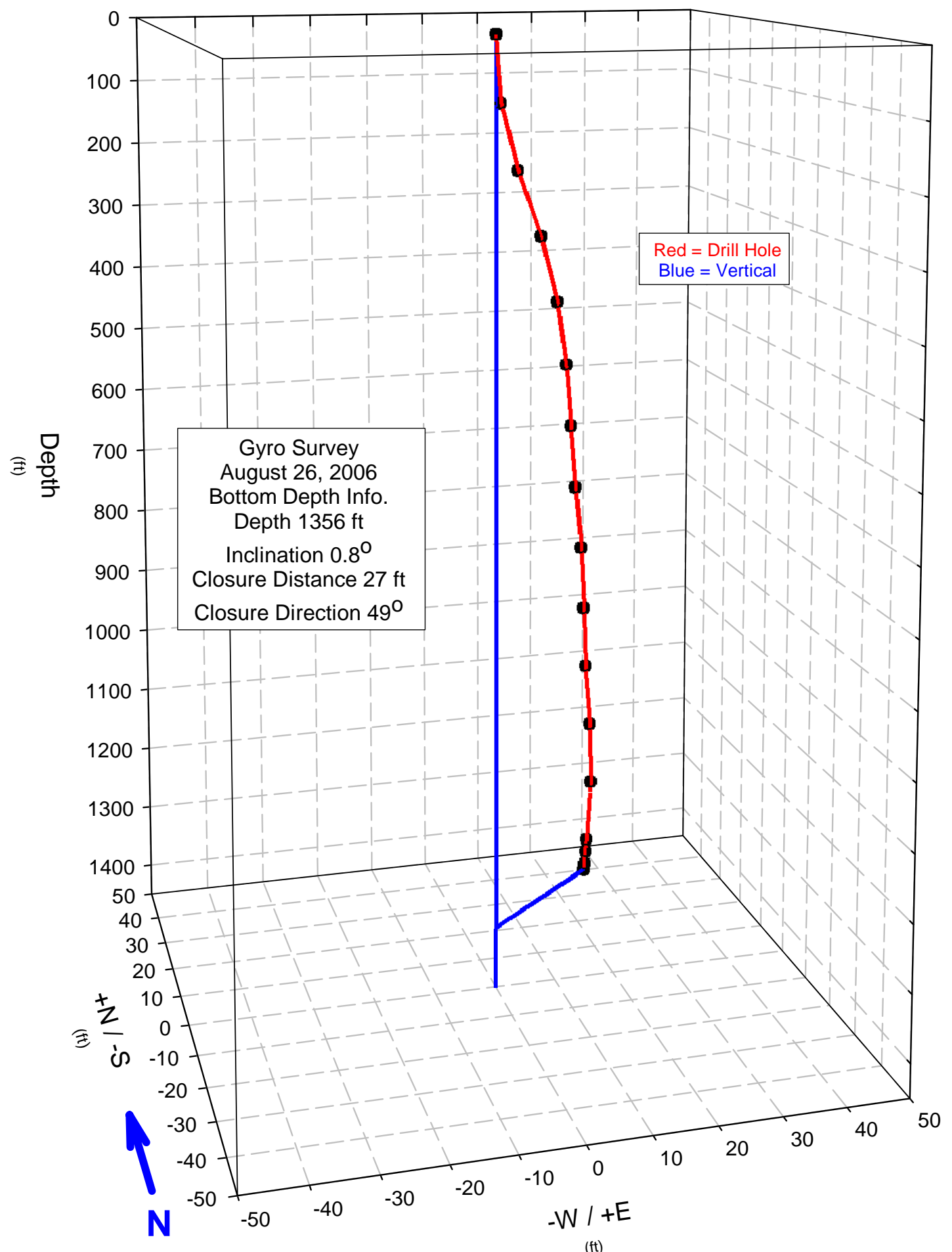


DTS-RPT-090, Rev. 0

Hole: C4996 Survey Date: 8/26/2006

\begin{tabular}{|c|c|c|c|c|c|c|c|}
\hline $\begin{array}{l}\text { Measured } \\
\text { Depth } \\
\text { (feet) }\end{array}$ & $\begin{array}{l}\text { TrueVert. } \\
\text { Depth } \\
\text { (feet) }\end{array}$ & $\begin{array}{l}\text { Inclination } \\
\text { from Vert. } \\
\text { (deg) }\end{array}$ & $\begin{array}{c}\text { Closure } \\
\text { Direction } \\
\text { (deg) }\end{array}$ & $\begin{array}{c}\text { Closure } \\
\text { Distance } \\
\text { (feet) }\end{array}$ & $\begin{array}{c}\text { Rectangular } \\
\text { Coordinates } \\
+ \text { N/-S }\end{array}$ & $\begin{array}{c}\text { Rectangular } \\
\text { Coordinates } \\
+E /-W\end{array}$ & $\begin{array}{l}\text { Dog-Leg } \\
\text { Severity } \\
0 / 100-f t\end{array}$ \\
\hline 5 & 5 & 0.13 & 274.79 & 0 & 0 & 0 & 4.8 \\
\hline 105 & 104.99 & 1.03 & 85.1 & 0.84 & 0.07 & 0.84 & 1.1 \\
\hline 205 & 204.94 & 2.51 & 77.5 & 3.92 & 0.85 & 3.83 & 1.5 \\
\hline 305 & 304.86 & 2.32 & 77.03 & 8.12 & 1.82 & 7.92 & 0.3 \\
\hline 405 & 404.8 & 1.37 & 76.16 & 11.32 & 2.71 & 10.99 & 1 \\
\hline 505 & 504.77 & 1.75 & 71.35 & 13.77 & 4.4 & 13.04 & 0.8 \\
\hline 605 & 604.73 & 1.53 & 64.97 & 16.07 & 6.8 & 14.56 & 0.5 \\
\hline 705 & 704.7 & 1.38 & 61.08 & 18.26 & 8.83 & 15.98 & 0.6 \\
\hline 805 & 804.68 & 0.9 & 59.88 & 20.2 & 10.14 & 17.48 & 0.5 \\
\hline 905 & 904.66 & 1.1 & 57.84 & 21.7 & 11.55 & 18.37 & 0.6 \\
\hline 1005 & 1004.64 & 1.46 & 54.97 & 23.6 & 13.55 & 19.33 & 0.5 \\
\hline 1105 & 1104.62 & 0.92 & 53.79 & 25.58 & 15.11 & 20.64 & 0.7 \\
\hline 1205 & 1204.6 & 0.99 & 52.26 & 26.93 & 16.48 & 21.3 & 0.8 \\
\hline 1305 & 1304.59 & 0.62 & 49.75 & 27.41 & 17.71 & 20.92 & 0.8 \\
\hline 1325 & 1324.59 & 0.47 & 49.37 & 27.36 & 17.82 & 20.76 & 1.1 \\
\hline 1345 & 1344.59 & 0.22 & 49.14 & 27.31 & 17.87 & 20.65 & 1.3 \\
\hline 1356 & 1355.59 & 0.82 & 48.93 & 27.3 & 17.94 & 20.58 & 5.7 \\
\hline
\end{tabular}


DTS-RPT-090, Rev. 0

Hole: C4996

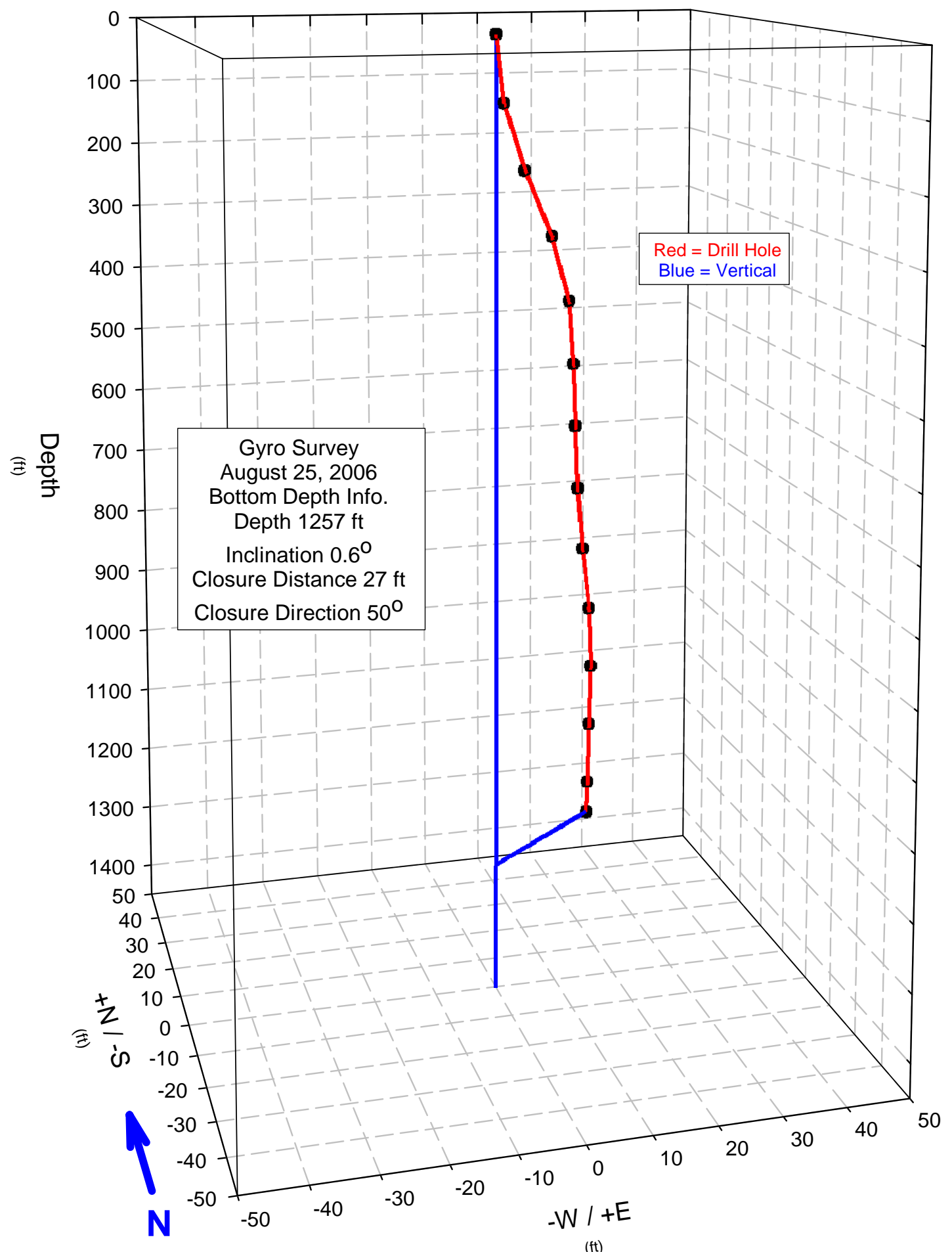


DTS-RPT-090, Rev. 0

Hole: C4996 Survey Date: 8/25/2006

$\begin{array}{cccccccc}\begin{array}{c}\text { Measured } \\ \text { Depth } \\ \text { (feet) }\end{array} & \begin{array}{c}\text { TrueVert. } \\ \text { Depth } \\ \text { (feet) }\end{array} & \begin{array}{c}\text { Inclination } \\ \text { from Vert. } \\ \text { (deg) }\end{array} & \begin{array}{c}\text { Closure } \\ \text { Direction } \\ \text { (deg) }\end{array} & \begin{array}{c}\text { Closure } \\ \text { Distance } \\ \text { (feet) }\end{array} & \begin{array}{c}\text { Rectangular } \\ \text { Coordinates } \\ \text { +N/-S }\end{array} & \begin{array}{c}\text { Rectangular } \\ \text { Coordinates } \\ + \text { E/-W }\end{array} & \begin{array}{c}\text { Dog-Leg } \\ \text { Severity } \\ \text { o/100-ft }\end{array} \\ 105 & 5 & 0.23 & 147.76 & 0.01 & -0.01 & 0 & 7.8 \\ 205 & 104.99 & 1.49 & 111.07 & 1.27 & -0.46 & 1.19 & 1.6 \\ 305 & 204.92 & 2.69 & 91.09 & 4.71 & -0.09 & 4.71 & 1.5 \\ 405 & 304.8 & 3.06 & 82.91 & 9.63 & 1.19 & 9.56 & 0.4 \\ 505 & 404.72 & 1.51 & 77.54 & 13.27 & 2.86 & 12.96 & 2.1 \\ 605 & 604.69 & 1.31 & 71.16 & 15.15 & 4.89 & 14.34 & 0.3 \\ 705 & 704.65 & 1.3 & 65.67 & 16.84 & 6.94 & 15.35 & 0.2 \\ 805 & 804.63 & 1.34 & 62.63 & 18.26 & 8.39 & 16.21 & 0.7 \\ 905 & 904.6 & 1.56 & 59.29 & 22.35 & 11.41 & 17.53 & 0.7 \\ 1005 & 1004.57 & 1.18 & 56.23 & 24.33 & 13.53 & 20.23 & 0.4 \\ 1105 & 1104.56 & 0.96 & 53.24 & 25.67 & 15.37 & 20.57 & 0.7 \\ 1205 & 1204.55 & 0.54 & 51.21 & 26.6 & 16.66 & 20.73 & 0.4 \\ 1257 & 1256.54 & 0.58 & 50.34 & 26.9 & 17.17 & 20.71 & 0.3\end{array}$


DTS-RPT-090, Rev. 0

Hole: C4996

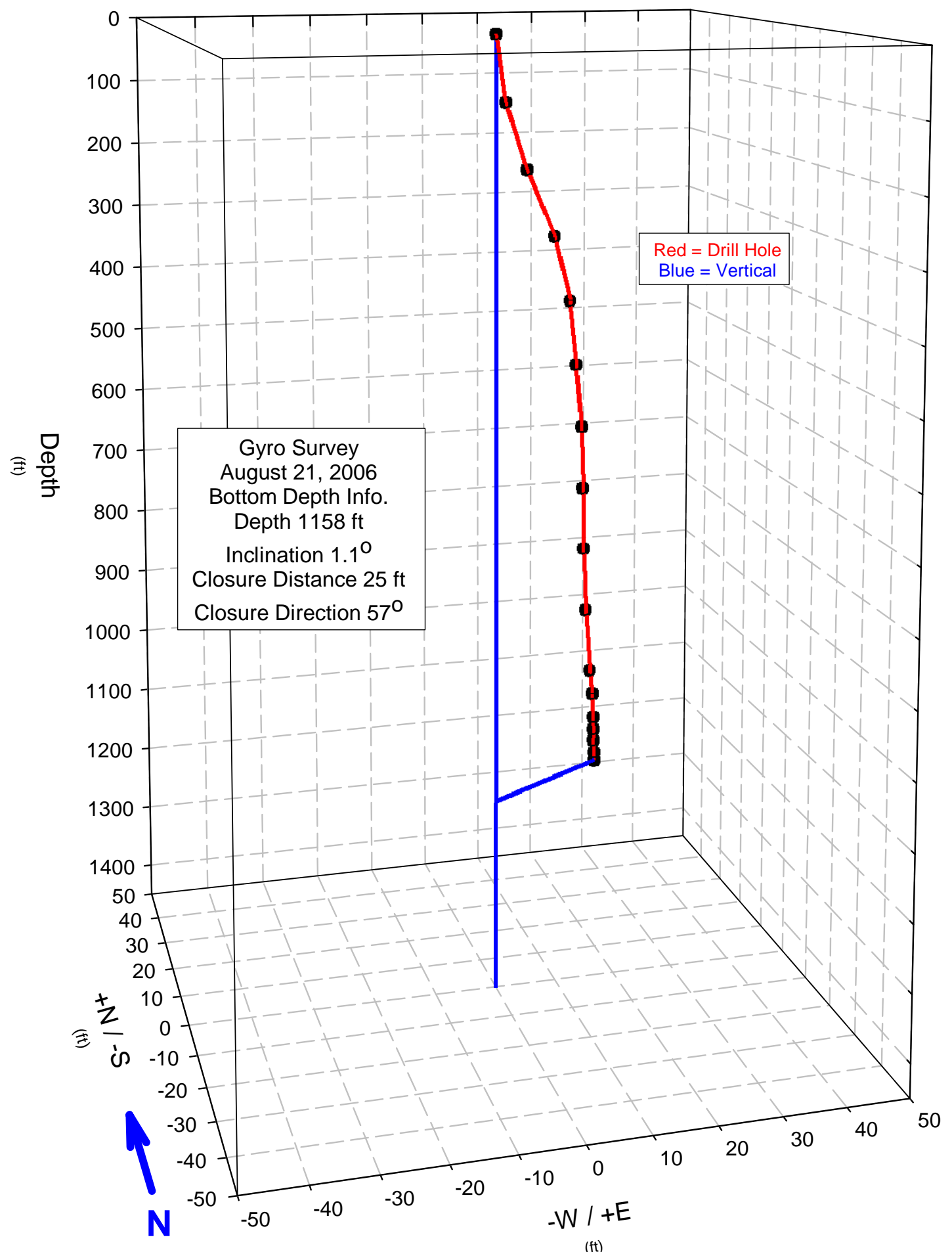


DTS-RPT-090, Rev. 0

Hole: C4996 Survey Date: 8/21/2006

\begin{tabular}{|c|c|c|c|c|c|c|c|}
\hline Measured & TrueVert. & Inclination & Closure & Closure & Rectangular & Rectangular & Dog-Leg \\
\hline $\begin{array}{l}\text { Depth } \\
\text { (feet) }\end{array}$ & $\begin{array}{l}\text { Depth } \\
\text { (feet) }\end{array}$ & $\begin{array}{l}\text { from Vert. } \\
\text { (deg) }\end{array}$ & $\begin{array}{l}\text { Direction } \\
\text { (deg) }\end{array}$ & $\begin{array}{c}\text { Distance } \\
\text { (feet) }\end{array}$ & $\begin{array}{c}\text { Coordinates } \\
+\mathrm{N} / \mathrm{SS}\end{array}$ & $\begin{array}{c}\text { Coordinates } \\
+E /-W\end{array}$ & $\begin{array}{l}\text { Severity } \\
\text { o/100-ft }\end{array}$ \\
\hline 4 & 4 & 0.65 & 64.65 & 0.05 & 0.02 & 0.04 & 11.1 \\
\hline 104 & 103.98 & 1.42 & 71.69 & 1.77 & 0.55 & 1.68 & 1 \\
\hline 204 & 203.92 & 2.71 & 81.77 & 5.33 & 0.76 & 5.27 & 1.3 \\
\hline 304 & 303.81 & 2.59 & 85.22 & 9.93 & 0.83 & 9.9 & 0.1 \\
\hline 404 & 403.76 & 1.3 & 82.24 & 12.92 & 1.75 & 12.81 & 2.1 \\
\hline 504 & 503.73 & 1.58 & 75.93 & 14.9 & 3.62 & 14.45 & 0.4 \\
\hline 604 & 603.69 & 1.55 & 70.25 & 17.07 & 5.77 & 16.07 & 0.5 \\
\hline 704 & 703.67 & 0.86 & 65.63 & 18.6 & 7.68 & 16.95 & 0.7 \\
\hline 804 & 803.65 & 0.94 & 62.55 & 19.78 & 9.12 & 17.55 & 0.1 \\
\hline 904 & 903.65 & 0.63 & 60.78 & 20.97 & 10.24 & 18.31 & 0.4 \\
\hline 1004 & 1003.63 & 1.12 & 59.92 & 22.46 & 11.26 & 19.44 & 0.5 \\
\hline 1044 & 1043.63 & 0.81 & 59.53 & 23.12 & 11.72 & 19.92 & 0.8 \\
\hline 1084 & 1083.62 & 0.86 & 58.98 & 23.65 & 12.19 & 20.27 & 0.4 \\
\hline 1104 & 1103.62 & 1.26 & 58.49 & 23.96 & 12.52 & 20.43 & 2.2 \\
\hline 1124 & 1123.62 & 0.69 & 57.97 & 24.22 & 12.85 & 20.53 & 3 \\
\hline 1144 & 1143.62 & 0.97 & 57.72 & 24.47 & 13.07 & 20.69 & 3.1 \\
\hline 1158 & 1157.61 & 1.1 & 57.46 & 24.68 & 13.27 & 20.81 & 5.3 \\
\hline
\end{tabular}


DTS-RPT-090, Rev. 0

Hole: C4996

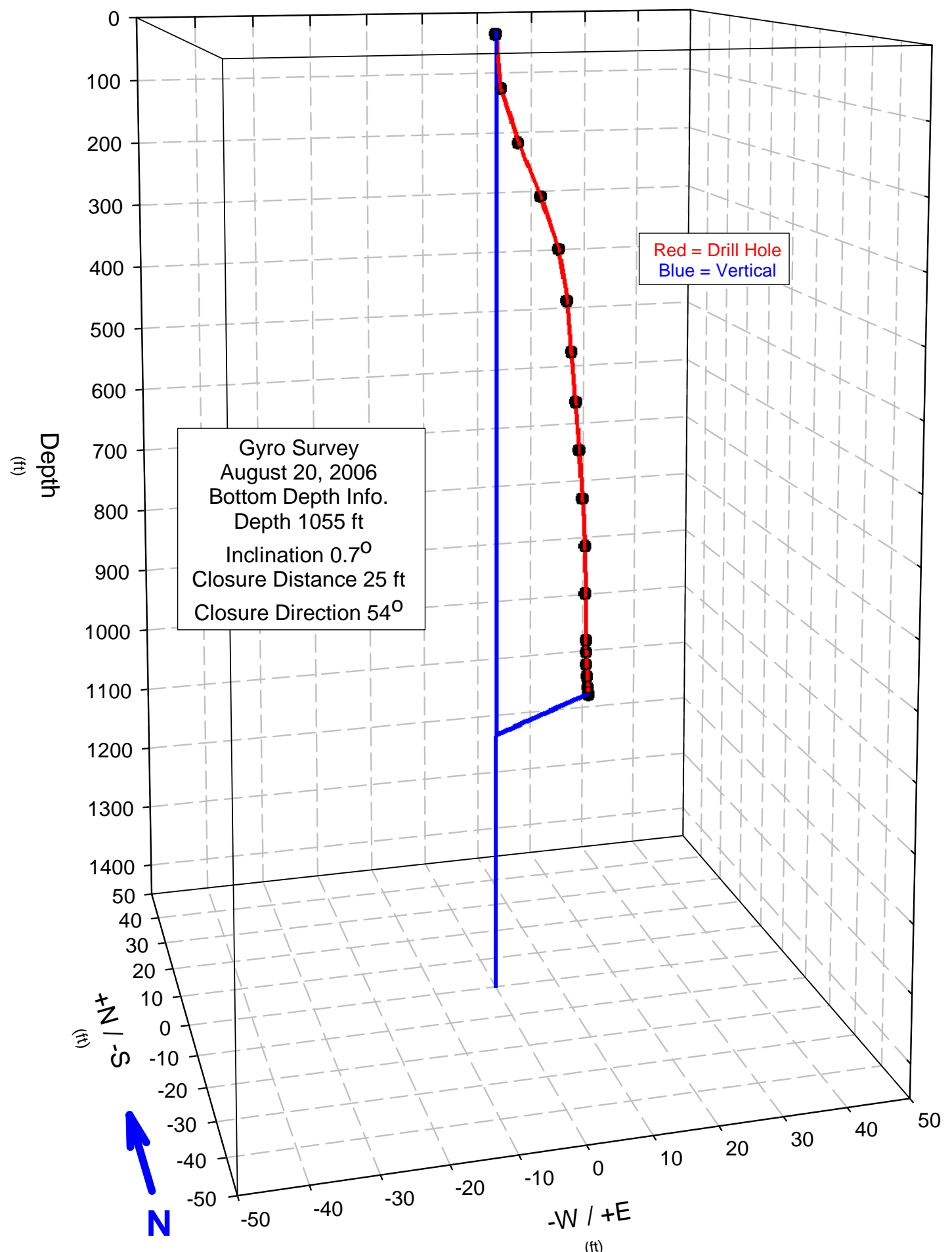


DTS-RPT-090, Rev. 0

Hole: C4996 Survey Date: 8/20/2006

$\begin{array}{cccccccc}\begin{array}{c}\text { Measured } \\ \text { Depth } \\ \text { (feet) }\end{array} & \begin{array}{c}\text { TrueVert. } \\ \text { Depth } \\ \text { (feet) }\end{array} & \begin{array}{c}\text { Inclination } \\ \text { from Vert. } \\ \text { (deg) }\end{array} & \begin{array}{c}\text { Closure } \\ \text { Direction } \\ \text { (deg) }\end{array} & \begin{array}{c}\text { Closure } \\ \text { Distance } \\ \text { (feet) }\end{array} & \begin{array}{c}\text { Rectangular } \\ \text { Coordinates } \\ +N /-S\end{array} & \begin{array}{c}\text { Rectangular } \\ \text { Coordinates } \\ + \text { E/-W }\end{array} & \begin{array}{c}\text { Dog-Leg } \\ \text { Severity } \\ \text { /100-ft }\end{array} \\ 84 & 4 & 0.47 & 320.99 & 0.02 & 0.02 & -0.01 & 10.4 \\ 164 & 83.99 & 1.5 & 82.08 & 0.76 & 0.1 & 0.75 & 2.4 \\ 244 & 163.94 & 2.65 & 88.67 & 3.65 & 0.08 & 3.65 & 1.5 \\ 324 & 323.75 & 2.6 & 87.78 & 7.31 & 0.28 & 7.31 & 0.1 \\ 404 & 403.76 & 1.99 & 85.88 & 10.49 & 0.75 & 10.46 & 0.9 \\ 484 & 483.74 & 1.29 & 81.49 & 12.44 & 1.84 & 12.3 & 1.7 \\ 564 & 563.7 & 1.68 & 75.57 & 13.86 & 3.45 & 13.42 & 0.3 \\ 644 & 643.67 & 1.53 & 65.98 & 15.64 & 5.27 & 14.73 & 0.2 \\ 724 & 723.65 & 1.39 & 62.68 & 19.25 & 8.13 & 15.99 & 0.2 \\ 804 & 803.62 & 1.53 & 59.64 & 20.99 & 10.61 & 17.1 & 0.2 \\ 884 & 883.6 & 1.23 & 56.57 & 22.5 & 12.4 & 18.11 & 0.2 \\ 964 & 963.58 & 0.94 & 54.5 & 23.74 & 13.79 & 19.32 & 0.6 \\ 984 & 983.58 & 0.92 & 54.17 & 24.03 & 14.07 & 19.48 & 0.7 \\ 1004 & 1003.58 & 0.73 & 53.89 & 24.29 & 14.32 & 19.63 & 1.2 \\ 1024 & 1023.58 & 0.86 & 53.76 & 24.56 & 14.52 & 19.81 & 1 \\ 1044 & 1043.57 & 1.11 & 53.63 & 24.9 & 14.77 & 20.05 & 1.3 \\ 1055 & 1054.57 & 0.68 & 53.53 & 25.07 & 14.9 & 20.16 & 4.2\end{array}$


DTS-RPT-090, Rev. 0

Hole: C4996

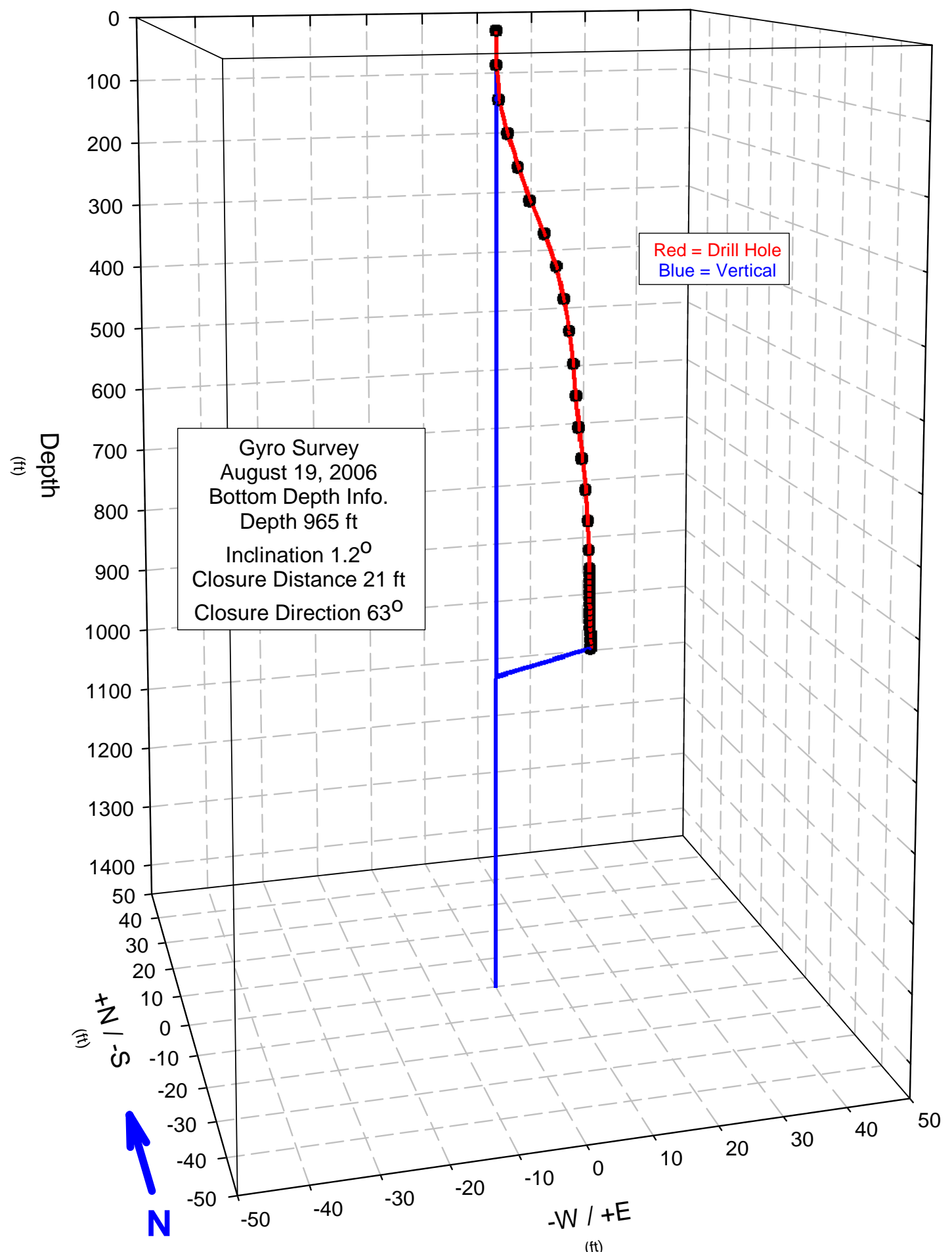


Hole: C4996 Survey Date: 8/19/2006

$\begin{array}{cccccccc}\begin{array}{c}\text { Measured } \\ \text { Depth } \\ \text { (feet) }\end{array} & \begin{array}{c}\text { TrueVert. } \\ \text { Depth } \\ \text { (feet) }\end{array} & \begin{array}{c}\text { Inclination } \\ \text { from Vert. } \\ \text { (deg) }\end{array} & \begin{array}{c}\text { Closure } \\ \text { Direction } \\ \text { (deg) }\end{array} & \begin{array}{c}\text { Closure } \\ \text { Distance } \\ \text { (feet) }\end{array} & \begin{array}{c}\text { Rectangular } \\ \text { Coordinates } \\ + \text { N/-S }\end{array} & \begin{array}{c}\text { Rectangular } \\ \text { Coordinates } \\ + \text { E/-W }\end{array} & \begin{array}{c}\text { Dog-Leg } \\ \text { Severity } \\ \text { o/100-ft }\end{array} \\ 50 & 0 & 0.68 & 0 & 0 & 0 & 0 & 0 \\ 100 & 50 & 0.61 & 20.44 & 0.43 & 0.4 & 0.15 & 1.7 \\ 150 & 100 & 0.59 & 49.73 & 0.85 & 0.55 & 0.64 & 0.4 \\ 200 & 199.98 & 2.46 & 74.17 & 2.06 & 0.56 & 1.98 & 3.8 \\ 250 & 249.9 & 1.95 & 78.14 & 3.95 & 0.81 & 3.86 & 1.7 \\ 300 & 299.84 & 2.68 & 79.77 & 5.94 & 1.05 & 5.84 & 2.1 \\ 350 & 349.8 & 1.94 & 82.29 & 8.31 & 1.11 & 8.24 & 0.5 \\ 400 & 399.78 & 1.33 & 82.2 & 10.39 & 1.31 & 10.3 & 1.8 \\ 450 & 449.76 & 1.33 & 80.87 & 12.93 & 1.6 & 11.7 & 1.3 \\ 500 & 499.75 & 0.83 & 79.45 & 13.81 & 2.53 & 12.76 & 0.5 \\ 550 & 549.75 & 1.04 & 77.96 & 14.53 & 3.03 & 13.57 & 1 \\ 600 & 599.74 & 0.89 & 76.67 & 15.3 & 3.53 & 14.21 & 0.5 \\ 650 & 649.73 & 1.19 & 75.63 & 16.16 & 4.01 & 15.65 & 0.5 \\ 700 & 699.72 & 1.02 & 74.5 & 17.06 & 4.56 & 16.44 & 0.6 \\ 750 & 749.71 & 1.58 & 72.28 & 17.93 & 5.46 & 17.08 & 1.7 \\ 800 & 799.69 & 1.6 & 69.32 & 18.93 & 6.68 & 17.71 & 0.4 \\ 830 & 829.68 & 1.3 & 67.8 & 19.49 & 7.36 & 18.04 & 1.4 \\ 840 & 839.68 & 1.24 & 67.31 & 19.63 & 7.57 & 18.11 & 0.6 \\ 850 & 849.68 & 0.95 & 66.89 & 19.76 & 7.76 & 18.17 & 3 \\ 860 & 859.68 & 1.25 & 66.48 & 19.89 & 7.94 & 18.24 & 3.1 \\ 870 & 869.67 & 0.73 & 66.13 & 20.01 & 8.1 & 18.3 & 5.2 \\ 880 & 879.67 & 0.84 & 65.86 & 20.11 & 8.22 & 18.35 & 1.3 \\ 890 & 889.67 & 0.8 & 65.59 & 20.22 & 8.35 & 18.41 & 1.6 \\ 900 & 899.67 & 1.09 & 65.31 & 20.35 & 8.5 & 18.49 & 2.9 \\ 910 & 909.67 & 1.12 & 64.97 & 20.49 & 8.67 & 18.57 & 1 \\ 920 & 919.67 & 1.06 & 64.57 & 20.62 & 8.85 & 18.62 & 2.4 \\ 930 & 929.66 & 1.13 & 64.18 & 20.75 & 9.04 & 18.68 & 2.1 \\ 940 & 939.66 & 1.09 & 63.87 & 20.9 & 9.21 & 18.77 & 3 \\ 950 & 949.66 & 1.06 & 63.65 & 21.07 & 9.35 & 18.88 & 0.8 \\ 960 & 959.66 & 1.15 & 63.38 & 21.23 & 9.51 & 18.98 & 3.4 \\ 965 & 964.66 & 1.15 & 63.21 & 21.31 & 9.61 & 19.02 & 0\end{array}$


DTS-RPT-090, Rev. 0

Hole: C4996

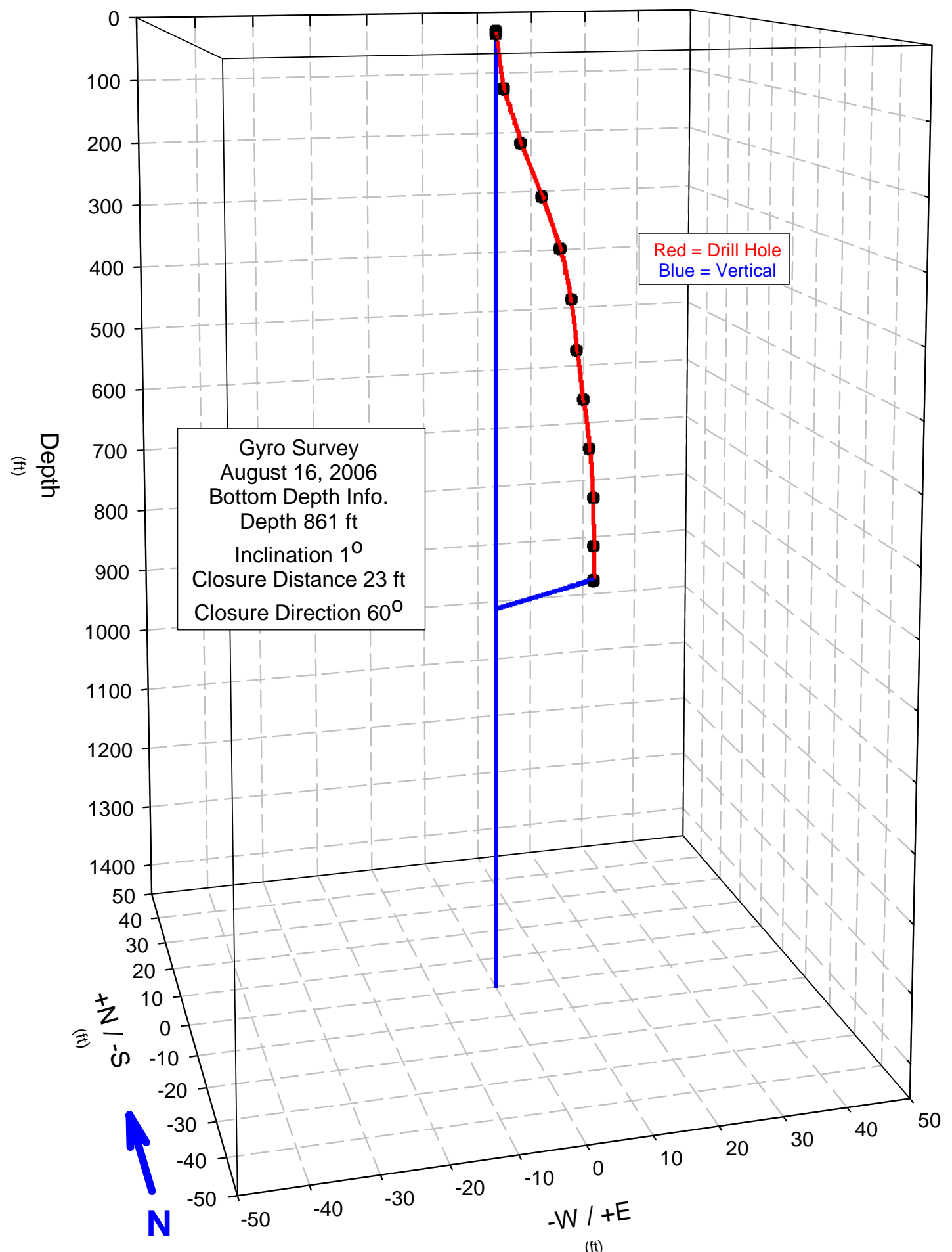


DTS-RPT-090, Rev. 0

Hole: C4996 Survey Date: 8/16/2006

$\begin{array}{cccccccc}\begin{array}{c}\text { Measured } \\ \text { Depth } \\ \text { (feet) }\end{array} & \begin{array}{c}\text { TrueVert. } \\ \text { Depth } \\ \text { (feet) }\end{array} & \begin{array}{c}\text { Inclination } \\ \text { from Vert. } \\ \text { (deg) }\end{array} & \begin{array}{c}\text { Closure } \\ \text { Direction } \\ \text { (deg) }\end{array} & \begin{array}{c}\text { Closure } \\ \text { Distance } \\ \text { (feet) }\end{array} & \begin{array}{c}\text { Rectangular } \\ \text { Coordinates } \\ \text { +N/-S }\end{array} & \begin{array}{c}\text { Rectangular } \\ \text { Coordinates } \\ \text { +E/-W }\end{array} & \begin{array}{c}\text { Dog-Leg } \\ \text { Severity } \\ \text { o /100-ft }\end{array} \\ 4 & 0 & 0.55 & 0 & 0 & 0 & 0 & 0 \\ 84 & 4 & 0.64 & 85.97 & 0.03 & 0 & 0.03 & 16.6 \\ 164 & 83.99 & 1.47 & 72.53 & 1.47 & 0.44 & 1.41 & 1.2 \\ 244 & 163.94 & 2.56 & 80.5 & 4.26 & 0.7 & 4.2 & 1.4 \\ 324 & 243.85 & 2.59 & 83.55 & 7.84 & 0.88 & 7.79 & 0.1 \\ 404 & 403.74 & 2.3 & 81.68 & 11.19 & 1.62 & 11.07 & 1.1 \\ 484 & 483.7 & 1.7 & 76.73 & 13.7 & 3.14 & 13.33 & 1.3 \\ 564 & 563.67 & 1.63 & 71.59 & 15.68 & 4.95 & 14.88 & 0.1 \\ 644 & 643.64 & 1.3 & 68.2 & 17.78 & 6.6 & 16.51 & 0.4 \\ 724 & 723.62 & 0.93 & 64.57 & 19.72 & 7.95 & 18.05 & 0.4 \\ 804 & 803.61 & 1.17 & 62.06 & 22.22 & 10.09 & 19.11 & 0.5 \\ 861.5 & 861.1 & 0.99 & 60.25 & 23 & 11.42 & 19.63 & 0.7 \\ & & & & & & & 0.8\end{array}$


DTS-RPT-090, Rev. 0

Hole: C4996

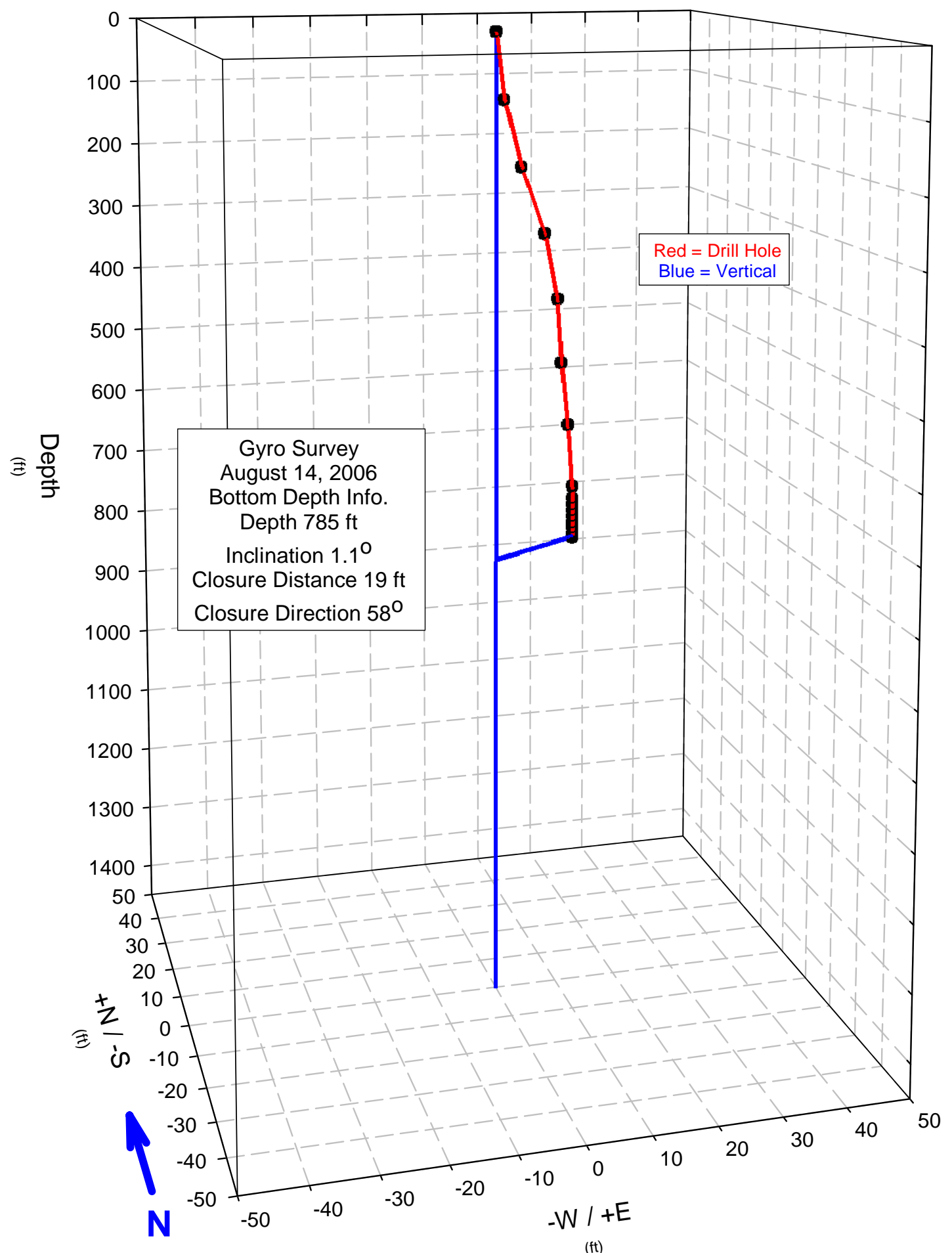


DTS-RPT-090, Rev. 0

Hole: C4996 Survey Date: 8/14/2006

$\begin{array}{cccccccc}\begin{array}{c}\text { Measured } \\ \text { Depth } \\ \text { (feet) }\end{array} & \begin{array}{c}\text { TrueVert. } \\ \text { Depth } \\ \text { (feet) }\end{array} & \begin{array}{c}\text { Inclination } \\ \text { from Vert. } \\ \text { (deg) }\end{array} & \begin{array}{c}\text { Closure } \\ \text { Direction } \\ \text { (deg) }\end{array} & \begin{array}{c}\text { Closure } \\ \text { Distance } \\ \text { (feet) }\end{array} & \begin{array}{c}\text { Rectangular } \\ \text { Coordinates } \\ \text { +N/-S }\end{array} & \begin{array}{c}\text { Rectangular } \\ \text { Coordinates } \\ \text { +E/-W }\end{array} & \begin{array}{c}\text { Dog-Leg } \\ \text { Severity } \\ \text { O/100-ft }\end{array} \\ 100 & 0 & 0.96 & 0 & 0 & 0 & 0 & 0 \\ 200 & 99.98 & 1.05 & 64.3 & 1.75 & 0.76 & 1.58 & 0.1 \\ 300 & 199.93 & 2.51 & 72 & 4.82 & 1.49 & 4.58 & 1.5 \\ 400 & 399.86 & 2.04 & 77.46 & 8.73 & 1.9 & 8.52 & 0.6 \\ 500 & 499.81 & 0.84 & 77.26 & 11.09 & 2.45 & 10.82 & 1.6 \\ 600 & 599.77 & 1.35 & 71.61 & 12.6 & 3.97 & 11.95 & 0.6 \\ 700 & 699.74 & 1.37 & 66.51 & 14.88 & 5.93 & 13.65 & 0.5 \\ 720 & 719.73 & 1.64 & 62.03 & 17.09 & 8.02 & 15.1 & 0.8 \\ 730 & 729.73 & 1.48 & 60.32 & 17.49 & 8.51 & 15.28 & 1.4 \\ 740 & 739.73 & 1.16 & 59.78 & 17.85 & 8.76 & 15.37 & 2.5 \\ 750 & 749.72 & 1.35 & 59.27 & 18 & 9.2 & 15.43 & 3.5 \\ 760 & 759.72 & 1.29 & 58.8 & 18.18 & 9.42 & 15.48 & 2.3 \\ 770 & 769.72 & 1.24 & 58.36 & 18.35 & 9.63 & 15.65 & 1.3 \\ 780 & 779.72 & 1.16 & 57.95 & 18.51 & 9.82 & 15.69 & 0.8 \\ 785 & 784.71 & 1.14 & 57.76 & 18.59 & 9.92 & 15.73 & 0.4\end{array}$


DTS-RPT-090, Rev. 0

Hole: C4996

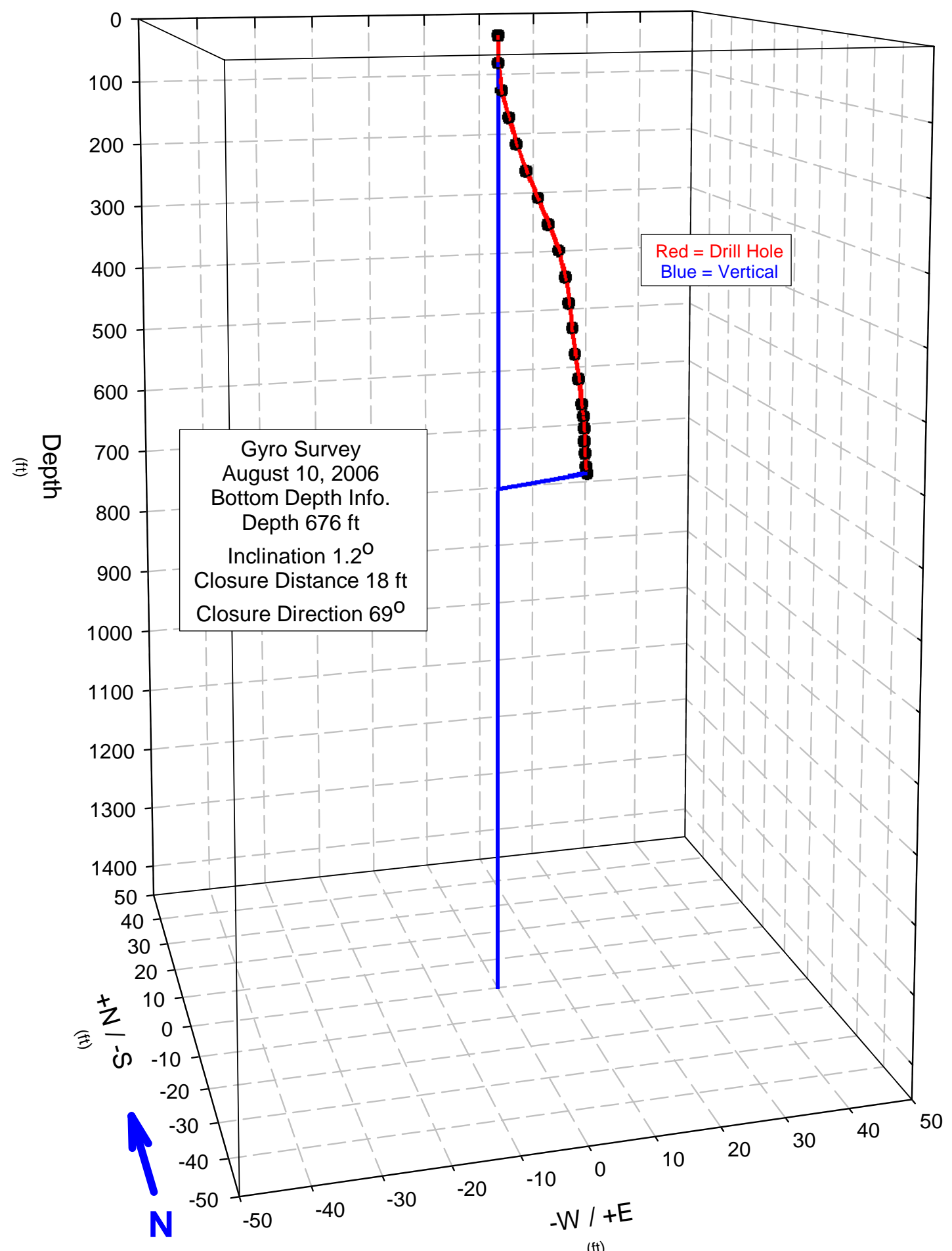


DTS-RPT-090, Rev. 0

Hole: C4996 Survey Date: 8/10/2006

$\begin{array}{cccccccc}\begin{array}{c}\text { Measured } \\ \text { Depth } \\ \text { (feet) }\end{array} & \begin{array}{c}\text { TrueVert. } \\ \text { Depth } \\ \text { (feet) }\end{array} & \begin{array}{c}\text { Inclination } \\ \text { from Vert. } \\ \text { (deg) }\end{array} & \begin{array}{c}\text { Closure } \\ \text { Direction } \\ \text { (deg) }\end{array} & \begin{array}{c}\text { Closure } \\ \text { Distance } \\ \text { (feet) }\end{array} & \begin{array}{c}\text { Rectangular } \\ \text { Coordinates } \\ +N /-S\end{array} & \begin{array}{c}\text { Rectangular } \\ \text { Coordinates } \\ + \text { E/-W }\end{array} & \begin{array}{c}\text { Dog-Leg } \\ \text { Severity } \\ \text { ofo0-ft }\end{array} \\ 44 & 4 & 0.28 & 168.07 & 0.02 & -0.02 & 0 & 6.5 \\ 84 & 44 & 0.18 & 153.66 & 0.1 & -0.09 & 0.04 & 1 \\ 124 & 84 & 1.39 & 106.16 & 0.59 & -0.17 & 0.57 & 3.1 \\ 164 & 163.98 & 1.85 & 96.65 & 1.7 & -0.2 & 1.68 & 1.8 \\ 204 & 203.96 & 2.05 & 89.07 & 3.02 & 0.05 & 3.02 & 0.8 \\ 244 & 243.87 & 2.68 & 87.47 & 4.66 & 0.21 & 4.65 & 2.1 \\ 284 & 283.83 & 2.5 & 86.28 & 6.61 & 0.43 & 6.6 & 1.8 \\ 324 & 323.79 & 2.49 & 85.32 & 8.51 & 0.69 & 8.48 & 1.8 \\ 364 & 363.77 & 1.26 & 83.94 & 10.25 & 0.83 & 10.22 & 0.5 \\ 404 & 403.76 & 1.42 & 82.04 & 12.33 & 1.21 & 11.42 & 3.9 \\ 444 & 443.75 & 1.44 & 79.73 & 13.15 & 2.31 & 12.21 & 0.8 \\ 484 & 483.74 & 1.4 & 77.69 & 13.98 & 2.98 & 12.94 & 1.8 \\ 524 & 523.72 & 1.76 & 75.71 & 14.93 & 3.69 & 14.66 & 1.8 \\ 564 & 563.71 & 1.34 & 73.76 & 15.86 & 4.44 & 15.23 & 2 \\ 584 & 583.7 & 1.71 & 72.99 & 16.34 & 4.78 & 15.63 & 2.4 \\ 604 & 603.69 & 1.4 & 71.9 & 16.78 & 5.21 & 15.95 & 2.8 \\ 624 & 623.69 & 1.2 & 70.82 & 17.1 & 5.62 & 16.15 & 1 \\ 644 & 643.68 & 0.89 & 70.05 & 17.38 & 5.93 & 16.34 & 1.7 \\ 664 & 663.68 & 1.2 & 69.51 & 17.7 & 6.2 & 16.58 & 1.9 \\ 676 & 675.68 & 1.24 & 69.2 & 17.94 & 6.37 & 16.77 & 0.5\end{array}$


DTS-RPT-090, Rev. 0

Hole: C4996

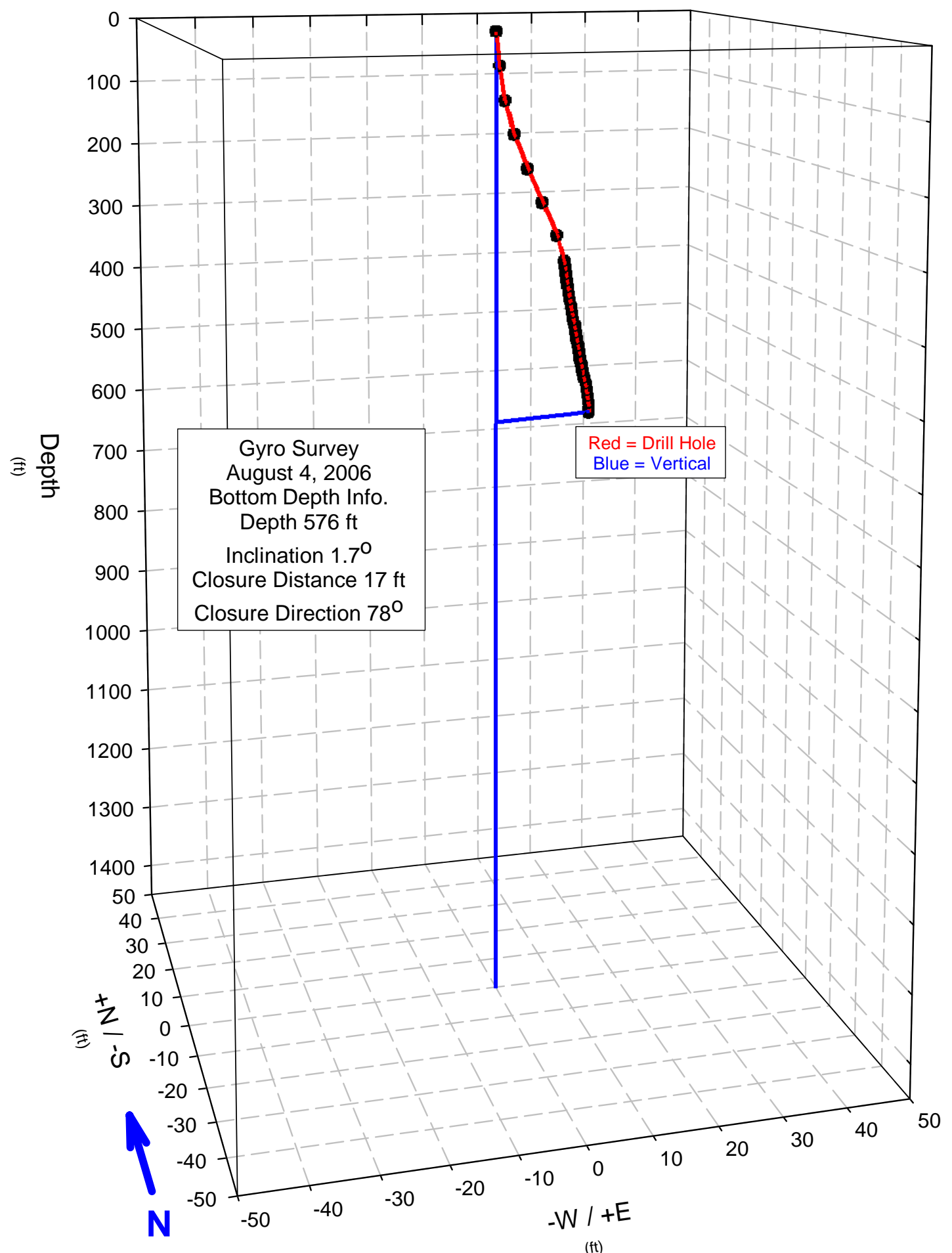


Hole: C4996 Survey Date: 8/4/2006

\begin{tabular}{|c|c|c|c|c|c|c|c|}
\hline Measured & TrueVert. & Inclination & Closure & Closure & Rectangular & Rectangular & Dog-Leg \\
\hline $\begin{array}{c}\text { Depth } \\
\text { (feet) }\end{array}$ & $\begin{array}{l}\text { Depth } \\
\text { (feet) }\end{array}$ & $\begin{array}{l}\text { from Vert. } \\
\text { (deg) }\end{array}$ & $\begin{array}{l}\text { Direction } \\
\text { (deg) }\end{array}$ & $\begin{array}{c}\text { Distance } \\
\text { (feet) }\end{array}$ & $\begin{array}{c}\text { Coordinates } \\
+\mathrm{N} /-\mathrm{S}\end{array}$ & $\begin{array}{c}\text { Coordinates } \\
+E /-W\end{array}$ & $\begin{array}{l}\text { Severity } \\
0 / 100-\mathrm{ft}\end{array}$ \\
\hline 0 & 0 & 0.41 & 0 & 0 & 0 & 0 & 0 \\
\hline 50 & 50 & 1.04 & 85.9 & 0.63 & 0.04 & 0.63 & 1.3 \\
\hline 100 & 99.99 & 0.71 & 90.48 & 1.39 & -0.01 & 1.39 & 0.7 \\
\hline 150 & 149.96 & 2.79 & 92.61 & 2.91 & -0.13 & 2.91 & 4.2 \\
\hline 200 & 199.92 & 2.18 & 93.22 & 5.07 & -0.28 & 5.07 & 1.2 \\
\hline 250 & 249.86 & 3.29 & 92.59 & 7.45 & -0.34 & 7.45 & 2.3 \\
\hline 300 & 299.79 & 2.56 & 90.26 & 9.97 & -0.05 & 9.97 & 1.9 \\
\hline 340 & 339.77 & 1.38 & 88.32 & 11.29 & 0.33 & 11.29 & 3 \\
\hline 350 & 349.77 & 1.82 & 87.76 & 11.55 & 0.45 & 11.54 & 4.9 \\
\hline 360 & 359.76 & 0.79 & 87.31 & 11.76 & 0.55 & 11.74 & 10.5 \\
\hline 370 & 369.76 & 1.38 & 86.92 & 11.93 & 0.64 & 11.91 & 6.2 \\
\hline 380 & 379.76 & 1.07 & 86.42 & 12.11 & 0.76 & 12.09 & 3 \\
\hline 390 & 389.76 & 1.23 & 86.02 & 12.29 & 0.85 & 12.26 & 2.1 \\
\hline 400 & 399.75 & 1.35 & 85.63 & 12.5 & 0.95 & 12.47 & 1.1 \\
\hline 410 & 409.75 & 1.38 & 85.24 & 12.72 & 1.05 & 12.68 & 0.5 \\
\hline 420 & 419.75 & 1.43 & 84.86 & 12.95 & 1.16 & 12.9 & 0.6 \\
\hline 430 & 429.75 & 1.44 & 84.49 & 13.19 & 1.27 & 13.13 & 0.8 \\
\hline 440 & 439.74 & 1.35 & 84.19 & 13.42 & 1.36 & 13.35 & 0.9 \\
\hline 450 & 449.74 & 1.35 & 83.91 & 13.65 & 1.45 & 13.57 & 0.1 \\
\hline 460 & 459.74 & 1.42 & 83.65 & 13.88 & 1.54 & 13.8 & 0.9 \\
\hline 470 & 469.73 & 1.27 & 83.42 & 14.11 & 1.62 & 14.02 & 1.5 \\
\hline 480 & 479.73 & 1.42 & 83.18 & 14.34 & 1.7 & 14.24 & 1.5 \\
\hline 490 & 489.73 & 1.55 & 82.91 & 14.59 & 1.8 & 14.48 & 1.3 \\
\hline 500 & 499.72 & 1.48 & 82.63 & 14.84 & 1.9 & 14.72 & 0.6 \\
\hline 510 & 509.72 & 1.67 & 82.34 & 15.11 & 2.01 & 14.97 & 2 \\
\hline 520 & 519.72 & 2.07 & 81.94 & 15.42 & 2.16 & 15.26 & 4.3 \\
\hline 530 & 529.71 & 1.84 & 81.43 & 15.73 & 2.34 & 15.55 & 2.9 \\
\hline 540 & 539.7 & 1.78 & 80.83 & 15.99 & 2.55 & 15.79 & 4.2 \\
\hline 550 & 549.7 & 1.83 & 80.14 & 16.24 & 2.78 & 16 & 0.5 \\
\hline 560 & 559.69 & 1.83 & 79.44 & 16.49 & 3.02 & 16.21 & 1.3 \\
\hline 570 & 569.69 & 1.71 & 78.7 & 16.71 & 3.27 & 16.39 & 2.9 \\
\hline 576.5 & 576.19 & 1.73 & 78.2 & 16.84 & 3.44 & 16.49 & 0.5 \\
\hline
\end{tabular}


DTS-RPT-090, Rev. 0

Hole: C4996

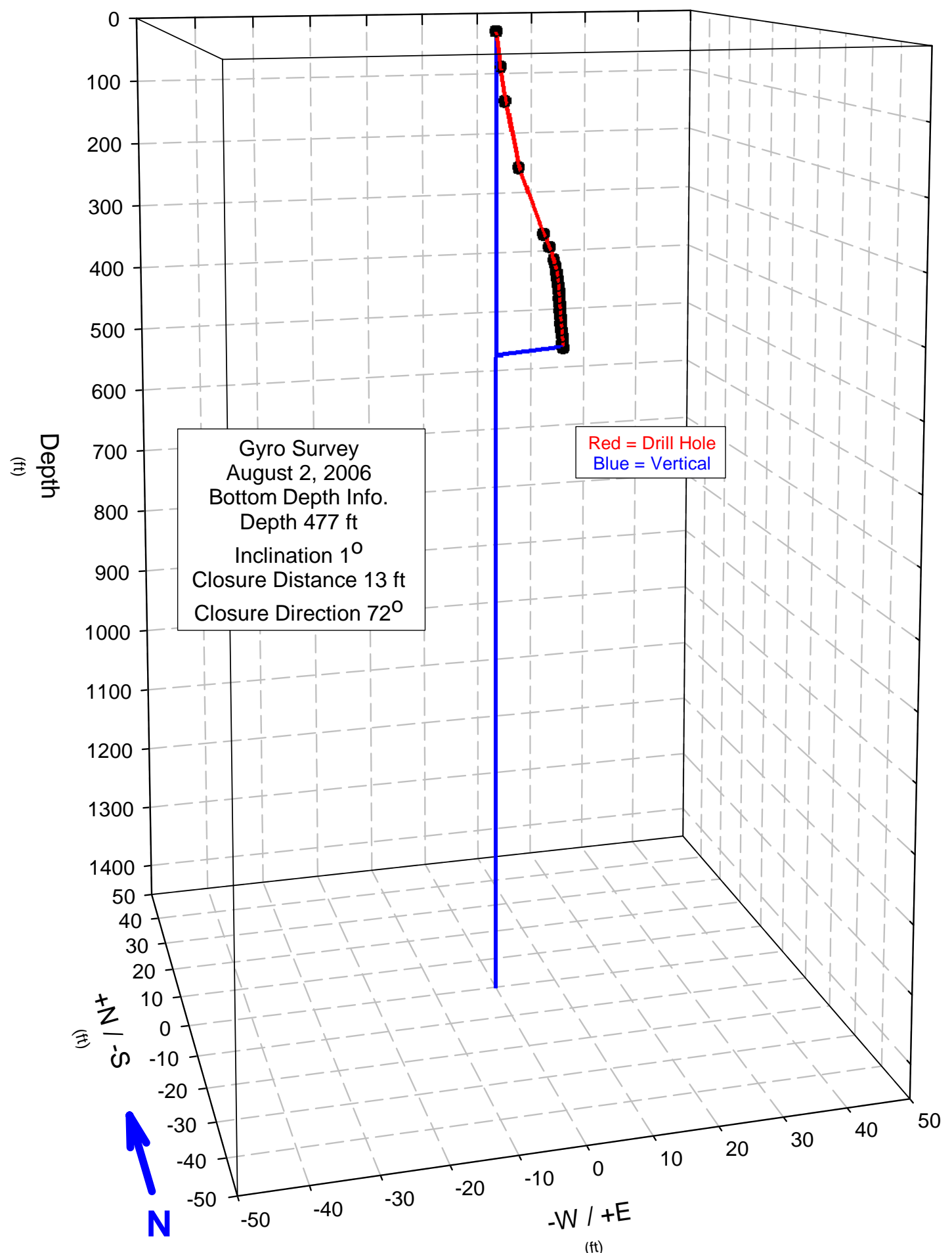


Hole: C4996 Survey Date: 8/2/2006

$\begin{array}{cccccccc}\begin{array}{c}\text { Measured } \\ \text { Depth } \\ \text { (feet) }\end{array} & \begin{array}{c}\text { TrueVert. } \\ \text { Depth } \\ \text { (feet) }\end{array} & \begin{array}{c}\text { Inclination } \\ \text { from Vert. } \\ \text { (deg) }\end{array} & \begin{array}{c}\text { Closure } \\ \text { Direction } \\ \text { (deg) }\end{array} & \begin{array}{c}\text { Closure } \\ \text { Distance } \\ \text { (feet) }\end{array} & \begin{array}{c}\text { Rectangular } \\ \text { Coordinates } \\ + \text { N/-S }\end{array} & \begin{array}{c}\text { Rectangular } \\ \text { Coordinates } \\ + \text { E/-W }\end{array} & \begin{array}{c}\text { Dog-Leg } \\ \text { Severity } \\ \text { o/100-ft }\end{array} \\ 50.5 & 0 & 0.49 & 0 & 0 & 0 & 0 & 0 \\ 101 & 50.49 & 1.22 & 80.19 & 0.74 & 0.13 & 0.73 & 1.6 \\ 200 & 100.99 & 0.8 & 80.05 & 1.61 & 0.28 & 1.59 & 1.1 \\ 300 & 299.96 & 1.94 & 81.01 & 3.96 & 0.62 & 3.91 & 1.2 \\ 320 & 319.84 & 2.93 & 82.51 & 8.2 & 1.07 & 8.13 & 1 \\ 340 & 339.82 & 2.8 & 82.27 & 9.2 & 1.24 & 9.11 & 1 \\ 350 & 349.81 & 1.93 & 81.38 & 10.06 & 1.51 & 9.95 & 4.3 \\ 360 & 359.81 & 1.88 & 79.69 & 10.4 & 1.68 & 10.27 & 3.8 \\ 370 & 369.8 & 1.68 & 79.08 & 10.97 & 1.87 & 10.54 & 1.6 \\ 380 & 379.8 & 1.56 & 78.15 & 11.18 & 2.08 & 10.77 & 4.2 \\ 390 & 389.8 & 1.45 & 77.24 & 11.38 & 2.5 & 10.95 & 1.9 \\ 400 & 399.79 & 1.33 & 76.4 & 11.55 & 2.72 & 11.1 & 1.3 \\ 410 & 409.79 & 1.22 & 75.68 & 11.72 & 2.9 & 11.23 & 1.3 \\ 420 & 419.79 & 1.54 & 74.95 & 11.91 & 3.09 & 11.5 & 1.6 \\ 430 & 429.79 & 1.34 & 74.21 & 12.1 & 3.29 & 11.65 & 2 \\ 440 & 439.78 & 1.21 & 73.6 & 12.28 & 3.47 & 11.78 & 1.4 \\ 450 & 449.78 & 1.12 & 73.16 & 12.46 & 3.61 & 11.93 & 2.5 \\ 460 & 459.78 & 1.05 & 72.8 & 12.63 & 3.74 & 12.07 & 1.3 \\ 470 & 469.78 & 1.02 & 72.38 & 12.79 & 3.87 & 12.19 & 1.3 \\ 477 & 476.78 & 1.03 & 72.11 & 12.9 & 3.96 & 12.27 & 2.4\end{array}$


DTS-RPT-090, Rev. 0

Hole: C4996

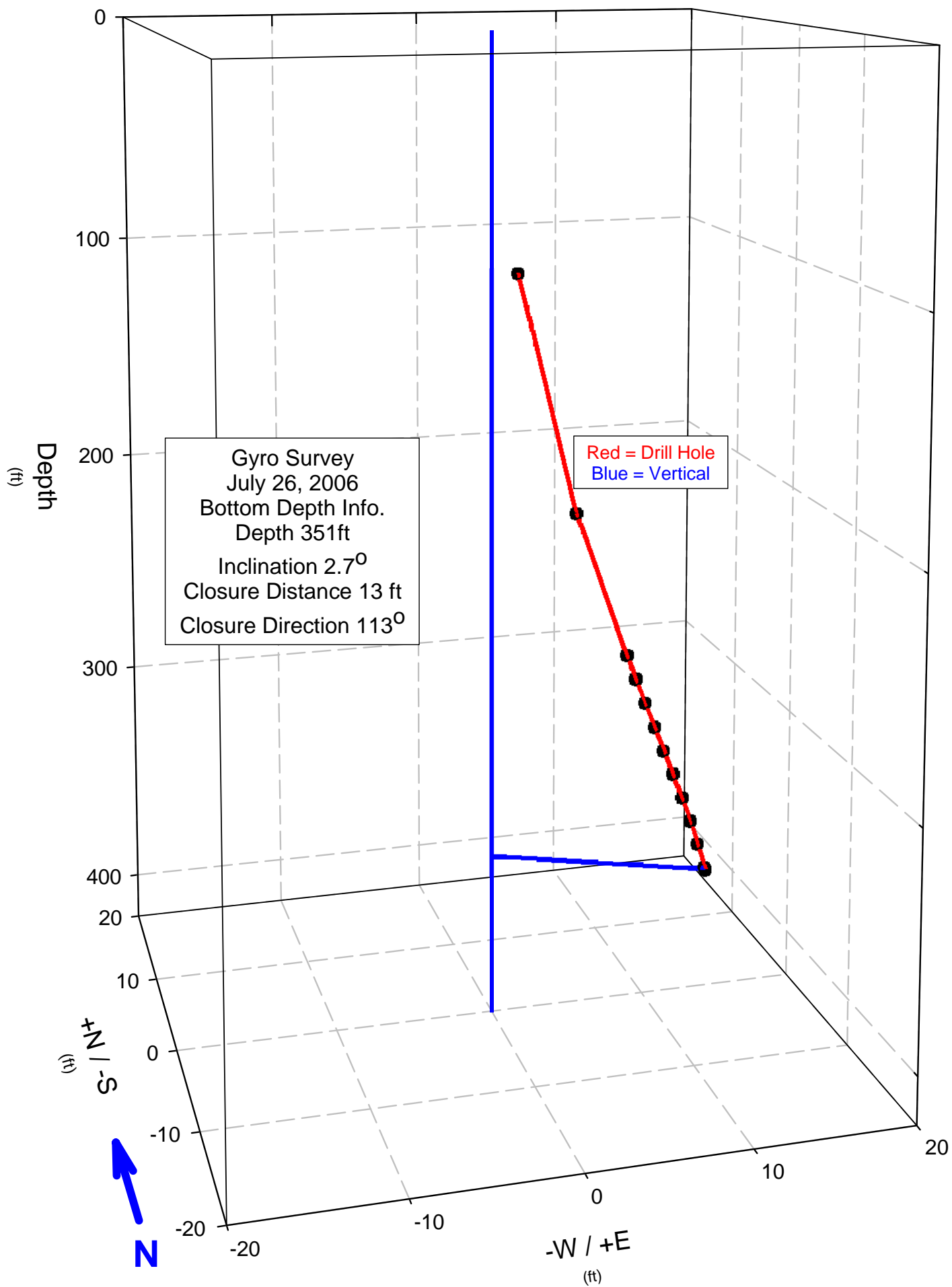


DTS-RPT-090, Rev. 0

Hole: C4996 Survey Date: 7/26/2006

$\begin{array}{cccccccc}\begin{array}{c}\text { Measured } \\ \text { Depth } \\ \text { (feet) }\end{array} & \begin{array}{c}\text { TrueVert. } \\ \text { Depth } \\ \text { (feet) }\end{array} & \begin{array}{c}\text { Inclination } \\ \text { from Vert. } \\ \text { (deg) }\end{array} & \begin{array}{c}\text { Closure } \\ \text { Direction } \\ \text { (deg) }\end{array} & \begin{array}{c}\text { Closure } \\ \text { Distance } \\ \text { (feet) }\end{array} & \begin{array}{c}\text { Rectangular } \\ \text { Coordinates } \\ +N /-S\end{array} & \begin{array}{c}\text { Rectangular } \\ \text { Coordinates } \\ +E /-W\end{array} & \begin{array}{c}\text { Dog-Leg } \\ \text { Severity } \\ \text { o/100-ft }\end{array} \\ 200 & 99.98 & 1.33 & 117.88 & 1.69 & -0.79 & 1.49 & 0.9 \\ 260 & 199.91 & 2.9 & 116.92 & 5.34 & -2.42 & 4.76 & 1.7 \\ 270 & 259.83 & 3.13 & 114.3 & 8.48 & -3.49 & 7.73 & 0.4 \\ 280 & 269.82 & 3.34 & 114.15 & 9.05 & -3.7 & 8.25 & 3.6 \\ 290 & 279.8 & 3.36 & 114.19 & 9.63 & -3.95 & 8.78 & 0.3 \\ 300 & 289.78 & 3.45 & 114.24 & 10.22 & -4.2 & 9.32 & 0.9 \\ 310 & 309.76 & 3.38 & 114.29 & 10.82 & -4.45 & 9.86 & 0.7 \\ 320 & 319.73 & 3.25 & 114.27 & 11.4 & -4.69 & 10.39 & 1.7 \\ 330 & 329.72 & 2.9 & 114.16 & 11.95 & -4.89 & 10.91 & 2 \\ 340 & 339.71 & 2.57 & 113.97 & 12.47 & -5.07 & 11.4 & 2.3 \\ 350 & 349.7 & 2.61 & 113.36 & 12.94 & -5.2 & 11.86 & 4.2 \\ 351.2 & 350.89 & 2.67 & 113.33 & 13.44 & -5.31 & 12.29 & 1.2 \\ & & & & & -5.33 & 12.35 & 10.5\end{array}$


DTS-RPT-090, Rev. 0

Hole: C4996

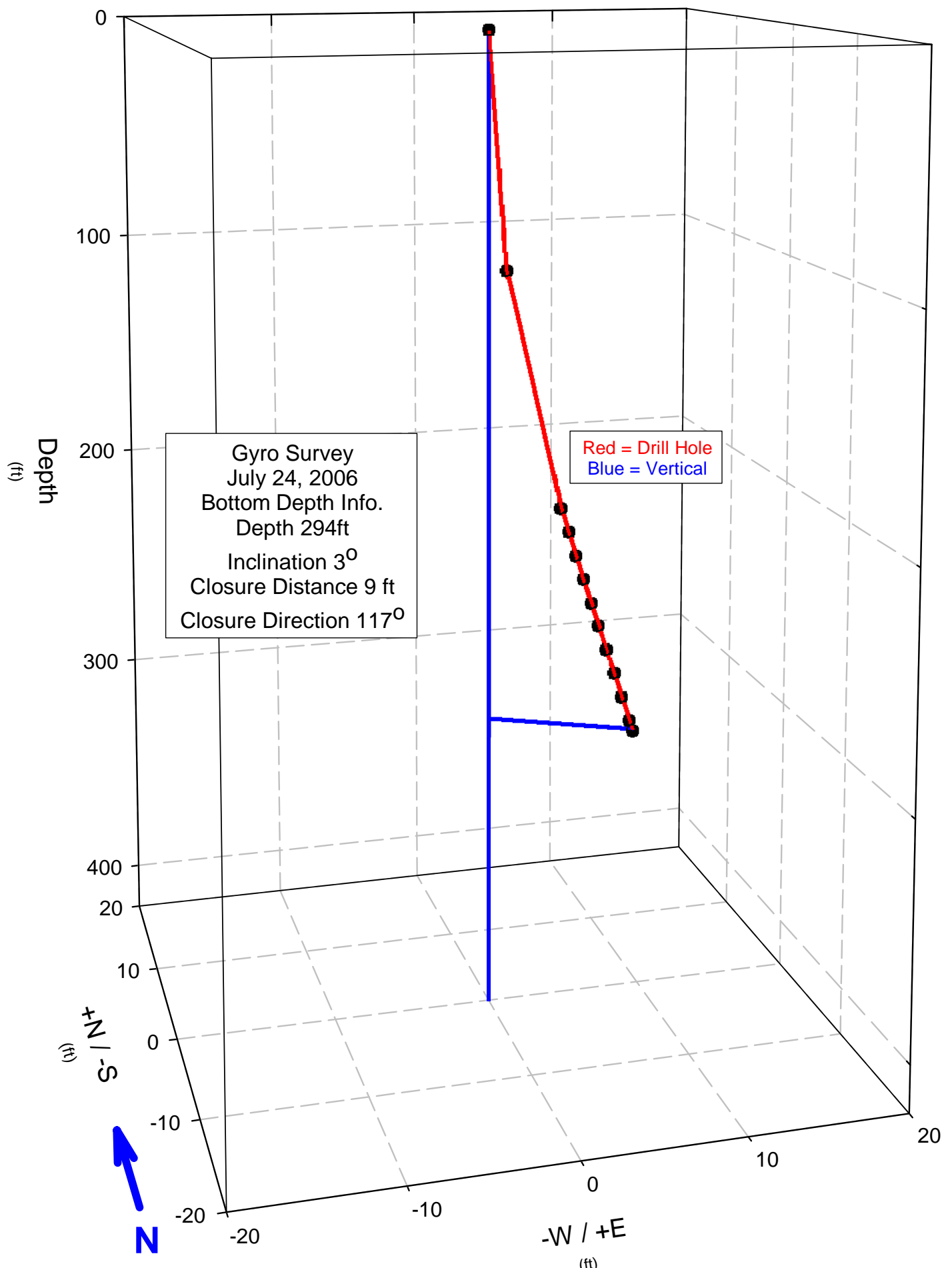


DTS-RPT-090, Rev. 0

Hole: C4996 Survey Date: 7/24/2006

$\begin{array}{cccccccc}\begin{array}{c}\text { Measured } \\ \text { Depth } \\ \text { (feet) }\end{array} & \begin{array}{c}\text { TrueVert. } \\ \text { Depth } \\ \text { (feet) }\end{array} & \begin{array}{c}\text { Inclination } \\ \text { from Vert. } \\ \text { (deg) }\end{array} & \begin{array}{c}\text { Closure } \\ \text { Direction } \\ \text { (deg) }\end{array} & \begin{array}{c}\text { Closure } \\ \text { Distance } \\ \text { (feet) }\end{array} & \begin{array}{c}\text { Rectangular } \\ \text { Coordinates } \\ + \text { N/-S }\end{array} & \begin{array}{c}\text { Rectangular } \\ \text { Coordinates } \\ + \text { E/-W }\end{array} & \begin{array}{c}\text { Dog-Leg } \\ \text { Severity } \\ \text { O/100-ft }\end{array} \\ 100 & 0 & 0.08 & 0 & 0 & 0 & 0 & 0 \\ 200 & 99.99 & 1.33 & 122.51 & 1.15 & -0.62 & 0.97 & 1.4 \\ 210 & 199.93 & 2.66 & 117.79 & 4.62 & -2.16 & 4.09 & 1.3 \\ 220 & 209.92 & 2.68 & 117.44 & 5.09 & -2.35 & 4.52 & 0.7 \\ 230 & 219.91 & 2.7 & 117.17 & 5.56 & -2.54 & 4.94 & 0.9 \\ 240 & 239.89 & 2.78 & 117.02 & 6.04 & -2.74 & 5.38 & 0.7 \\ 250 & 249.87 & 2.81 & 116.86 & 6.52 & -2.95 & 5.82 & 0.6 \\ 260 & 259.86 & 2.82 & 116.63 & 7.01 & -3.14 & 6.27 & 0.8 \\ 270 & 269.85 & 2.83 & 116.45 & 7.5 & -3.34 & 6.71 & 1.3 \\ 280 & 279.83 & 2.84 & 116.44 & 7.99 & -3.56 & 7.15 & 1.2 \\ 290 & 289.82 & 2.85 & 116.55 & 8.48 & -3.78 & 7.59 & 0.1 \\ 294.5 & 294.32 & 2.9 & 116.59 & 9.2 & -4.01 & 8.03 & 0.2 \\ & & & & & & 8.23 & 1.3\end{array}$


DTS-RPT-090, Rev. 0

Hole: C4996

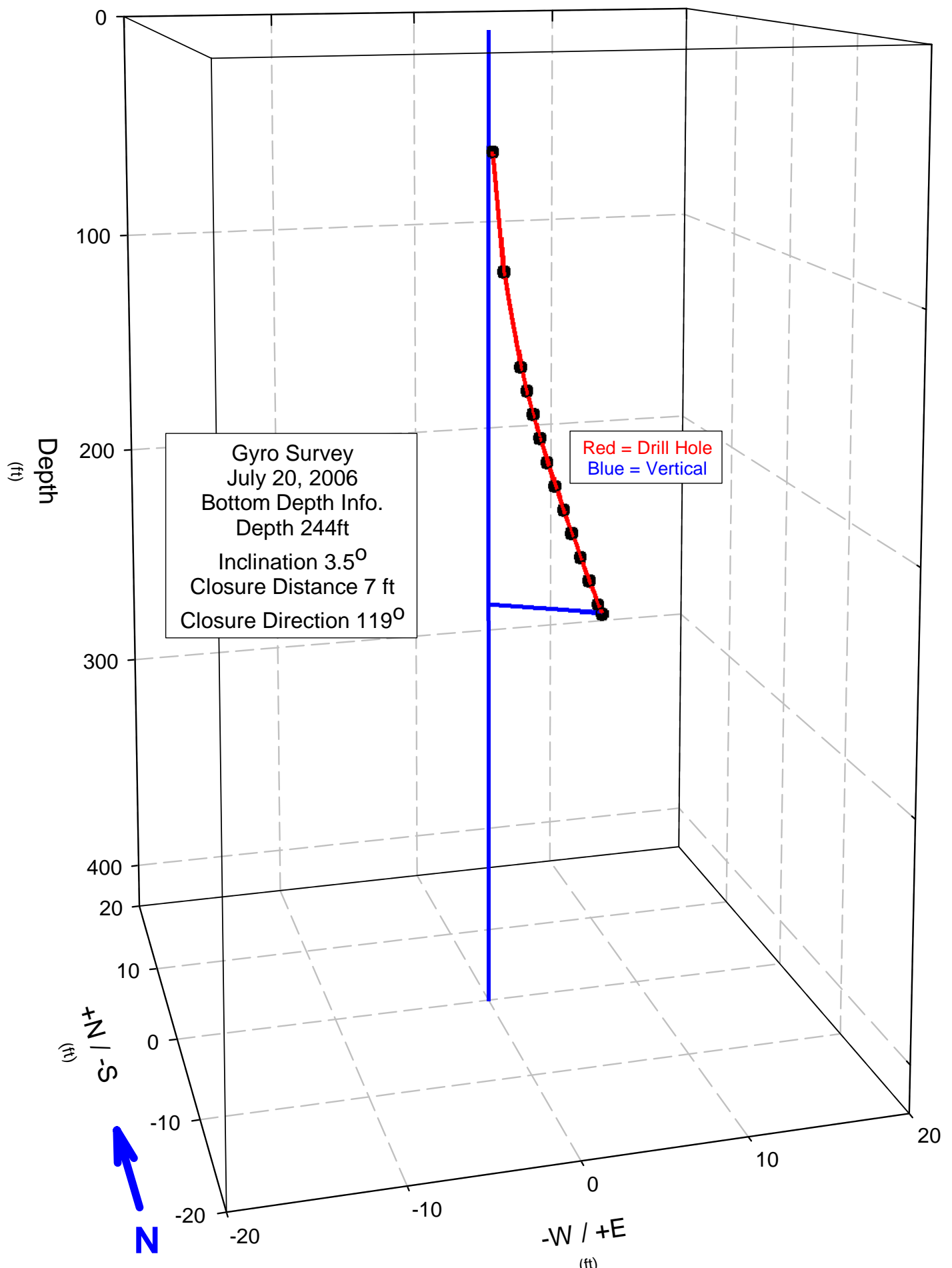


DTS-RPT-090, Rev. 0

Hole: C4996 Survey Date: 7/20/2006

$\begin{array}{cccccccc}\begin{array}{c}\text { Measured } \\ \text { Depth } \\ \text { (feet) }\end{array} & \begin{array}{c}\text { TrueVert. } \\ \text { Depth } \\ \text { (feet) }\end{array} & \begin{array}{c}\text { Inclination } \\ \text { from Vert. } \\ \text { (deg) }\end{array} & \begin{array}{c}\text { Closure } \\ \text { Direction } \\ \text { (deg) }\end{array} & \begin{array}{c}\text { Closure } \\ \text { Distance } \\ \text { (feet) }\end{array} & \begin{array}{c}\text { Rectangular } \\ \text { Coordinates } \\ \text { +N/-S }\end{array} & \begin{array}{c}\text { Rectangular } \\ \text { Coordinates } \\ + \text { E/-W }\end{array} & \begin{array}{c}\text { Dog-Leg } \\ \text { Severity } \\ \text { o/100-ft }\end{array} \\ 100 & 50 & 0.57 & 154.8 & 0.44 & -0.4 & 0.19 & 0.5 \\ 140 & 99.99 & 1.2 & 139.56 & 1.18 & -0.9 & 0.77 & 1.4 \\ 150 & 149.98 & 1.95 & 129.88 & 2.24 & -1.44 & 1.72 & 2 \\ 160 & 159.96 & 2.22 & 127.83 & 2.6 & -1.59 & 2.05 & 2.9 \\ 170 & 169.95 & 2.43 & 125.95 & 2.99 & -1.76 & 2.42 & 2.1 \\ 180 & 179.94 & 2.75 & 124.46 & 3.42 & -1.94 & 2.82 & 1.6 \\ 190 & 189.93 & 2.87 & 123.27 & 3.88 & -2.13 & 3.24 & 1.7 \\ 200 & 199.92 & 3 & 121.42 & 4.36 & -2.33 & 3.69 & 1.2 \\ 210 & 209.9 & 3.04 & 120.65 & 5.4 & -2.54 & 4.16 & 1.4 \\ 220 & 219.89 & 3.14 & 119.98 & 5.93 & -2.75 & 4.64 & 0.9 \\ 230 & 229.87 & 3.22 & 119.47 & 6.48 & -3.19 & 5.14 & 1.1 \\ 240 & 239.86 & 3.23 & 118.97 & 7.04 & -3.41 & 6.64 & 0.9 \\ 244.4 & 244.25 & 3.49 & 118.75 & 7.3 & -3.51 & 6.4 & 1 \\ & & & & & & & \end{array}$


DTS-RPT-090, Rev. 0

Hole: C4996

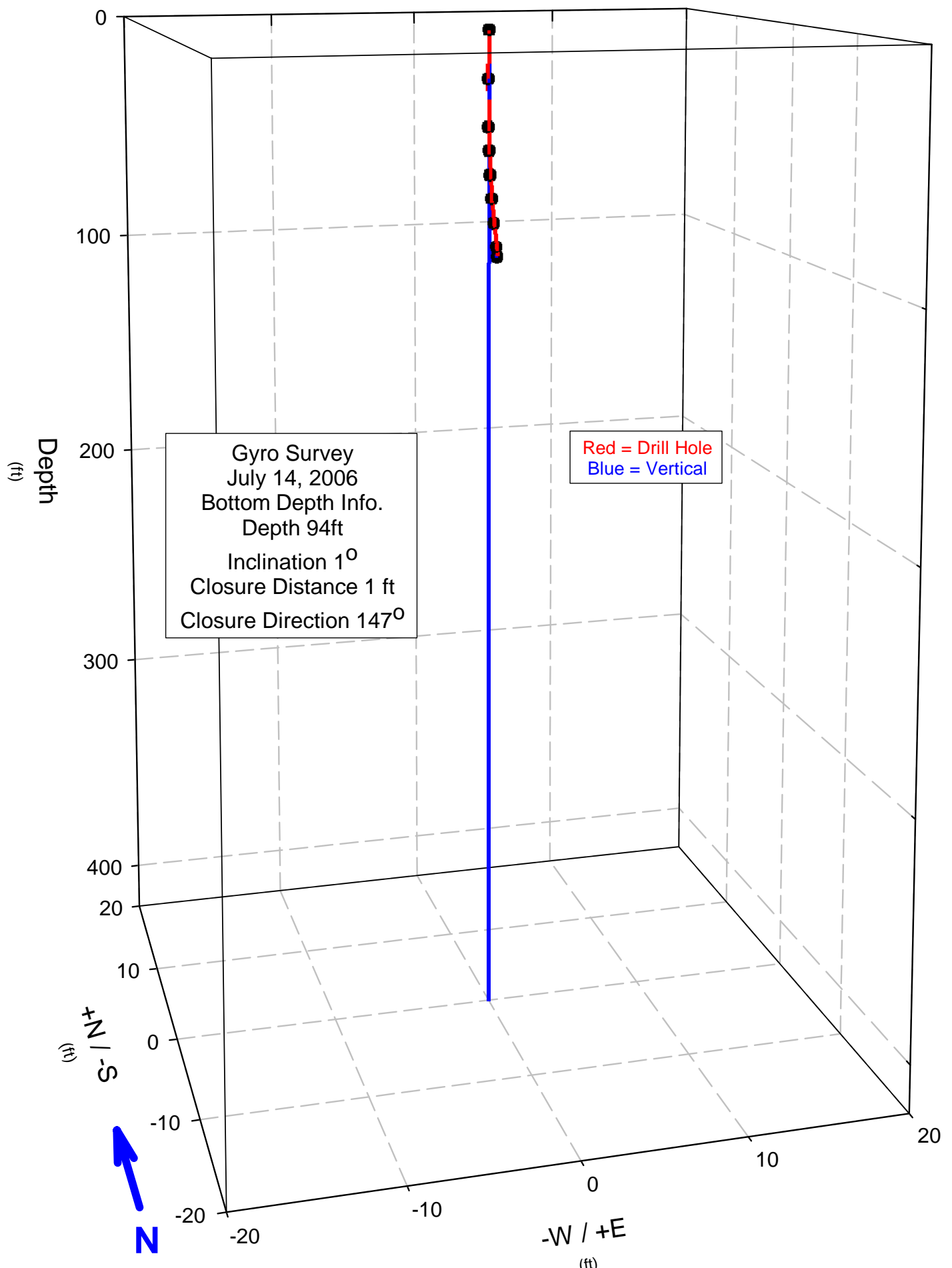


DTS-RPT-090, Rev. 0

Hole: C4996 Survey Date: 7/14/2006

$\begin{array}{cccccccc}\begin{array}{c}\text { Measured } \\ \text { Depth } \\ \text { (feet) }\end{array} & \begin{array}{c}\text { TrueVert. } \\ \text { Depth } \\ \text { (feet) }\end{array} & \begin{array}{c}\text { Inclination } \\ \text { from Vert. } \\ \text { (deg) }\end{array} & \begin{array}{c}\text { Closure } \\ \text { Direction } \\ \text { (deg) }\end{array} & \begin{array}{c}\text { Closure } \\ \text { Distance } \\ \text { (feet) }\end{array} & \begin{array}{c}\text { Rectangular } \\ \text { Coordinates } \\ + \text { N/-S }\end{array} & \begin{array}{c}\text { Rectangular } \\ \text { Coordinates } \\ + \text { E/-W }\end{array} & \begin{array}{c}\text { Dog-Leg } \\ \text { Severity } \\ \text { o/100-ft }\end{array} \\ 20 & 0 & 0.12 & 0 & 0 & 0 & 0 & 0 \\ 40 & 20 & 0.16 & 291.4 & 0.03 & 0.01 & -0.03 & 1.2 \\ 50 & 40 & 0.35 & 214.27 & 0.07 & -0.06 & -0.04 & 1.8 \\ 60 & 50 & 0.52 & 185.08 & 0.13 & -0.13 & -0.01 & 2.4 \\ 70 & 60 & 0.63 & 168.44 & 0.22 & -0.21 & 0.04 & 1.1 \\ 80 & 70 & 0.81 & 161.37 & 0.34 & -0.32 & 0.11 & 1.9 \\ 90 & 80 & 1 & 155.5 & 0.49 & -0.44 & 0.2 & 3.1 \\ 94 & 90 & 1.1 & 149.35 & 0.66 & -0.57 & 0.34 & 1.5 \\ & 93.99 & 1.12 & 147.67 & 0.73 & -0.62 & 0.39 & 3.3\end{array}$


DTS-RPT-090, Rev. 0

Hole: C4996

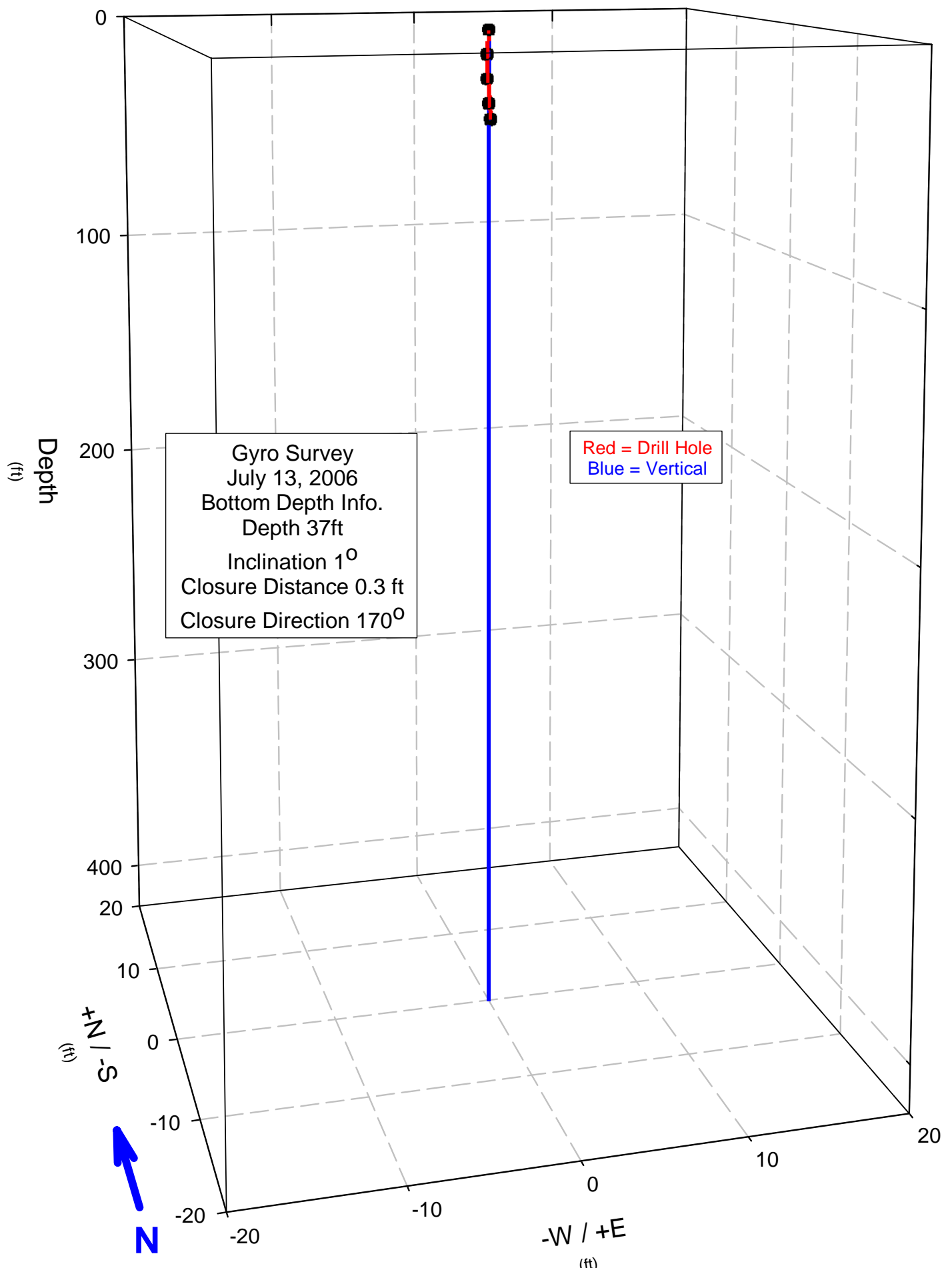


DTS-RPT-090, Rev. 0

Hole: C4996 Survey Date: 7/13/2006

$\begin{array}{cccccccc}\begin{array}{c}\text { Measured } \\ \text { Depth } \\ \text { (feet) }\end{array} & \begin{array}{c}\text { TrueVert. } \\ \text { Depth } \\ \text { (feet) }\end{array} & \begin{array}{c}\text { Inclination } \\ \text { from Vert. } \\ \text { (deg) }\end{array} & \begin{array}{c}\text { Closure } \\ \text { Direction } \\ \text { (deg) }\end{array} & \begin{array}{c}\text { Closure } \\ \text { Distance } \\ \text { (feet) }\end{array} & \begin{array}{c}\text { Rectangular } \\ \text { Coordinates } \\ + \text { N/-S }\end{array} & \begin{array}{c}\text { Rectangular } \\ \text { Coordinates } \\ + \text { E/-W }\end{array} & \begin{array}{c}\text { Dog-Leg } \\ \text { Severity } \\ \text { o/100-ft }\end{array} \\ 10 & 0 & 0.55 & 0 & 0 & 0 & 0 & 0 \\ 20 & 10 & 0.76 & 231.17 & 0.11 & -0.07 & -0.09 & 2.2 \\ 30 & 20 & 0.77 & 213.51 & 0.21 & -0.18 & -0.12 & 8.6 \\ 36.9 & 30 & 0.68 & 188.86 & 0.27 & -0.27 & -0.04 & 5.9 \\ & 36.9 & 0.85 & 170.33 & 0.28 & -0.28 & 0.05 & 5.7\end{array}$


DTS-RPT-090, Rev. 0

\section{B1.2 ENERGYSOLUTIONS AND PACIFIC NORTHWEST GEOPHYSICS CALIPER LOGS}
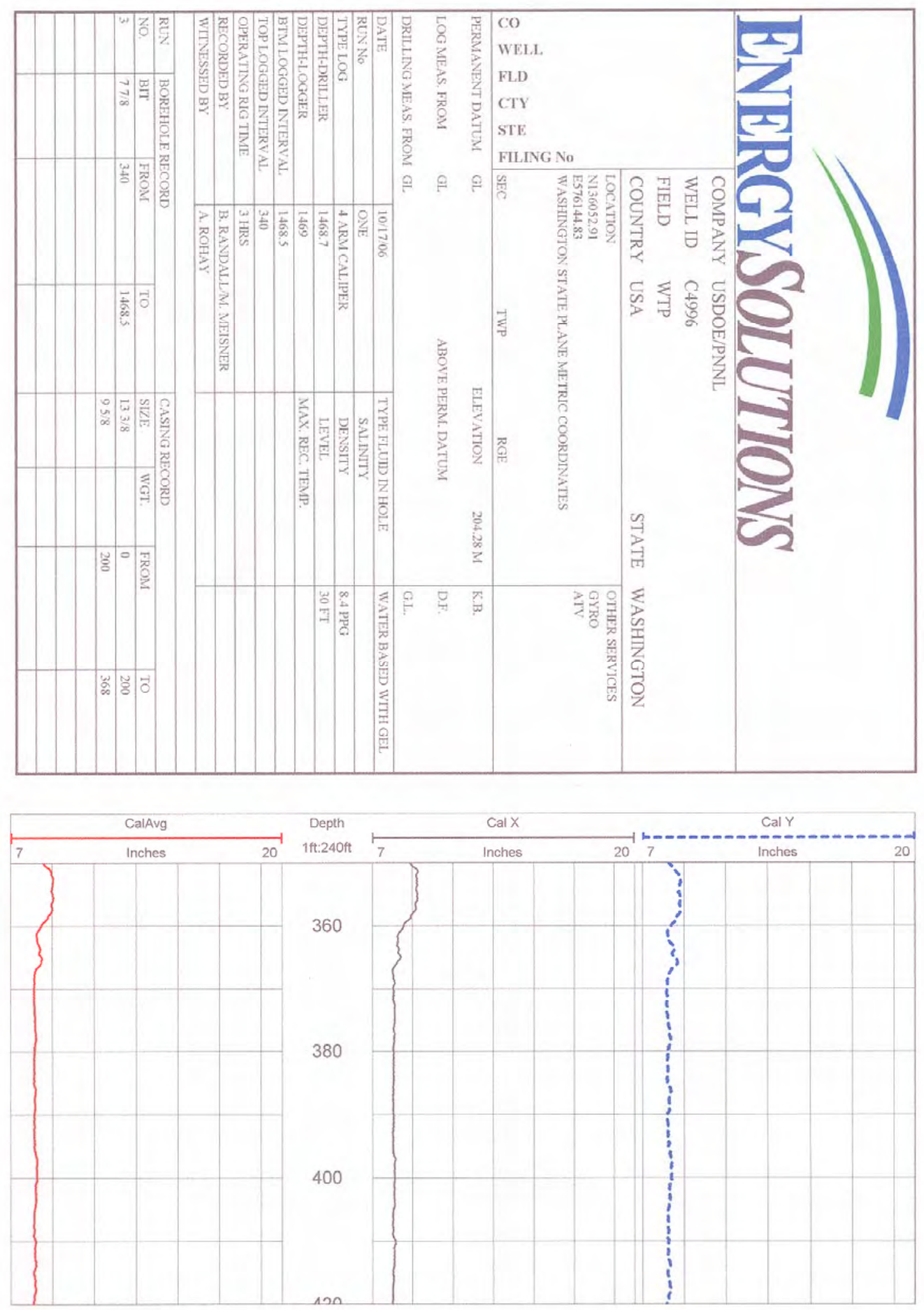
DTS-RPT-090, Rev. 0

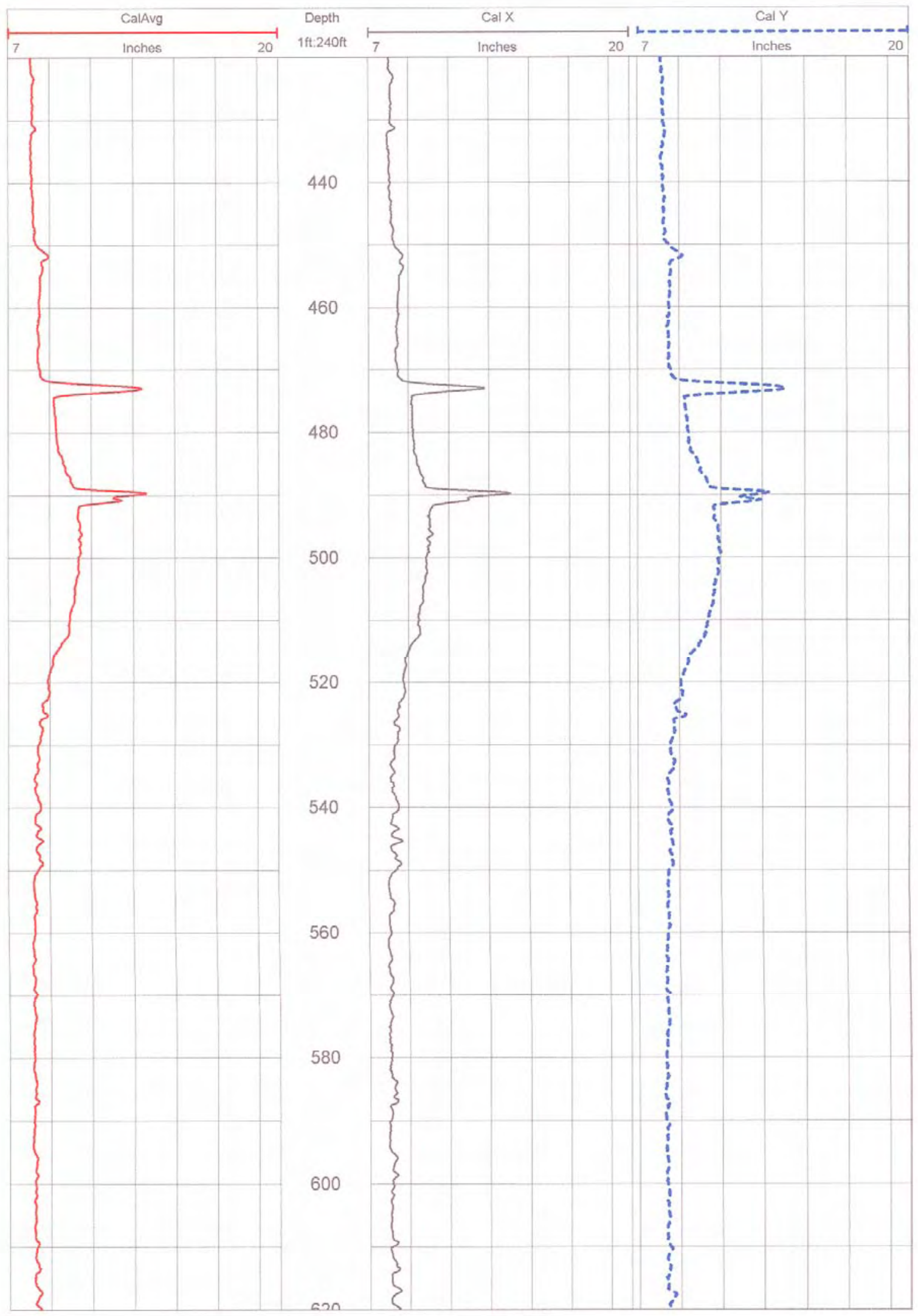


DTS-RPT-090, Rev. 0

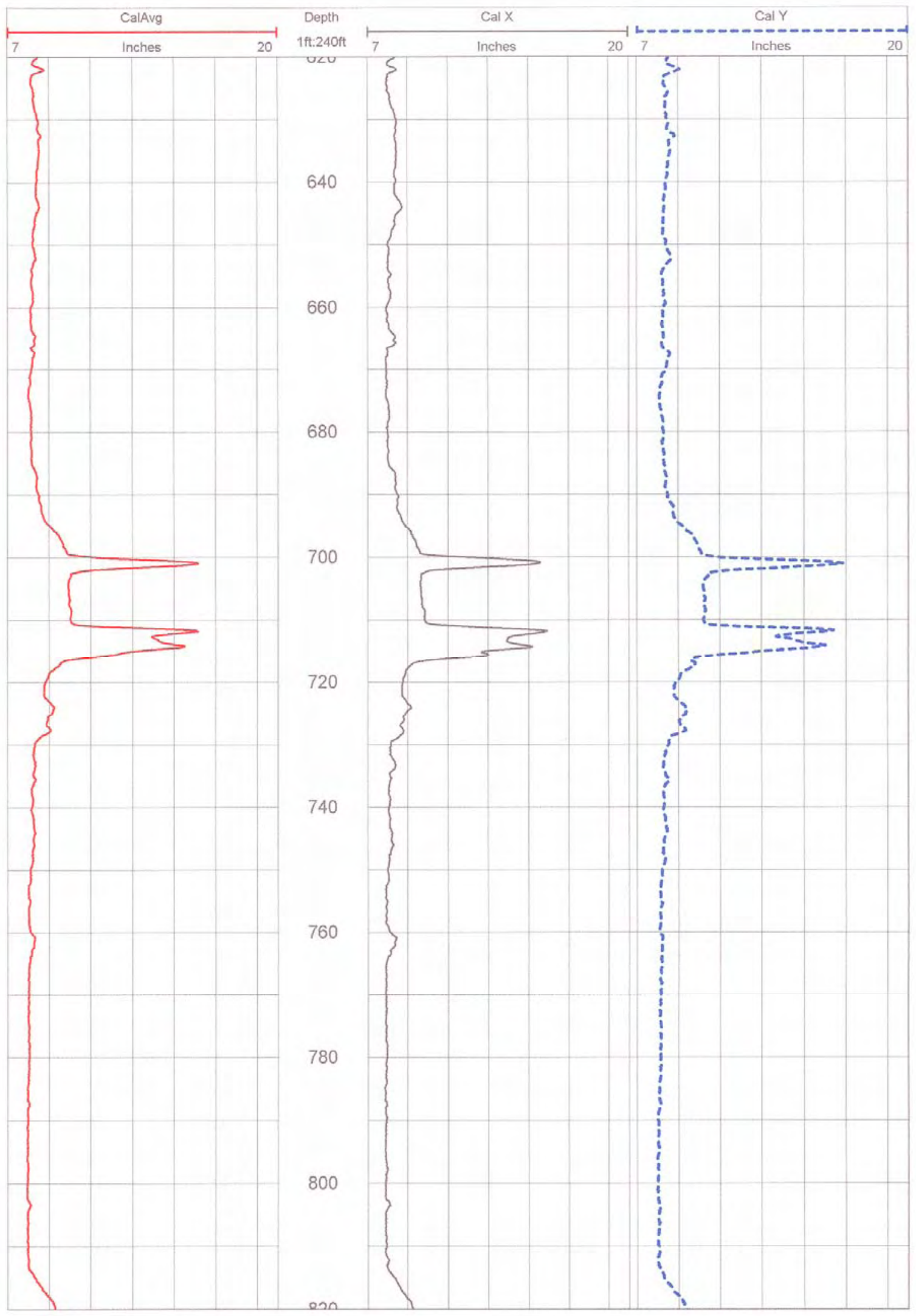


DTS-RPT-090, Rev. 0

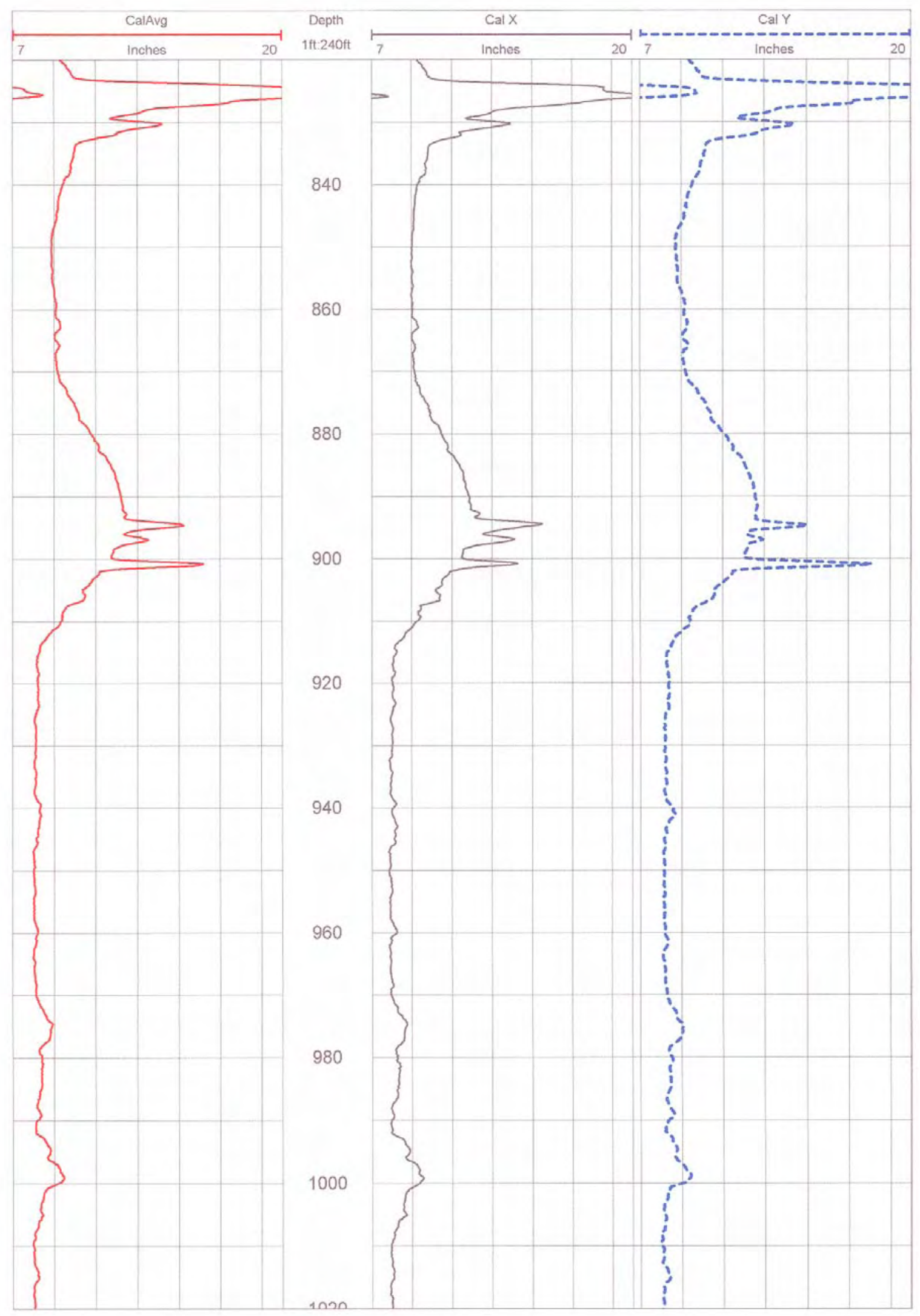


DTS-RPT-090, Rev. 0

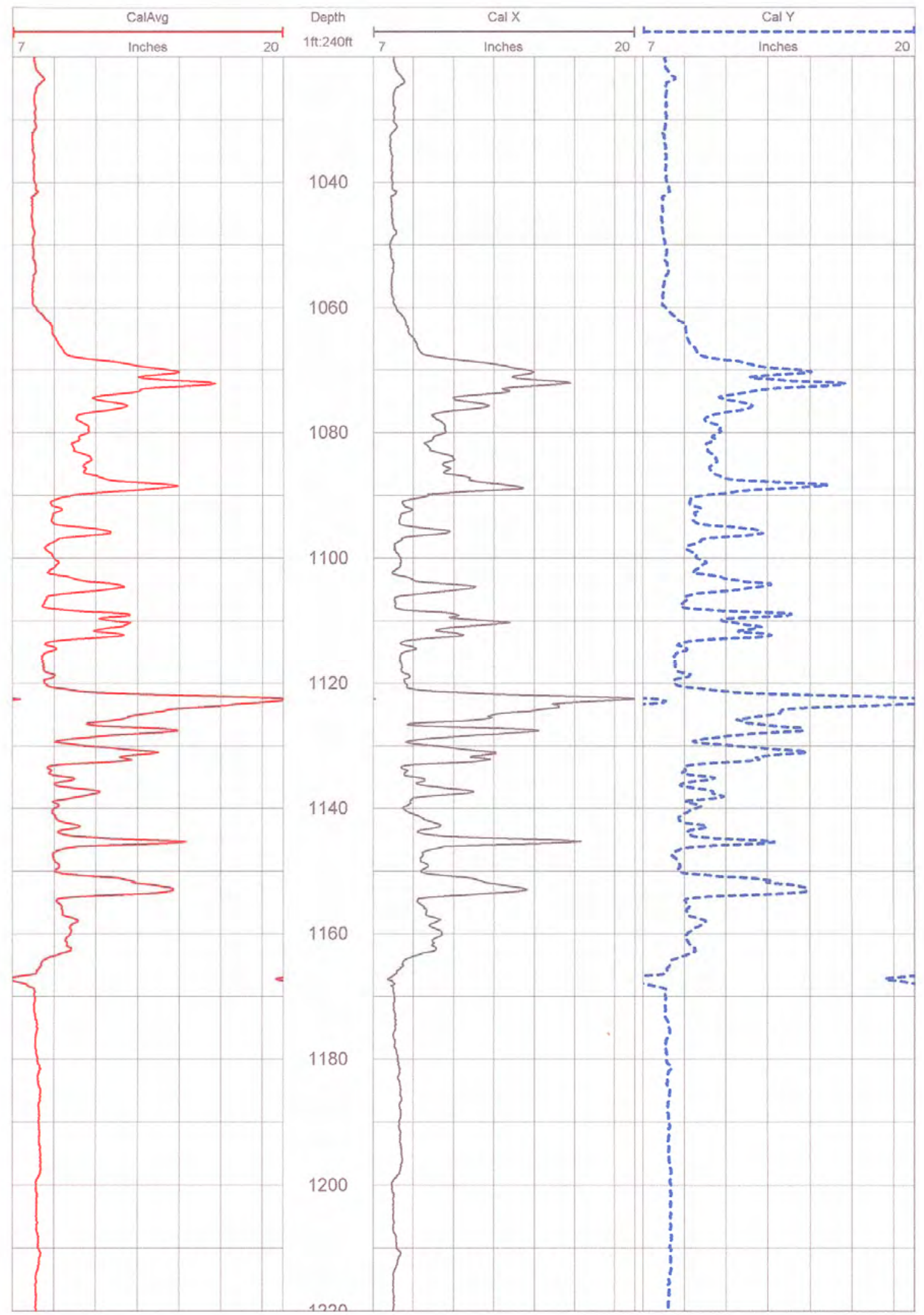


DTS-RPT-090, Rev. 0

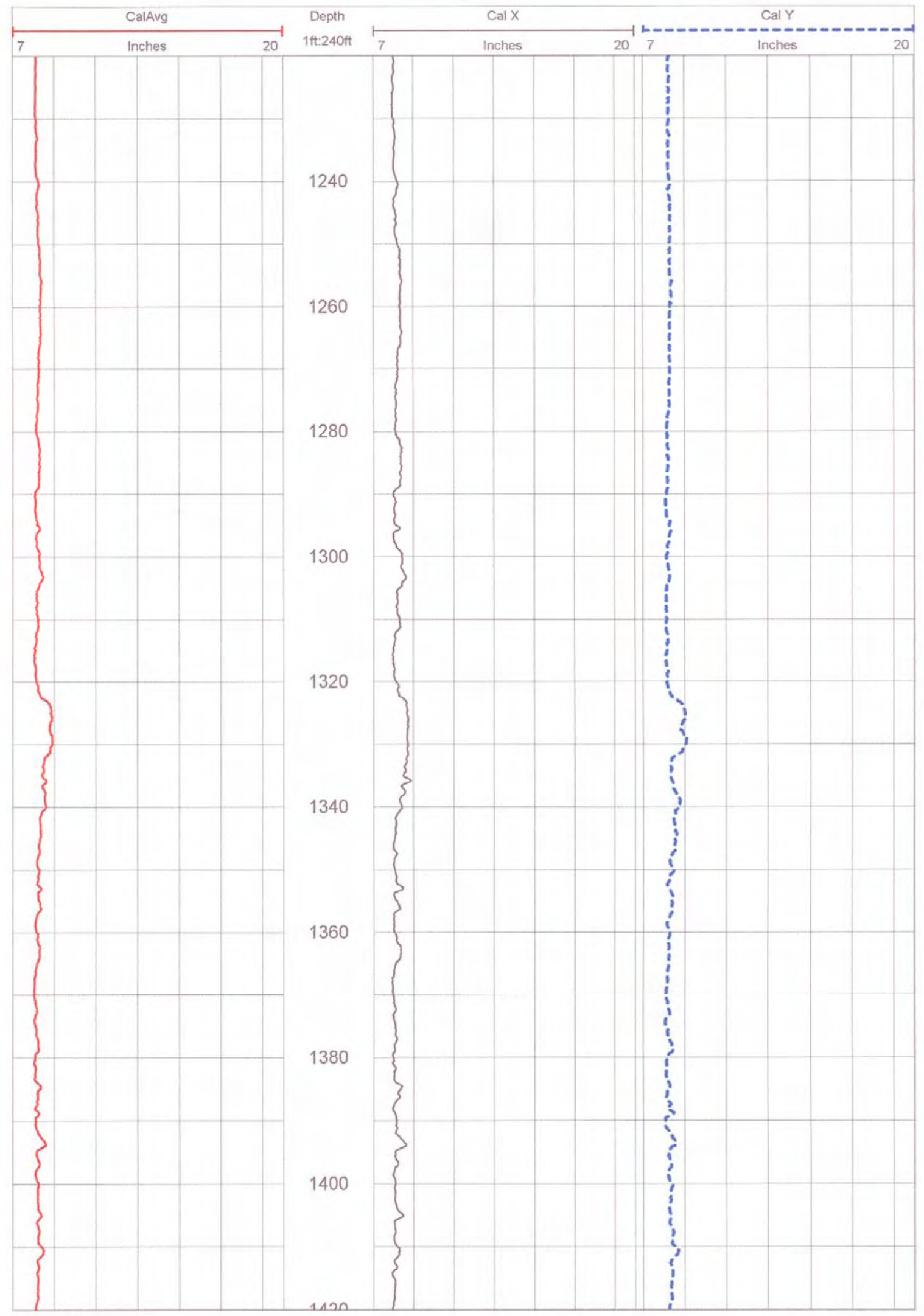


DTS-RPT-090, Rev. 0

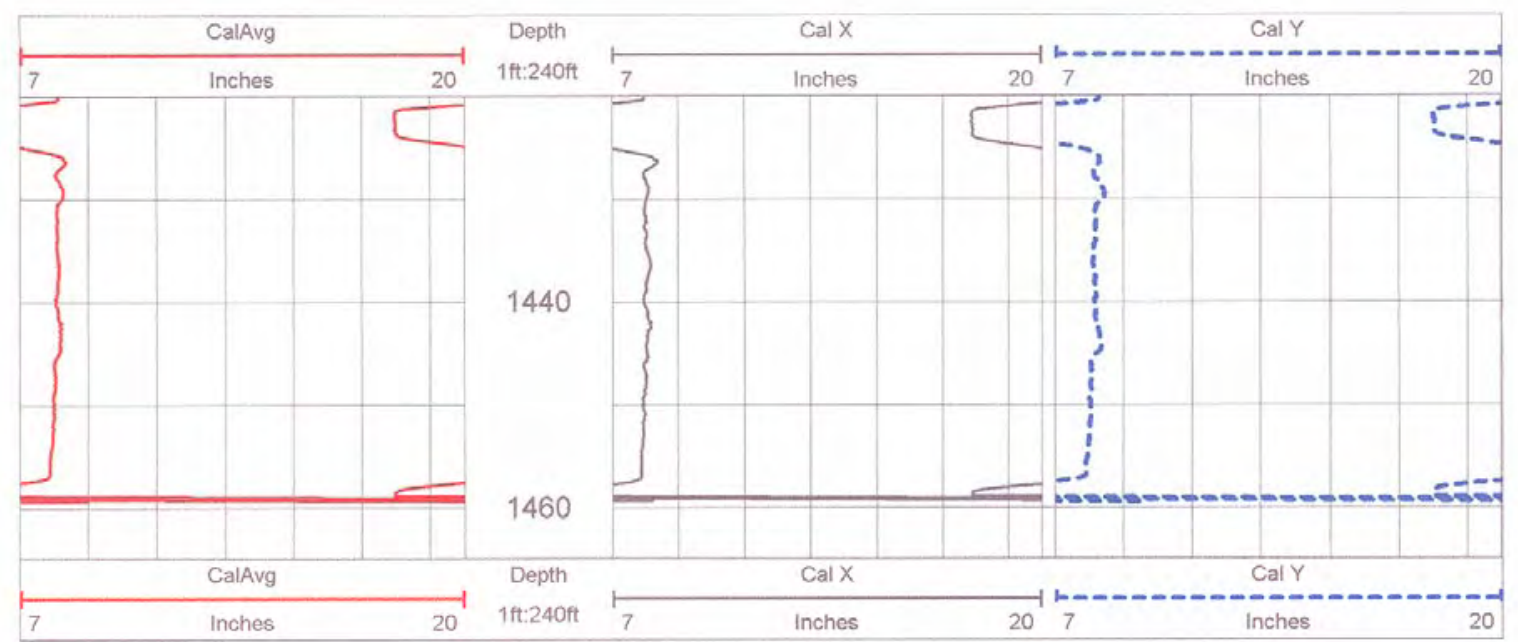


DTS-RPT-090, Rev. 0
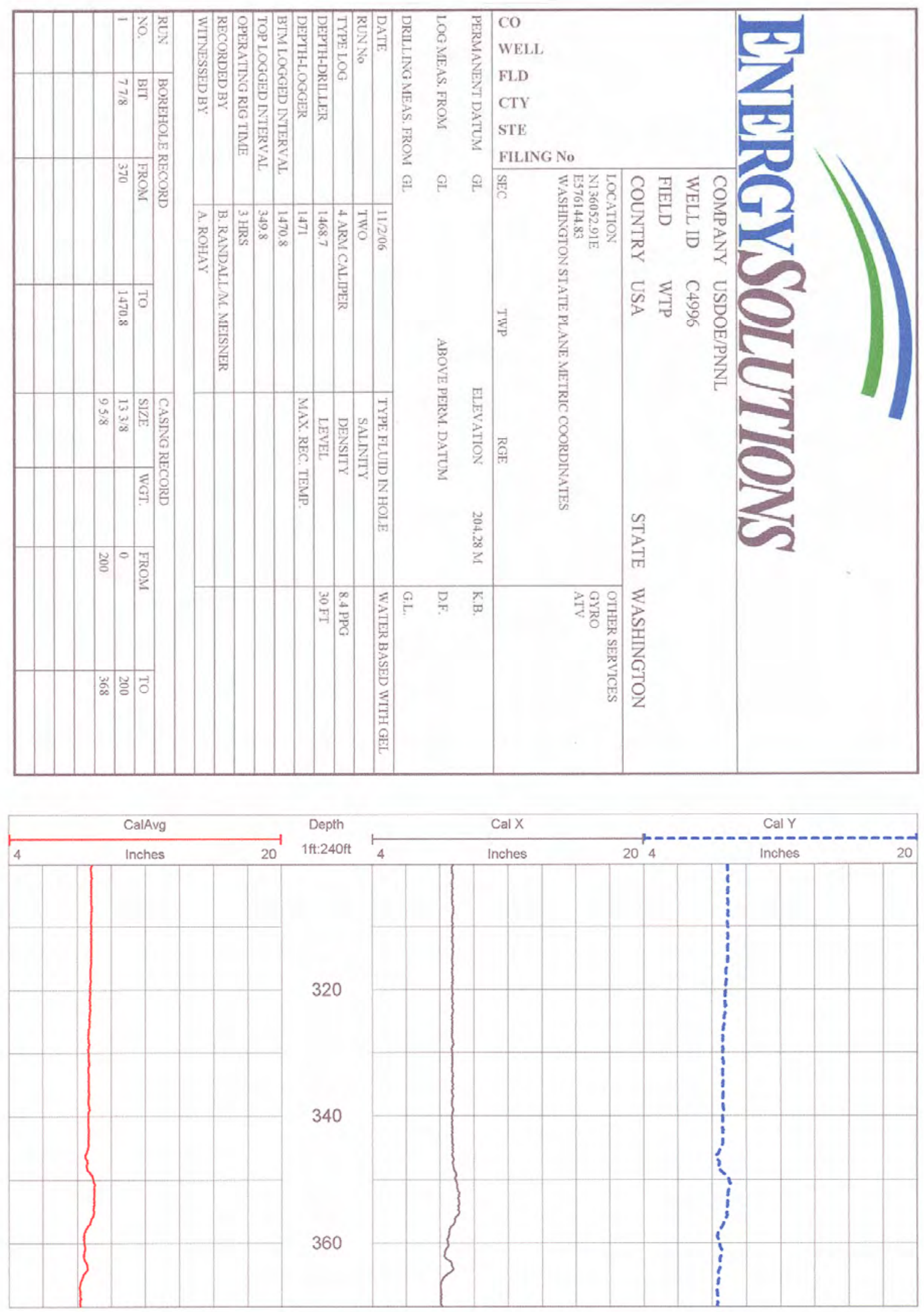
DTS-RPT-090, Rev. 0

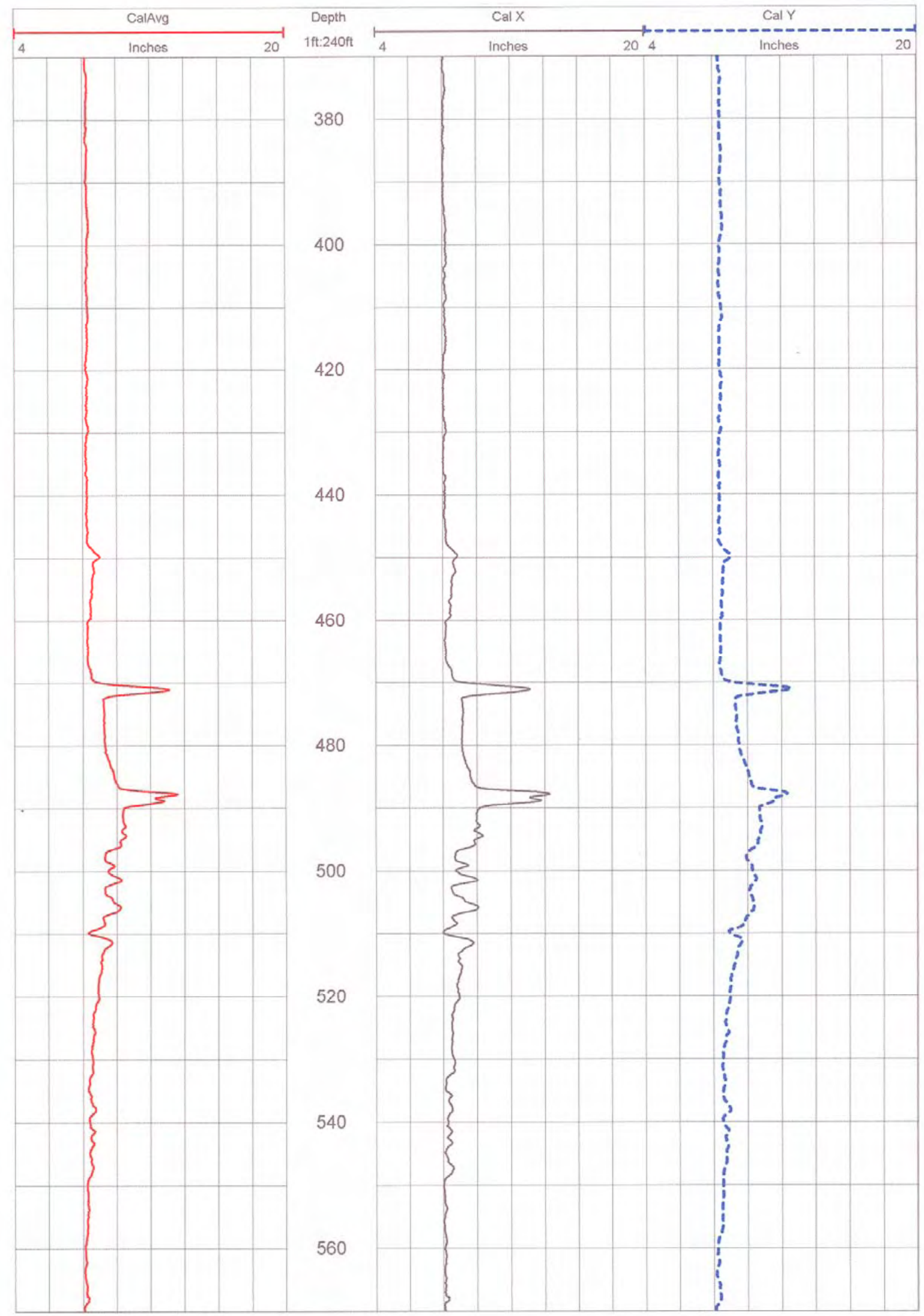


DTS-RPT-090, Rev. 0

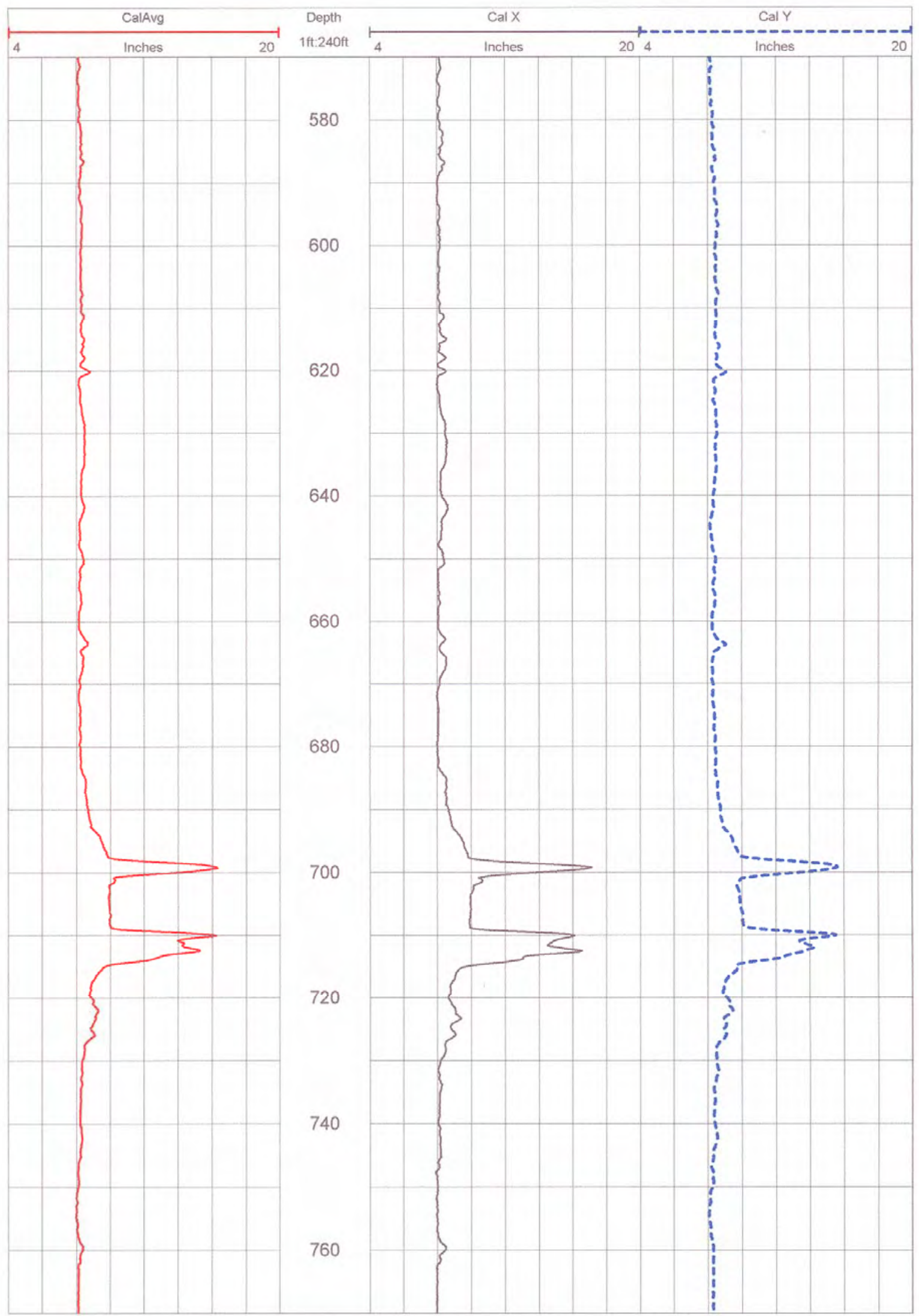


DTS-RPT-090, Rev. 0

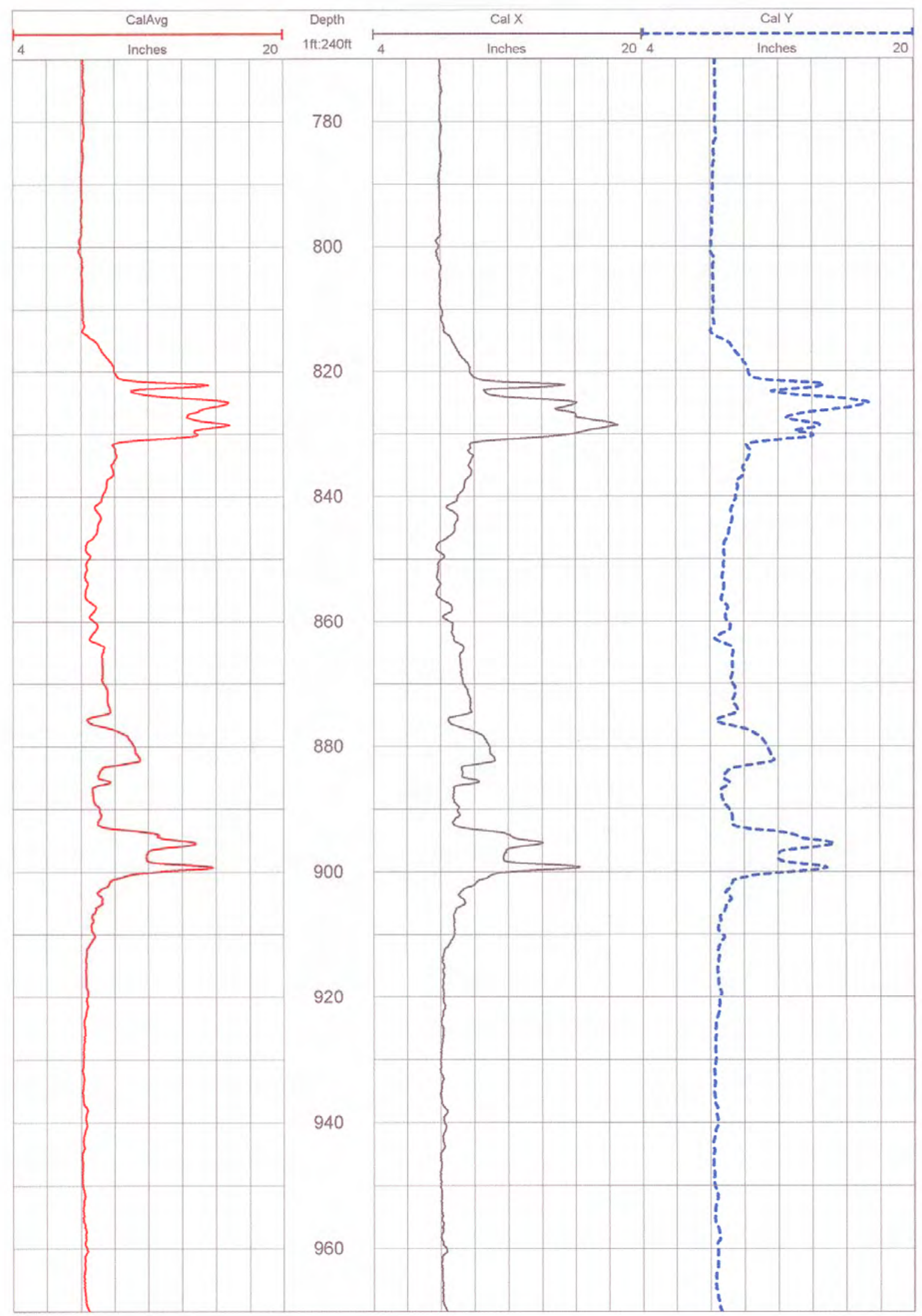


DTS-RPT-090, Rev. 0

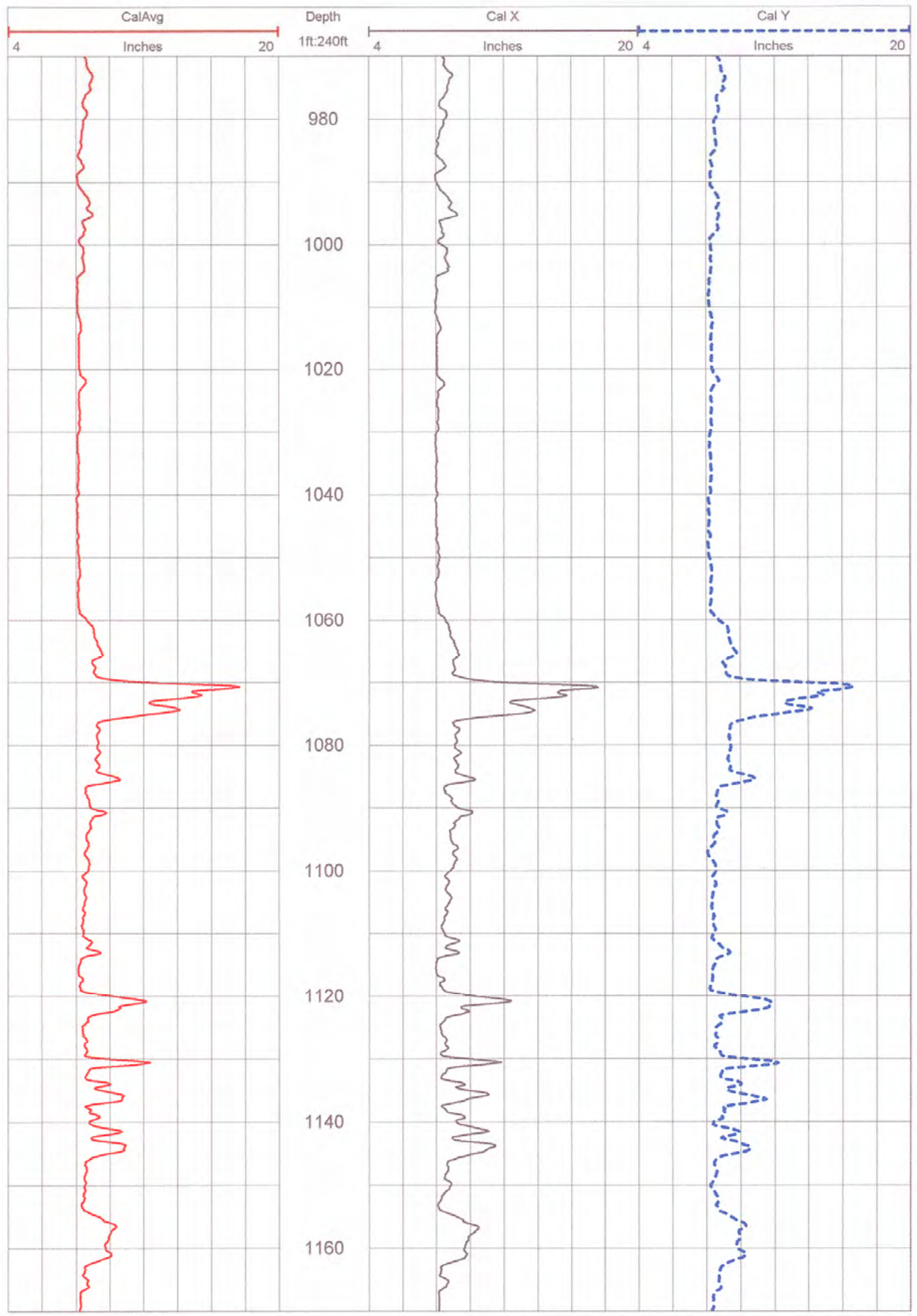


DTS-RPT-090, Rev. 0

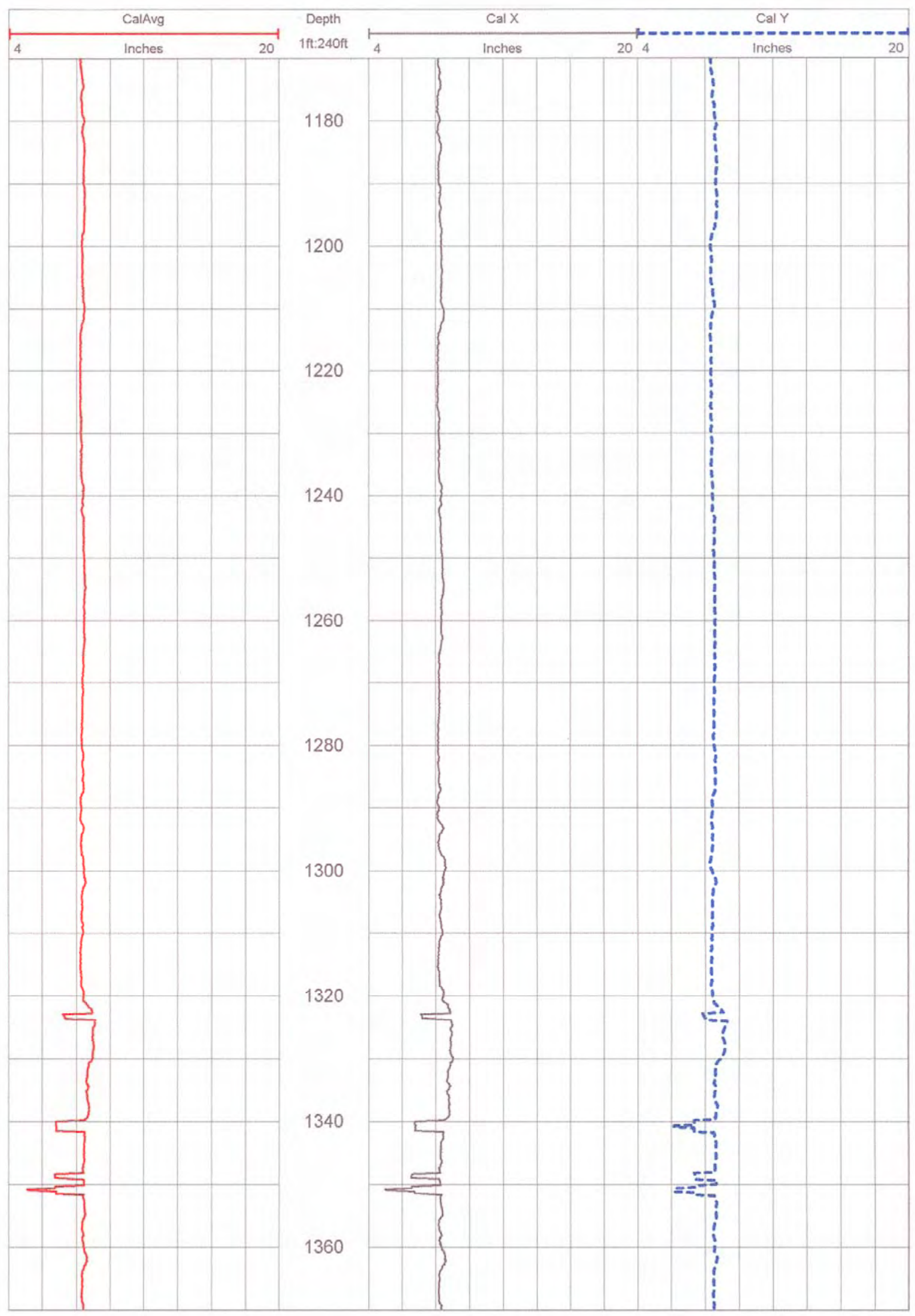


DTS-RPT-090, Rev. 0

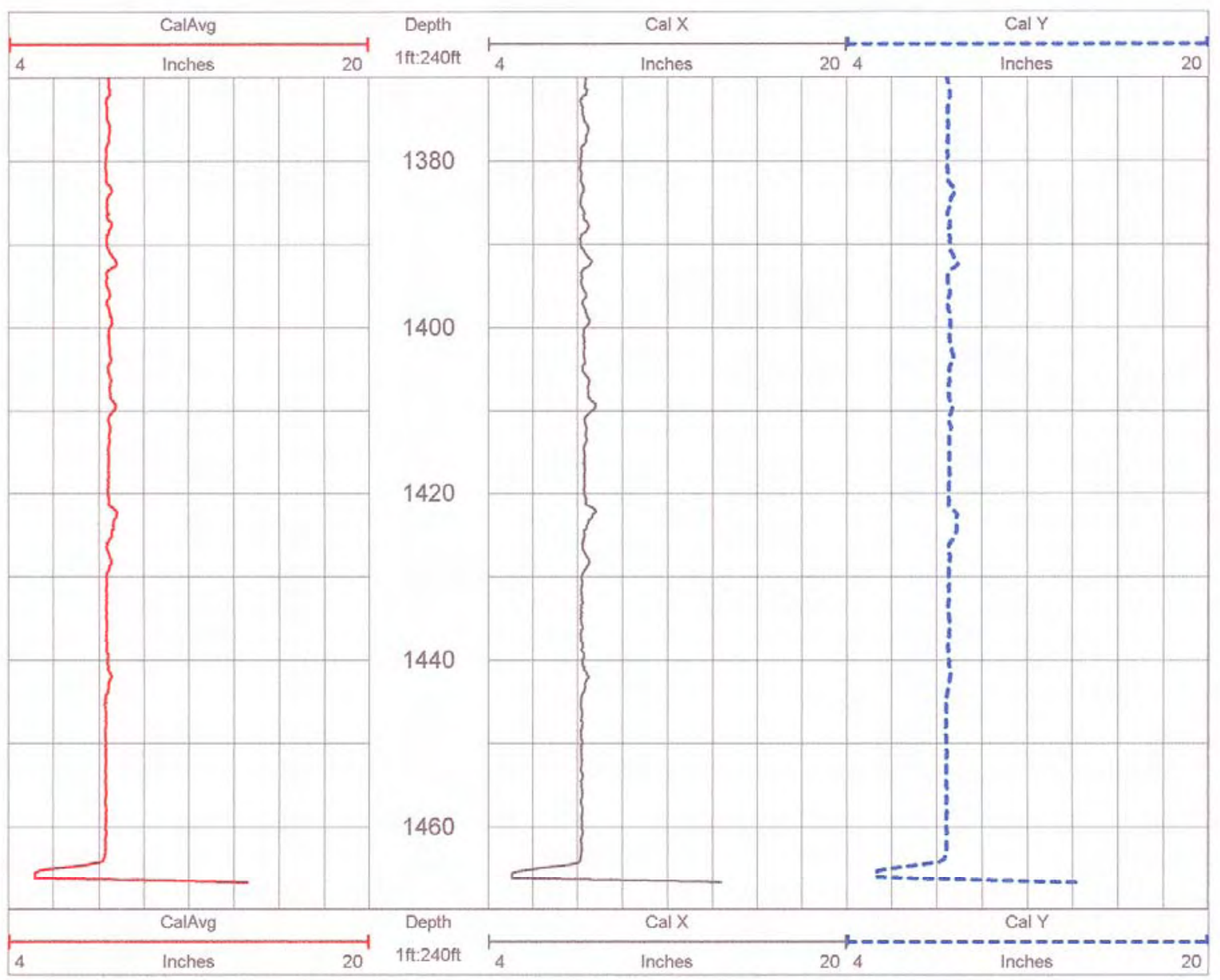


DTS-RPT-090, Rev. 0
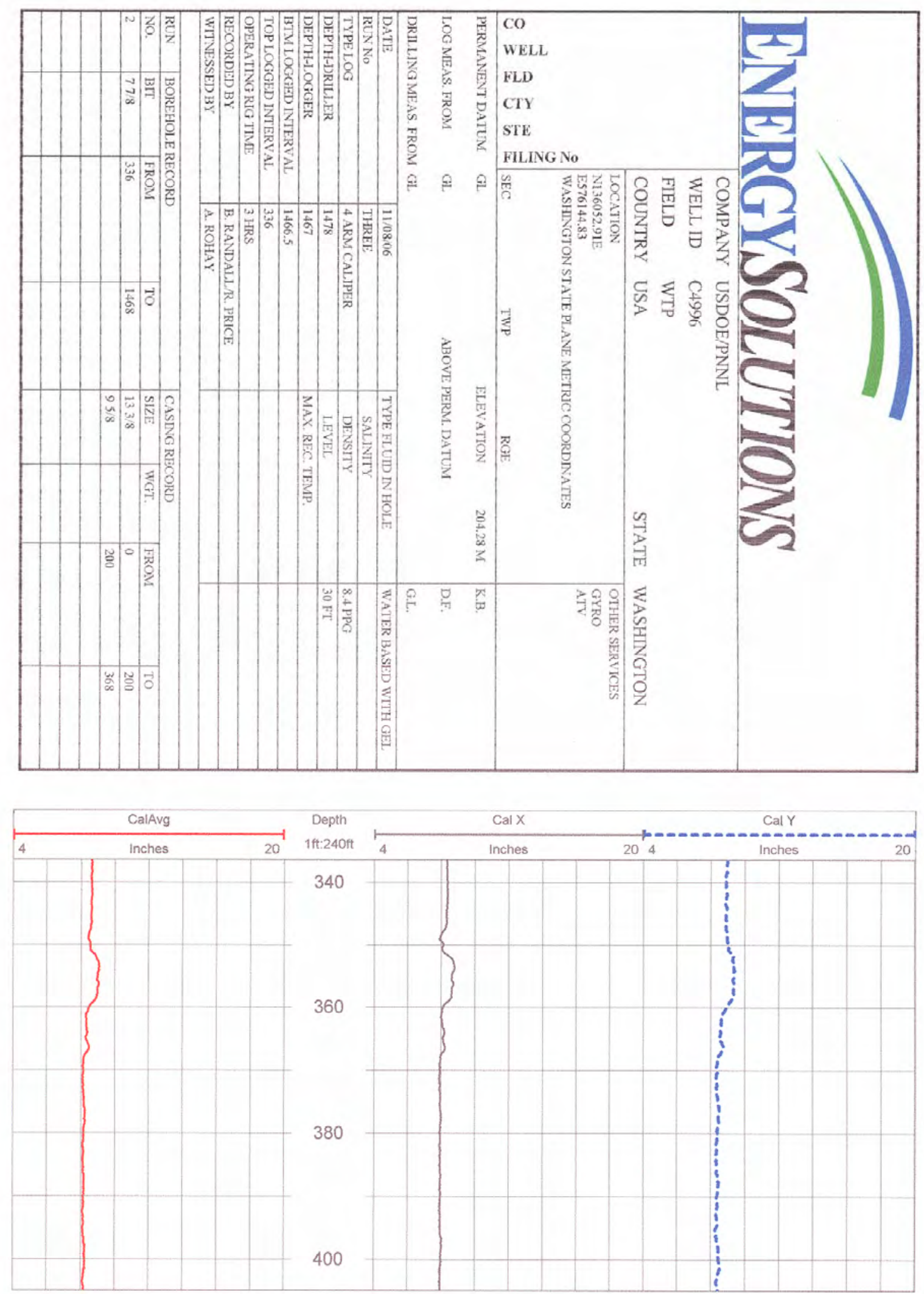
DTS-RPT-090, Rev. 0

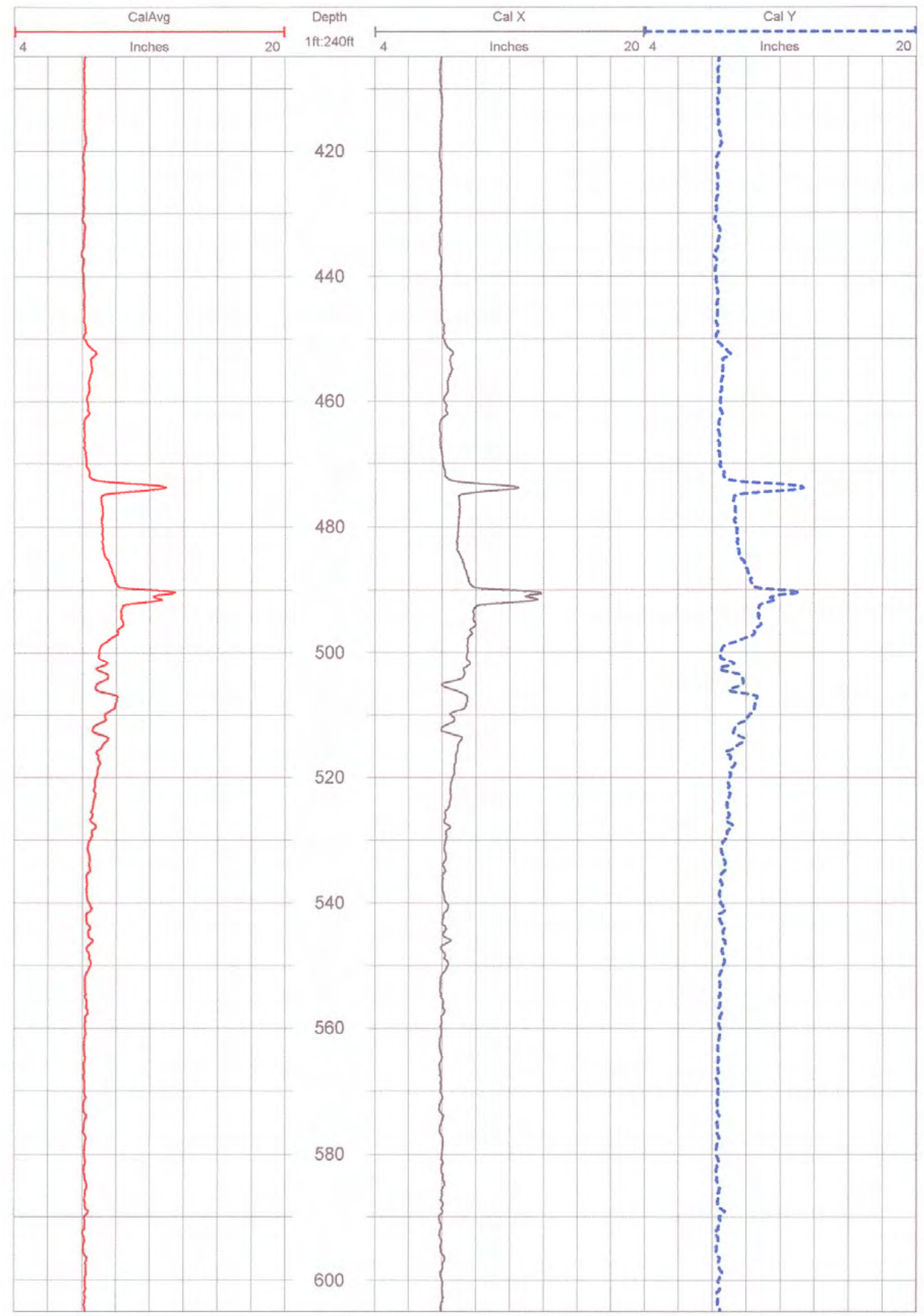


DTS-RPT-090, Rev. 0

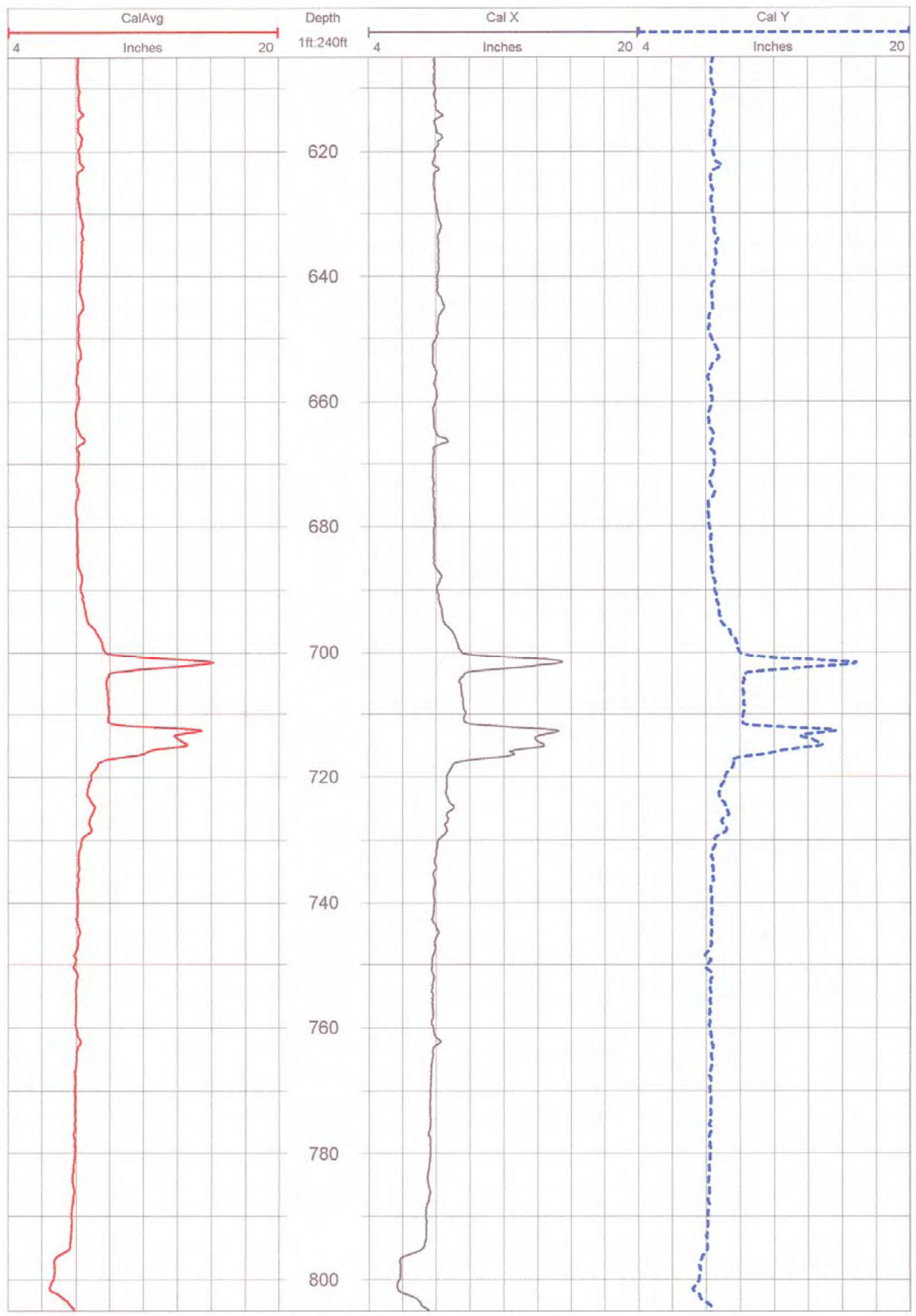


DTS-RPT-090, Rev. 0

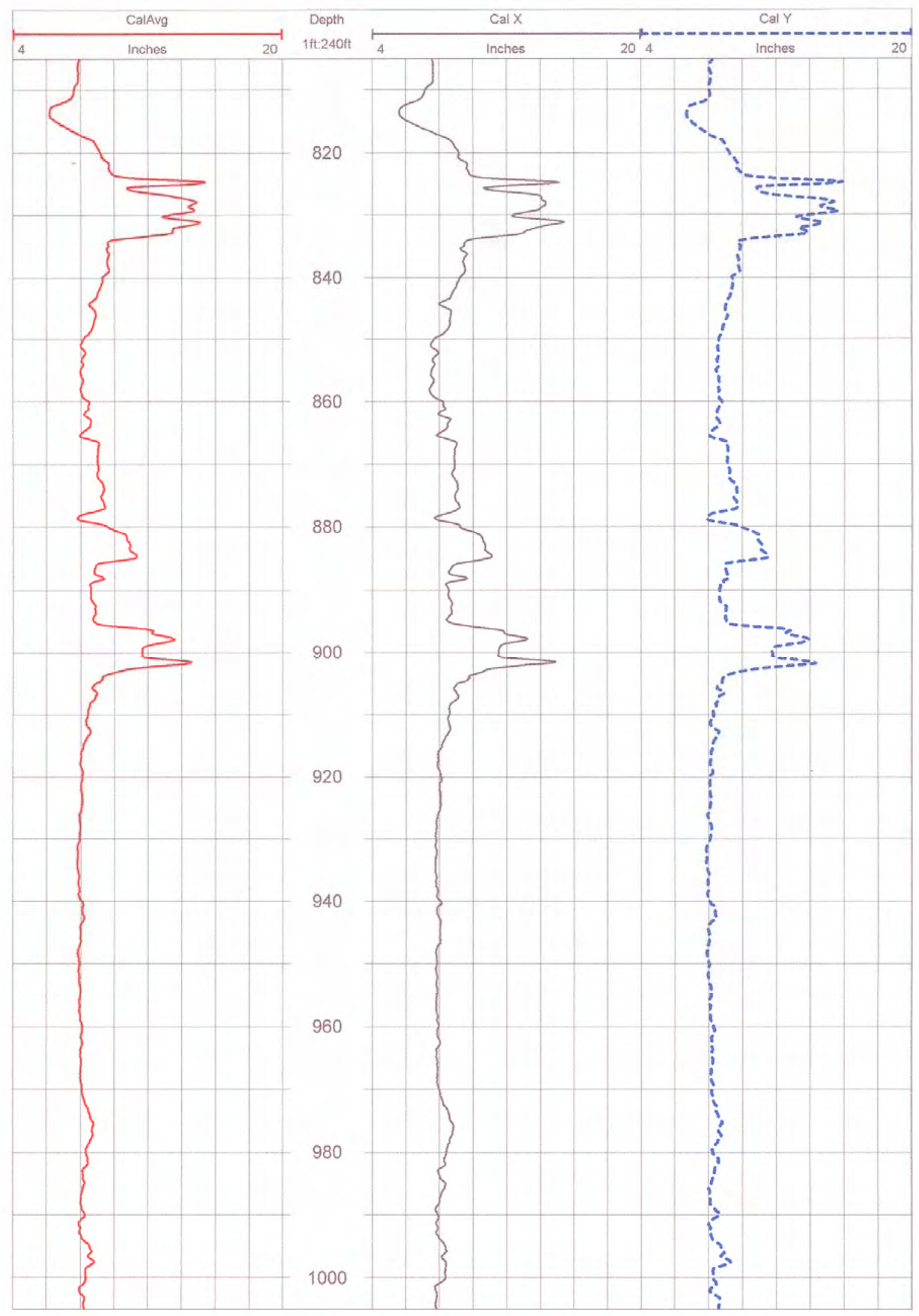


DTS-RPT-090, Rev. 0

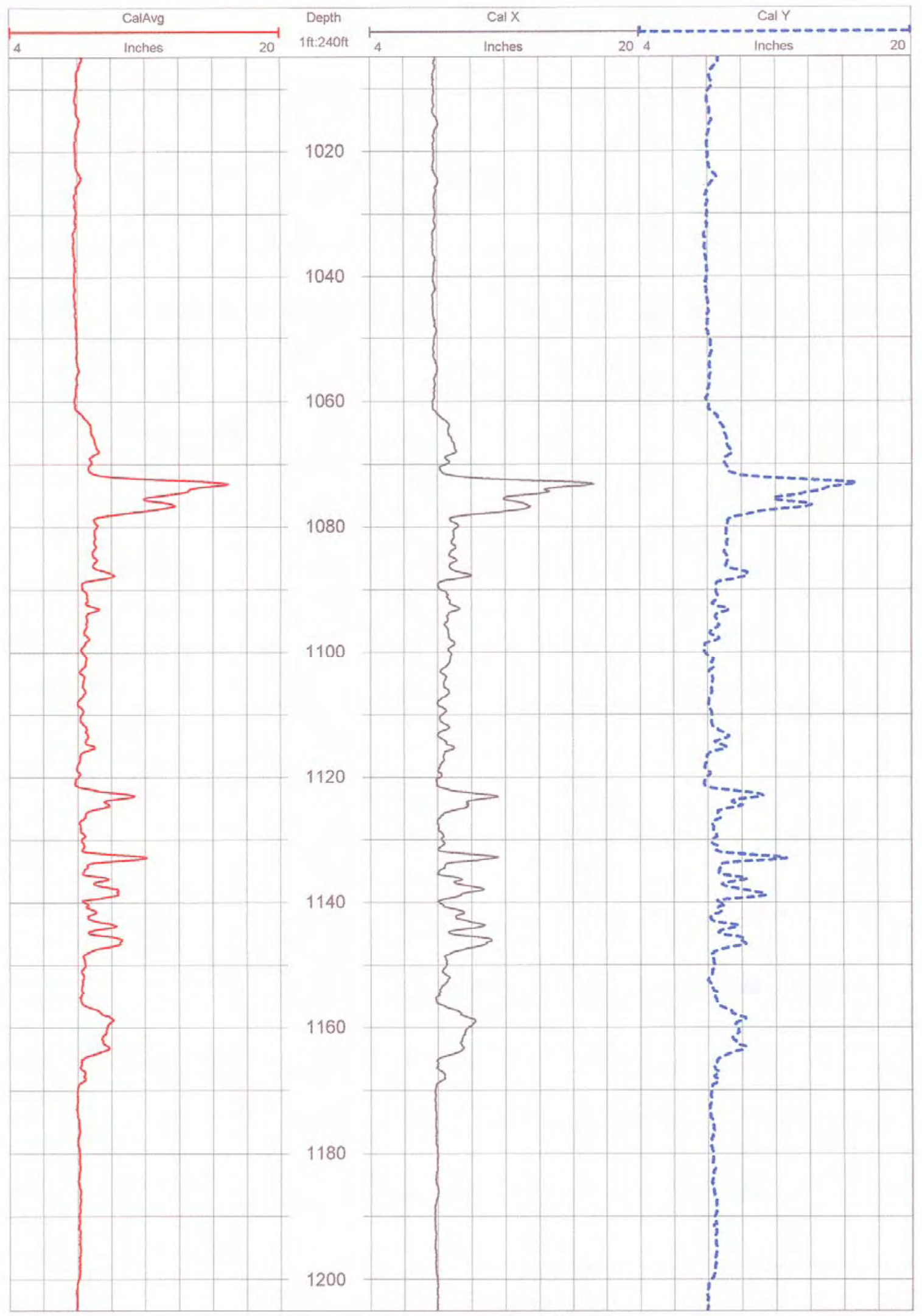


DTS-RPT-090, Rev. 0

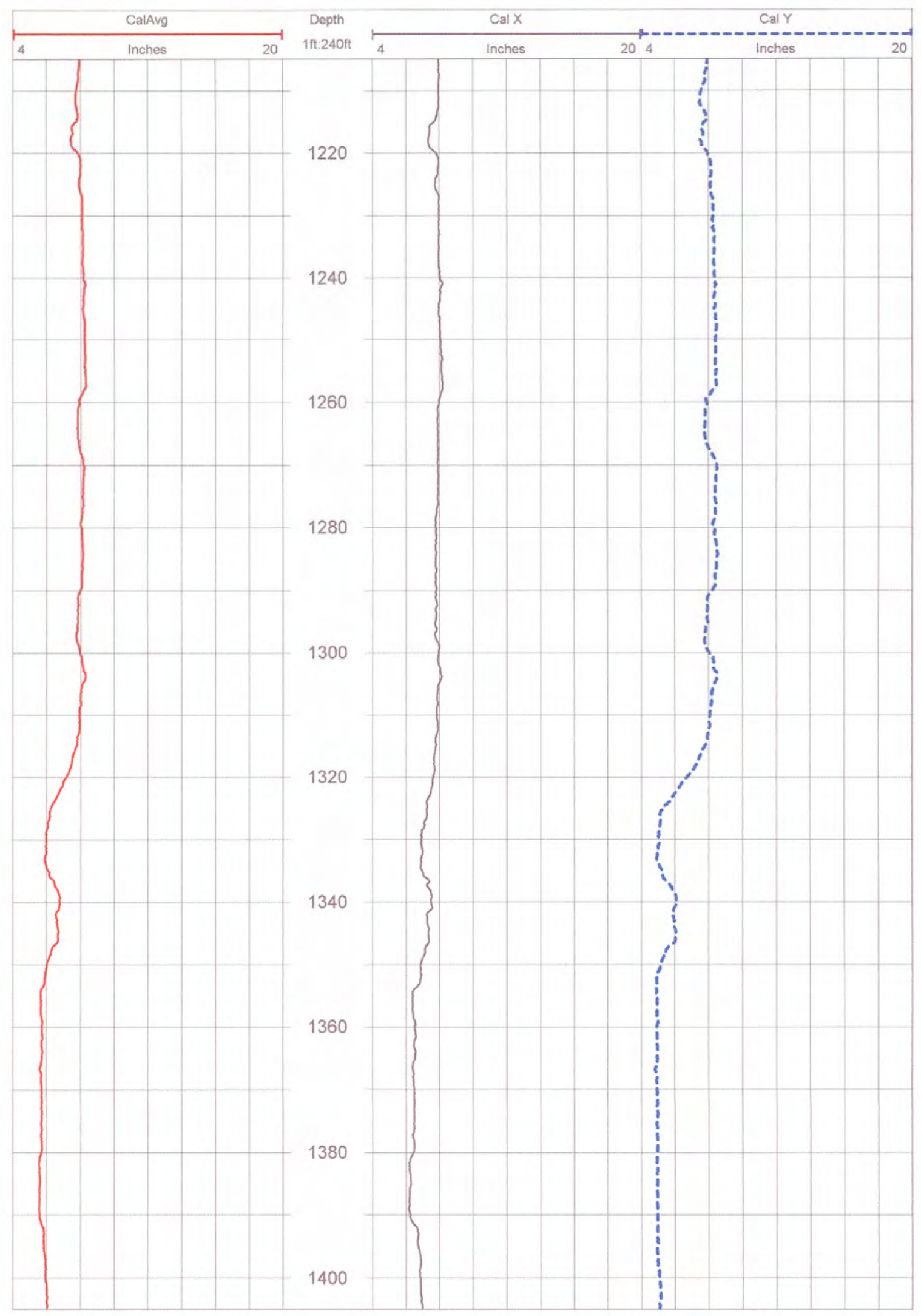


DTS-RPT-090, Rev. 0

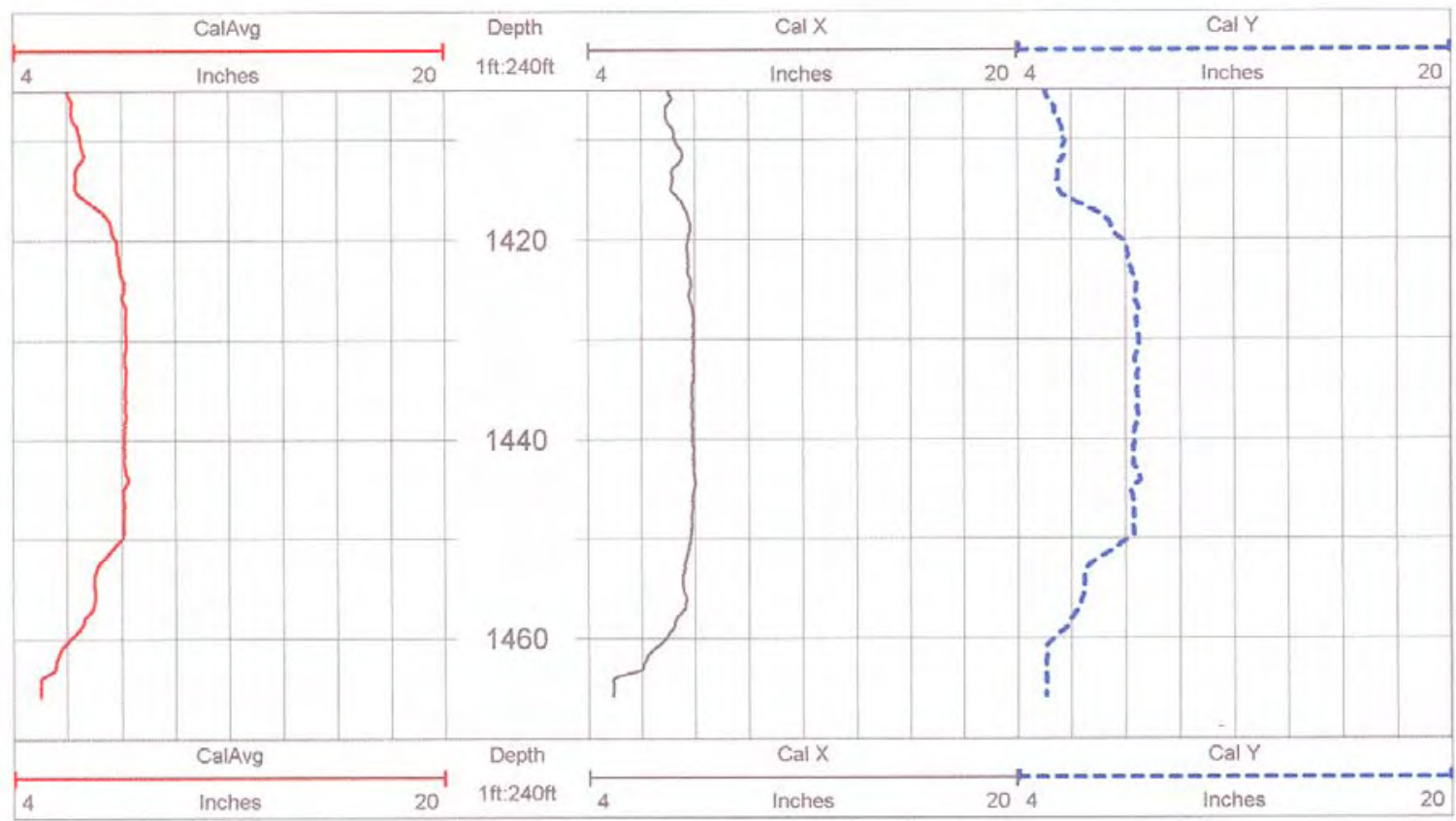


DTS-RPT-090, Rev. 0
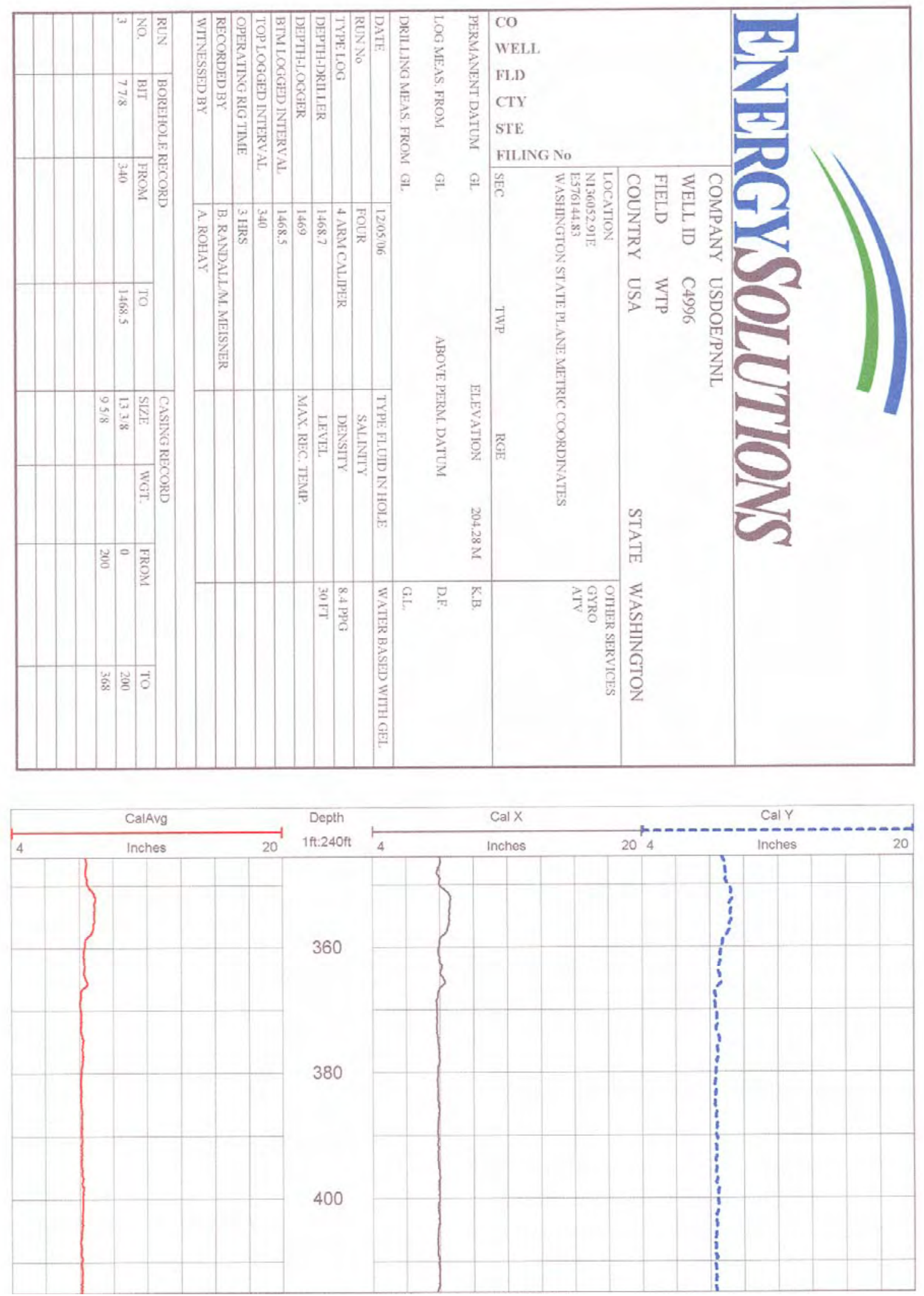
DTS-RPT-090, Rev. 0

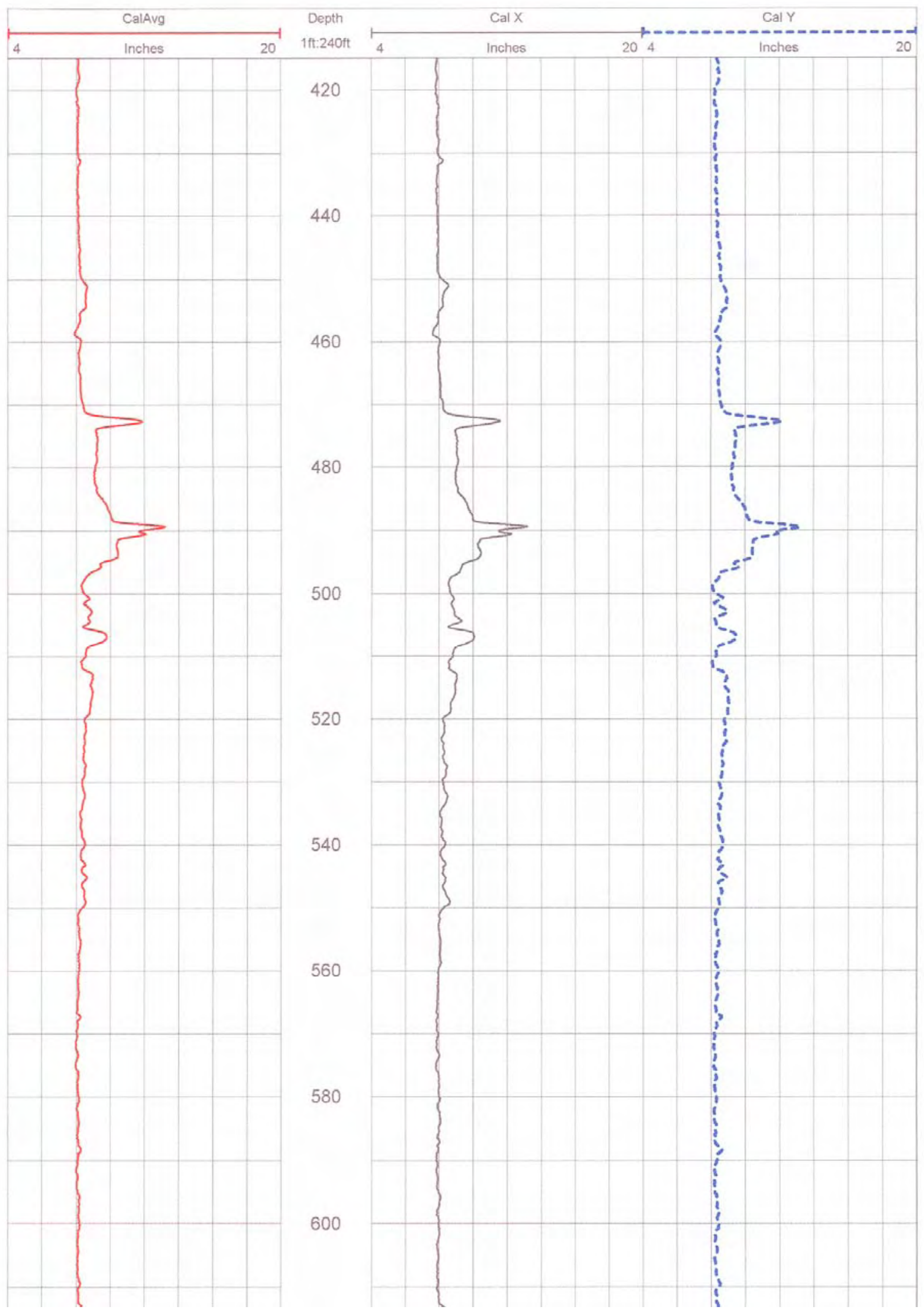


DTS-RPT-090, Rev. 0

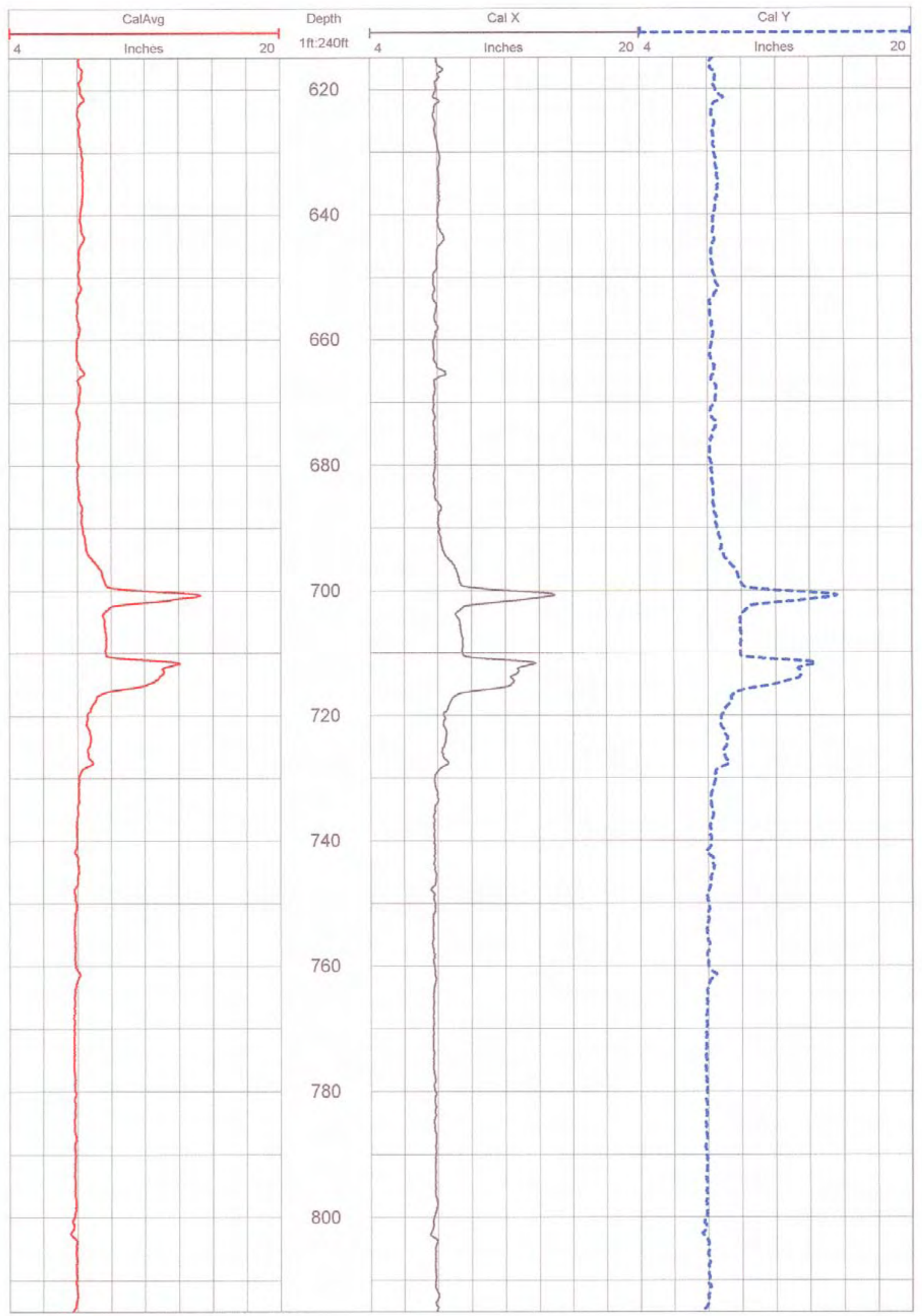


DTS-RPT-090, Rev. 0

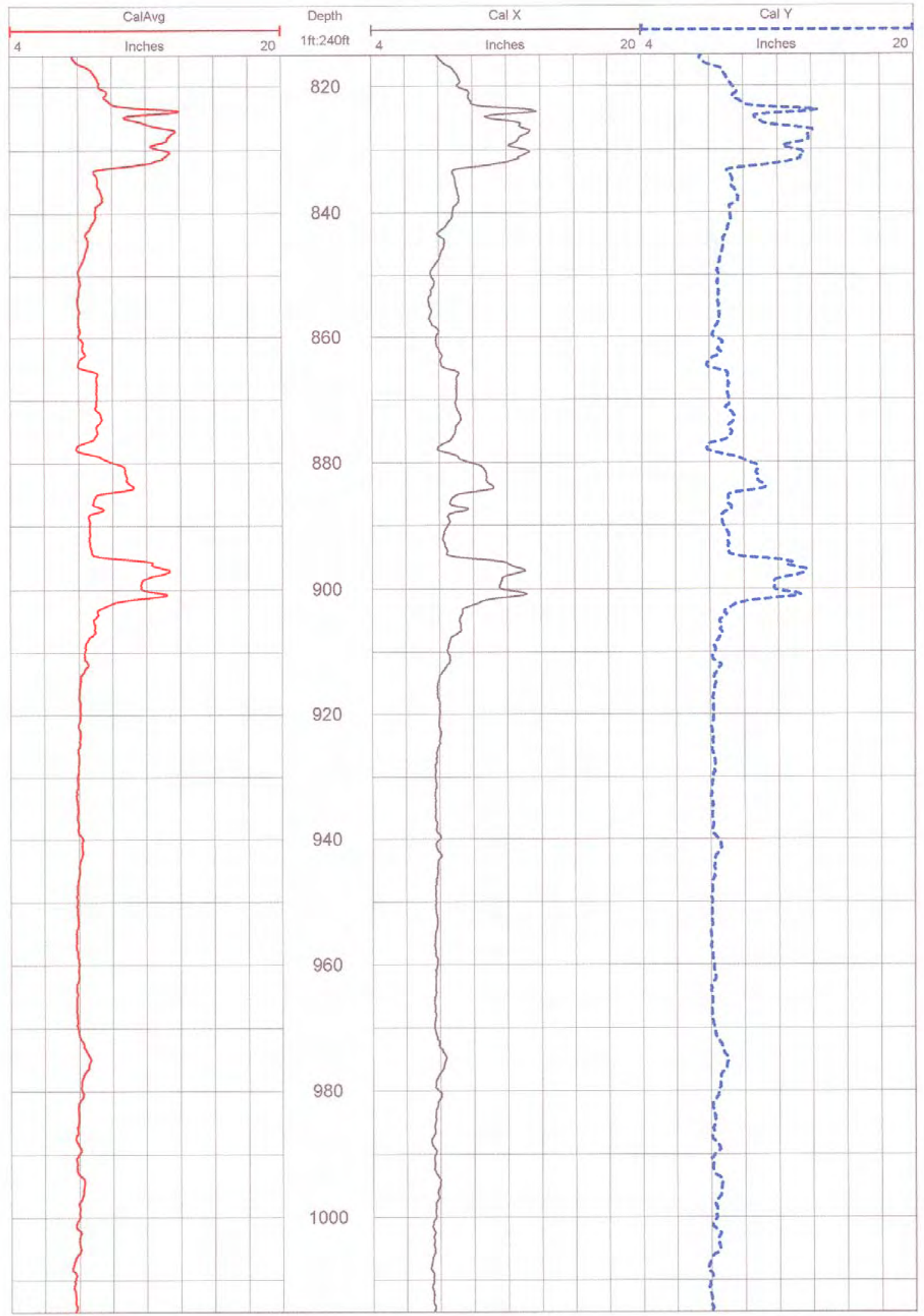


DTS-RPT-090, Rev. 0

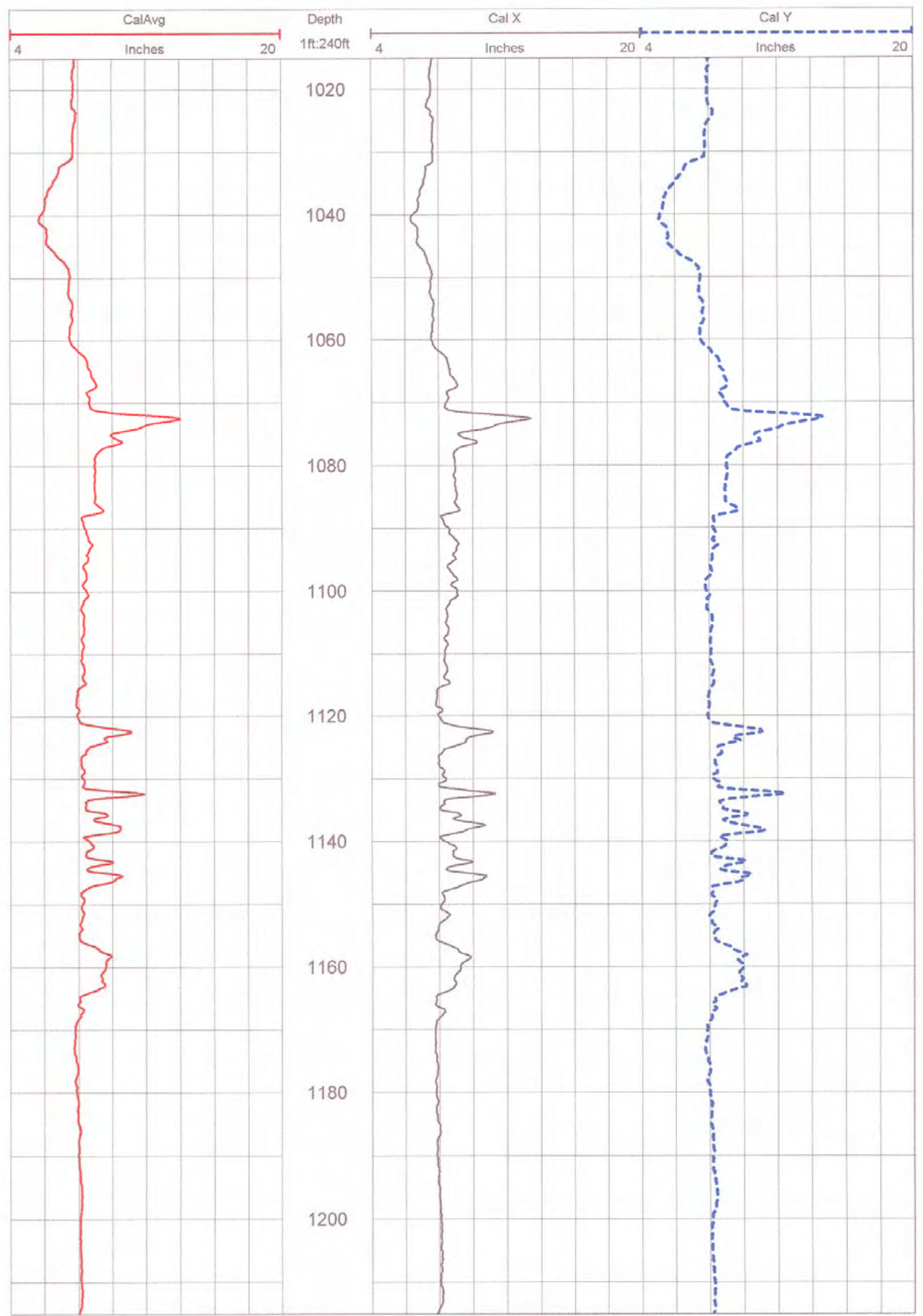


DTS-RPT-090, Rev. 0

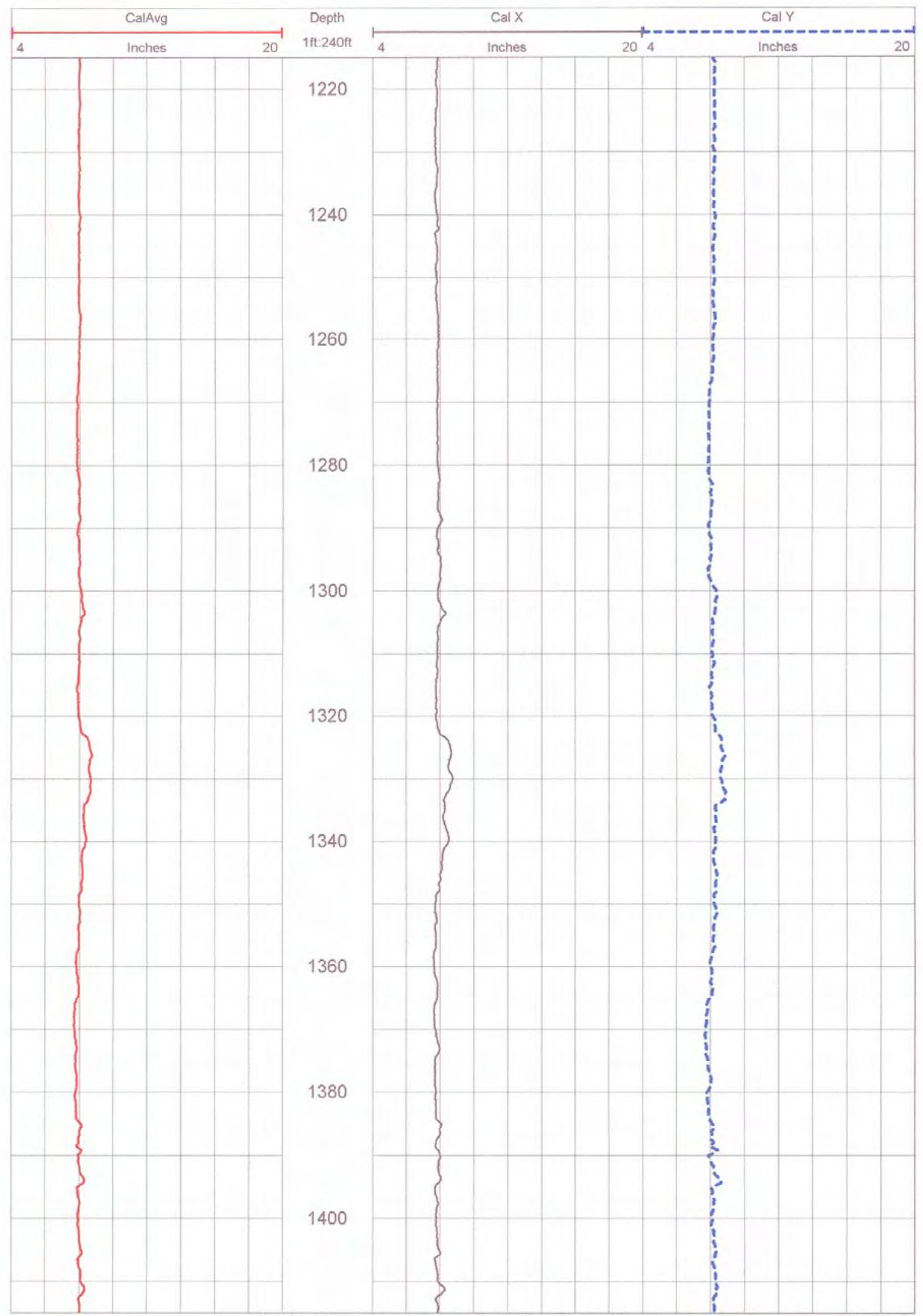


DTS-RPT-090, Rev. 0

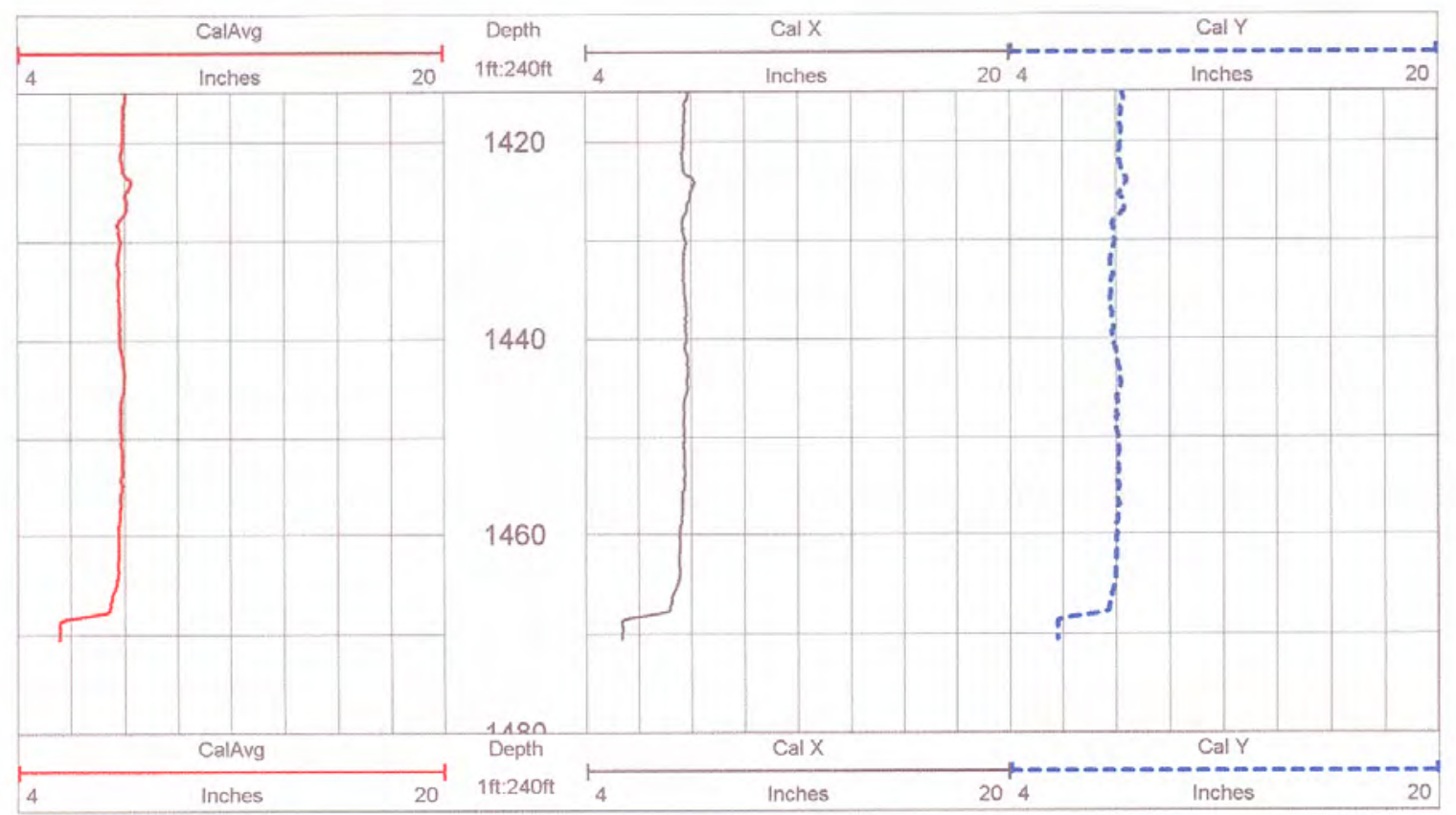


DTS-RPT-090, Rev. 0

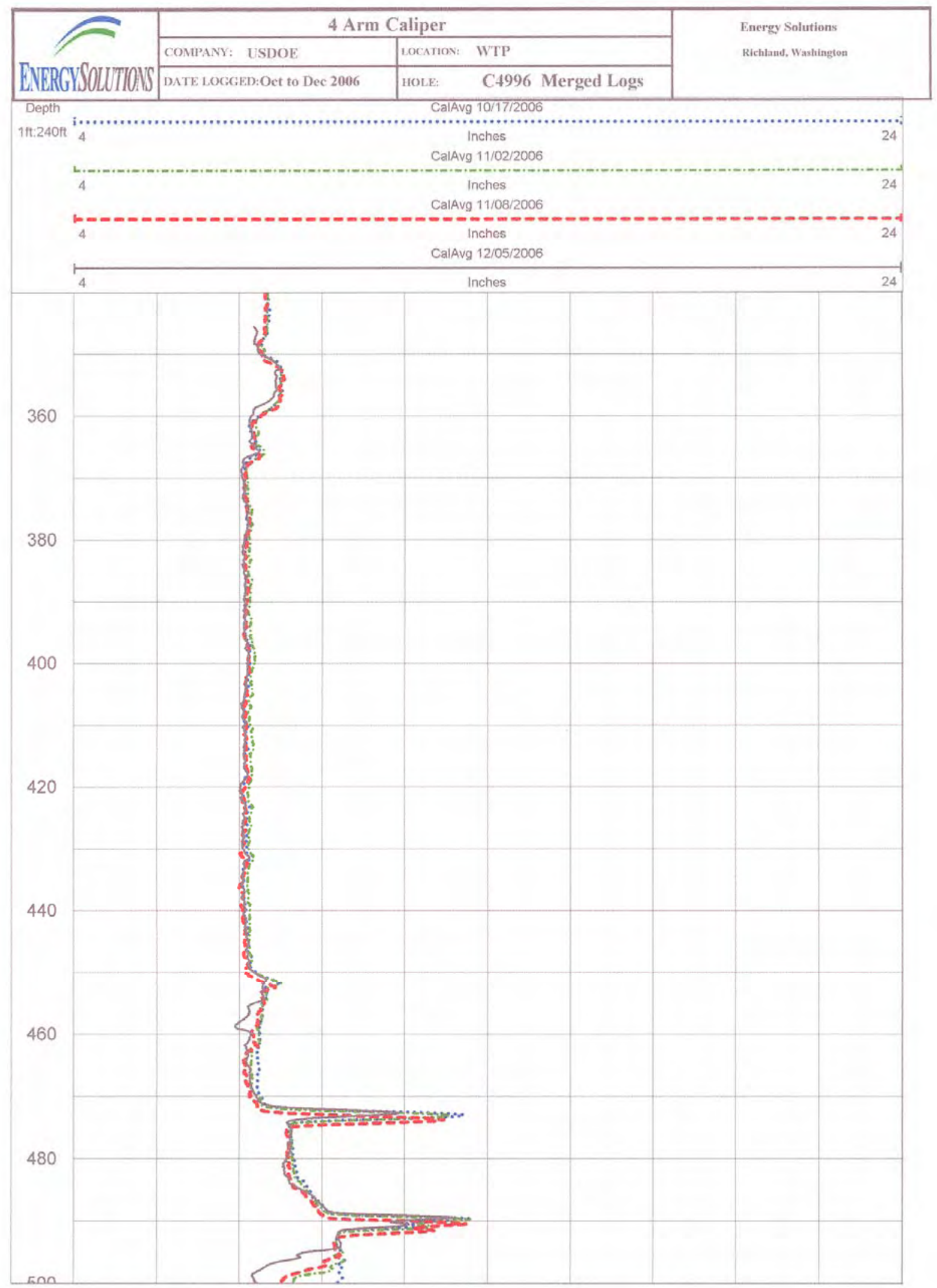


DTS-RPT-090, Rev. 0

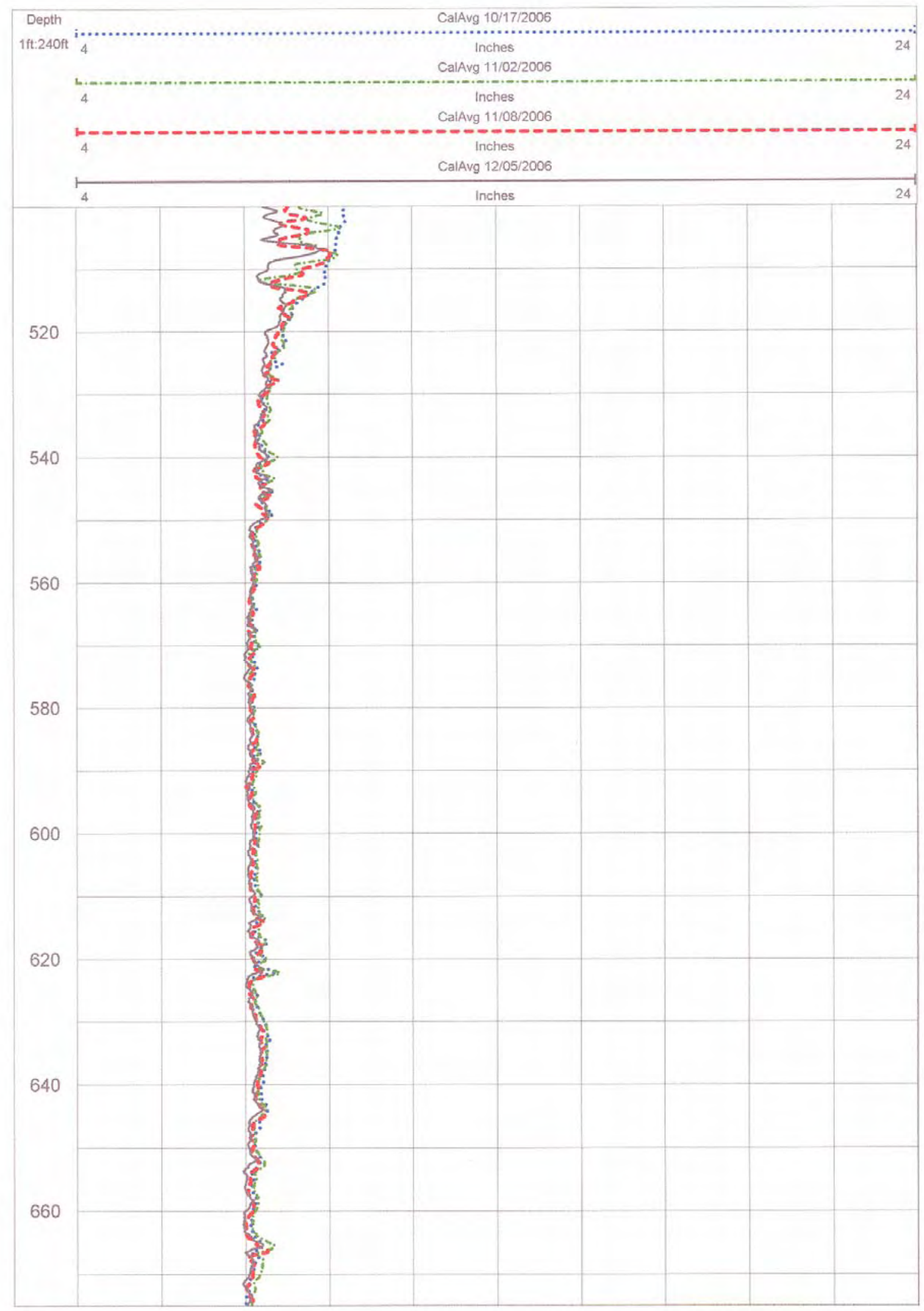


DTS-RPT-090, Rev. 0

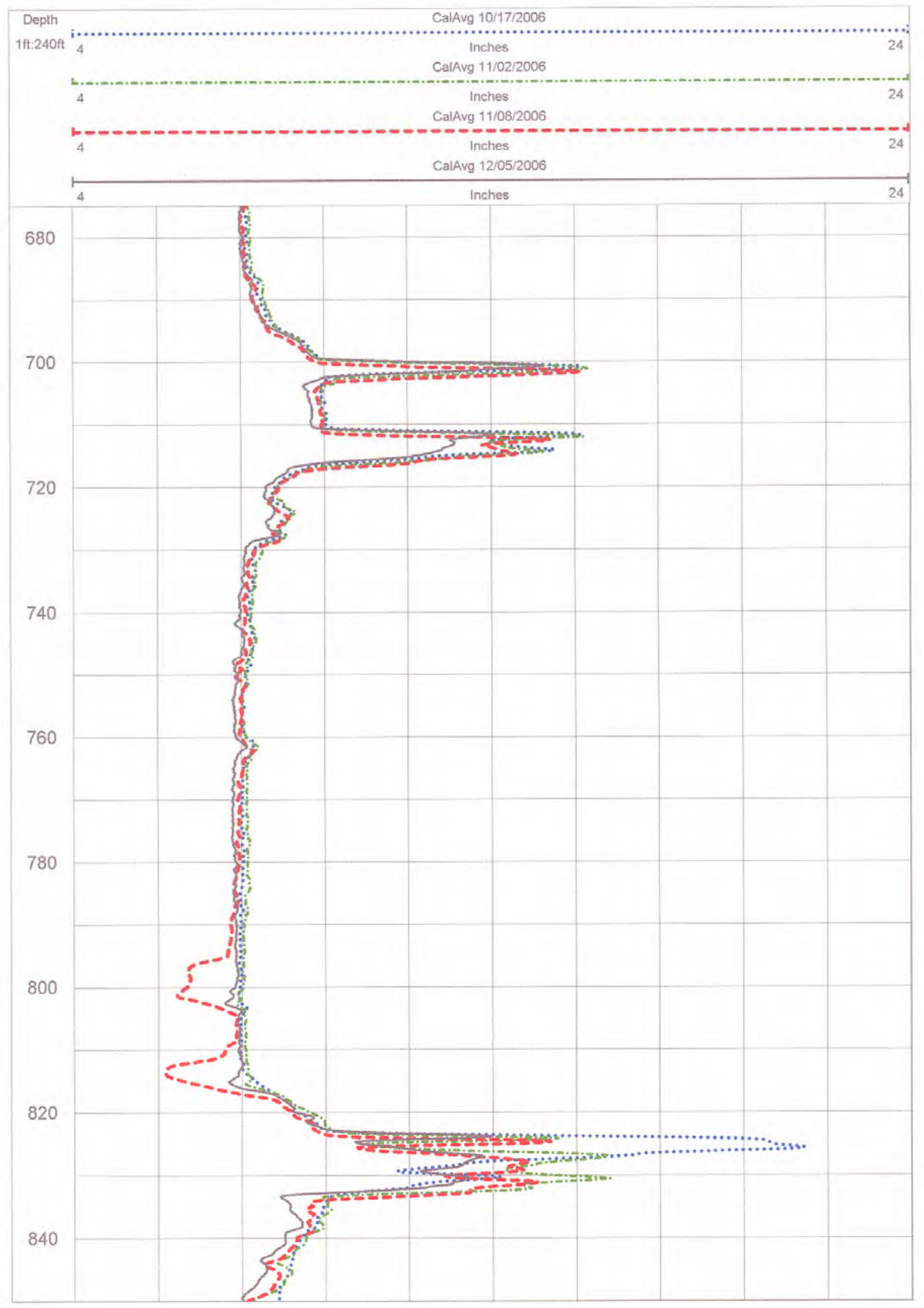

B-64 
DTS-RPT-090, Rev. 0

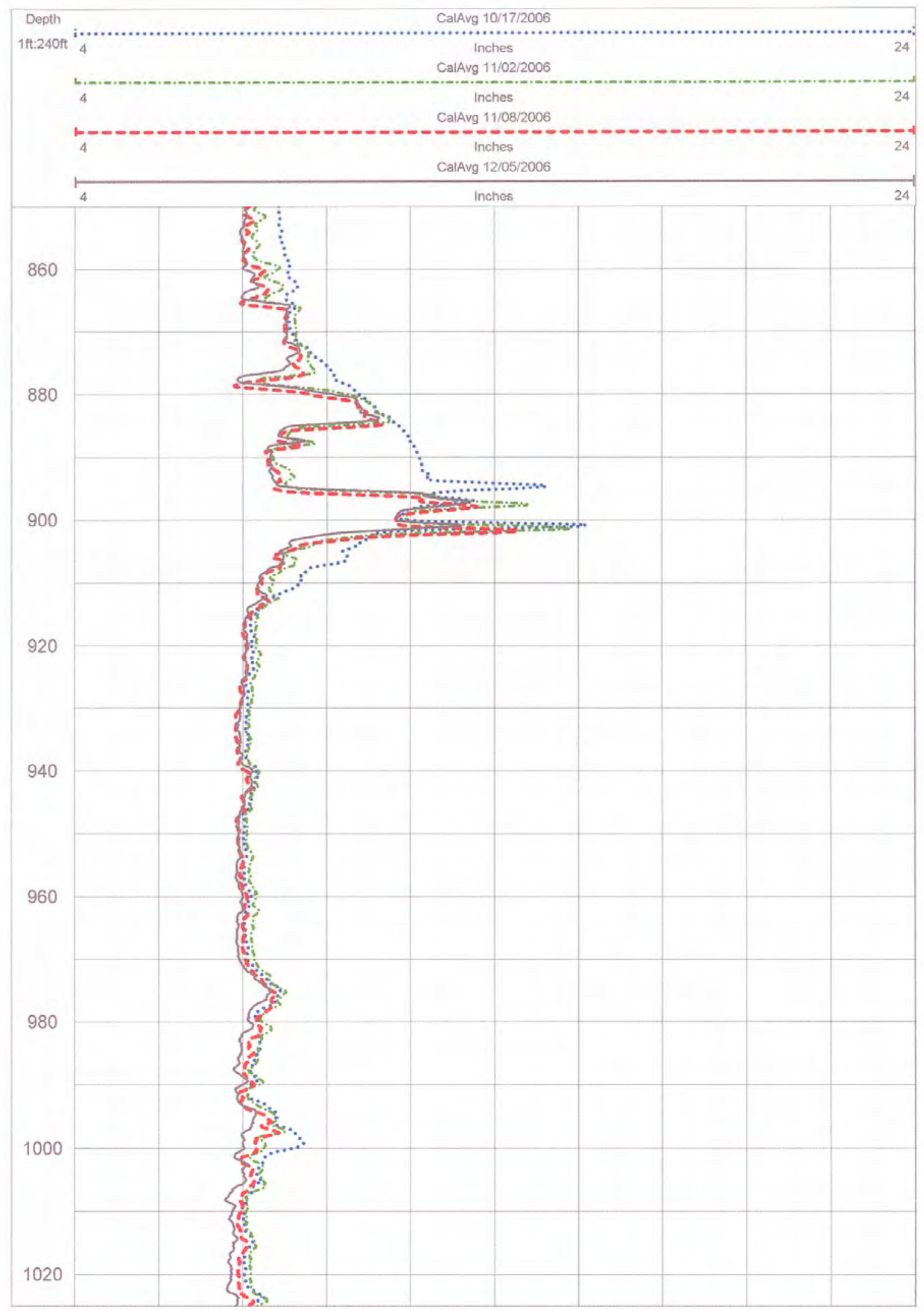


DTS-RPT-090, Rev. 0

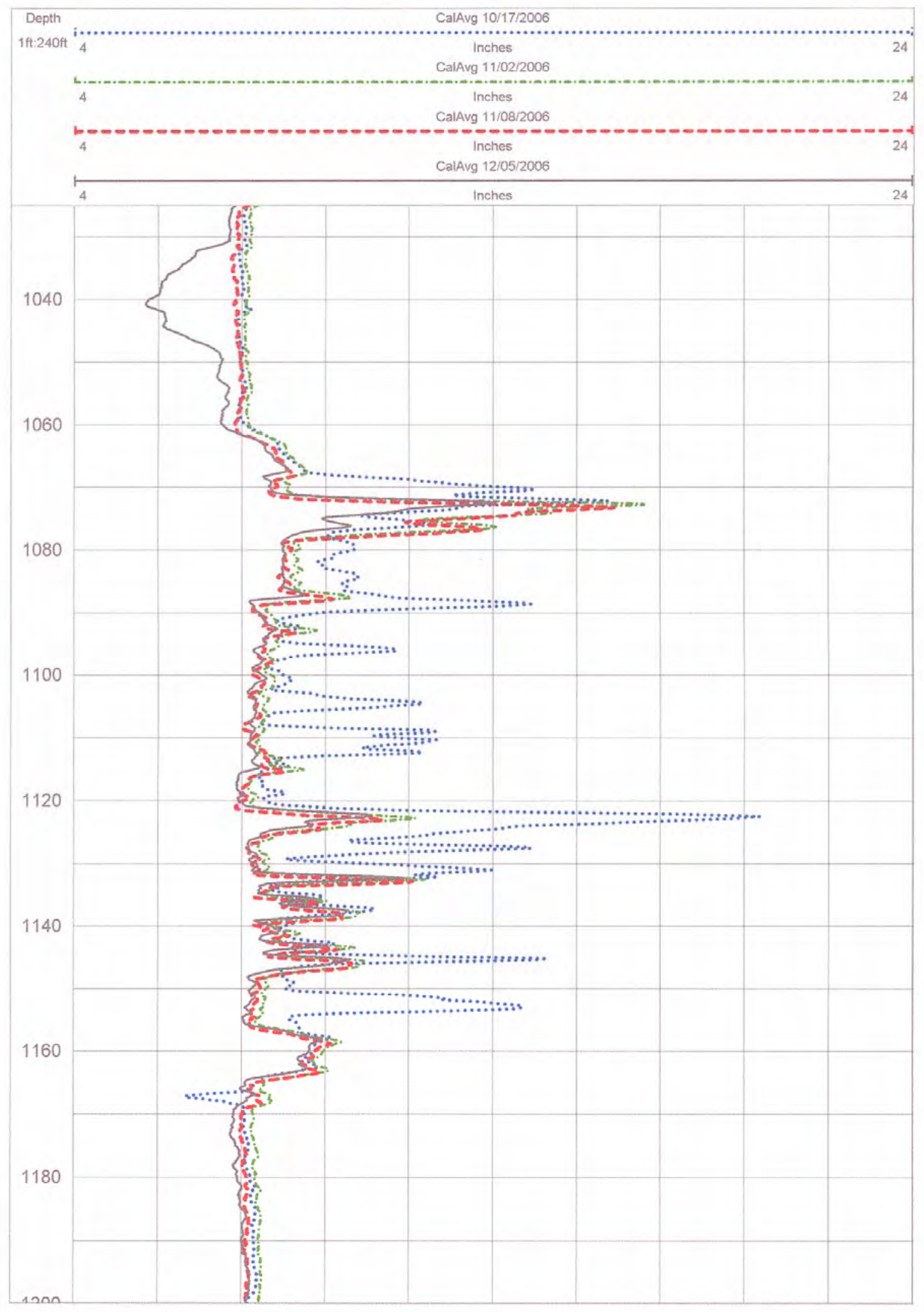


DTS-RPT-090, Rev. 0

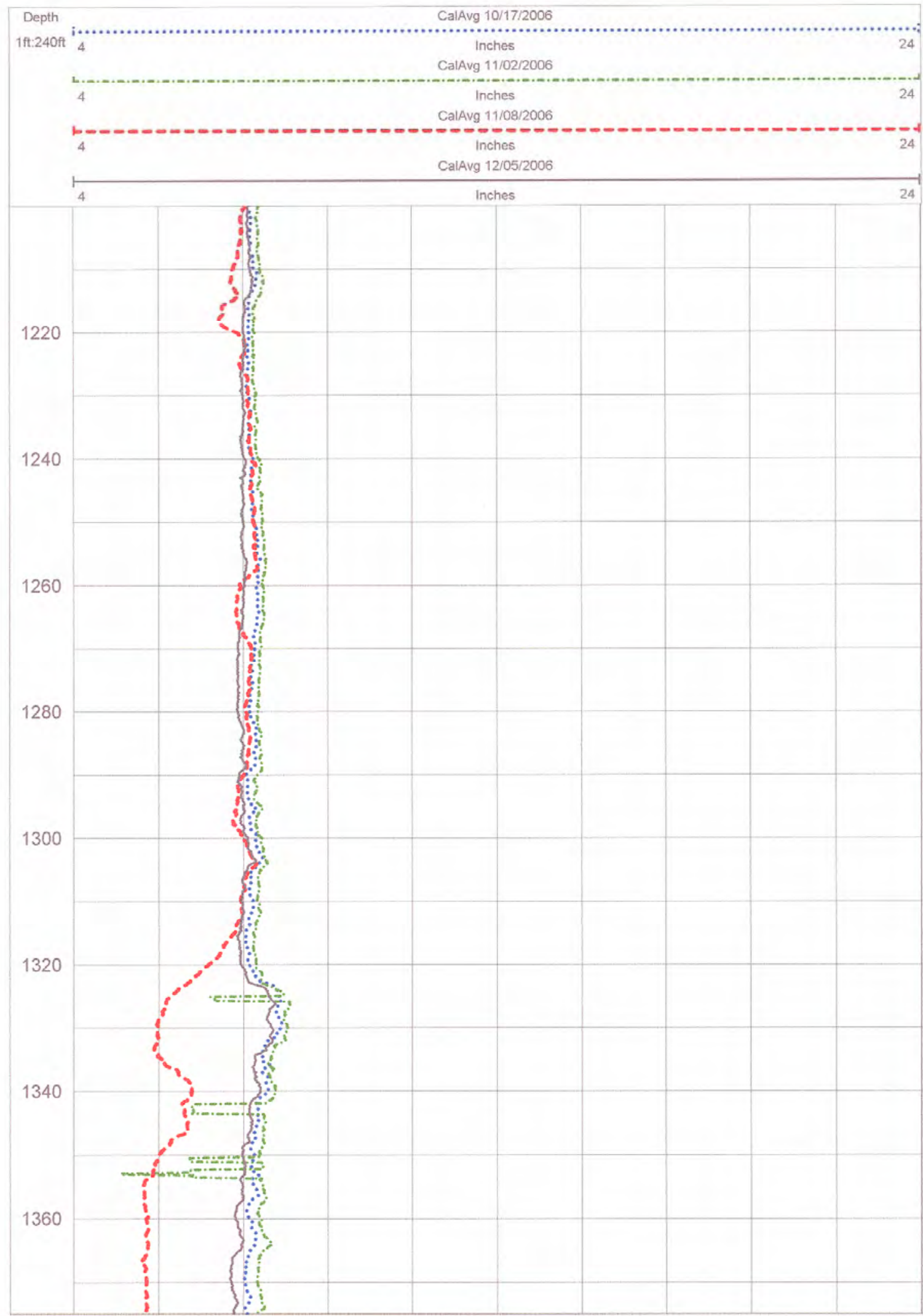


DTS-RPT-090, Rev. 0

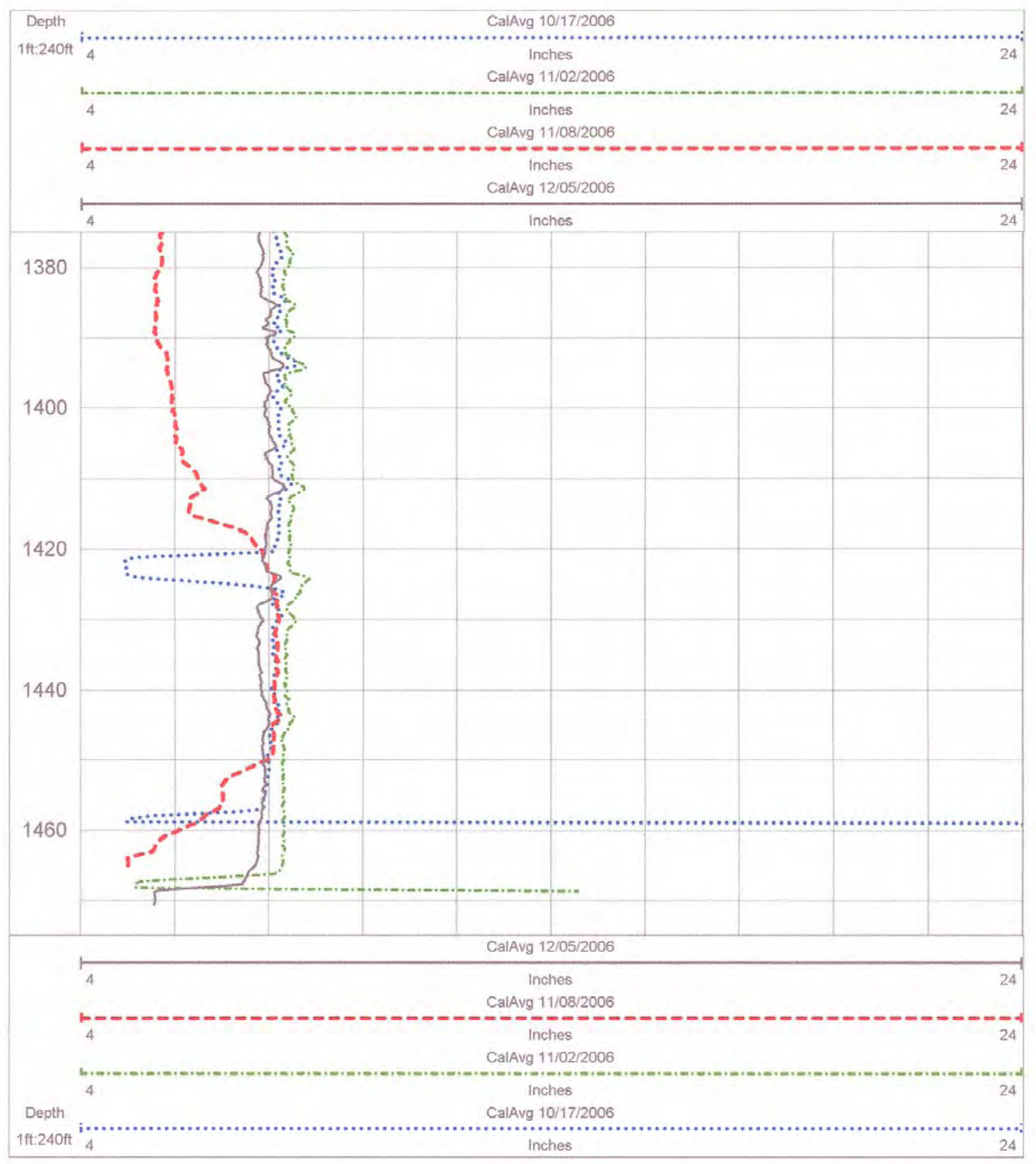


DTS-RPT-090, Rev. 0

\section{B1.3 COLOG ACOUSTIC TELEVIEWER}
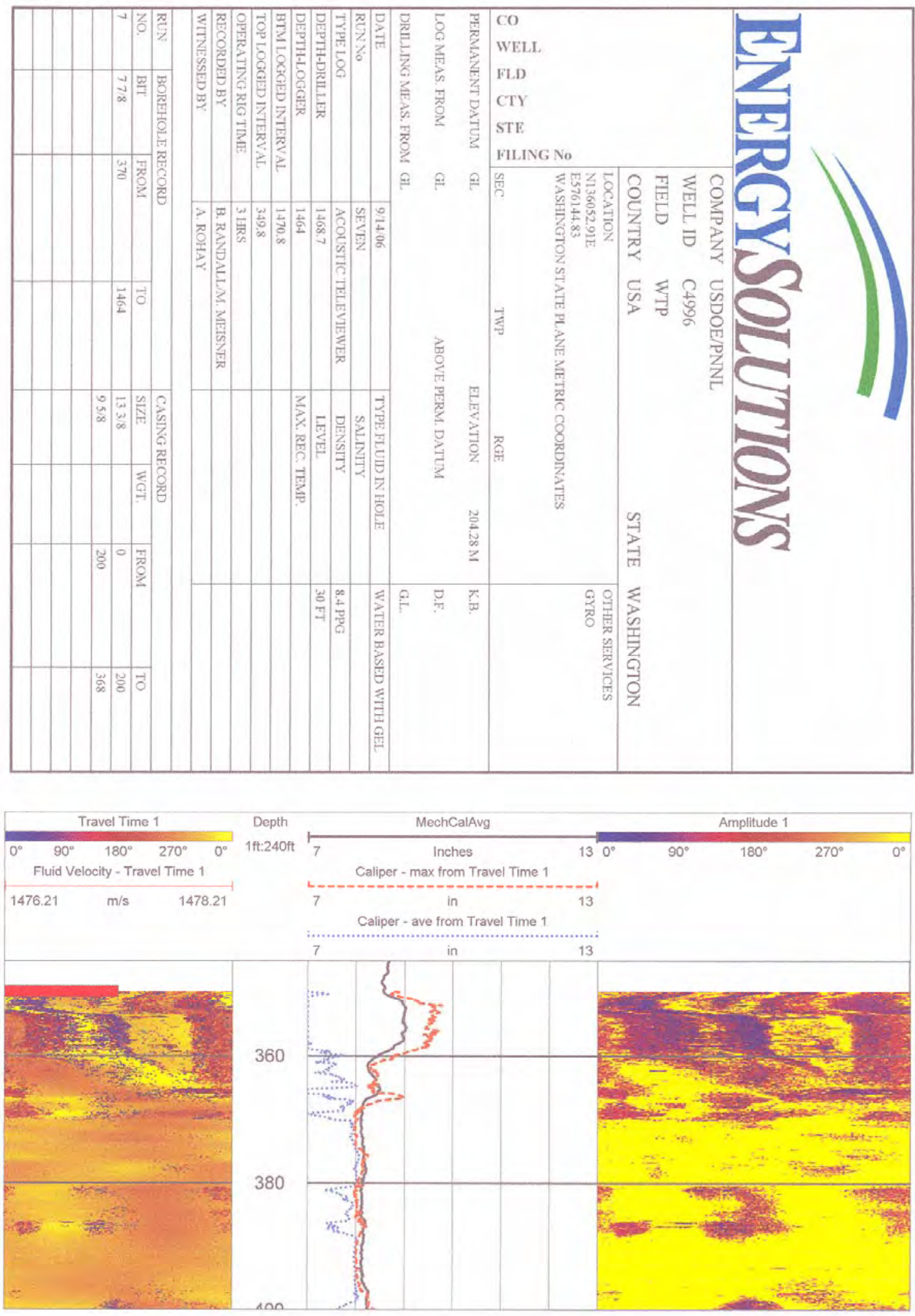
DTS-RPT-090, Rev. 0

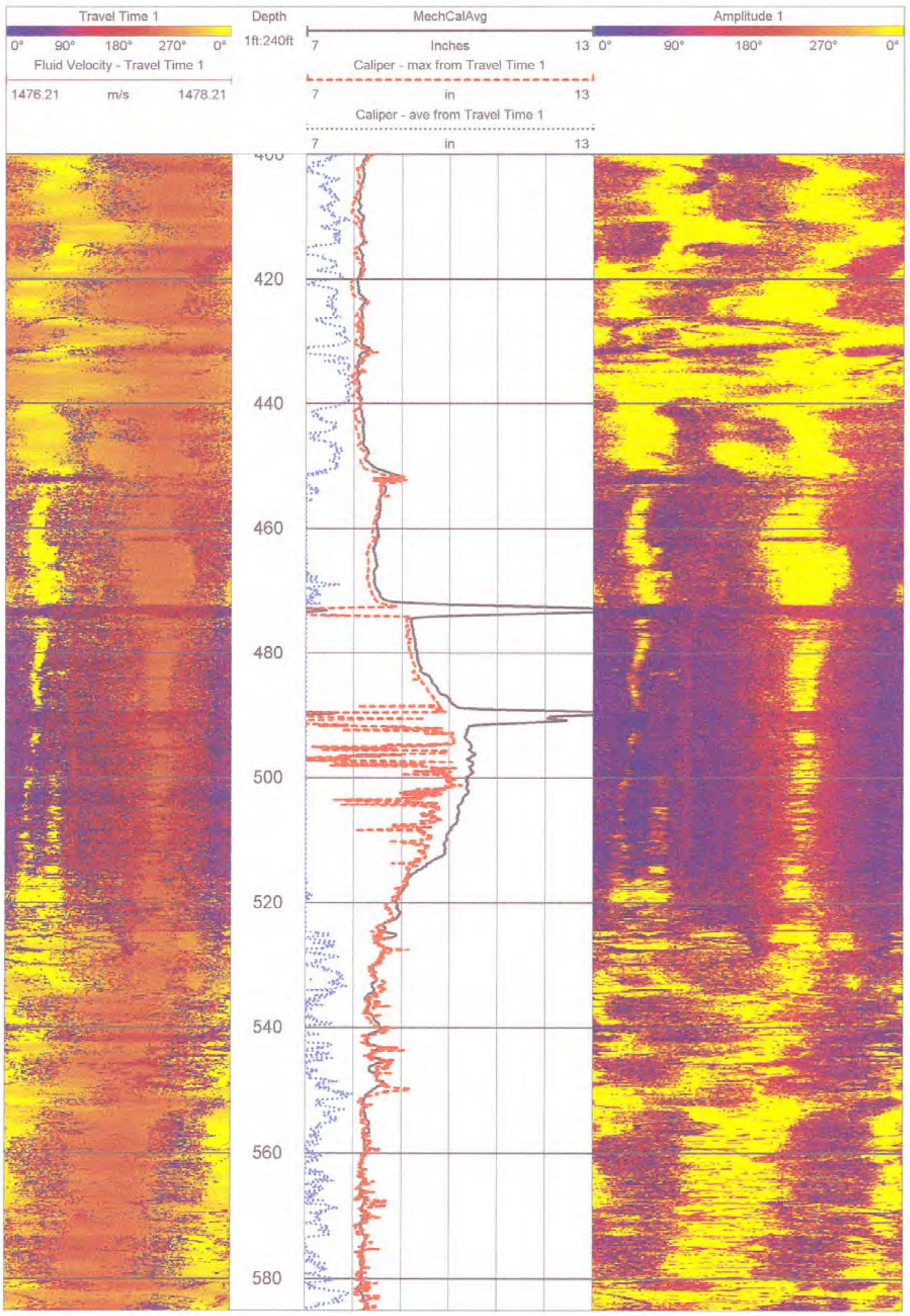


DTS-RPT-090, Rev. 0

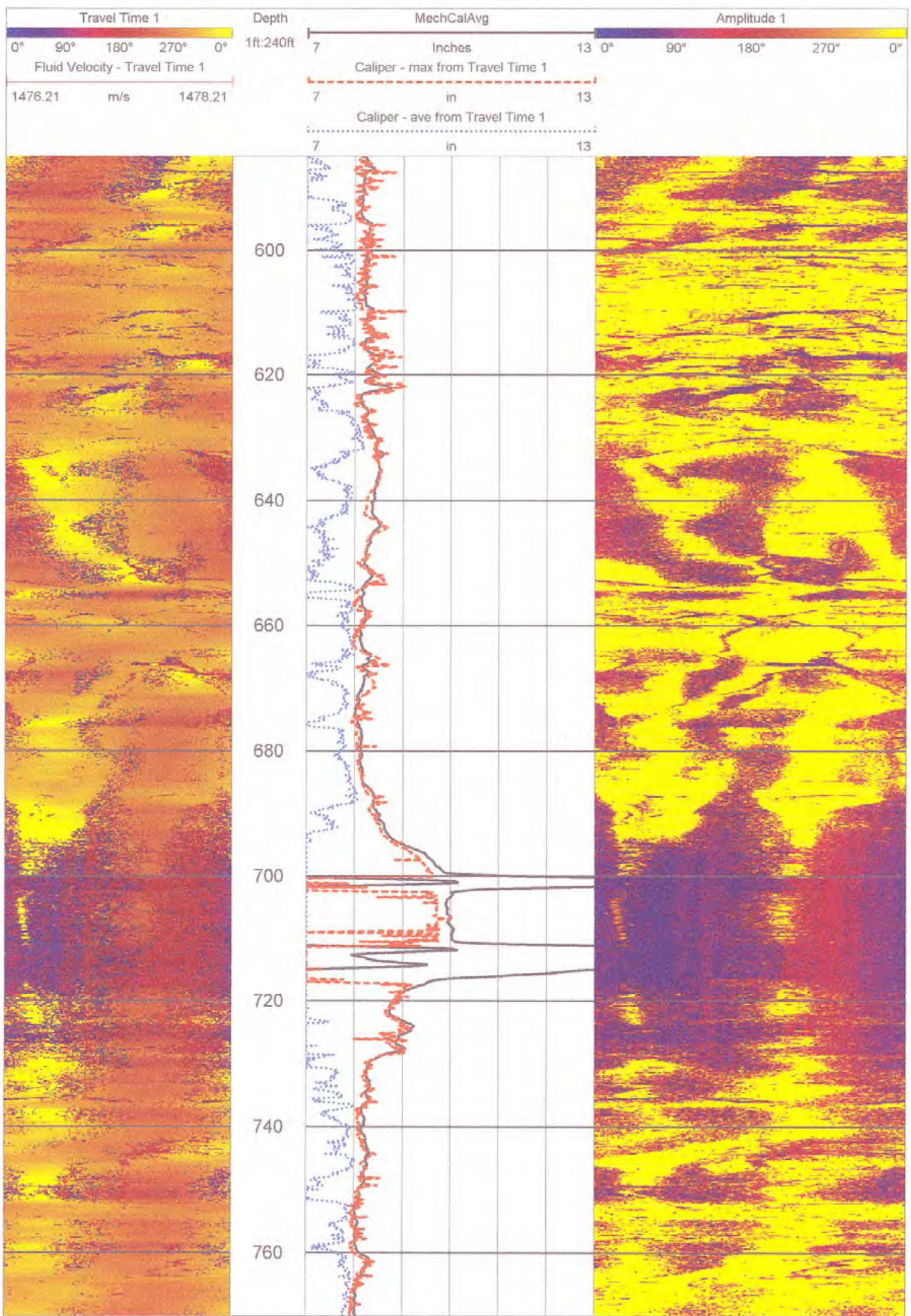


DTS-RPT-090, Rev. 0

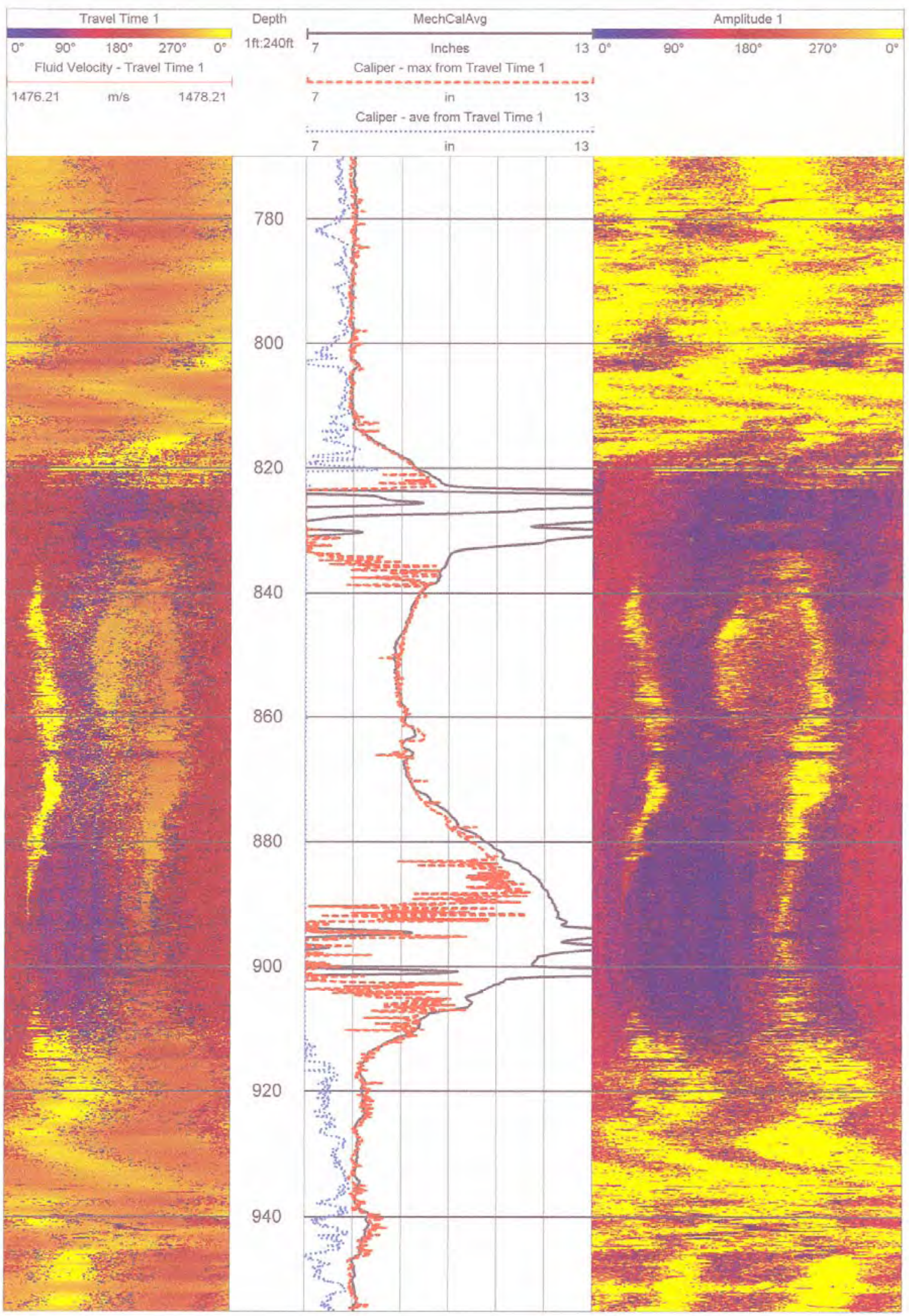


DTS-RPT-090, Rev. 0

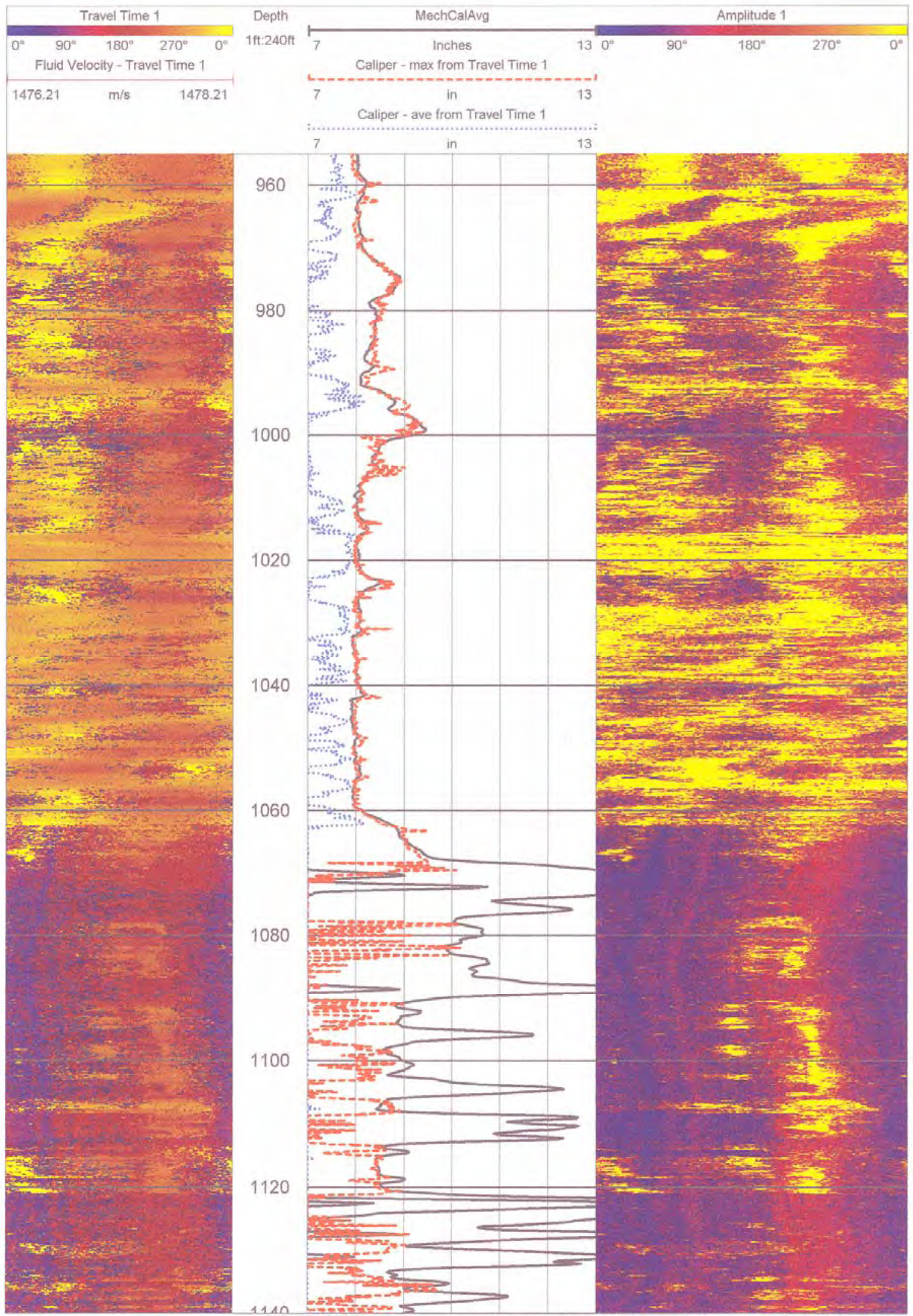


DTS-RPT-090, Rev. 0
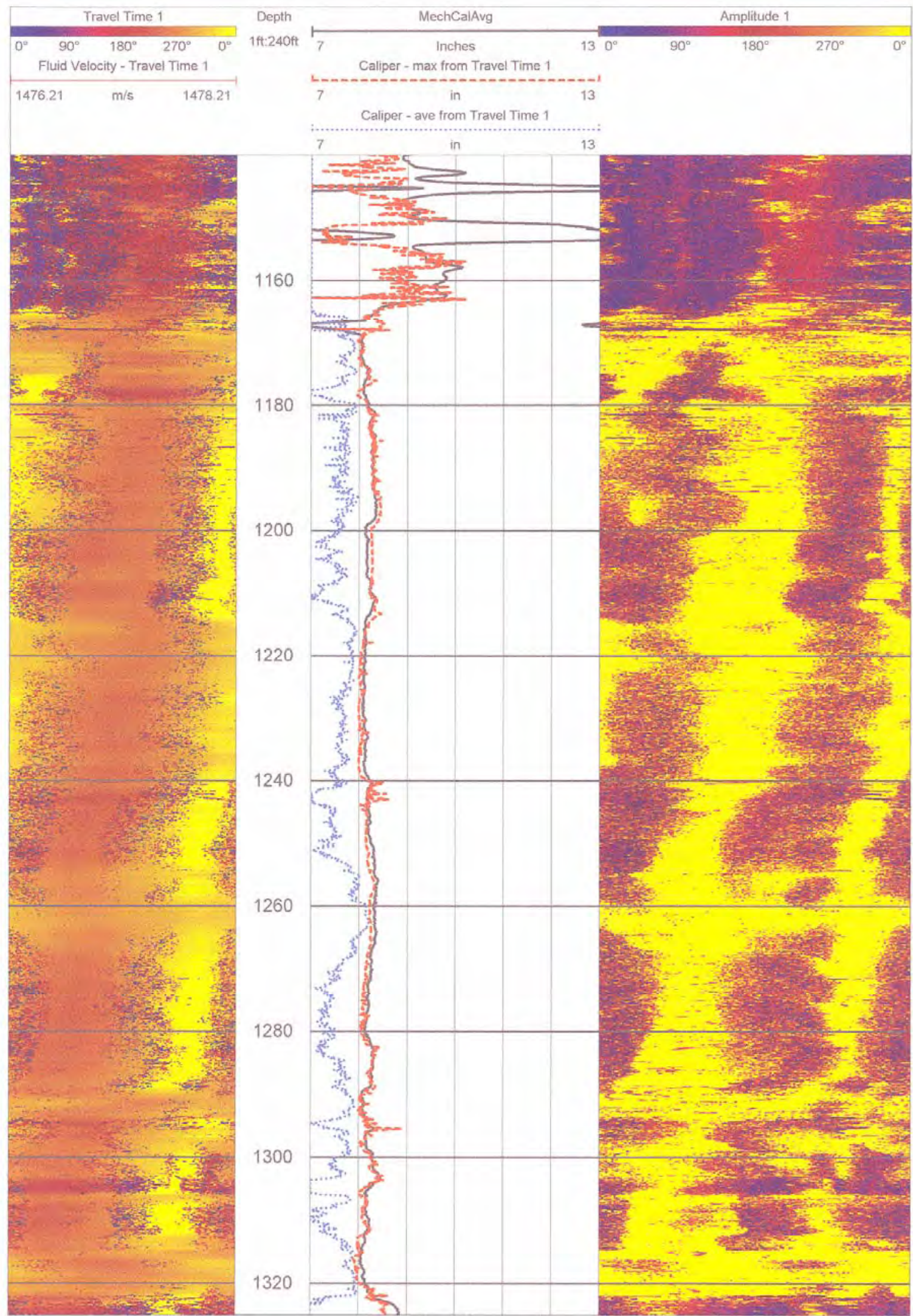
DTS-RPT-090, Rev. 0

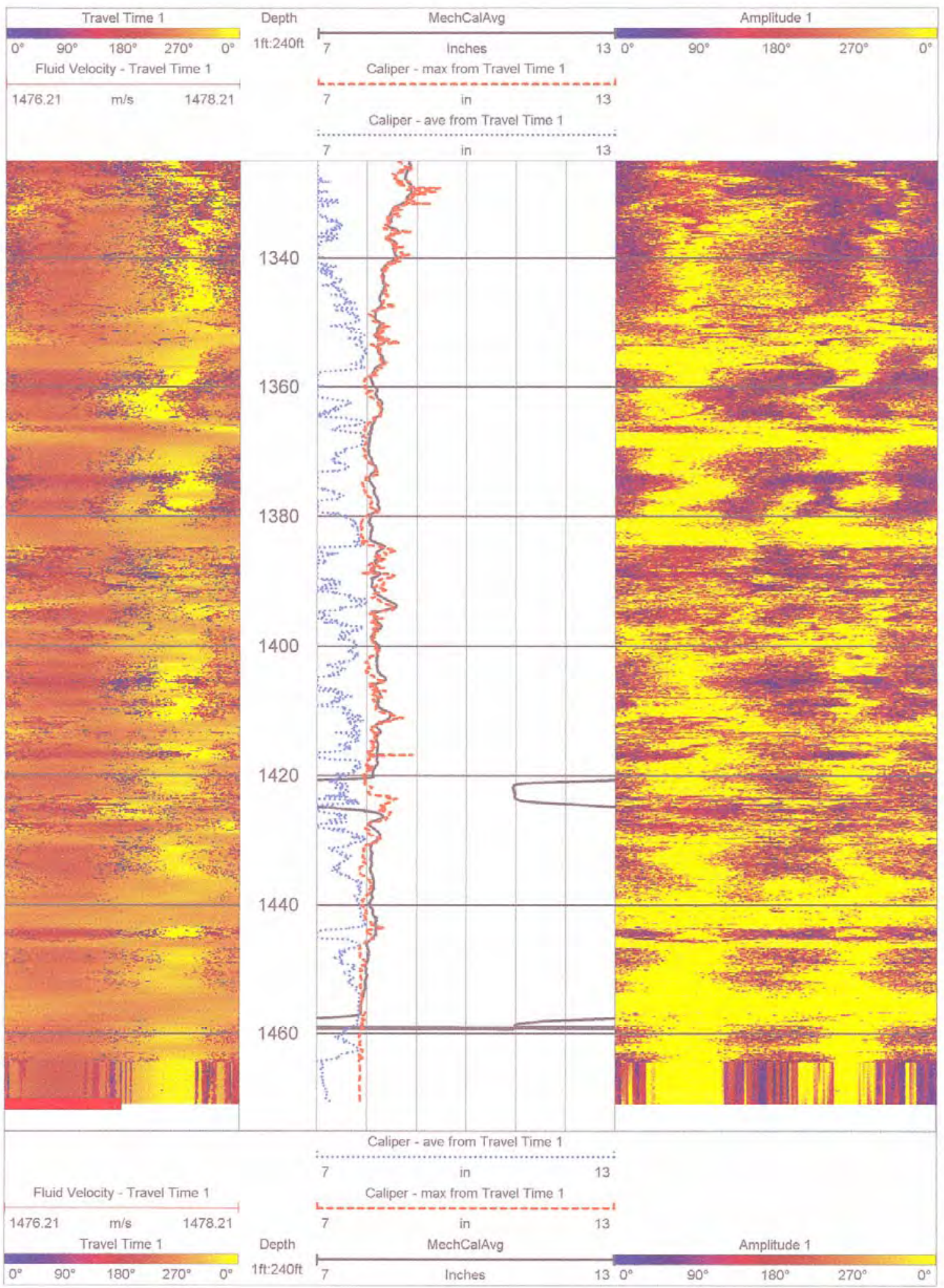


DTS-RPT-090, Rev. 0

\section{B1.4 COLOG MERGED LOG}

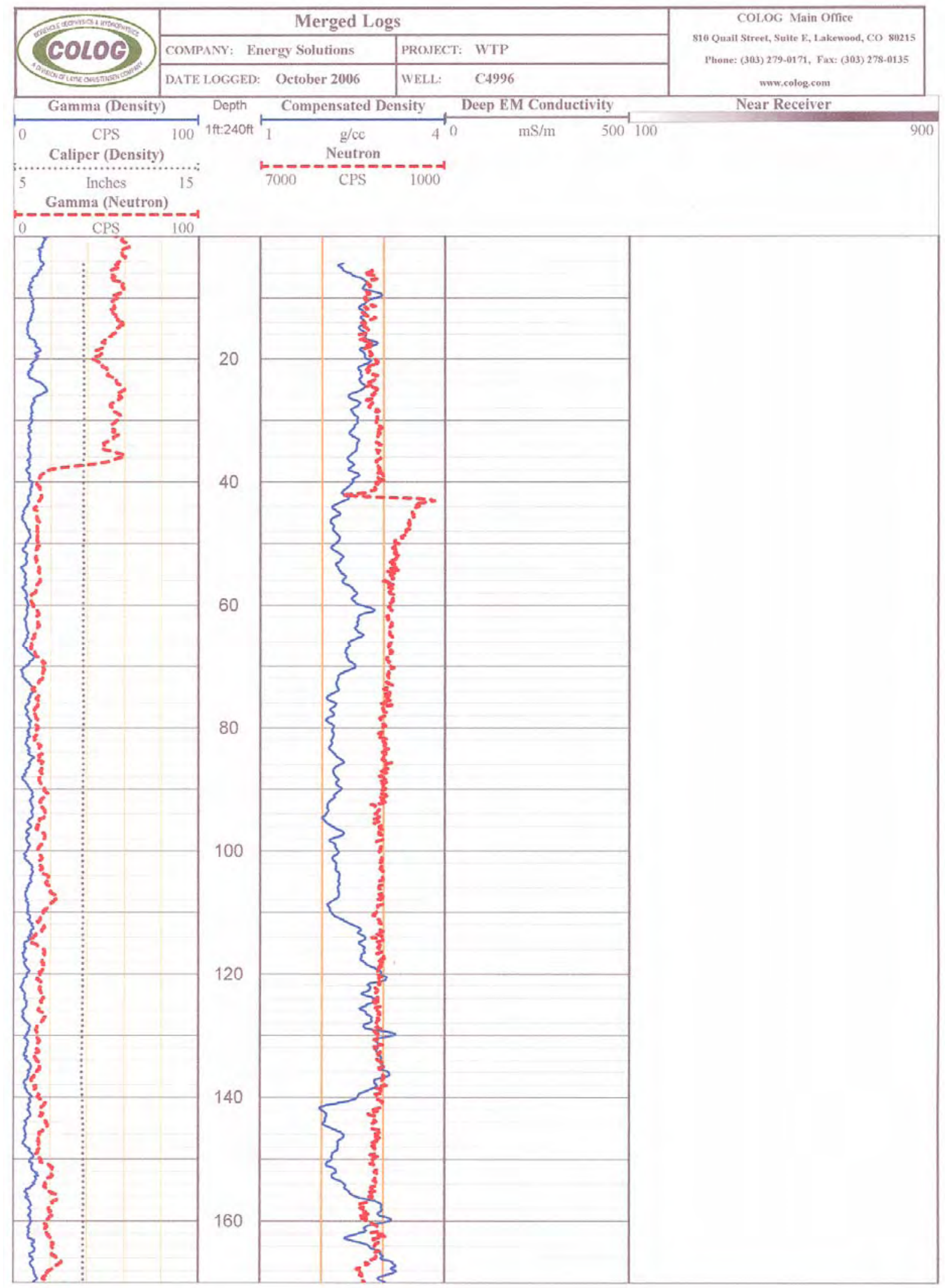


DTS-RPT-090, Rev. 0

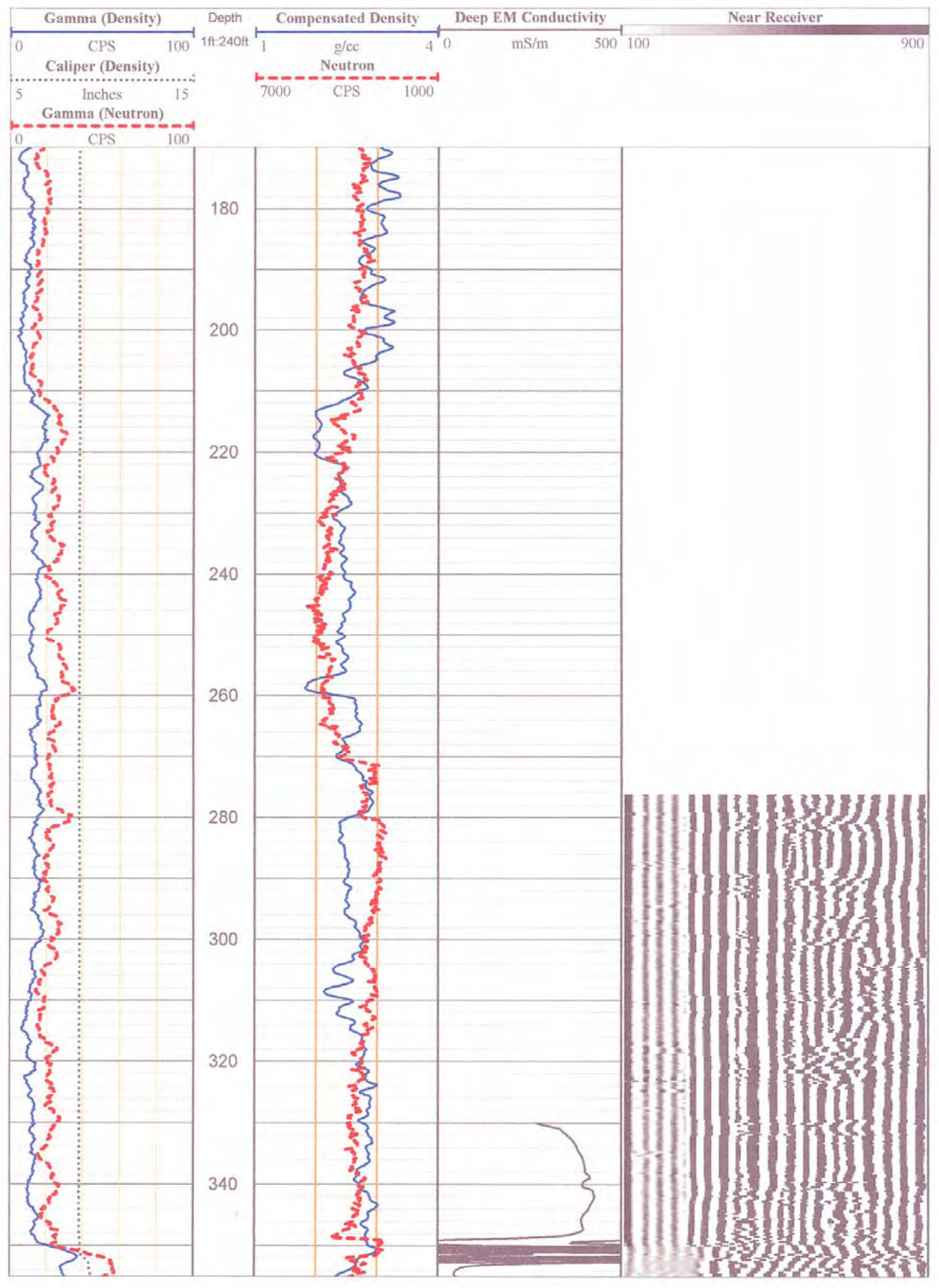


DTS-RPT-090, Rev. 0

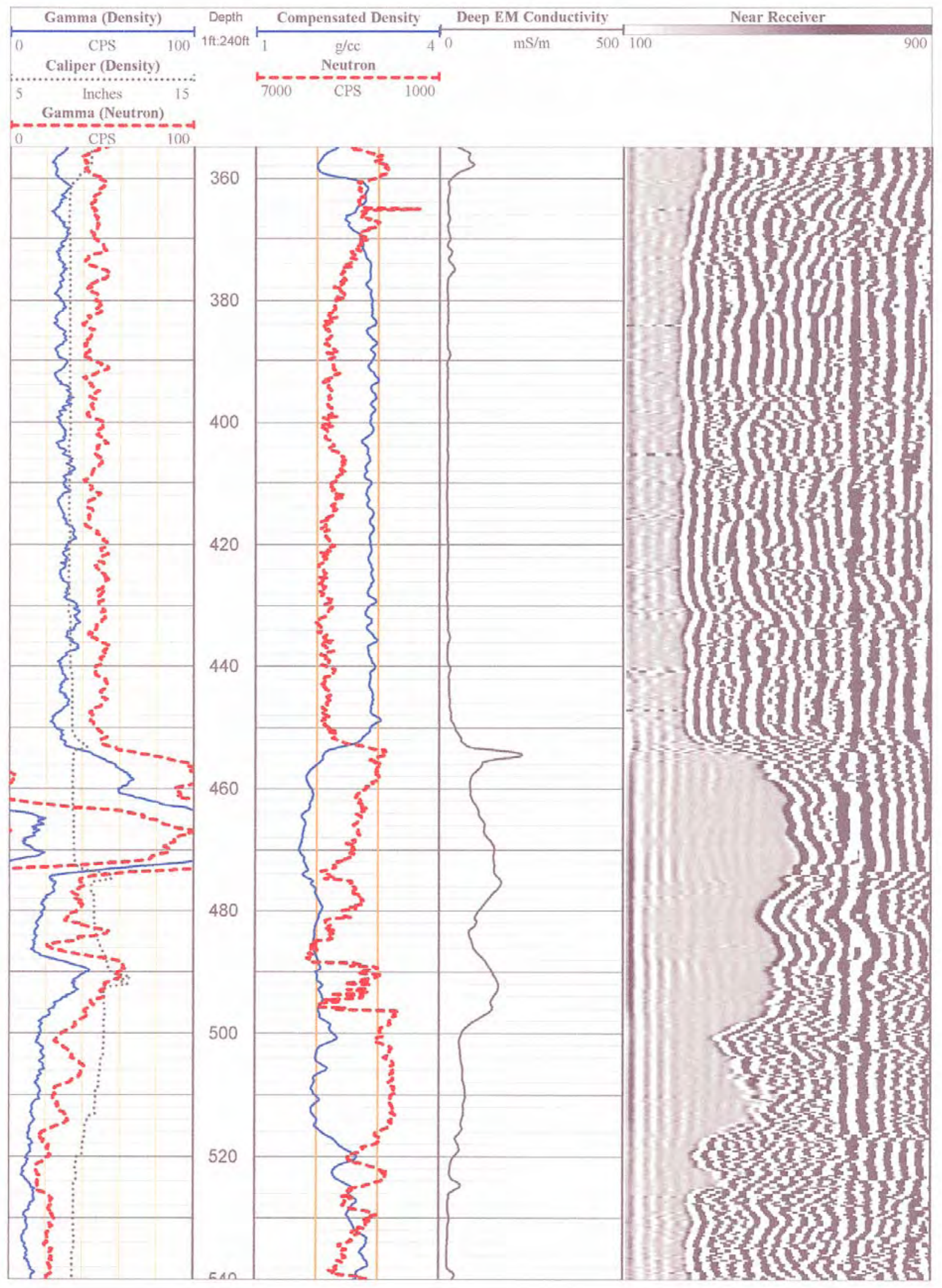


DTS-RPT-090, Rev. 0

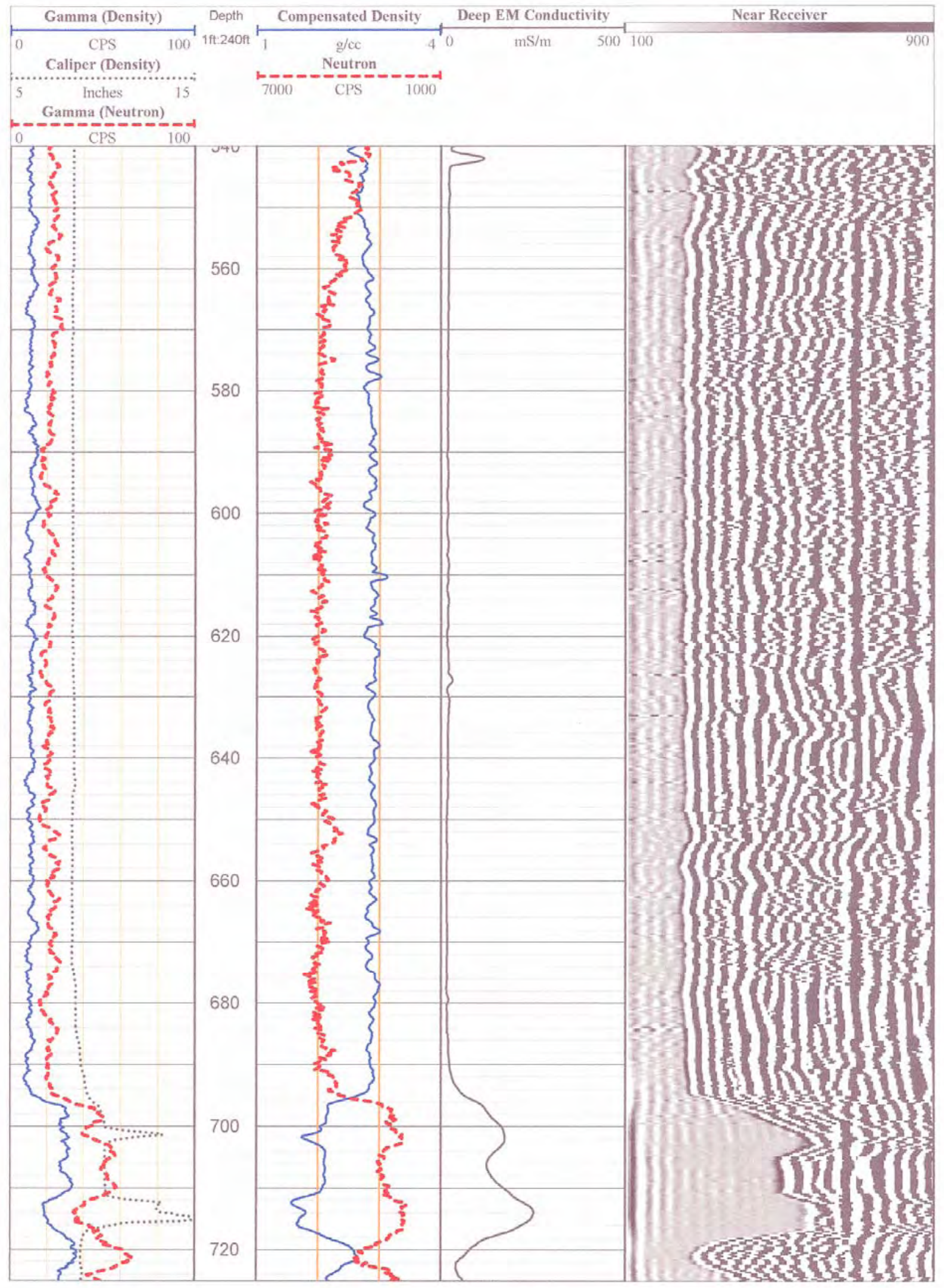


DTS-RPT-090, Rev. 0

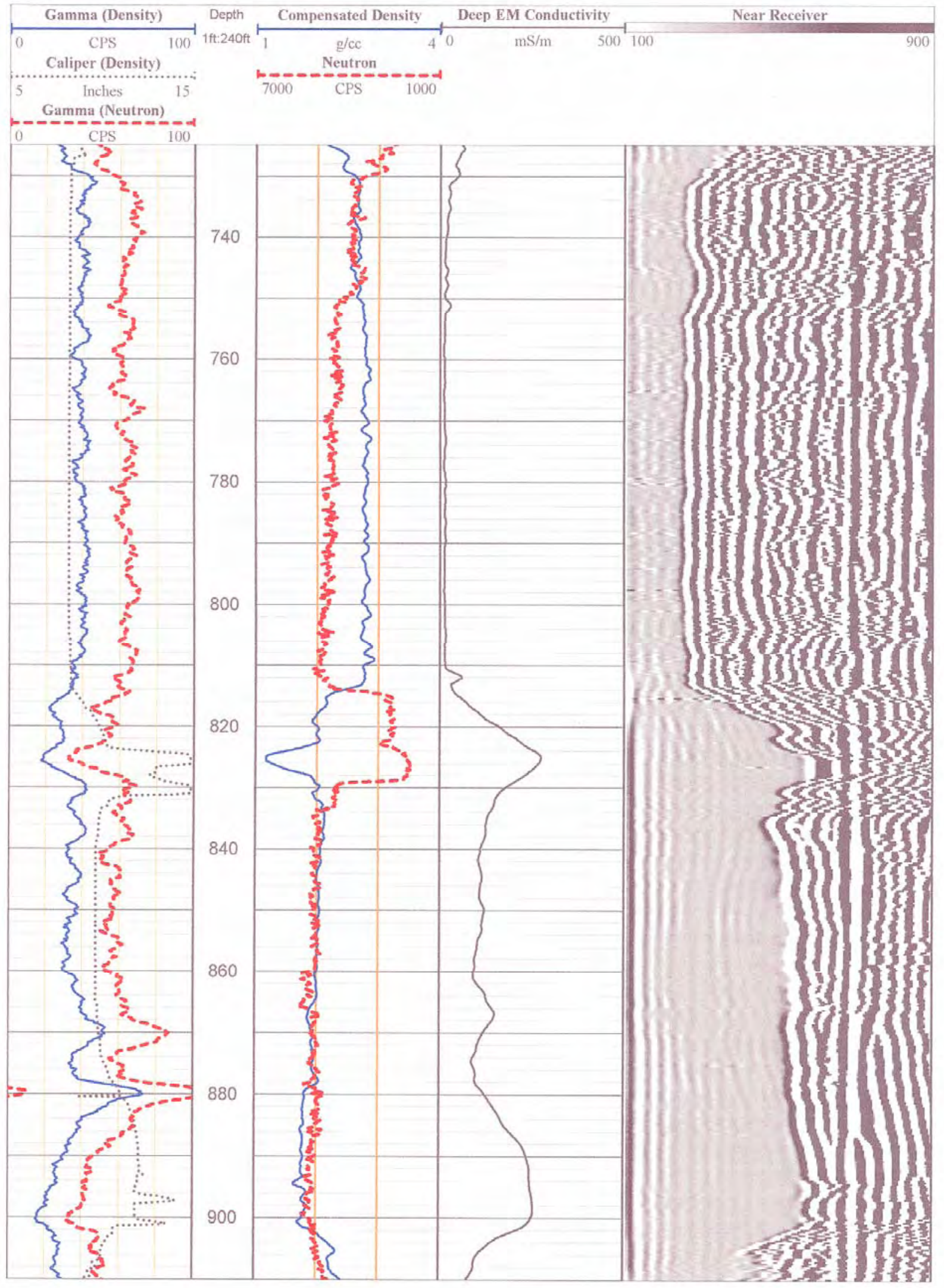




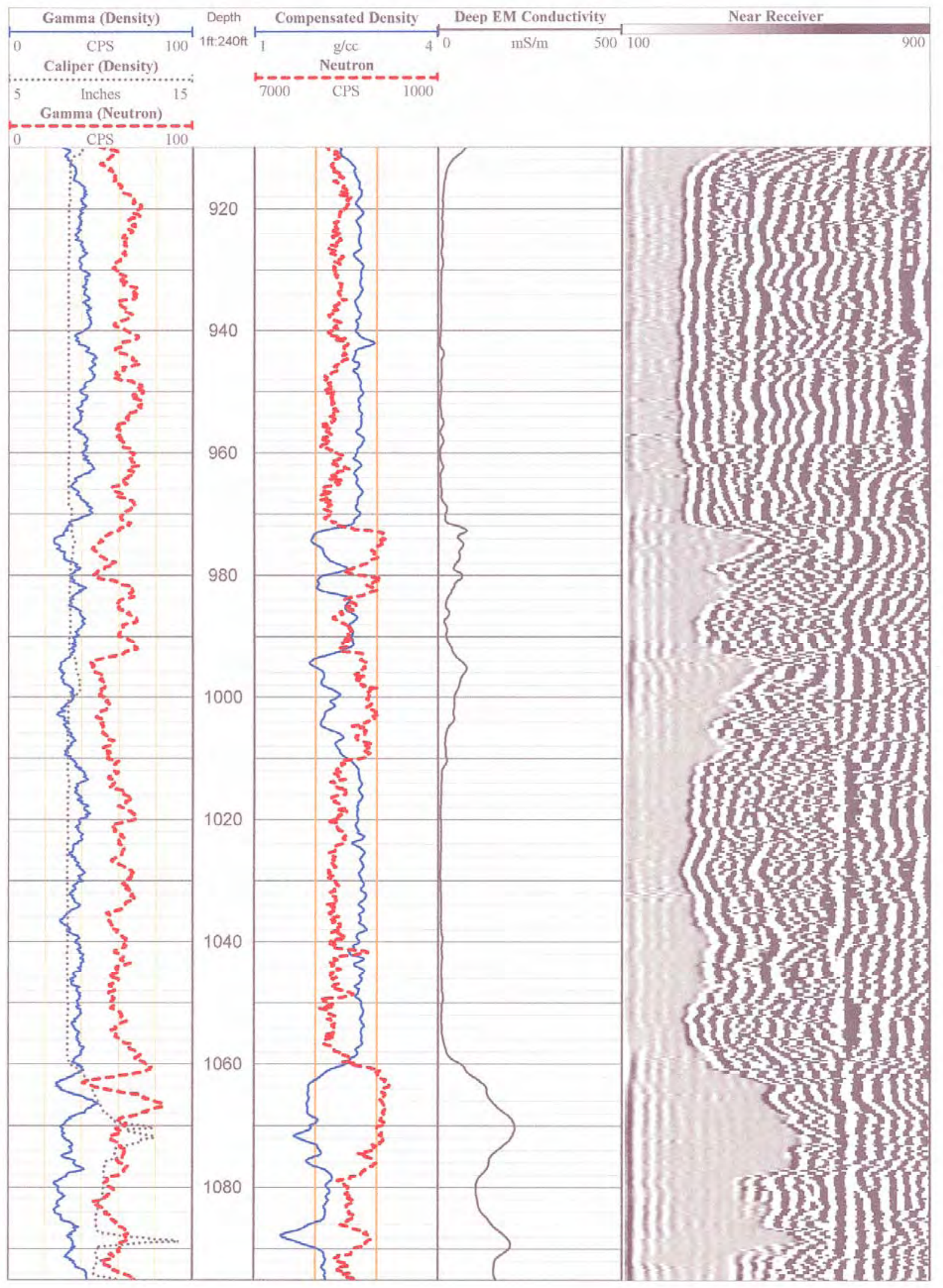


DTS-RPT-090, Rev. 0

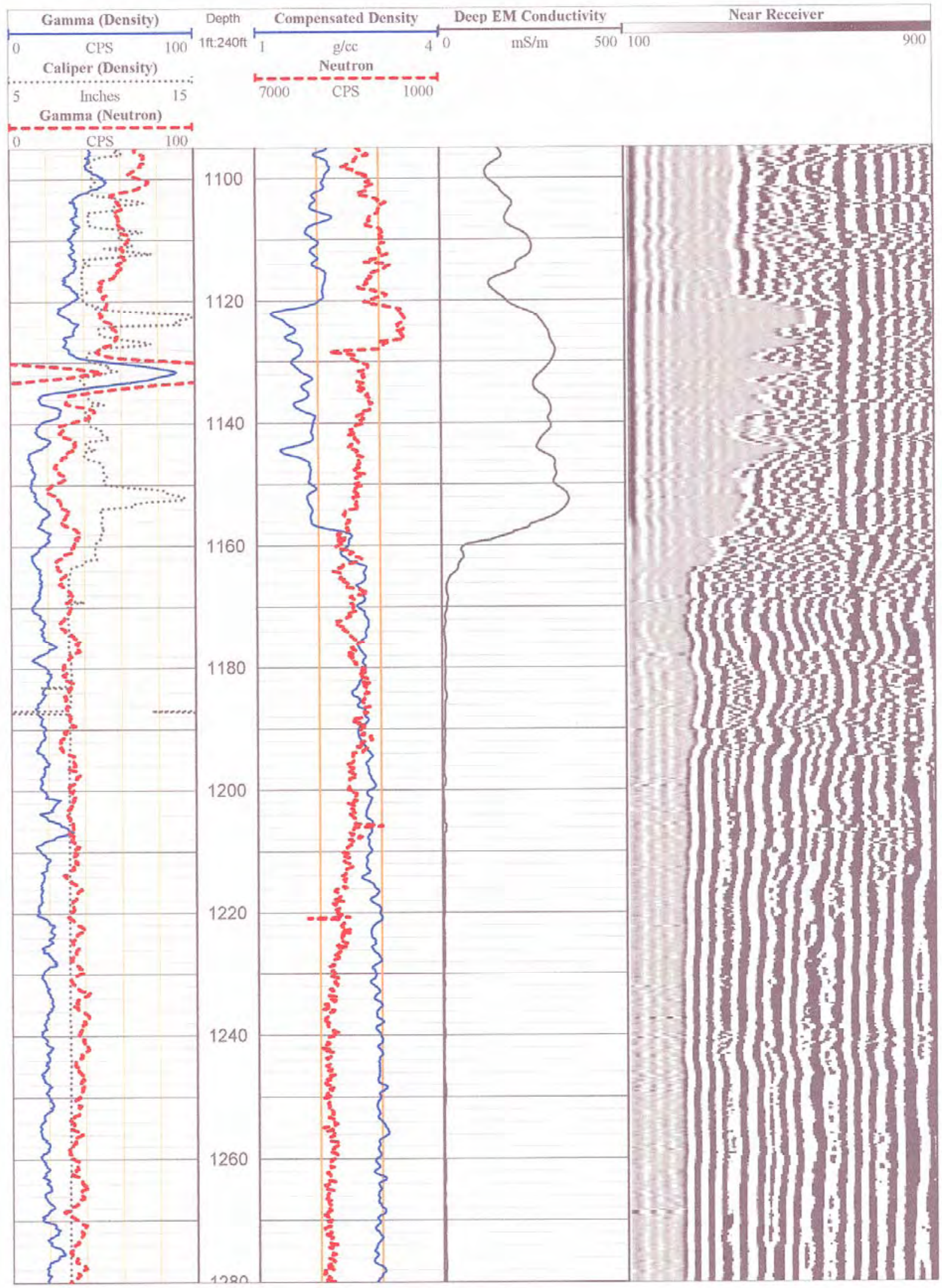


DTS-RPT-090, Rev. 0

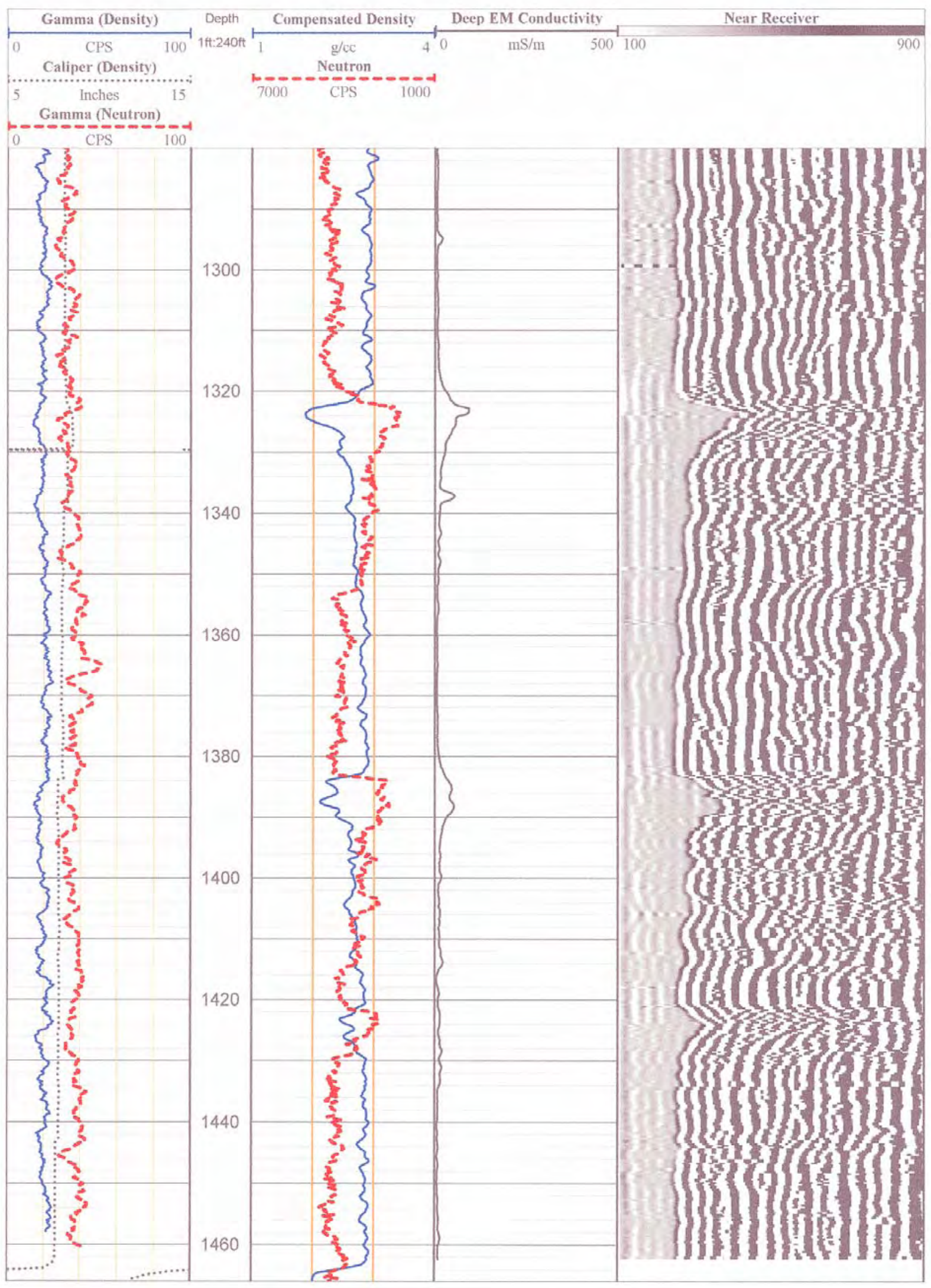


DTS-RPT-090, Rev. 0

\section{B1.5 COLOG COMPENSATED DENSITY LOG}

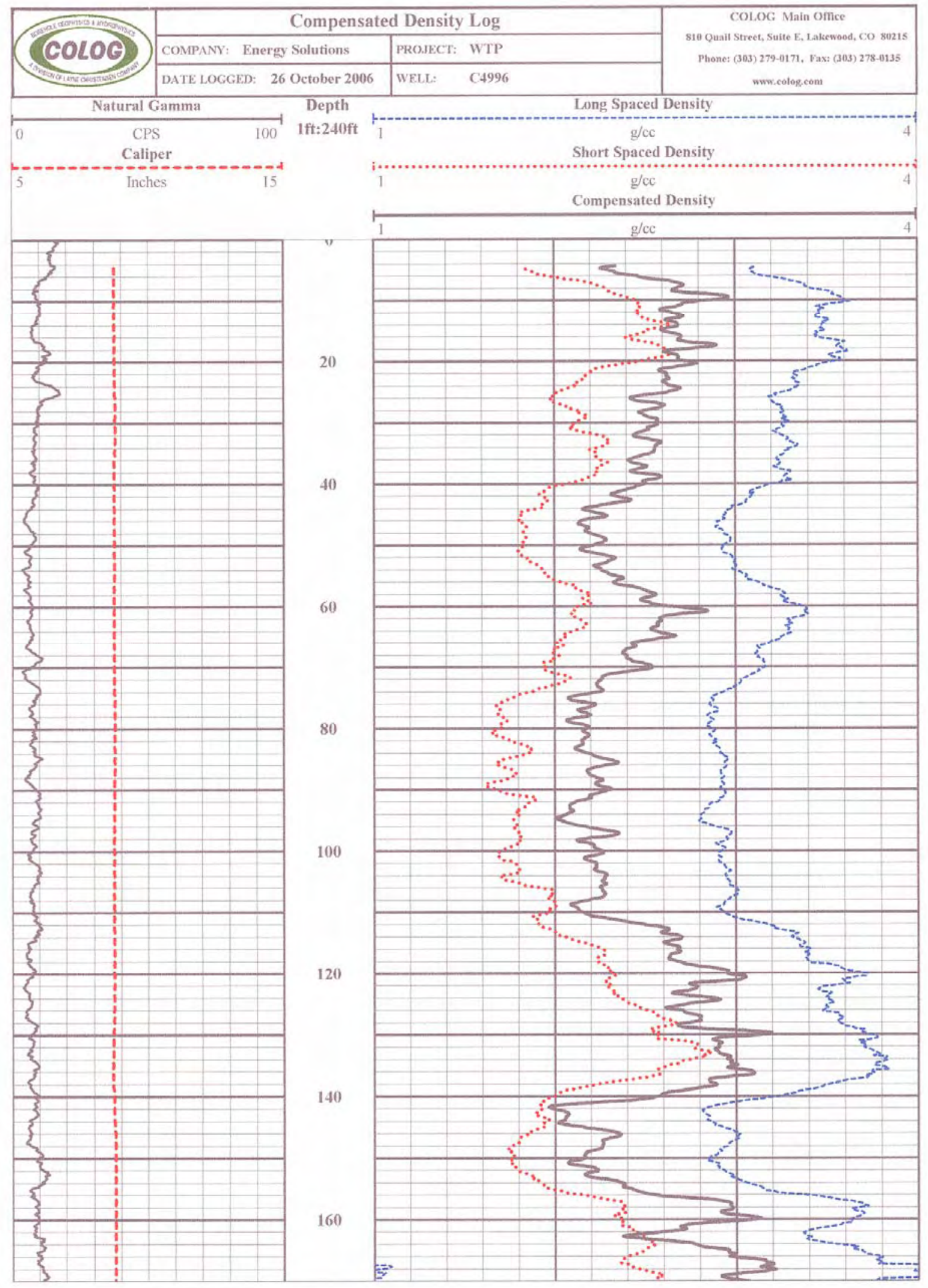


DTS-RPT-090, Rev. 0

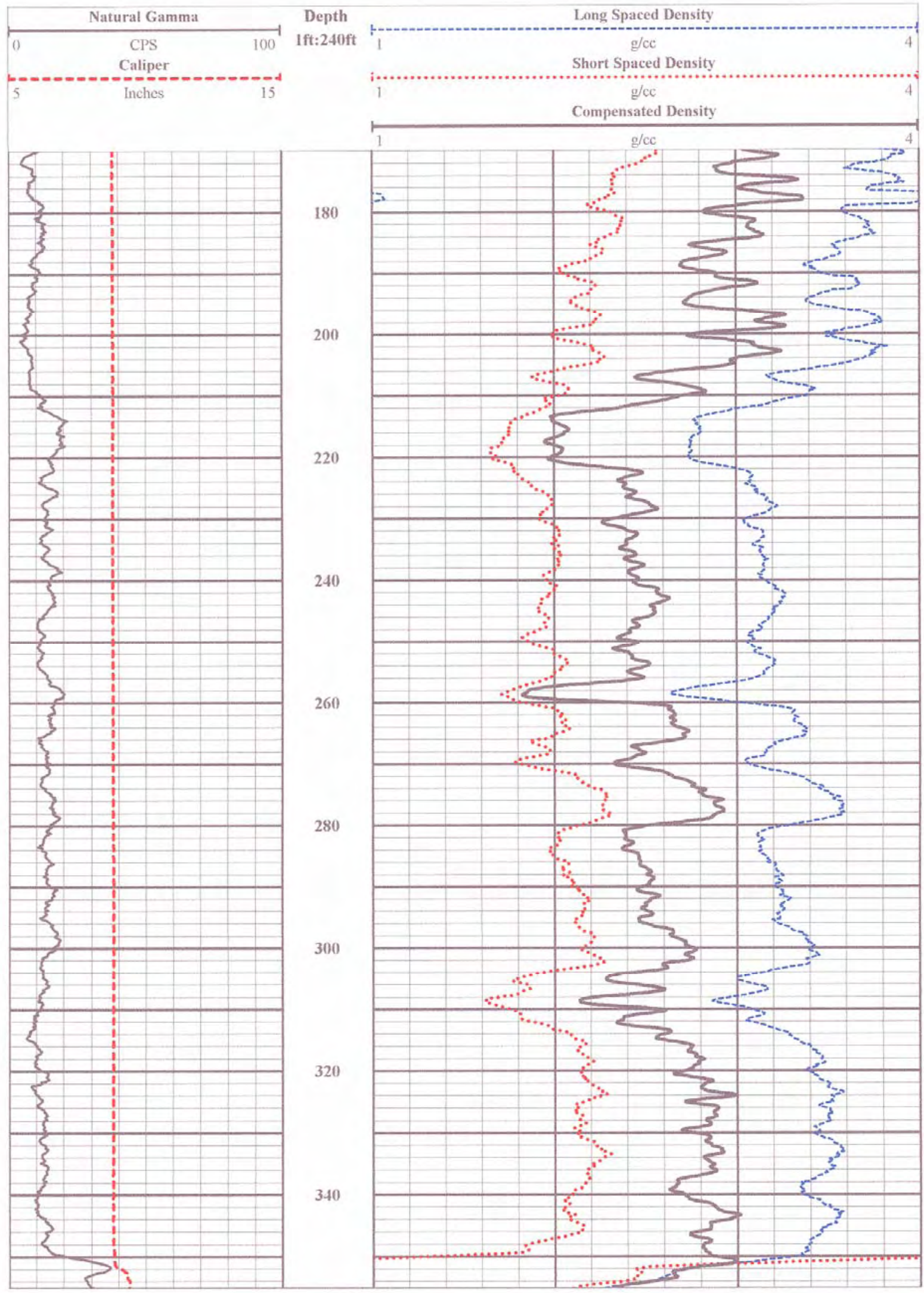


DTS-RPT-090, Rev. 0

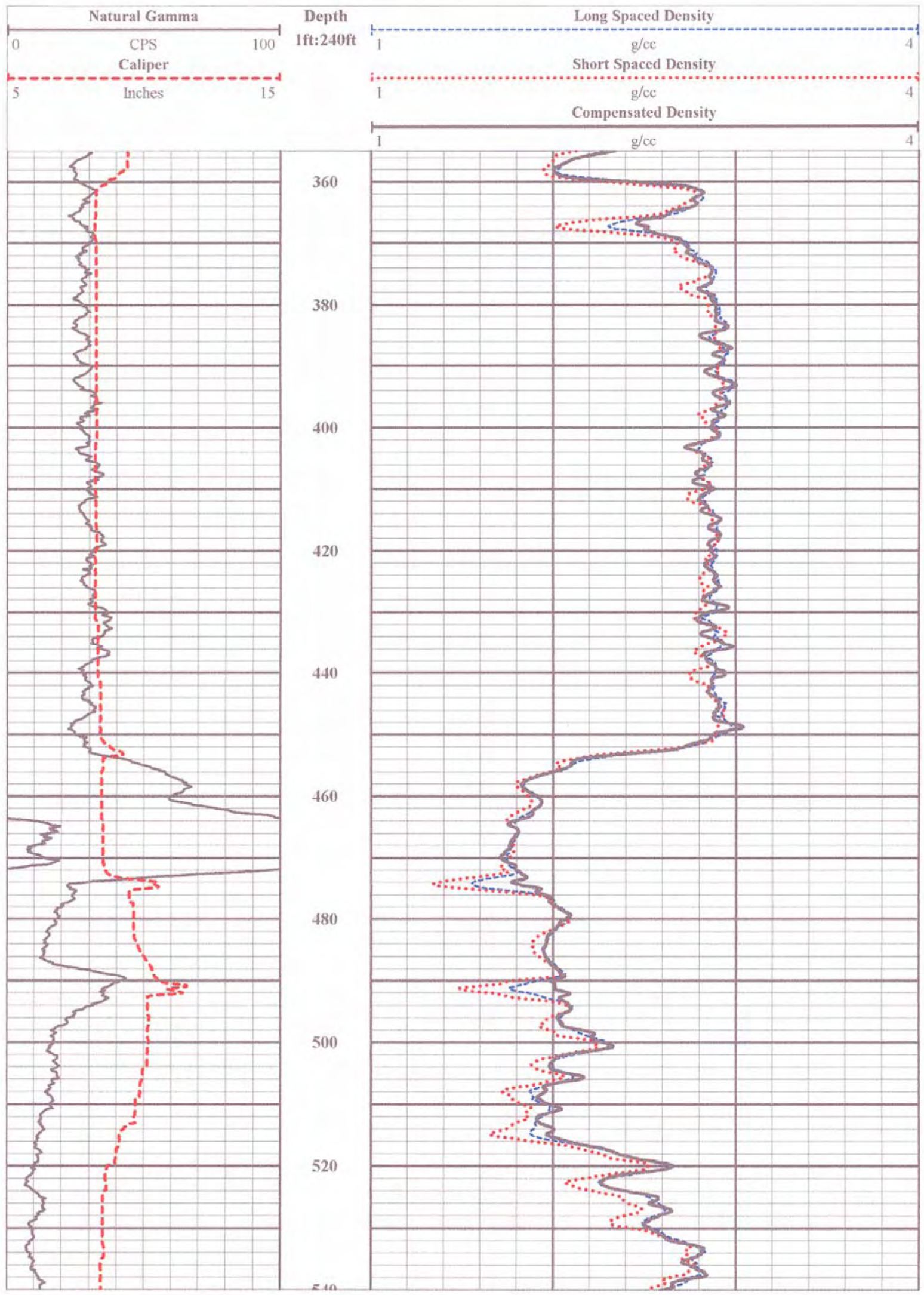


DTS-RPT-090, Rev. 0

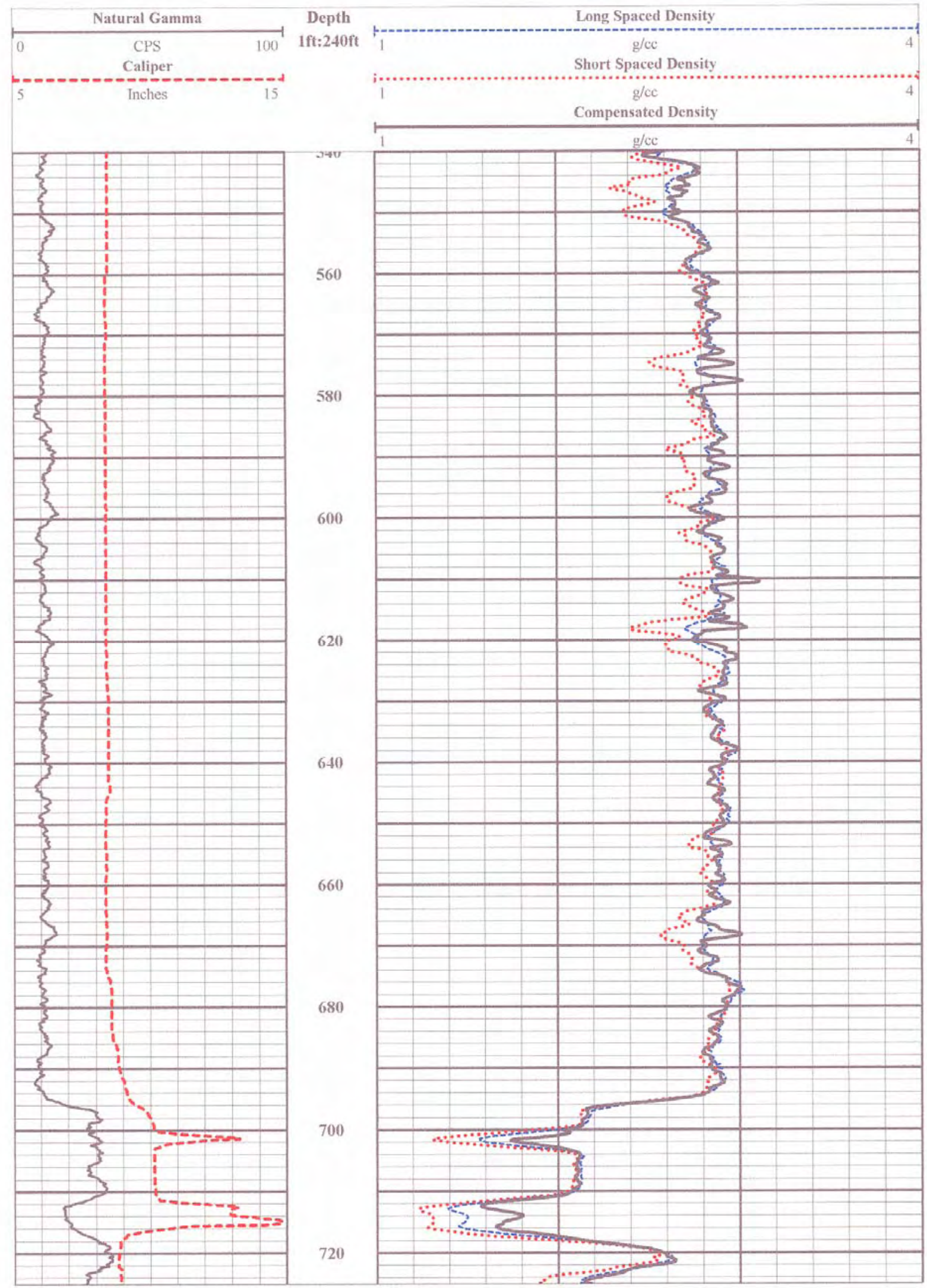


DTS-RPT-090, Rev. 0

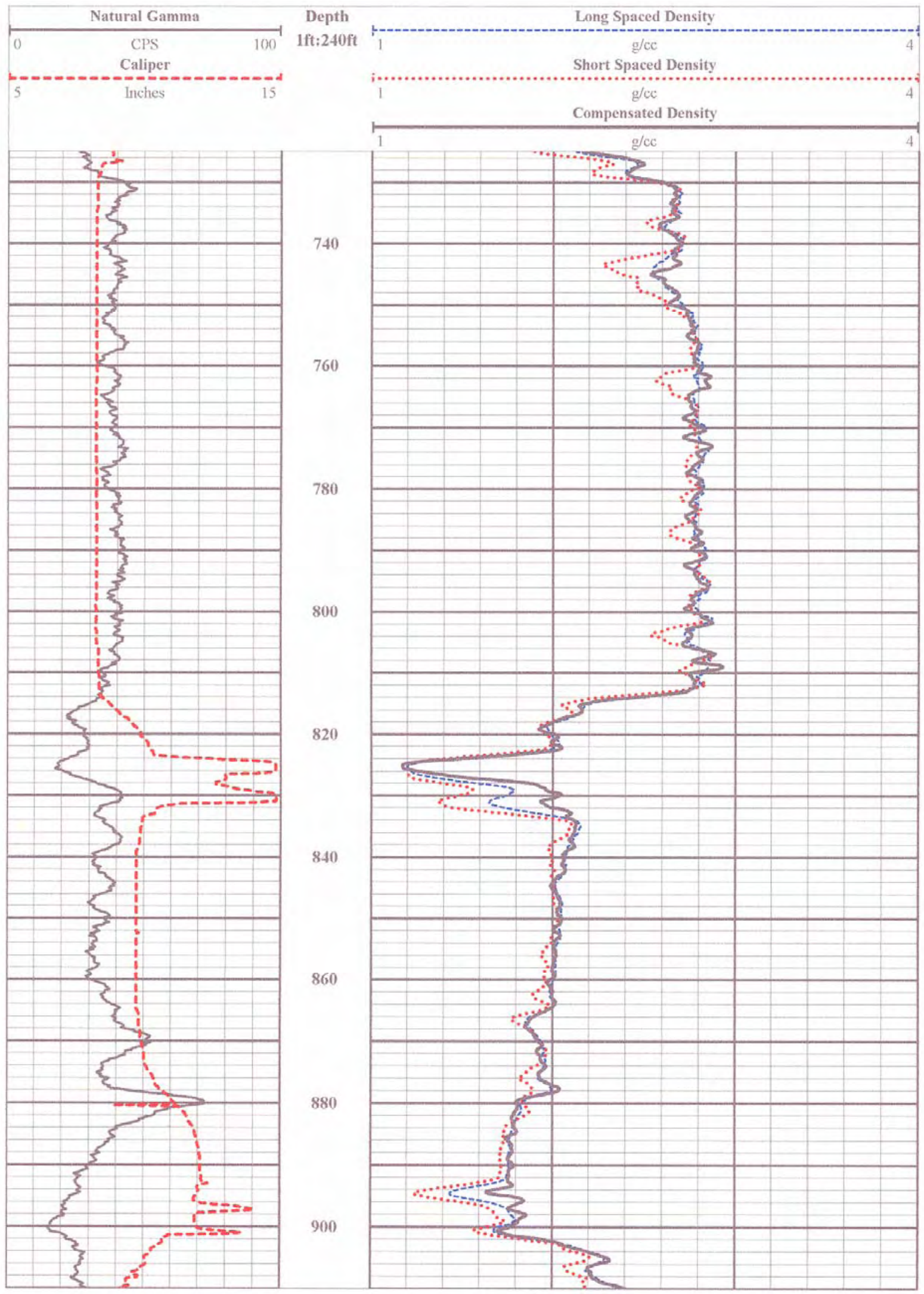


DTS-RPT-090, Rev. 0

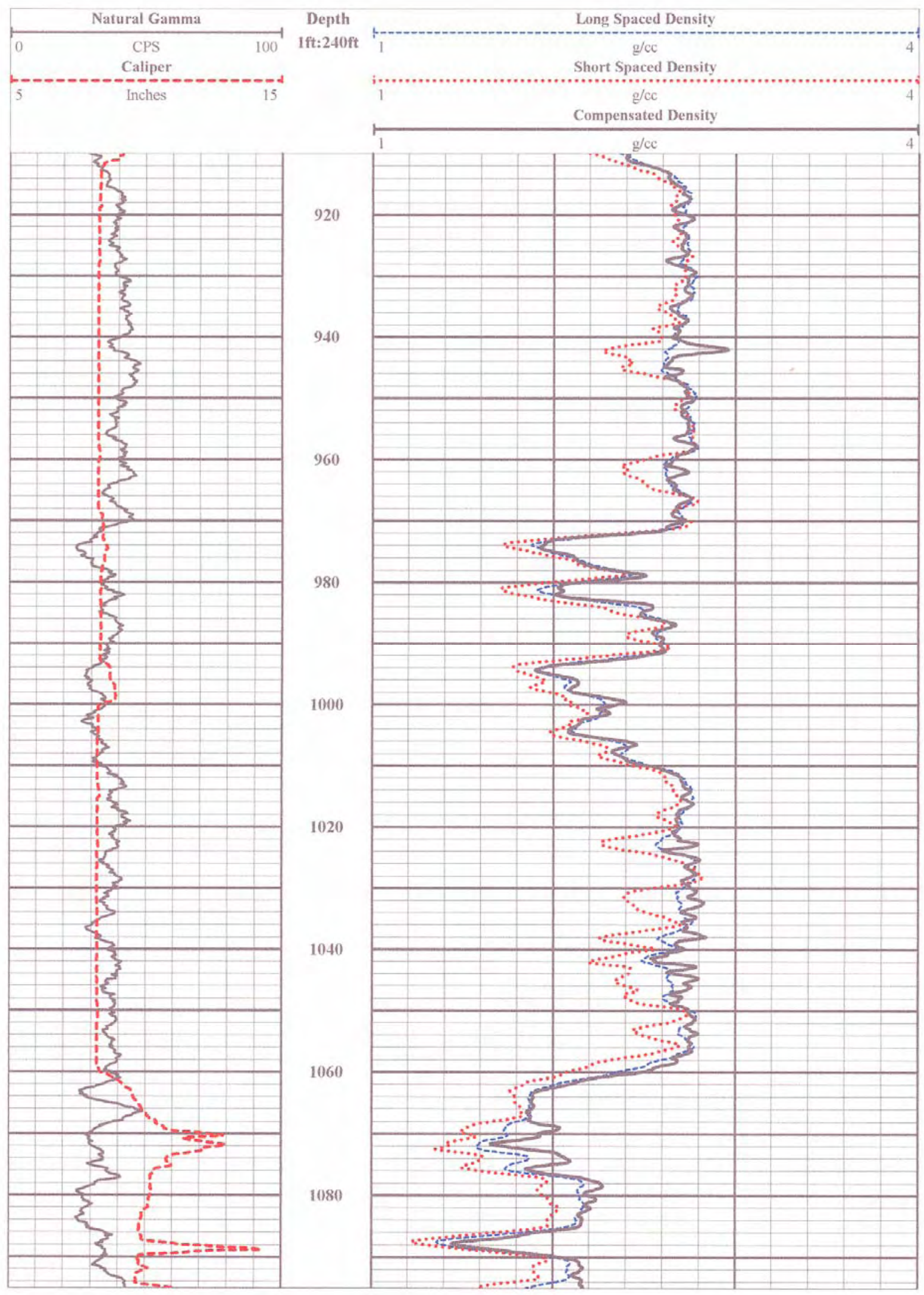


DTS-RPT-090, Rev. 0

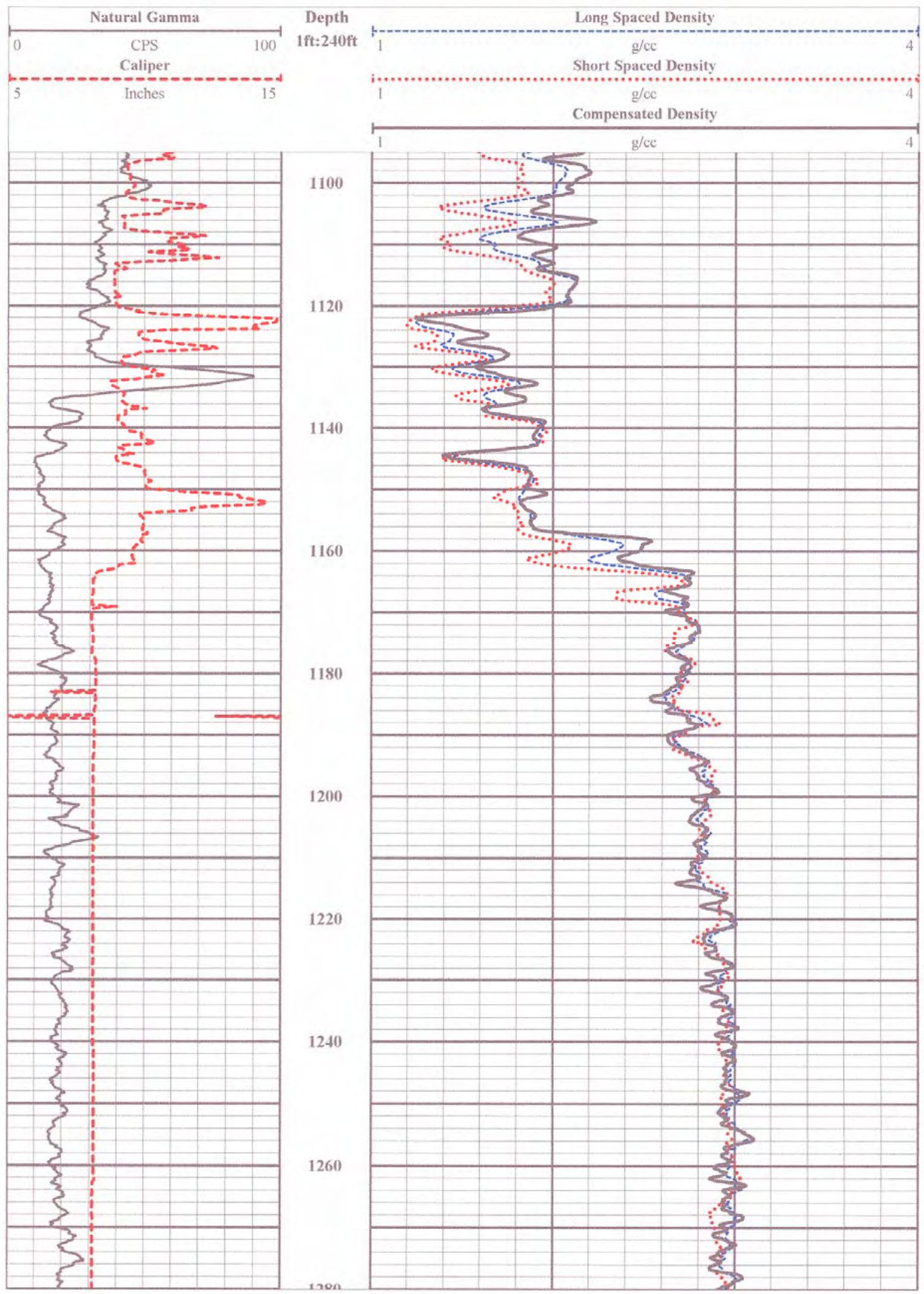


DTS-RPT-090, Rev. 0

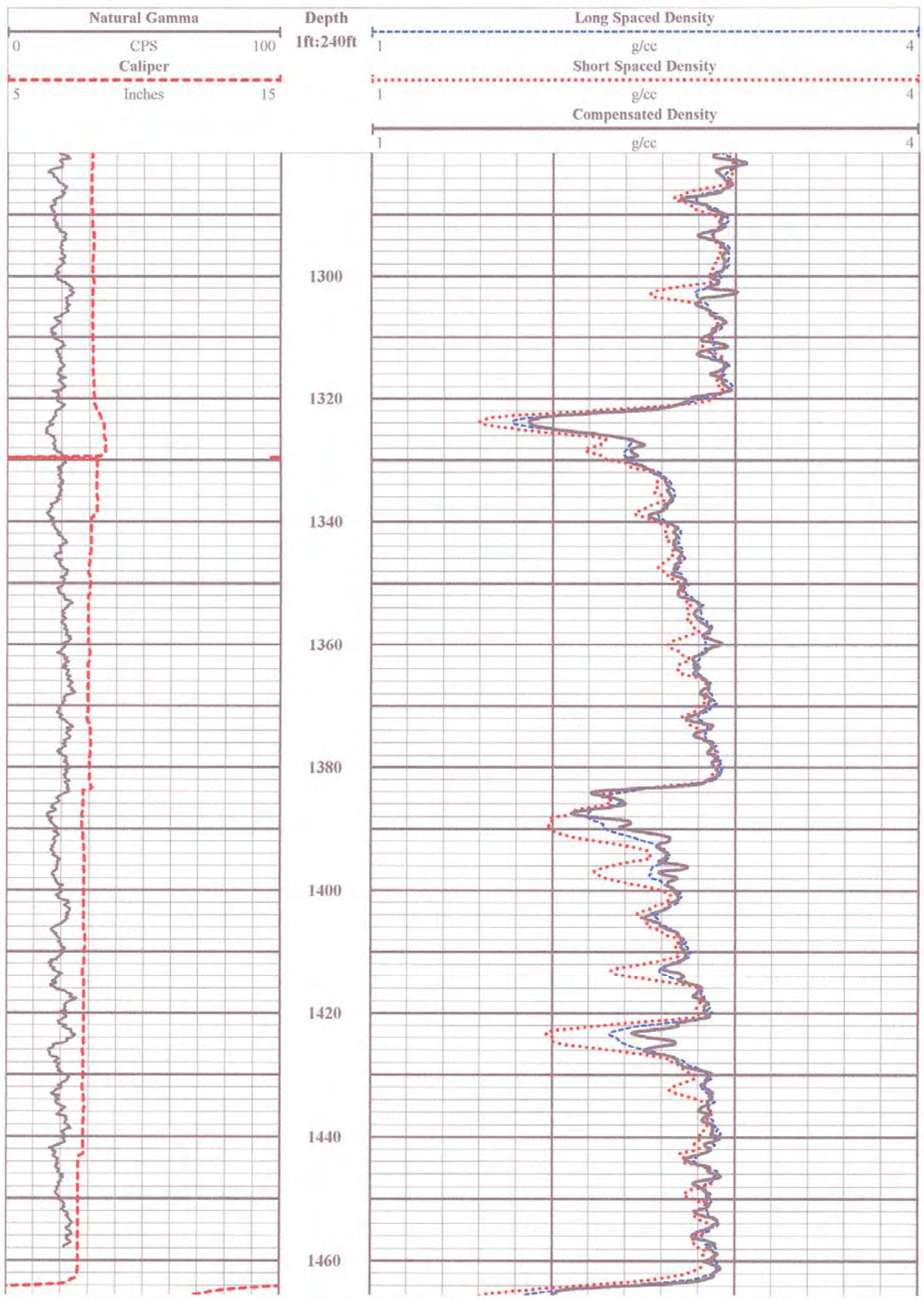


DTS-RPT-090, Rev. 0

\section{B1.6 COLOG NEUTRON/POROSITY LOG}

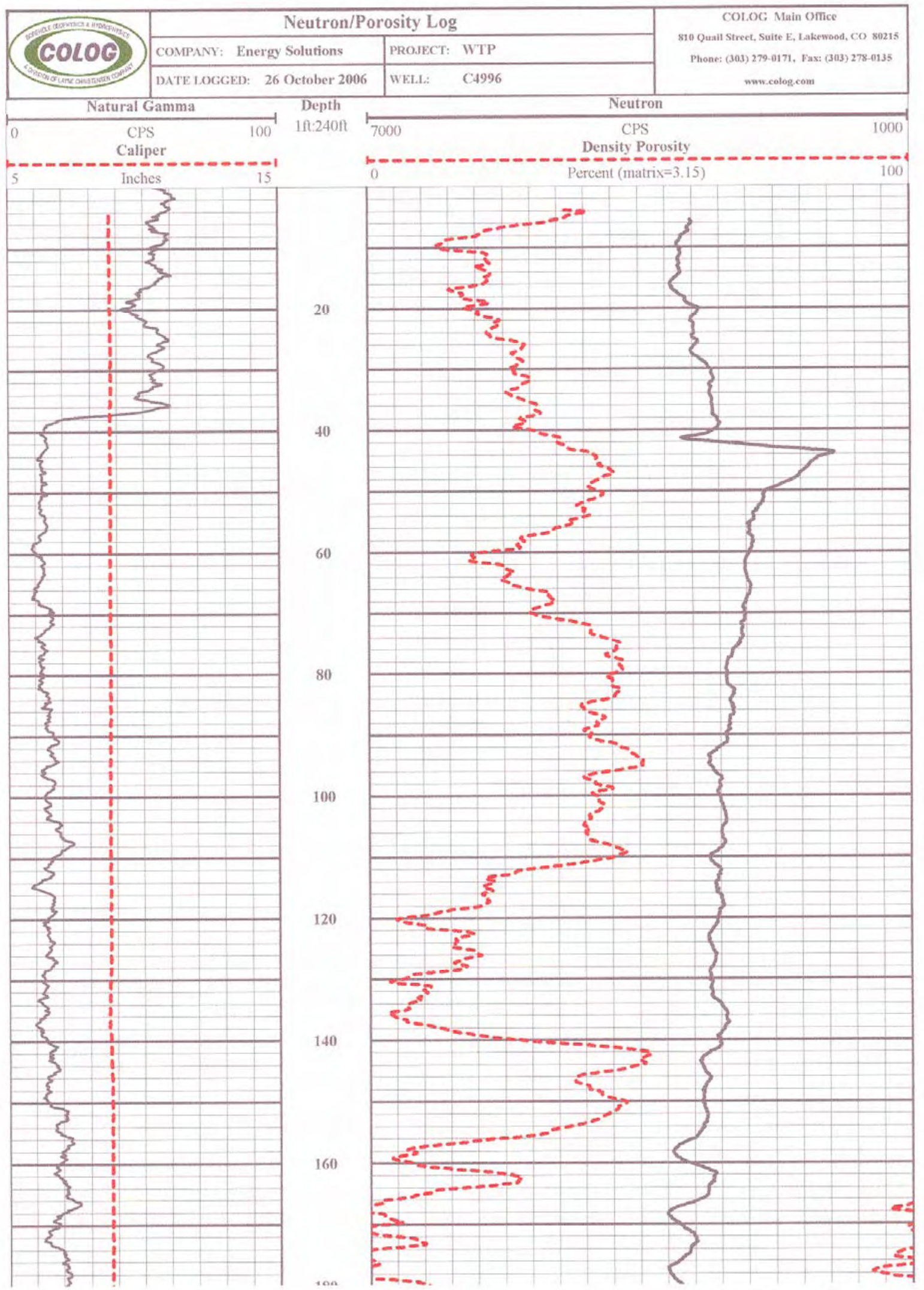


DTS-RPT-090, Rev. 0

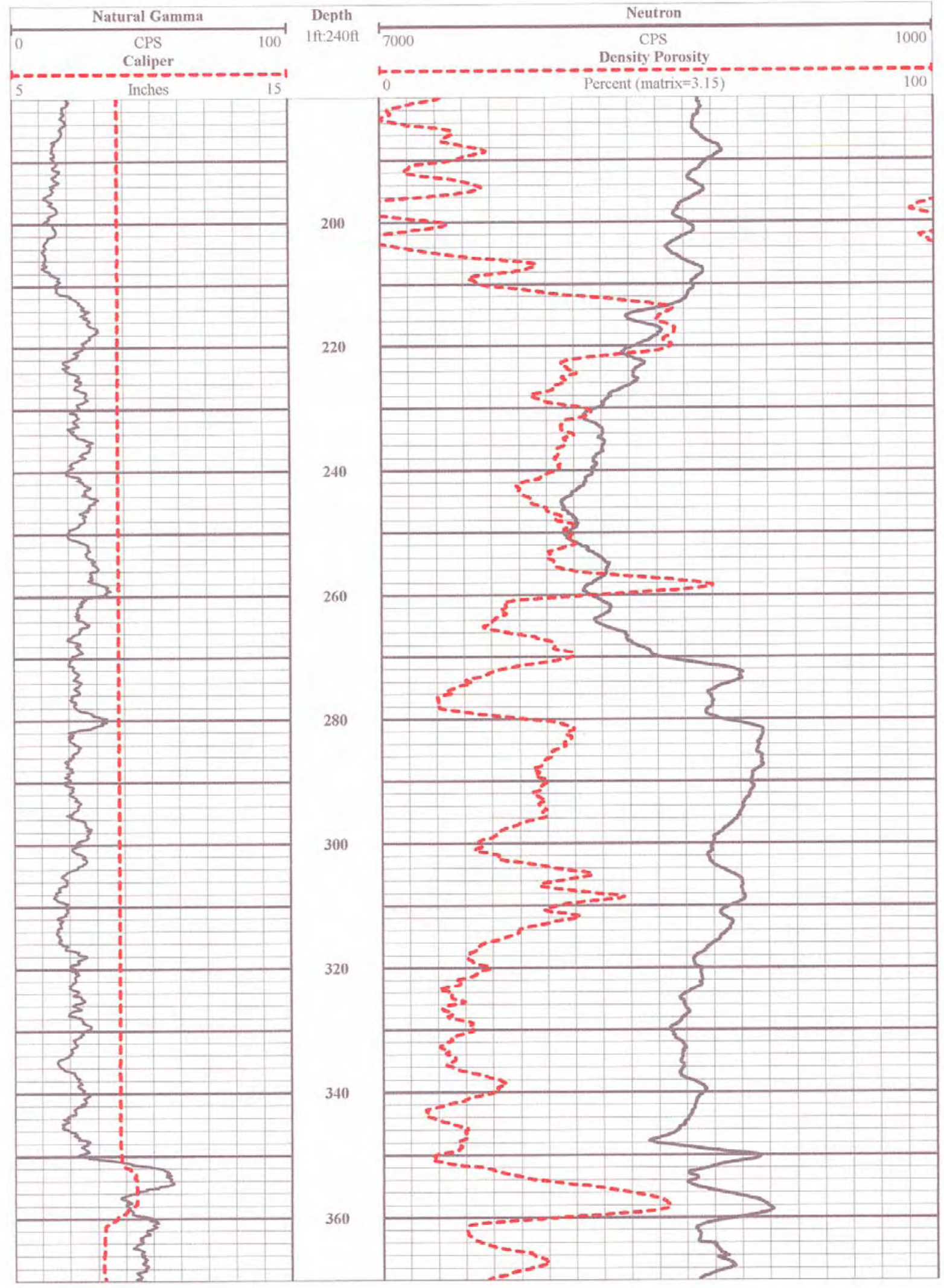


DTS-RPT-090, Rev. 0

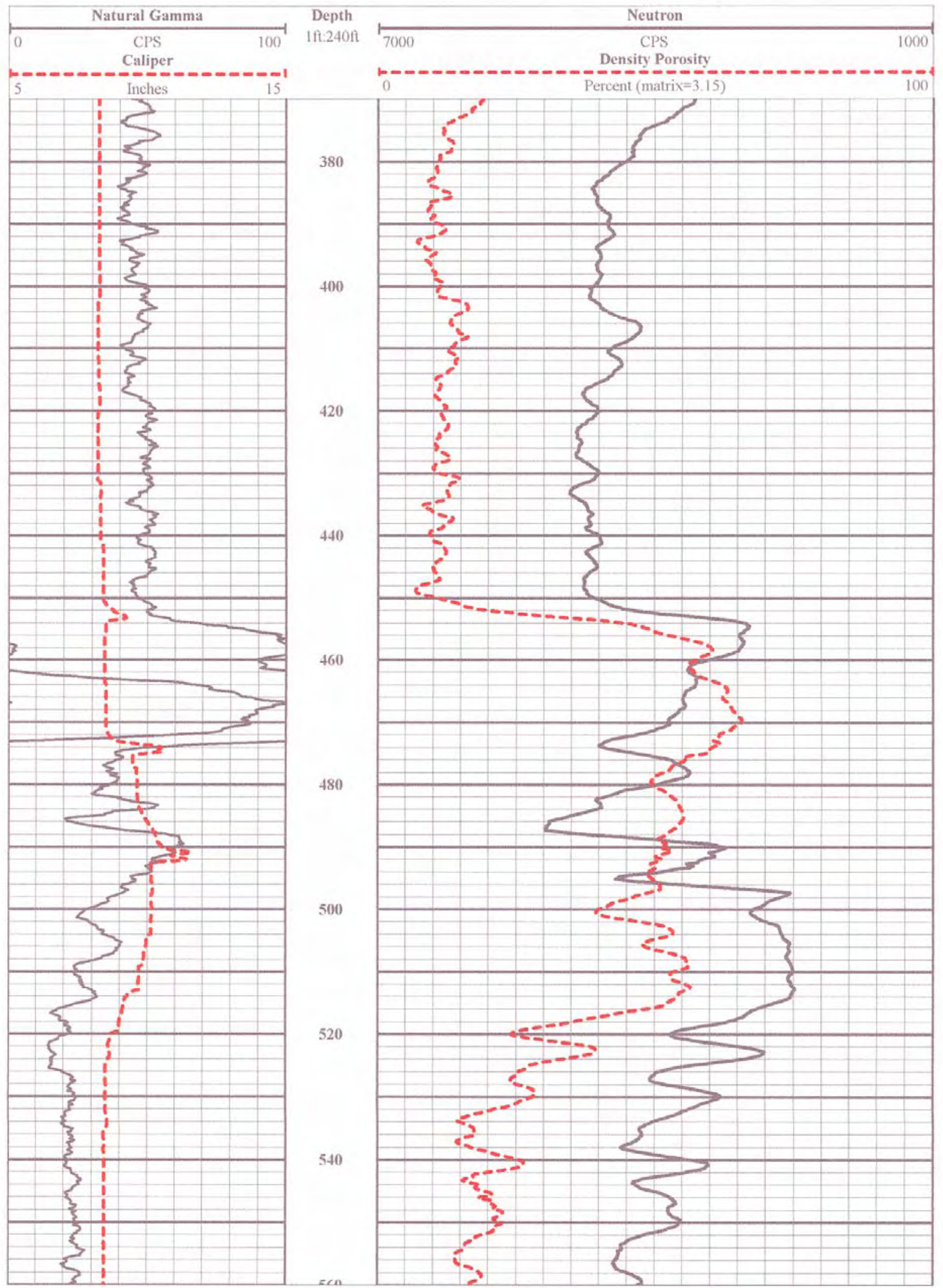


DTS-RPT-090, Rev. 0

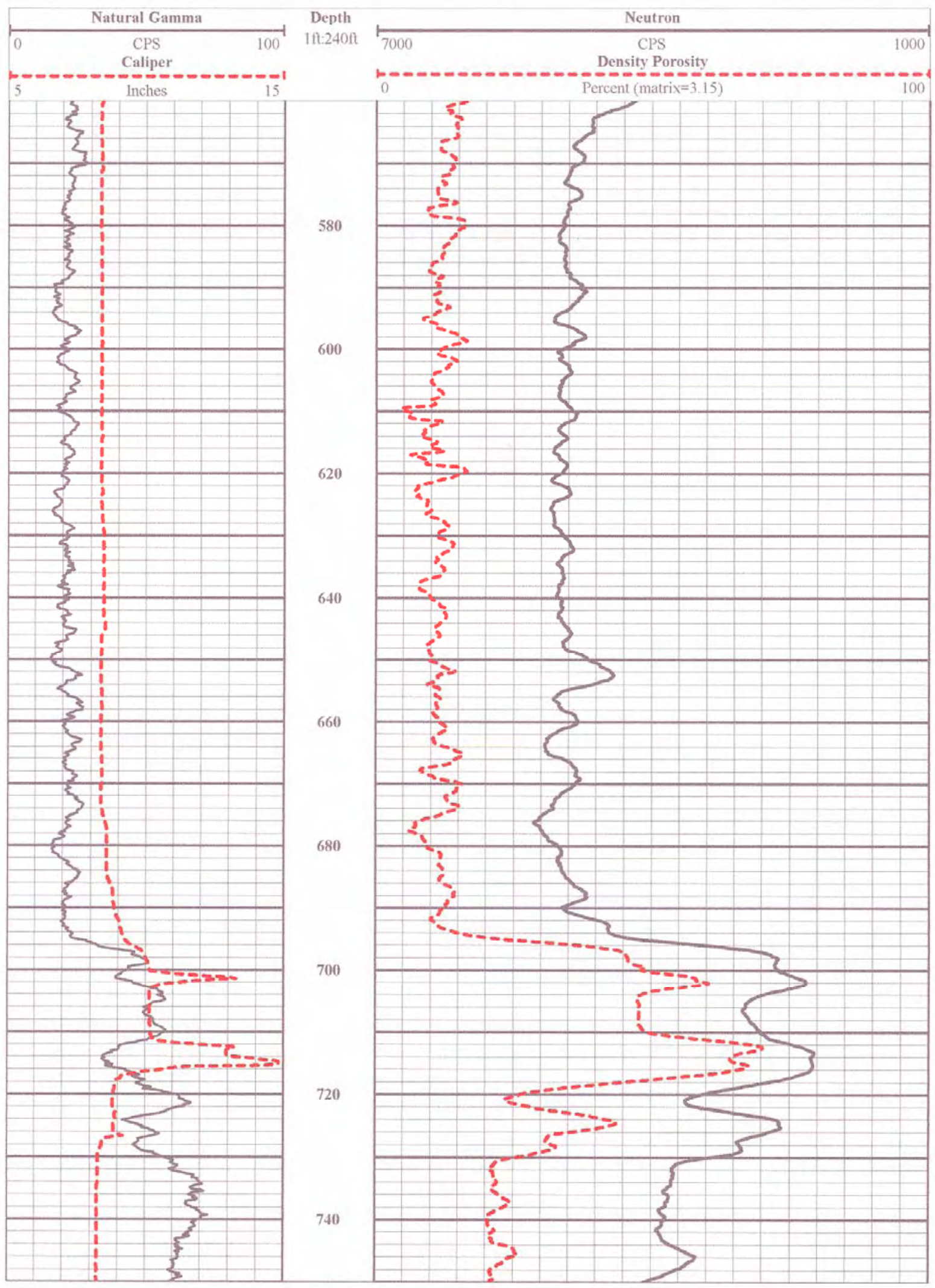


DTS-RPT-090, Rev. 0

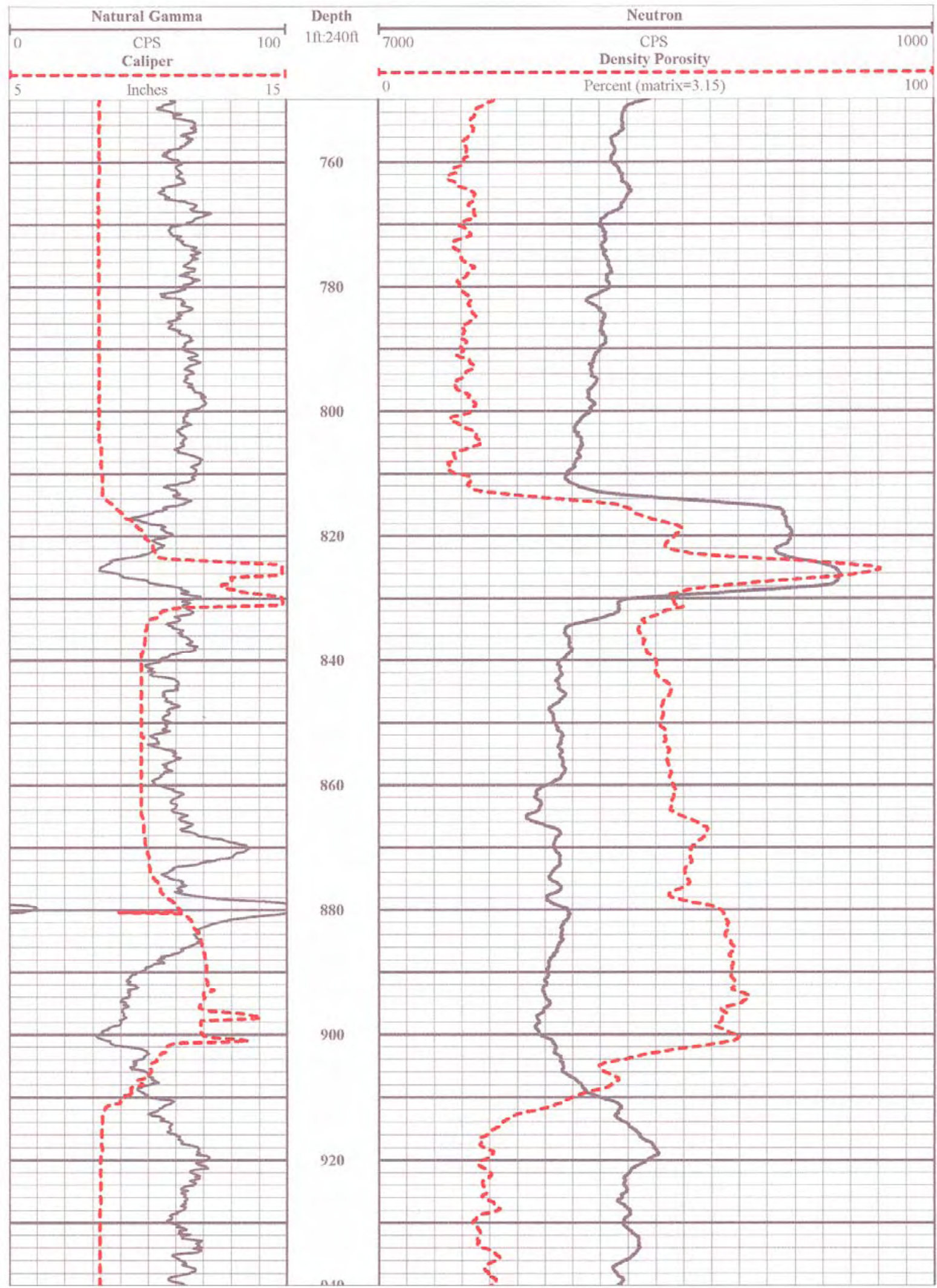


DTS-RPT-090, Rev. 0

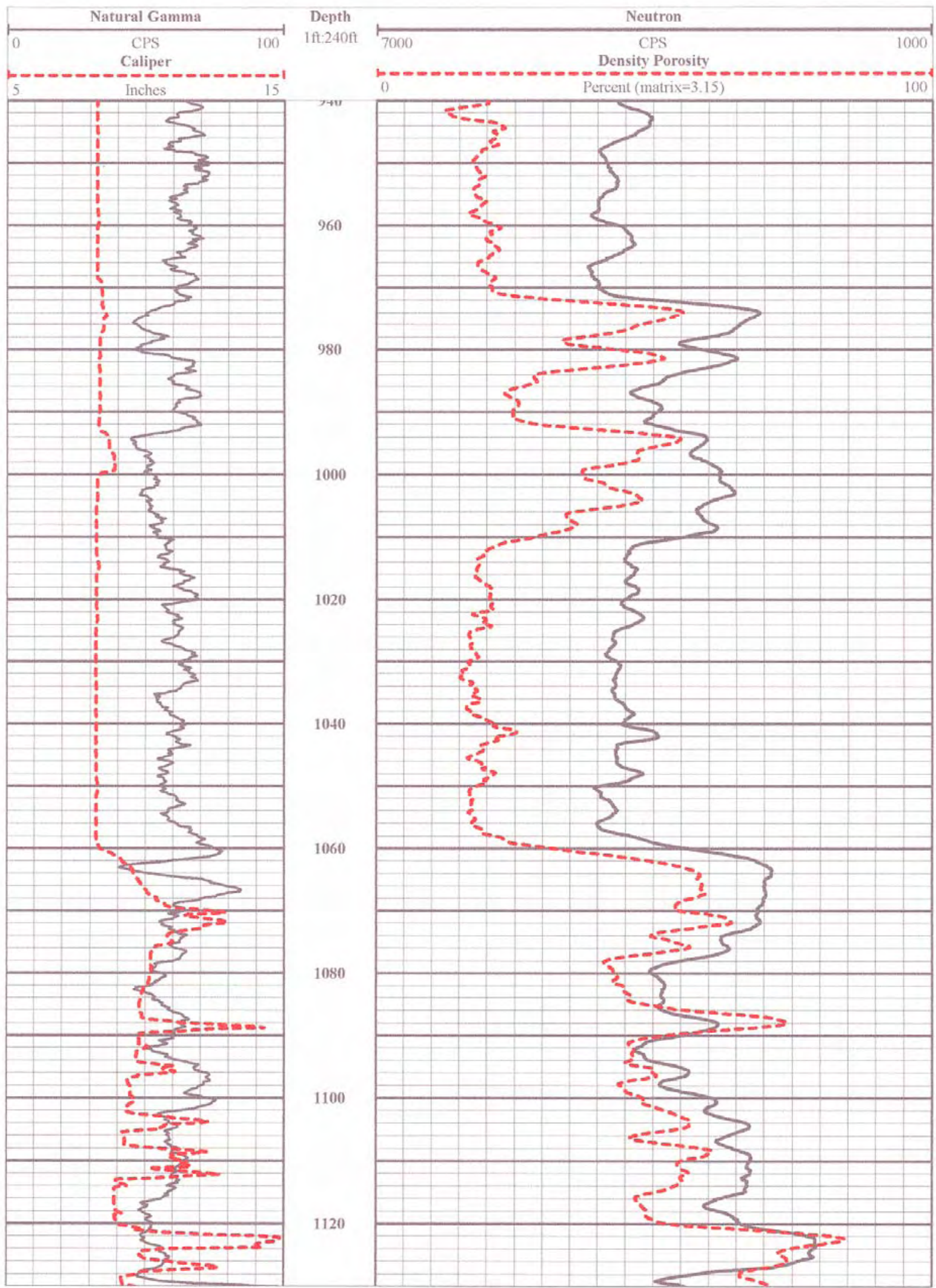


DTS-RPT-090, Rev. 0

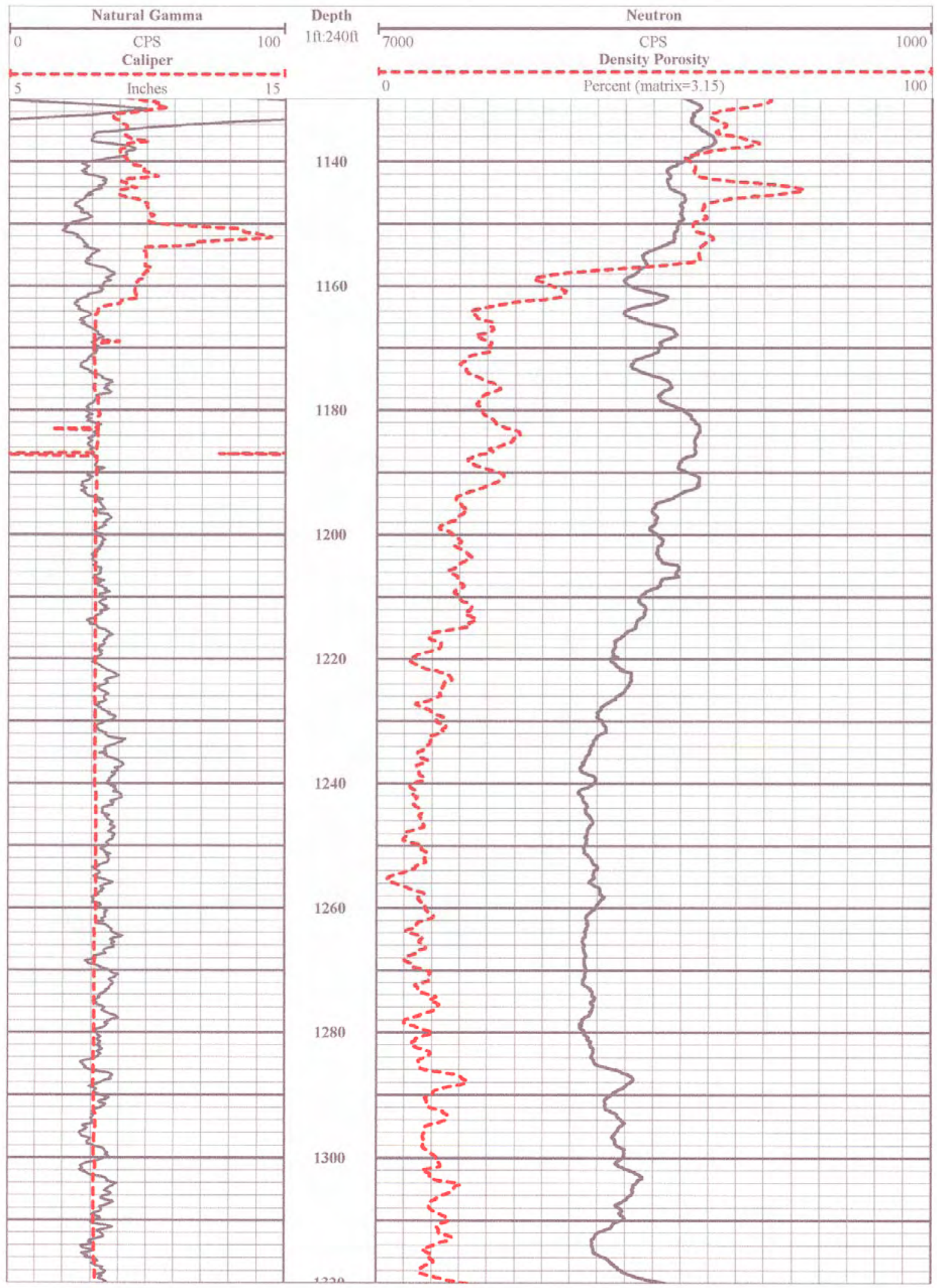


DTS-RPT-090, Rev. 0

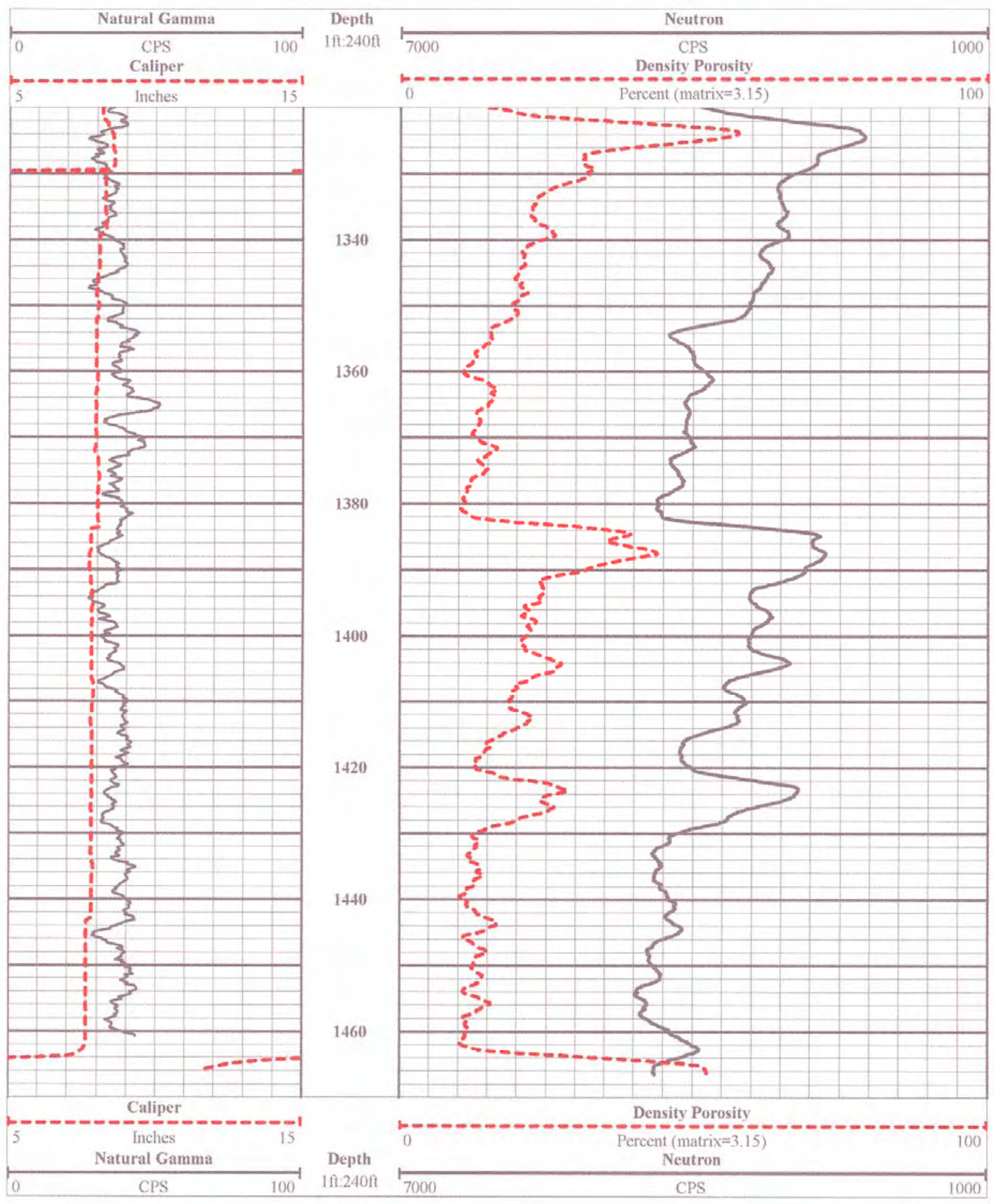


DTS-RPT-090, Rev. 0

\section{B1.7 COLOG DUAL INDUCTION LOG}

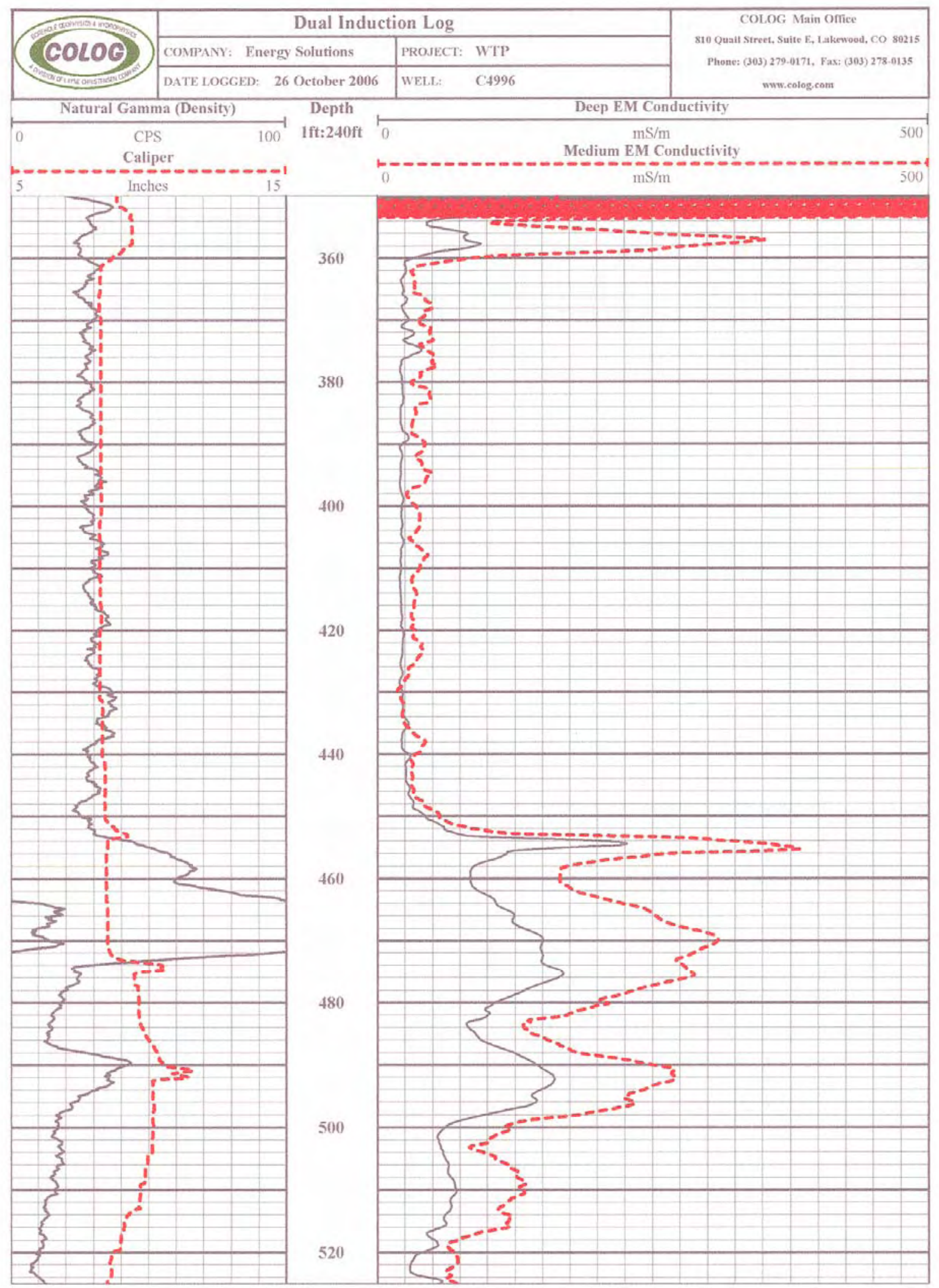


DTS-RPT-090, Rev. 0

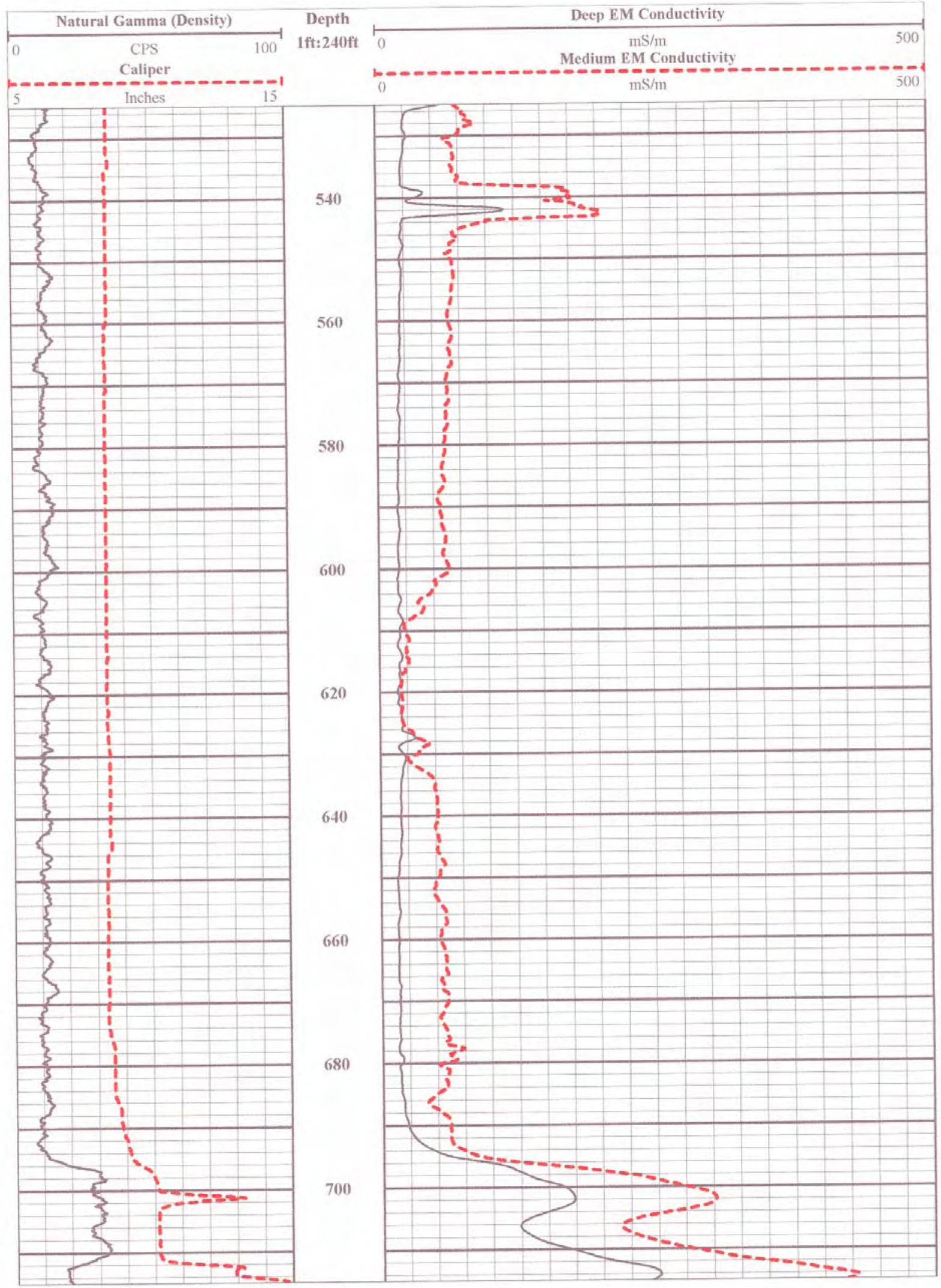


DTS-RPT-090, Rev. 0

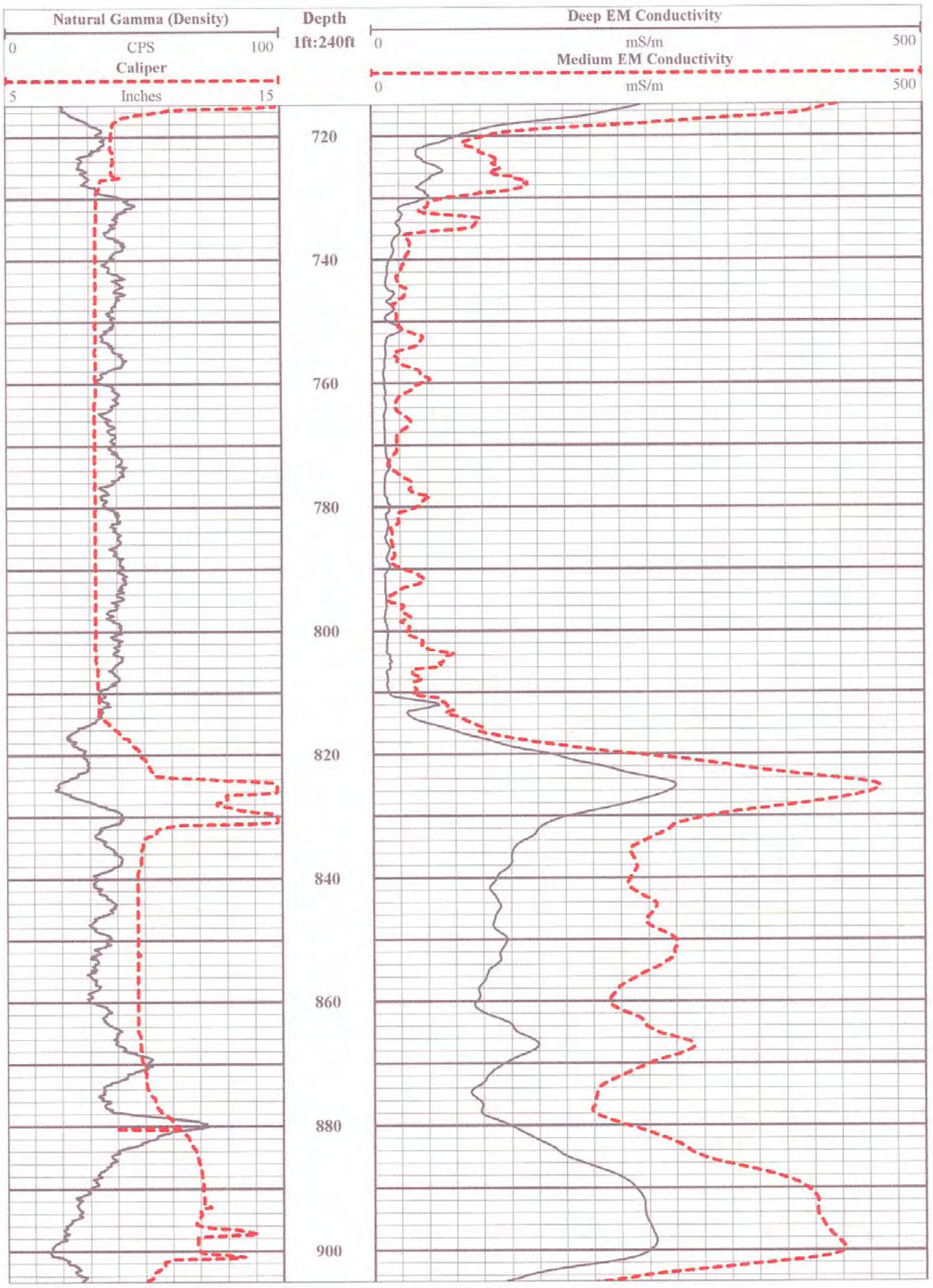


DTS-RPT-090, Rev. 0

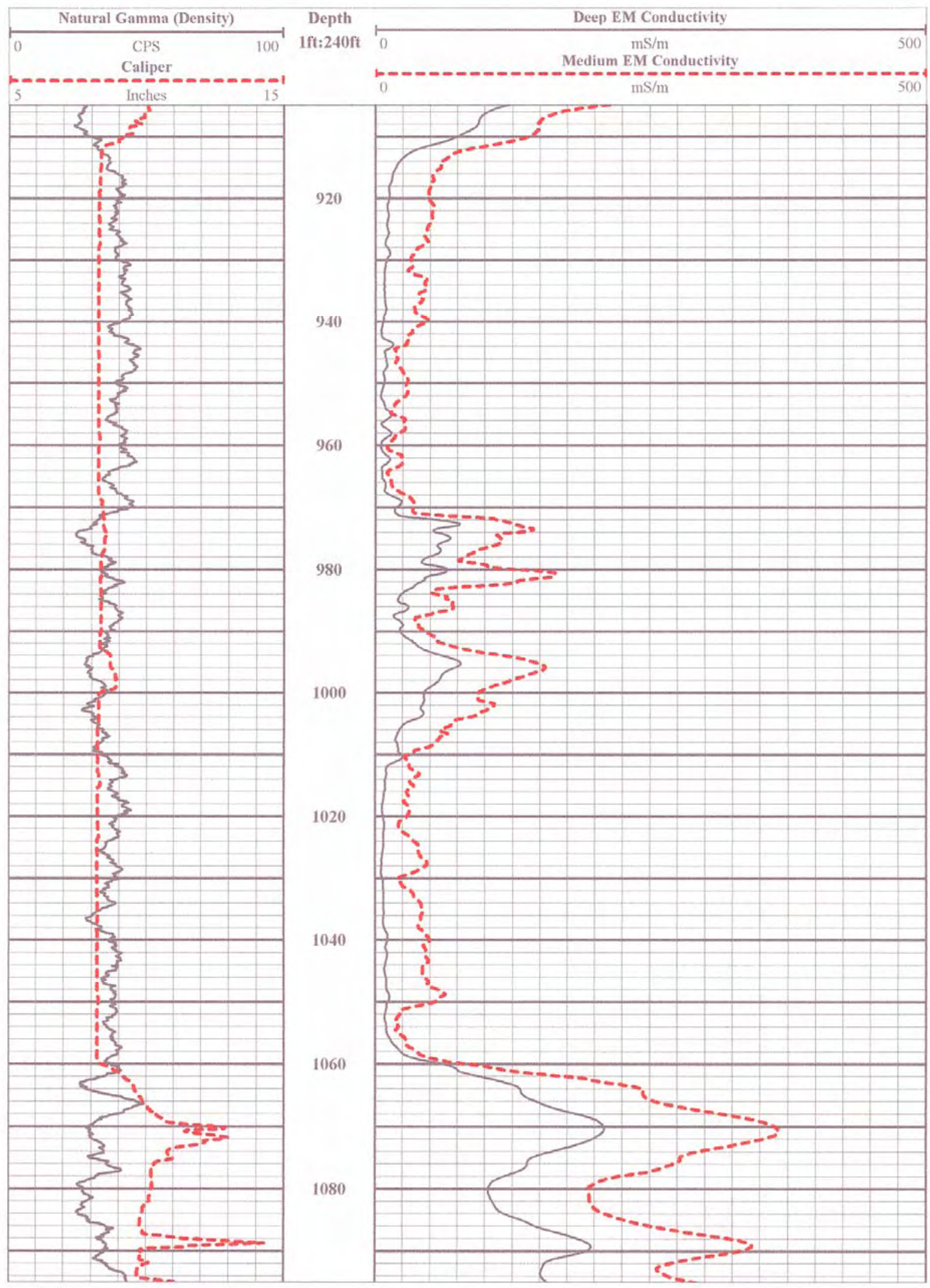


DTS-RPT-090, Rev. 0

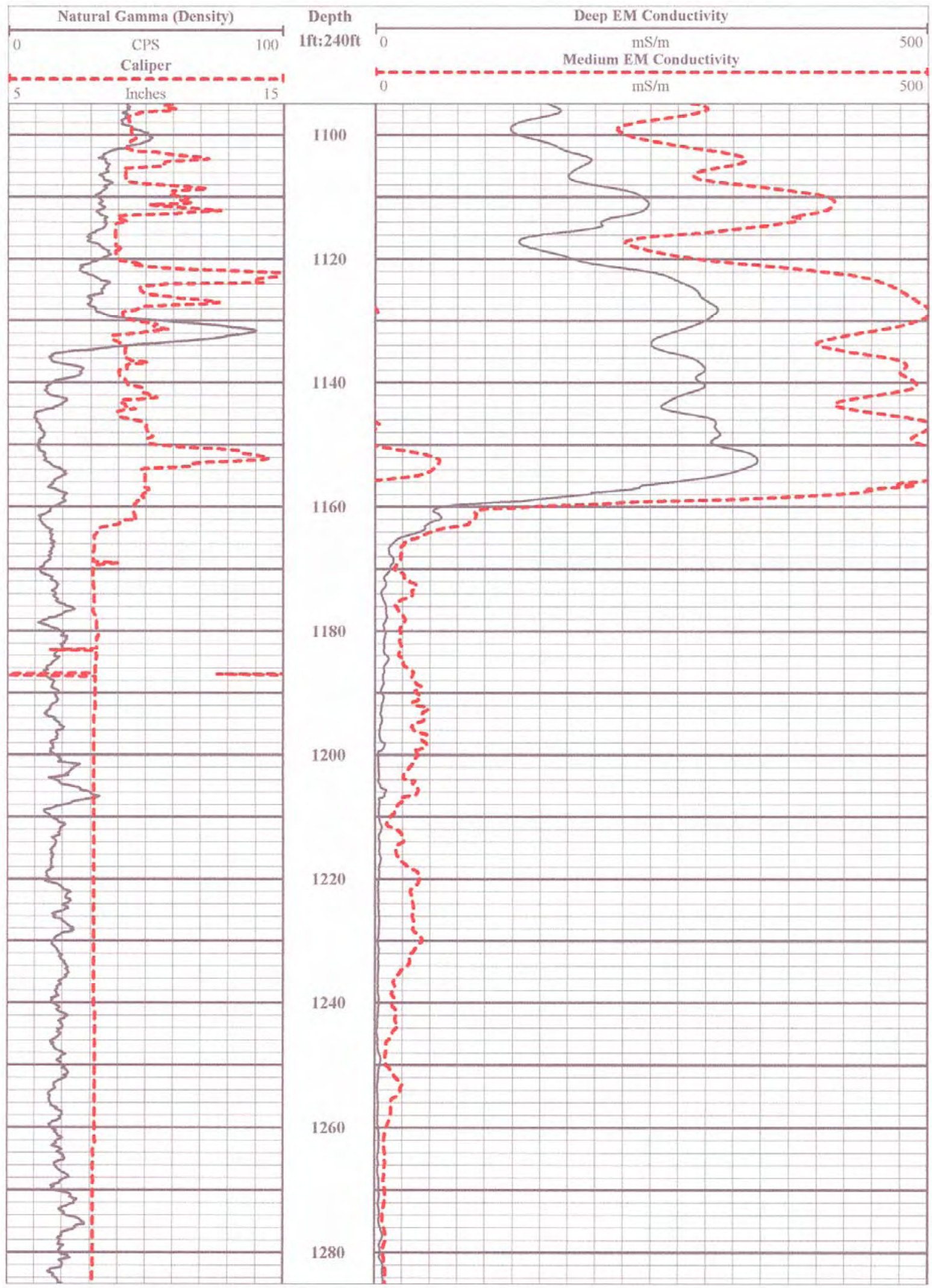


DTS-RPT-090, Rev. 0

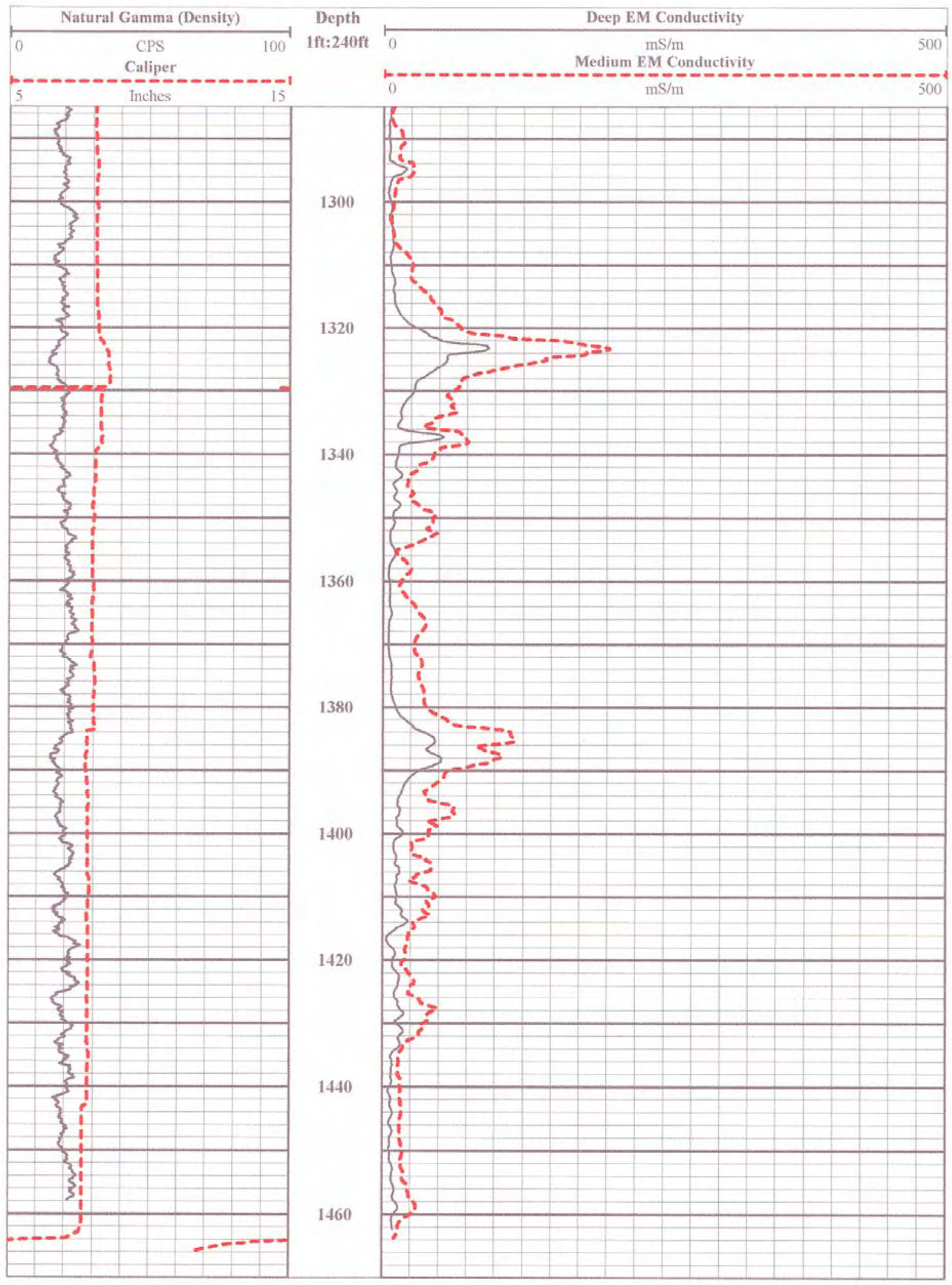


DTS-RPT-090, Rev. 0

\section{B1.8 COLOG FULL WAVEFORM SONIC LOG}

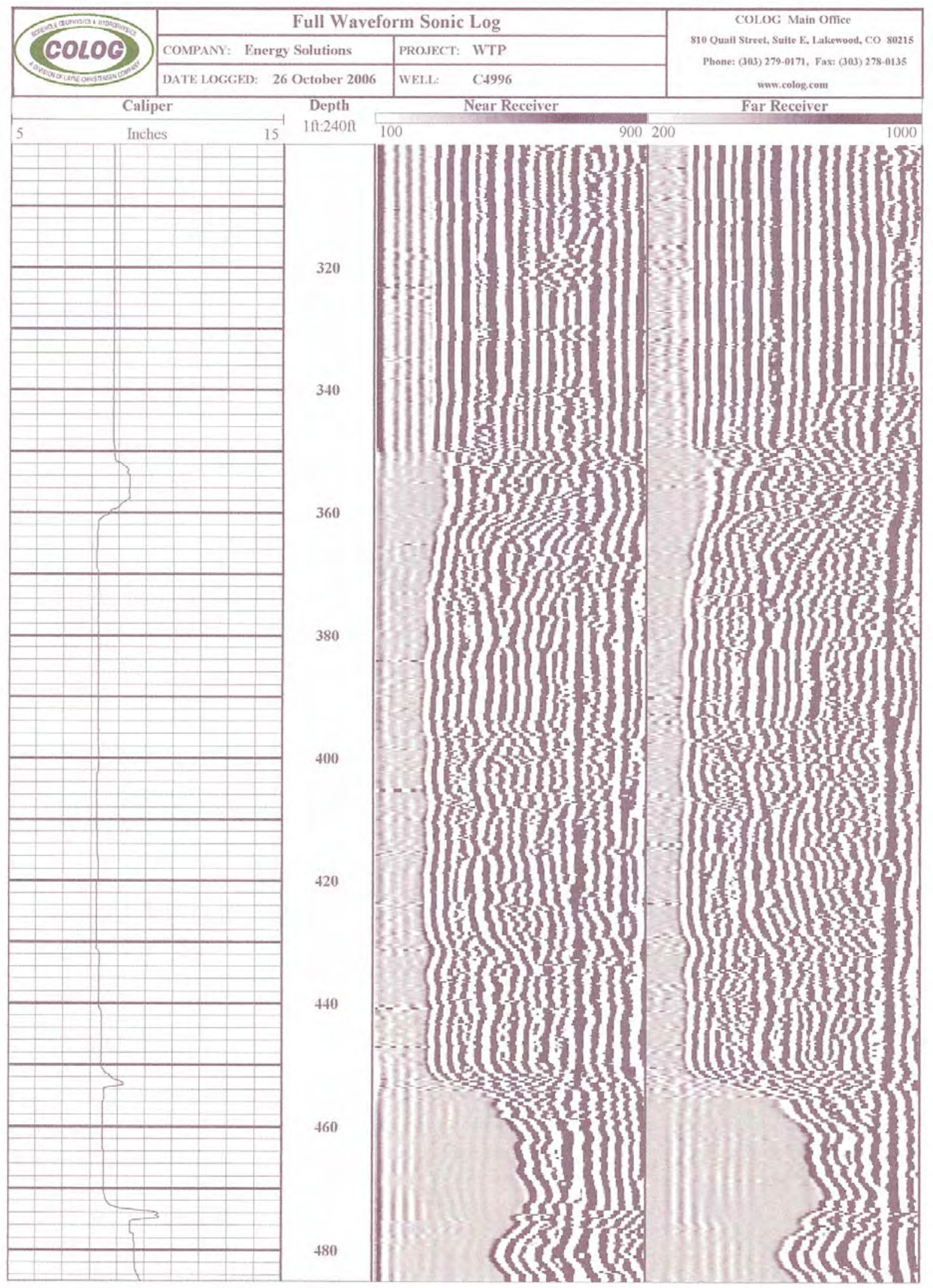


DTS-RPT-090, Rev. 0

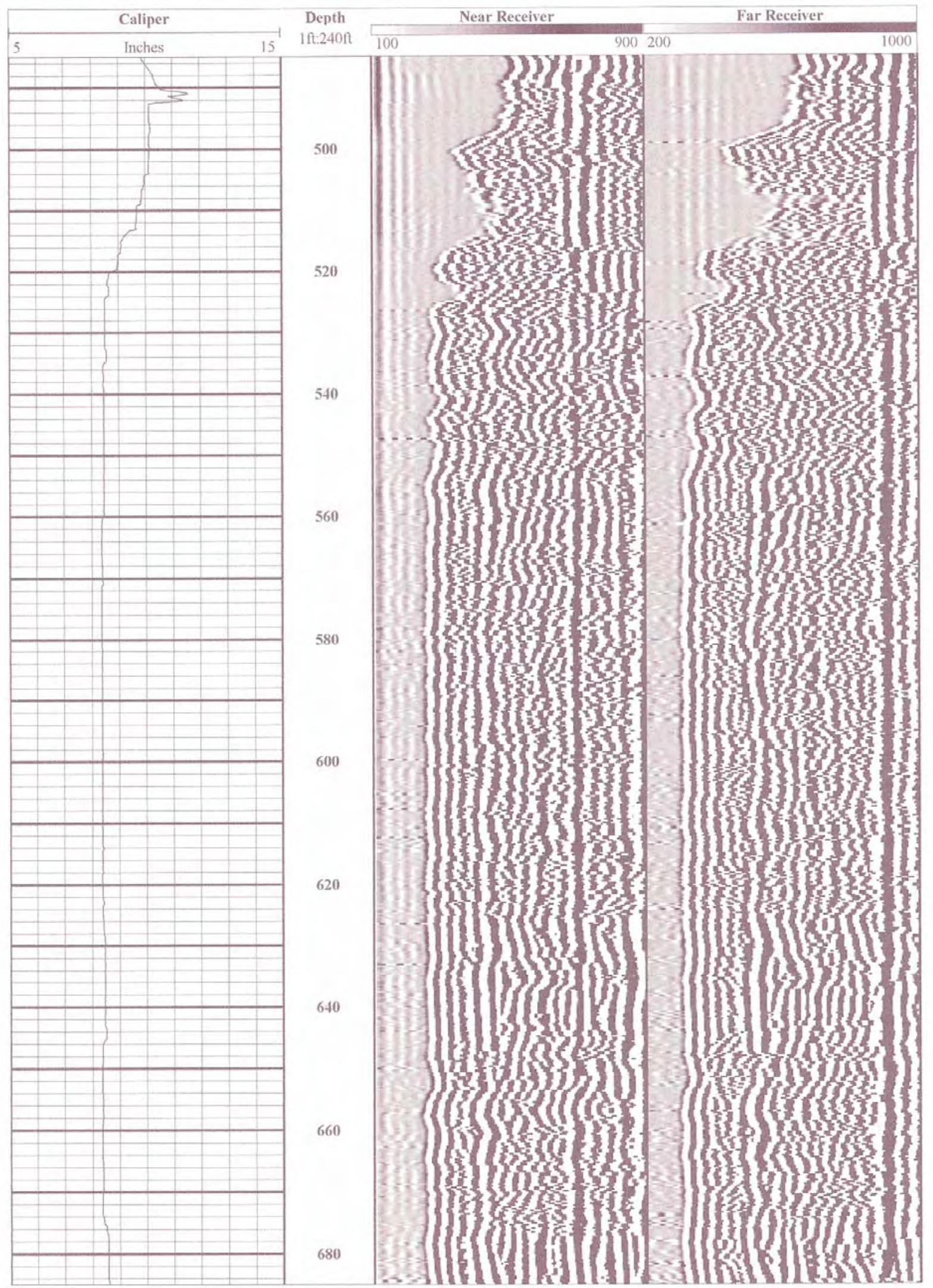


DTS-RPT-090, Rev. 0

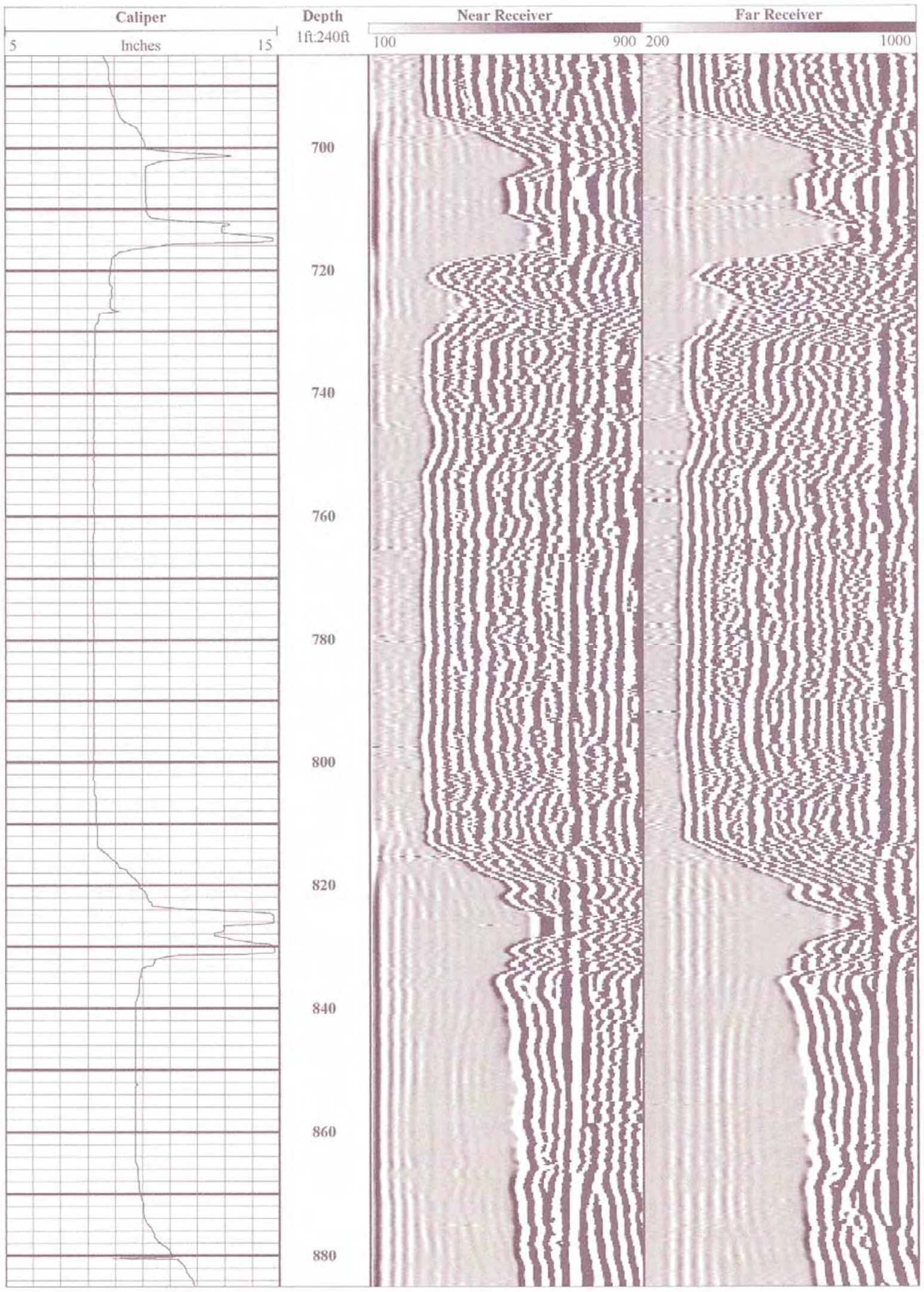


DTS-RPT-090, Rev. 0

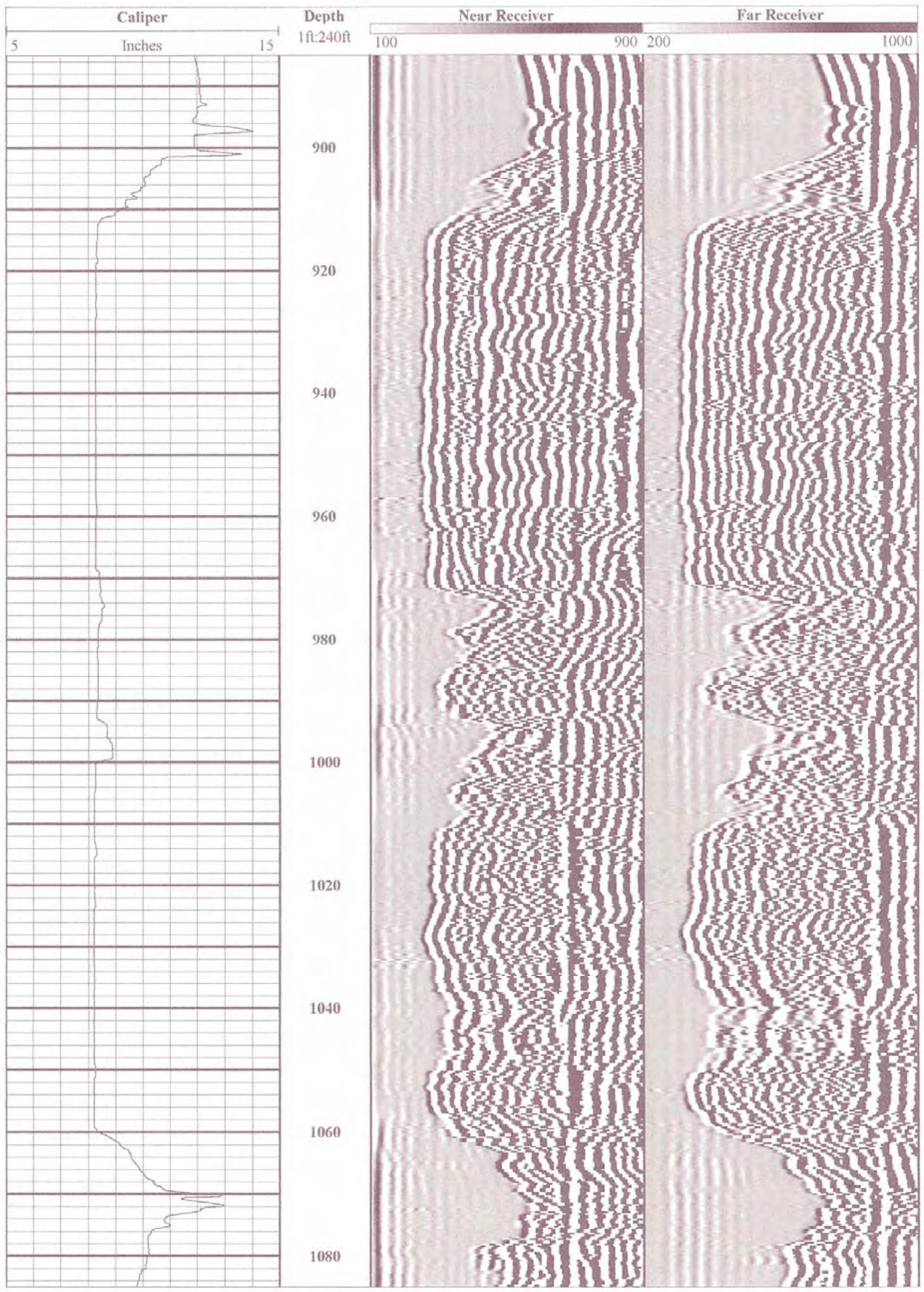


DTS-RPT-090, Rev. 0

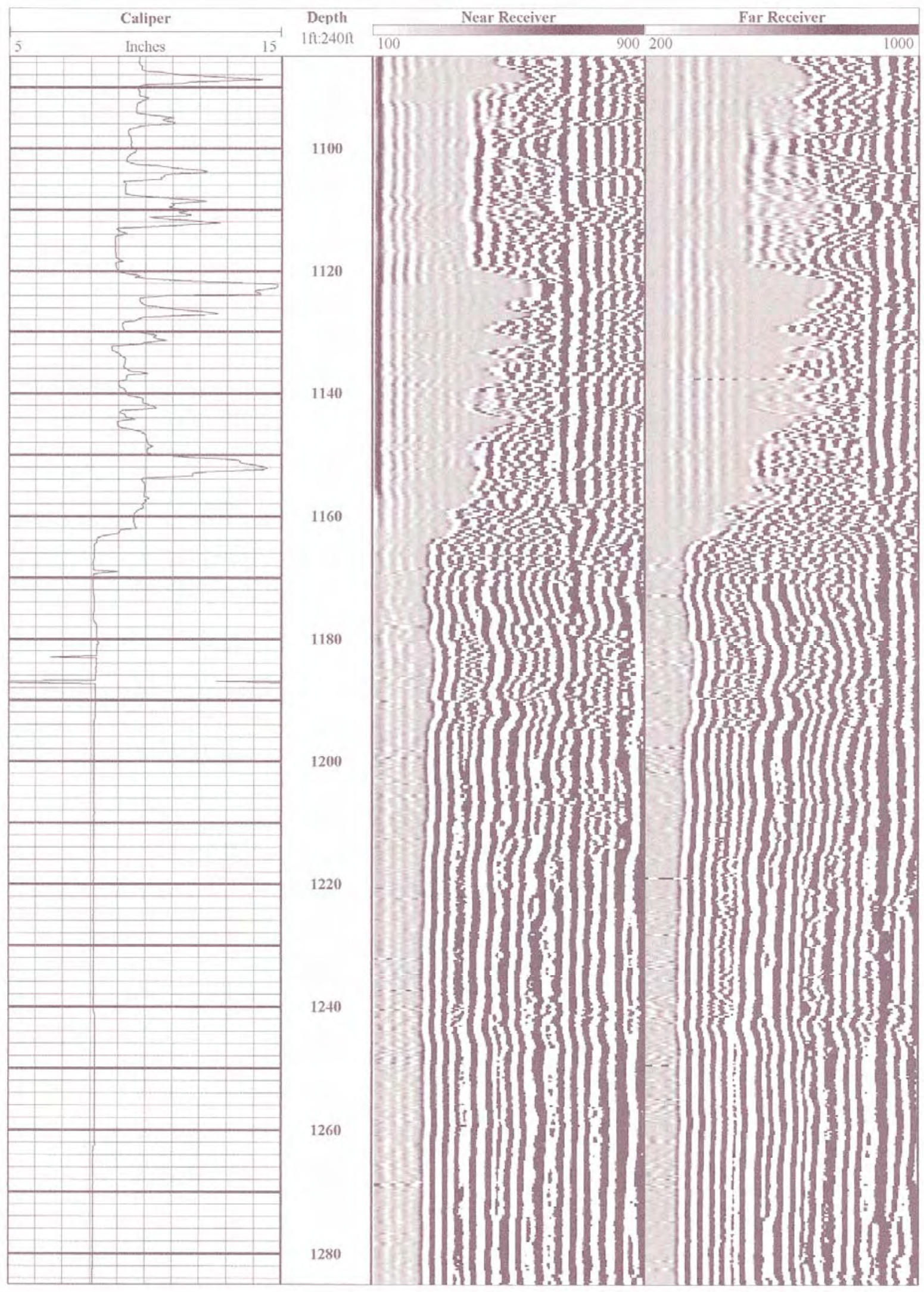


DTS-RPT-090, Rev. 0

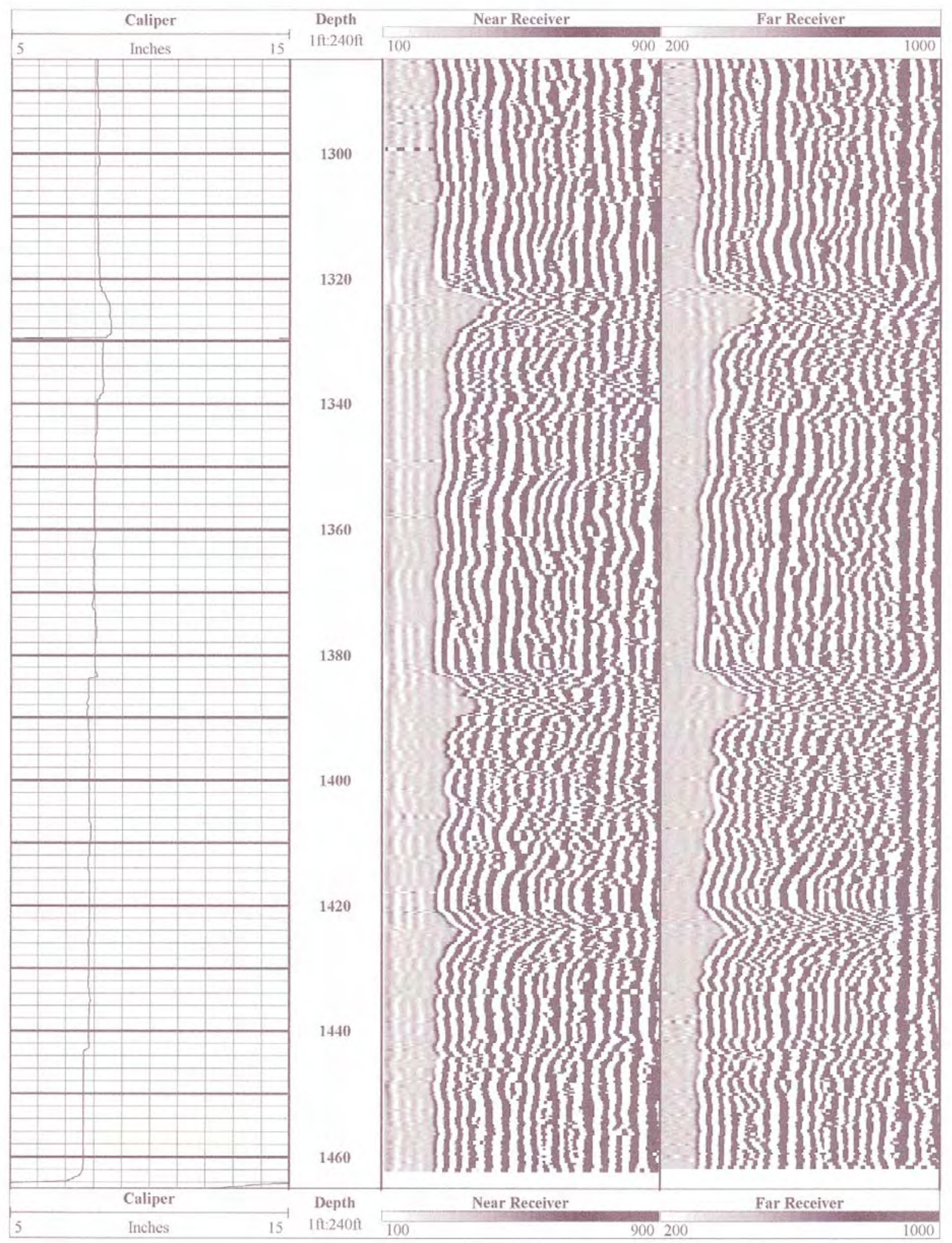




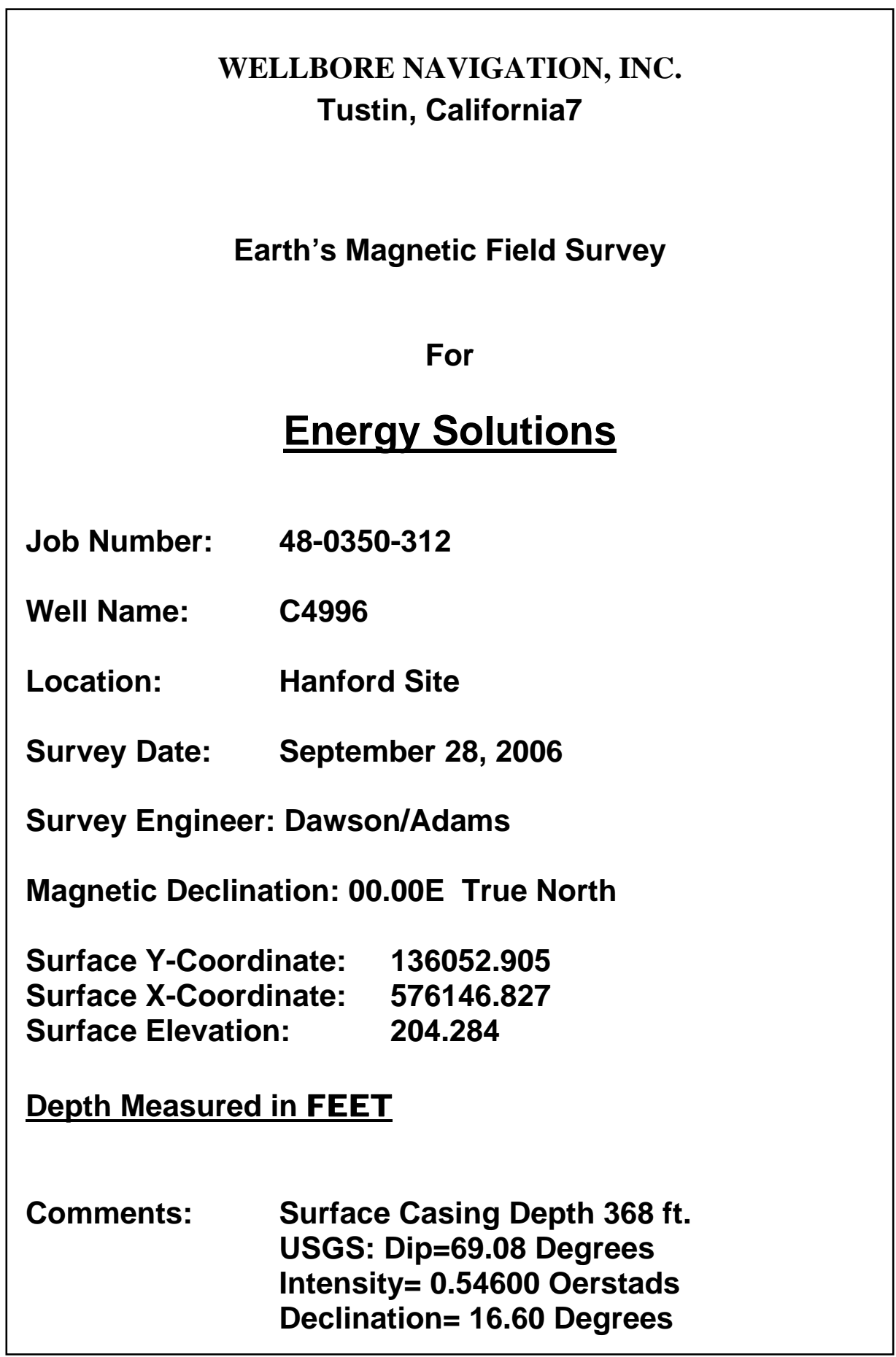


DTS-RPT-090, Rev. 0

\begin{tabular}{|c|c|c|c|c|c|c|c|c|}
\hline $\begin{array}{c}\text { Hole } \\
\text { ID }\end{array}$ & $\begin{array}{l}\text { Measured } \\
\text { Depth }\end{array}$ & $\begin{array}{c}\text { Magnetic } \\
\text { Declination }\end{array}$ & $\begin{array}{l}\text { Magnetic } \\
\text { Intensity }\end{array}$ & $\begin{array}{l}\text { Magnetic } \\
\text { Dip }\end{array}$ & HFS & X-HFS & Y-HFS & Z-HFS \\
\hline C4996 & 400 & 13.14886 & 0.53293 & 67.5 & 0.20394 & 0.04639 & 0.1986 & 0.49236 \\
\hline C4996 & 420 & 17.75369 & 0.52286 & 67.34 & 0.20144 & 0.06142 & 0.19184 & 0.4825 \\
\hline C4996 & 440 & 14.4785 & 0.55297 & 64.88 & 0.23474 & 0.05869 & 0.22729 & 0.50067 \\
\hline C4996 & 460 & 15.38715 & 0.55158 & 69.06 & 0.19713 & 0.05231 & 0.19006 & 0.51515 \\
\hline C4996 & 480 & 16.02503 & 0.54774 & 69.55 & 0.19137 & 0.05283 & 0.18394 & 0.51322 \\
\hline C4996 & 500 & 15.86295 & 0.56213 & 70.39 & 0.18866 & 0.05157 & 0.18148 & 0.52953 \\
\hline C4996 & 520 & 15.75388 & 0.58305 & 71.2 & 0.1879 & 0.05102 & 0.18084 & 0.55194 \\
\hline C4996 & 540 & 16.89365 & 0.57538 & 72.39 & 0.17407 & 0.05059 & 0.16656 & 0.54842 \\
\hline C4996 & 560 & 14.60812 & 0.57823 & 72.19 & 0.17686 & 0.0446 & 0.17114 & 0.55052 \\
\hline C4996 & 580 & 20.2299 & 0.5928 & 72.15 & 0.18171 & 0.06283 & 0.1705 & 0.56426 \\
\hline C4996 & 600 & 16.93821 & 0.59722 & 72.17 & 0.18287 & 0.05328 & 0.17493 & 0.56854 \\
\hline C4996 & 620 & 15.10383 & 0.51151 & 75.17 & 0.13092 & 0.03411 & 0.1264 & 0.49447 \\
\hline C4996 & 640 & 15.75906 & 0.5398 & 69.62 & 0.18798 & 0.05105 & 0.18092 & 0.50601 \\
\hline C4996 & 660 & 15.57894 & 0.55591 & 70.21 & 0.18822 & 0.05055 & 0.1813 & 0.52308 \\
\hline C4996 & 680 & 14.1782 & 0.55428 & 69.62 & 0.19303 & 0.04728 & 0.18715 & 0.51958 \\
\hline C4996 & 700 & 14.25806 & 0.55352 & 69.63 & 0.19267 & 0.04745 & 0.18673 & 0.51891 \\
\hline C4996 & 720 & 14.97595 & 0.48807 & 57.91 & 0.25929 & 0.067 & 0.25048 & 0.4135 \\
\hline C4996 & 740 & 12.21576 & 0.49379 & 64.96 & 0.209 & 0.04422 & 0.20426 & 0.44738 \\
\hline C4996 & 760 & 1.365936 & 0.40099 & 48.34 & 0.26654 & 0.00635 & 0.26647 & 0.29958 \\
\hline C4996 & 780 & 10.2558 & 0.4534 & 59.5 & 0.23012 & 0.04097 & 0.22644 & 0.39066 \\
\hline C4996 & 800 & 15.40527 & 0.49162 & 66.5 & 0.19603 & 0.05208 & 0.18899 & 0.45085 \\
\hline C4996 & 820 & 14.96817 & 0.5324 & 67.96 & 0.19979 & 0.0516 & 0.19301 & 0.49349 \\
\hline C4996 & 840 & 15.12643 & 0.54942 & 69.11 & 0.19591 & 0.05112 & 0.18912 & 0.5133 \\
\hline C4996 & 860 & 14.62396 & 0.54967 & 68.98 & 0.19716 & 0.04978 & 0.19078 & 0.51309 \\
\hline C4996 & 880 & 14.80106 & 0.55028 & 69.03 & 0.19693 & 0.05031 & 0.1904 & 0.51383 \\
\hline C4996 & 900 & 14.81705 & 0.55153 & 68.79 & 0.19954 & 0.05103 & 0.1929 & 0.51417 \\
\hline C4996 & 920 & 8.869976 & 0.4885 & 62.76 & 0.2236 & 0.03448 & 0.22092 & 0.43432 \\
\hline C4996 & 940 & 9.852539 & 0.48397 & 62.32 & 0.22482 & 0.03847 & 0.2215 & 0.42858 \\
\hline C4996 & 960 & 8.559692 & 0.49096 & 61 & 0.23802 & 0.03543 & 0.23537 & 0.4294 \\
\hline C4996 & 980 & 6.445282 & 0.50478 & 59.72 & 0.25452 & 0.02857 & 0.25291 & 0.43591 \\
\hline C4996 & 1000 & 6.372803 & 0.52753 & 63.34 & 0.2367 & 0.02627 & 0.23524 & 0.47145 \\
\hline C4996 & 1020 & 6.883774 & 0.48582 & 61.29 & 0.23338 & 0.02797 & 0.23169 & 0.42609 \\
\hline C4996 & 1040 & 15.25523 & 0.47085 & 60.37 & 0.23279 & 0.06125 & 0.22458 & 0.40928 \\
\hline C4996 & 1060 & 16.1512 & 0.50165 & 63.12 & 0.22681 & 0.06309 & 0.21786 & 0.44745 \\
\hline C4996 & 1080 & 19.56986 & 0.54475 & 68.98 & 0.1954 & 0.06545 & 0.18411 & 0.5085 \\
\hline C4996 & 1100 & 18.52356 & 0.5445 & 69.06 & 0.1946 & 0.06182 & 0.18452 & 0.50854 \\
\hline C4996 & 1120 & 18.16028 & 0.54499 & 68.96 & 0.19566 & 0.06098 & 0.18592 & 0.50866 \\
\hline C4996 & 1140 & 19.0874 & 0.54469 & 68.68 & 0.19804 & 0.06476 & 0.18715 & 0.50741 \\
\hline C4996 & 1160 & 27.21414 & 0.60158 & 74.73 & 0.15844 & 0.07246 & 0.1409 & 0.58034 \\
\hline C4996 & 1180 & 18.53077 & 0.58539 & 70.93 & 0.19126 & 0.06079 & 0.18134 & 0.55326 \\
\hline C4996 & 1200 & 17.21326 & 0.5532 & 68.09 & 0.20643 & 0.06109 & 0.19718 & 0.51324 \\
\hline C4996 & 1220 & 17.68686 & 0.5802 & 69.74 & 0.20091 & 0.06104 & 0.19142 & 0.5443 \\
\hline C4996 & 1240 & 20.10511 & 0.5497 & 68.5 & 0.20147 & 0.06925 & 0.18919 & 0.51145 \\
\hline C4996 & 1260 & 21.41417 & 0.54365 & 68.71 & 0.19739 & 0.07207 & 0.18377 & 0.50655 \\
\hline C4996 & 1280 & 25.46976 & 0.53864 & 70.04 & 0.18387 & 0.07907 & 0.166 & 0.50628 \\
\hline C4996 & 1300 & 8.078034 & 0.60556 & 71.28 & 0.19435 & 0.02731 & 0.19242 & 0.57352 \\
\hline C4996 & 1320 & 15.57593 & 0.61044 & 71.77 & 0.19097 & 0.05128 & 0.18395 & 0.5798 \\
\hline C4996 & 1340 & 15.98691 & 0.63817 & 74.75 & 0.16786 & 0.04623 & 0.16137 & 0.6157 \\
\hline C4996 & 1360 & 19.6102 & 0.58309 & 70.67 & 0.19301 & 0.06478 & 0.18181 & 0.55022 \\
\hline C4996 & 1380 & 13.71393 & 0.61308 & 72.97 & 0.17955 & 0.04257 & 0.17444 & 0.5862 \\
\hline C4996 & 1400 & 7.977265 & 0.54348 & 68.38 & 0.20024 & 0.02779 & 0.19831 & 0.50525 \\
\hline C4996 & 1420 & 20.901 & 0.53476 & 69.72 & 0.18535 & 0.06613 & 0.17316 & 0.50161 \\
\hline C4996 & 1440 & 18.9102 & 0.53605 & 69.49 & 0.18782 & 0.06087 & 0.17768 & 0.50207 \\
\hline C4996 & 1450 & 21.3151 & 0.52865 & 70.08 & 0.18012 & 0.06547 & 0.16779 & 0.49702 \\
\hline
\end{tabular}


DTS-RPT-090, Rev. 0

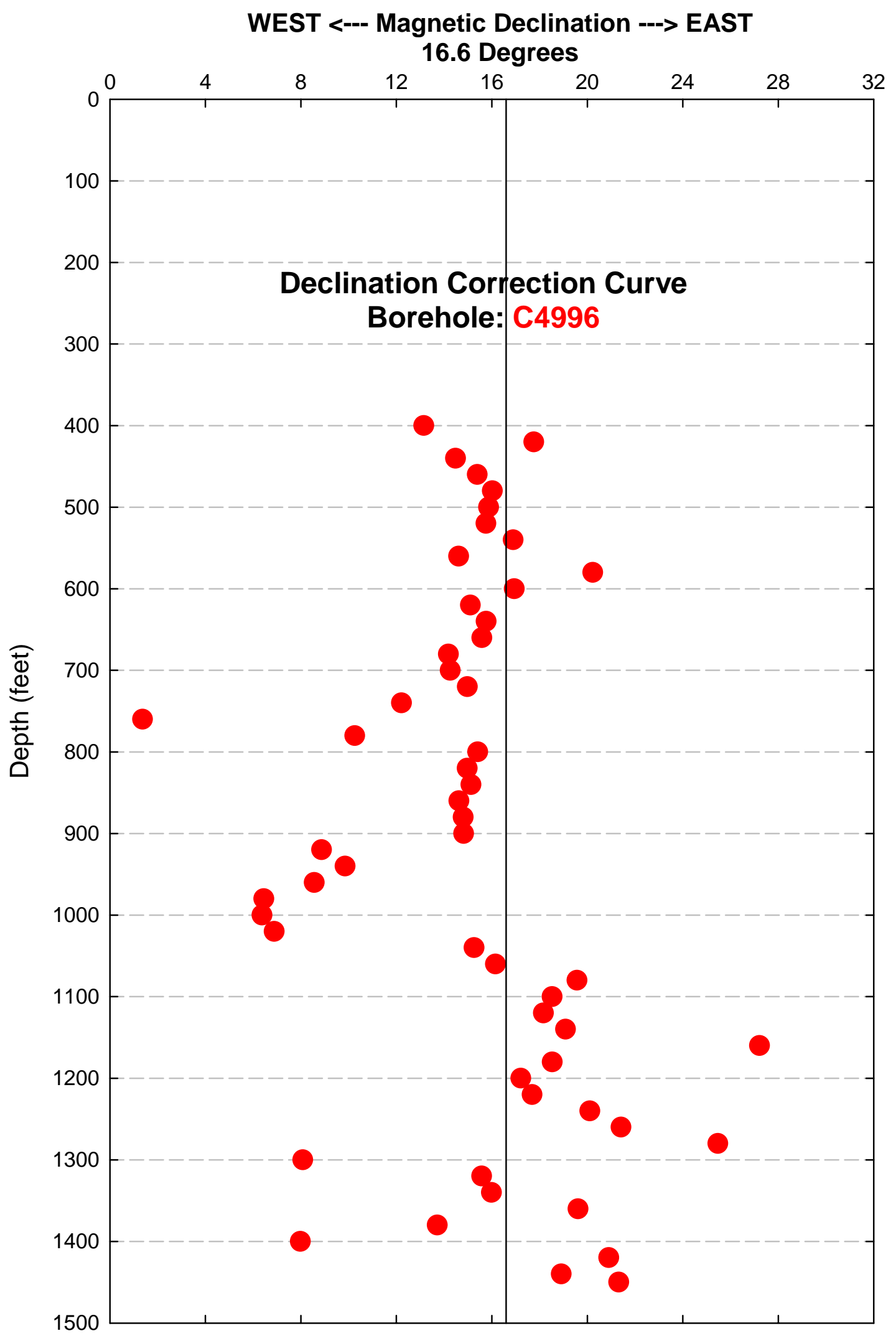

B-114 
DTS-RPT-090, Rev. 0

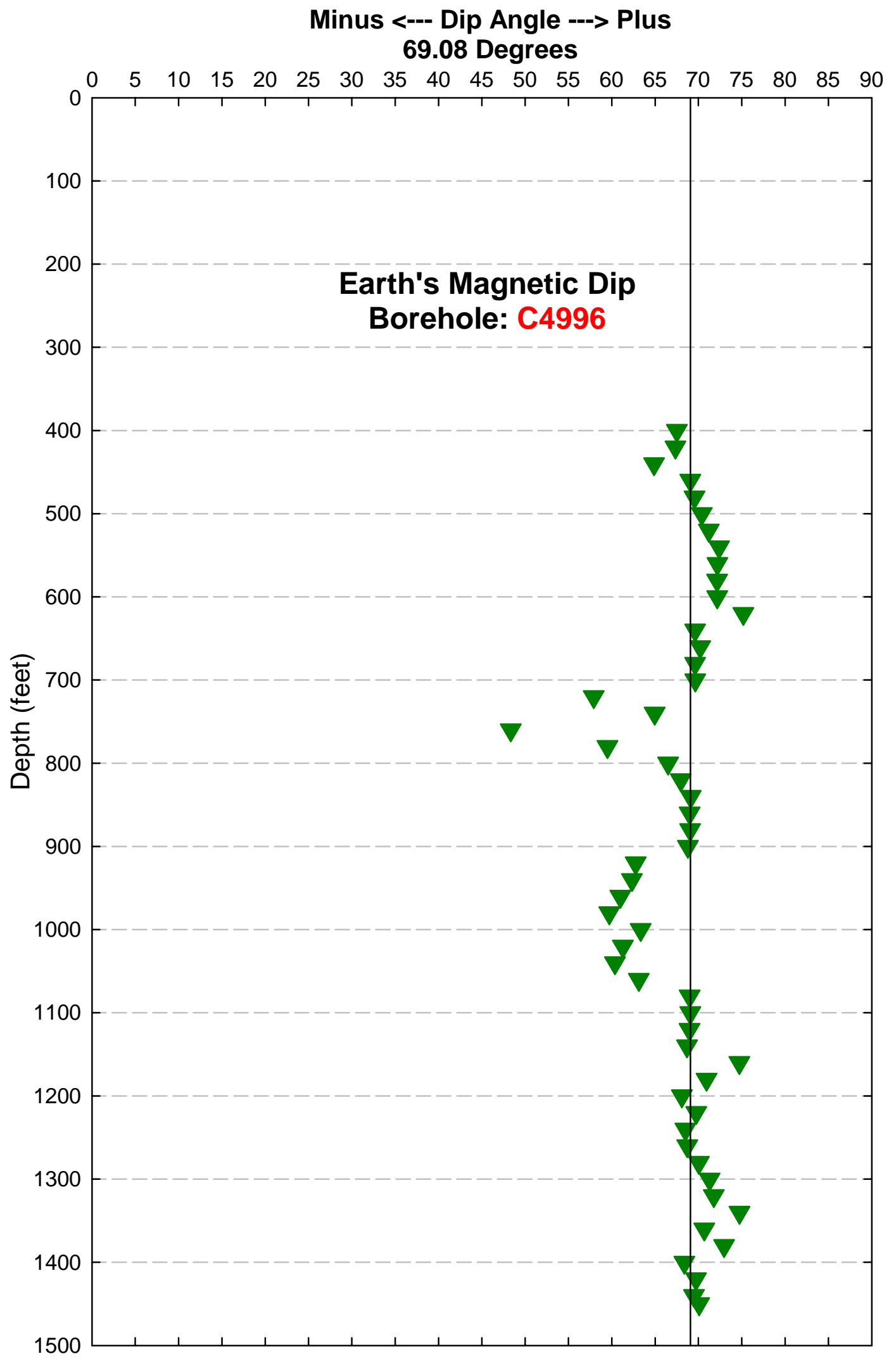


DTS-RPT-090, Rev. 0

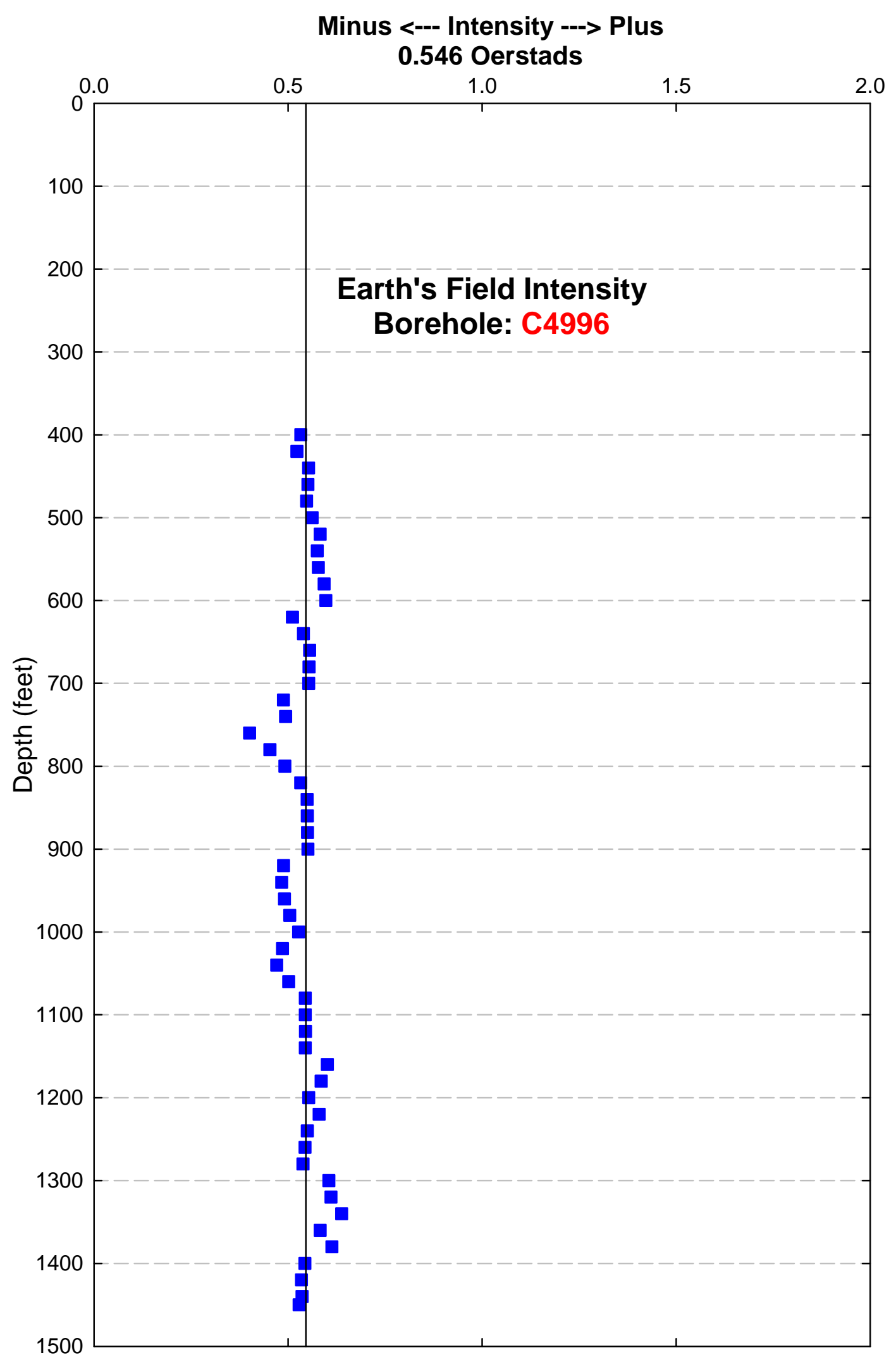

B-116 
DTS-RPT-090, Rev. 0

APPENDIX C

BOREHOLE C4997 
DTS-RPT-090, Rev. 0

This page intentionally left blank. 
DTS-RPT-090, Rev. 0

\section{C1.0 BOREHOLE C4997}

\section{C1.1 ENERGYSOLUTIONS AND PACIFIC NORTHWEST GEOPHYSICS GYROSCOPIC LOGS}

\begin{tabular}{|c|c|c|c|c|}
\hline \multicolumn{5}{|c|}{ Hole: C4997 } \\
\hline $\begin{array}{l}\text { Survey } \\
\text { Date }\end{array}$ & $\begin{array}{l}\text { Survey } \\
\text { Number }\end{array}$ & $\begin{array}{l}\text { Maximum } \\
\text { Depth } \\
\text { (feet) }\end{array}$ & $\begin{array}{l}\text { Inclination } \\
\text { From Vertical } \\
\text { (deg) }\end{array}$ & $\begin{array}{c}\text { Closure } \\
\text { Distance } \\
\text { (feet) }\end{array}$ \\
\hline $11 / 16 / 2006$ & $21^{*}$ & 1425 & 2.5 & 32 \\
\hline 11/4/2006 & $20 *$ & 1261 & 2.6 & 26 \\
\hline $10 / 8 / 2006$ & $19^{*}$ & 1416 & 1.5 & 33 \\
\hline $10 / 6 / 2006$ & $18 A^{*}$ & 1336 & 2.5 & 29 \\
\hline $10 / 1 / 2006$ & $17^{*}$ & 1237 & 1.3 & 23 \\
\hline 9/27/2006 & $16^{*}$ & 1117 & 1.1 & 23 \\
\hline $9 / 21 / 2006$ & $14^{*}$ & 1033 & 1 & 21 \\
\hline $9 / 17 / 2006$ & $13^{*}$ & 956 & 1.5 & 19 \\
\hline $9 / 12 / 2006$ & $12^{*}$ & 958 & 1.0 & 20 \\
\hline $9 / 5 / 2006$ & 11 & 782 & 0.8 & 14 \\
\hline 9/2/2006 & $10^{*}$ & 656 & 1.5 & 13 \\
\hline $8 / 27 / 2006$ & $9 *$ & 559 & 1.5 & 13 \\
\hline Casing & Cable-Tool & & & \\
\hline $8 / 17 / 2006$ & 8 & 371 & 3.1 & 7 \\
\hline $8 / 15 / 2006$ & 7 & 336 & 2.1 & 5 \\
\hline $8 / 9 / 2006$ & $6^{*}$ & 270 & 1.9 & 3 \\
\hline $8 / 8 / 2006$ & 5 & 235 & 2.5 & 1 \\
\hline $8 / 4 / 2006$ & 4 & 197 & 1.3 & 1 \\
\hline $8 / 3 / 2006$ & 3 & 175 & 1 & 1 \\
\hline $8 / 2 / 2006$ & 2 & 130 & 0.5 & 1.5 \\
\hline 8/1/2006 & 1 & 71 & 0.6 & 0.7 \\
\hline
\end{tabular}


DTS-RPT-090, Rev. 0

Hole: C4997

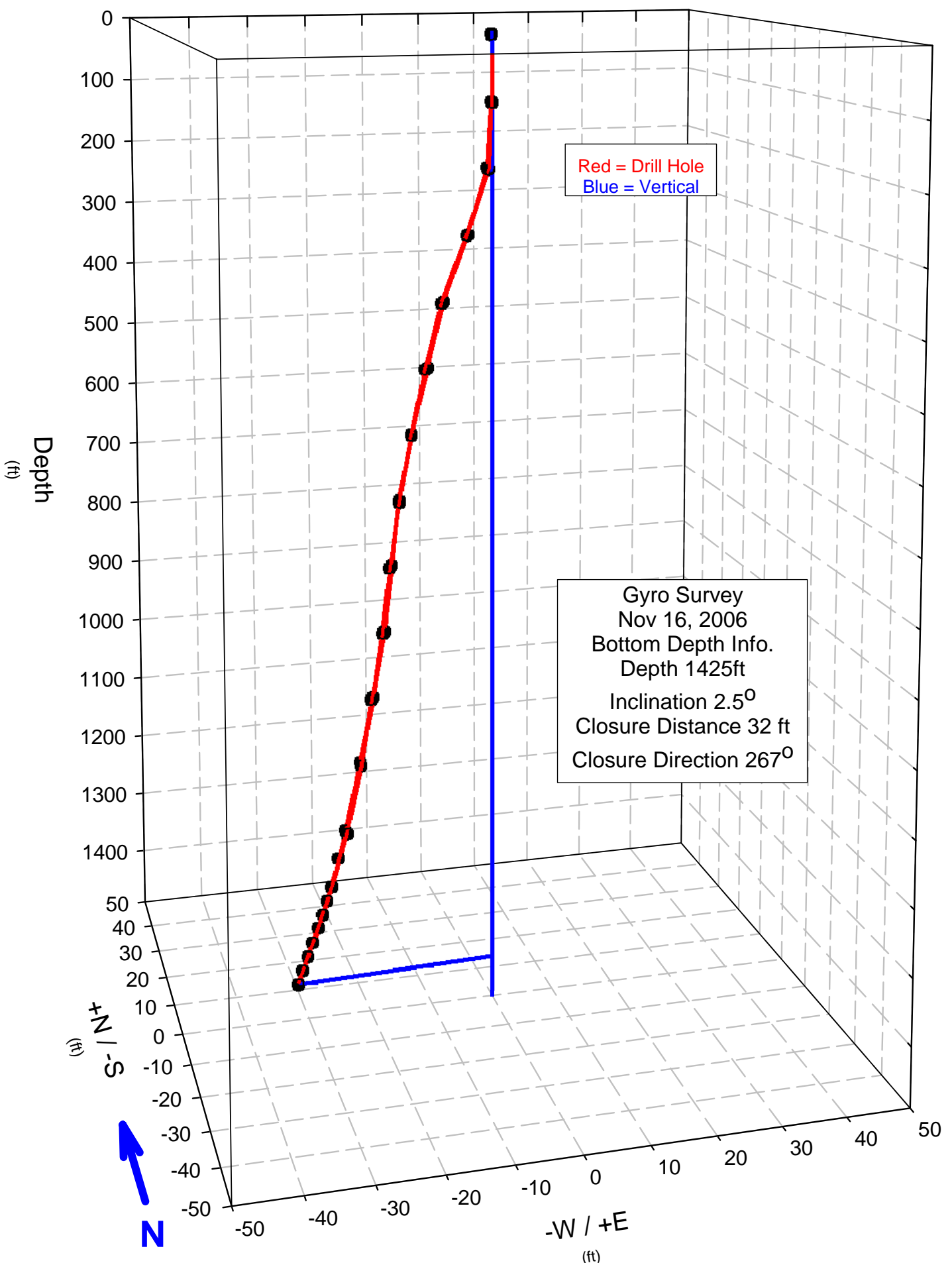

C-2 
DTS-RPT-090, Rev. 0

Hole: C4997 Survey Date: 11/16/2006

$\begin{array}{cccccccc}\begin{array}{c}\text { Measured } \\ \text { Depth } \\ \text { (feet) }\end{array} & \begin{array}{c}\text { TrueVert. } \\ \text { Depth } \\ \text { (feet) }\end{array} & \begin{array}{c}\text { Inclination } \\ \text { from Vert. } \\ \text { (deg) }\end{array} & \begin{array}{c}\text { Closure } \\ \text { Direction } \\ \text { (deg) }\end{array} & \begin{array}{c}\text { Closure } \\ \text { Distance } \\ \text { (feet) }\end{array} & \begin{array}{c}\text { Rectangular } \\ \text { Coordinates } \\ +N / \text {-S }\end{array} & \begin{array}{c}\text { Rectangular } \\ \text { Coordinates } \\ + \text { E/-W }\end{array} & \begin{array}{c}\text { Dog-Leg } \\ \text { Severity } \\ \text { o/100-ft }\end{array} \\ 105 & 5 & 0.46 & 217.35 & 0.05 & -0.04 & -0.03 & 12.2 \\ 205 & 105 & 0.55 & 190.24 & 0.54 & -0.53 & -0.1 & 0.8 \\ 305 & 204.99 & 1.38 & 284.14 & 0.47 & 0.11 & -0.45 & 1.9 \\ 405 & 404.92 & 2.91 & 293.4 & 3.94 & 1.56 & -3.62 & 2.2 \\ 505 & 504.84 & 1.81 & 282.47 & 7.84 & 1.69 & -7.66 & 1.4 \\ 605 & 604.78 & 1.34 & 279.49 & 10.46 & 1.72 & -10.31 & 0.9 \\ 705 & 704.75 & 1.33 & 278.59 & 12.72 & 1.9 & -12.57 & 0.6 \\ 805 & 804.74 & 0.74 & 275.93 & 14.74 & 1.52 & -14.66 & 0.2 \\ 905 & 904.73 & 0.81 & 275.91 & 16.23 & 1.67 & -16.14 & 0.8 \\ 1005 & 1004.72 & 1.32 & 274.55 & 17.45 & 1.81 & -17.36 & 0.7 \\ 1105 & 1104.7 & 1.03 & 272.57 & 21.09 & 1.53 & -19.18 & 0.6 \\ 1205 & 1204.66 & 2.08 & 270.42 & 23.61 & 0.17 & -21.07 & 0.7 \\ 1305 & 1304.6 & 1.8 & 269.18 & 26.95 & -0.39 & -23.61 & 1.3 \\ 1345 & 1344.57 & 2.68 & 268.52 & 28.48 & -0.74 & -28.44 & 0.3 \\ 1385 & 1384.53 & 2.67 & 267.5 & 30.26 & -1.32 & -30.24 & 2.2 \\ 1425 & 1424.49 & 2.54 & 266.69 & 32.02 & -1.85 & -31.96 & 1.4\end{array}$


DTS-RPT-090, Rev. 0

Hole: C4997

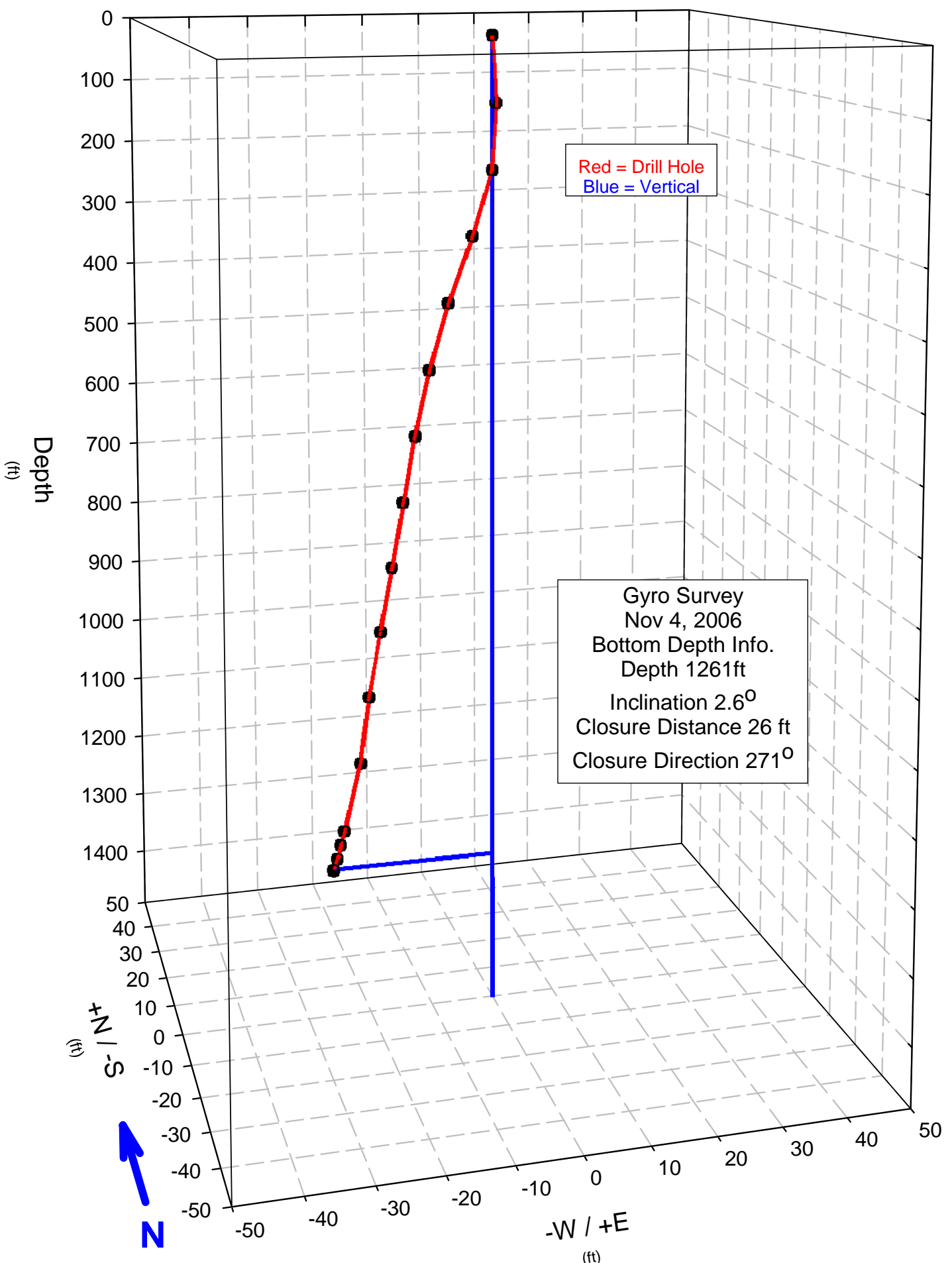


DTS-RPT-090, Rev. 0

Hole: C4997 Survey Date: 11/4/2006

$\begin{array}{cccccccc}\begin{array}{c}\text { Measured } \\ \text { Depth } \\ \text { (feet) }\end{array} & \begin{array}{c}\text { TrueVert. } \\ \text { Depth } \\ \text { (feet) }\end{array} & \begin{array}{c}\text { Inclination } \\ \text { from Vert. } \\ \text { (deg) }\end{array} & \begin{array}{c}\text { Closure } \\ \text { Direction } \\ \text { (deg) }\end{array} & \begin{array}{c}\text { Closure } \\ \text { Distance } \\ \text { (feet) }\end{array} & \begin{array}{c}\text { Rectangular } \\ \text { Coordinates } \\ \text { +N/-S }\end{array} & \begin{array}{c}\text { Rectangular } \\ \text { Coordinates } \\ \text { +E/-W }\end{array} & \begin{array}{c}\text { Dog-Leg } \\ \text { Severity } \\ \text { o/100-ft }\end{array} \\ 105 & 5 & 0.4 & 77.93 & 0.04 & 0.01 & 0.04 & 4.9 \\ 205 & 105 & 0.51 & 104.31 & 0.68 & -0.17 & 0.66 & 0.5 \\ 305 & 204.99 & 1.45 & 20.88 & 0.53 & 0.5 & 0.19 & 2 \\ 405 & 404.94 & 2.44 & 299.43 & 3.13 & 1.54 & -2.72 & 1.9 \\ 505 & 504.86 & 2.02 & 284.03 & 6.82 & 1.65 & -6.62 & 0.4 \\ 605 & 604.79 & 1.5 & 281.14 & 9.86 & 1.9 & -9.67 & 0.6 \\ 705 & 704.77 & 1.15 & 279.74 & 12.14 & 2.05 & -11.97 & 0.4 \\ 805 & 804.75 & 1.03 & 277.64 & 14.07 & 1.87 & -13.94 & 0.1 \\ 905 & 904.73 & 1.24 & 277.8 & 15.85 & 2.15 & -15.71 & 0.7 \\ 1005 & 1004.71 & 0.86 & 278.1 & 17.77 & 2.61 & -17.58 & 0.6 \\ 1105 & 1104.7 & 1.32 & 275.79 & 21.13 & 2.76 & -19.4 & 0.4 \\ 1205 & 1204.65 & 2.33 & 272.34 & 23.92 & 0.98 & -21.02 & 1 \\ 1225 & 1224.64 & 1.82 & 271.76 & 24.59 & 0.76 & -24.9 & 1.3 \\ 1245 & 1244.63 & 1.62 & 271.24 & 25.15 & 0.54 & -25.14 & 3.6 \\ 1261.5 & 1261.11 & 2.57 & 270.92 & 25.73 & 0.41 & -25.73 & 5.8\end{array}$


DTS-RPT-090, Rev. 0

Hole: C4997

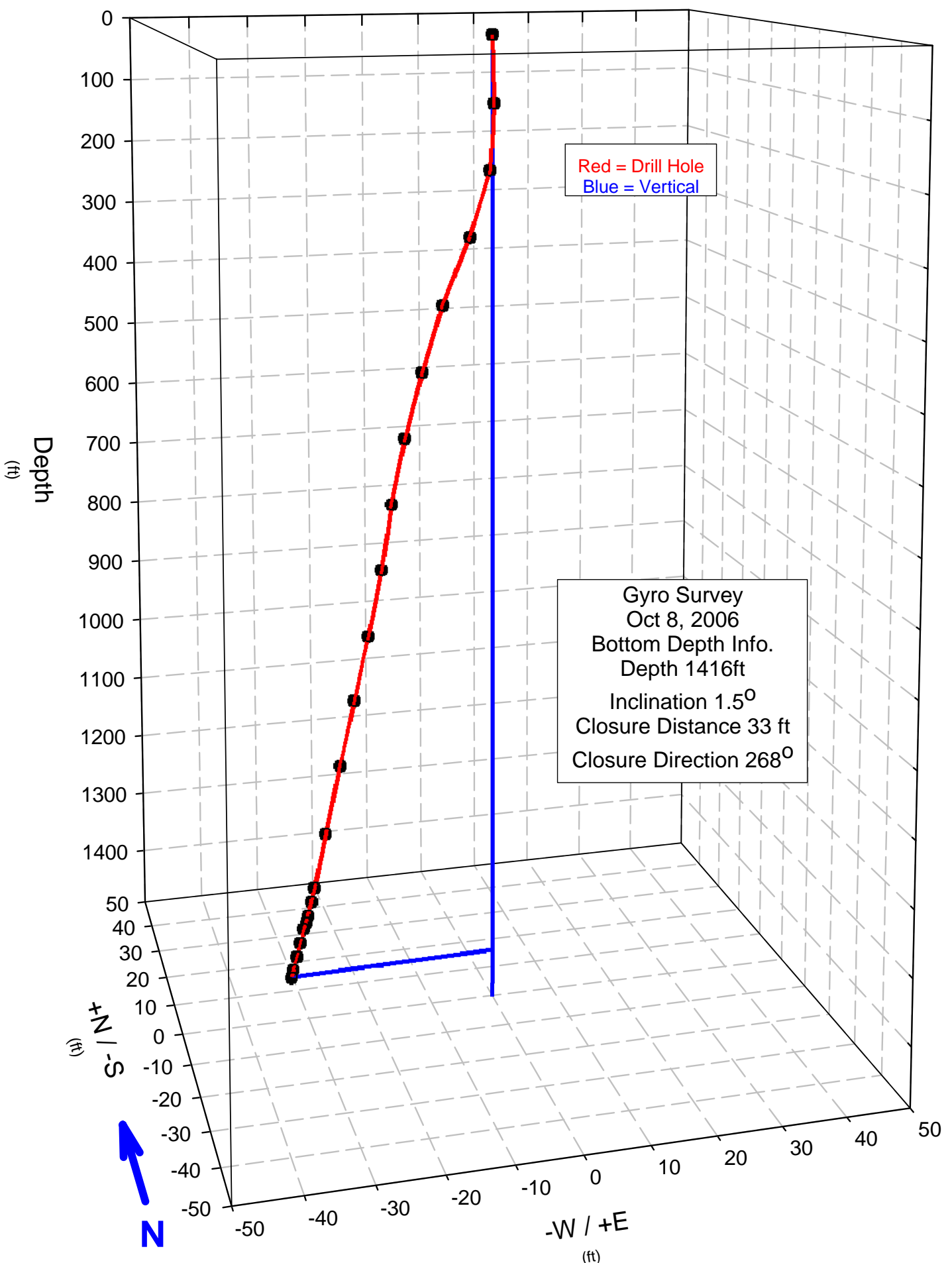


Hole: C4997 Survey Date: 10/8/2006

$\begin{array}{cccccccc}\begin{array}{c}\text { Measured } \\ \text { Depth } \\ \text { (feet) }\end{array} & \begin{array}{c}\text { TrueVert. } \\ \text { Depth } \\ \text { (feet) }\end{array} & \begin{array}{c}\text { Inclination } \\ \text { from Vert. } \\ \text { (deg) }\end{array} & \begin{array}{c}\text { Closure } \\ \text { Direction } \\ \text { (deg) }\end{array} & \begin{array}{c}\text { Closure } \\ \text { Distance } \\ \text { (feet) }\end{array} & \begin{array}{c}\text { Rectangular } \\ \text { Coordinates } \\ +N /-S\end{array} & \begin{array}{c}\text { Rectangular } \\ \text { Coordinates } \\ \text { +E/-W }\end{array} & \begin{array}{c}\text { Dog-Leg } \\ \text { Severity } \\ \text { o /100-ft }\end{array} \\ 105 & 5 & 0.41 & 168.5 & 0.05 & -0.05 & 0.01 & 12.7 \\ 205 & 105 & 0.58 & 175.8 & 0.88 & -0.88 & 0.06 & 0.3 \\ 305 & 204.99 & 1.01 & 210.75 & 1.07 & -0.92 & -0.55 & 1.5 \\ 405 & 404.94 & 2.76 & 263.51 & 3.75 & -0.42 & -3.72 & 1.9 \\ 505 & 504.79 & 2.11 & 268.8 & 7.96 & -0.17 & -7.96 & 0.7 \\ 605 & 604.75 & 1.59 & 272.15 & 11.13 & 0.42 & -11.12 & 0.6 \\ 705 & 704.73 & 0.88 & 273 & 13.9 & 0.73 & -13.88 & 0.6 \\ 805 & 804.72 & 1.09 & 273.53 & 16.03 & 0.99 & -16 & 1 \\ 905 & 904.69 & 1.44 & 273.78 & 17.66 & 1.14 & -17.62 & 0.7 \\ 1005 & 1004.67 & 1.16 & 274.98 & 22.03 & 1.31 & -19.76 & 0.7 \\ 1105 & 1104.64 & 1.66 & 274.18 & 24.38 & 1.91 & -21.95 & 0.3 \\ 1205 & 1204.6 & 1.47 & 271.87 & 26.91 & 0.88 & -24.32 & 0.9 \\ 1285 & 1284.57 & 1.56 & 270.23 & 28.86 & 0.12 & -26.89 & 0.3 \\ 1305 & 1304.56 & 1.85 & 269.86 & 29.43 & -0.07 & -29.43 & 0.2 \\ 1325 & 1324.55 & 1.86 & 269.49 & 30.05 & -0.27 & -30.04 & 0.1 \\ 1335 & 1334.55 & 2.04 & 269.3 & 30.37 & -0.37 & -30.37 & 1.8 \\ 1345 & 1344.54 & 2.03 & 269.12 & 30.71 & -0.47 & -30.71 & 0.4 \\ 1365 & 1364.53 & 1.83 & 268.8 & 31.36 & -0.66 & -31.36 & 1 \\ 1385 & 1384.52 & 1.76 & 268.56 & 31.98 & -0.81 & -31.97 & 0.7 \\ 1405 & 1404.51 & 1.64 & 268.41 & 32.56 & -0.91 & -32.55 & 0.9 \\ 1416 & 1415.51 & 1.46 & 268.3 & 32.85 & -0.98 & -32.84 & 3.7\end{array}$


DTS-RPT-090, Rev. 0

Hole: C4997

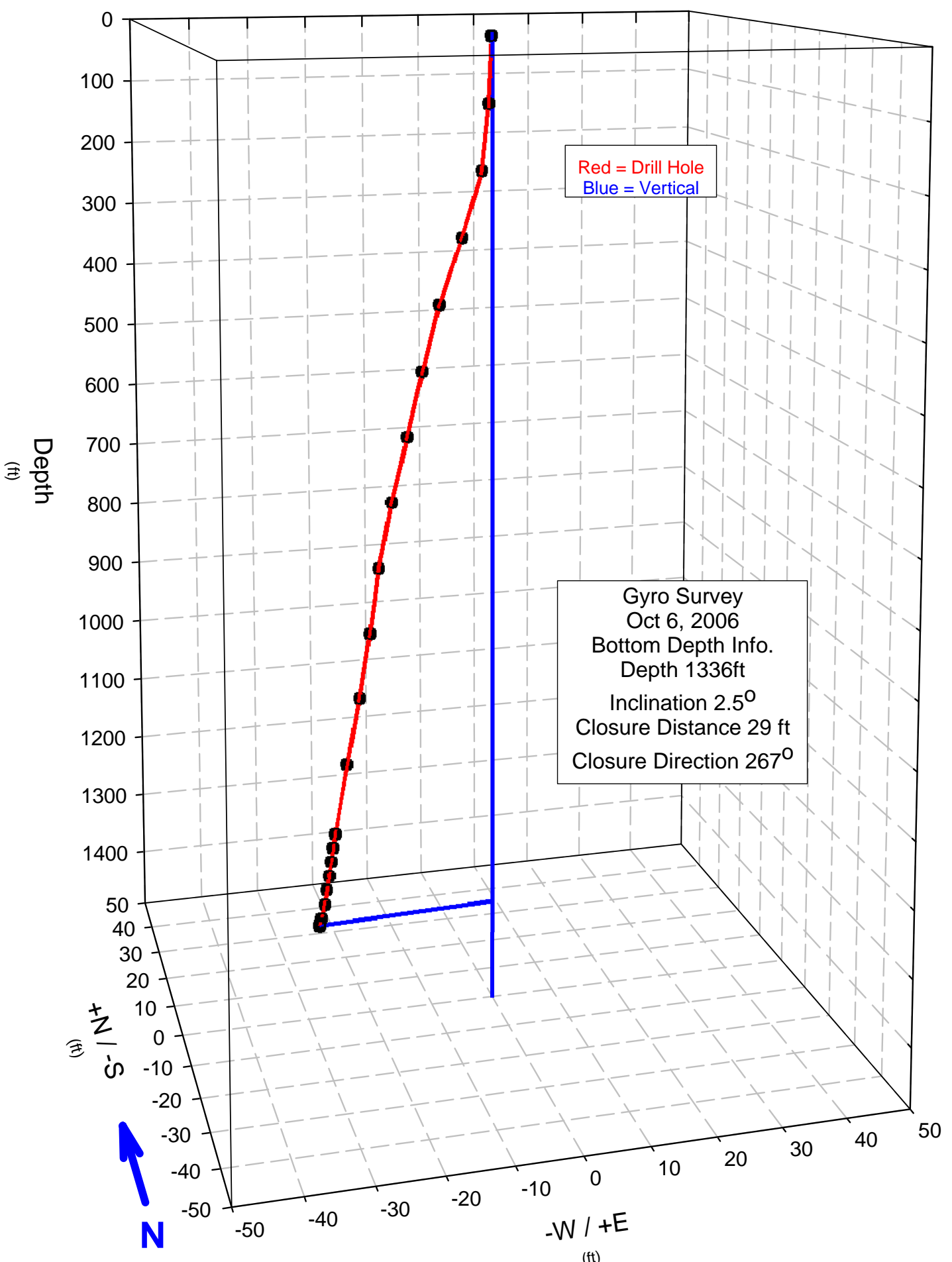


Hole: C4997 Survey Date: 10/6/2006

$\begin{array}{cccccccc}\begin{array}{c}\text { Measured } \\ \text { Depth } \\ \text { (feet) }\end{array} & \begin{array}{c}\text { TrueVert. } \\ \text { Depth } \\ \text { (feet) }\end{array} & \begin{array}{c}\text { Inclination } \\ \text { from Vert. } \\ \text { (deg) }\end{array} & \begin{array}{c}\text { Closure } \\ \text { Direction } \\ \text { (deg) }\end{array} & \begin{array}{c}\text { Closure } \\ \text { Distance } \\ \text { (feet) }\end{array} & \begin{array}{c}\text { Rectangular } \\ \text { Coordinates } \\ + \text { N/-S }\end{array} & \begin{array}{c}\text { Rectangular } \\ \text { Coordinates } \\ + \text { E/-W }\end{array} & \begin{array}{c}\text { Dog-Leg } \\ \text { Severity } \\ \text { o/100-ft }\end{array} \\ 105 & 5 & 0.56 & 309.12 & 0.04 & 0.02 & -0.03 & 8.9 \\ 205 & 105 & 0.59 & 241.84 & 0.67 & -0.32 & -0.59 & 0.9 \\ 305 & 204.99 & 1.46 & 273.54 & 1.58 & 0.1 & -1.58 & 1.9 \\ 405 & 404.93 & 2.32 & 288.45 & 4.67 & 1.48 & -4.43 & 1.3 \\ 505 & 504.83 & 1.93 & 281.49 & 8.23 & 1.64 & -8.06 & 1 \\ 605 & 604.8 & 1.3 & 278.36 & 10.94 & 1.59 & -10.82 & 0.9 \\ 705 & 704.77 & 1.37 & 279.63 & 13.36 & 2.23 & -13.17 & 0.2 \\ 805 & 804.74 & 1.16 & 278.01 & 15.86 & 2.76 & -15.62 & 0.3 \\ 905 & 904.73 & 0.56 & 277.72 & 19.44 & 2.61 & -17.8 & 0.4 \\ 1005 & 1004.72 & 1.38 & 278.33 & 21.12 & 3.06 & -19.27 & 0.7 \\ 1105 & 1104.69 & 1.58 & 276.29 & 23.28 & 2.55 & -23.9 & 0.8 \\ 1205 & 1204.64 & 1.81 & 271.61 & 25.46 & 0.72 & -25.45 & 1.4 \\ 1225 & 1224.64 & 1.46 & 270.74 & 25.88 & 0.34 & -25.88 & 0.2 \\ 1245 & 1244.63 & 1.68 & 269.94 & 26.28 & -0.03 & -26.28 & 1.6 \\ 1265 & 1264.62 & 1.5 & 269.19 & 26.71 & -0.38 & -26.71 & 1 \\ 1285 & 1284.61 & 1.48 & 268.48 & 27.11 & -0.72 & -27.1 & 0.2 \\ 1305 & 1304.61 & 1.85 & 267.76 & 27.58 & -1.08 & -27.56 & 1.9 \\ 1325 & 1324.59 & 2.03 & 267.04 & 28.16 & -1.45 & -28.12 & 1.3 \\ 1333 & 1332.59 & 2.43 & 266.81 & 28.45 & -1.58 & -28.4 & 7.5 \\ 1334 & 1333.59 & 2.45 & 266.78 & 28.49 & -1.6 & -28.44 & 2.6 \\ 1335 & 1334.59 & 2.49 & 266.76 & 28.53 & -1.61 & -28.48 & 6.2 \\ 1336 & 1335.59 & 2.48 & 266.73 & 28.57 & -1.63 & -28.52 & 0.9\end{array}$


DTS-RPT-090, Rev. 0

Hole: C4997

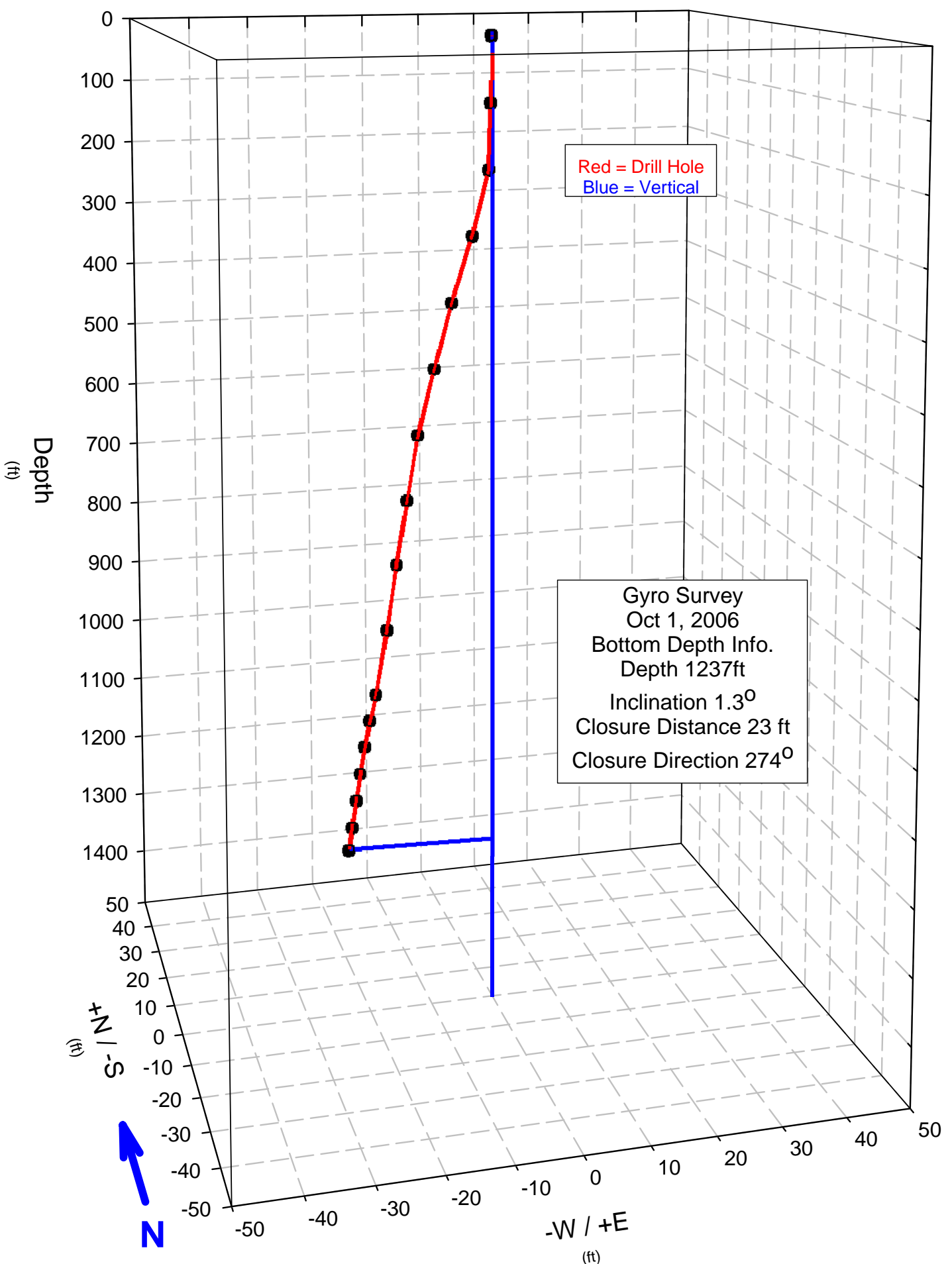


DTS-RPT-090, Rev. 0

Hole: C4997 Survey Date: 10/1/2006

\begin{tabular}{|c|c|c|c|c|c|c|c|}
\hline Measured & TrueVert. & Inclination & Closure & Closure & Rectangular & Rectangular & Dog-Leg \\
\hline $\begin{array}{l}\text { Depth } \\
\text { (feet) }\end{array}$ & $\begin{array}{l}\text { Depth } \\
\text { (feet) }\end{array}$ & $\begin{array}{c}\text { from Vert. } \\
\text { (deq) }\end{array}$ & $\begin{array}{l}\text { Direction } \\
\text { (deq) }\end{array}$ & $\begin{array}{l}\text { Distance } \\
\text { (feet) }\end{array}$ & $\begin{array}{c}\text { Coordinates } \\
+\mathrm{N} / \mathrm{S}\end{array}$ & $\begin{array}{c}\text { Coordinates } \\
+E /-W\end{array}$ & $\begin{array}{l}\text { Severity } \\
0 / 100-\mathrm{ft}\end{array}$ \\
\hline 5 & 5 & 0.69 & 216.7 & 0.08 & -0.06 & -0.05 & 7.4 \\
\hline 6 & 6 & 0.49 & 218.91 & 0.08 & -0.07 & -0.05 & 43.9 \\
\hline 105 & 105 & 0.33 & 231.18 & 0.24 & -0.15 & -0.19 & 0.8 \\
\hline 205 & 204.99 & 1.12 & 336.89 & 0.79 & 0.73 & -0.31 & 1.3 \\
\hline 305 & 304.95 & 2.34 & 302.22 & 3.26 & 1.74 & -2.76 & 2.1 \\
\hline 405 & 404.9 & 1.41 & 288.28 & 6.33 & 1.99 & -6.01 & 0.9 \\
\hline 505 & 504.86 & 1.78 & 283.88 & 9.06 & 2.17 & -8.79 & 0.4 \\
\hline 605 & 604.82 & 1.21 & 282.95 & 11.63 & 2.6 & -11.33 & 0.8 \\
\hline 705 & 704.81 & 0.81 & 282.73 & 13.35 & 2.94 & -13.02 & 0.6 \\
\hline 805 & 804.79 & 1.22 & 282.44 & 15.08 & 3.25 & -14.72 & 0.6 \\
\hline 905 & 904.78 & 0.7 & 281.71 & 16.64 & 3.38 & -16.3 & 0.8 \\
\hline 1005 & 1004.76 & 1.47 & 280.75 & 18.44 & 3.44 & -18.12 & 1 \\
\hline 1045 & 1044.75 & 1.21 & 280.84 & 19.38 & 3.64 & -19.03 & 0.6 \\
\hline 1085 & 1084.74 & 1.36 & 280.46 & 20.25 & 3.68 & -19.91 & 1.2 \\
\hline 1125 & 1124.73 & 1.44 & 278.95 & 21 & 3.27 & -20.75 & 2.2 \\
\hline 1165 & 1164.72 & 1.3 & 277.21 & 21.69 & 2.72 & -21.52 & 1.1 \\
\hline 1205 & 1204.71 & 1.71 & 275.36 & 22.44 & 2.1 & -22.34 & 1.7 \\
\hline 1237.5 & 1237.2 & 1.29 & 273.78 & 23.02 & 1.52 & -22.97 & 1.4 \\
\hline
\end{tabular}


DTS-RPT-090, Rev. 0

Hole: C4997

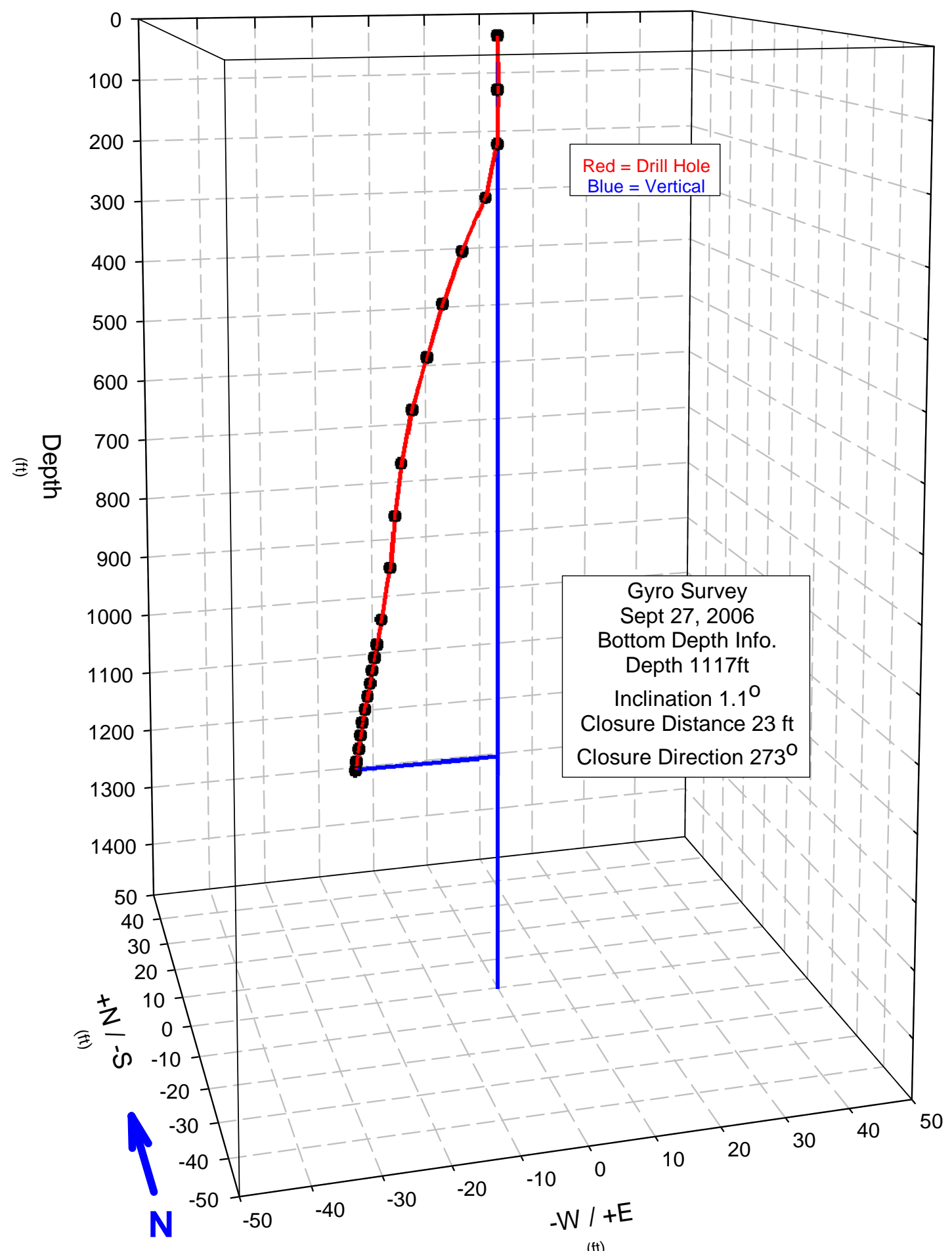


Hole: C4997 Survey Date: 9/27/2006

$\begin{array}{cccccccc}\begin{array}{c}\text { Measured } \\ \text { Depth } \\ \text { (feet) }\end{array} & \begin{array}{c}\text { TrueVert. } \\ \text { Depth } \\ \text { (feet) }\end{array} & \begin{array}{c}\text { Inclination } \\ \text { from Vert. } \\ \text { (deg) }\end{array} & \begin{array}{c}\text { Closure } \\ \text { Direction } \\ \text { (deg) }\end{array} & \begin{array}{c}\text { Closure } \\ \text { Distance } \\ \text { (feet) }\end{array} & \begin{array}{c}\text { Rectangular } \\ \text { Coordinates } \\ \text { +N/-S }\end{array} & \begin{array}{c}\text { Rectangular } \\ \text { Coordinates } \\ + \text { E/-W }\end{array} & \begin{array}{c}\text { Dog-Leg } \\ \text { Severity } \\ \text { o/100-ft }\end{array} \\ 85 & 5 & 0.93 & 192.08 & 0.07 & -0.07 & -0.01 & 8.3 \\ 165 & 84.99 & 0.68 & 189.95 & 1.18 & -1.16 & -0.2 & 0.5 \\ 245 & 164.99 & 0.14 & 194.03 & 1.55 & -1.5 & -0.38 & 1 \\ 325 & 324.96 & 2.63 & 240.2 & 2.53 & -1.26 & -2.2 & 3.3 \\ 405 & 404.82 & 2.73 & 262.78 & 5.95 & -0.75 & -5.9 & 0.4 \\ 485 & 484.78 & 1.61 & 269.28 & 8.86 & -0.11 & -8.86 & 1.4 \\ 565 & 564.74 & 1.53 & 271.43 & 11.32 & 0.28 & -11.32 & 0.5 \\ 645 & 644.72 & 1.05 & 271.37 & 13.75 & 0.33 & -13.74 & 0.6 \\ 725 & 724.71 & 0.61 & 269.56 & 15.53 & 0.1 & -15.53 & 0.6 \\ 805 & 804.71 & 0.67 & 270.18 & 17.48 & -0.13 & -16.67 & 0.6 \\ 885 & 884.69 & 1.35 & 271.88 & 18.77 & 0.05 & -17.48 & 0.6 \\ 925 & 924.69 & 0.84 & 272.64 & 19.49 & 0.9 & -18.76 & 0.9 \\ 945 & 944.68 & 1.54 & 272.93 & 19.88 & 1.02 & -19.46 & 1.3 \\ 965 & 964.68 & 0.99 & 272.95 & 20.32 & 1.05 & -20.29 & 3.9 \\ 985 & 984.67 & 0.81 & 272.97 & 20.62 & 1.07 & -20.6 & 2.4 \\ 1005 & 1004.67 & 1.41 & 273.11 & 21.01 & 1.14 & -20.98 & 3.2 \\ 1025 & 1024.67 & 1.37 & 272.97 & 21.48 & 1.11 & -21.45 & 2.5 \\ 1045 & 1044.66 & 0.92 & 272.66 & 21.86 & 1.01 & -21.84 & 2.3 \\ 1065 & 1064.66 & 1.02 & 272.43 & 22.19 & 0.94 & -22.17 & 0.7 \\ 1085 & 1084.65 & 1.2 & 272.18 & 22.56 & 0.86 & -22.54 & 1 \\ 1105 & 1104.65 & 1 & 271.84 & 22.92 & 0.74 & -22.91 & 1.3 \\ 1117.5 & 1117.15 & 1.1 & 271.58 & 23.12 & 0.64 & -23.11 & 1.3\end{array}$


DTS-RPT-090, Rev. 0

Hole: C4997

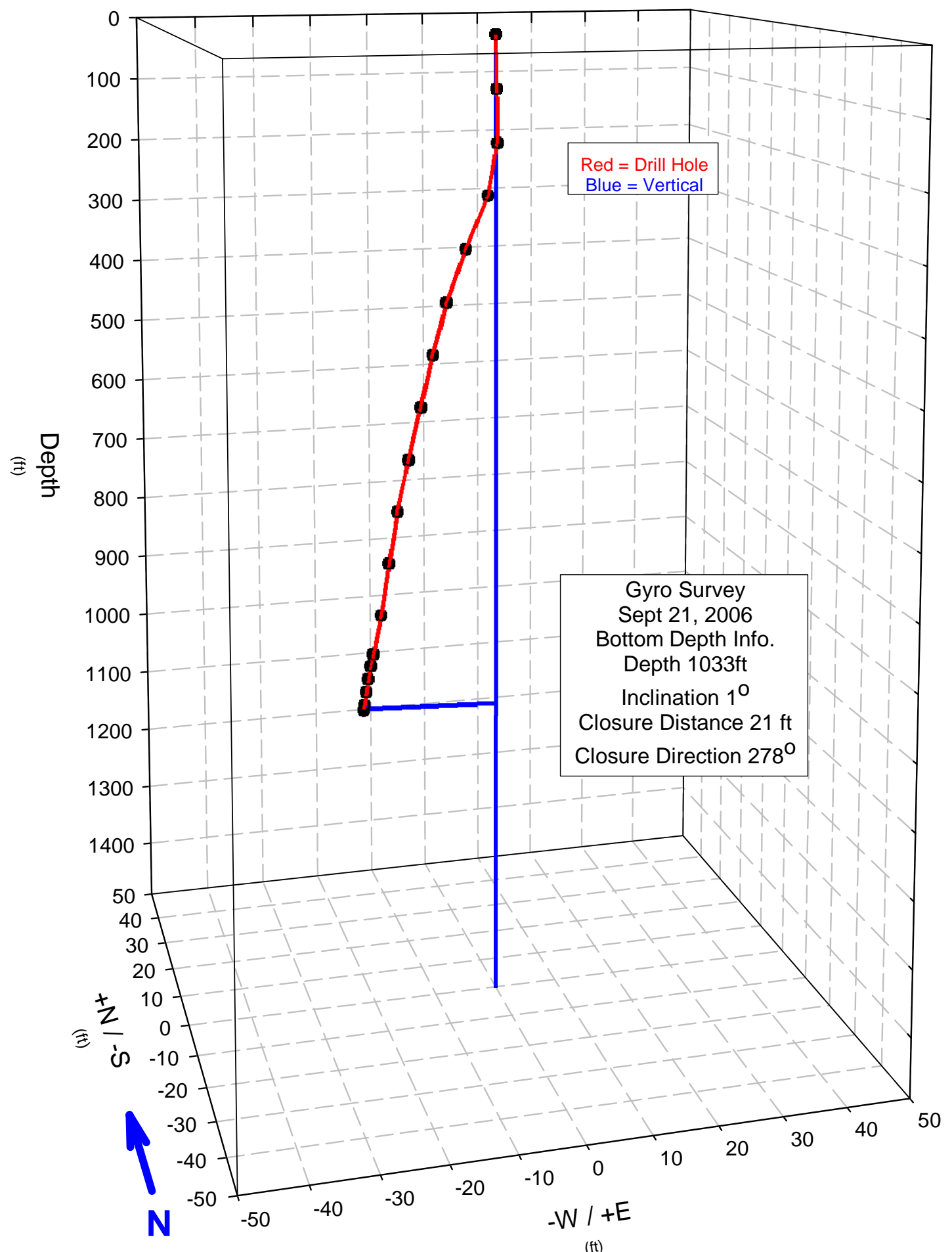


DTS-RPT-090, Rev. 0

Hole: C4997 Survey Date: 8/21/2006

\begin{tabular}{|c|c|c|c|c|c|c|c|}
\hline $\begin{array}{l}\text { Measured } \\
\text { Depth } \\
\text { (feet) }\end{array}$ & $\begin{array}{l}\text { TrueVert. } \\
\text { Depth } \\
\text { (feet) }\end{array}$ & $\begin{array}{l}\text { Inclination } \\
\text { from Vert. } \\
\text { (deg) }\end{array}$ & $\begin{array}{l}\text { Closure } \\
\text { Direction } \\
\text { (deg) }\end{array}$ & $\begin{array}{c}\text { Closure } \\
\text { Distance } \\
\text { (feet) }\end{array}$ & $\begin{array}{c}\text { Rectangular } \\
\text { Coordinates } \\
+\mathrm{N} / \mathrm{S} S\end{array}$ & $\begin{array}{c}\text { Rectangular } \\
\text { Coordinates } \\
+E /-W\end{array}$ & $\begin{array}{l}\text { Dog-Leg } \\
\text { Severity } \\
0 / 100-f t\end{array}$ \\
\hline 5 & 5 & 0.45 & 141.4 & 0.03 & -0.03 & 0.02 & 12.6 \\
\hline 85 & 85 & 0.4 & 174.52 & 0.46 & -0.46 & 0.04 & 0.7 \\
\hline 165 & 165 & 0.71 & 145.99 & 0.45 & -0.37 & 0.25 & 1.4 \\
\hline 245 & 244.97 & 2.61 & 270.38 & 1.18 & 0.01 & -1.18 & 4 \\
\hline 325 & 324.89 & 2.58 & 271.43 & 4.8 & 0.12 & -4.8 & 0.1 \\
\hline 405 & 404.83 & 1.77 & 272.62 & 7.83 & 0.36 & -7.82 & 1.1 \\
\hline 485 & 484.8 & 1.42 & 275.02 & 10.02 & 0.88 & -9.98 & 0.5 \\
\hline 565 & 564.78 & 1.38 & 275.52 & 11.93 & 1.15 & -11.88 & 0.6 \\
\hline 645 & 644.75 & 1.46 & 275.42 & 13.9 & 1.31 & -13.83 & 0.4 \\
\hline 725 & 724.73 & 1.12 & 276.82 & 15.65 & 1.86 & -15.54 & 0.6 \\
\hline 805 & 804.72 & 0.82 & 277.44 & 16.95 & 2.19 & -16.81 & 0.7 \\
\hline 885 & 884.71 & 1.1 & 276.79 & 18.28 & 2.16 & -18.15 & 0.4 \\
\hline 945 & 944.7 & 1.35 & 276.9 & 19.54 & 2.35 & -19.4 & 0.8 \\
\hline 965 & 964.69 & 1.31 & 277.18 & 20 & 2.5 & -19.84 & 0.5 \\
\hline 985 & 984.69 & 0.96 & 277.35 & 20.39 & 2.61 & -20.22 & 2.1 \\
\hline 1005 & 1004.69 & 0.81 & 277.37 & 20.69 & 2.65 & -20.52 & 0.7 \\
\hline 1025 & 1024.68 & 0.71 & 277.45 & 20.96 & 2.72 & -20.78 & 0.9 \\
\hline 1033 & 1032.68 & 0.96 & 277.48 & 21.07 & 2.74 & -20.89 & 3.6 \\
\hline
\end{tabular}


DTS-RPT-090, Rev. 0

Hole: C4997

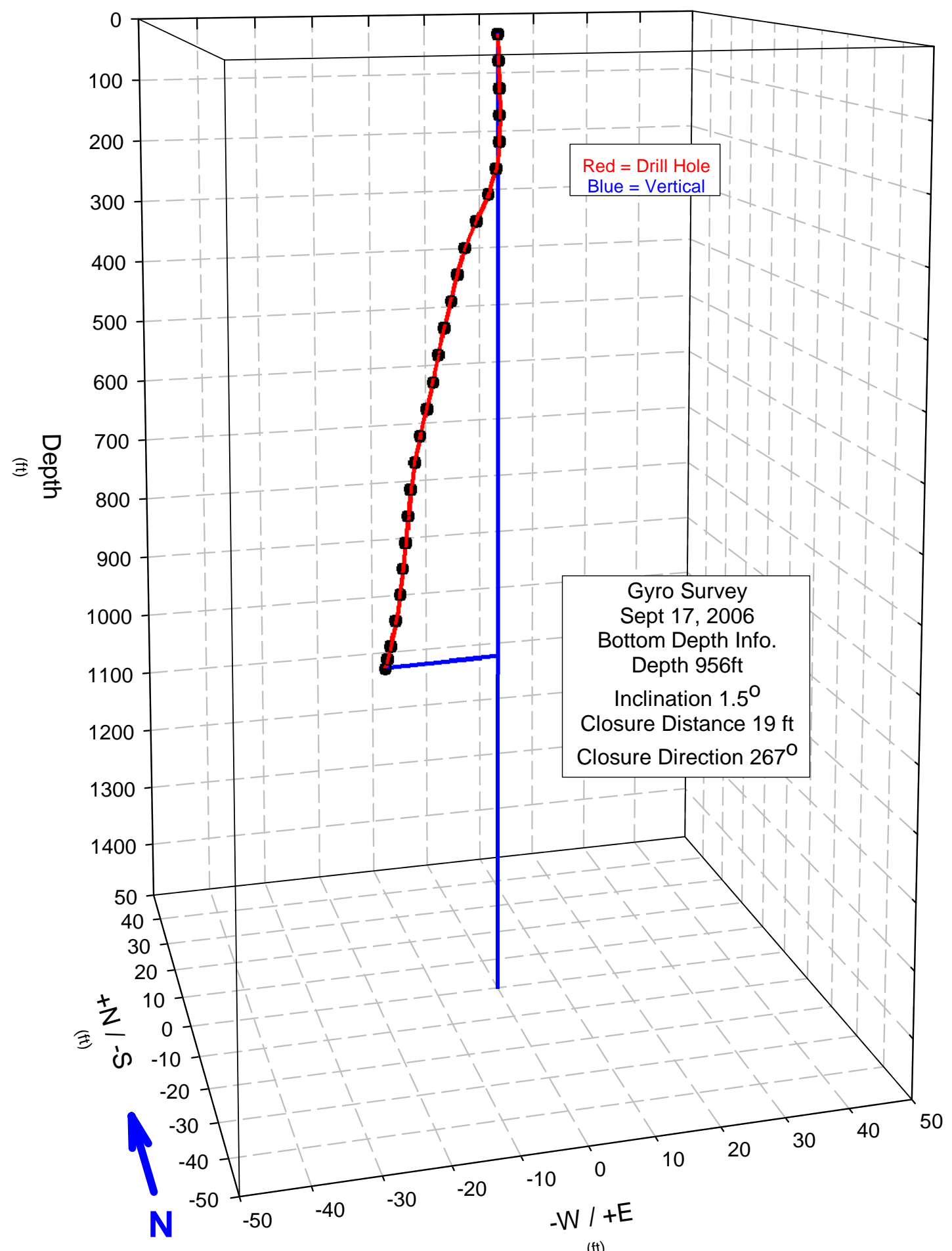

C-16 
Hole: C4997 Survey Date: 9/17/2006

$\begin{array}{cccccccc}\begin{array}{c}\text { Measured } \\ \text { Depth } \\ \text { (feet) }\end{array} & \begin{array}{c}\text { TrueVert. } \\ \text { Depth } \\ \text { (feet) }\end{array} & \begin{array}{c}\text { Inclination } \\ \text { from Vert. } \\ \text { (deg) }\end{array} & \begin{array}{c}\text { Closure } \\ \text { Direction } \\ \text { (deg) }\end{array} & \begin{array}{c}\text { Closure } \\ \text { Distance } \\ \text { (feet) }\end{array} & \begin{array}{c}\text { Rectangular } \\ \text { Coordinates } \\ + \text { N/-S }\end{array} & \begin{array}{c}\text { Rectangular } \\ \text { Coordinates } \\ + \text { E/-W }\end{array} & \begin{array}{c}\text { Dog-Leg } \\ \text { Severity } \\ \text { O/100-ft }\end{array} \\ 42 & 2 & 0.54 & 131.78 & 0.03 & -0.02 & 0.02 & 33.7 \\ 82 & 42 & 0.61 & 169.65 & 0.41 & -0.41 & 0.07 & 0.6 \\ 122 & 121.99 & 0.66 & 173.78 & 0.85 & -0.85 & 0.09 & 0.3 \\ 162 & 161.99 & 0.37 & 177.41 & 1.24 & -1.24 & 0.06 & 0.8 \\ 202 & 201.99 & 1.28 & 204.38 & 1.28 & -1.28 & -0.05 & 2.1 \\ 242 & 241.97 & 2.59 & 262.46 & 0.87 & -0.79 & -0.36 & 2.3 \\ 282 & 281.92 & 2.89 & 273.59 & 3.36 & -0.2 & -1.49 & 4.5 \\ 322 & 321.88 & 2.23 & 275.35 & 5.14 & 0.48 & -3.35 & 1 \\ 362 & 361.86 & 1.44 & 274.33 & 6.41 & 0.48 & -5.12 & 1.7 \\ 402 & 401.84 & 1.8 & 271.57 & 7.48 & 0.21 & -7.48 & 2.4 \\ 442 & 441.83 & 1.56 & 269.65 & 8.62 & -0.05 & -8.62 & 0.9 \\ 482 & 481.81 & 1.51 & 268.3 & 9.66 & -0.29 & -9.66 & 0.7 \\ 522 & 521.8 & 1.31 & 266.87 & 10.61 & -0.58 & -10.6 & 0.5 \\ 562 & 561.79 & 1.75 & 266.05 & 11.67 & -0.8 & -11.64 & 1.2 \\ 602 & 601.77 & 1.54 & 265.48 & 12.81 & -1.01 & -12.77 & 0.6 \\ 642 & 641.76 & 1.21 & 264.81 & 13.76 & -1.24 & -13.7 & 0.9 \\ 682 & 681.75 & 1.05 & 264.01 & 14.52 & -1.52 & -14.44 & 0.5 \\ 722 & 721.75 & 0.49 & 263.31 & 15.02 & -1.75 & -14.92 & 1.4 \\ 762 & 761.74 & 0.82 & 262.85 & 15.46 & -1.92 & -15.34 & 0.9 \\ 802 & 801.74 & 0.6 & 262.83 & 15.95 & -1.99 & -15.82 & 0.9 \\ 842 & 841.74 & 0.8 & 263.51 & 16.39 & -1.85 & -16.28 & 0.8 \\ 882 & 881.73 & 1.01 & 264.67 & 16.93 & -1.57 & -16.85 & 0.5 \\ 922 & 921.72 & 1.52 & 265.77 & 17.74 & -1.31 & -17.69 & 1.5 \\ 942 & 941.72 & 1.58 & 266.32 & 18.25 & -1.17 & -18.21 & 0.6 \\ 956.5 & 956.21 & 1.42 & 266.76 & 18.6 & -1.05 & -18.57 & 1.4\end{array}$


DTS-RPT-090, Rev. 0

Hole: C4997

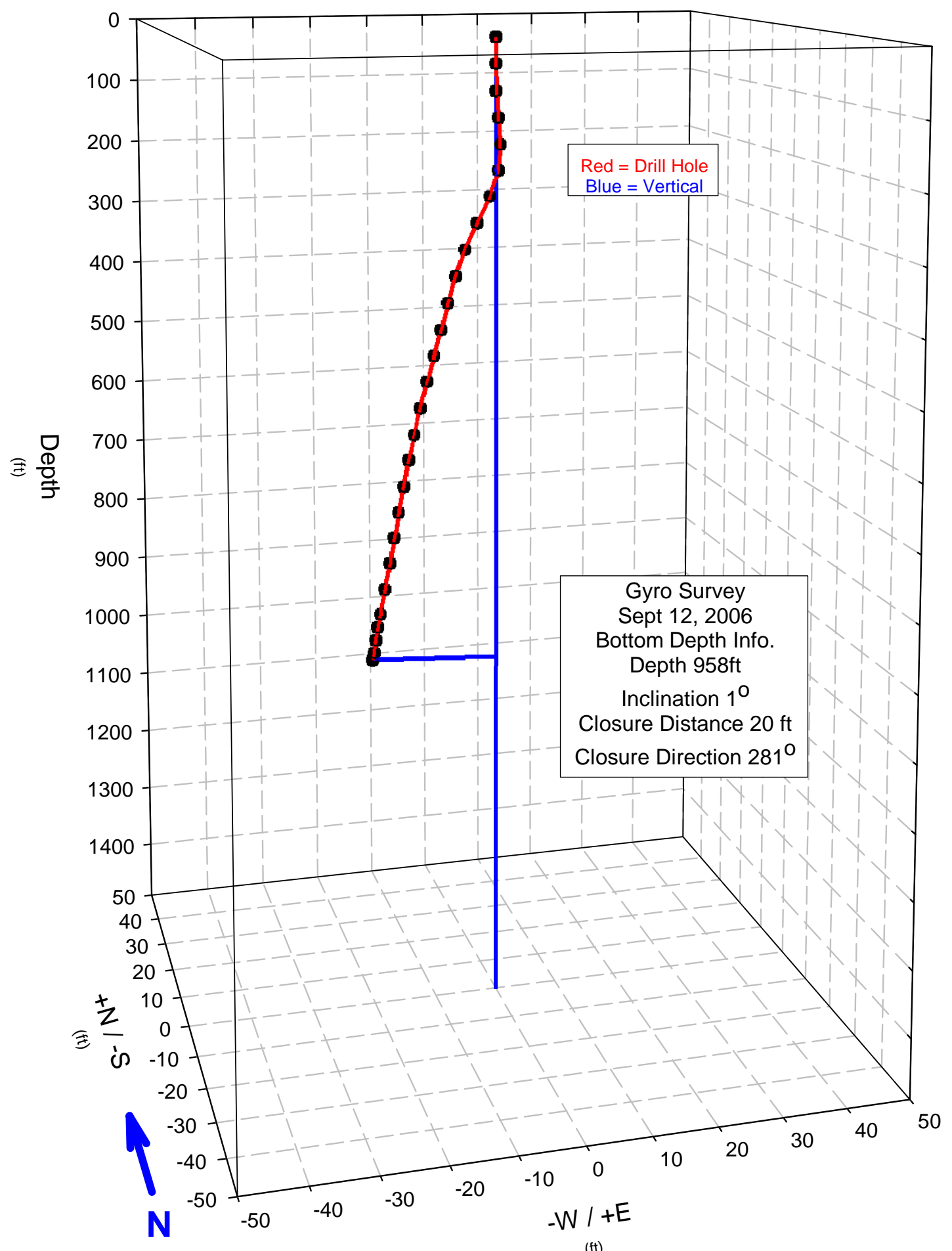

C-18 
Hole: C4997 Survey Date: 9/12/2006

$\begin{array}{cccccccc}\begin{array}{c}\text { Measured } \\ \text { Depth } \\ \text { (feet) }\end{array} & \begin{array}{c}\text { TrueVert. } \\ \text { Depth } \\ \text { (feet) }\end{array} & \begin{array}{c}\text { Inclination } \\ \text { from Vert. } \\ \text { (deg) }\end{array} & \begin{array}{c}\text { Closure } \\ \text { Direction } \\ \text { (deg) }\end{array} & \begin{array}{c}\text { Closure } \\ \text { Distance } \\ \text { (feet) }\end{array} & \begin{array}{c}\text { Rectangular } \\ \text { Coordinates } \\ + \text { N/-S }\end{array} & \begin{array}{c}\text { Rectangular } \\ \text { Coordinates } \\ + \text { E/-W }\end{array} & \begin{array}{c}\text { Dog-Leg } \\ \text { Severity } \\ \text { o/100-ft }\end{array} \\ 46 & 6 & 0.39 & 165.83 & 0.07 & -0.06 & 0.02 & 11.2 \\ 86 & 46 & 0.62 & 185.23 & 0.33 & -0.33 & -0.03 & 1.7 \\ 126 & 125.99 & 0.66 & 186.43 & 0.72 & -0.72 & -0.08 & 1.6 \\ 166 & 165.99 & 0.9 & 169.07 & 0.95 & -0.93 & 0.18 & 1.6 \\ 206 & 205.98 & 1.5 & 90.59 & 0.45 & -0.69 & 0.55 & 1.8 \\ 246 & 245.96 & 2.66 & 313.31 & 1 & 0.69 & -0.75 & 3.7 \\ 286 & 285.91 & 2.99 & 293.96 & 2.89 & 1.17 & -2.64 & 0.9 \\ 326 & 325.86 & 2.71 & 287.05 & 4.81 & 1.41 & -4.6 & 1.6 \\ 366 & 365.83 & 1.96 & 281.86 & 6.36 & 1.31 & -6.22 & 2.2 \\ 406 & 405.81 & 1.72 & 278.03 & 7.56 & 1.06 & -7.48 & 0.6 \\ 446 & 445.79 & 1.57 & 276.79 & 8.67 & 1.02 & -8.61 & 1.8 \\ 486 & 485.78 & 1.56 & 277.63 & 9.75 & 1.29 & -9.66 & 0.5 \\ 526 & 525.76 & 1.65 & 278.66 & 10.85 & 1.63 & -10.73 & 0.2 \\ 566 & 565.74 & 1.71 & 278.35 & 12 & 1.74 & -11.87 & 1.7 \\ 606 & 605.73 & 1.07 & 277.96 & 12.95 & 1.79 & -12.82 & 2.1 \\ 646 & 645.72 & 1.38 & 278.52 & 13.79 & 2.04 & -13.64 & 0.8 \\ 686 & 685.71 & 1.26 & 278.24 & 14.69 & 2.1 & -14.54 & 1.5 \\ 726 & 725.71 & 0.99 & 278.09 & 15.44 & 2.17 & -15.28 & 1.8 \\ 766 & 765.7 & 0.95 & 278.83 & 16.08 & 2.47 & -15.89 & 0.2 \\ 806 & 805.69 & 1.25 & 279.41 & 16.82 & 2.75 & -16.6 & 0.9 \\ 846 & 845.68 & 1.09 & 279.79 & 17.63 & 3 & -17.38 & 0.4 \\ 886 & 885.68 & 1.06 & 279.98 & 18.38 & 3.18 & -18.1 & 0.3 \\ 906 & 905.67 & 1.04 & 279.98 & 18.75 & 3.25 & -18.47 & 0.2 \\ 926 & 925.67 & 1.01 & 280.18 & 19.1 & 3.37 & -18.8 & 2.1 \\ 946 & 945.67 & 1 & 280.36 & 19.44 & 3.49 & -19.12 & 2.1 \\ 958 & 957.67 & 0.96 & 280.52 & 19.62 & 3.58 & -19.29 & 5.4\end{array}$


DTS-RPT-090, Rev. 0

Hole: C4997

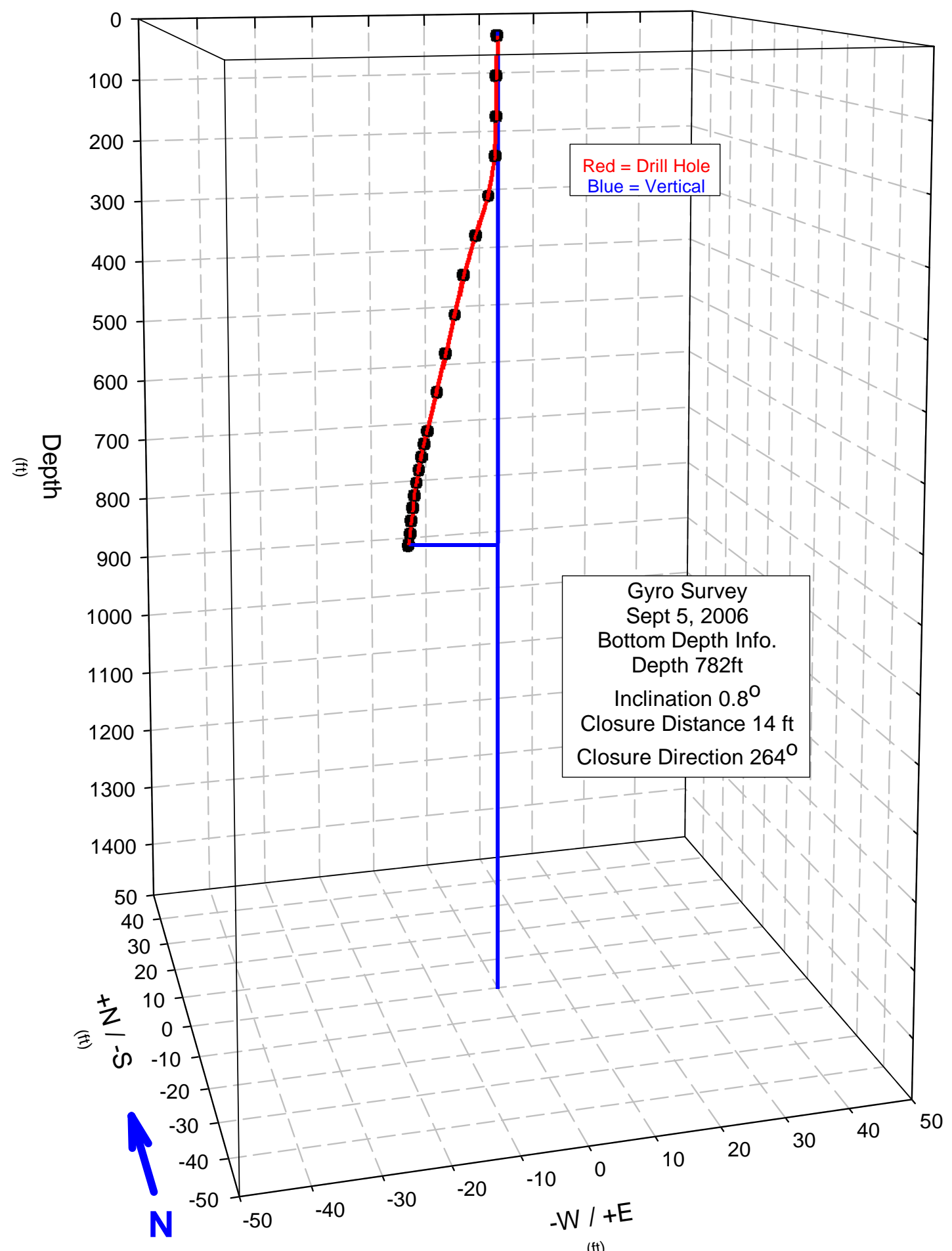


DTS-RPT-090, Rev. 0

Hole: C4997 Survey Date: 9/5/2006

$\begin{array}{cccccccc}\begin{array}{c}\text { Measured } \\ \text { Depth } \\ \text { (feet) }\end{array} & \begin{array}{c}\text { TrueVert. } \\ \text { Depth } \\ \text { (feet) }\end{array} & \begin{array}{c}\text { Inclination } \\ \text { from Vert. } \\ \text { (deg) }\end{array} & \begin{array}{c}\text { Closure } \\ \text { Direction } \\ \text { (deg) }\end{array} & \begin{array}{c}\text { Closure } \\ \text { Distance } \\ \text { (feet) }\end{array} & \begin{array}{c}\text { Rectangular } \\ \text { Coordinates } \\ + \text { N/-S }\end{array} & \begin{array}{c}\text { Rectangular } \\ \text { Coordinates } \\ + \text { E/-W }\end{array} & \begin{array}{c}\text { Dog-Leg } \\ \text { Severity } \\ \text { o/100-ft }\end{array} \\ 65 & 5 & 0.57 & 226.23 & 0.06 & -0.04 & -0.04 & 7.7 \\ 125 & 65 & 0.46 & 215.16 & 0.54 & -0.44 & -0.31 & 0.8 \\ 185 & 125 & 0.32 & 211.66 & 0.6 & -0.51 & -0.31 & 1.3 \\ 245 & 185 & 0.24 & 233.12 & 0.55 & -0.33 & -0.44 & 0.6 \\ 305 & 244.98 & 1.84 & 265.5 & 1.51 & -0.12 & -1.51 & 2.7 \\ 365 & 364.95 & 2.04 & 276.01 & 3.5 & 0.37 & -3.48 & 0.4 \\ 425 & 424.9 & 1.47 & 279.72 & 5.32 & 0.9 & -5.24 & 1 \\ 485 & 484.89 & 1.3 & 281.31 & 6.76 & 1.33 & -6.63 & 0.3 \\ 545 & 544.87 & 1.27 & 282.18 & 8.21 & 1.73 & -8.03 & 0.3 \\ 605 & 604.85 & 1.69 & 284.48 & 9.64 & 2.25 & -9.37 & 0.5 \\ 625 & 624.84 & 1.34 & 284.68 & 11.18 & 2.8 & -10.82 & 0.8 \\ 645 & 644.84 & 1.25 & 284.91 & 12.15 & 2.97 & -11.32 & 1.8 \\ 665 & 664.83 & 1.11 & 285.18 & 12.56 & 3.13 & -11.75 & 0.5 \\ 685 & 684.83 & 0.96 & 285.42 & 12.92 & 3.44 & -12.12 & 0.7 \\ 705 & 704.83 & 0.85 & 285.61 & 13.23 & 3.56 & -12.45 & 0.8 \\ 725 & 724.82 & 0.74 & 285.68 & 13.51 & 3.65 & -13 & 0.6 \\ 745 & 744.82 & 0.68 & 285.7 & 13.75 & 3.72 & -13.24 & 0.7 \\ 765 & 764.82 & 0.57 & 285.71 & 13.97 & 3.78 & -13.45 & 0.6 \\ 782 & 781.82 & 0.78 & 285.52 & 14.16 & 3.79 & -13.65 & 1.9\end{array}$


DTS-RPT-090, Rev. 0

Hole: C4997

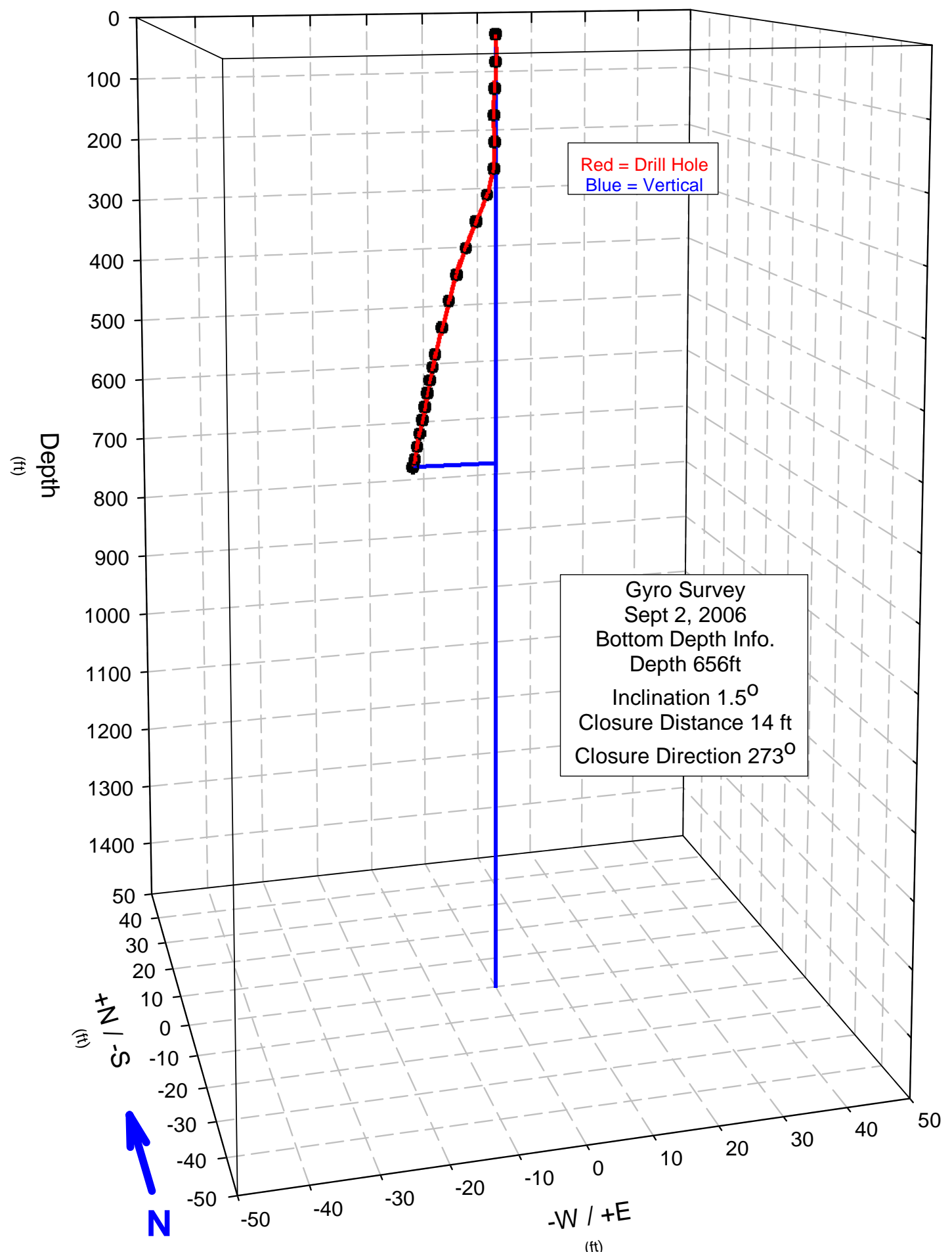


Hole: C4997 Survey Date: 9/2/2006

$\begin{array}{cccccccc}\begin{array}{c}\text { Measured } \\ \text { Depth } \\ \text { (feet) }\end{array} & \begin{array}{c}\text { TrueVert. } \\ \text { Depth } \\ \text { (feet) }\end{array} & \begin{array}{c}\text { Inclination } \\ \text { from Vert. } \\ \text { (deg) }\end{array} & \begin{array}{c}\text { Closure } \\ \text { Direction } \\ \text { (deg) }\end{array} & \begin{array}{c}\text { Closure } \\ \text { Distance } \\ \text { (feet) }\end{array} & \begin{array}{c}\text { Rectangular } \\ \text { Coordinates } \\ + \text { N/-S }\end{array} & \begin{array}{c}\text { Rectangular } \\ \text { Coordinates } \\ + \text { E/-W }\end{array} & \begin{array}{c}\text { Dog-Leg } \\ \text { Severity } \\ \text { o/100-ft }\end{array} \\ 45 & 5 & 0.37 & 147.81 & 0.06 & -0.05 & 0.03 & 19.4 \\ 85 & 45 & 0.5 & 171.8 & 0.22 & -0.22 & 0.03 & 1.9 \\ 125 & 85 & 0.46 & 205.92 & 0.49 & -0.44 & -0.22 & 0.1 \\ 165 & 125 & 0.37 & 210.62 & 0.77 & -0.66 & -0.39 & 0.5 \\ 205 & 165 & 0.32 & 203.39 & 0.85 & -0.78 & -0.34 & 1.5 \\ 245 & 205 & 0.73 & 213.65 & 0.69 & -0.58 & -0.38 & 2.4 \\ 285 & 284.98 & 2.41 & 262.86 & 1.37 & -0.17 & -1.36 & 4.7 \\ 325 & 324.9 & 2.52 & 274.13 & 3.04 & 0.22 & -3.04 & 0.3 \\ 365 & 364.88 & 1.44 & 277.26 & 4.76 & 0.6 & -4.73 & 0.2 \\ 405 & 404.86 & 1.61 & 277.79 & 6.22 & 0.84 & -6.16 & 2 \\ 445 & 444.84 & 1.66 & 277.18 & 7.38 & 0.92 & -7.33 & 0.3 \\ 485 & 484.83 & 1.42 & 276.82 & 8.53 & 1.04 & -8.46 & 0.3 \\ 505 & 504.82 & 1.23 & 276.78 & 10.06 & 1.14 & -9.53 & 0.7 \\ 525 & 524.82 & 1.2 & 276.73 & 10.49 & 1.19 & -9.99 & 1.5 \\ 545 & 544.82 & 1.22 & 276.38 & 10.9 & 1.21 & -10.41 & 1.3 \\ 565 & 564.81 & 1.23 & 275.91 & 11.32 & 1.17 & -10.84 & 0.4 \\ 585 & 584.81 & 1.32 & 275.42 & 11.75 & 1.11 & -11.7 & 0.4 \\ 605 & 604.8 & 1.41 & 274.86 & 12.22 & 1.04 & -12.17 & 0.7 \\ 625 & 624.8 & 1.23 & 274.21 & 12.65 & 0.93 & -12.62 & 1.1 \\ 645 & 644.79 & 1.13 & 273.63 & 13.05 & 0.83 & -13.02 & 0.7 \\ 656.5 & 656.29 & 1.52 & 273.55 & 13.31 & 0.82 & -13.28 & 5.4\end{array}$


DTS-RPT-090, Rev. 0

Hole: C4997

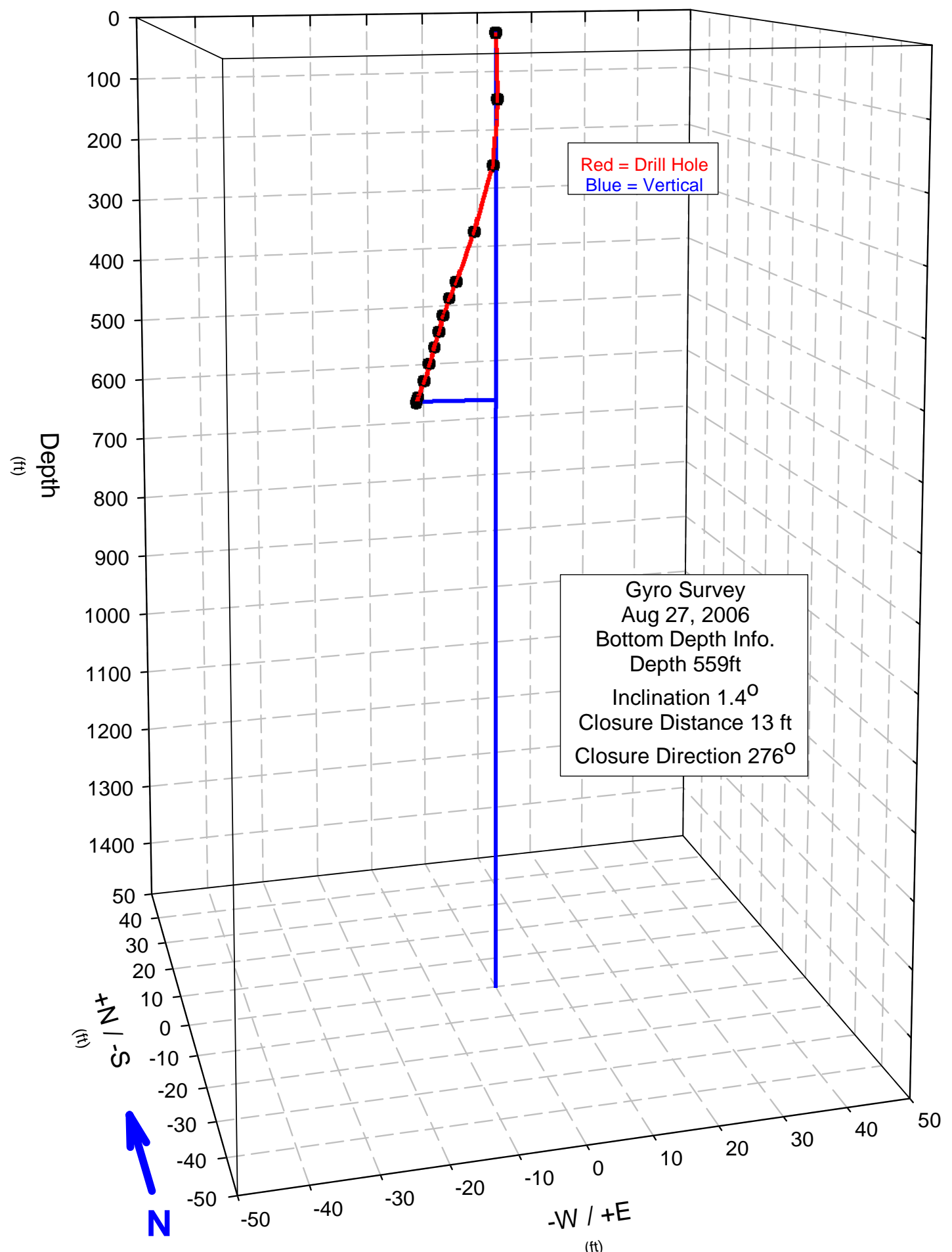


DTS-RPT-090, Rev. 0

Hole: C4997 Survey Date: 8/27/2006

\begin{tabular}{|c|c|c|c|c|c|c|c|}
\hline $\begin{array}{l}\text { Measured } \\
\text { Depth } \\
\text { (feet) }\end{array}$ & $\begin{array}{l}\text { TrueVert. } \\
\text { Depth } \\
\text { (feet) }\end{array}$ & $\begin{array}{l}\text { Inclination } \\
\text { from Vert. } \\
\text { (deg) }\end{array}$ & $\begin{array}{c}\text { Closure } \\
\text { Direction } \\
\text { (deg) }\end{array}$ & $\begin{array}{c}\text { Closure } \\
\text { Distance } \\
\text { (feet) }\end{array}$ & $\begin{array}{c}\text { Rectangular } \\
\text { Coordinates } \\
+\mathrm{N} / \mathrm{S}\end{array}$ & $\begin{array}{c}\text { Rectangular } \\
\text { Coordinates } \\
\text { +E/-W }\end{array}$ & $\begin{array}{l}\text { Dog-Leg } \\
\text { Severity } \\
0 / 100-f t\end{array}$ \\
\hline 2 & 2 & 0.62 & 183.92 & 0.03 & -0.03 & 0 & 16.6 \\
\hline 100 & 99.99 & 0.57 & 176.99 & 1.04 & -1.04 & 0.05 & 0.1 \\
\hline 200 & 199.99 & 1.09 & 215.52 & 1.13 & -0.92 & -0.66 & 1.5 \\
\hline 300 & 299.94 & 2.43 & 267.46 & 3.5 & -0.16 & -3.49 & 1.7 \\
\hline 375 & 374.89 & 1.89 & 272.35 & 6.28 & 0.26 & -6.28 & 0.9 \\
\hline 400 & 399.86 & 3.15 & 272.78 & 7.37 & 0.36 & -7.36 & 5.6 \\
\hline 425 & 424.84 & 1.46 & 272.9 & 8.37 & 0.42 & -8.36 & 7 \\
\hline 450 & 449.84 & 1.56 & 274.13 & 8.99 & 0.65 & -8.97 & 1.7 \\
\hline 475 & 474.82 & 1.9 & 275.36 & 9.72 & 0.91 & -9.67 & 2.1 \\
\hline 500 & 499.81 & 1.55 & 275.64 & 10.46 & 1.03 & -10.41 & 1.9 \\
\hline 525 & 524.8 & 2.26 & 275.93 & 11.29 & 1.17 & -11.23 & 3.2 \\
\hline 550 & 549.78 & 2.14 & 276.39 & 12.24 & 1.36 & -12.17 & 0.9 \\
\hline 559 & 558.78 & 1.44 & 276.36 & 12.52 & 1.39 & -12.44 & 8.4 \\
\hline
\end{tabular}


DTS-RPT-090, Rev. 0

\section{Hole: C4997}

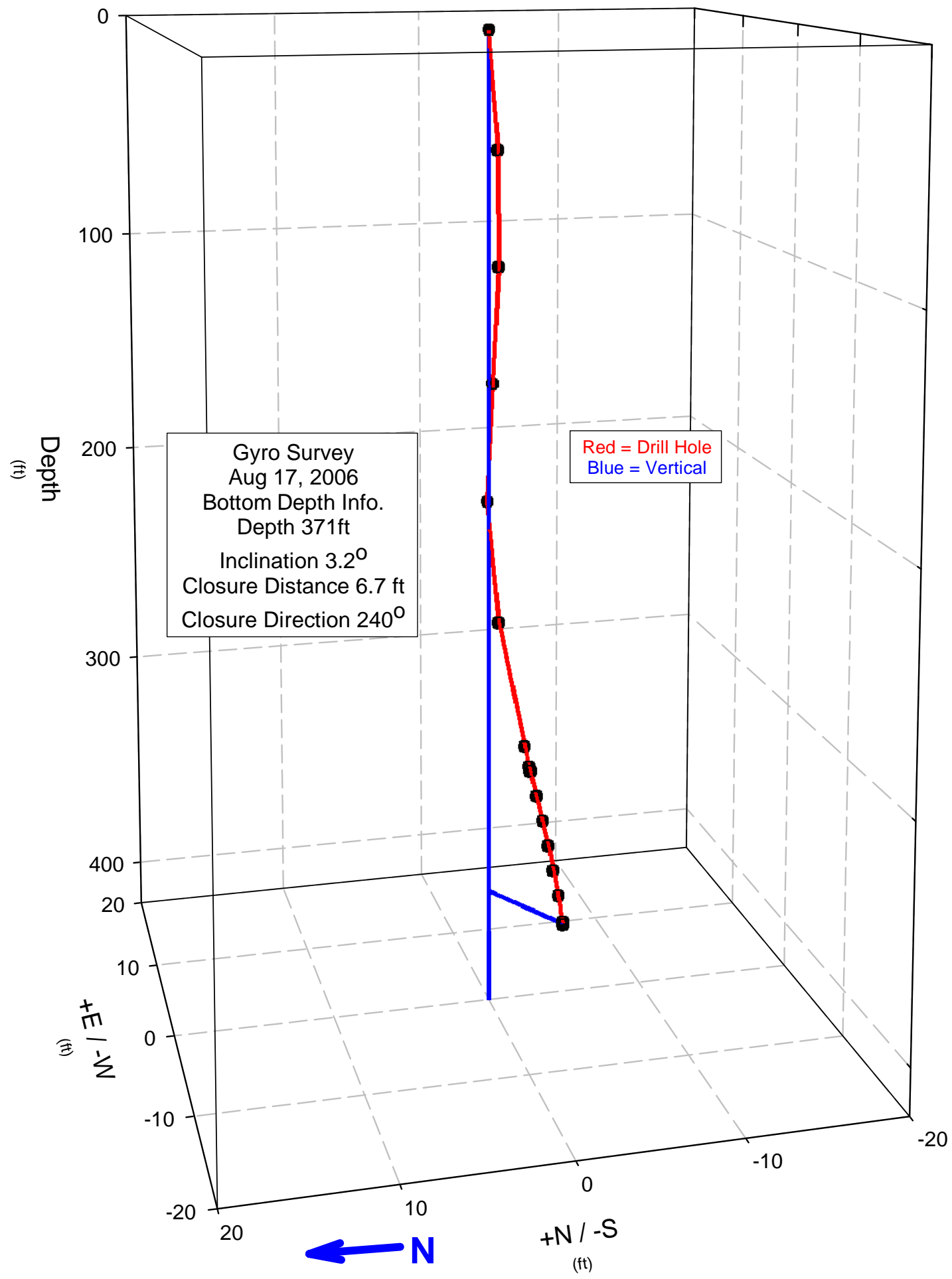


DTS-RPT-090, Rev. 0

Hole: C4997 Survey Date: 8/17/2006

$\begin{array}{cccccccc}\begin{array}{c}\text { Measured } \\ \text { Depth } \\ \text { (feet) }\end{array} & \begin{array}{c}\text { TrueVert. } \\ \text { Depth } \\ \text { (feet) }\end{array} & \begin{array}{c}\text { Inclination } \\ \text { from Vert. } \\ \text { (deg) }\end{array} & \begin{array}{c}\text { Closure } \\ \text { Direction } \\ \text { (deg) }\end{array} & \begin{array}{c}\text { Closure } \\ \text { Distance } \\ \text { (feet) }\end{array} & \begin{array}{c}\text { Rectangular } \\ \text { Coordinates } \\ + \text { N/-S }\end{array} & \begin{array}{c}\text { Rectangular } \\ \text { Coordinates } \\ + \text { E/-W }\end{array} & \begin{array}{c}\text { Dog-Leg } \\ \text { Severity } \\ \text { \%100-ft }\end{array} \\ 50 & 0 & 0.98 & 0 & 0 & 0 & 0 & 0 \\ 100 & 50 & 0.67 & 163.86 & 0.65 & -0.63 & 0.18 & 1.5 \\ 150 & 149.99 & 0.54 & 142.56 & 1.03 & -0.82 & 0.63 & 1 \\ 200 & 199.98 & 0.72 & 118.06 & 1.06 & -0.5 & 0.94 & 1.5 \\ 250 & 249.96 & 2.32 & 91.82 & 0.47 & -0.01 & 0.47 & 2.9 \\ 300 & 299.91 & 2.64 & 249.86 & 1.13 & -0.39 & -1.07 & 3.9 \\ 310 & 309.89 & 2.64 & 242.65 & 3.4 & -1.56 & -3.02 & 0.3 \\ 308 & 307.9 & 2.64 & 242.16 & 3.86 & -1.81 & -3.41 & 0 \\ 310 & 309.89 & 2.87 & 241.98 & 3.87 & -1.76 & -3.33 & 0.3 \\ 320 & 319.88 & 2.83 & 240.85 & 4.36 & -2.12 & -3.41 & 18.2 \\ 330 & 329.87 & 2.62 & 239.99 & 4.83 & -2.41 & -4.8 & 0.4 \\ 340 & 339.86 & 2.45 & 239.33 & 5.26 & -2.69 & -4.53 & 1.8 \\ 350 & 349.85 & 2.18 & 238.79 & 5.66 & -2.94 & -4.84 & 2.7 \\ 360 & 359.84 & 2.93 & 239.17 & 6.1 & -3.13 & -5.24 & 12.4 \\ 370 & 369.83 & 3.1 & 240.36 & 6.61 & -3.27 & -5.74 & 1.8 \\ 371 & 370.83 & 3.13 & 240.47 & 6.66 & -3.28 & -5.8 & 3.1\end{array}$


DTS-RPT-090, Rev. 0

\section{Hole: C4997}

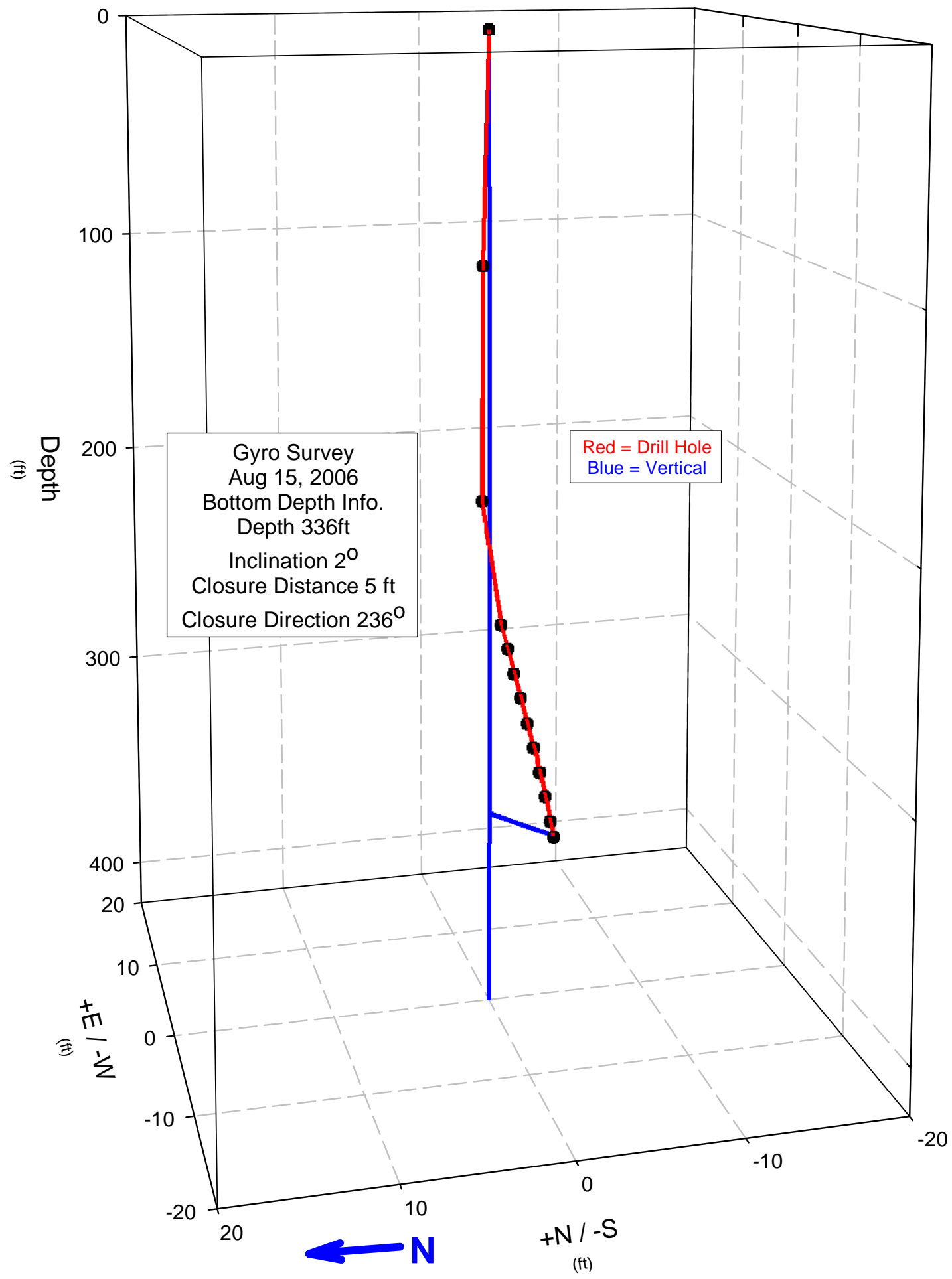


DTS-RPT-090, Rev. 0

Hole: C4997 Survey Date: 8/15/2006

$\begin{array}{cccccccc}\begin{array}{c}\text { Measured } \\ \text { Depth } \\ \text { (feet) }\end{array} & \begin{array}{c}\text { TrueVert. } \\ \text { Depth } \\ \text { (feet) }\end{array} & \begin{array}{c}\text { Inclination } \\ \text { from Vert. } \\ \text { (deg) }\end{array} & \begin{array}{c}\text { Closure } \\ \text { Direction } \\ \text { (deg) }\end{array} & \begin{array}{c}\text { Closure } \\ \text { Distance } \\ \text { (feet) }\end{array} & \begin{array}{c}\text { Rectangular } \\ \text { Coordinates } \\ + \text { N/-S }\end{array} & \begin{array}{c}\text { Rectangular } \\ \text { Coordinates } \\ \text { +E/-W }\end{array} & \begin{array}{c}\text { Dog-Leg } \\ \text { Severity } \\ \text { o /100-ft }\end{array} \\ 100 & 0 & 0.23 & 0 & 0 & 0 & 0 & 0 \\ 200 & 99.99 & 1.15 & 80.77 & 0.93 & 0.15 & 0.92 & 1.3 \\ 250 & 199.98 & 1.74 & 52.47 & 0.53 & 0.32 & 0.42 & 2.9 \\ 260 & 249.94 & 3.08 & 253.4 & 1.45 & -0.41 & -1.39 & 4.5 \\ 270 & 259.93 & 2.96 & 247.42 & 1.94 & -0.75 & -1.79 & 1.4 \\ 280 & 279.91 & 2.83 & 243.83 & 2.43 & -1.07 & -2.18 & 1.3 \\ 290 & 289.89 & 2.86 & 241.33 & 2.91 & -1.4 & -2.55 & 0.7 \\ 300 & 299.88 & 2.69 & 239.37 & 3.39 & -1.73 & -2.92 & 0.8 \\ 310 & 309.87 & 2.42 & 237.94 & 3.87 & -2.05 & -3.28 & 1.4 \\ 320 & 319.86 & 2.27 & 236.26 & 4.31 & -2.35 & -3.61 & 2.7 \\ 330 & 329.85 & 2.05 & 235.78 & 5.71 & -2.62 & -3.92 & 1.6 \\ 336.5 & 336.35 & 2.05 & 235.53 & 5.32 & -2.86 & -4.21 & 2.2 \\ & & & & & & -4.38 & 0.4\end{array}$


DTS-RPT-090, Rev. 0

Hole: C4997

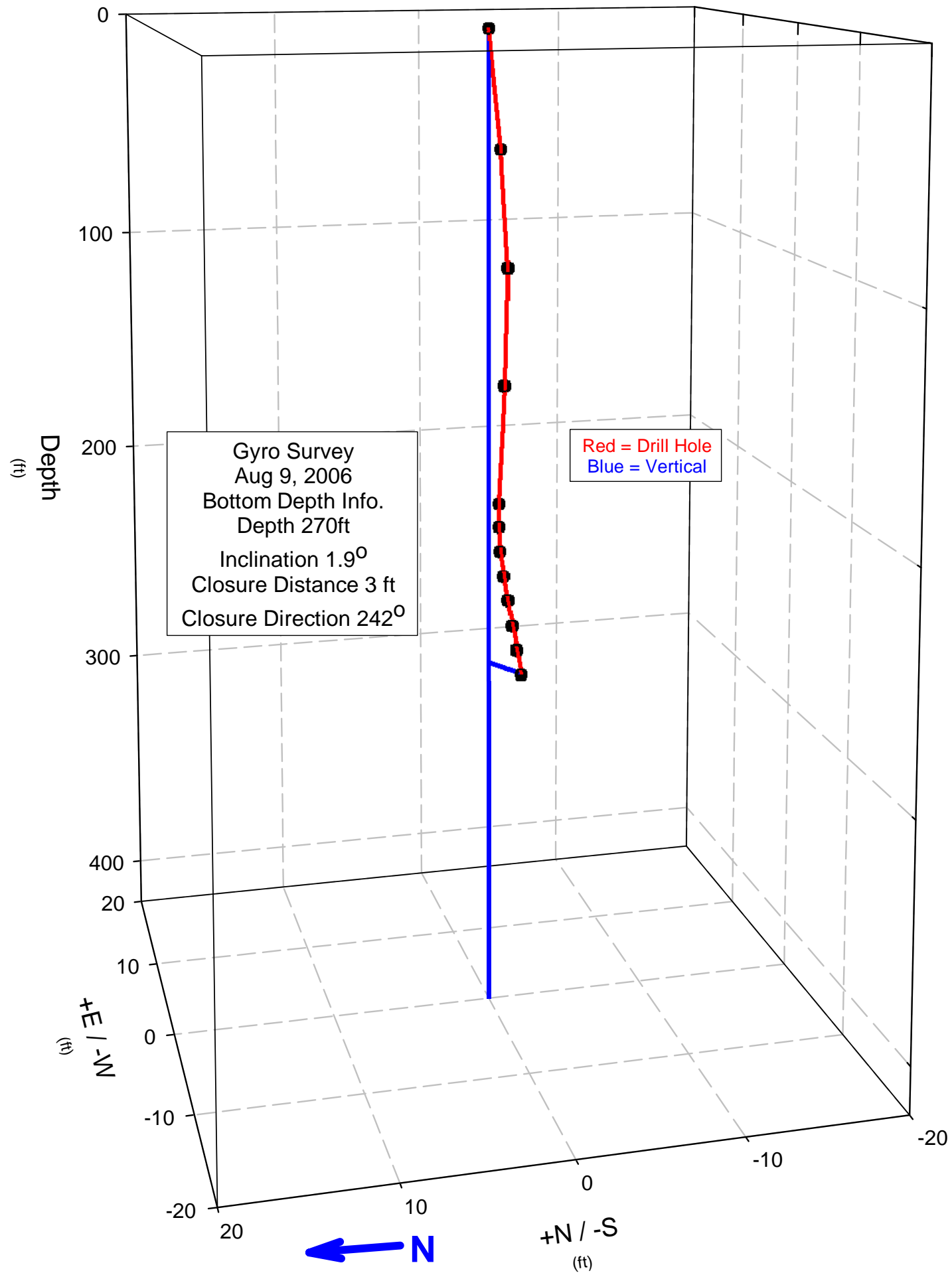


DTS-RPT-090, Rev. 0

Hole: C4997 Survey Date: 8/9/2006

\begin{tabular}{|c|c|c|c|c|c|c|c|}
\hline $\begin{array}{l}\text { Measured } \\
\text { Depth } \\
\text { (feet) }\end{array}$ & $\begin{array}{l}\text { TrueVert. } \\
\text { Depth } \\
\text { (feet) }\end{array}$ & $\begin{array}{l}\text { Inclination } \\
\text { from Vert. } \\
\text { (deg) }\end{array}$ & $\begin{array}{l}\text { Closure } \\
\text { Direction } \\
\text { (deg) }\end{array}$ & $\begin{array}{c}\text { Closure } \\
\text { Distance } \\
\text { (feet) }\end{array}$ & $\begin{array}{c}\text { Rectangular } \\
\text { Coordinates } \\
+\mathrm{N} / \mathrm{S} S\end{array}$ & $\begin{array}{c}\text { Rectangular } \\
\text { Coordinates } \\
+\mathrm{E} / \mathrm{-W}\end{array}$ & $\begin{array}{l}\text { Dog-Leg } \\
\text { Severity } \\
0 / 100-f t\end{array}$ \\
\hline 0 & 0 & 1.02 & 0 & 0 & 0 & 0 & 0 \\
\hline 50 & 49.99 & 0.95 & 219.6 & 0.83 & -0.64 & -0.53 & 0.9 \\
\hline 100 & 99.99 & 0.42 & 206.4 & 1.23 & -1.1 & -0.55 & 2.1 \\
\hline 150 & 149.99 & 0.51 & 194.86 & 1.02 & -0.99 & -0.26 & 1.3 \\
\hline 200 & 199.99 & 1.09 & 225 & 0.77 & -0.55 & -0.55 & 2.4 \\
\hline 210 & 209.98 & 1.34 & 236.88 & 0.89 & -0.49 & -0.74 & 6 \\
\hline 220 & 219.98 & 1.74 & 242.78 & 1.13 & -0.52 & -1.01 & 7.2 \\
\hline 230 & 229.97 & 2.16 & 243.91 & 1.47 & -0.65 & -1.32 & 5.4 \\
\hline 240 & 239.97 & 2.32 & 243.4 & 1.86 & -0.83 & -1.66 & 2 \\
\hline 250 & 249.96 & 2.35 & 242.89 & 2.27 & -1.03 & -2.02 & 0.5 \\
\hline 260 & 259.95 & 2.31 & 242.77 & 2.67 & -1.22 & -2.38 & 1 \\
\hline 270.2 & 270.14 & 1.88 & 242.12 & 3.04 & -1.42 & -2.69 & 6.3 \\
\hline
\end{tabular}


DTS-RPT-090, Rev. 0

\section{Hole: C4997}

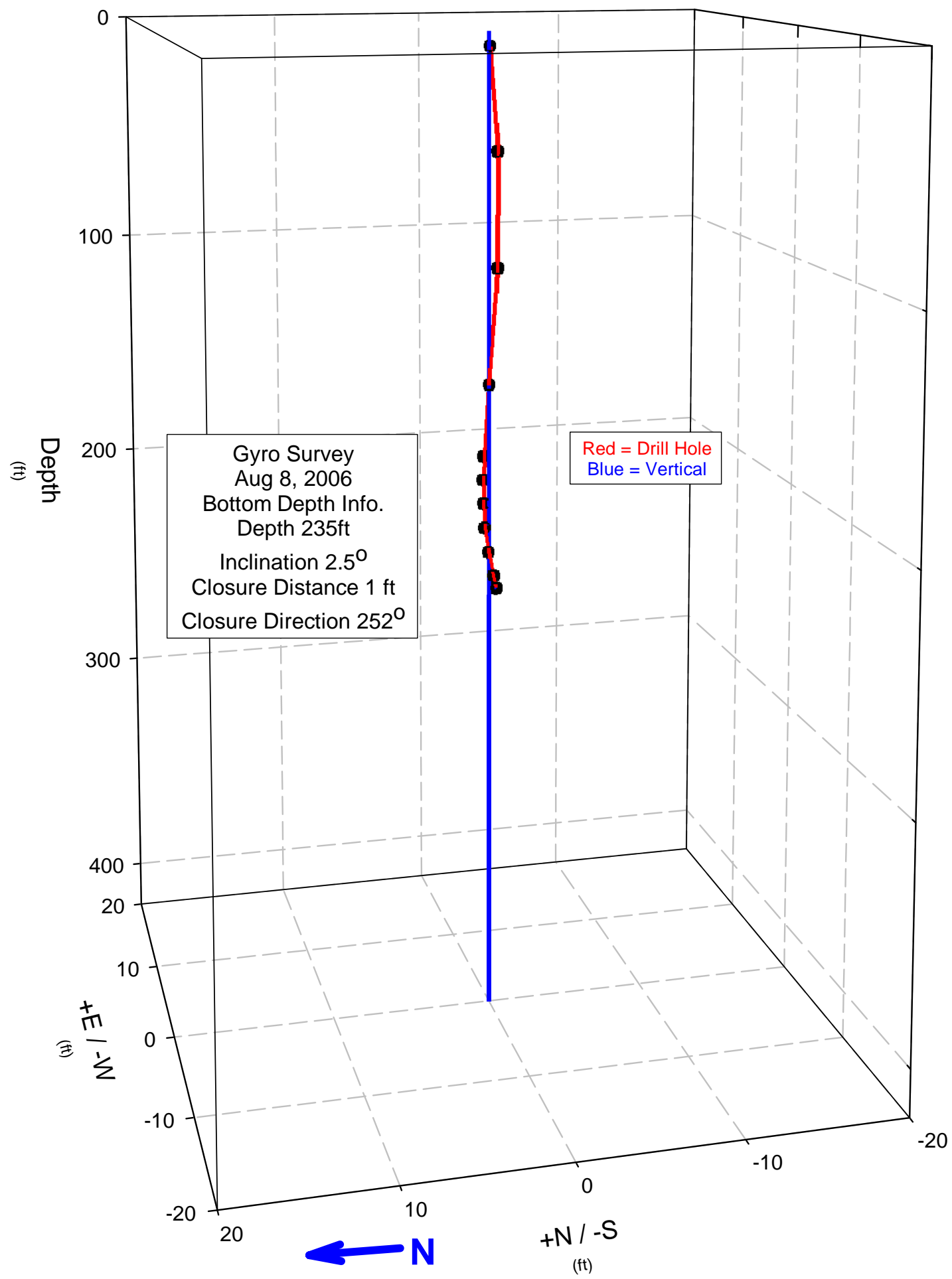


DTS-RPT-090, Rev. 0

Hole: C4997 Survey Date: $\mathbf{8 / 8 / 2 0 0 6}$

\begin{tabular}{|c|c|c|c|c|c|c|c|}
\hline Measured & TrueVert. & Inclination & Closure & Closure & Rectangular & Rectangular & Dog-Leg \\
\hline $\begin{array}{l}\text { Depth } \\
\text { (feet) }\end{array}$ & $\begin{array}{c}\text { Depth } \\
\text { (feet) }\end{array}$ & $\begin{array}{c}\text { from Vert. } \\
(\text { deq) }\end{array}$ & $\begin{array}{l}\text { Direction } \\
\text { (deq) }\end{array}$ & $\begin{array}{l}\text { Distance } \\
\text { (feet) }\end{array}$ & $\begin{array}{c}\text { Coordinates } \\
+\mathrm{N} / \mathrm{S}\end{array}$ & $\begin{array}{c}\text { Coordinates } \\
+E /-W\end{array}$ & $\begin{array}{l}\text { Severity } \\
0 / 100-\mathrm{ft}\end{array}$ \\
\hline 6.1 & 6.1 & 0.84 & 175.6 & 0.11 & -0.11 & 0.01 & 11.3 \\
\hline 50 & 50 & 0.73 & 168.89 & 0.64 & -0.63 & 0.12 & 1.7 \\
\hline 100 & 99.99 & 0.78 & 138.29 & 0.98 & -0.73 & 0.65 & 1.8 \\
\hline 150 & 149.99 & 0.9 & 104.34 & 0.88 & -0.22 & 0.86 & 2.2 \\
\hline 180 & 179.98 & 1.11 & 73.15 & 0.58 & 0.17 & 0.55 & 2.4 \\
\hline 190 & 189.98 & 1.07 & 56.76 & 0.46 & 0.25 & 0.38 & 2.9 \\
\hline 200 & 199.98 & 1.18 & 34.03 & 0.34 & 0.28 & 0.19 & 3.6 \\
\hline 210 & 209.98 & 1.51 & 351.34 & 0.24 & 0.24 & -0.04 & 5.8 \\
\hline 220 & 219.97 & 2.15 & 286.89 & 0.34 & 0.1 & -0.32 & 7.5 \\
\hline 230 & 229.96 & 2.49 & 258.49 & 0.67 & -0.13 & -0.65 & 4.1 \\
\hline 235 & 234.96 & 2.51 & 252.31 & 0.87 & -0.26 & -0.83 & 0.6 \\
\hline
\end{tabular}


DTS-RPT-090, Rev. 0

Hole: C4997

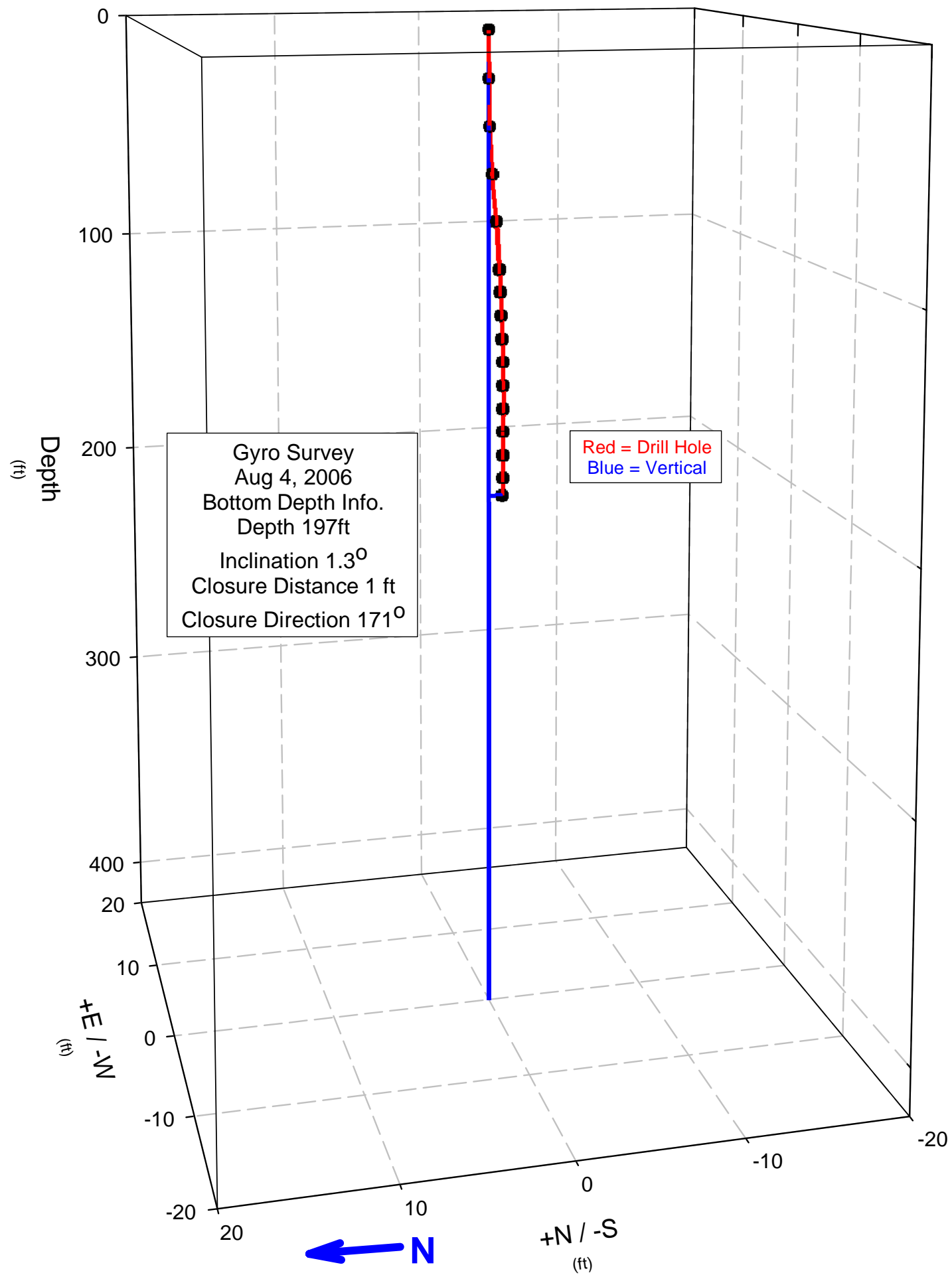


DTS-RPT-090, Rev. 0

Hole: C4997 Survey Date: 8/4/2006

$\begin{array}{cccccccc}\begin{array}{c}\text { Measured } \\ \text { Depth } \\ \text { (feet) }\end{array} & \begin{array}{c}\text { TrueVert. } \\ \text { Depth } \\ \text { (feet) }\end{array} & \begin{array}{c}\text { Inclination } \\ \text { from Vert. } \\ \text { (deg) }\end{array} & \begin{array}{c}\text { Closure } \\ \text { Direction } \\ \text { (deg) }\end{array} & \begin{array}{c}\text { Closure } \\ \text { Distance } \\ \text { (feet) }\end{array} & \begin{array}{c}\text { Rectangular } \\ \text { Coordinates } \\ + \text { N/-S }\end{array} & \begin{array}{c}\text { Rectangular } \\ \text { Coordinates } \\ + \text { E/-W }\end{array} & \begin{array}{c}\text { Dog-Leg } \\ \text { Severity } \\ 0\end{array} \\ 0 & 0.400-f t & 0 & 0 & 0 \\ 20 & 20 & 0.15 & 151.78 & 0.06 & -0.06 & 0.03 & 2.4 \\ 40 & 40 & 0.36 & 181.56 & 0.07 & -0.07 & 0 & 2.5 \\ 60 & 60 & 0.7 & 204.44 & 0.24 & -0.22 & -0.1 & 2.4 \\ 80 & 80 & 0.61 & 199.6 & 0.47 & -0.44 & -0.16 & 0.8 \\ 100 & 100 & 0.73 & 188.69 & 0.66 & -0.65 & -0.1 & 2.5 \\ 110 & 110 & 0.59 & 182.14 & 0.74 & -0.74 & -0.03 & 1.9 \\ 120 & 120 & 0.63 & 177.11 & 0.82 & -0.82 & 0.04 & 1.1 \\ 130 & 129.99 & 0.46 & 173.57 & 0.9 & -0.89 & 0.1 & 1.8 \\ 140 & 139.99 & 0.28 & 171.13 & 0.95 & -0.94 & 0.15 & 2 \\ 150 & 149.99 & 0.33 & 169.14 & 0.99 & -0.97 & 0.19 & 0.6 \\ 160 & 159.99 & 0.44 & 166.04 & 1.02 & -0.99 & 0.25 & 3.3 \\ 170 & 169.99 & 0.12 & 163.39 & 1.03 & -0.99 & 0.29 & 3.2 \\ 180 & 179.99 & 0.13 & 163.47 & 1.03 & -0.99 & 0.29 & 2.5 \\ 190 & 189.99 & 0.52 & 166.32 & 1 & -0.98 & 0.24 & 4 \\ 197.4 & 197.39 & 1.3 & 171.17 & 0.92 & -0.91 & 0.14 & 11.7\end{array}$


DTS-RPT-090, Rev. 0

\section{Hole: C4997}

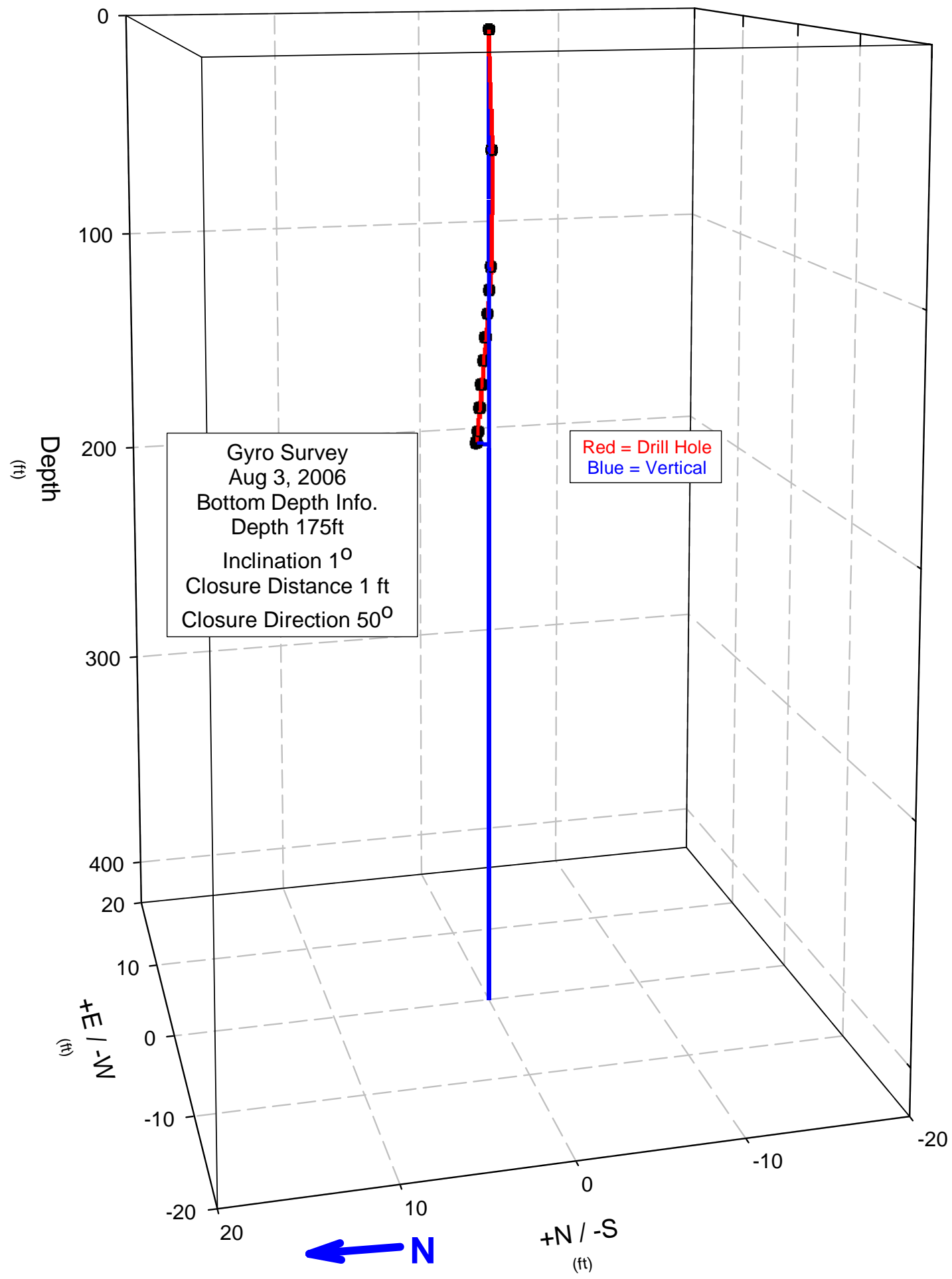


DTS-RPT-090, Rev. 0

Hole: C4997 Survey Date: $\mathbf{8 / 3 / 2 0 0 6}$

\begin{tabular}{|c|c|c|c|c|c|c|c|}
\hline $\begin{array}{l}\text { Measured } \\
\text { Depth } \\
\text { (feet) }\end{array}$ & $\begin{array}{l}\text { TrueVert. } \\
\text { Depth } \\
\text { (feet) }\end{array}$ & $\begin{array}{l}\text { Inclination } \\
\text { from Vert. } \\
\text { (deg) }\end{array}$ & $\begin{array}{l}\text { Closure } \\
\text { Direction } \\
\text { (deg) }\end{array}$ & $\begin{array}{c}\text { Closure } \\
\text { Distance } \\
\text { (feet) }\end{array}$ & $\begin{array}{c}\text { Rectangular } \\
\text { Coordinates } \\
+\mathrm{N} / \mathrm{S} S\end{array}$ & $\begin{array}{c}\text { Rectangular } \\
\text { Coordinates } \\
+\mathrm{E} / \mathrm{-W}\end{array}$ & $\begin{array}{l}\text { Dog-Leg } \\
\text { Severity } \\
0 / 100-f t\end{array}$ \\
\hline 0 & 0 & 0.27 & 0 & 0 & 0 & 0 & 0 \\
\hline 50 & 50 & 0.65 & 134.1 & 0.4 & -0.28 & 0.29 & 0.8 \\
\hline 100 & 100 & 0.65 & 114.6 & 0.81 & -0.34 & 0.74 & 1.6 \\
\hline 110 & 110 & 0.79 & 107.29 & 0.87 & -0.26 & 0.83 & 2.5 \\
\hline 120 & 119.99 & 0.68 & 99.89 & 0.93 & -0.16 & 0.91 & 2 \\
\hline 130 & 129.99 & 0.72 & 92.77 & 0.95 & -0.05 & 0.94 & 3.7 \\
\hline 140 & 139.99 & 0.87 & 84.39 & 0.94 & 0.09 & 0.94 & 1.8 \\
\hline 150 & 149.99 & 0.79 & 75.63 & 0.93 & 0.23 & 0.9 & 2.4 \\
\hline 160 & 159.99 & 0.98 & 66.06 & 0.91 & 0.37 & 0.84 & 2.1 \\
\hline 170 & 169.99 & 1.02 & 55.16 & 0.93 & 0.53 & 0.76 & 0.8 \\
\hline 175 & 174.99 & 1 & 49.98 & 0.95 & 0.61 & 0.73 & 1.6 \\
\hline
\end{tabular}


DTS-RPT-090, Rev. 0

Hole: C4997

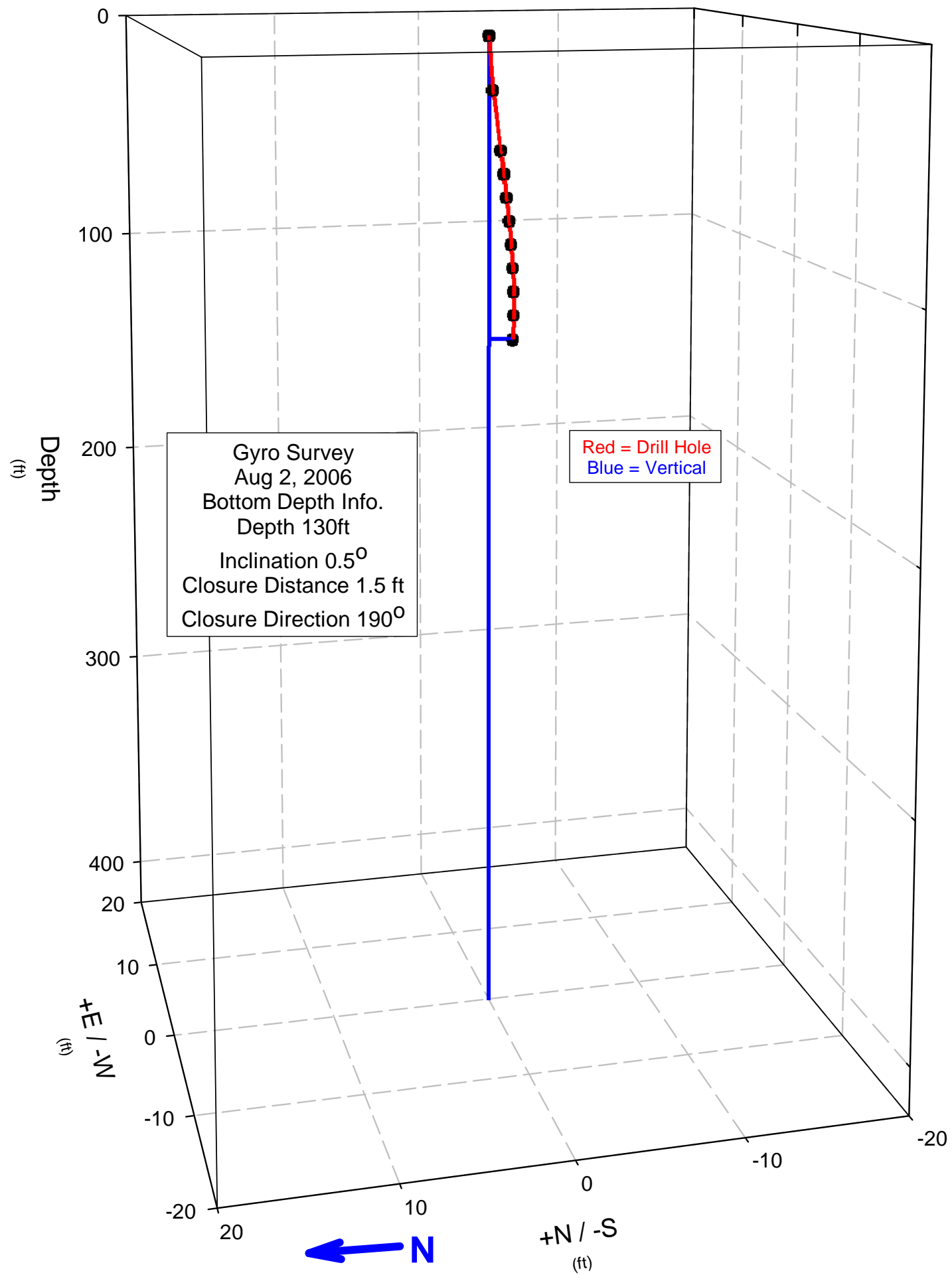


DTS-RPT-090, Rev. 0

Hole: C4997 Survey Date: 8/2/2006

$\begin{array}{cccccccc}\begin{array}{c}\text { Measured } \\ \text { Depth } \\ \text { (feet) }\end{array} & \begin{array}{c}\text { TrueVert. } \\ \text { Depth } \\ \text { (feet) }\end{array} & \begin{array}{c}\text { Inclination } \\ \text { from Vert. } \\ \text { (deg) }\end{array} & \begin{array}{c}\text { Closure } \\ \text { Direction } \\ \text { (deg) }\end{array} & \begin{array}{c}\text { Closure } \\ \text { Distance } \\ \text { (feet) }\end{array} & \begin{array}{c}\text { Rectangular } \\ \text { Coordinates } \\ + \text { N/-S }\end{array} & \begin{array}{c}\text { Rectangular } \\ \text { Coordinates } \\ + \text { E/-W }\end{array} & \begin{array}{c}\text { Dog-Leg } \\ \text { Severity } \\ \text { o/100-ft }\end{array} \\ 25 & 2.4 & 0.69 & 258.07 & 0.03 & -0.01 & -0.03 & 7.5 \\ 50 & 25 & 1.03 & 230.82 & 0.32 & -0.2 & -0.25 & 4.1 \\ 60 & 49.99 & 1.15 & 206.19 & 0.73 & -0.66 & -0.32 & 2.2 \\ 70 & 59.99 & 1.16 & 199.27 & 0.91 & -0.86 & -0.3 & 1.2 \\ 80 & 69.99 & 1.02 & 194.28 & 1.08 & -1.04 & -0.27 & 1.4 \\ 90 & 79.99 & 1.06 & 190.45 & 1.24 & -1.22 & -0.23 & 0.8 \\ 100 & 89.99 & 0.8 & 187.93 & 1.39 & -1.38 & -0.19 & 2.8 \\ 110 & 109.99 & 0.43 & 187.24 & 1.5 & -1.49 & -0.19 & 4.1 \\ 120 & 119.99 & 0.17 & 187.35 & 1.55 & -1.54 & -0.2 & 2.6 \\ 130 & 129.99 & 0.39 & 188.44 & 1.55 & -1.53 & -0.23 & 5 \\ & 0.45 & 190.73 & 1.5 & -1.48 & -0.28 & 0.9\end{array}$


DTS-RPT-090, Rev. 0

Hole: C4997

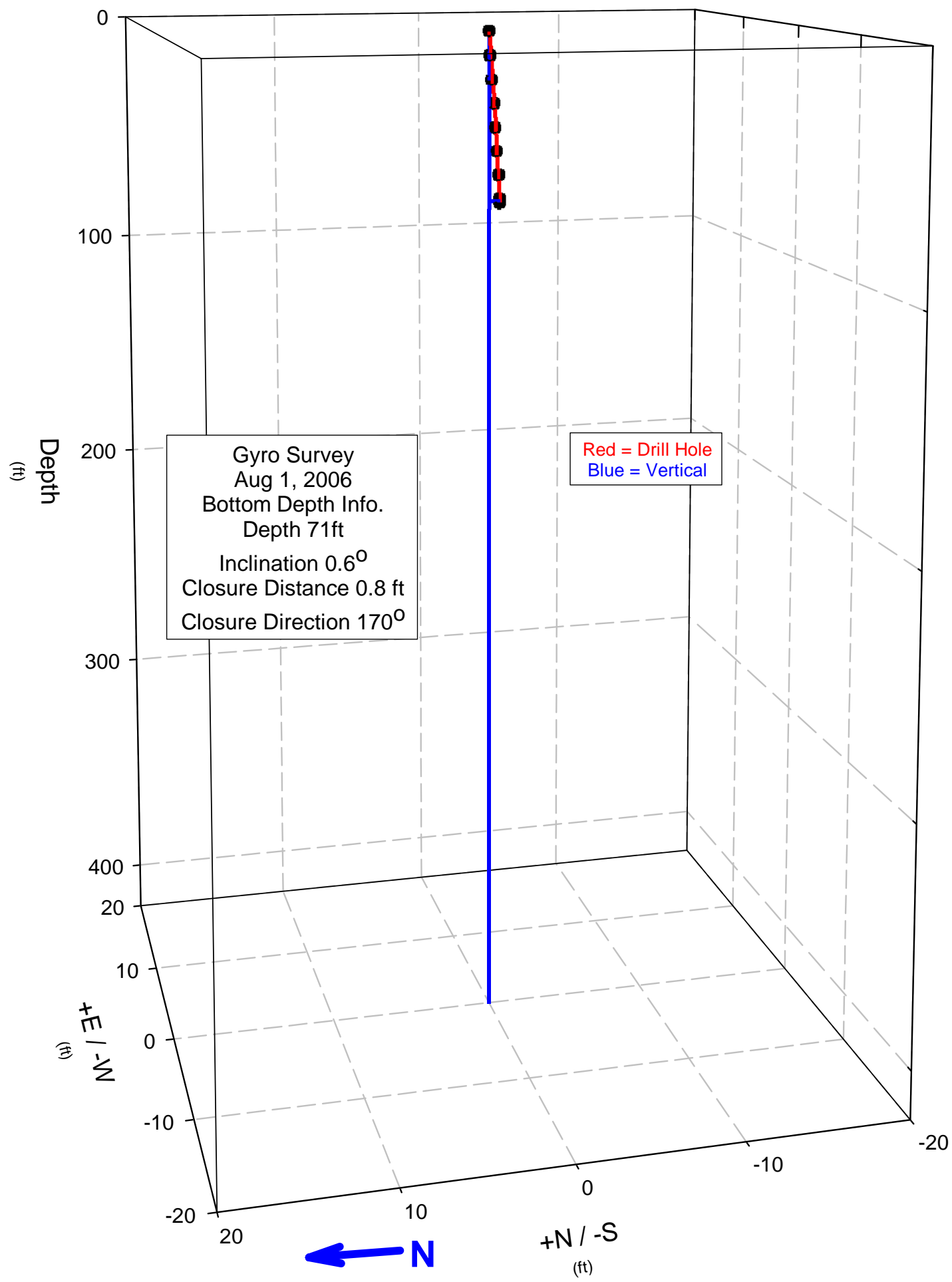


DTS-RPT-090, Rev. 0

Hole: C4997 Survey Date: 8/1/2006

$\begin{array}{cccccccc}\begin{array}{c}\text { Measured } \\ \text { Depth } \\ \text { (feet) }\end{array} & \begin{array}{c}\text { TrueVert. } \\ \text { Depth } \\ \text { (feet) }\end{array} & \begin{array}{c}\text { Inclination } \\ \text { from Vert. } \\ \text { (deg) }\end{array} & \begin{array}{c}\text { Closure } \\ \text { Direction } \\ \text { (deg) }\end{array} & \begin{array}{c}\text { Closure } \\ \text { Distance } \\ \text { (feet) }\end{array} & \begin{array}{c}\text { Rectangular } \\ \text { Coordinates } \\ + \text { N/-S }\end{array} & \begin{array}{c}\text { Rectangular } \\ \text { Coordinates } \\ +E /-W\end{array} & \begin{array}{c}\text { Dog-Leg } \\ \text { Severity } \\ \text { oflo0-ft }\end{array} \\ 10 & 0 & 0.58 & 0 & 0 & 0 & 0 & 0 \\ 20 & 10 & 0.62 & 197.65 & 0.1 & -0.1 & -0.03 & 1.8 \\ 30 & 20 & 0.62 & 191.99 & 0.21 & -0.21 & -0.04 & 0.7 \\ 40 & 30 & 0.73 & 188.91 & 0.33 & -0.32 & -0.05 & 1.2 \\ 50 & 40 & 0.4 & 188.16 & 0.43 & -0.42 & -0.06 & 3.4 \\ 60 & 50 & 0.71 & 184.29 & 0.51 & -0.51 & -0.04 & 4.6 \\ 70 & 60 & 0.81 & 176.87 & 0.62 & -0.62 & 0.03 & 1.8 \\ 71.6 & 70 & 0.67 & 170.8 & 0.73 & -0.72 & 0.12 & 1.4 \\ & 71.6 & 0.61 & 170.05 & 0.74 & -0.73 & 0.13 & 4\end{array}$


DTS-RPT-090, Rev. 0

\section{C1.2 ENERGYSOLUTIONS AND PACIFIC NORTHWEST GEOPHYSICS CALIPER LOGS}
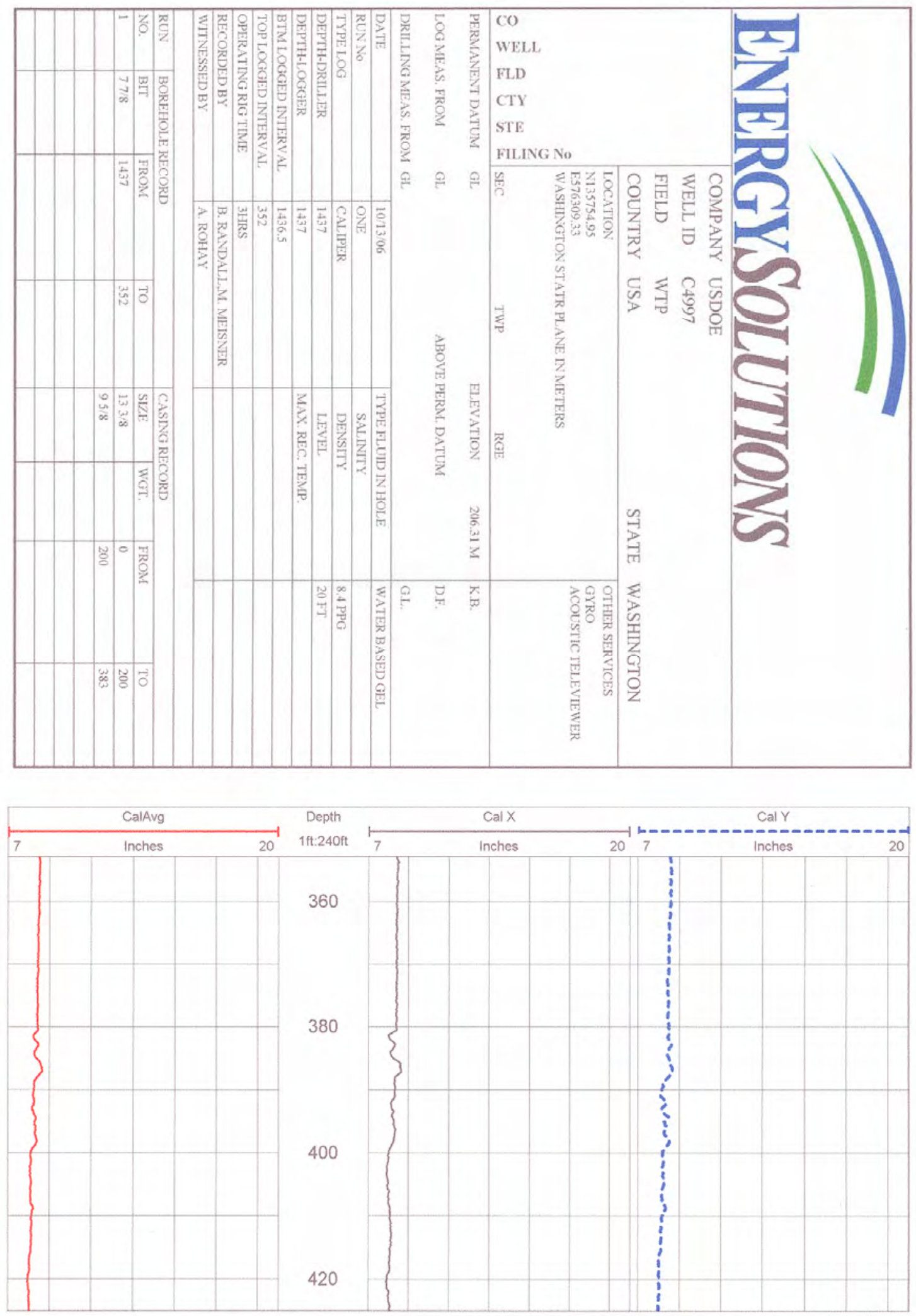
DTS-RPT-090, Rev. 0

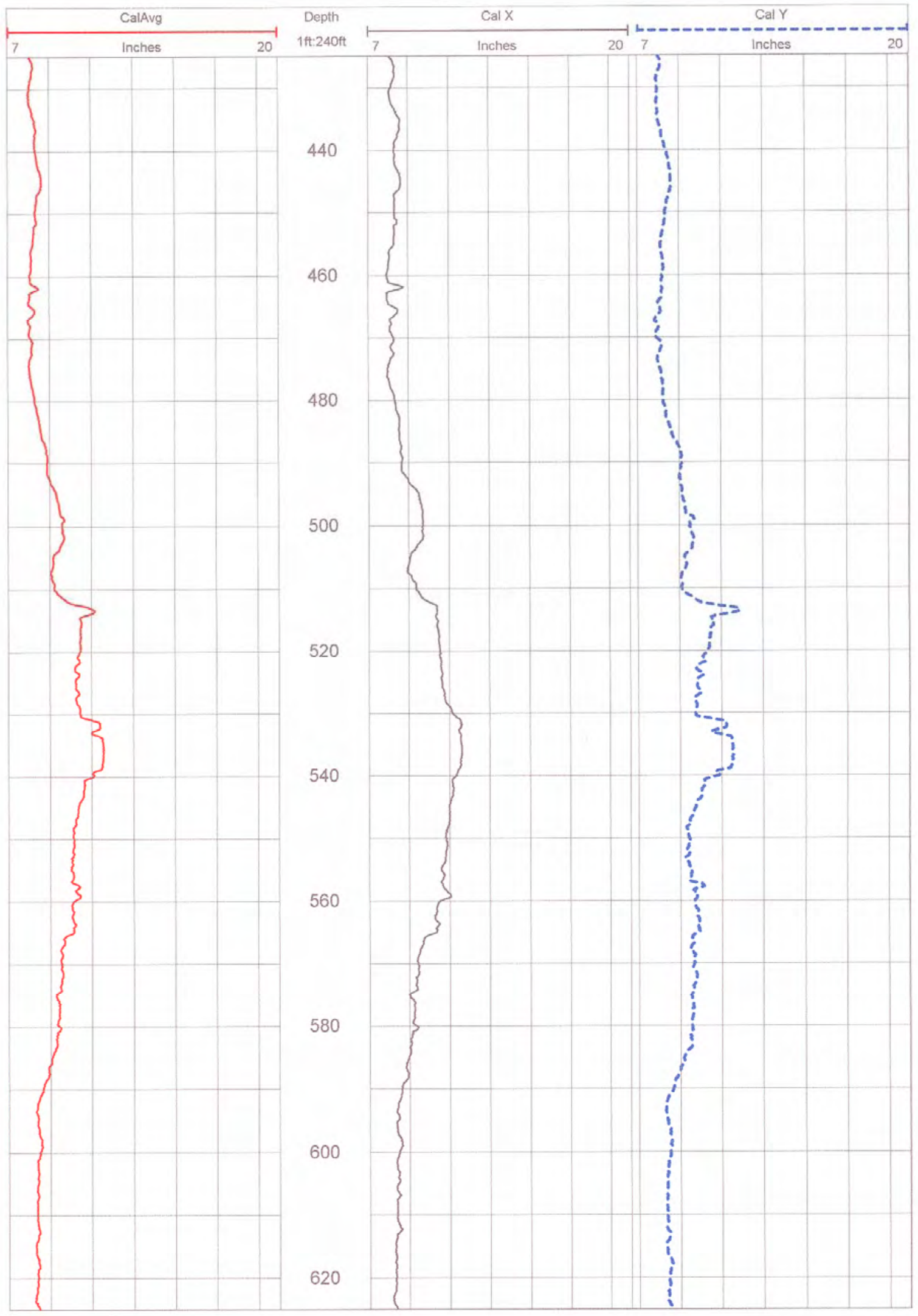


DTS-RPT-090, Rev. 0

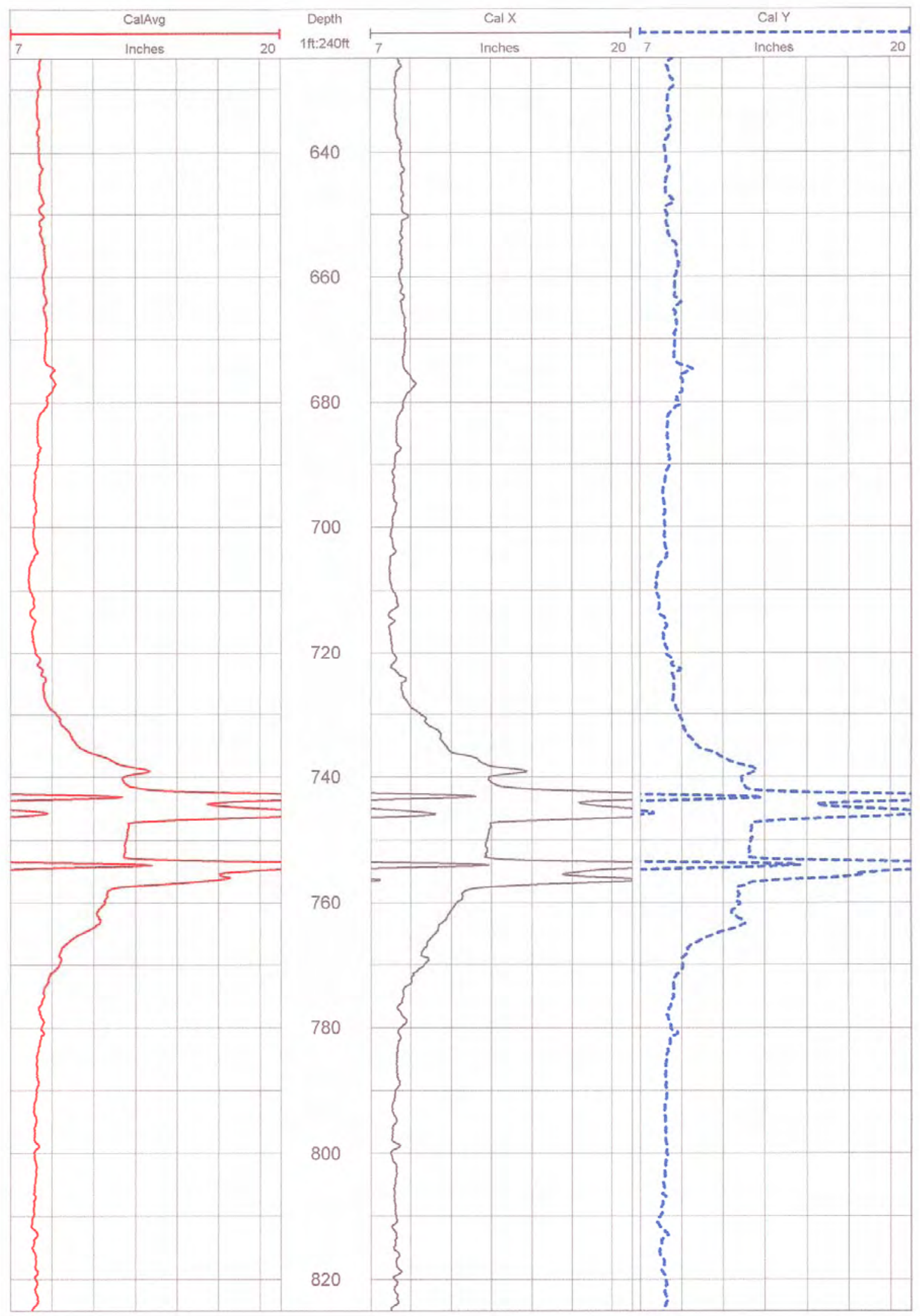


DTS-RPT-090, Rev. 0

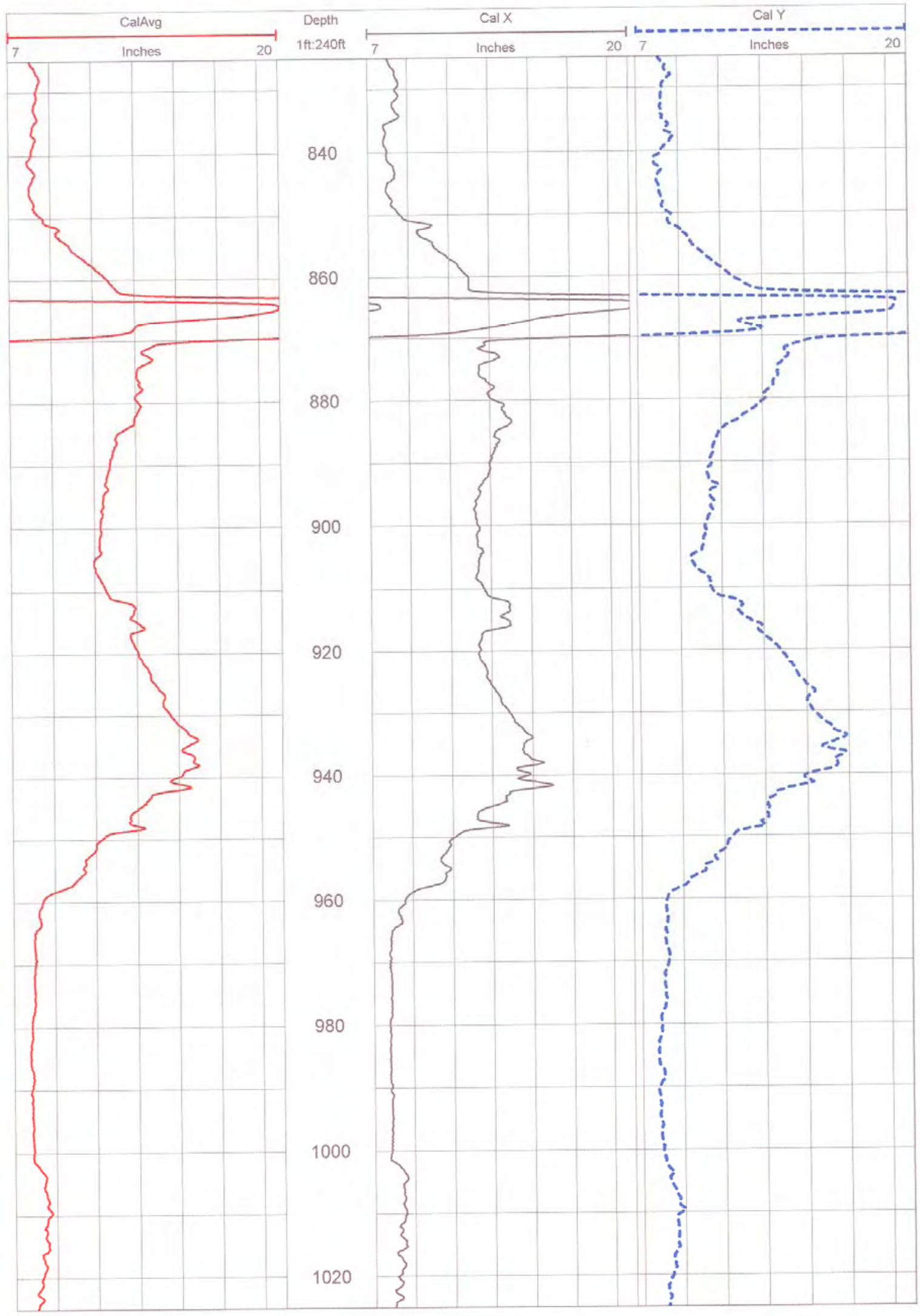


DTS-RPT-090, Rev. 0

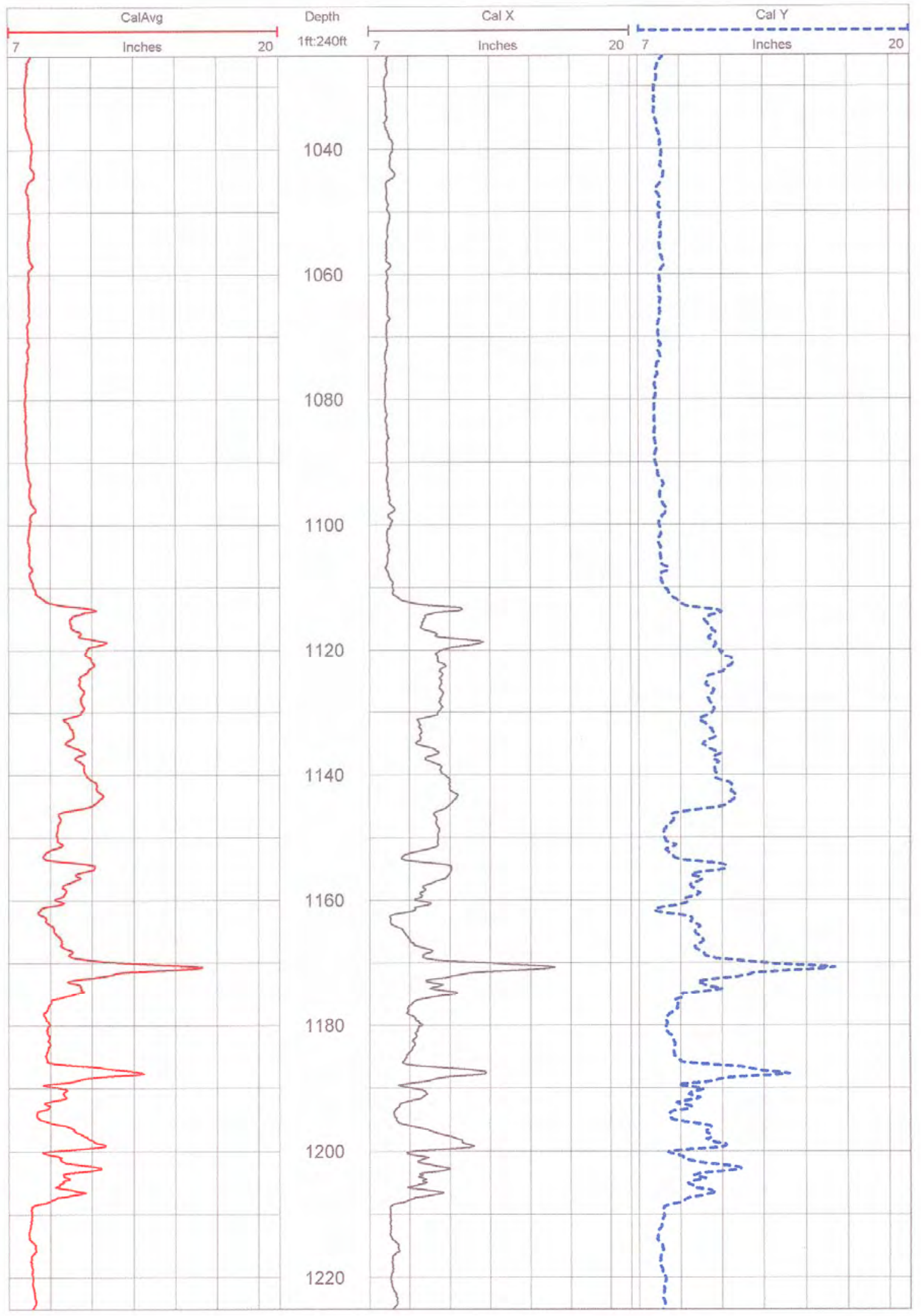


DTS-RPT-090, Rev. 0

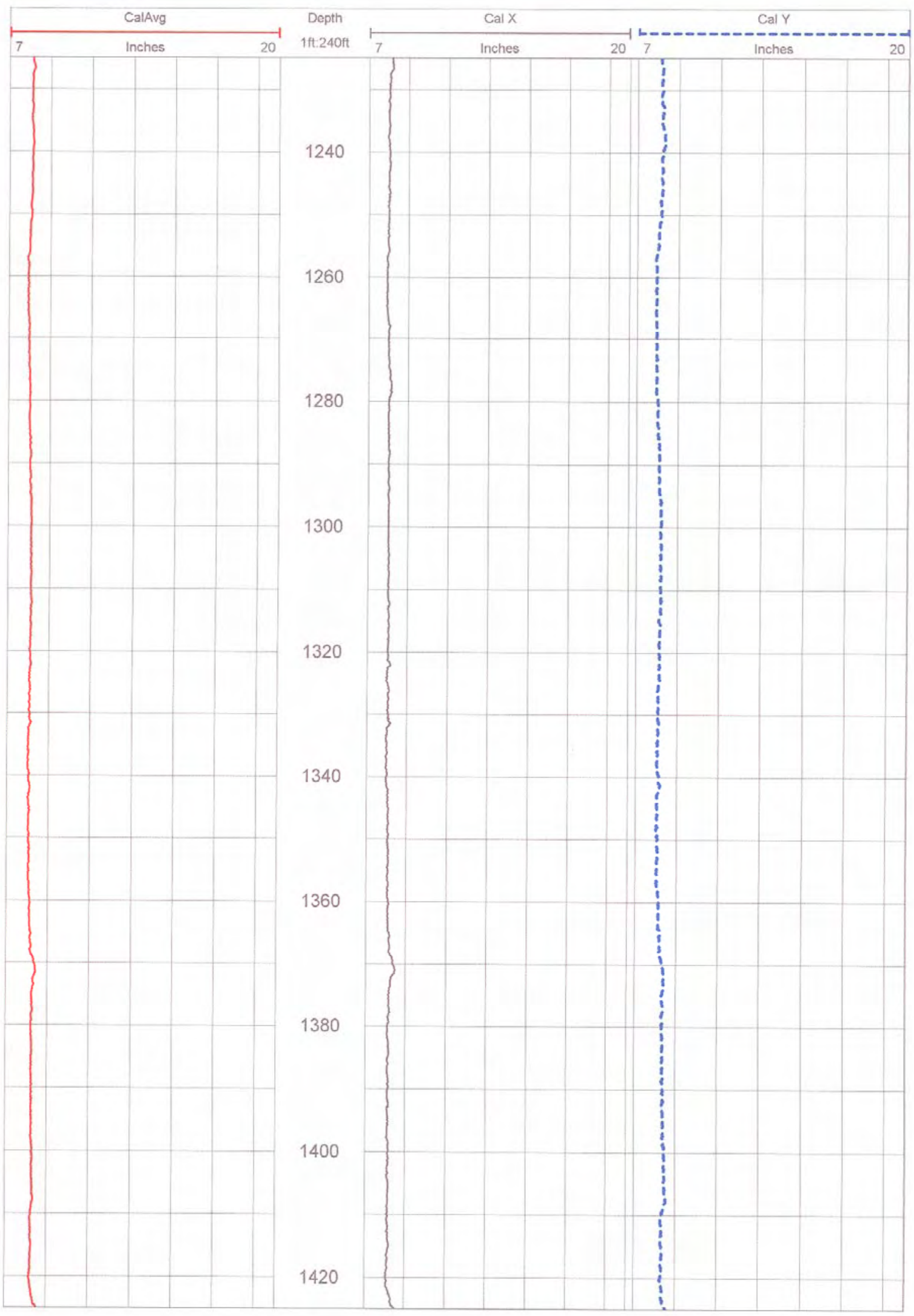


DTS-RPT-090, Rev. 0

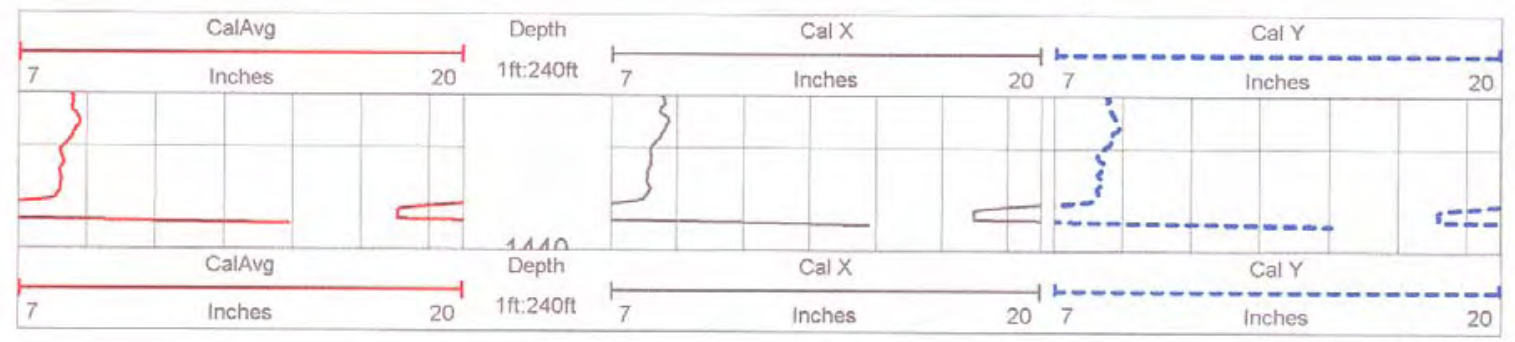


DTS-RPT-090, Rev. 0
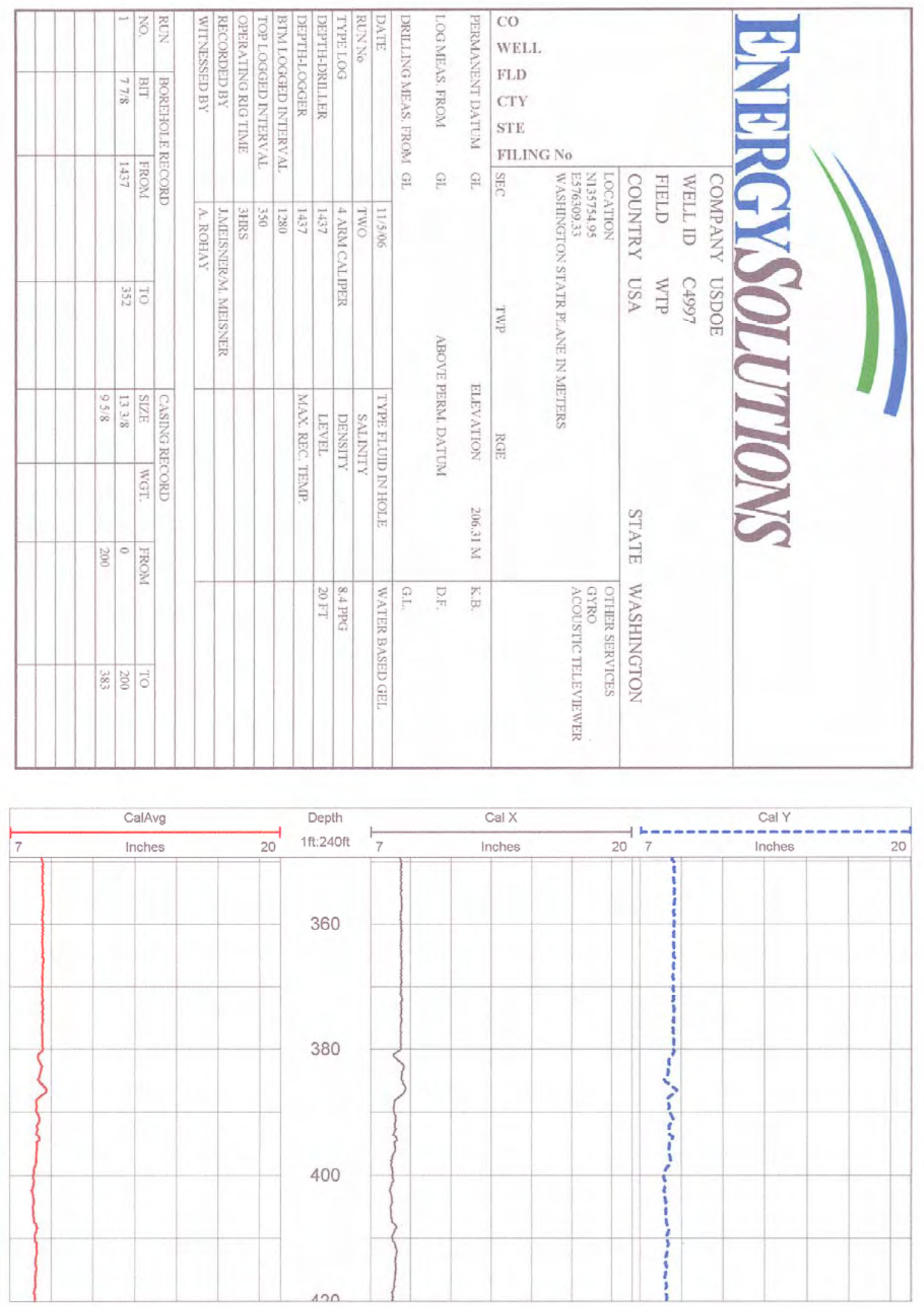
DTS-RPT-090, Rev. 0

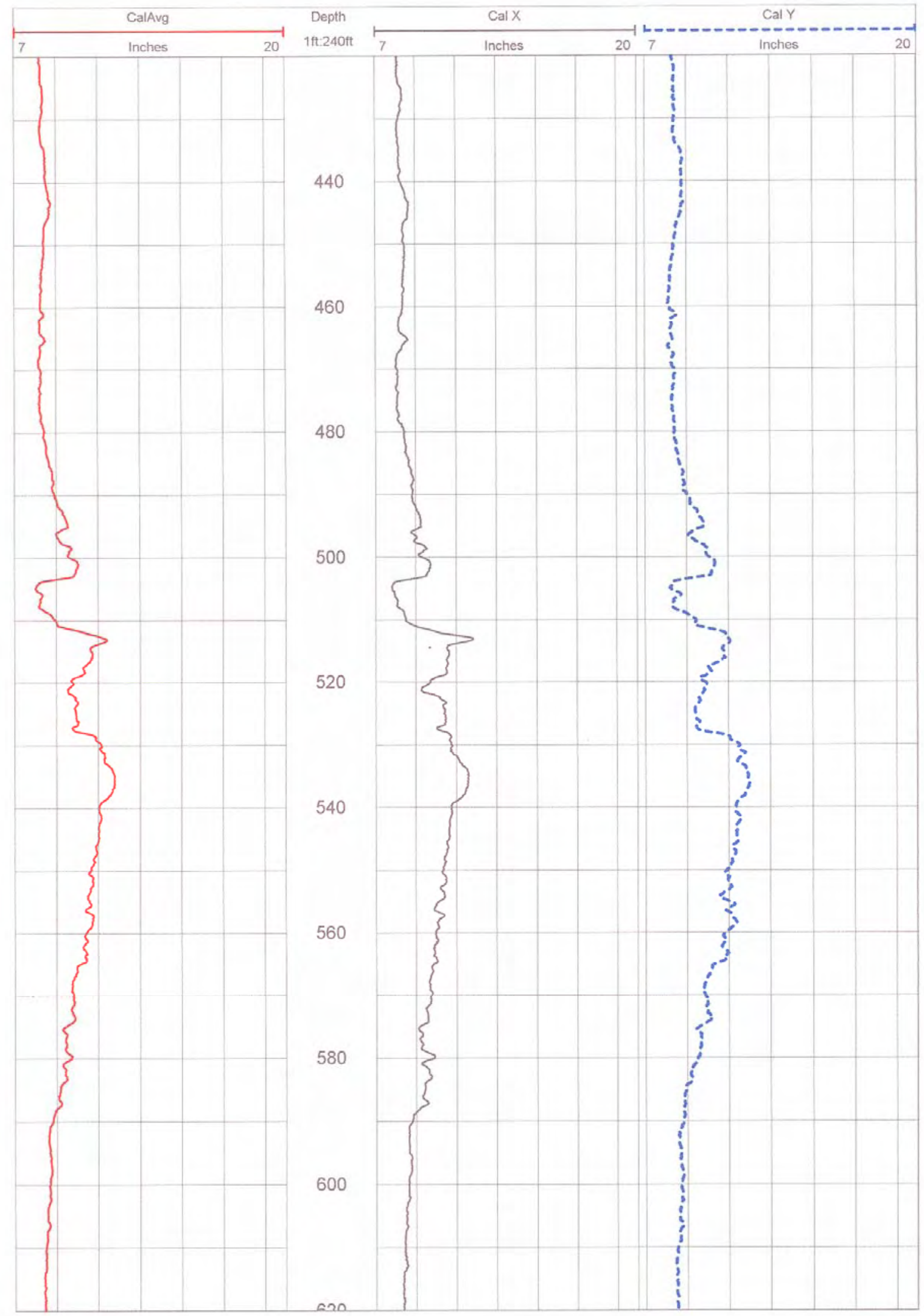


DTS-RPT-090, Rev. 0

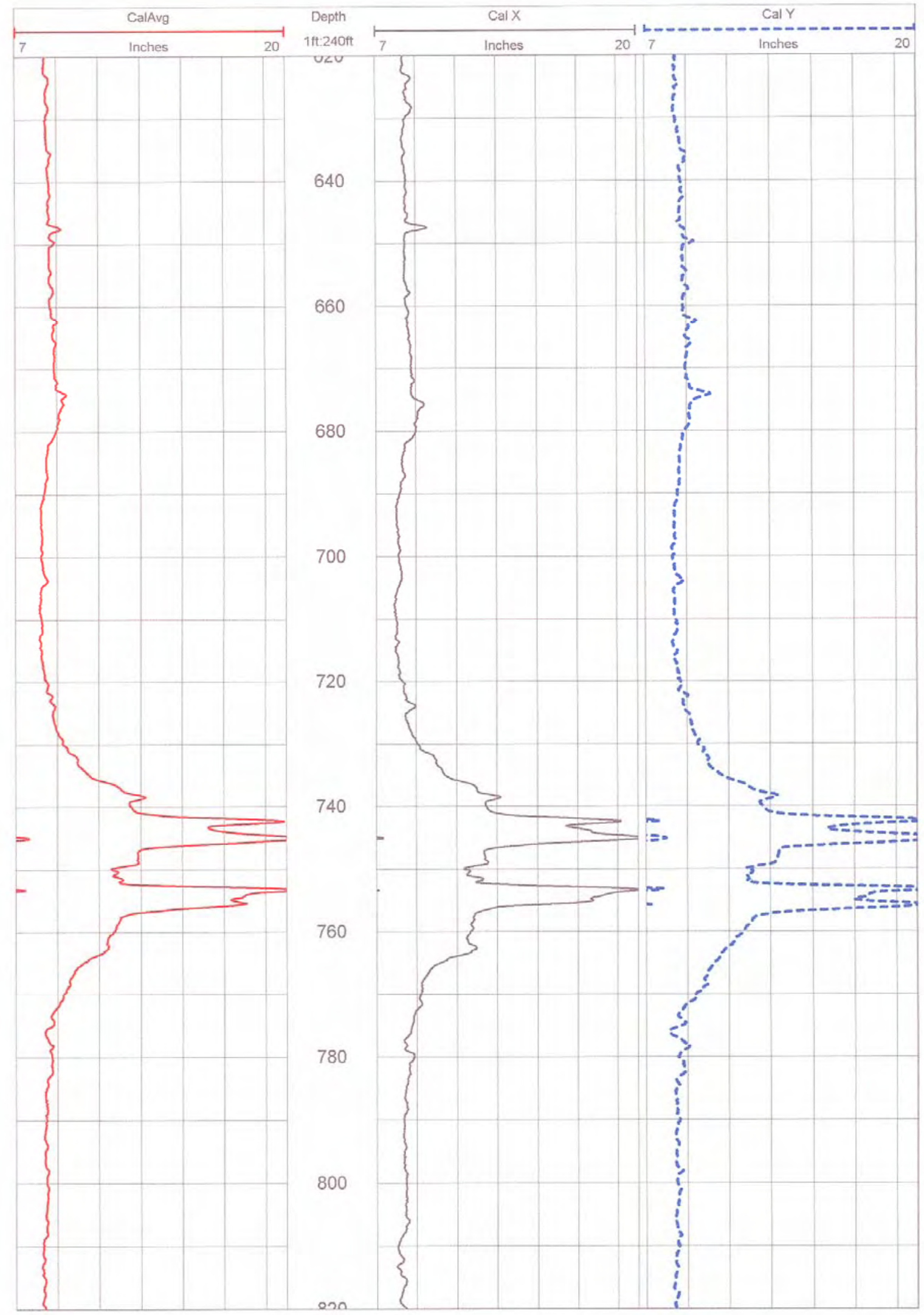


DTS-RPT-090, Rev. 0

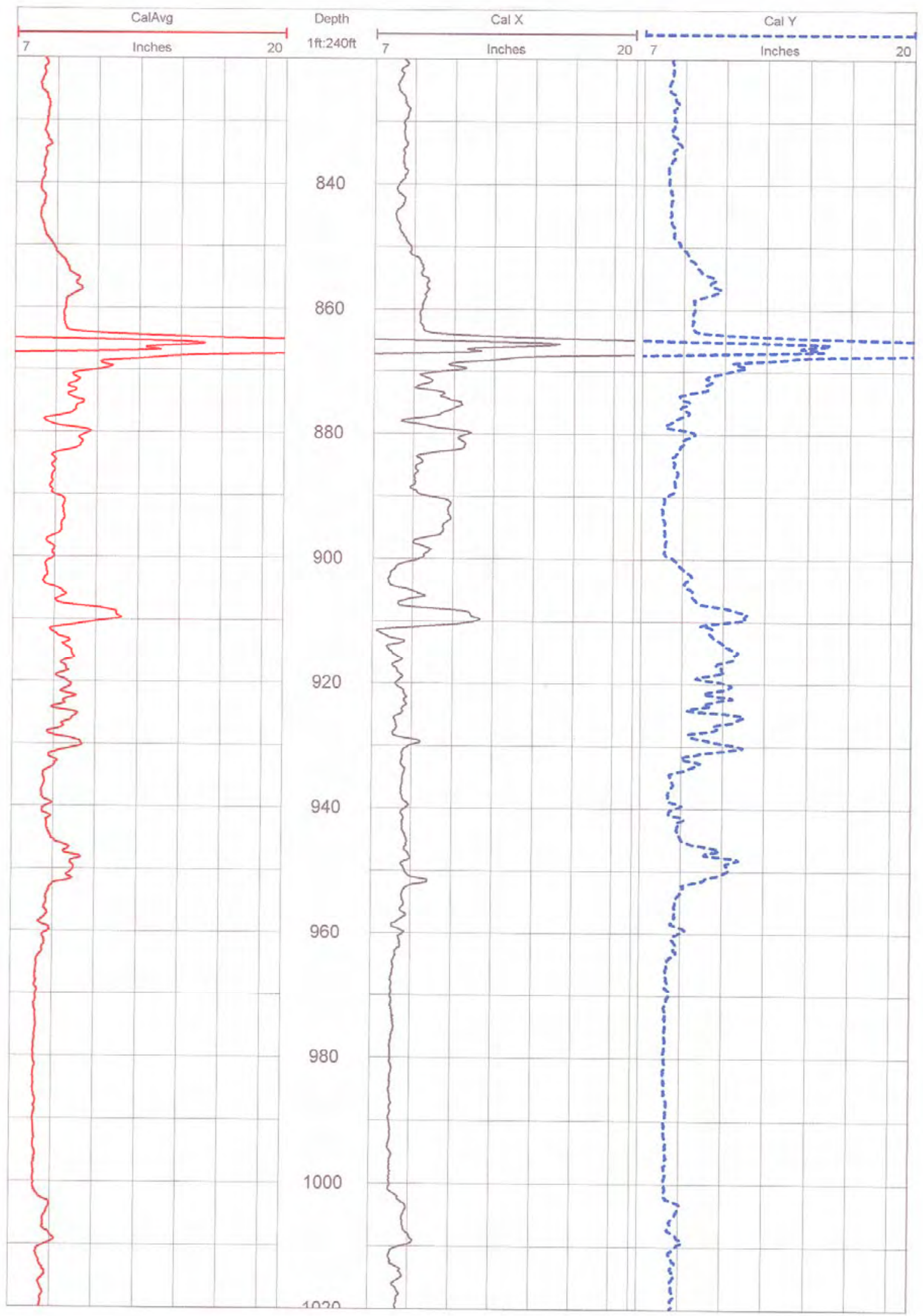


DTS-RPT-090, Rev. 0

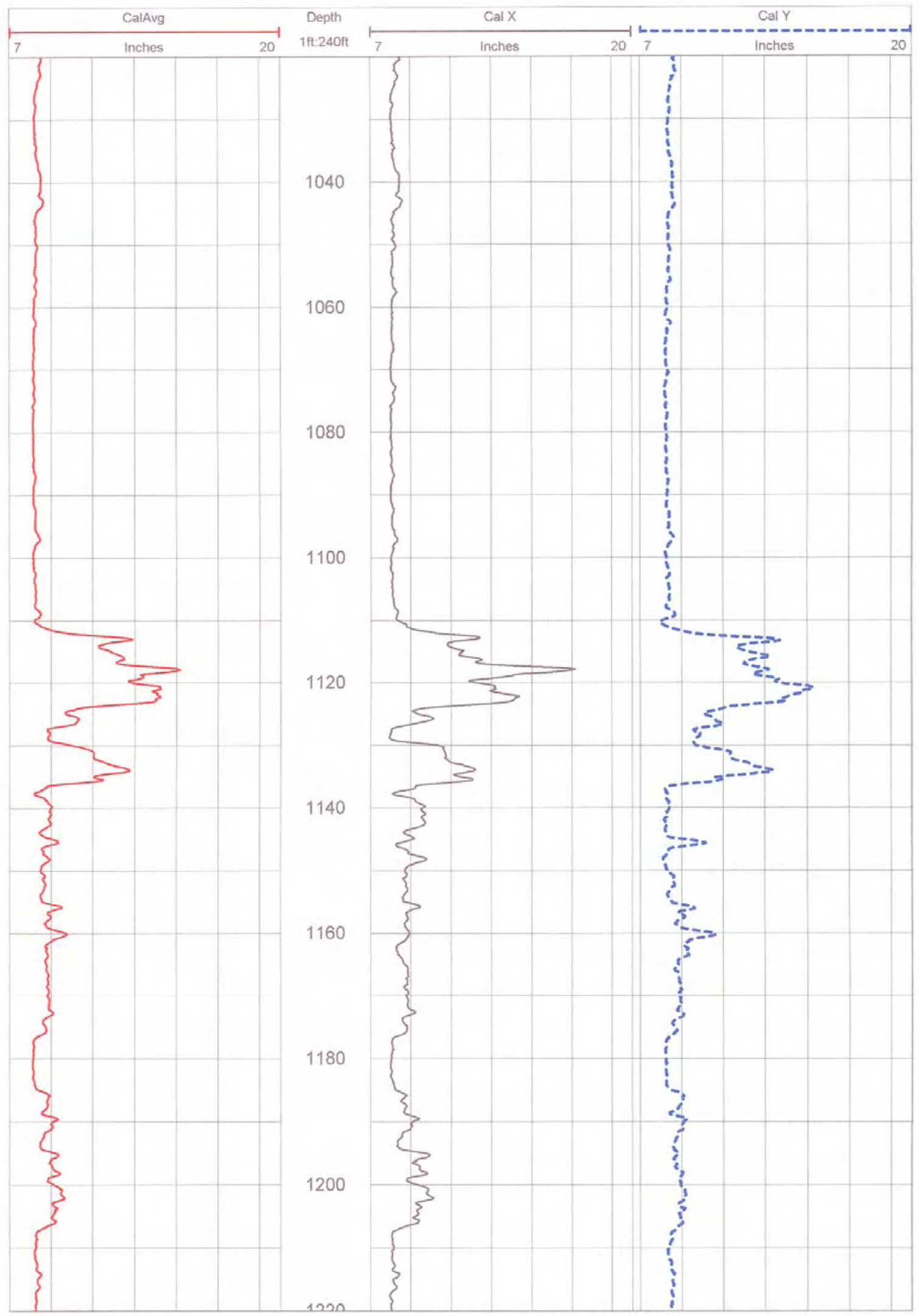


DTS-RPT-090, Rev. 0

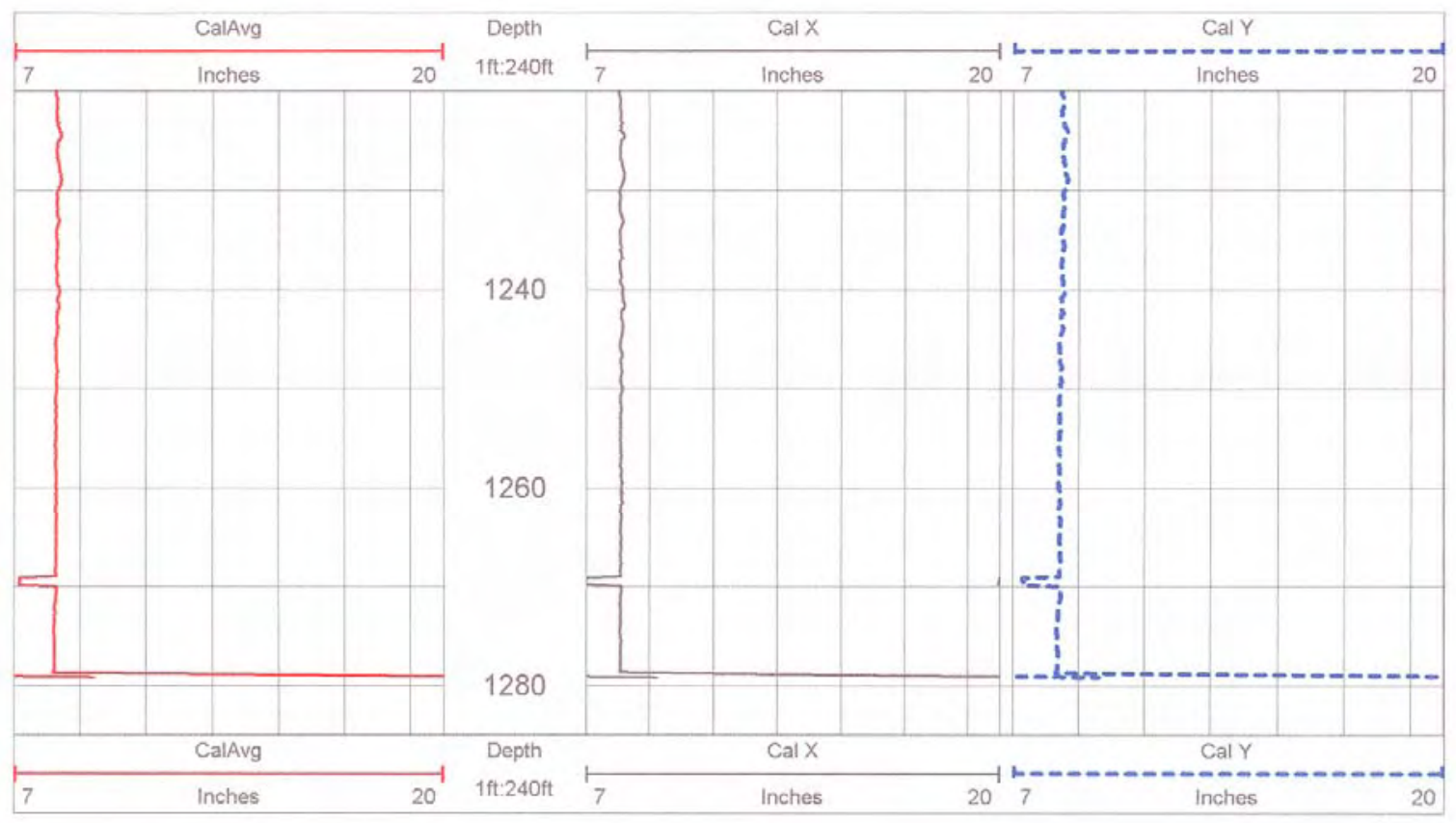


DTS-RPT-090, Rev. 0
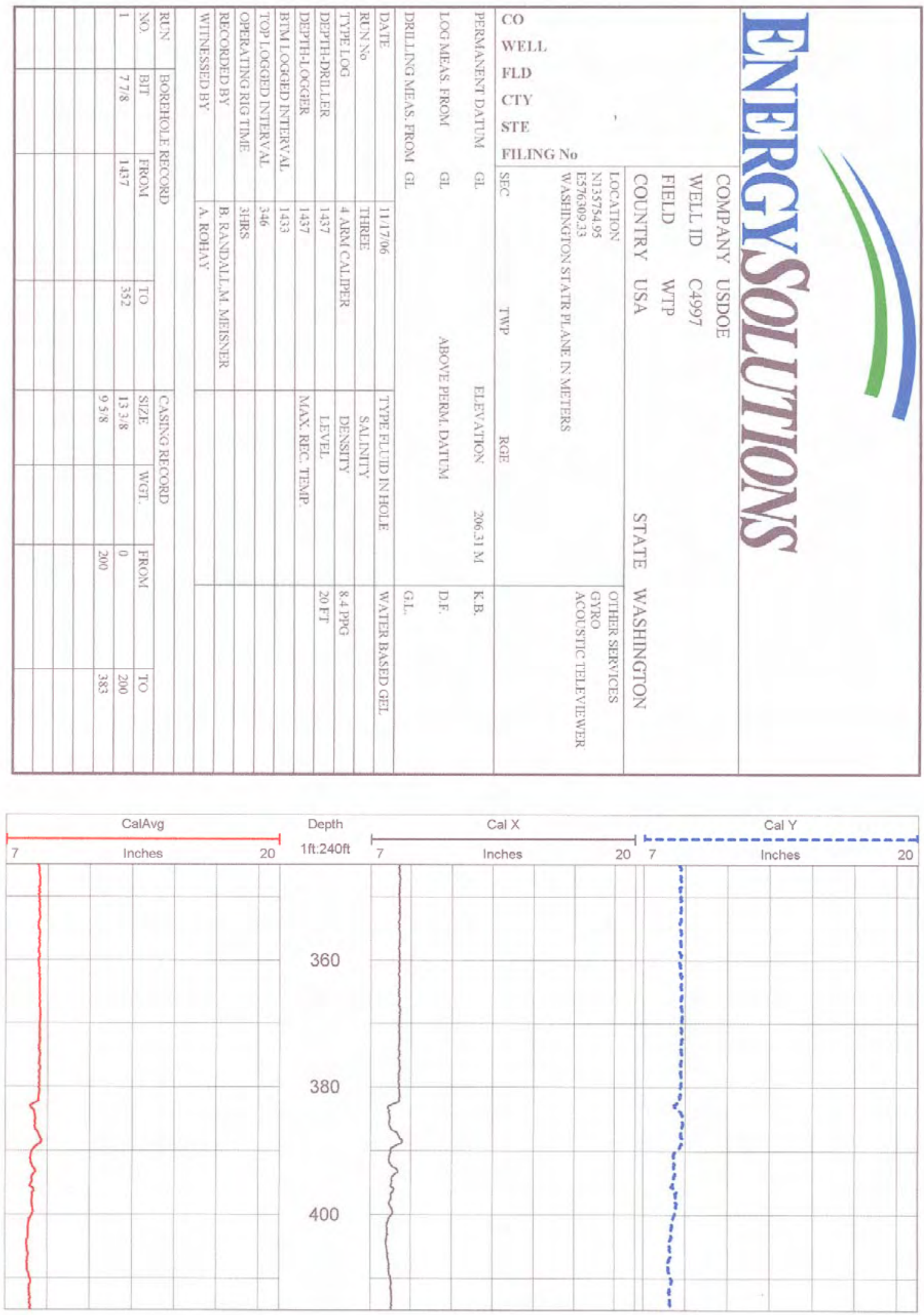
DTS-RPT-090, Rev. 0

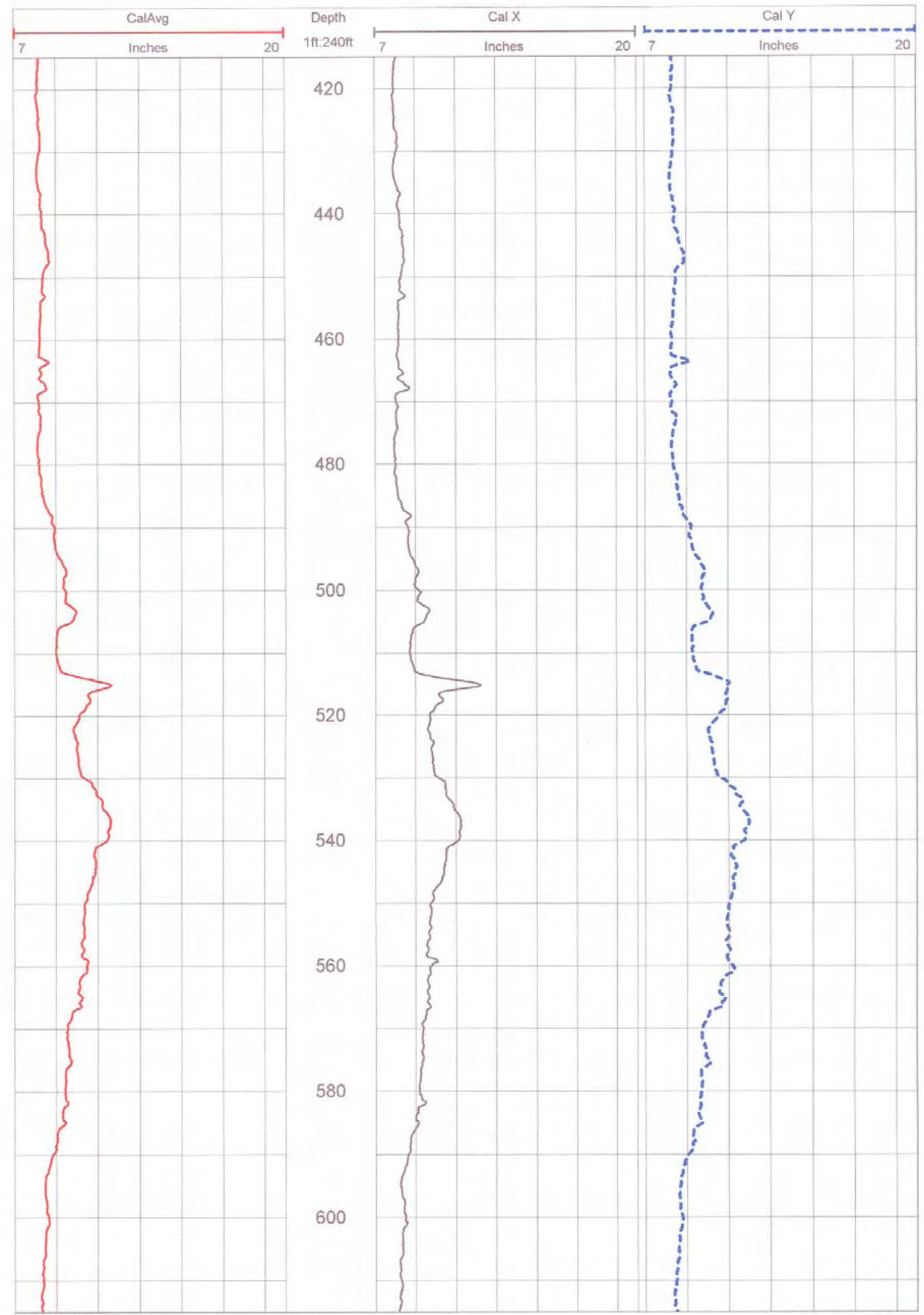


DTS-RPT-090, Rev. 0

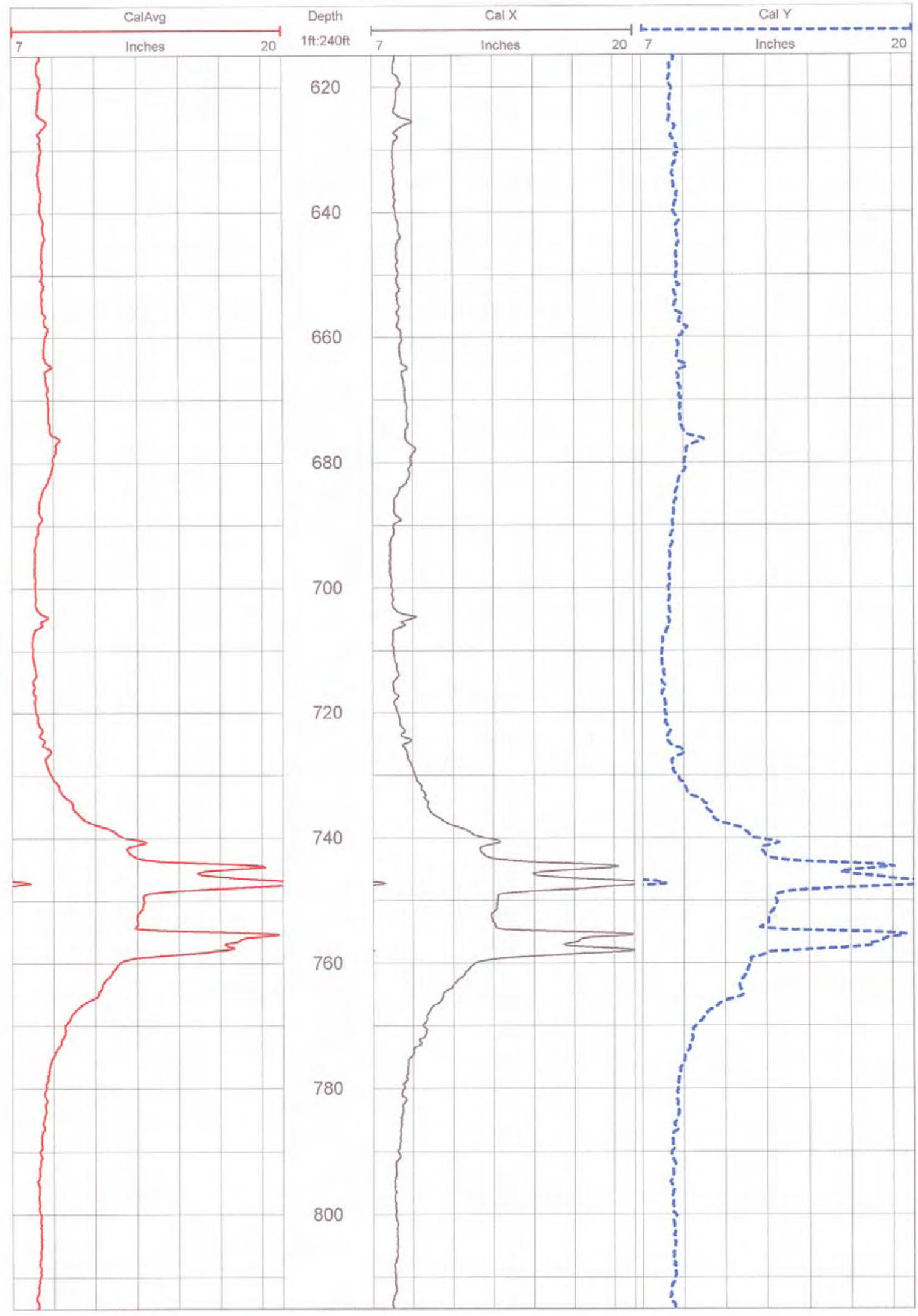


DTS-RPT-090, Rev. 0

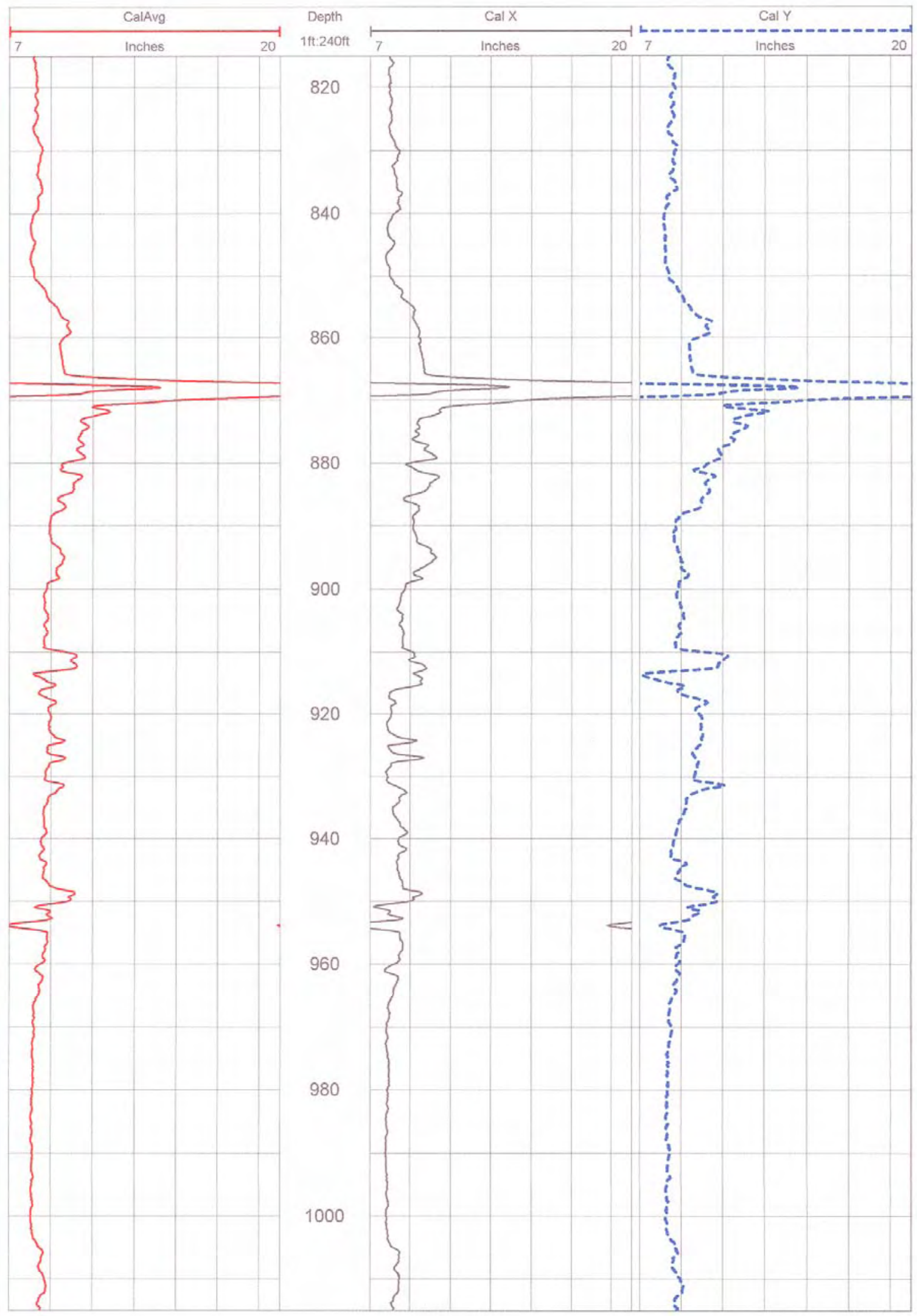


DTS-RPT-090, Rev. 0

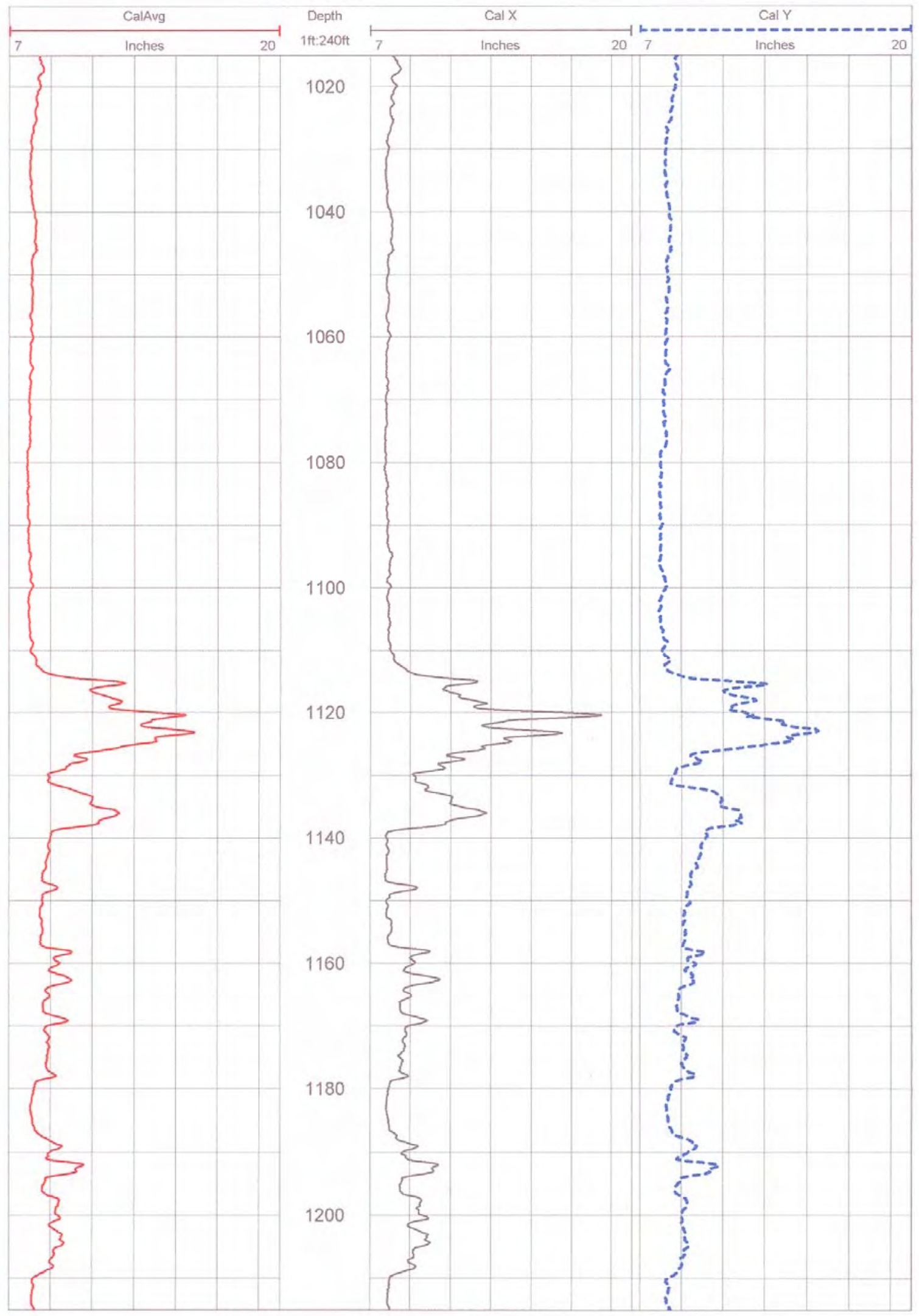


DTS-RPT-090, Rev. 0

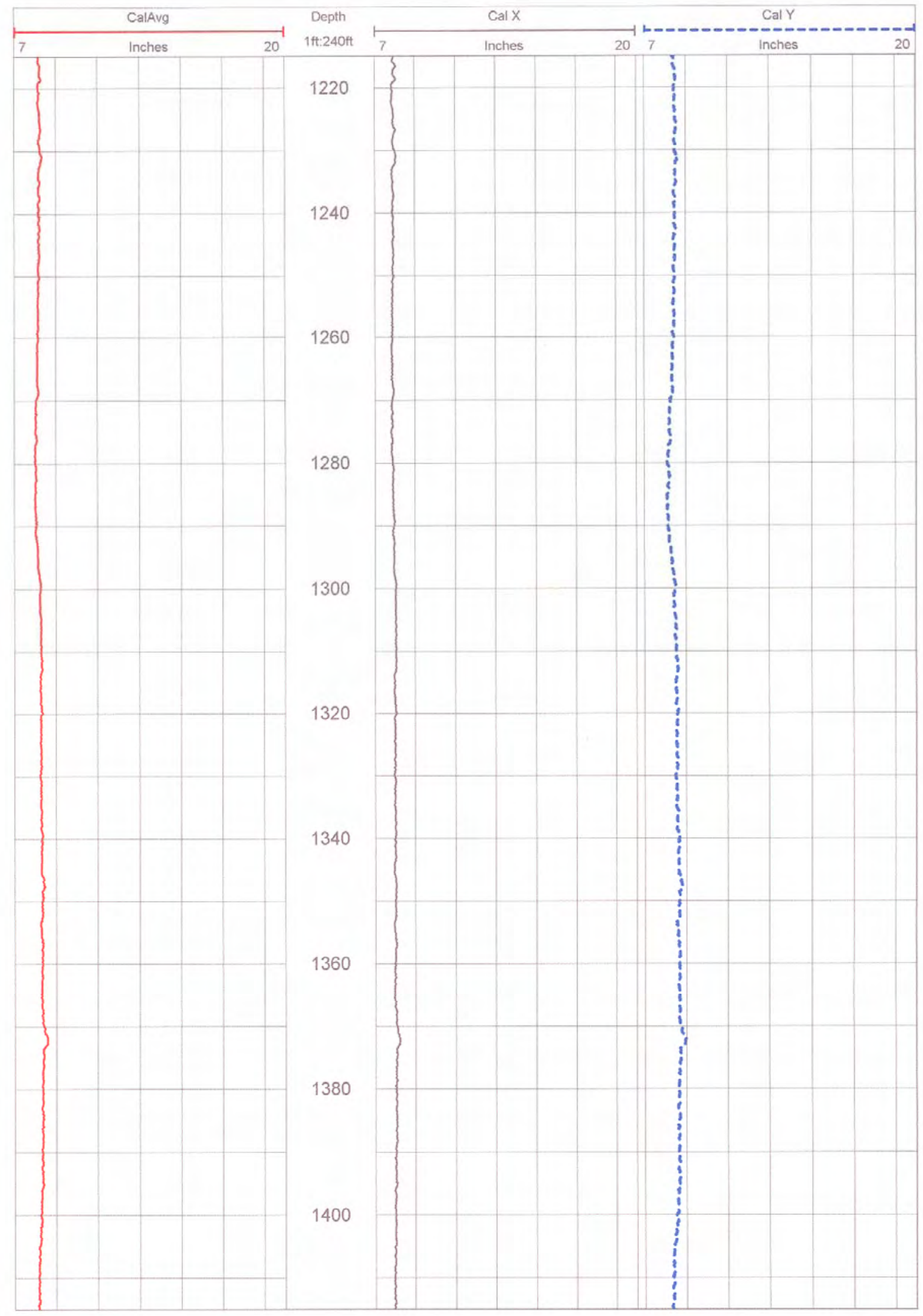


DTS-RPT-090, Rev. 0

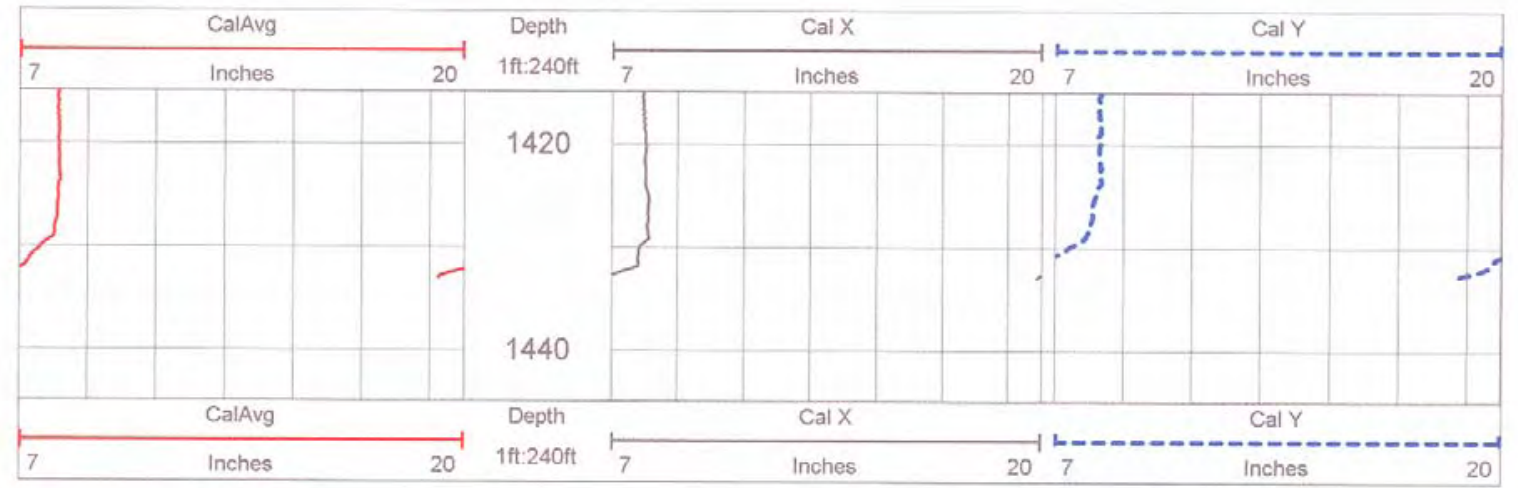


DTS-RPT-090, Rev. 0

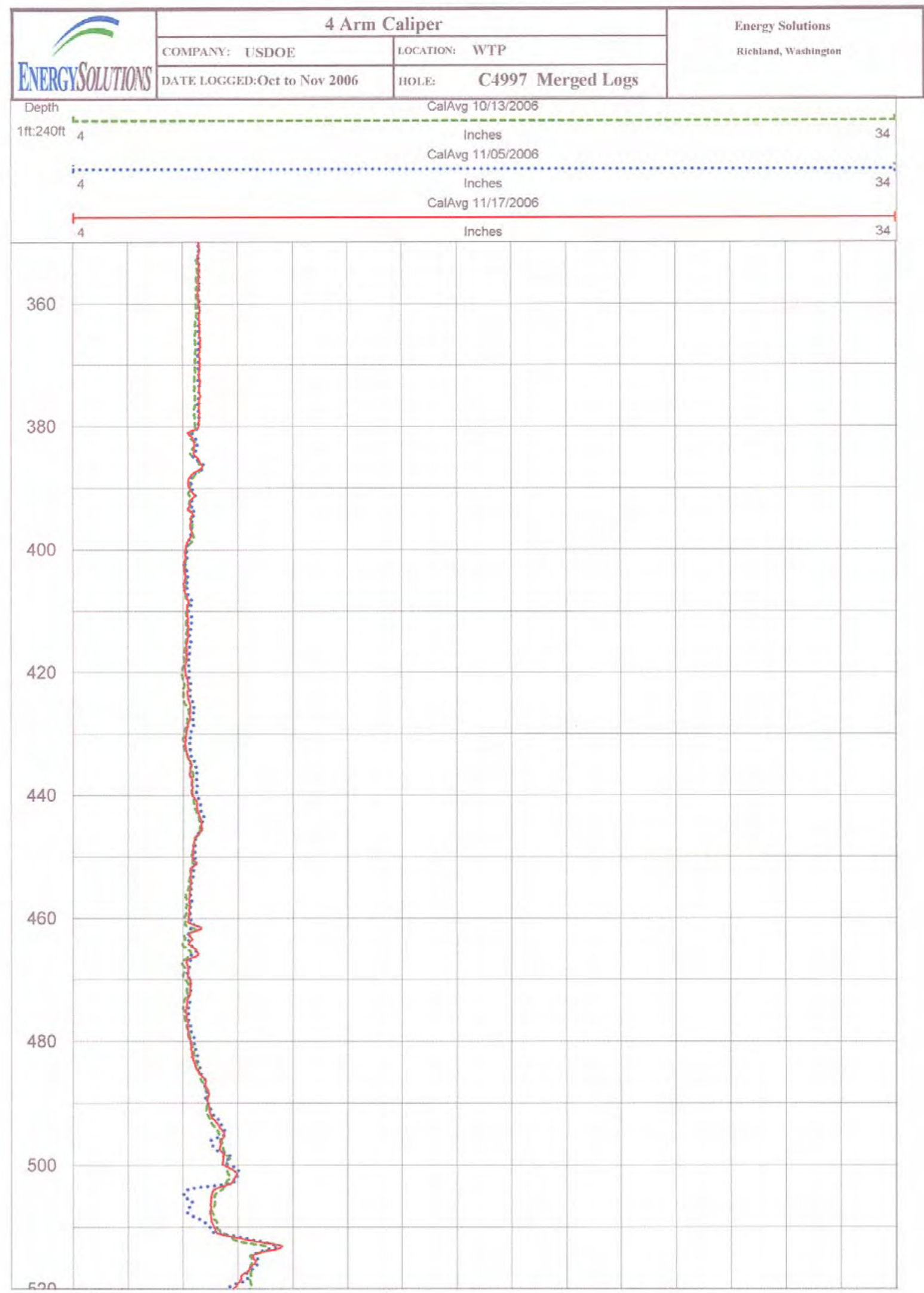


DTS-RPT-090, Rev. 0

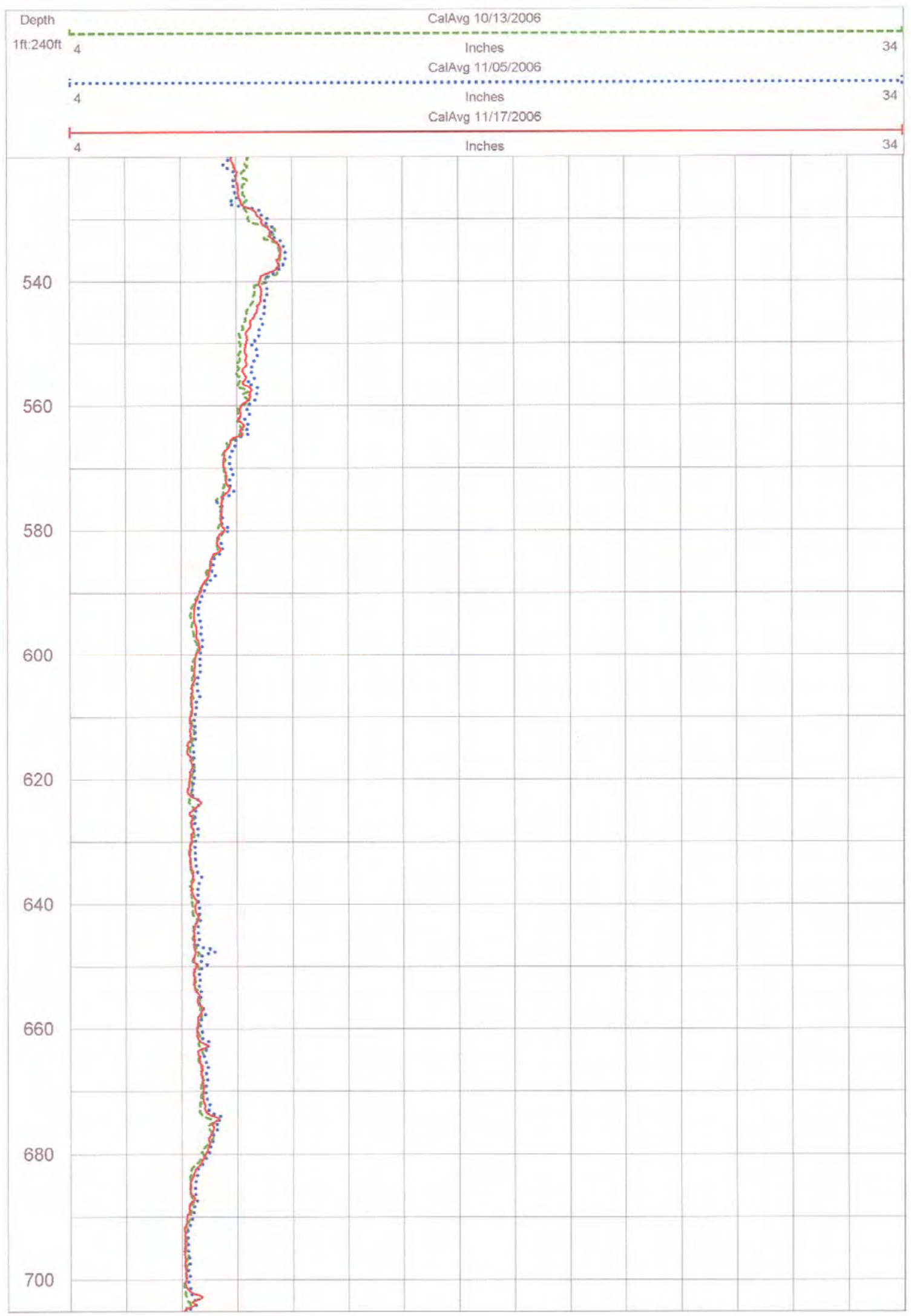


DTS-RPT-090, Rev. 0

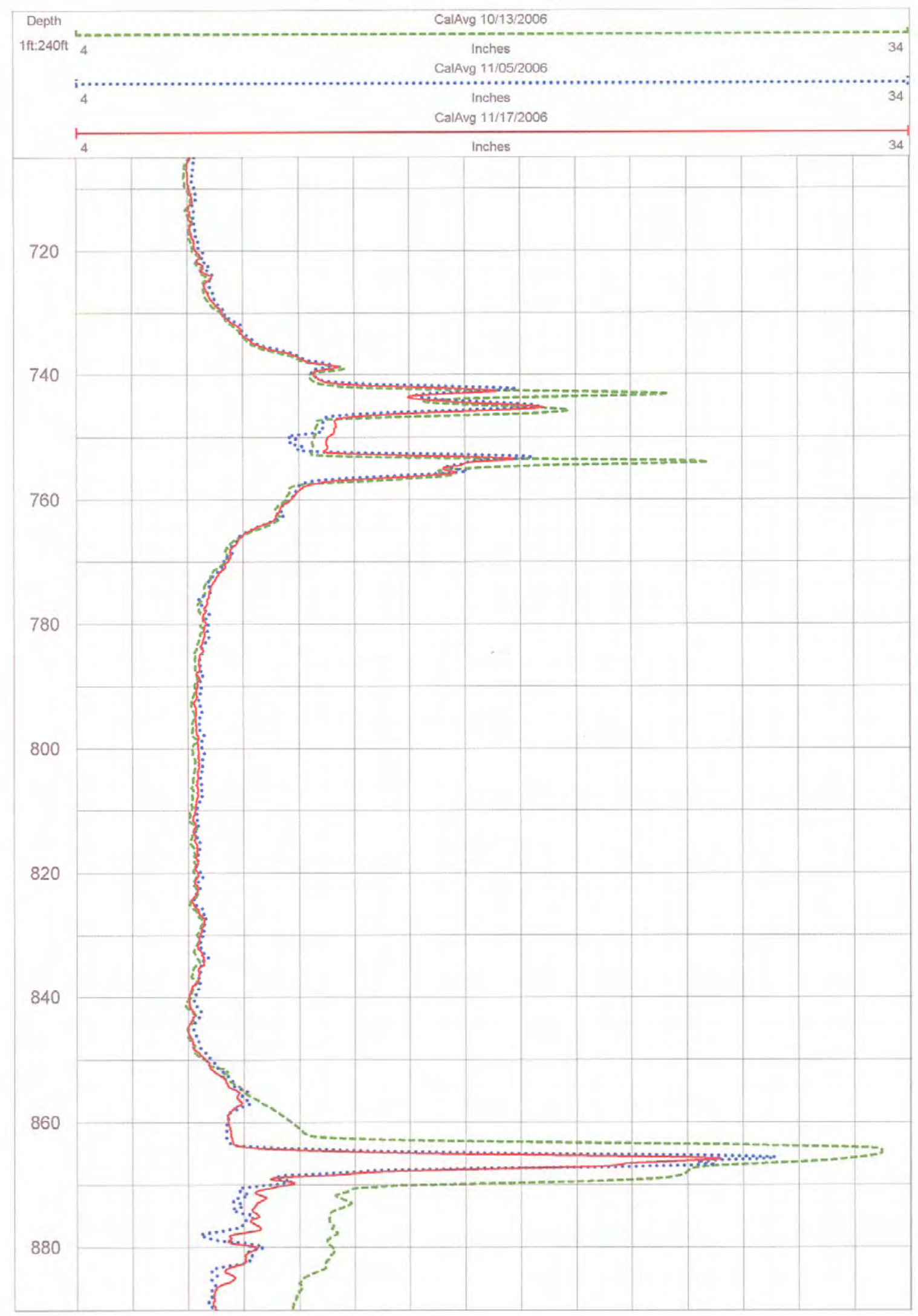


DTS-RPT-090, Rev. 0

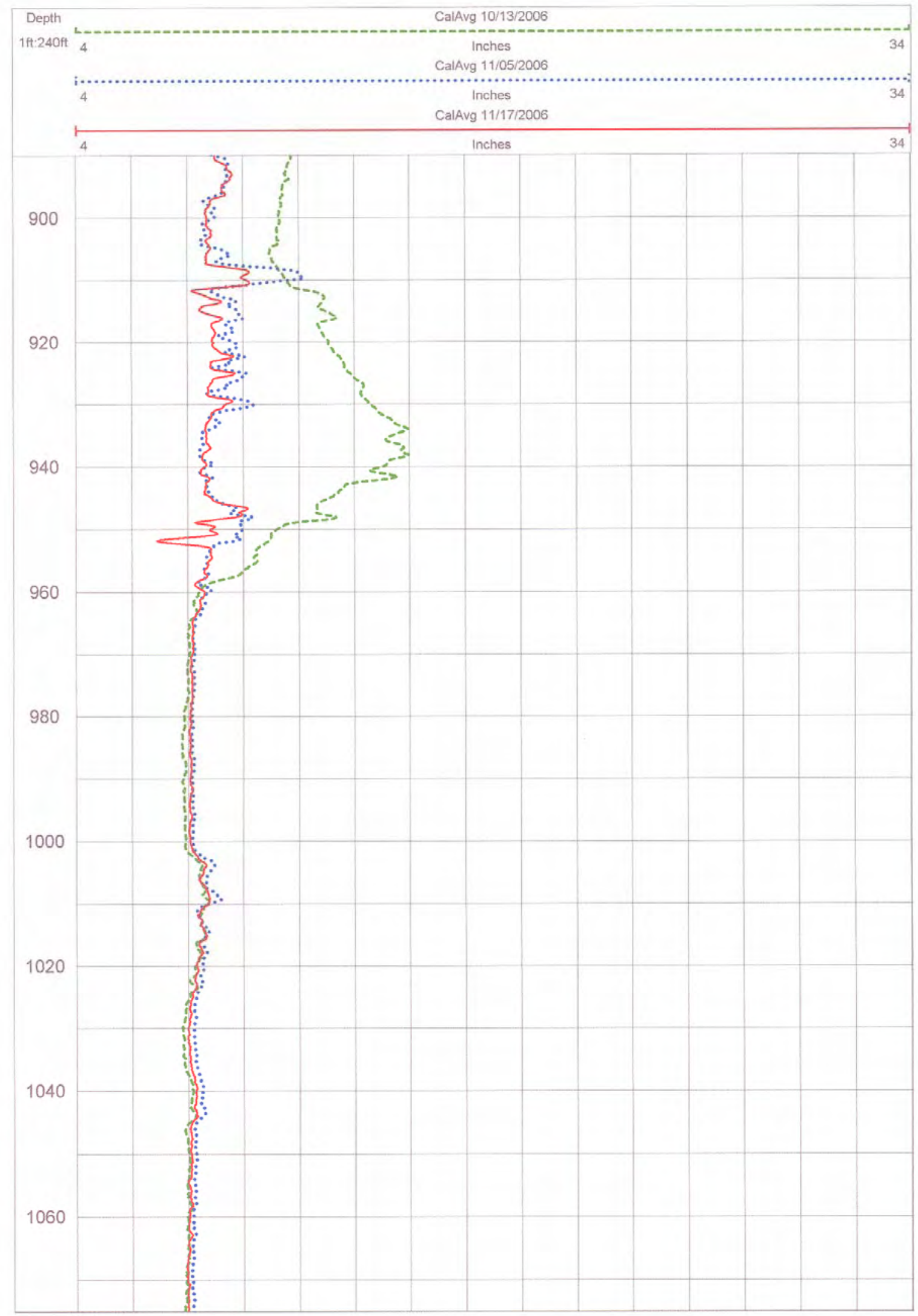


DTS-RPT-090, Rev. 0

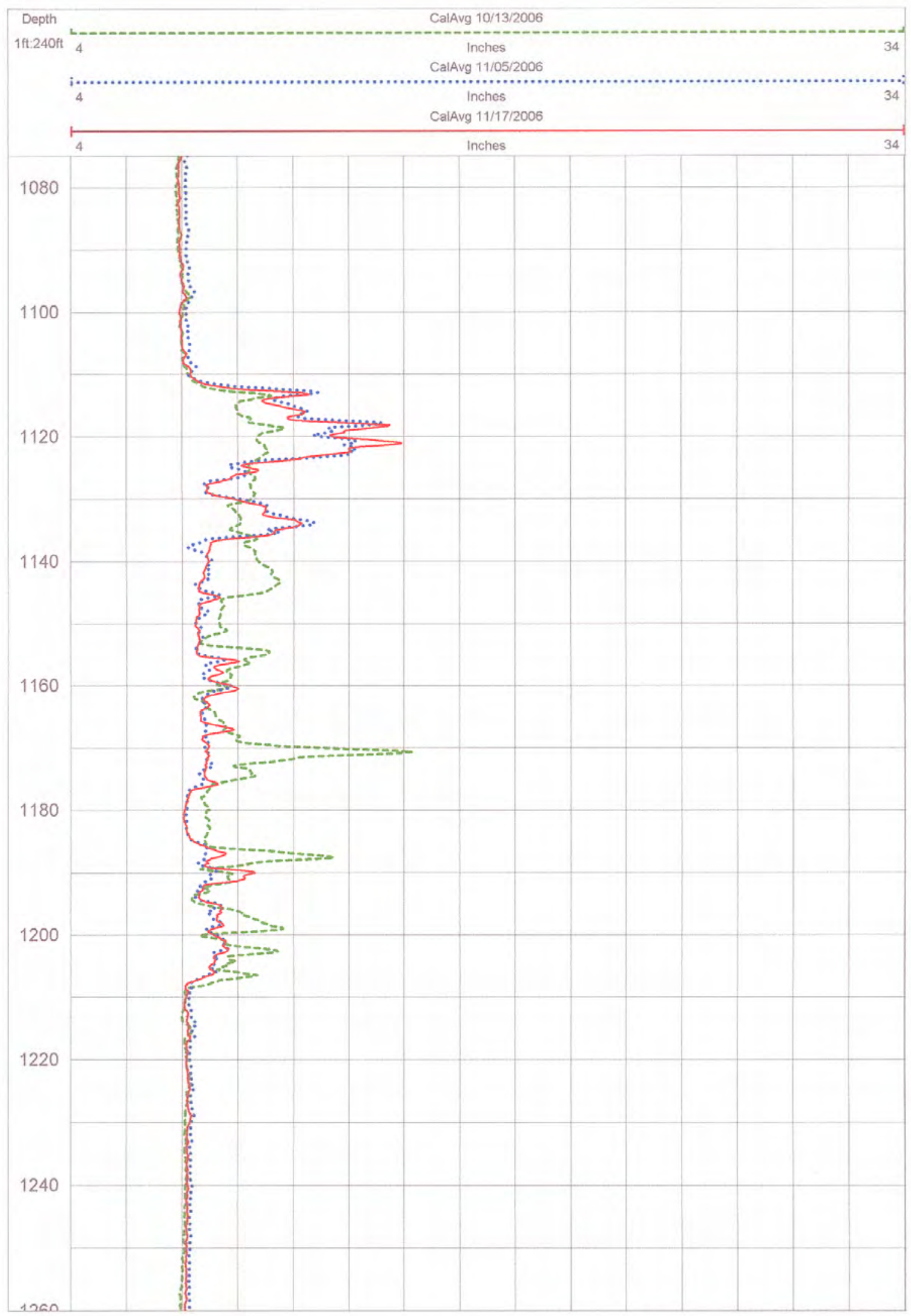


DTS-RPT-090, Rev. 0

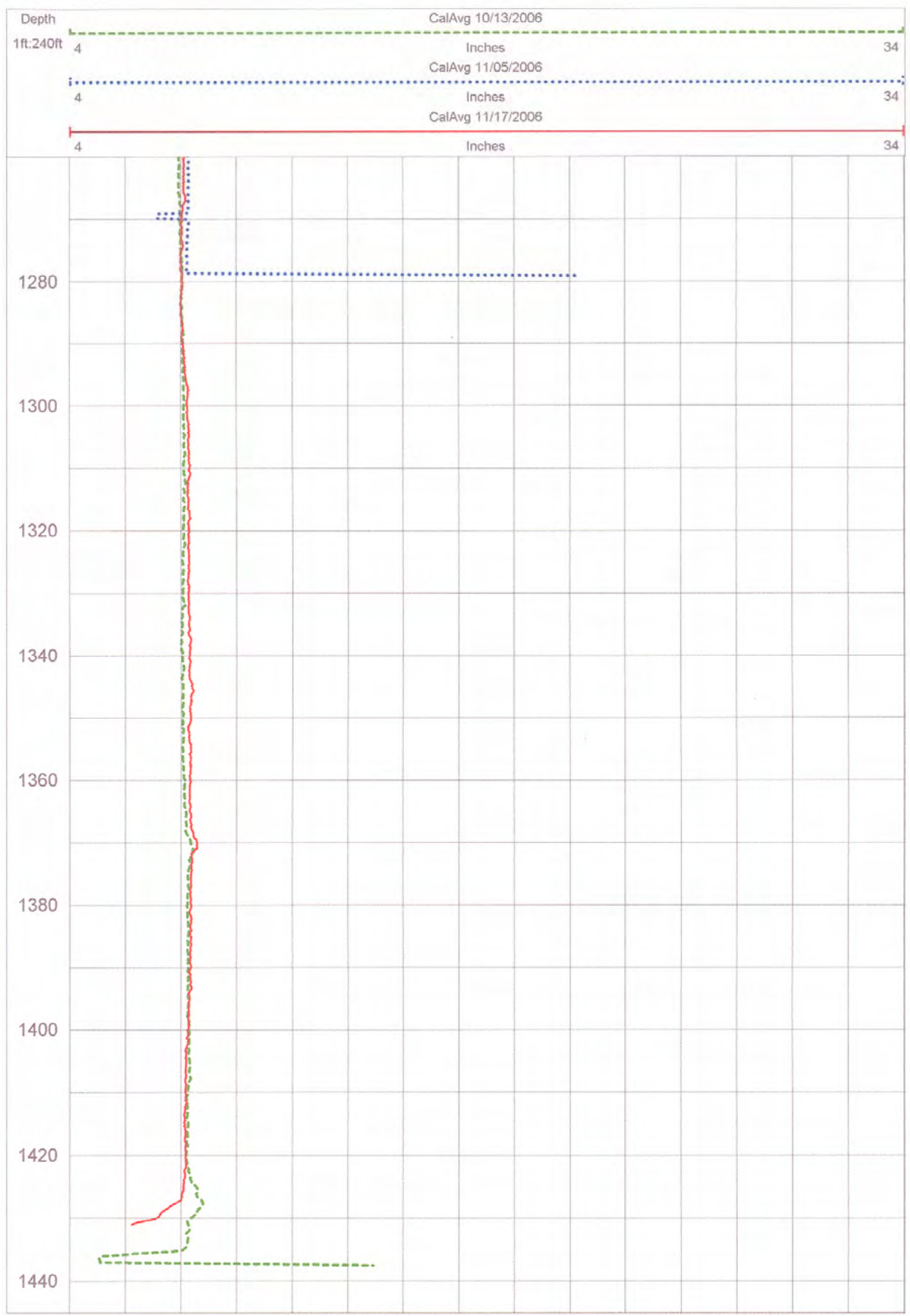


DTS-RPT-090, Rev. 0

\section{C1.3 COLOG MERGED LOGS}

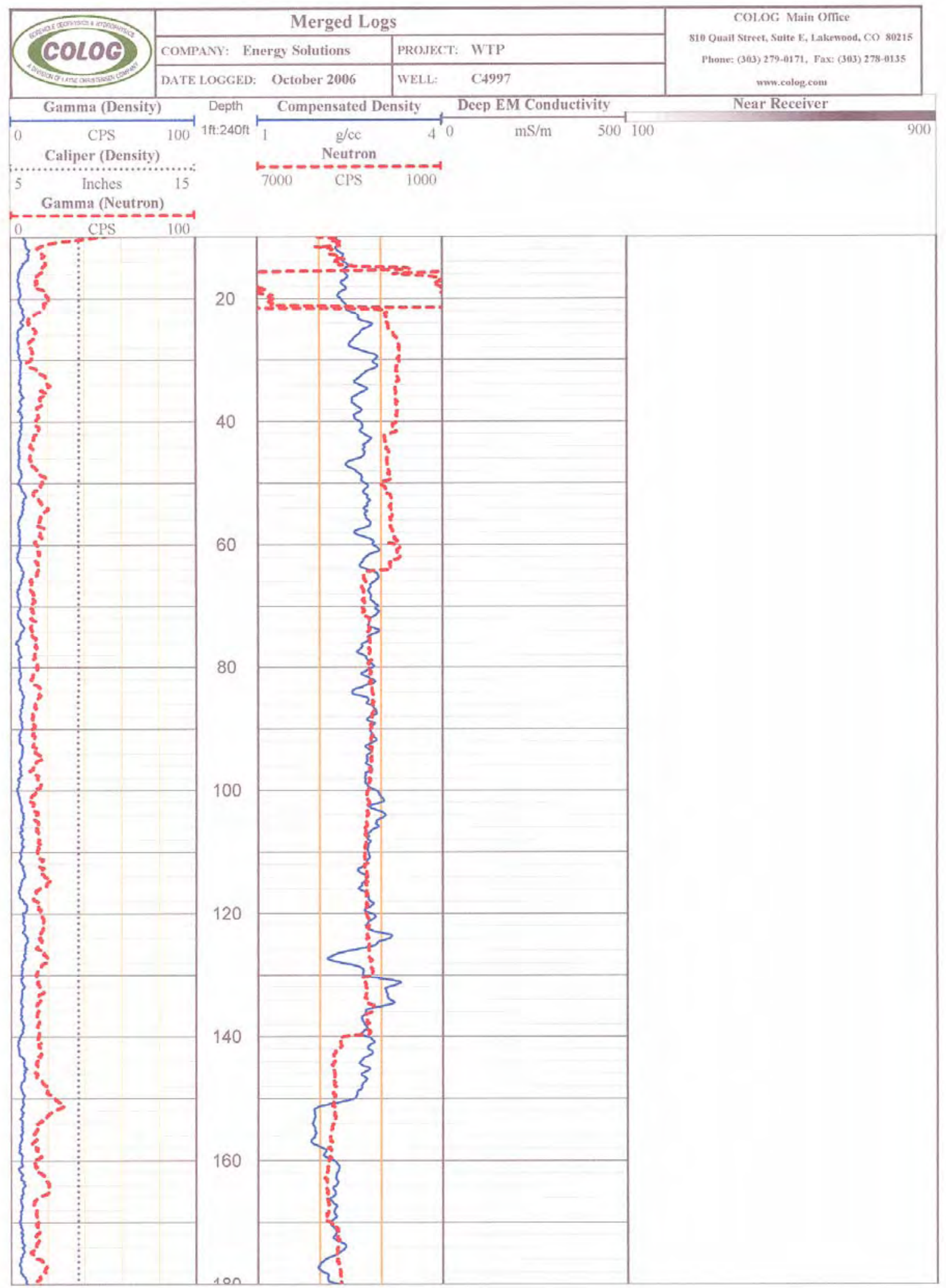


DTS-RPT-090, Rev. 0

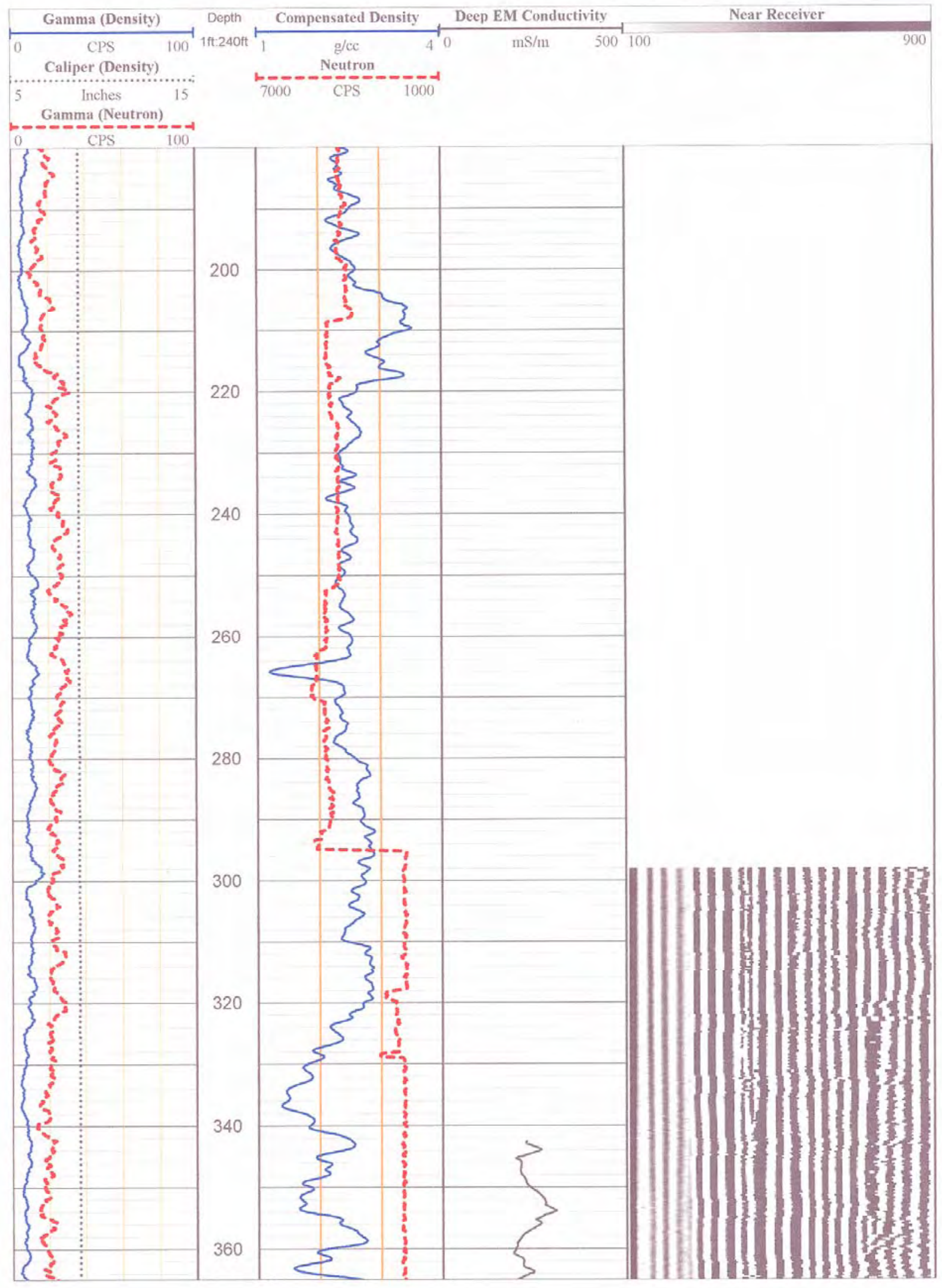




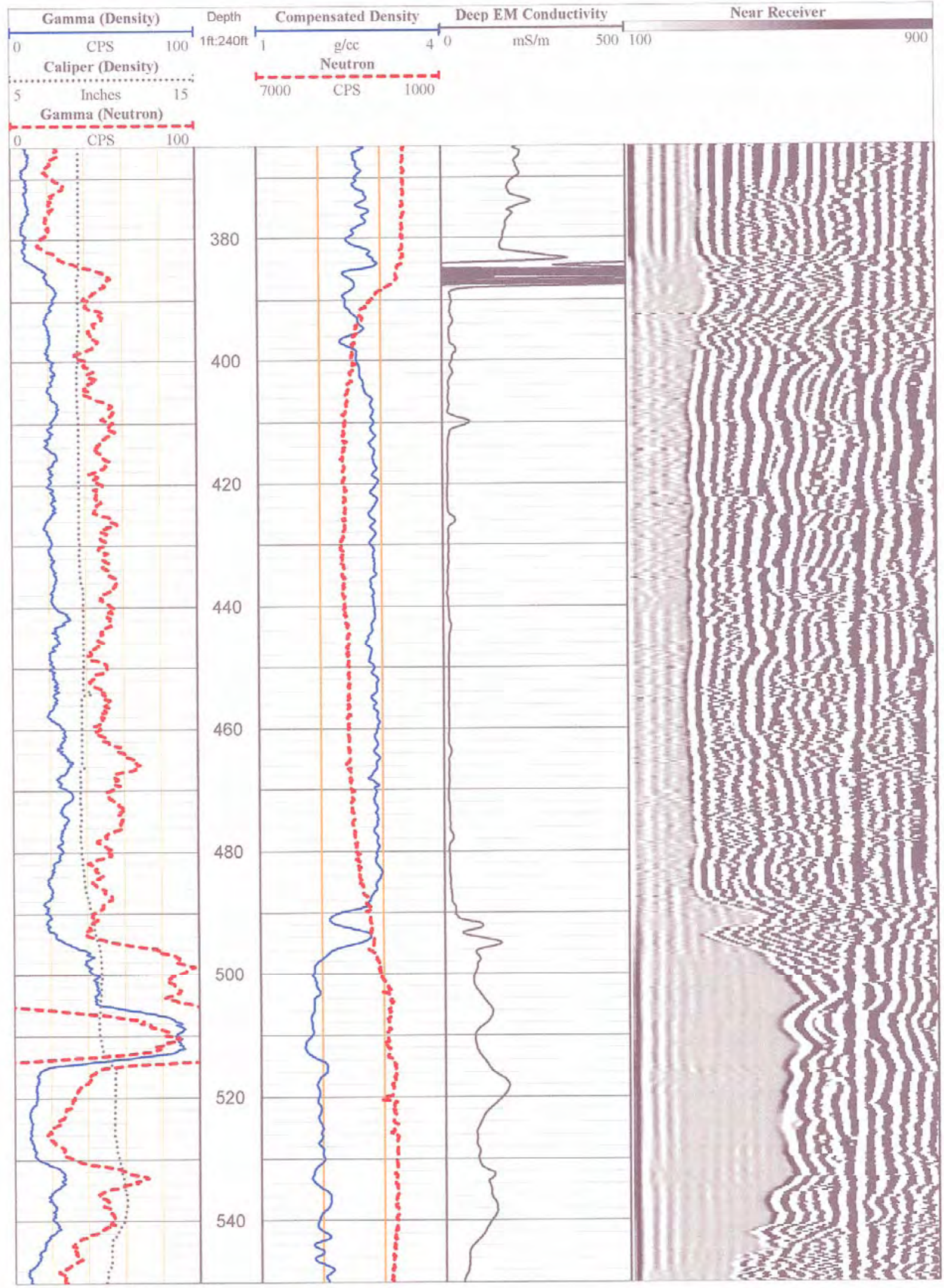


DTS-RPT-090, Rev. 0

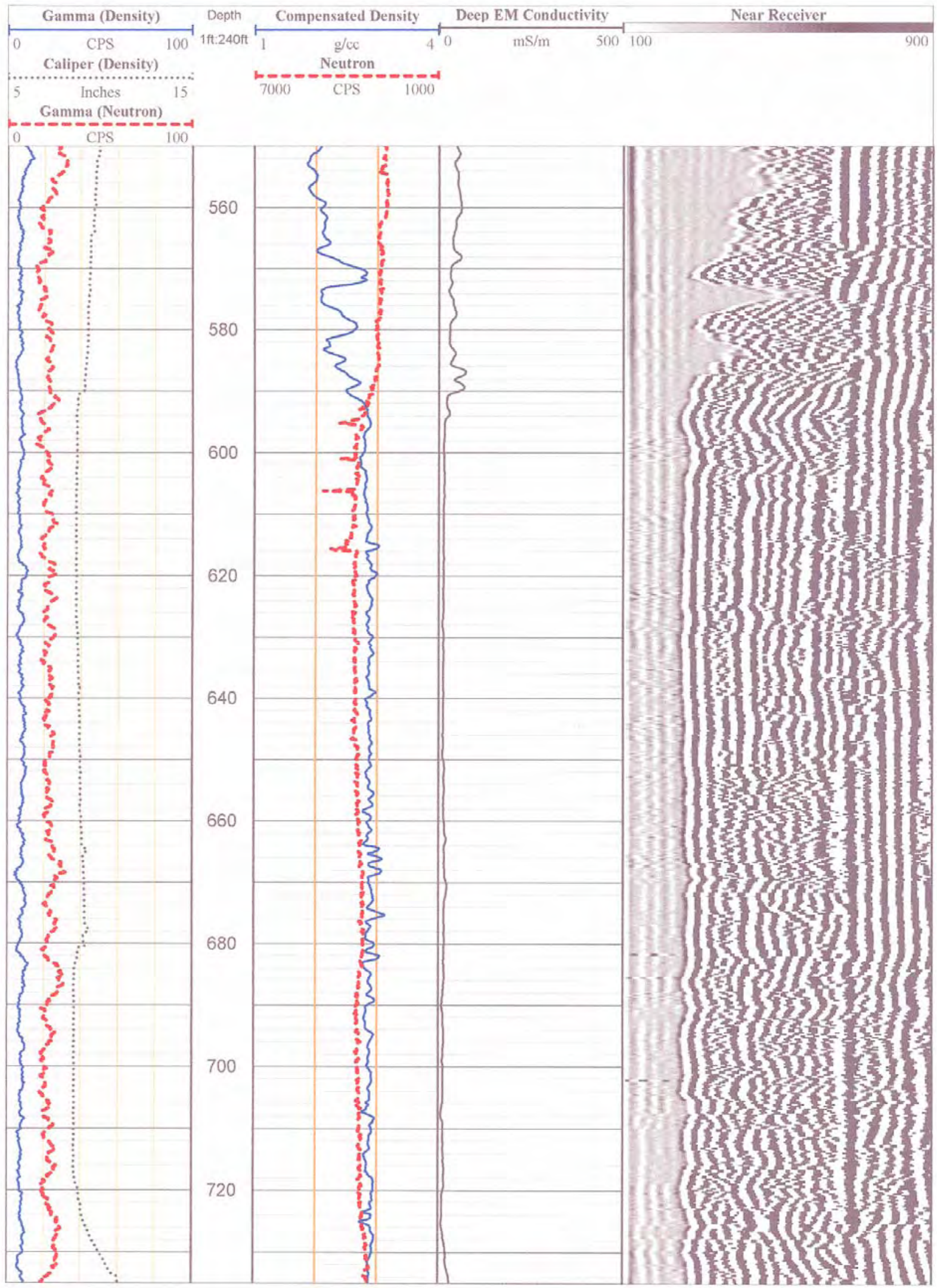


DTS-RPT-090, Rev. 0

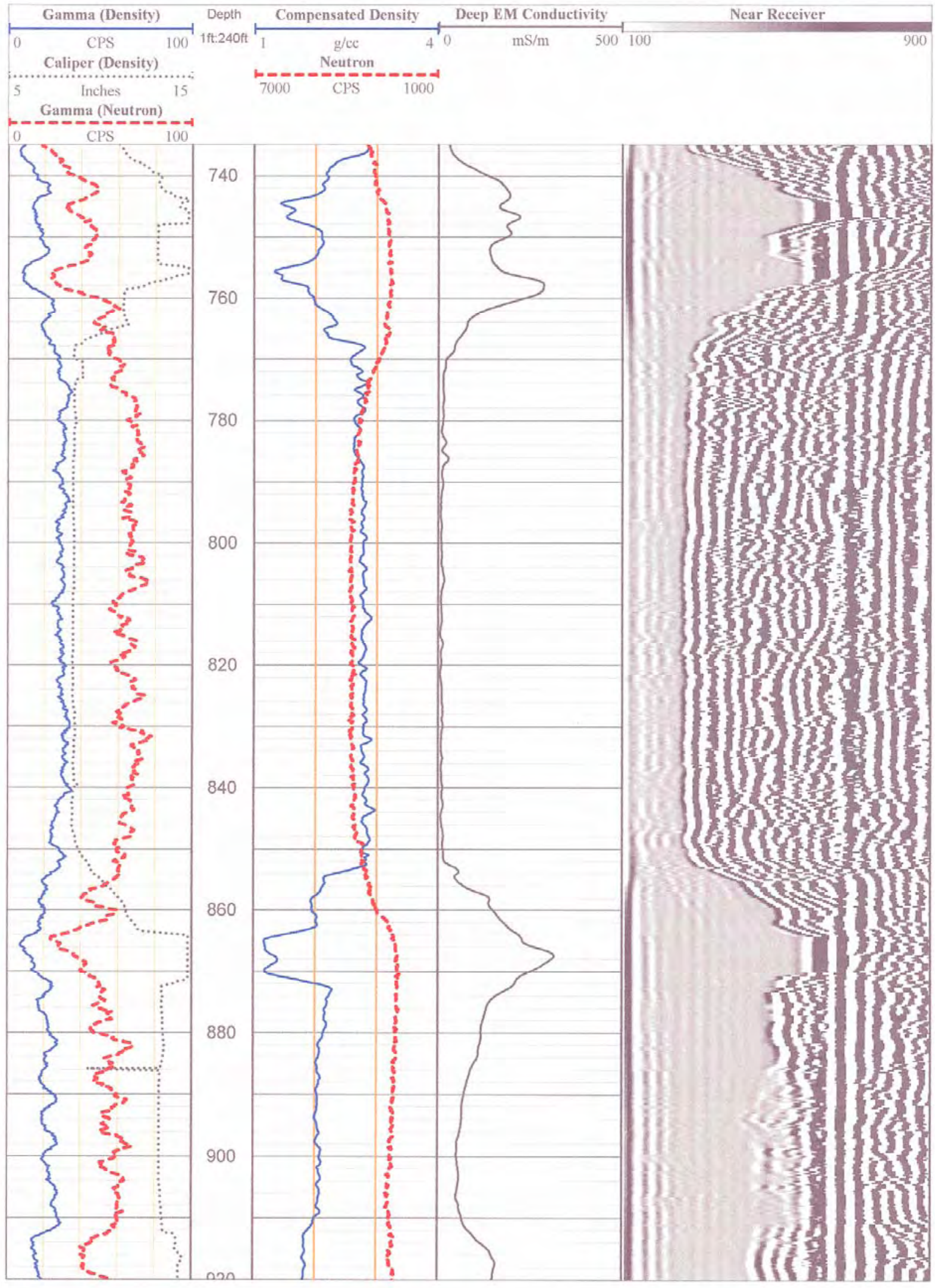


DTS-RPT-090, Rev. 0

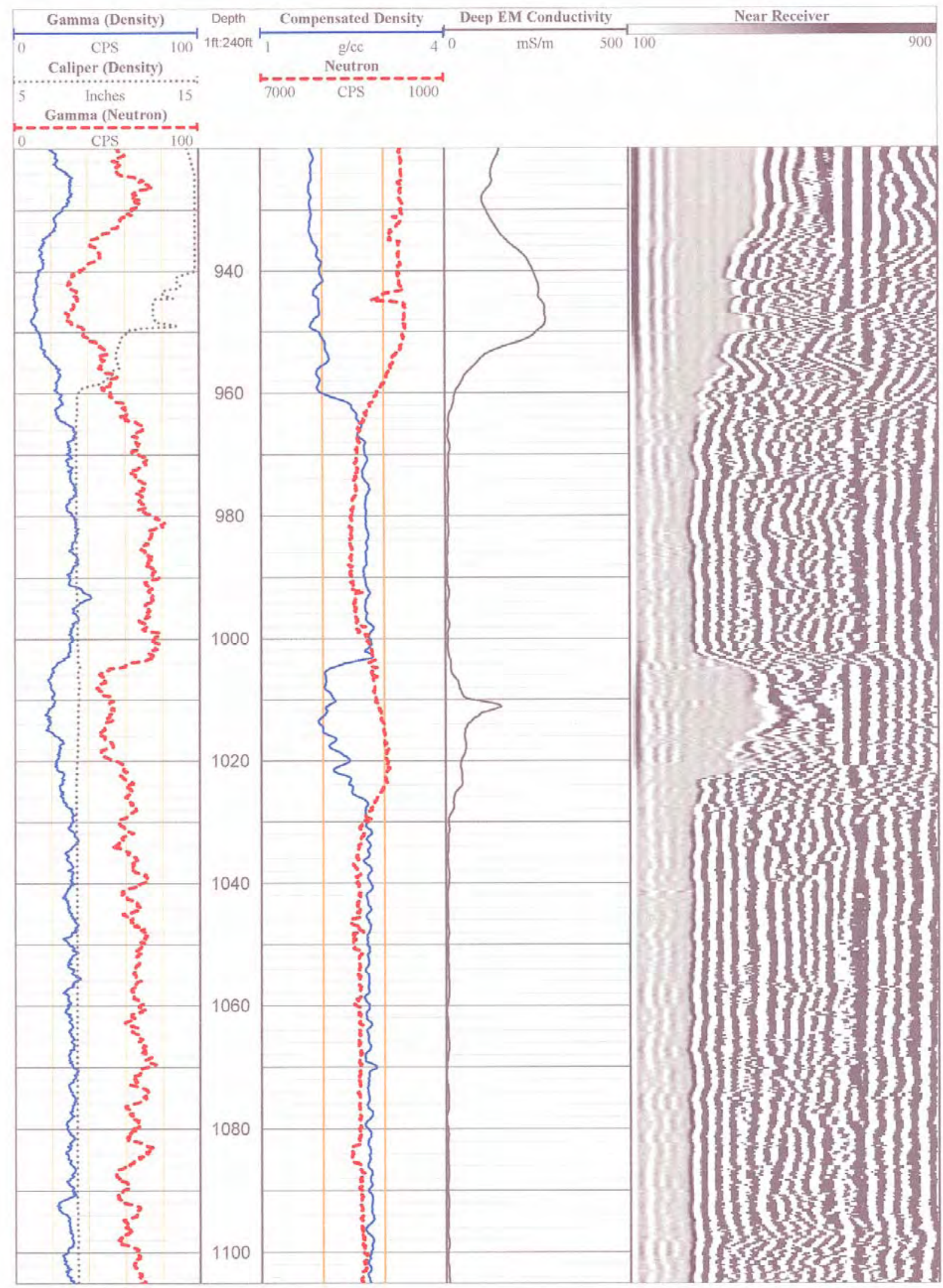




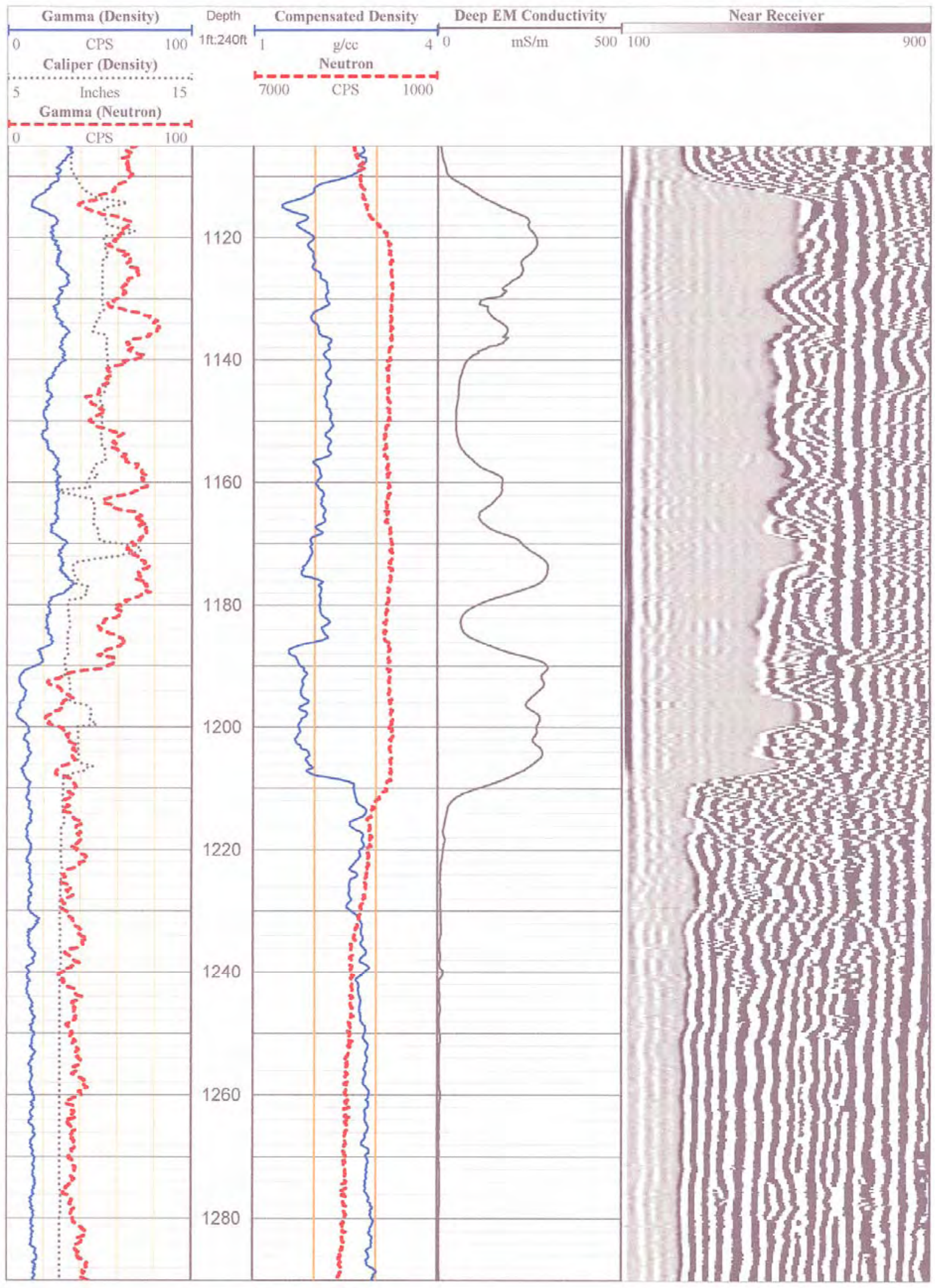




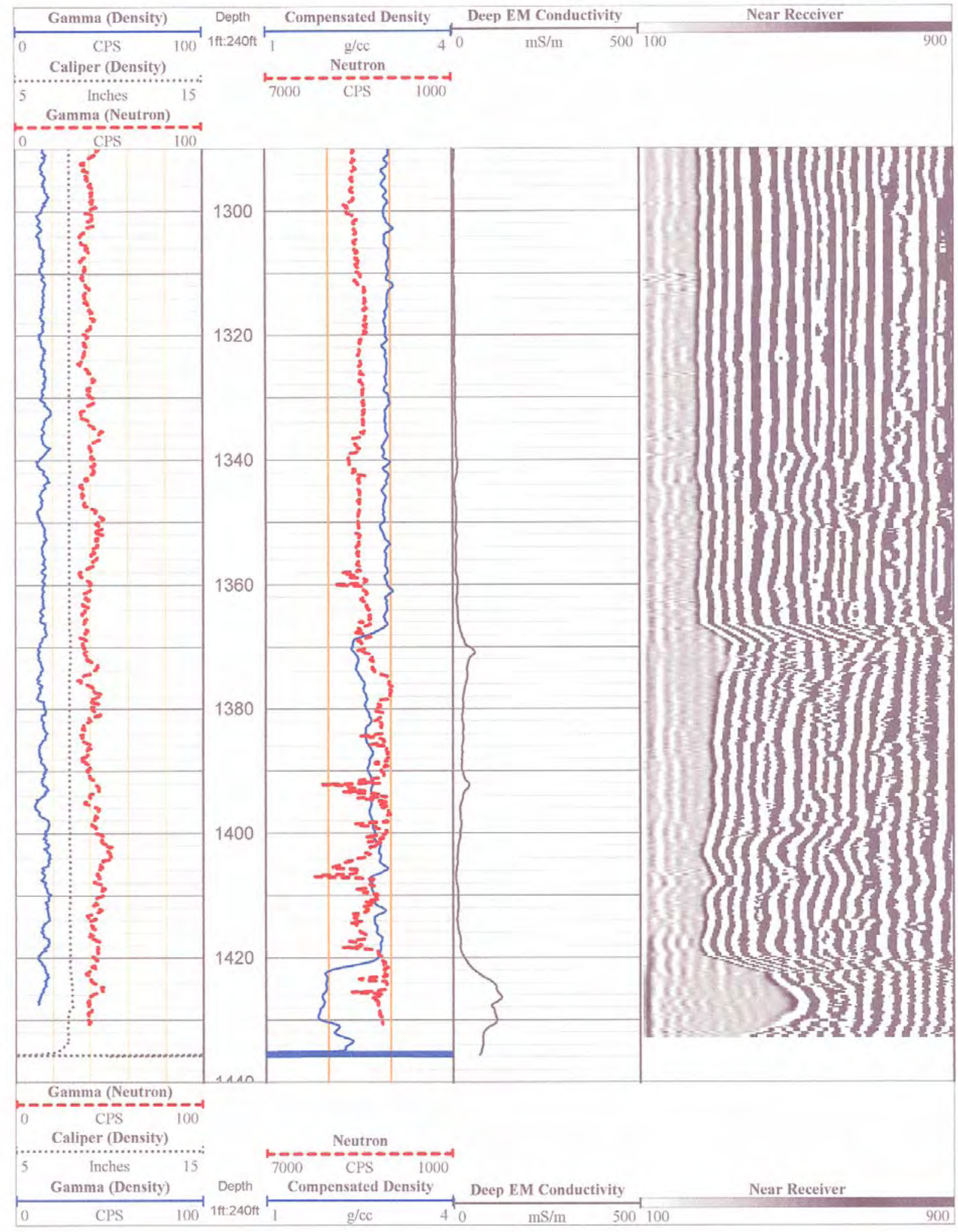


DTS-RPT-090, Rev. 0

\section{C1.4 COLOG COMPENSATED DENSITY LOGS}

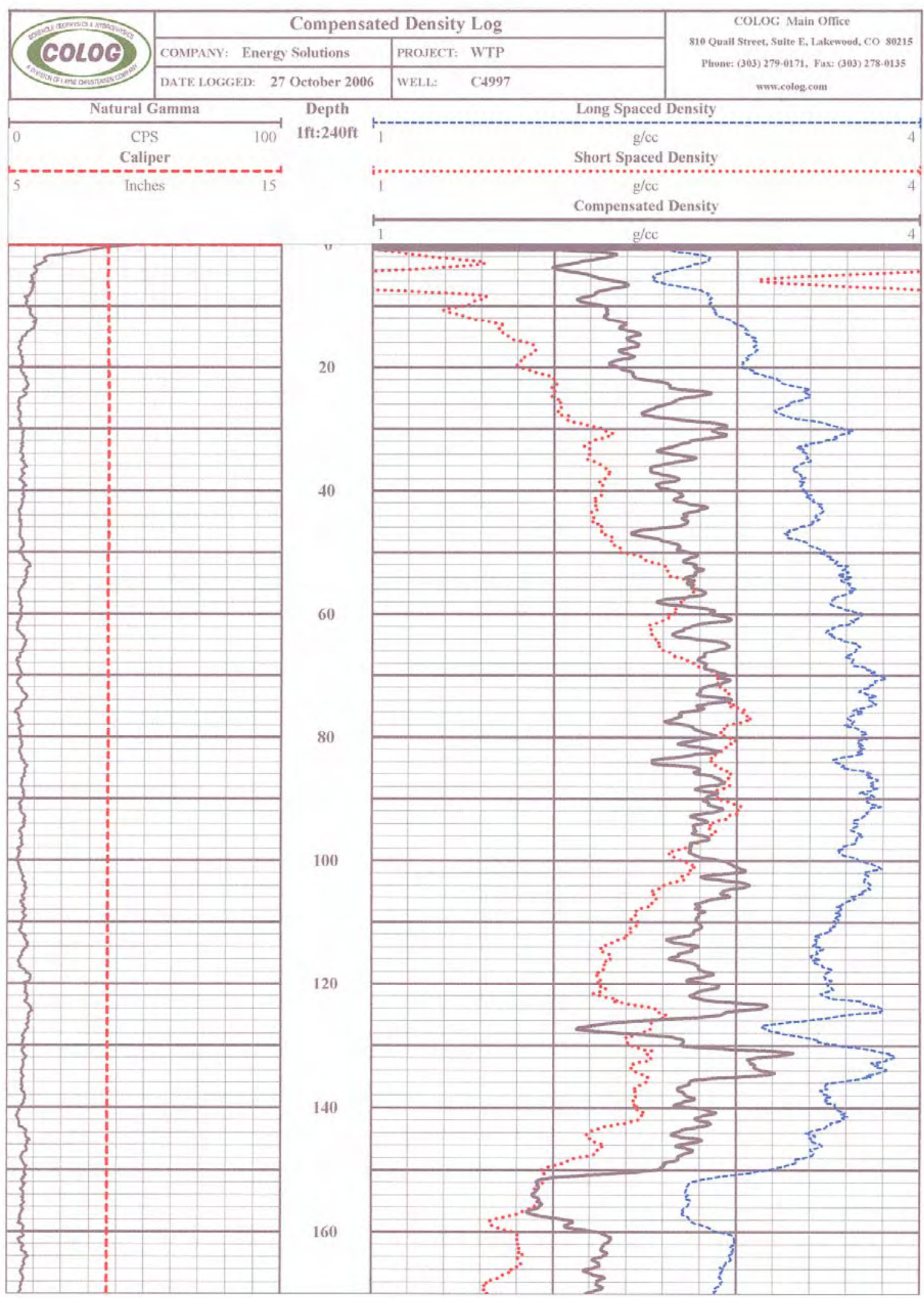


DTS-RPT-090, Rev. 0

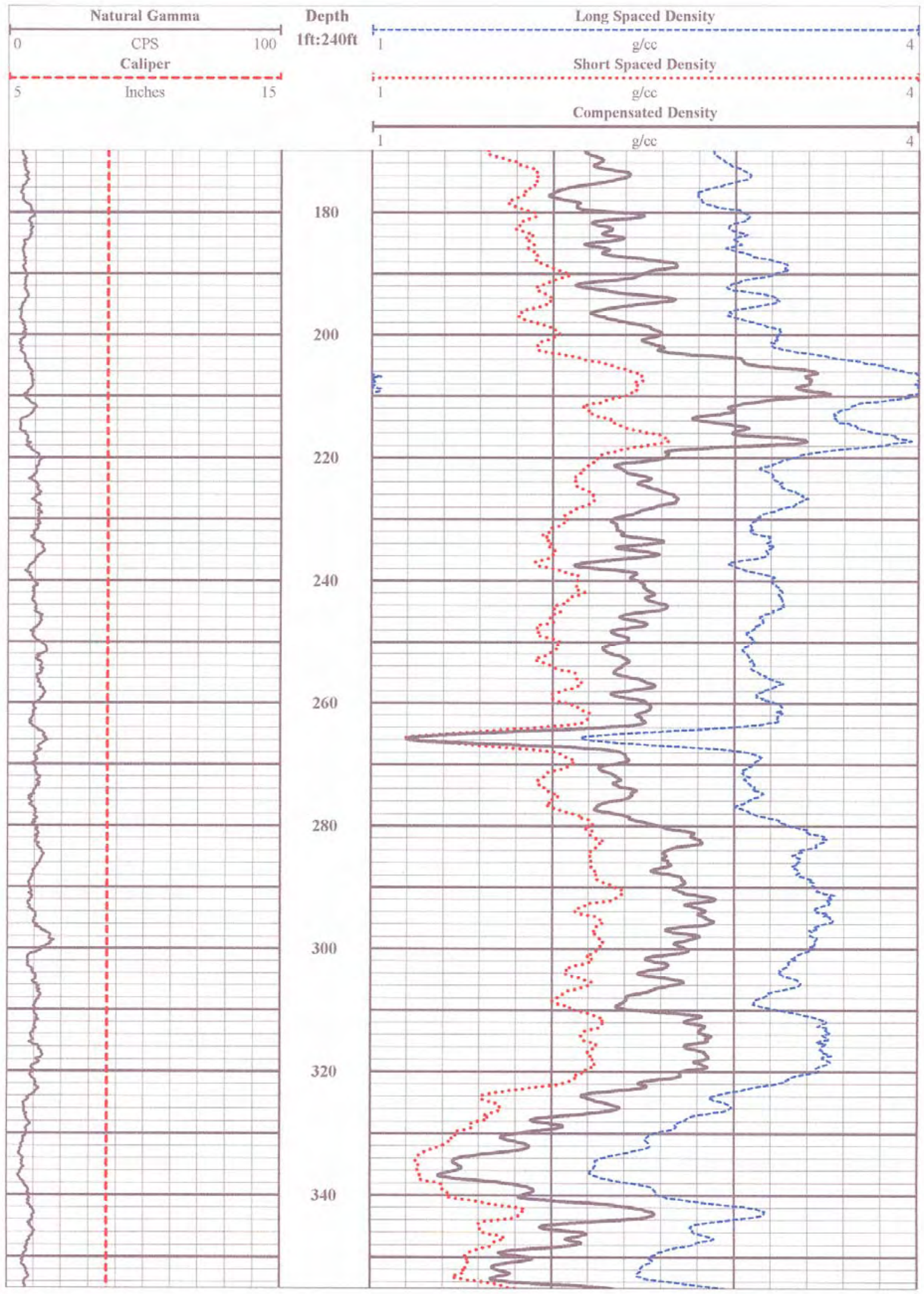


DTS-RPT-090, Rev. 0

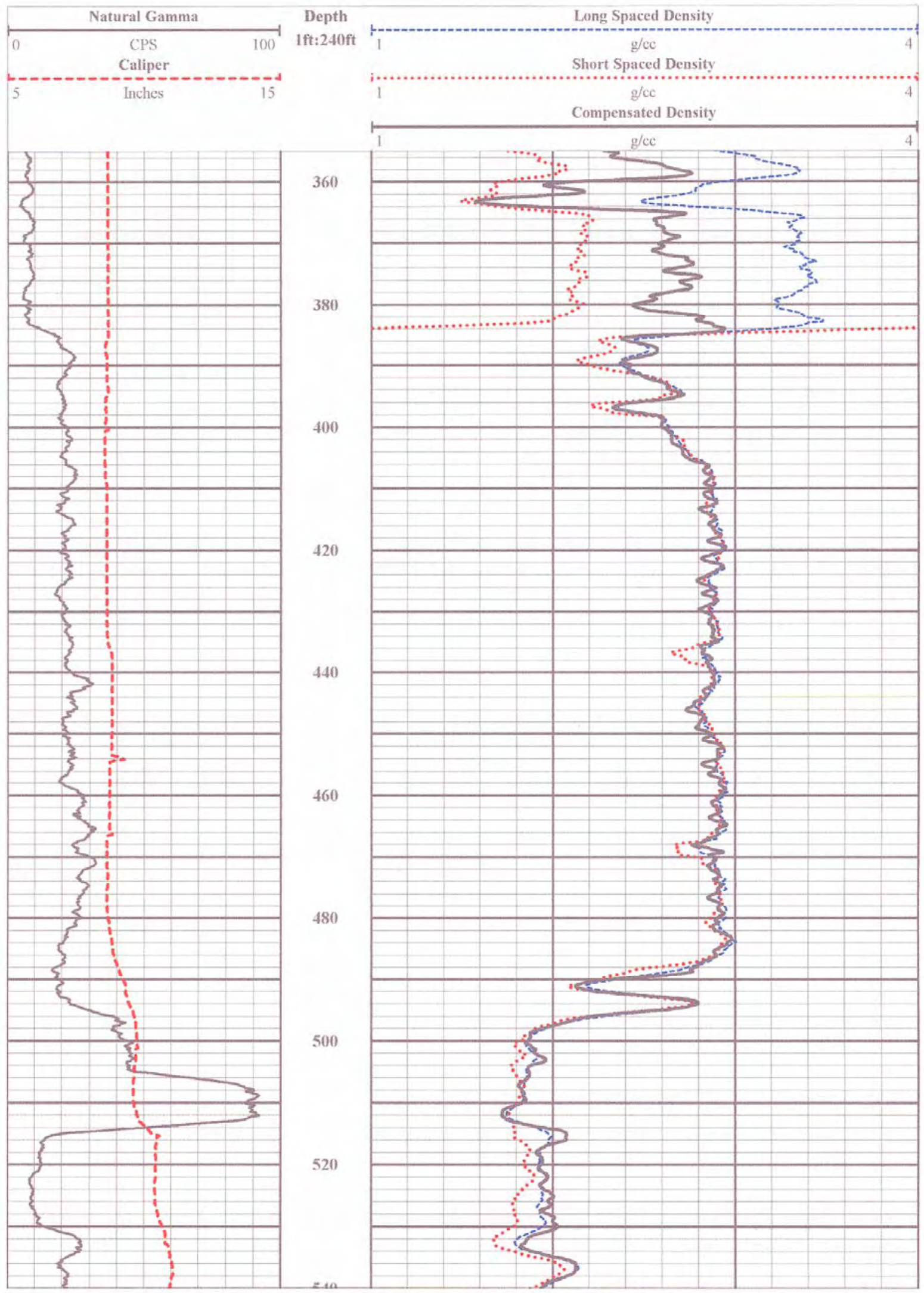


DTS-RPT-090, Rev. 0

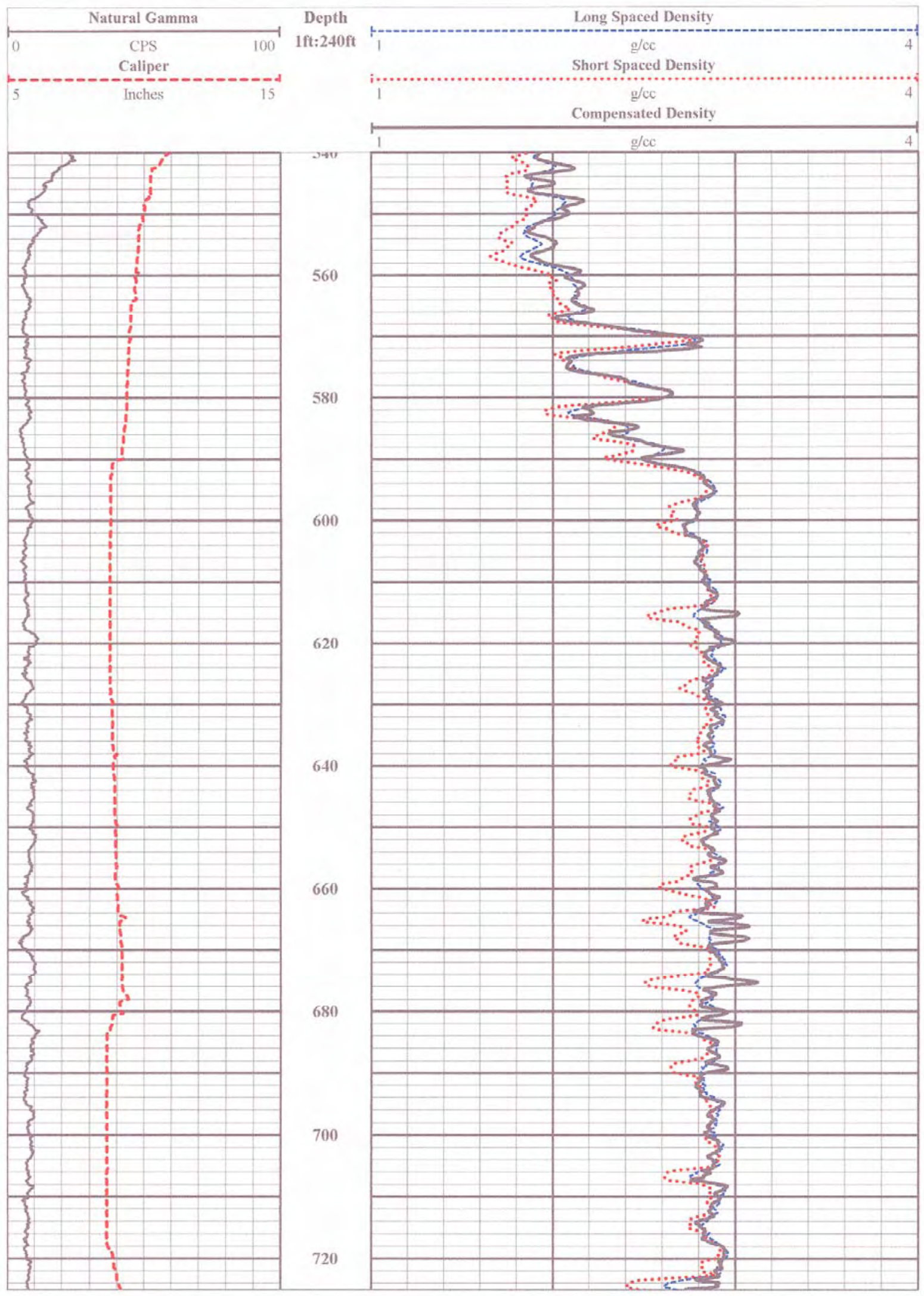


DTS-RPT-090, Rev. 0

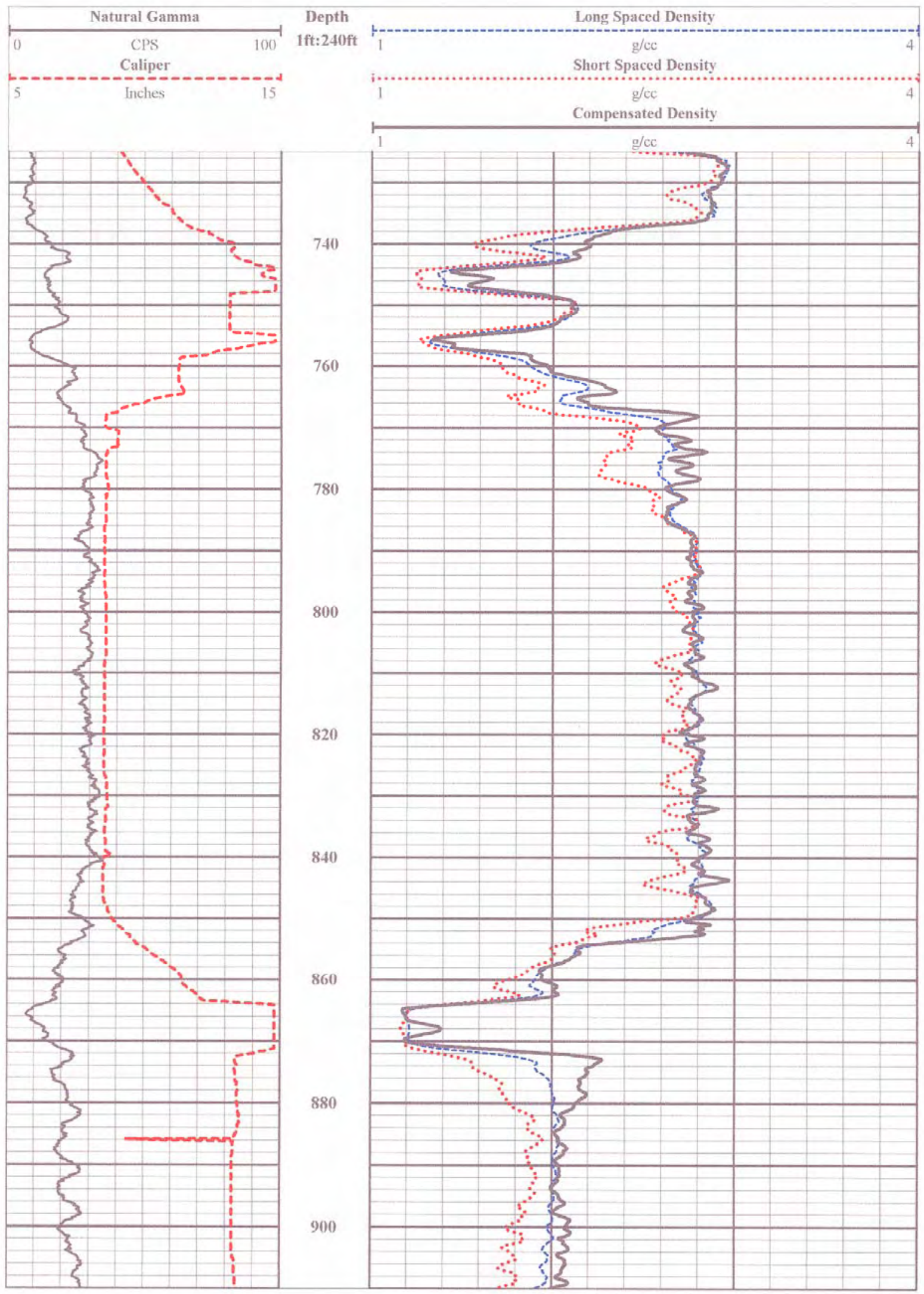


DTS-RPT-090, Rev. 0

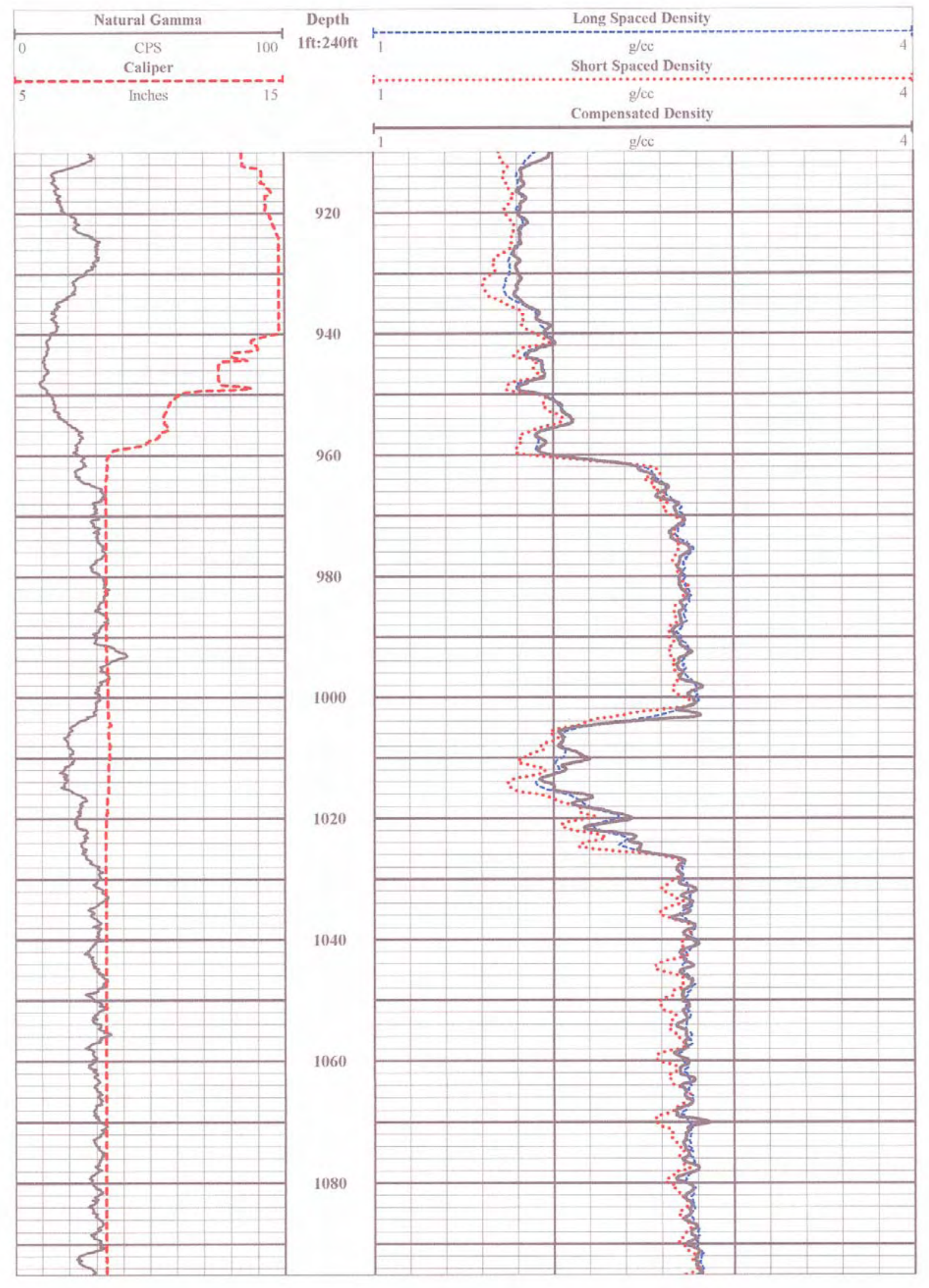

C-81 
DTS-RPT-090, Rev. 0

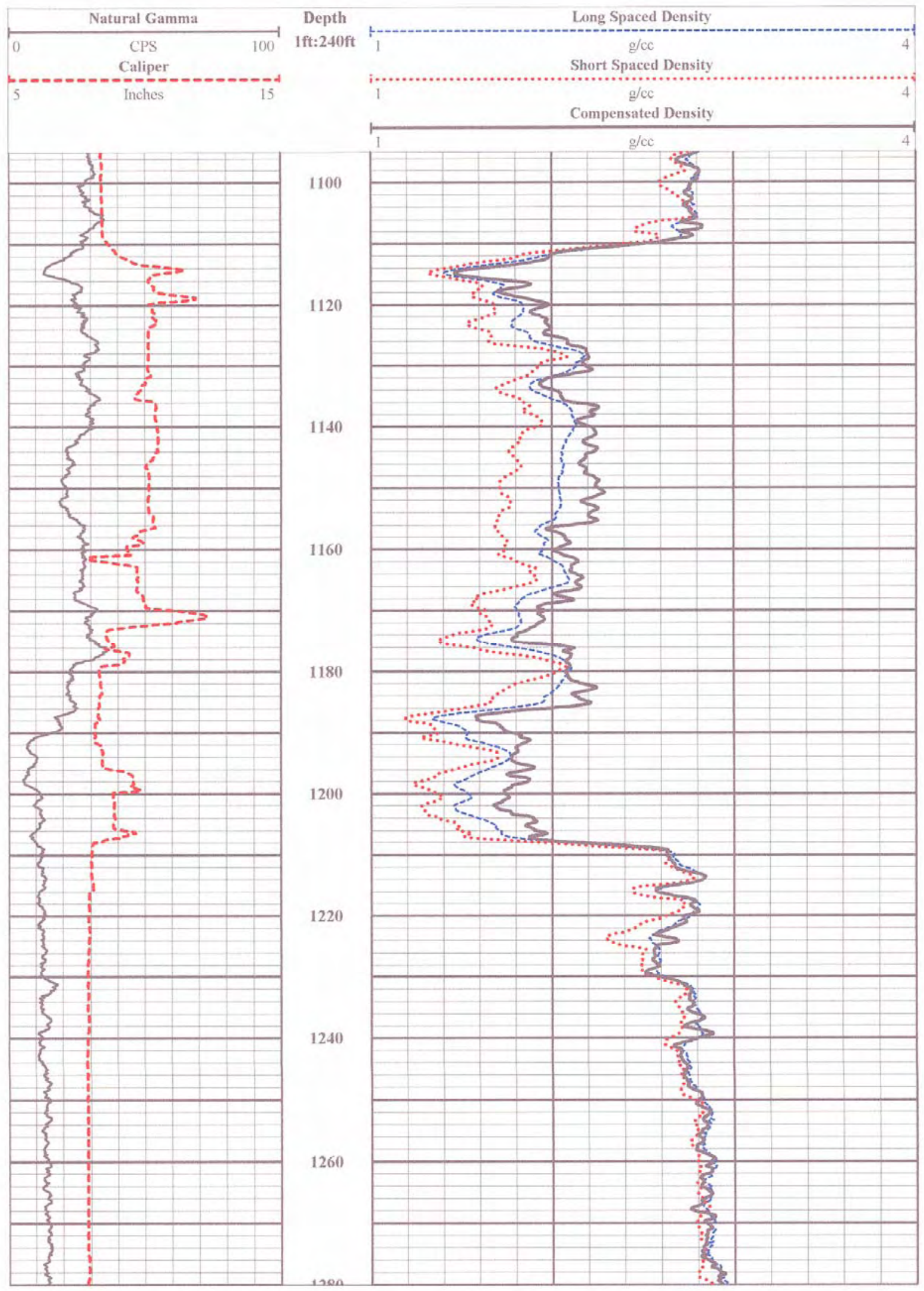


DTS-RPT-090, Rev. 0

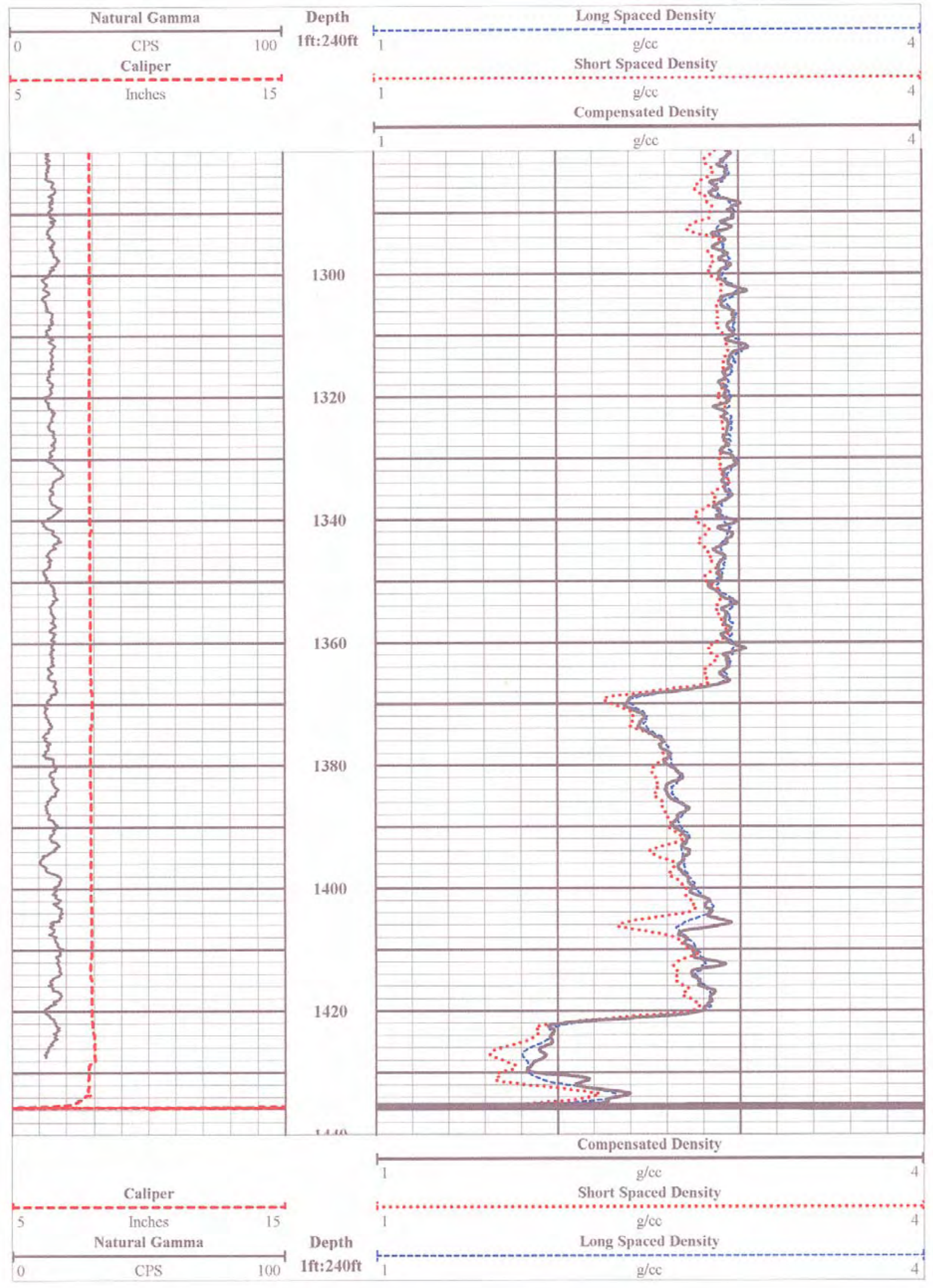


DTS-RPT-090, Rev. 0

\section{C1.5 COLOG NEUTRON/POROSITY LOGS}

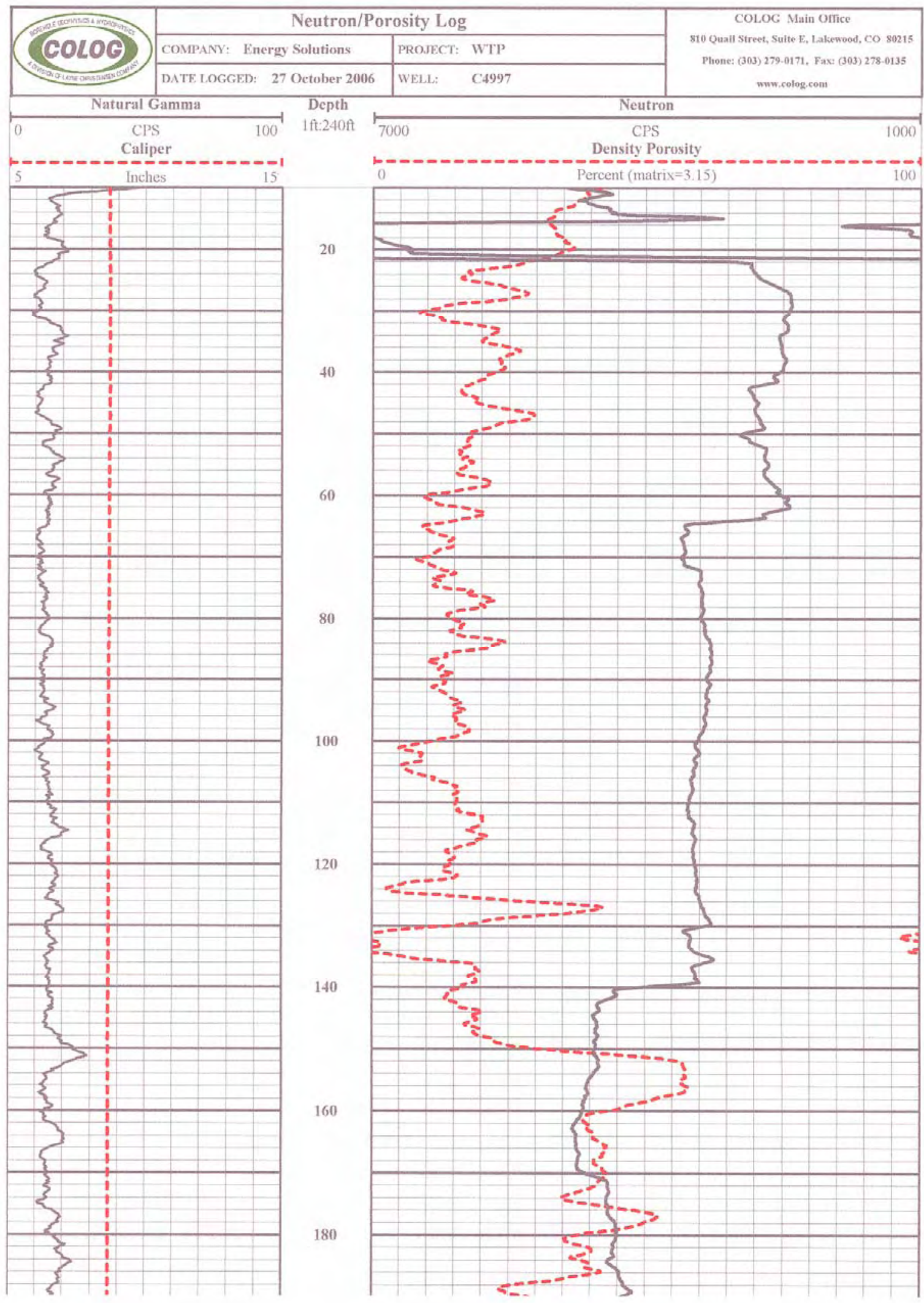


DTS-RPT-090, Rev. 0

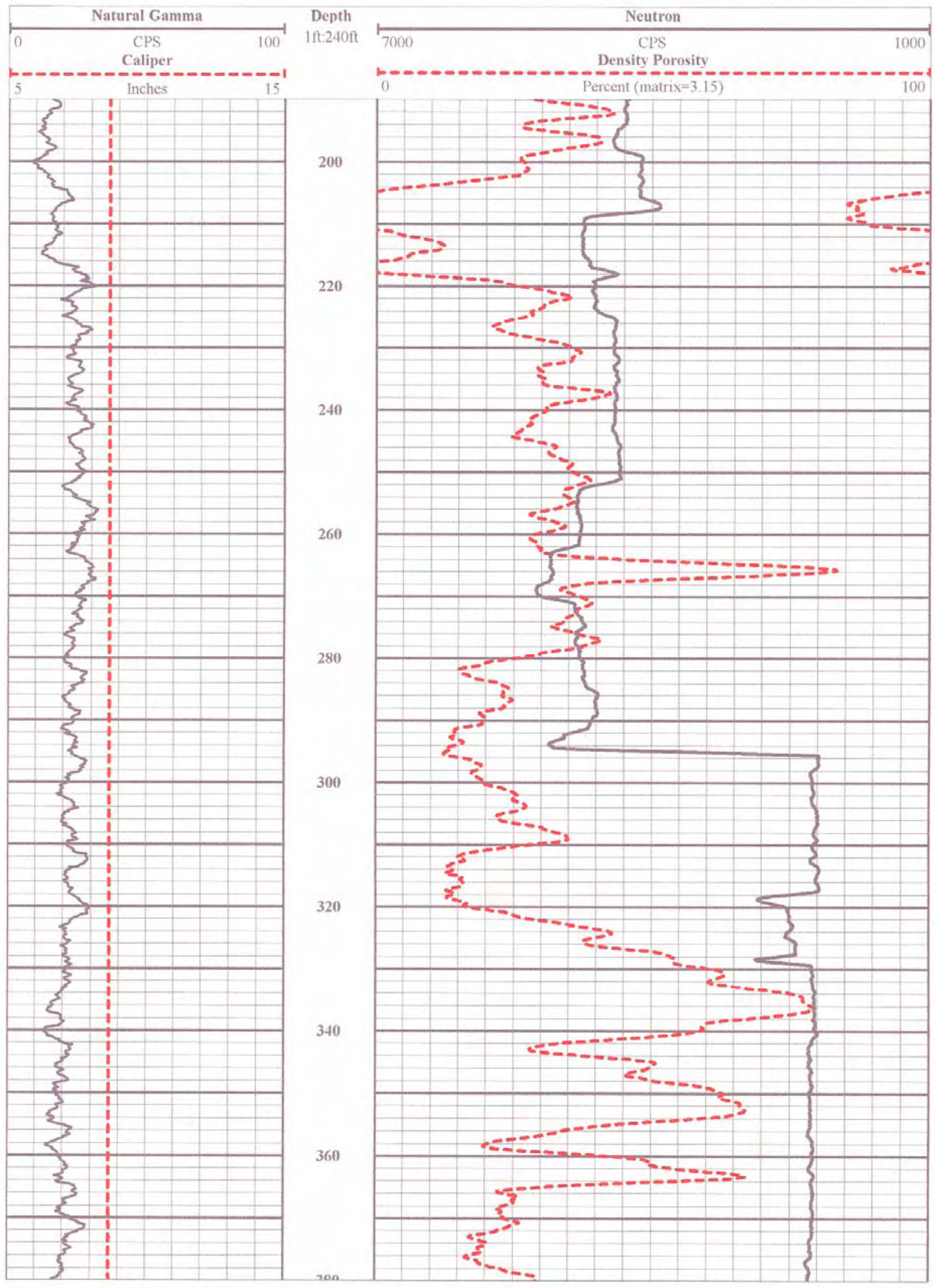


DTS-RPT-090, Rev. 0

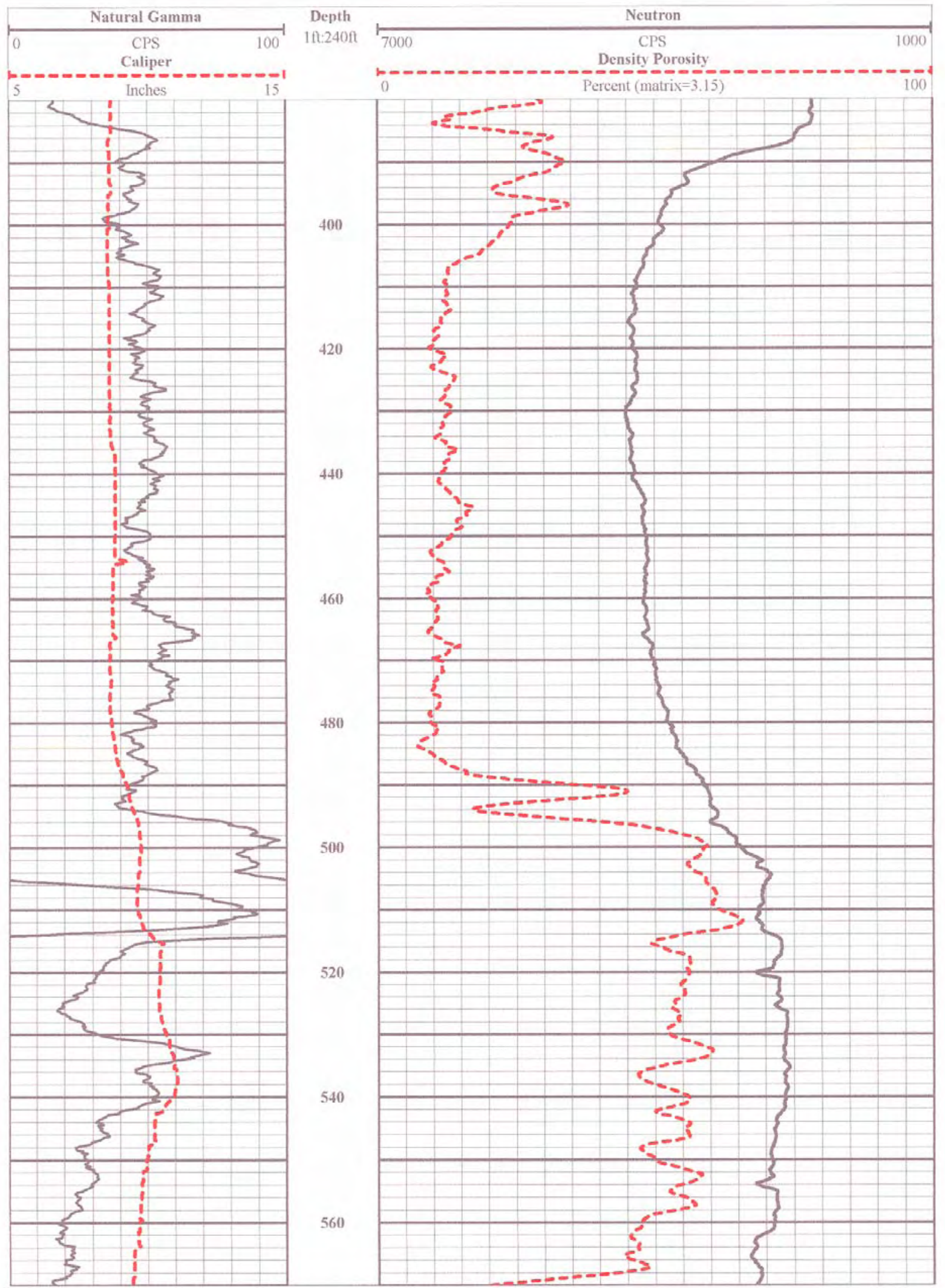


DTS-RPT-090, Rev. 0

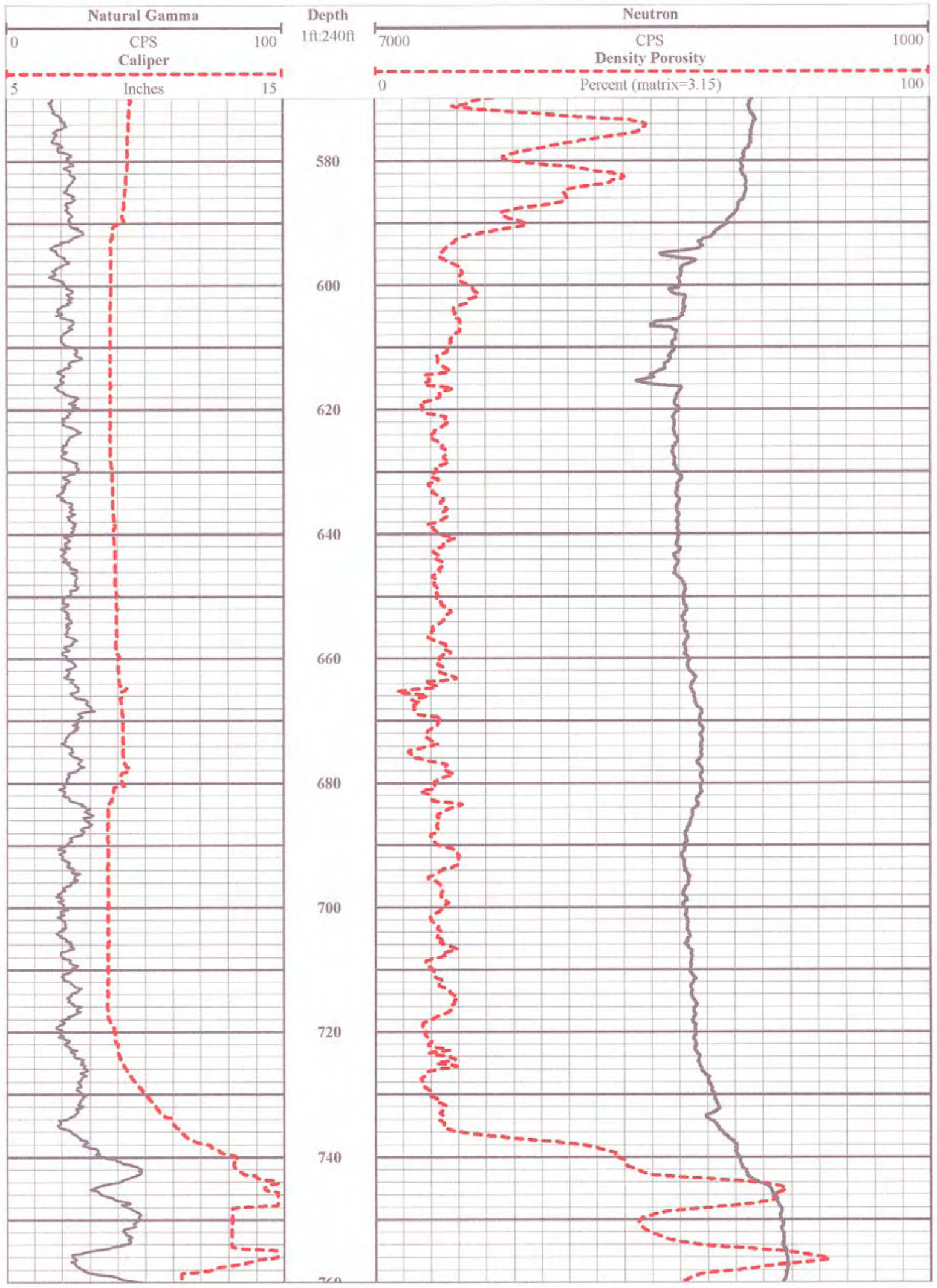


DTS-RPT-090, Rev. 0

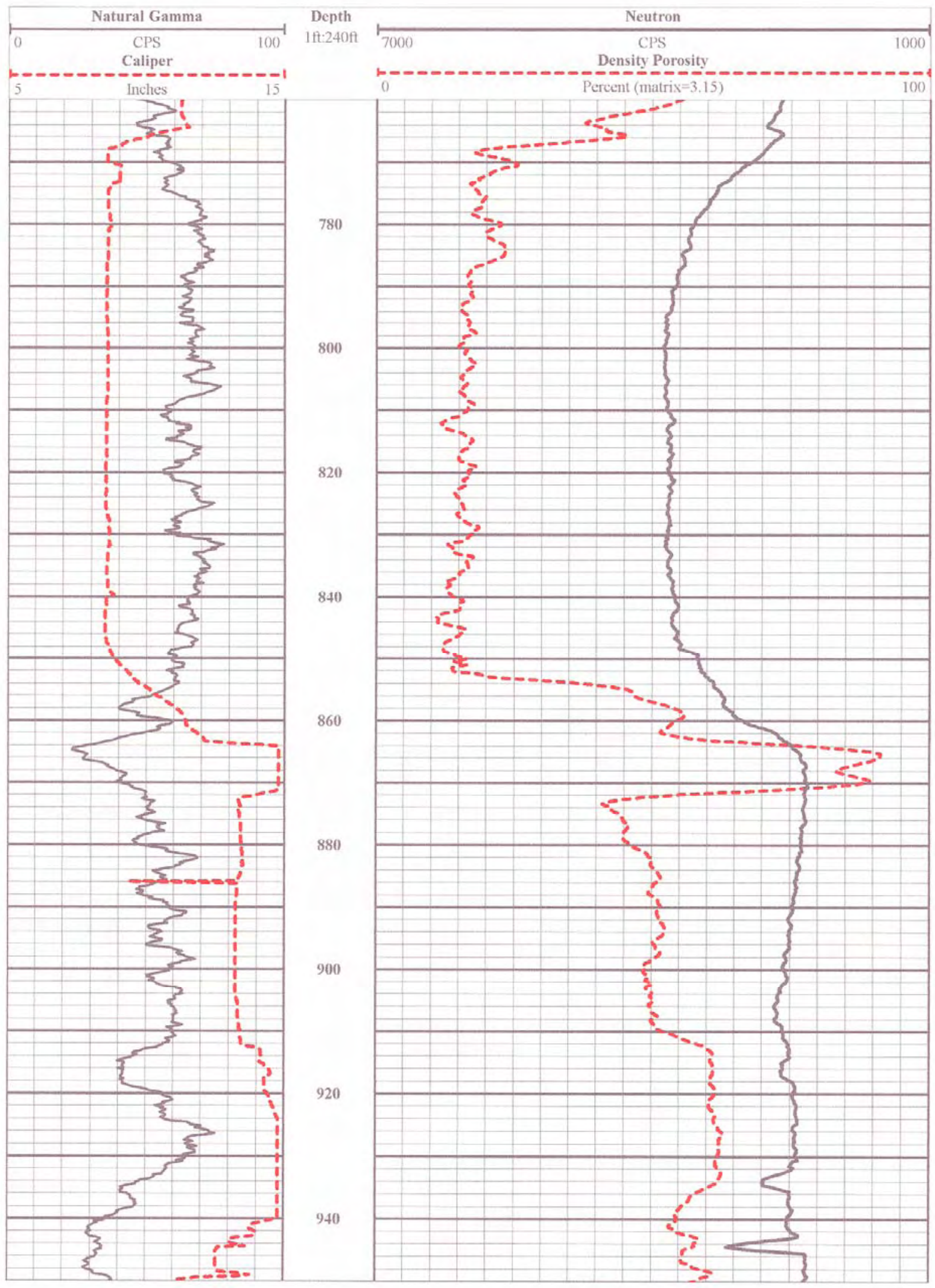


DTS-RPT-090, Rev. 0

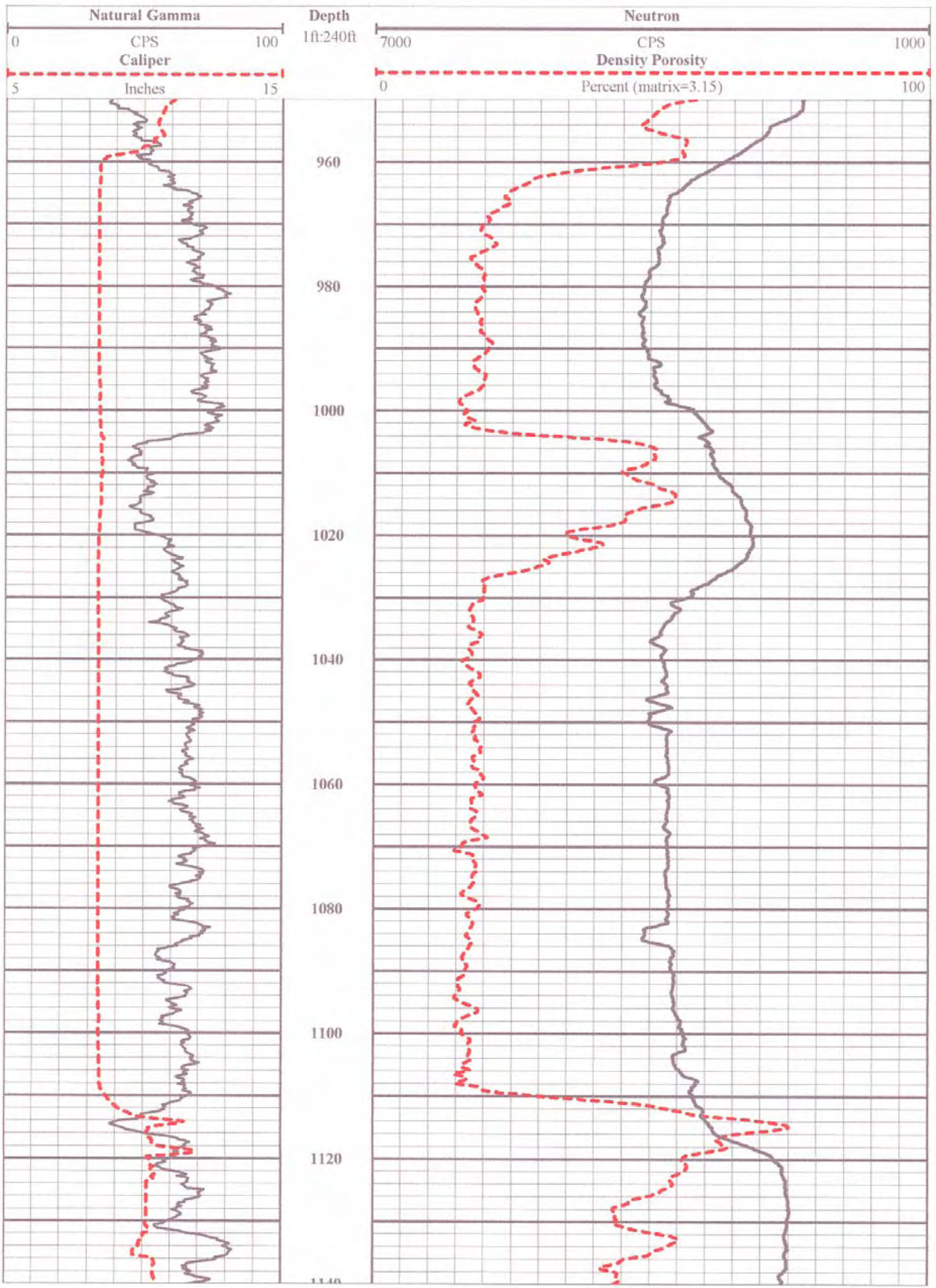


DTS-RPT-090, Rev. 0

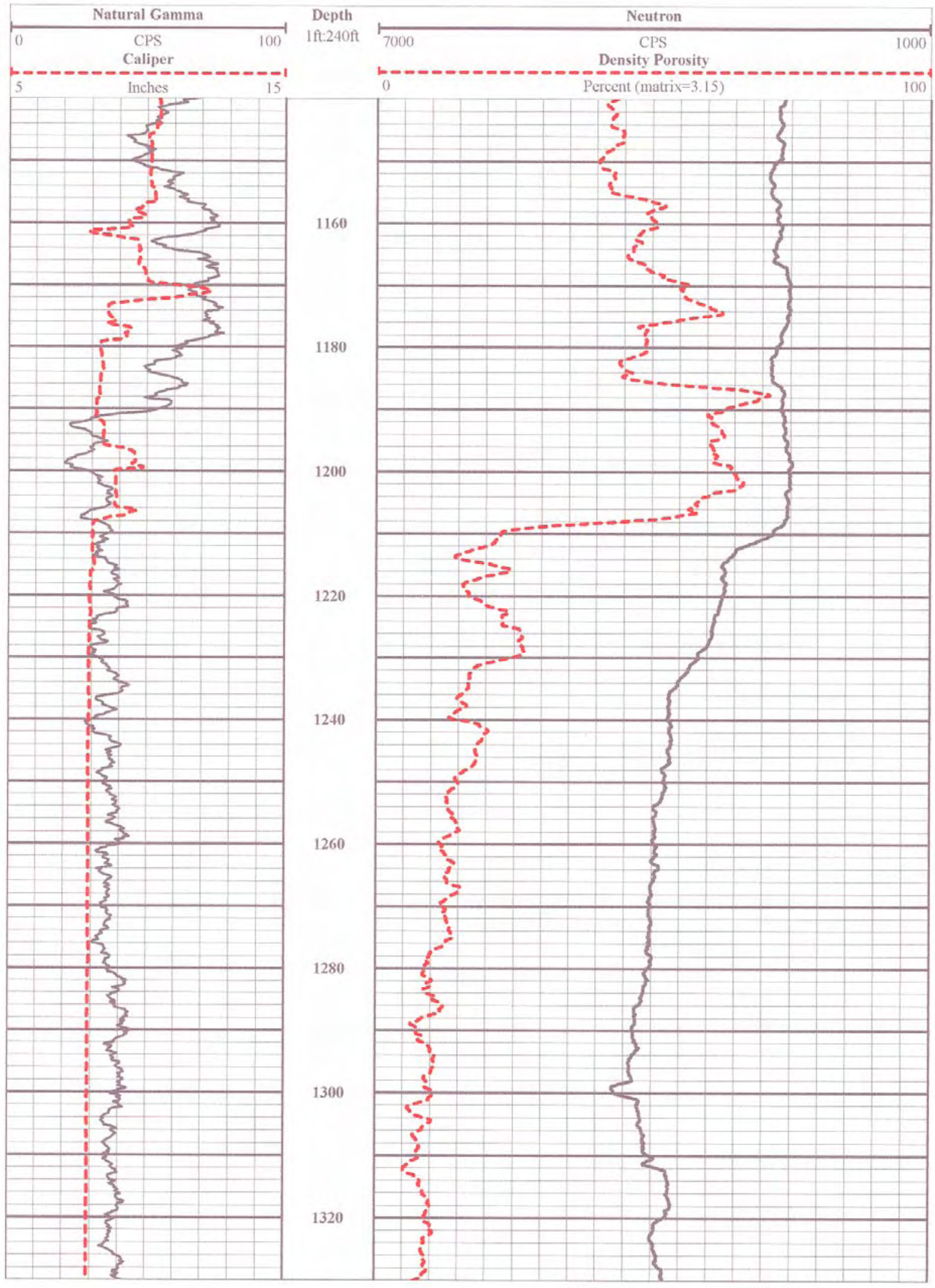


DTS-RPT-090, Rev. 0

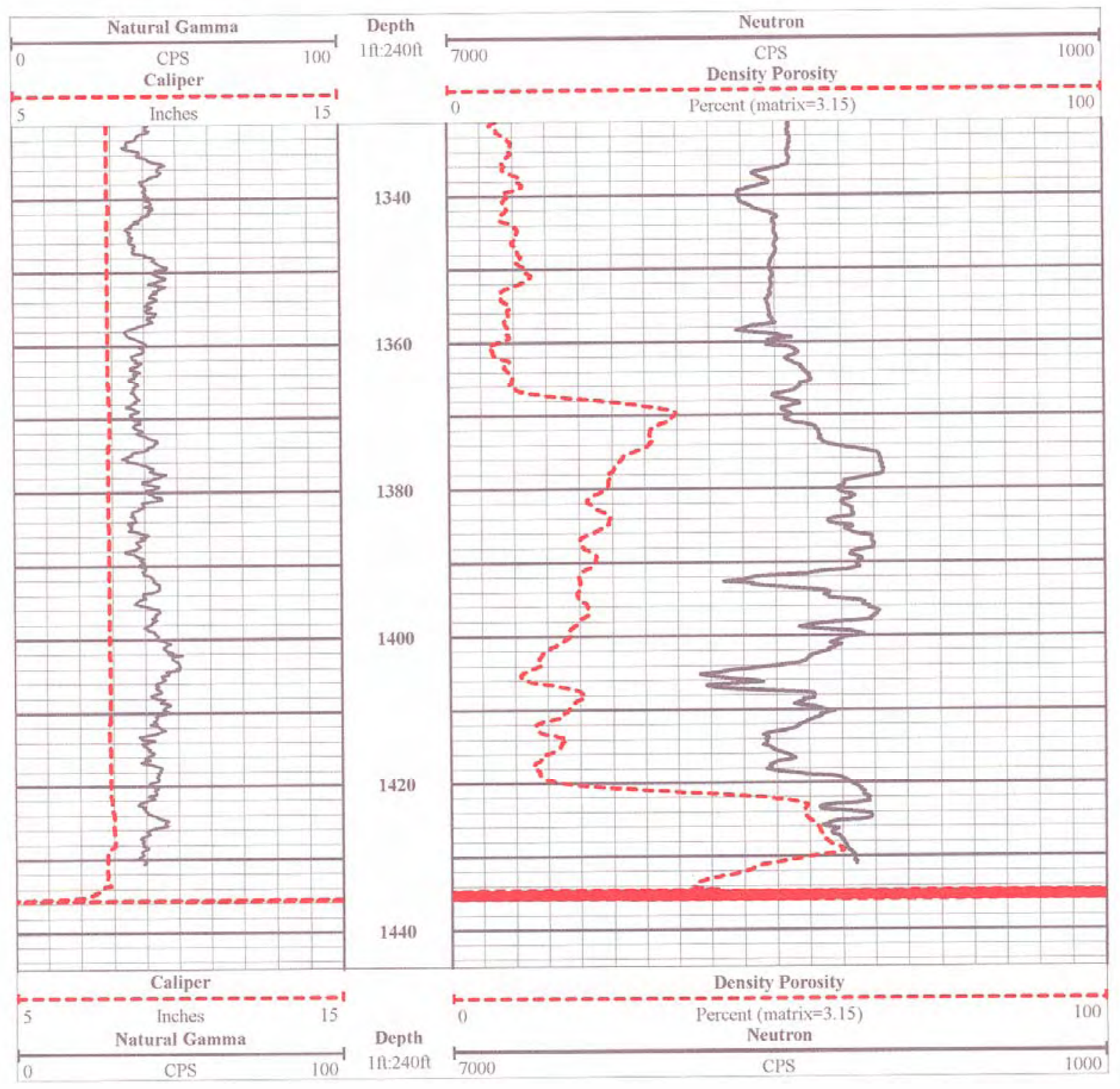


DTS-RPT-090, Rev. 0

\section{C1.6 COLOG DUAL INDUCTION LOG}

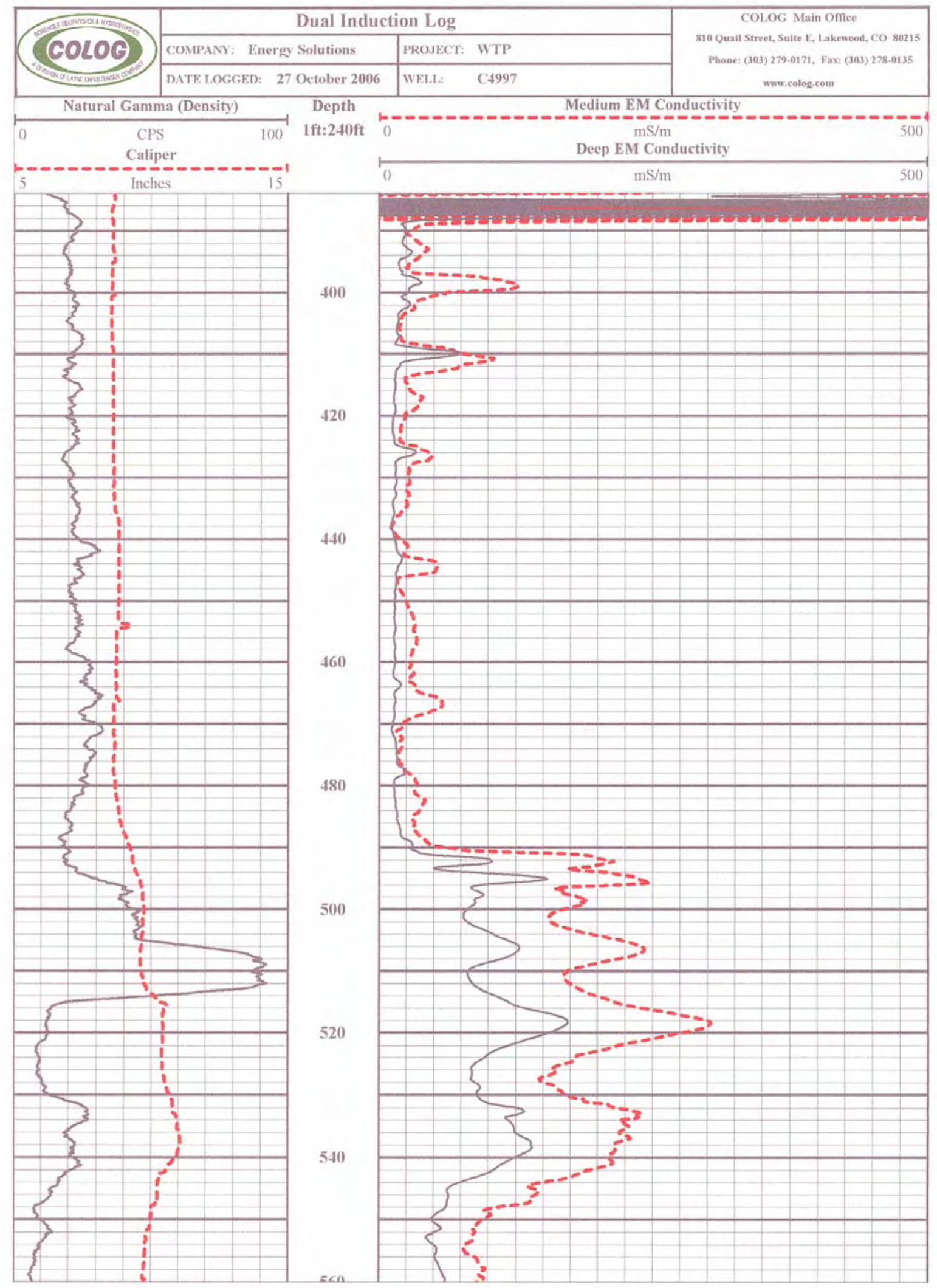


DTS-RPT-090, Rev. 0

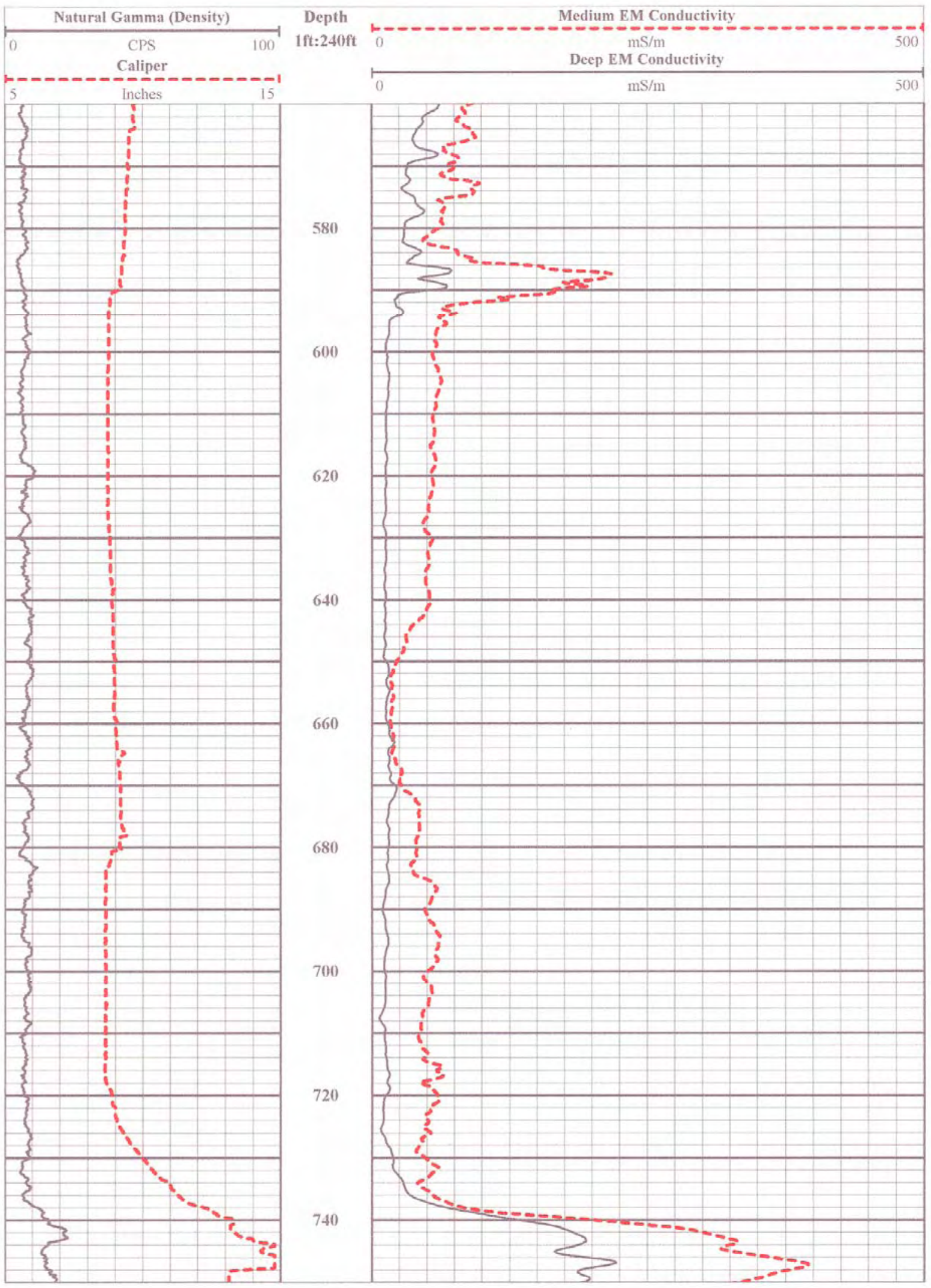


DTS-RPT-090, Rev. 0

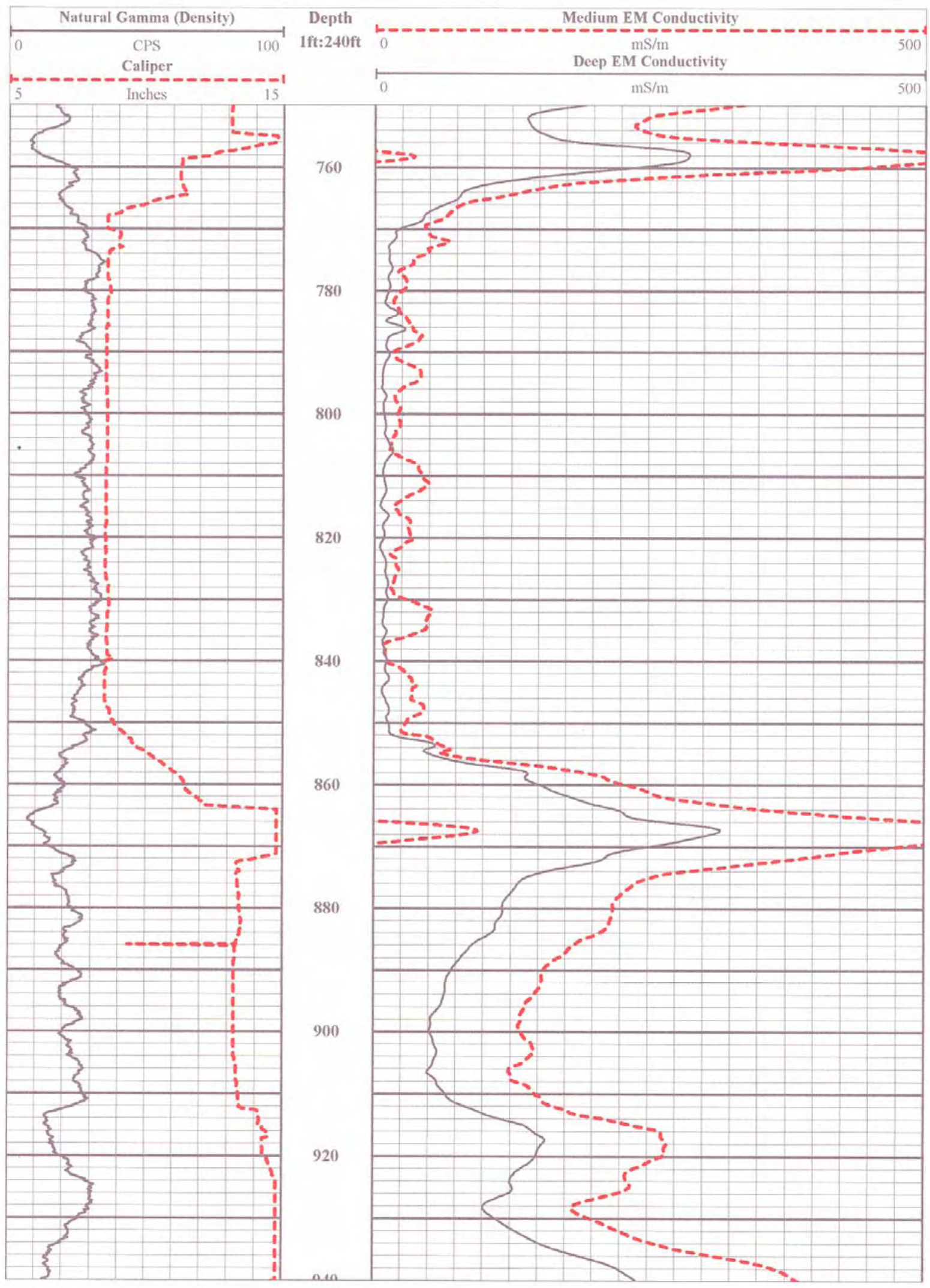


DTS-RPT-090, Rev. 0

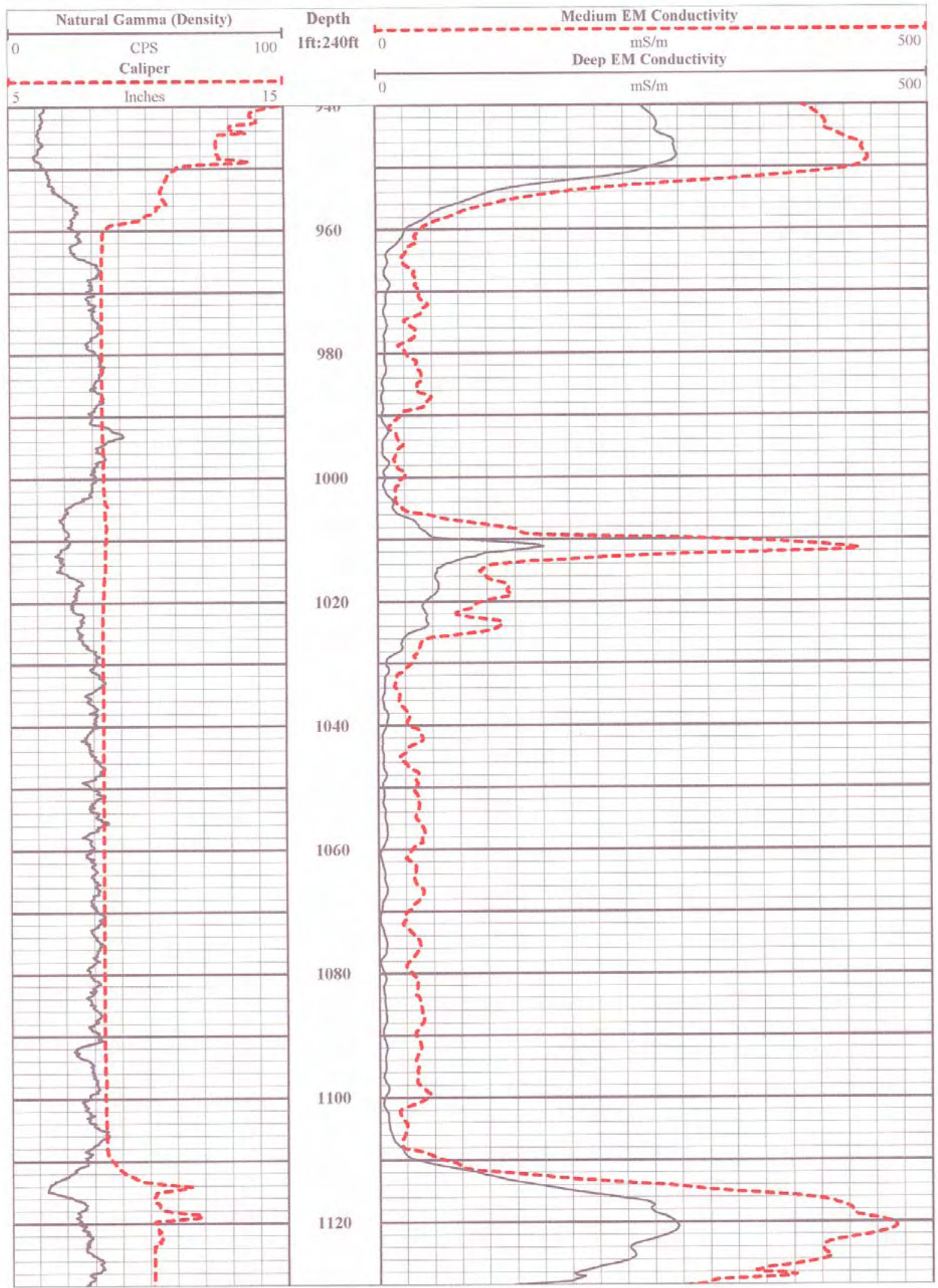


DTS-RPT-090, Rev. 0

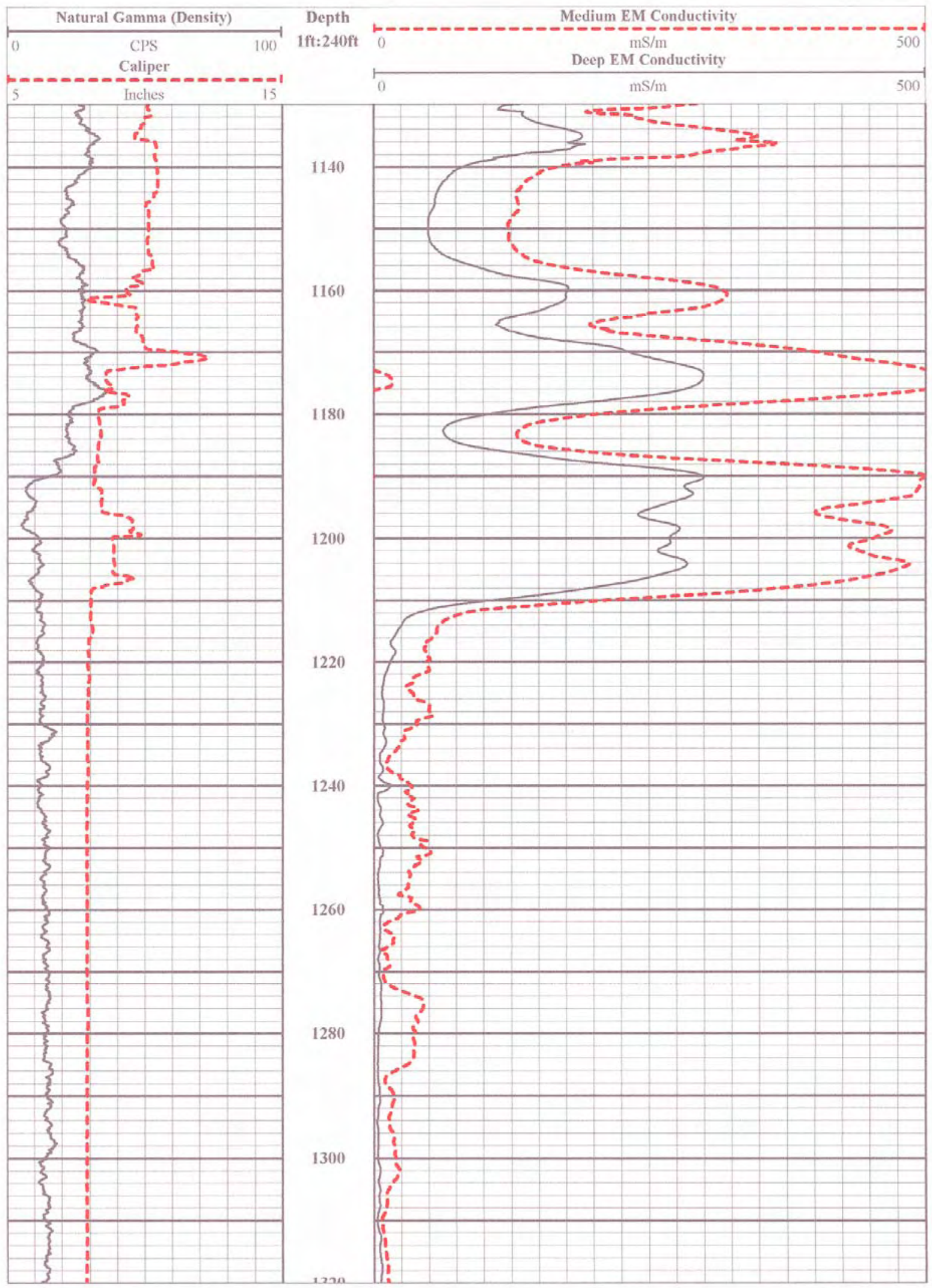


DTS-RPT-090, Rev. 0

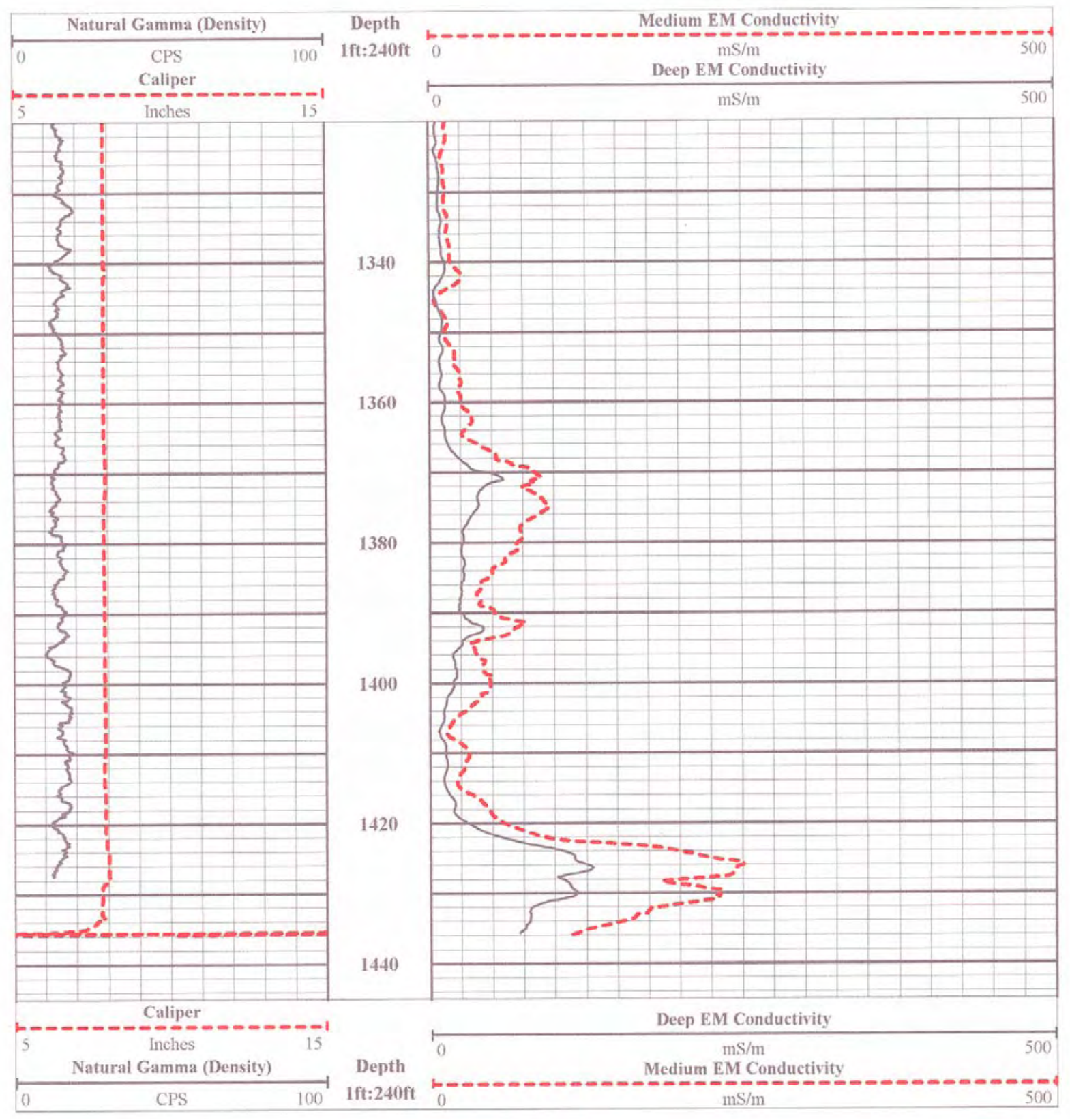


DTS-RPT-090, Rev. 0

\section{C1.7 COLOG FULL WAVEFORM SONIC LOG}

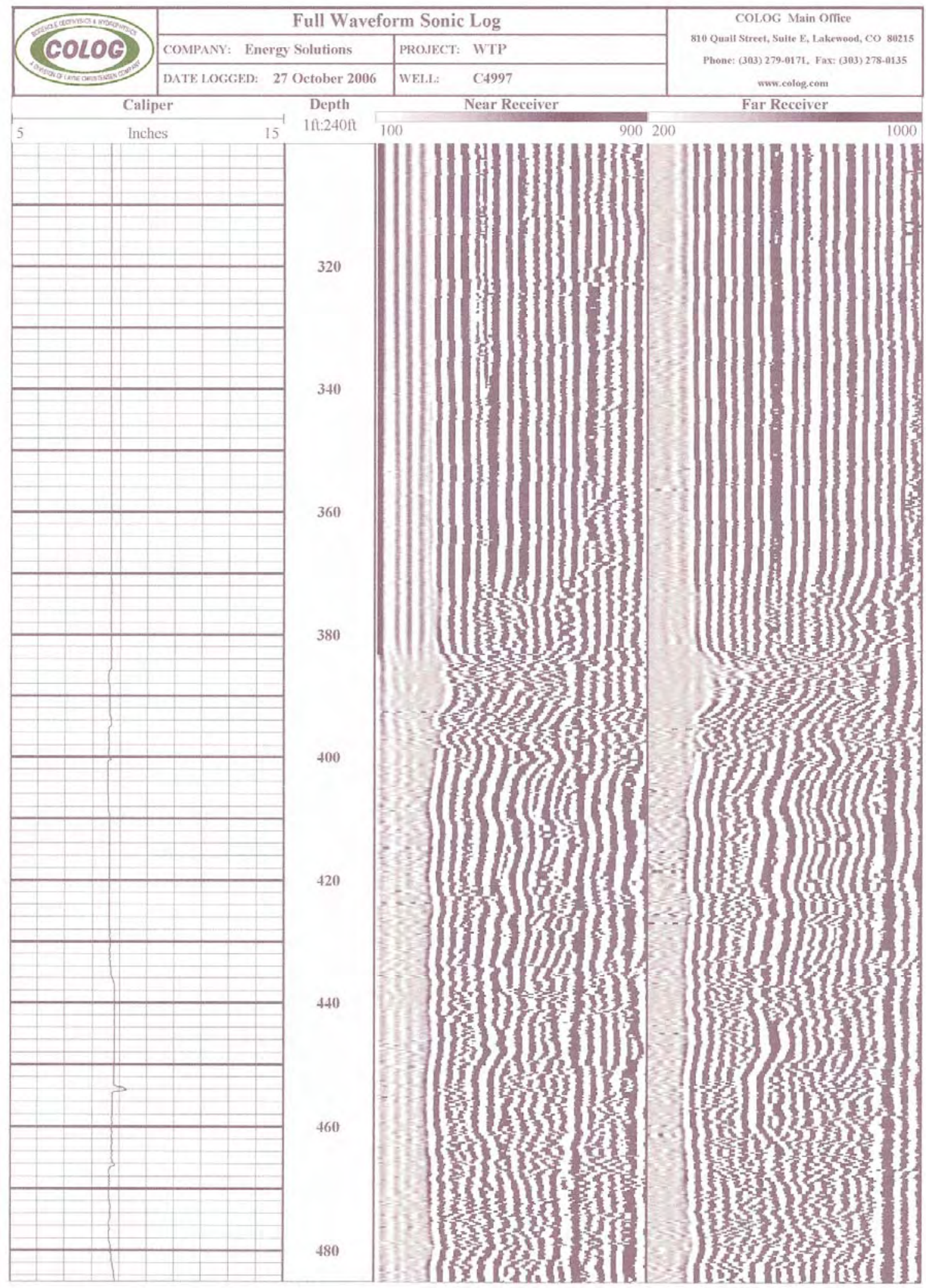


DTS-RPT-090, Rev. 0

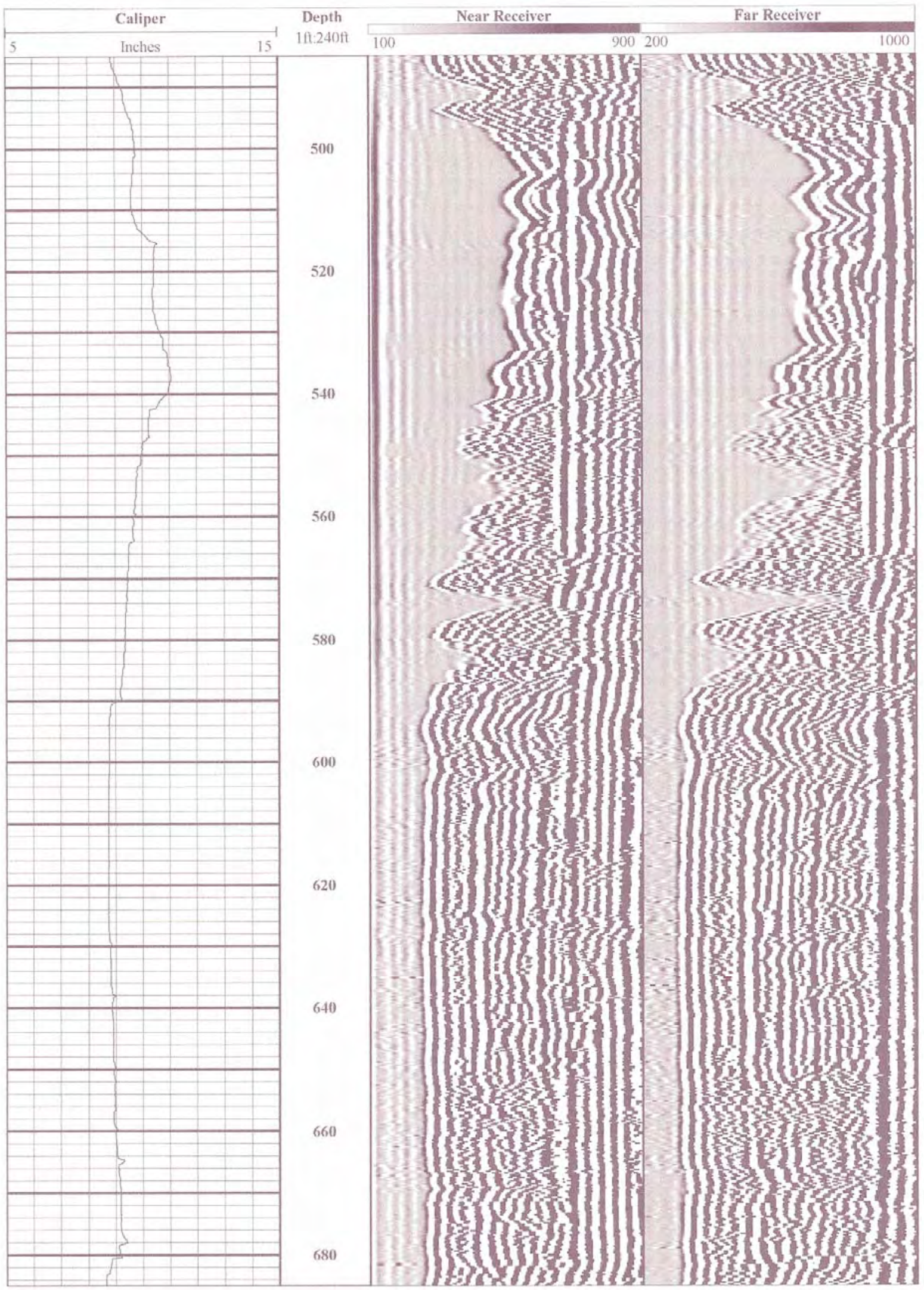


DTS-RPT-090, Rev. 0

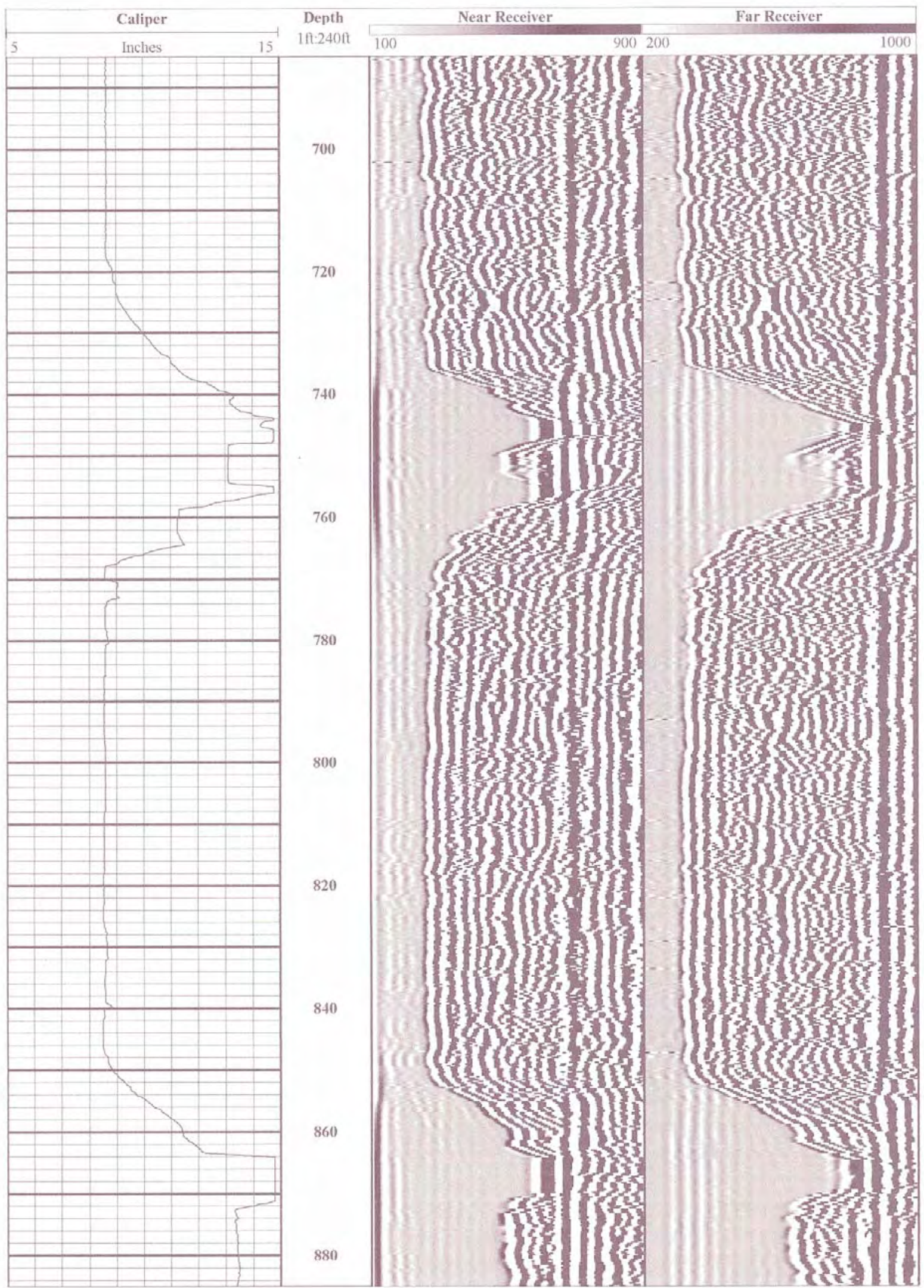


DTS-RPT-090, Rev. 0

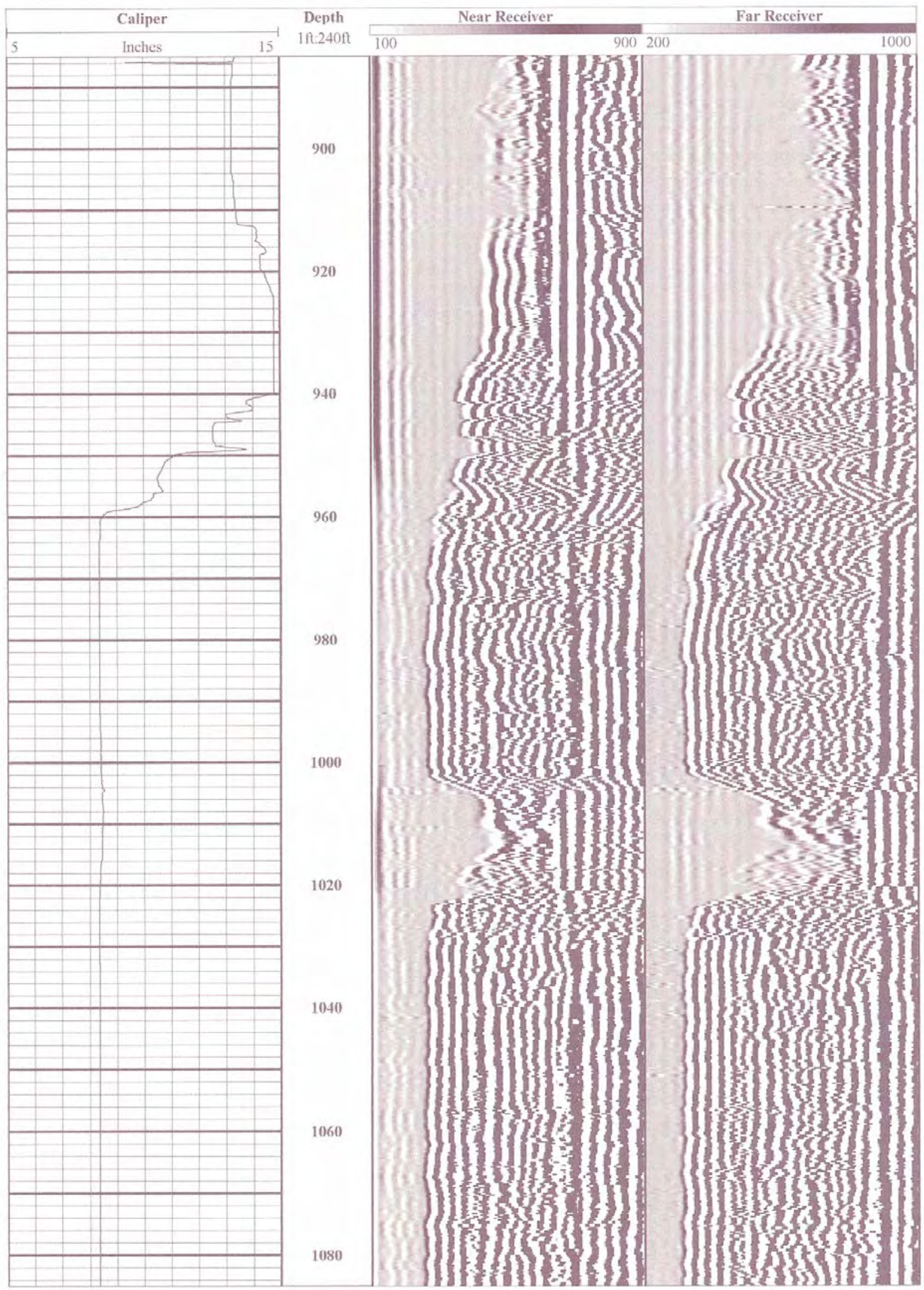


DTS-RPT-090, Rev. 0

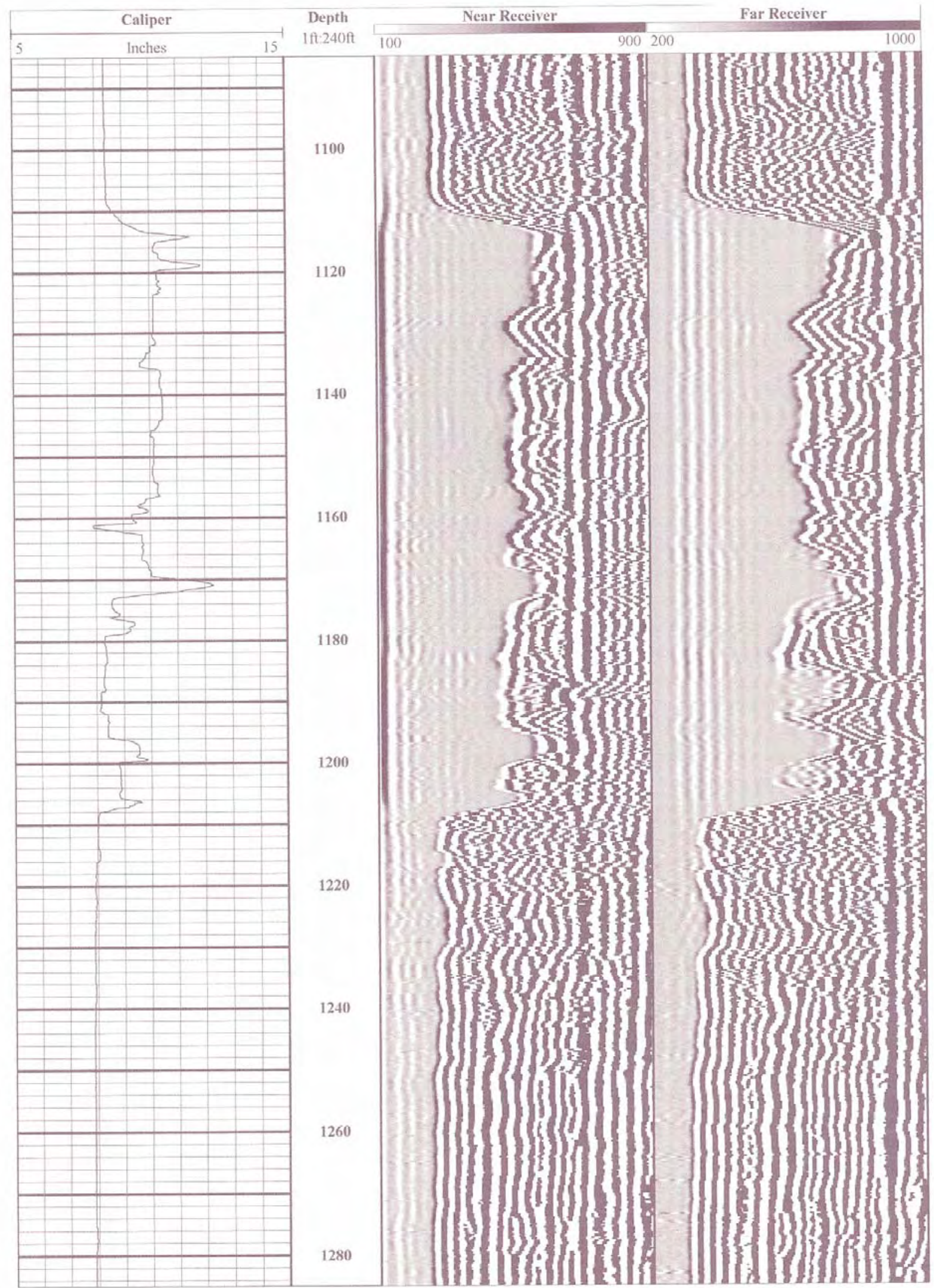


DTS-RPT-090, Rev. 0

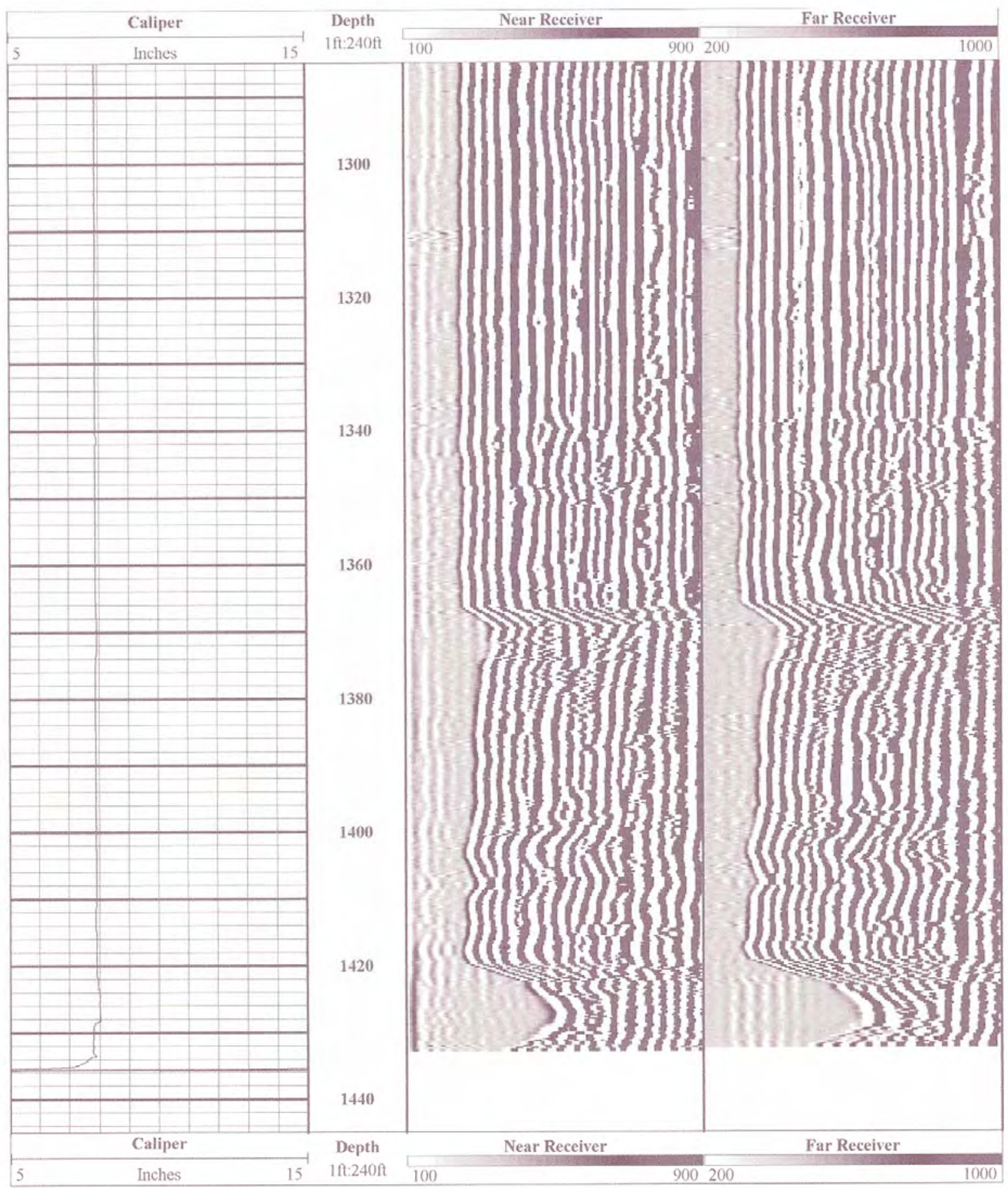




\section{WELLBORE NAVIGATION, INC.}

Tustin, California

Earth's Magnetic Field Survey

For

\section{Energy Solutions}

Job Number: $\quad 48-0350-312$

Well Name: $\quad$ C4997

Location: Hanford Site

Survey Date: $\quad$ October 24, 2006

Survey Engineer: Dawson/Adams

Magnetic Declination: 00.00E True North

Surface Y-Coordinate: $\quad 135754.95$

Surface X-Coordinate: $\mathbf{5 7 6 3 0 9 . 3 3}$

Surface Elevation: $\quad 206.31$

Depth Measured in FEET

Comments: $\quad$ Surface Casing Depth $383 \mathrm{ft}$. USGS: Dip=69.08 Degrees Intensity $=0.54600$ Oerstads Declination= 16.60 Degrees 
DTS-RPT-090, Rev. 0

\begin{tabular}{|c|c|c|c|c|c|c|c|c|}
\hline $\begin{array}{c}\text { Hole } \\
\text { ID }\end{array}$ & $\begin{array}{l}\text { Measured } \\
\text { Depth }\end{array}$ & $\begin{array}{c}\text { Magnetic } \\
\text { Declination }\end{array}$ & $\begin{array}{l}\text { Magnetic } \\
\text { Intensity }\end{array}$ & $\begin{array}{l}\text { Magnetic } \\
\text { Dip }\end{array}$ & HFS & X-HFS & Y-HFS & Z-HFS \\
\hline C4997 & 360 & 163.046 & 1.45031 & 35.9 & 1.17481 & 0.34258 & -1.12375 & 0.85042 \\
\hline C4997 & 380 & 257.777 & 1.01501 & 9.69 & 1.00053 & -0.97785 & -0.21183 & 0.17084 \\
\hline C4997 & 400 & 13.98435 & 0.5655 & 71.06 & 0.18355 & 0.04436 & 0.17811 & 0.53488 \\
\hline C4997 & 420 & 14.27173 & 0.53112 & 66.93 & 0.20812 & 0.05131 & 0.2017 & 0.48864 \\
\hline C4997 & 440 & 15.3306 & 0.53305 & 69.34 & 0.18807 & 0.04972 & 0.18138 & 0.49877 \\
\hline C4997 & 460 & 13.22662 & 0.51886 & 70.28 & 0.17508 & 0.04006 & 0.17043 & 0.48843 \\
\hline C4997 & 480 & 14.4913 & 0.53291 & 67.78 & 0.20153 & 0.05043 & 0.19512 & 0.49334 \\
\hline C4997 & 500 & 18.88808 & 0.54627 & 70.17 & 0.18531 & 0.05999 & 0.17533 & 0.51388 \\
\hline C4997 & 520 & 18.40216 & 0.54778 & 69.94 & 0.18789 & 0.05931 & 0.17828 & 0.51455 \\
\hline C4997 & 540 & 18.11105 & 0.55431 & 69.73 & 0.19204 & 0.0597 & 0.18252 & 0.51998 \\
\hline C4997 & 560 & 21.11438 & 0.58915 & 70.86 & 0.19317 & 0.06959 & 0.1802 & 0.55658 \\
\hline C4997 & 580 & 15.16221 & 0.61398 & 72.14 & 0.1883 & 0.04925 & 0.18175 & 0.58439 \\
\hline C4997 & 600 & 18.7808 & 0.58583 & 71.14 & 0.18937 & 0.06097 & 0.17929 & 0.55438 \\
\hline C4997 & 620 & 15.9222 & 0.59666 & 71.39 & 0.19041 & 0.05224 & 0.1831 & 0.56546 \\
\hline C4997 & 640 & 15.30343 & 0.60658 & 72.61 & 0.18129 & 0.04785 & 0.17486 & 0.57885 \\
\hline C4997 & 660 & 18.01677 & 0.62585 & 76.55 & 0.14557 & 0.04502 & 0.13843 & 0.60869 \\
\hline C4997 & 680 & 15.78565 & 0.54965 & 68.27 & 0.2035 & 0.05536 & 0.19582 & 0.51059 \\
\hline C4997 & 700 & 14.50858 & 0.56486 & 69.98 & 0.19338 & 0.04845 & 0.18721 & 0.53073 \\
\hline C4997 & 720 & 13.83206 & 0.5523 & 70.19 & 0.18718 & 0.04475 & 0.18175 & 0.51962 \\
\hline C4997 & 740 & 16.68556 & 0.55522 & 71.29 & 0.1781 & 0.05114 & 0.1706 & 0.52588 \\
\hline C4997 & 760 & 21.73694 & 0.50879 & 64.26 & 0.22096 & 0.08183 & 0.20525 & 0.4583 \\
\hline C4997 & 780 & 17.6445 & 0.50258 & 65.46 & 0.20874 & 0.06327 & 0.19892 & 0.45718 \\
\hline C4997 & 800 & 15.33085 & 0.49064 & 66.32 & 0.19705 & 0.0521 & 0.19004 & 0.44933 \\
\hline C4997 & 820 & 7.131653 & 0.40217 & 51.86 & 0.24837 & 0.03084 & 0.24645 & 0.31631 \\
\hline C4997 & 840 & 14.54573 & 0.50711 & 67.08 & 0.19749 & 0.0496 & 0.19116 & 0.46707 \\
\hline C4997 & 860 & 16.30135 & 0.53504 & 68.76 & 0.19383 & 0.05441 & 0.18604 & 0.4987 \\
\hline C4997 & 880 & 15.70038 & 0.54625 & 68.76 & 0.19789 & 0.05355 & 0.19051 & 0.50914 \\
\hline C4997 & 900 & 14.19806 & 0.54674 & 68.84 & 0.19736 & 0.04841 & 0.19133 & 0.50988 \\
\hline C4997 & 920 & 13.46695 & 0.54613 & 69.36 & 0.19251 & 0.04483 & 0.18722 & 0.51108 \\
\hline C4997 & 940 & 17.42268 & 0.43755 & 69.97 & 0.14987 & 0.04487 & 0.14299 & 0.41108 \\
\hline C4997 & 960 & 5.738295 & 0.47873 & 62.04 & 0.22445 & 0.02244 & 0.22333 & 0.42285 \\
\hline C4997 & 980 & 10.76254 & 0.48491 & 60.27 & 0.24047 & 0.04491 & 0.23624 & 0.42108 \\
\hline C4997 & 1000 & 12.85248 & 0.48468 & 64.53 & 0.20843 & 0.04636 & 0.20321 & 0.43757 \\
\hline C4997 & 1020 & 17.58212 & 0.50633 & 66.47 & 0.20214 & 0.06106 & 0.1927 & 0.46423 \\
\hline C4997 & 1040 & 19.08427 & 0.47845 & 61.93 & 0.22513 & 0.07361 & 0.21276 & 0.42217 \\
\hline C4997 & 1060 & 10.71945 & 0.46429 & 57.06 & 0.25246 & 0.04696 & 0.24806 & 0.38965 \\
\hline C4997 & 1080 & 9.786827 & 0.47128 & 58.22 & 0.2482 & 0.04219 & 0.24459 & 0.40062 \\
\hline C4997 & 1100 & 8.973358 & 0.46909 & 58.78 & 0.24314 & 0.03792 & 0.24017 & 0.40116 \\
\hline C4997 & 1120 & 18.42572 & 0.55842 & 70.19 & 0.18925 & 0.05982 & 0.17955 & 0.52537 \\
\hline C4997 & 1140 & 17.74608 & 0.55425 & 70.24 & 0.18738 & 0.05711 & 0.17847 & 0.52161 \\
\hline C4997 & 1160 & 13.35764 & 0.5573 & 69.18 & 0.19808 & 0.04576 & 0.19272 & 0.52091 \\
\hline C4997 & 1180 & 14.92804 & 0.55599 & 68.56 & 0.20323 & 0.05235 & 0.19637 & 0.51752 \\
\hline C4997 & 1200 & 14.90219 & 0.55528 & 68.5 & 0.20351 & 0.05234 & 0.19667 & 0.51664 \\
\hline C4997 & 1220 & 16.54583 & 0.59796 & 73.47 & 0.17013 & 0.04845 & 0.16309 & 0.57325 \\
\hline C4997 & 1240 & 16.35144 & 0.56203 & 70.79 & 0.18493 & 0.05206 & 0.17745 & 0.53074 \\
\hline C4997 & 1260 & 16.25079 & 0.56109 & 70 & 0.1919 & 0.0537 & 0.18424 & 0.52725 \\
\hline C4997 & 1280 & 17.53906 & 0.57493 & 70.38 & 0.19305 & 0.05818 & 0.18408 & 0.54155 \\
\hline C4997 & 1300 & 15.24263 & 0.55589 & 68.56 & 0.20319 & 0.05342 & 0.19604 & 0.51742 \\
\hline C4997 & 1320 & 16.19437 & 0.55958 & 69.05 & 0.20008 & 0.0558 & 0.19214 & 0.52259 \\
\hline C4997 & 1340 & 16.85475 & 0.55882 & 70.38 & 0.18764 & 0.05441 & 0.17958 & 0.52638 \\
\hline C4997 & 1360 & 17.55141 & 0.56508 & 69.46 & 0.19826 & 0.05979 & 0.18903 & 0.52916 \\
\hline C4997 & 1380 & 13.71987 & 0.62744 & 71.85 & 0.19545 & 0.04636 & 0.18987 & 0.59622 \\
\hline C4997 & 1400 & 11.90224 & 0.62019 & 69.94 & 0.21273 & 0.04387 & 0.20815 & 0.58257 \\
\hline C4997 & 1420 & 14.5152 & 0.59882 & 71.62 & 0.18882 & 0.04732 & 0.18279 & 0.56827 \\
\hline
\end{tabular}


DTS-RPT-090, Rev. 0

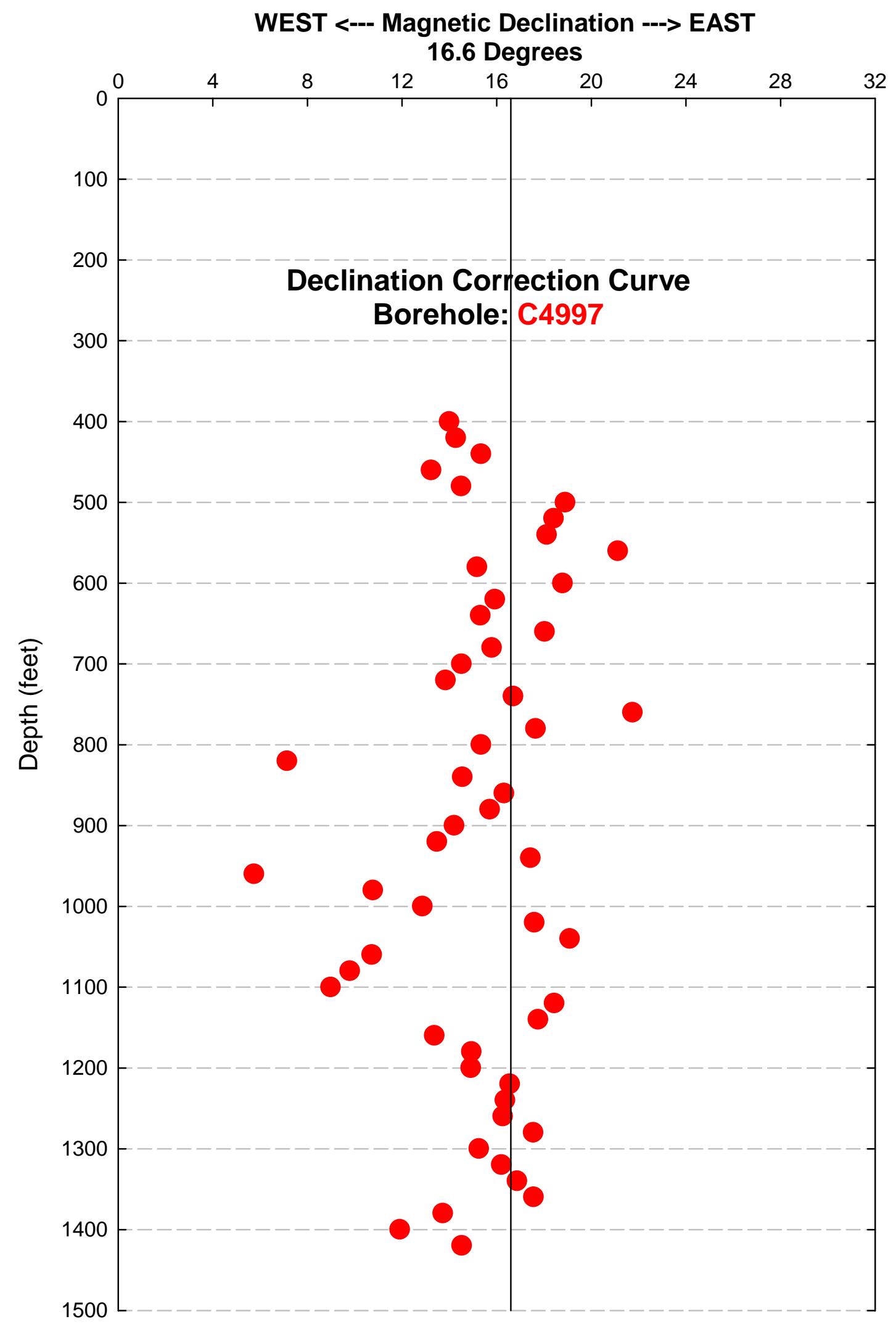

C-106 
DTS-RPT-090, Rev. 0

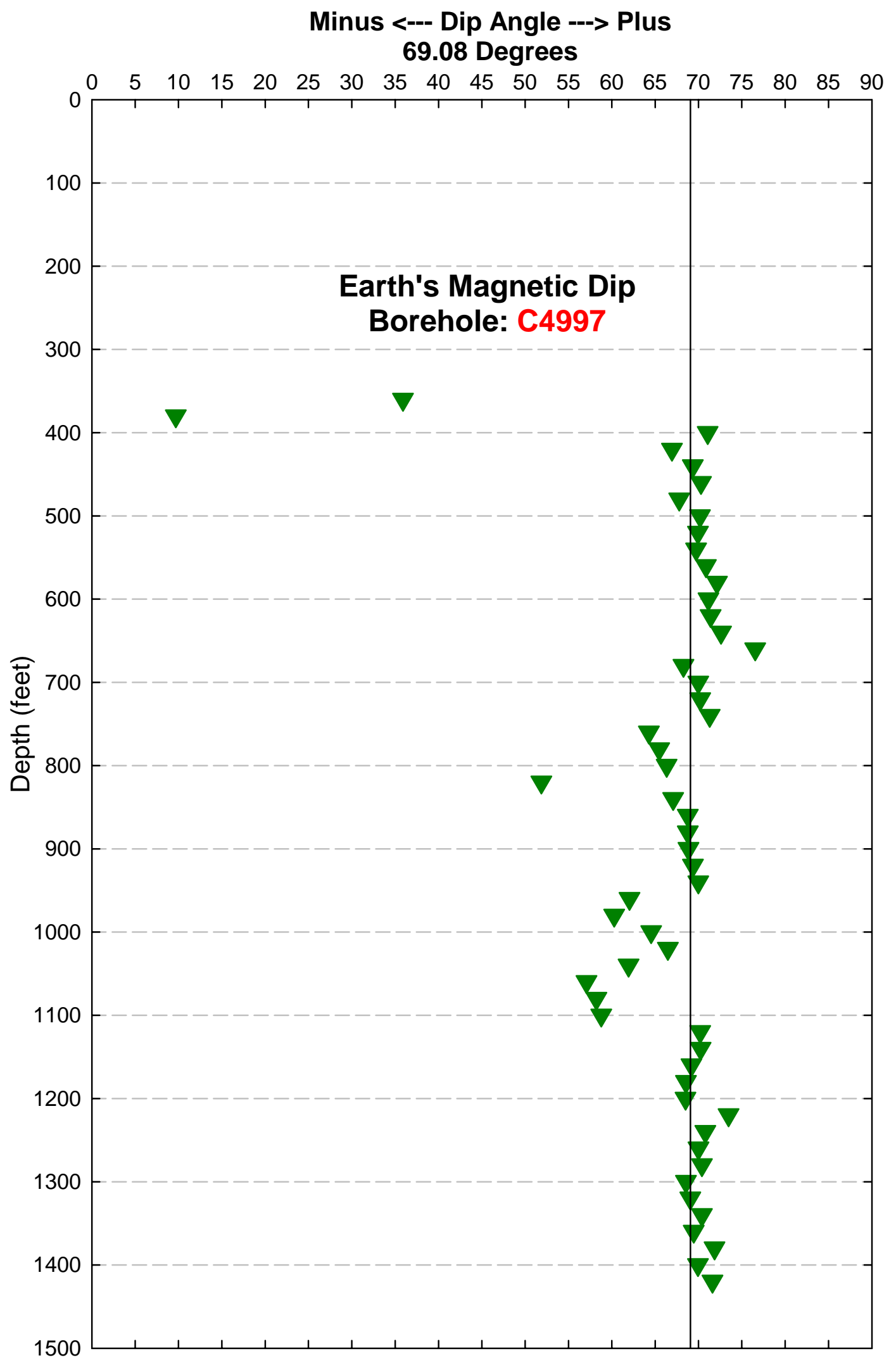


DTS-RPT-090, Rev. 0

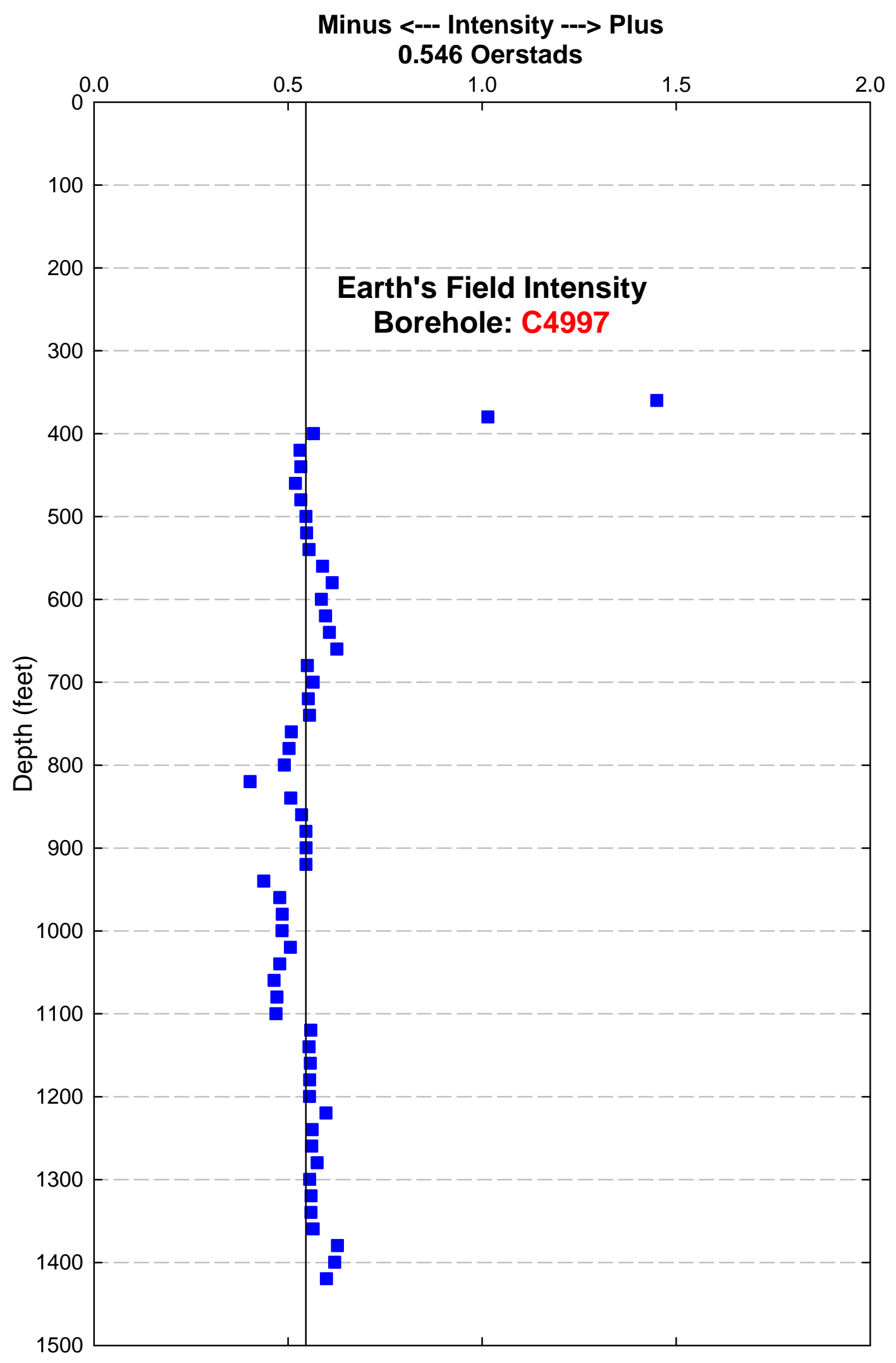

C-108 
DTS-RPT-090, Rev. 0

APPENDIX D

BOREHOLE C4998

D-i 
DTS-RPT-090, Rev. 0

This page intentionally left blank.

D-ii 
DTS-RPT-090, Rev. 0

\section{D1.0 COREHOLE C4998}

\section{D1.1 ENERGYSOLUTIONS AND PACIFIC NORTHWEST GEOPHYSICS GYROSCOPIC LOGS}

Hole: $\mathbf{C 4 9 9 8}$

\begin{tabular}{|c|c|c|c|c|}
\hline $\begin{array}{c}\text { Survey } \\
\text { Date }\end{array}$ & $\begin{array}{c}\text { Survey } \\
\text { Number }\end{array}$ & $\begin{array}{c}\text { Maximum } \\
\text { Depth } \\
\text { (feet) }\end{array}$ & $\begin{array}{c}\text { Inclination } \\
\text { From Vertical } \\
\text { (deg) }\end{array}$ & $\begin{array}{c}\text { Closure } \\
\text { Distance } \\
\text { (feet) }\end{array}$ \\
\hline Casing & Cable-Tool & & & \\
\hline $7 / 10 / 2006$ & 8 & 382 & 2.6 & 12 \\
\hline $7 / 7 / 2006$ & 7 & 340 & 3.1 & 13 \\
\hline $7 / 5 / 2006$ & 6 & 313 & 3.7 & 8 \\
\hline $6 / 28 / 2006$ & 5 & 250 & 2.9 & 4.4 \\
\hline $6 / 21 / 2006$ & 4 & 191 & 0.7 & 0.7 \\
\hline $6 / 19 / 2006$ & 3 & 145 & 0.5 & 0.2 \\
\hline $6 / 15 / 2006$ & 2 & 101 & 0.5 & 0.1 \\
\hline $6 / 14 / 2006$ & 1 & 73 & 0.5 & \\
\hline & & & & \\
\hline
\end{tabular}


DTS-RPT-090, Rev. 0

Hole: C4998

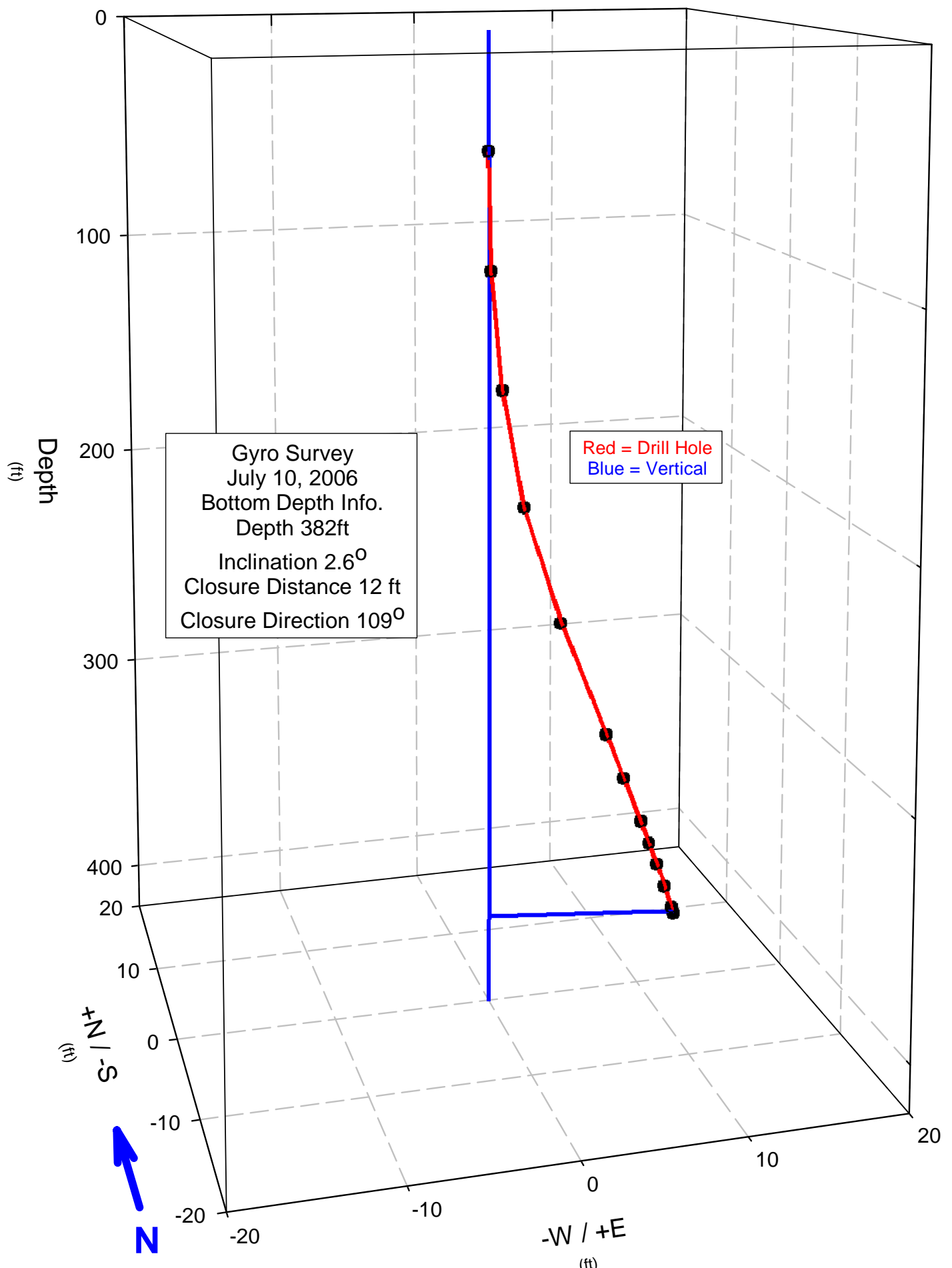

D-2 
DTS-RPT-090, Rev. 0

Hole: C4998 Survey Date: 7/10/2006

\begin{tabular}{|c|c|c|c|c|c|c|c|}
\hline Measured & TrueVert. & Inclination & Closure & Closure & Rectangular & Rectangular & Dog-Leg \\
\hline $\begin{array}{l}\text { Depth } \\
\text { (feet) }\end{array}$ & $\begin{array}{l}\text { Depth } \\
\text { (feet) }\end{array}$ & $\begin{array}{c}\text { from Vert. } \\
\text { (deg) }\end{array}$ & $\begin{array}{l}\text { Direction } \\
\text { (deg) }\end{array}$ & $\begin{array}{l}\text { Distance } \\
\text { (feet) }\end{array}$ & $\begin{array}{c}\text { Coordinates } \\
+\mathrm{N} / \mathrm{-S}\end{array}$ & $\begin{array}{c}\text { Coordinates } \\
+E /-W\end{array}$ & $\begin{array}{l}\text { Severity } \\
\text { o/100-ft }\end{array}$ \\
\hline 50 & 50 & 0.44 & 221.89 & 0.1 & -0.07 & -0.07 & 1.4 \\
\hline 100 & 100 & 0.56 & 177.38 & 0.44 & -0.44 & 0.02 & 1.1 \\
\hline 150 & 149.99 & 1.21 & 146.92 & 1.11 & -0.93 & 0.61 & 1.4 \\
\hline 200 & 199.97 & 2 & 127.9 & 2.38 & -1.46 & 1.88 & 2 \\
\hline 250 & 249.92 & 3.4 & 114.11 & 4.6 & -1.88 & 4.2 & 2.9 \\
\hline 300 & 299.83 & 3.39 & 106.59 & 7.45 & -2.13 & 7.14 & 0.6 \\
\hline 320 & 319.79 & 3.34 & 104.71 & 8.59 & -2.18 & 8.31 & 0.3 \\
\hline 340 & 339.76 & 3.2 & 103.33 & 9.71 & -2.24 & 9.45 & 0.7 \\
\hline 350 & 349.75 & 3.2 & 102.73 & 10.26 & -2.26 & 10.01 & 0.6 \\
\hline 360 & 359.73 & 3.22 & 102.09 & 10.81 & -2.26 & 10.57 & 1.5 \\
\hline 370 & 369.72 & 2.99 & 101.51 & 11.34 & -2.26 & 11.11 & 2.5 \\
\hline 380 & 379.7 & 2.45 & 101.14 & 11.81 & -2.28 & 11.58 & 5.5 \\
\hline 382.6 & 382.3 & 2.59 & 101.09 & 11.92 & -2.29 & 11.7 & 10.5 \\
\hline
\end{tabular}


DTS-RPT-090, Rev. 0

Hole: C4998

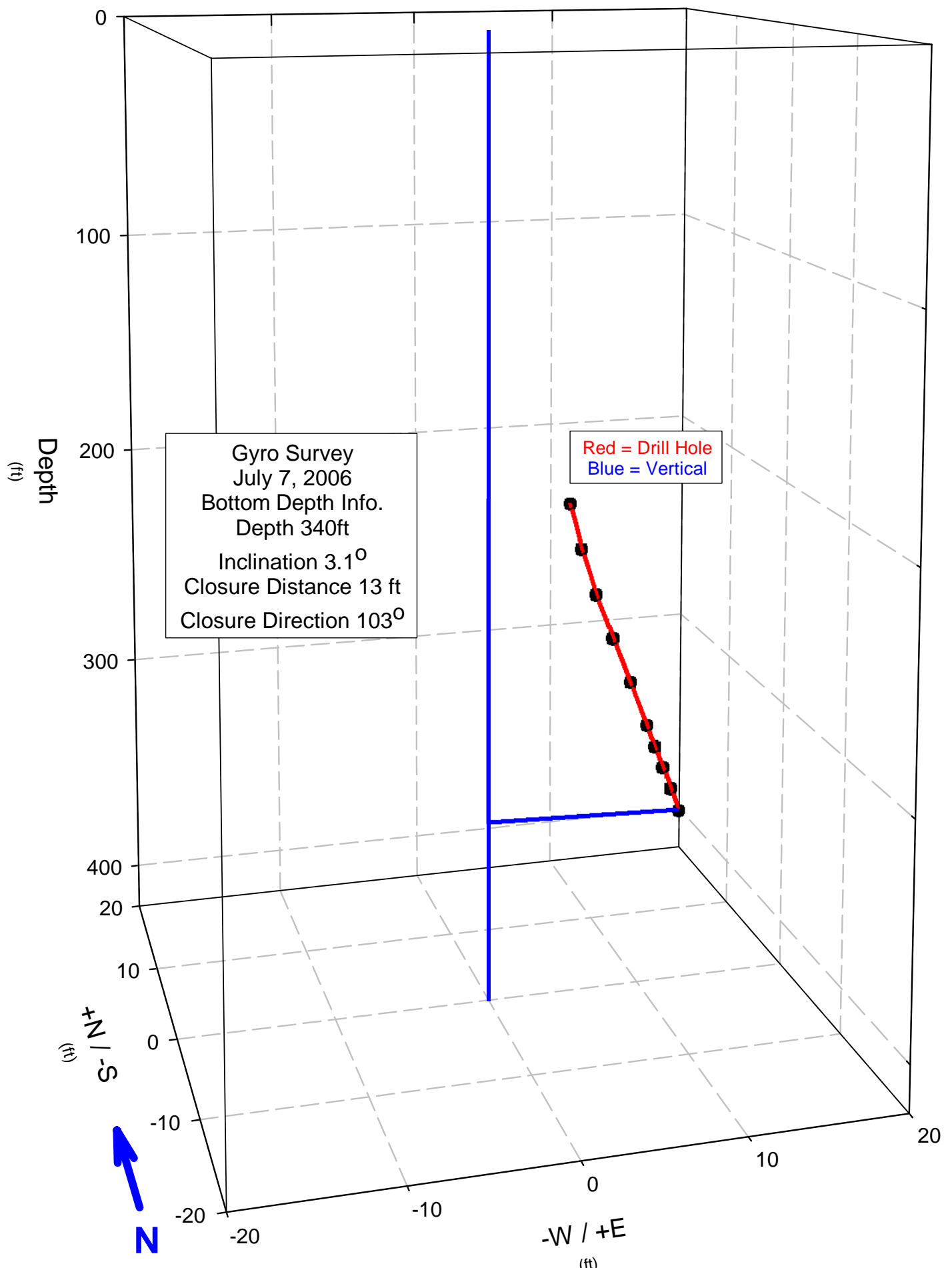

D-4 
DTS-RPT-090, Rev. 0

Hole: C4998 Survey Date: 7/7/2006

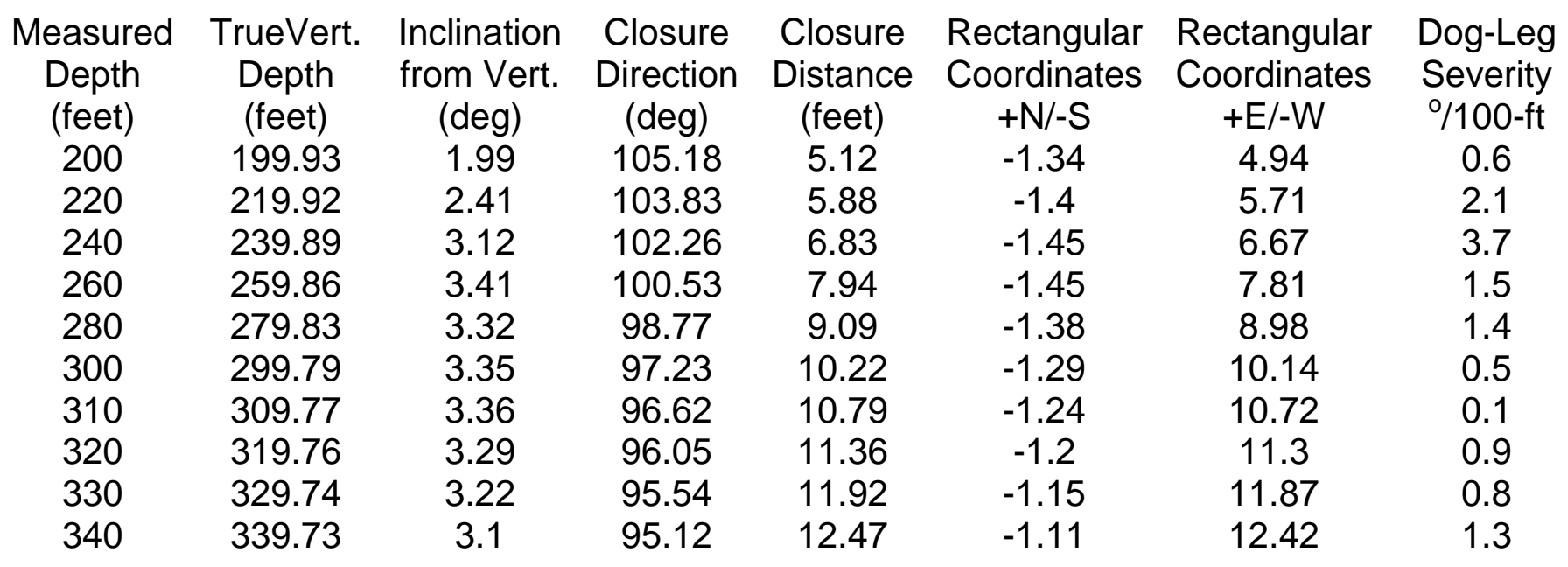


DTS-RPT-090, Rev. 0

Hole: C4998

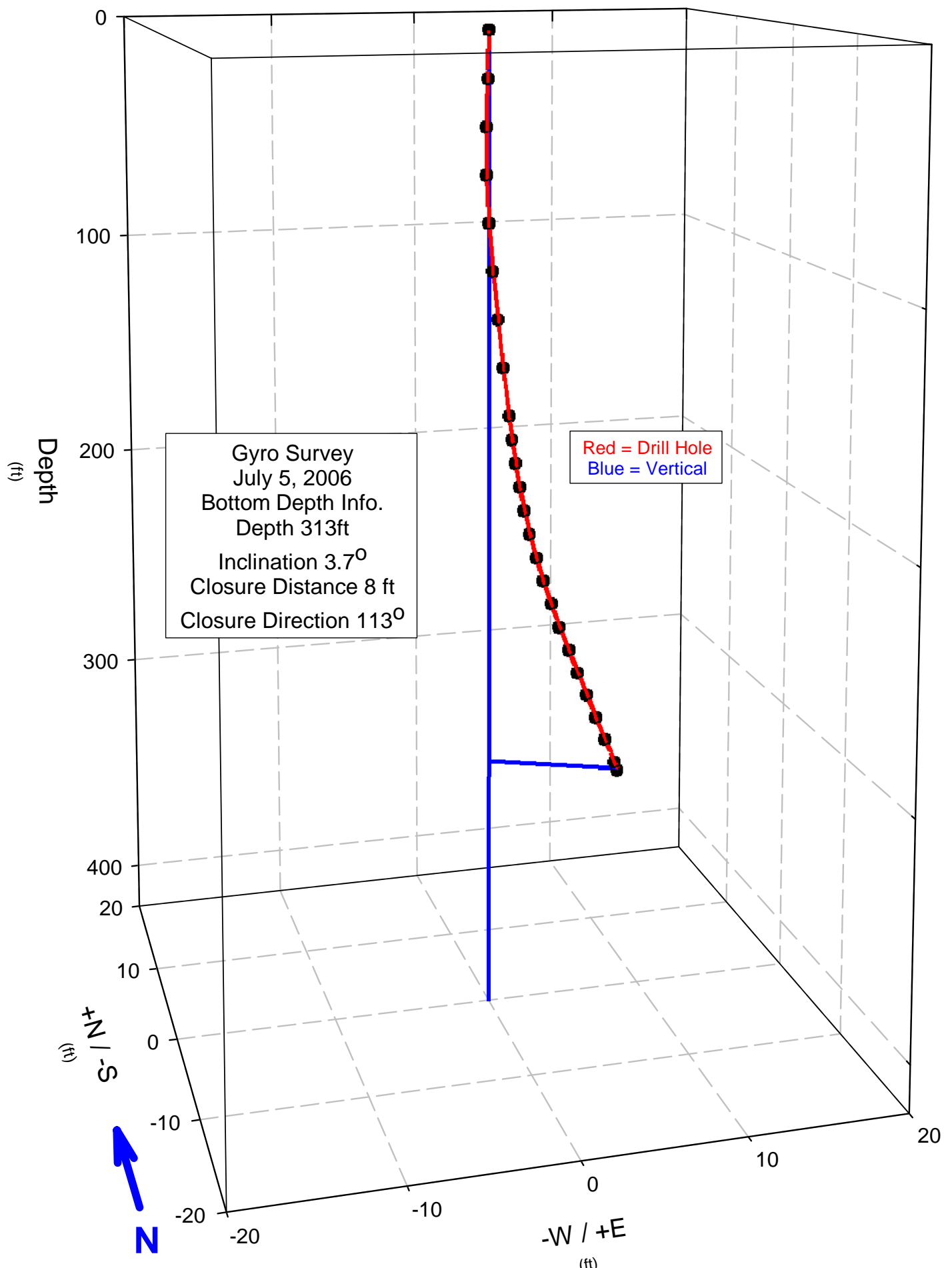

D-6 
Hole: C4998 Survey Date: 7/5/2006

$\begin{array}{cccccccc}\begin{array}{c}\text { Measured } \\ \text { Depth } \\ \text { (feet) }\end{array} & \begin{array}{c}\text { TrueVert. } \\ \text { Depth } \\ \text { (feet) }\end{array} & \begin{array}{c}\text { Inclination } \\ \text { from Vert. } \\ \text { (deg) }\end{array} & \begin{array}{c}\text { Closure } \\ \text { Direction } \\ \text { (deg) }\end{array} & \begin{array}{c}\text { Closure } \\ \text { Distance } \\ \text { (feet) }\end{array} & \begin{array}{c}\text { Rectangular } \\ \text { Coordinates } \\ + \text { N/-S }\end{array} & \begin{array}{c}\text { Rectangular } \\ \text { Coordinates } \\ + \text { E/-W }\end{array} & \begin{array}{c}\text { Dog-Leg } \\ \text { Severity } \\ \text { o/100-ft }\end{array} \\ 20 & 0 & 0.44 & 0 & 0 & 0 & 0 & 0 \\ 40 & 20 & 0.56 & 207.93 & 0.17 & -0.15 & -0.08 & 1.4 \\ 60 & 40 & 0.28 & 216.31 & 0.31 & -0.25 & -0.18 & 1.5 \\ 80 & 60 & 0.49 & 212.17 & 0.43 & -0.36 & -0.23 & 2 \\ 100 & 99 & 0.8 & 195.19 & 0.58 & -0.56 & -0.15 & 2.5 \\ 120 & 119.99 & 1.24 & 177.09 & 0.86 & -0.86 & 0.04 & 2.2 \\ 140 & 139.99 & 1.14 & 167.22 & 1.23 & -1.2 & 0.27 & 0.7 \\ 160 & 159.98 & 1.12 & 150.85 & 1.59 & -1.5 & 0.52 & 0.9 \\ 170 & 169.98 & 1.24 & 151.97 & 1.93 & -1.75 & 0.82 & 1.1 \\ 180 & 179.98 & 1.43 & 148.71 & 2.31 & -1.86 & 0.99 & 1.6 \\ 190 & 189.97 & 1.52 & 145.53 & 2.53 & -1.97 & 1.2 & 2.1 \\ 200 & 199.97 & 1.78 & 142.4 & 2.78 & -2.2 & 1.43 & 1 \\ 210 & 209.96 & 2.14 & 138.9 & 3.07 & -2.31 & 2.69 & 2.8 \\ 220 & 219.96 & 2.39 & 135.24 & 3.4 & -2.42 & 2.4 & 4 \\ 230 & 229.95 & 2.63 & 131.79 & 3.78 & -2.52 & 2.82 & 2.6 \\ 240 & 239.93 & 2.97 & 128.5 & 4.22 & -2.62 & 3.3 & 3.5 \\ 250 & 249.92 & 3.2 & 125.48 & 4.7 & -2.73 & 3.83 & 2.3 \\ 260 & 259.9 & 3.37 & 122.82 & 5.22 & -2.83 & 4.39 & 1.7 \\ 270 & 269.89 & 3.36 & 120.49 & 5.77 & -2.93 & 4.97 & 1.1 \\ 280 & 279.87 & 3.25 & 118.38 & 6.3 & -2.99 & 5.54 & 2 \\ 290 & 289.85 & 3.42 & 116.4 & 6.83 & -3.04 & 6.12 & 2 \\ 300 & 299.84 & 3.42 & 114.71 & 7.39 & -3.09 & 6.72 & 1.4 \\ 310 & 309.82 & 3.48 & 113.3 & 7.96 & -3.15 & 7.31 & 0.7 \\ 313.5 & 313.31 & 3.7 & 112.82 & 8.17 & -3.17 & 7.53 & 6.2\end{array}$


DTS-RPT-090, Rev. 0

Hole: C4998

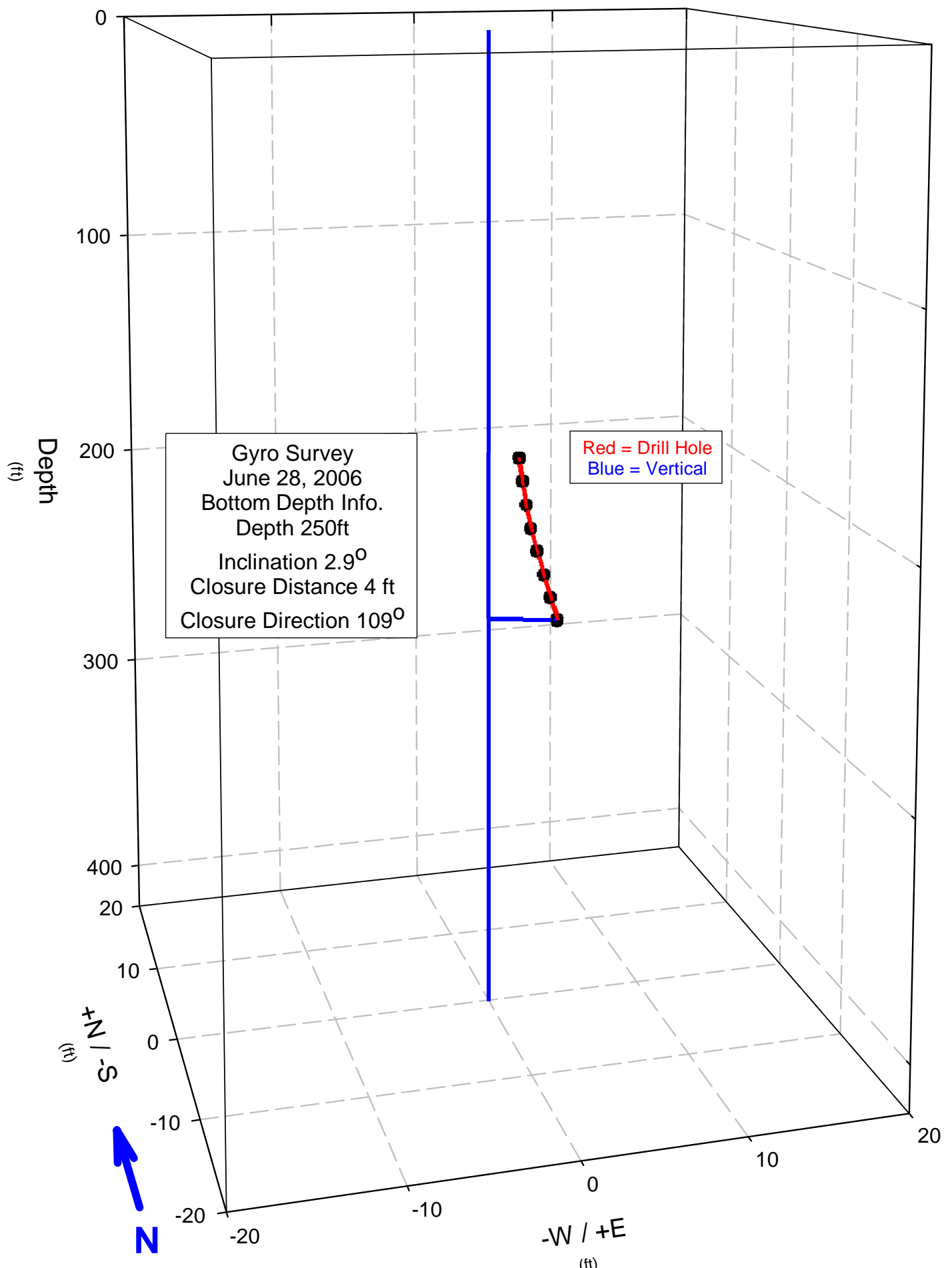


DTS-RPT-090, Rev. 0

Hole: C4998 Survey Date: 6/28/2006

$\begin{array}{cccccccc}\begin{array}{c}\text { Measured } \\ \text { Depth } \\ \text { (feet) }\end{array} & \begin{array}{c}\text { TrueVert. } \\ \text { Depth } \\ \text { (feet) }\end{array} & \begin{array}{c}\text { Inclination } \\ \text { from Vert. } \\ \text { (deg) }\end{array} & \begin{array}{c}\text { Closure } \\ \text { Direction } \\ \text { (deg) }\end{array} & \begin{array}{c}\text { Closure } \\ \text { Distance } \\ \text { (feet) }\end{array} & \begin{array}{c}\text { Rectangular } \\ \text { Coordinates } \\ + \text { N/-S }\end{array} & \begin{array}{c}\text { Rectangular } \\ \text { Coordinates } \\ + \text { E/-W }\end{array} & \begin{array}{c}\text { Dog-Leg } \\ \text { Severity } \\ \text { o/100-ft }\end{array} \\ 180 & 179.99 & 1.18 & 106.4 & 1.94 & -0.55 & 1.86 & 0.7 \\ 200 & 189.98 & 1.31 & 108.51 & 2.14 & -0.68 & 2.03 & 1.9 \\ 210 & 199.98 & 1.52 & 109.79 & 2.38 & -0.81 & 2.24 & 2.7 \\ 220 & 209.98 & 1.94 & 110.19 & 2.68 & -0.93 & 2.52 & 4.7 \\ 230 & 219.97 & 2.36 & 110.05 & 3.06 & -1.05 & 2.87 & 4.2 \\ 240 & 229.96 & 2.51 & 109.7 & 3.48 & -1.17 & 3.28 & 1.8 \\ 250 & 239.95 & 2.27 & 109.26 & 3.9 & -1.29 & 3.68 & 2.5 \\ & 249.94 & 2.92 & 109.05 & 4.35 & -1.42 & 4.11 & 6.7\end{array}$


DTS-RPT-090, Rev. 0

Hole: C4998

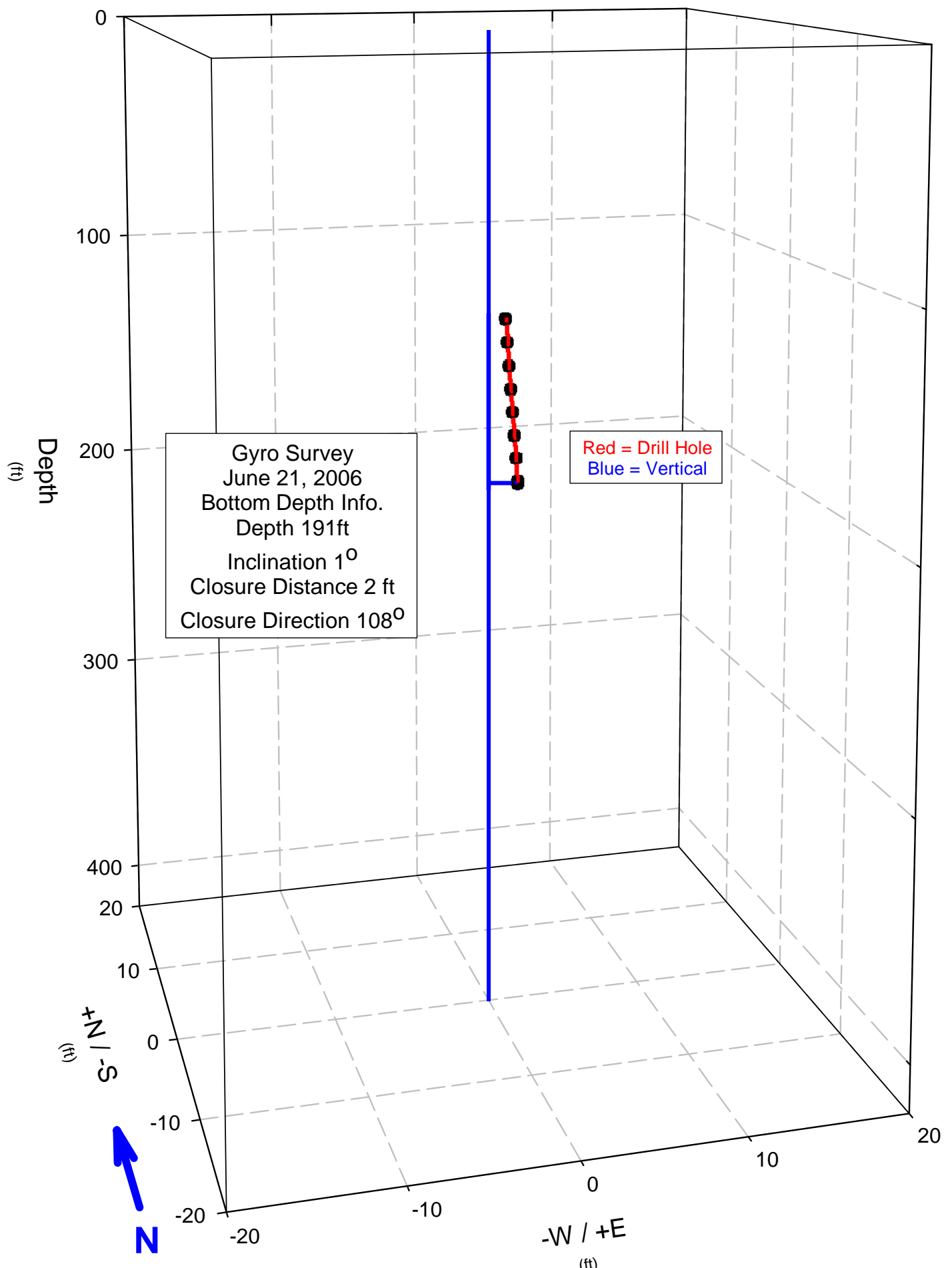


DTS-RPT-090, Rev. 0

Hole: C4998 Survey Date: 6/21/2006

\begin{tabular}{|c|c|c|c|c|c|c|c|}
\hline $\begin{array}{l}\text { Measured } \\
\text { Depth } \\
\text { (feet) }\end{array}$ & $\begin{array}{l}\text { TrueVert. } \\
\text { Depth } \\
\text { (feet) }\end{array}$ & $\begin{array}{l}\text { Inclination } \\
\text { from Vert. } \\
\text { (deg) }\end{array}$ & $\begin{array}{l}\text { Closure } \\
\text { Direction } \\
\text { (deg) }\end{array}$ & $\begin{array}{c}\text { Closure } \\
\text { Distance } \\
\text { (feet) }\end{array}$ & $\begin{array}{c}\text { Rectangular } \\
\text { Coordinates } \\
+\mathrm{N} / \mathrm{-S}\end{array}$ & $\begin{array}{c}\text { Rectangular } \\
\text { Coordinates } \\
+\mathrm{E} / \mathrm{-W}\end{array}$ & $\begin{array}{l}\text { Dog-Leg } \\
\text { Severity } \\
0 / 100-f t\end{array}$ \\
\hline 120 & 119.99 & 0.5 & 123.6 & 1.14 & -0.63 & 0.95 & 0.3 \\
\hline 130 & 129.99 & 0.57 & 122.41 & 1.23 & -0.66 & 1.04 & 0.7 \\
\hline 140 & 139.99 & 0.57 & 121.3 & 1.32 & -0.69 & 1.13 & 0.1 \\
\hline 150 & 149.99 & 0.62 & 119.52 & 1.42 & -0.7 & 1.23 & 2.2 \\
\hline 160 & 159.99 & 0.71 & 116.94 & 1.51 & -0.69 & 1.35 & 1 \\
\hline 170 & 169.99 & 0.7 & 114.39 & 1.61 & -0.67 & 1.47 & 0 \\
\hline 180 & 179.99 & 0.76 & 111.88 & 1.72 & -0.64 & 1.6 & 0.9 \\
\hline 190 & 189.99 & 0.89 & 108.56 & 1.82 & -0.58 & 1.72 & 3.4 \\
\hline 191 & 190.99 & 0.66 & 108.26 & 1.83 & -0.57 & 1.73 & 35.8 \\
\hline
\end{tabular}


DTS-RPT-090, Rev. 0

Hole: C4998

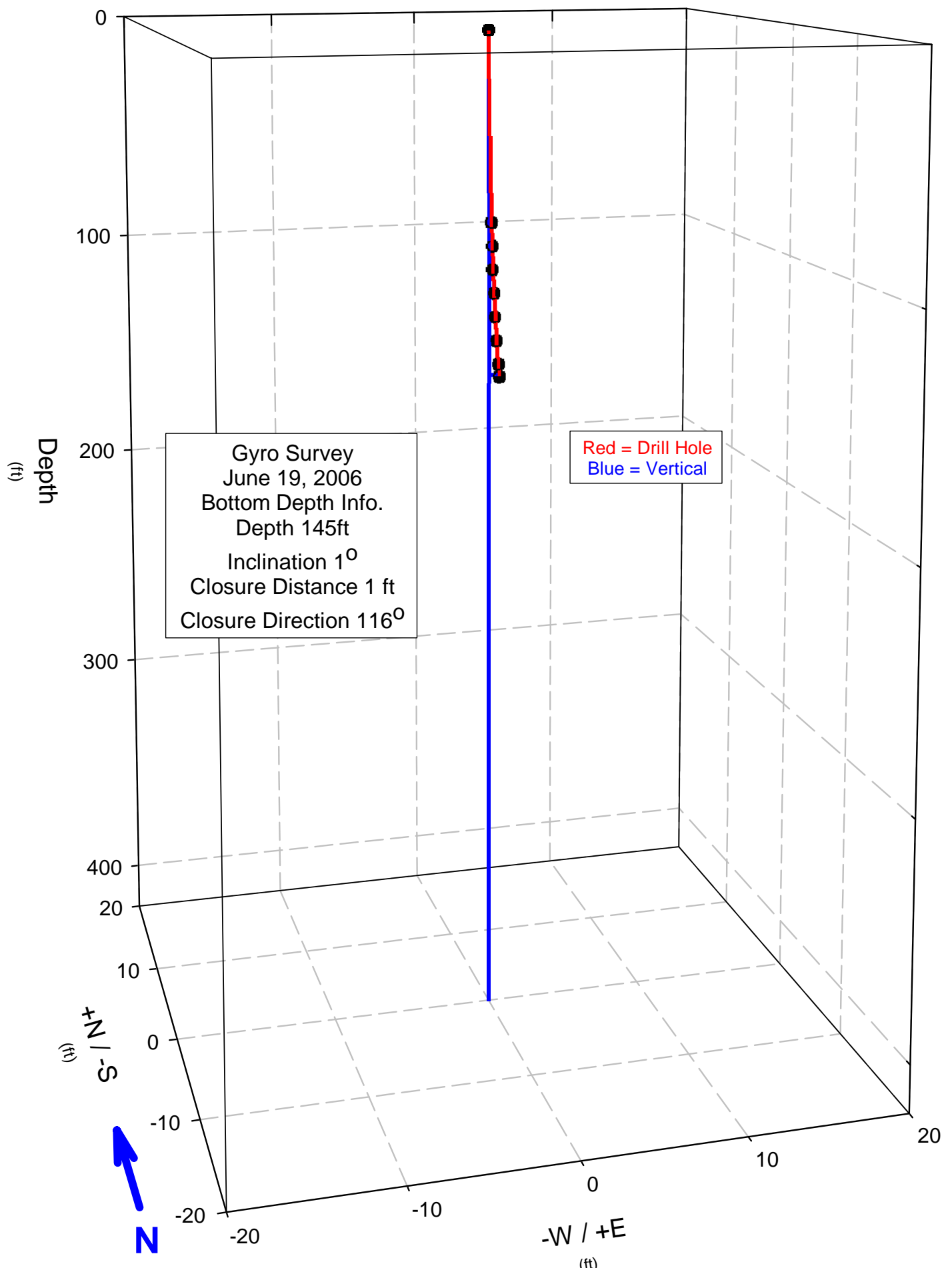


DTS-RPT-090, Rev. 0

Hole: C4998 Survey Date: 6/19/2006

$\begin{array}{cccccccc}\begin{array}{c}\text { Measured } \\ \begin{array}{c}\text { Depth } \\ \text { (feet) }\end{array}\end{array} & \begin{array}{c}\text { TrueVert. } \\ \text { Depth } \\ \text { (feet) }\end{array} & \begin{array}{c}\text { Inclination } \\ \text { from Vert. } \\ \text { (deg) }\end{array} & \begin{array}{c}\text { Closure } \\ \text { Direction } \\ \text { (deg) }\end{array} & \begin{array}{c}\text { Closure } \\ \text { Distance } \\ \text { (feet) }\end{array} & \begin{array}{c}\text { Rectangular } \\ \text { Coordinates } \\ + \text { N/-S }\end{array} & \begin{array}{c}\text { Rectangular } \\ \text { Coordinates } \\ +E /-W\end{array} & \begin{array}{c}\text { Dog-Leg } \\ \text { Severity } \\ \text { oflo0-ft }\end{array} \\ 80 & 0 & 0.09 & 0 & 0 & 0 & 0 & 0 \\ 90 & 80 & 0.25 & 108.43 & 0.18 & -0.06 & 0.17 & 0.3 \\ 100 & 90 & 0.28 & 113.26 & 0.22 & -0.09 & 0.21 & 0.5 \\ 110 & 100 & 0.33 & 115.67 & 0.28 & -0.12 & 0.25 & 1.1 \\ 120 & 110 & 0.46 & 116.61 & 0.34 & -0.15 & 0.31 & 1.3 \\ 130 & 120 & 0.45 & 117.29 & 0.42 & -0.19 & 0.38 & 0.4 \\ 140 & 140 & 0.51 & 118.09 & 0.51 & -0.24 & 0.45 & 1 \\ 145.3 & 145.3 & 0.91 & 117.12 & 0.63 & -0.29 & 0.56 & 4.7 \\ & & 0.52 & 116.26 & 0.69 & -0.31 & 0.62 & 7.4\end{array}$


DTS-RPT-090, Rev. 0

Hole: C4998

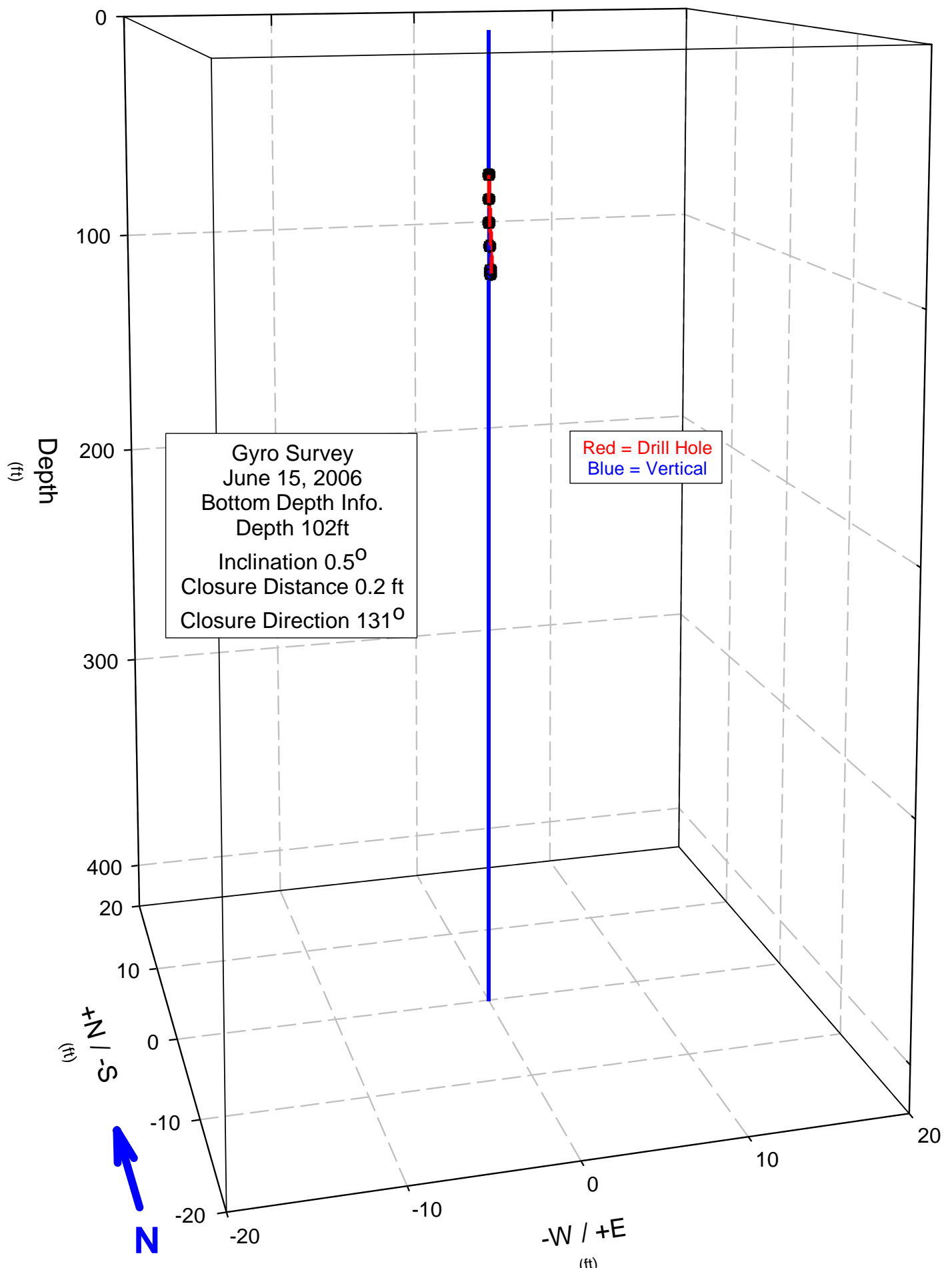


DTS-RPT-090, Rev. 0

Hole: C4998 Survey Date: 6/15/2006

$\begin{array}{cccccccc}\begin{array}{c}\text { Measured } \\ \text { Depth } \\ \text { (feet) }\end{array} & \begin{array}{c}\text { TrueVert. } \\ \text { Depth } \\ \text { (feet) }\end{array} & \begin{array}{c}\text { Inclination } \\ \text { from Vert. } \\ \text { (deg) }\end{array} & \begin{array}{c}\text { Closure } \\ \text { Direction } \\ \text { (deg) }\end{array} & \begin{array}{c}\text { Closure } \\ \text { Distance } \\ \text { (feet) }\end{array} & \begin{array}{c}\text { Rectangular } \\ \text { Coordinates } \\ + \text { N/-S }\end{array} & \begin{array}{c}\text { Rectangular } \\ \text { Coordinates } \\ + \text { E/-W }\end{array} & \begin{array}{c}\text { Dog-Leg } \\ \text { Severity } \\ \text { o/100-ft }\end{array} \\ 70 & 60 & 0.06 & 181.91 & 0.08 & -0.08 & 0 & 0.4 \\ 80 & 70 & 0.06 & 176.77 & 0.08 & -0.08 & 0 & 0.9 \\ 90 & 80 & 0.28 & 159.67 & 0.09 & -0.08 & 0.03 & 2.7 \\ 100 & 90 & 0.26 & 140.18 & 0.12 & -0.09 & 0.07 & 1.5 \\ 101.8 & 100 & 0.32 & 133.15 & 0.16 & -0.11 & 0.12 & 0.6 \\ & 101.8 & 0.48 & 131.46 & 0.18 & -0.12 & 0.13 & 10.4\end{array}$


DTS-RPT-090, Rev. 0

Hole: C4998

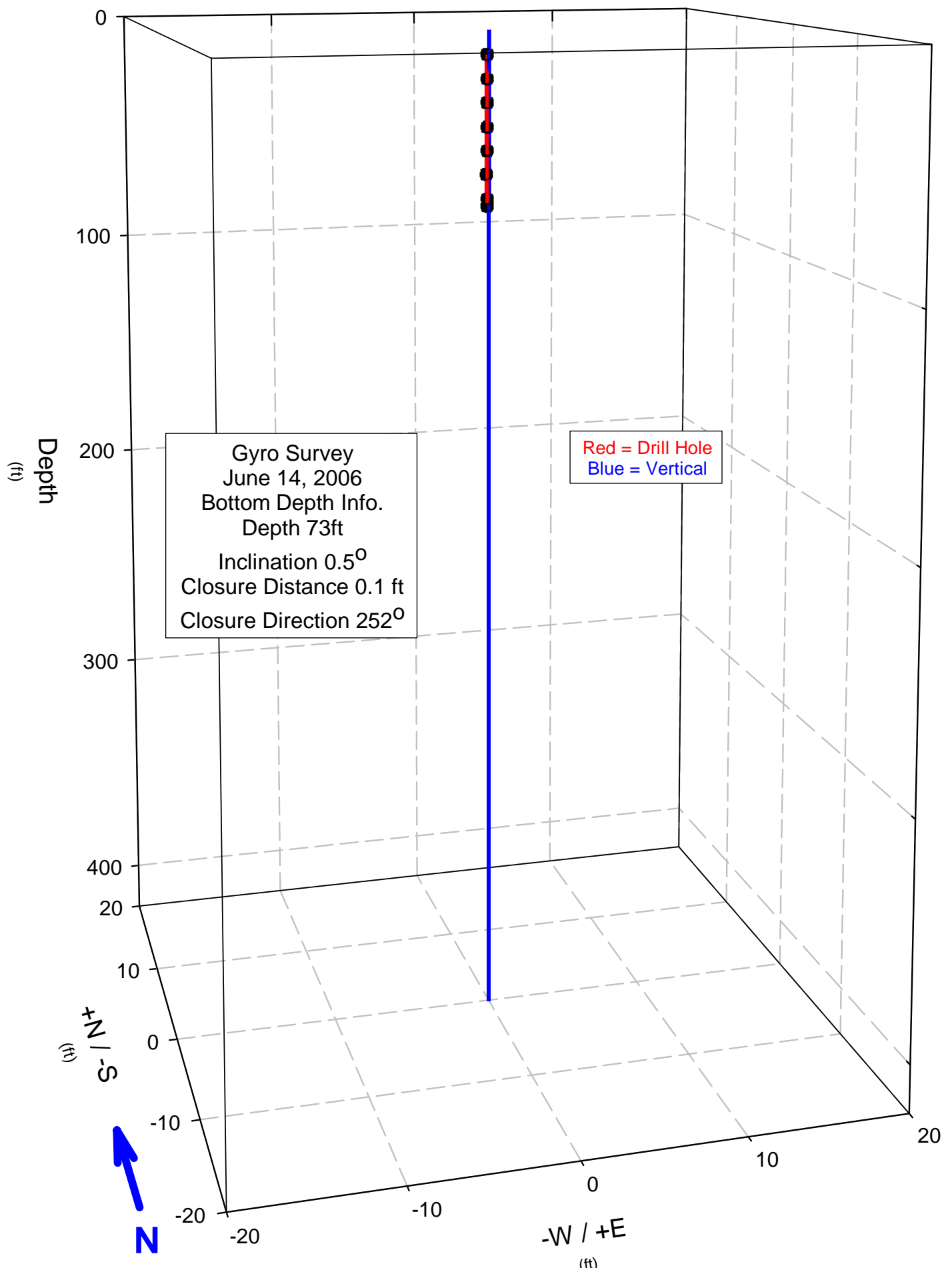


DTS-RPT-090, Rev. 0

Hole: C4998 Survey Date: 6/14/2006

$\begin{array}{cccccccc}\begin{array}{c}\text { Measured } \\ \begin{array}{c}\text { Depth } \\ \text { (feet) }\end{array}\end{array} & \begin{array}{c}\text { TrueVert. } \\ \text { Depth } \\ \text { (feet) }\end{array} & \begin{array}{c}\text { Inclination } \\ \text { from Vert. } \\ \text { (deg) }\end{array} & \begin{array}{c}\text { Closure } \\ \text { Direction } \\ \text { (deg) }\end{array} & \begin{array}{c}\text { Closure } \\ \text { Distance } \\ \text { (feet) }\end{array} & \begin{array}{c}\text { Rectangular } \\ \text { Coordinates } \\ + \text { N/-S }\end{array} & \begin{array}{c}\text { Rectangular } \\ \text { Coordinates } \\ + \text { E/-W }\end{array} & \begin{array}{c}\text { Dog-Leg } \\ \text { Severity } \\ \text { ofl100-ft }\end{array} \\ 20 & 10 & 0.03 & 265.13 & 0.09 & -0.01 & -0.09 & 10.5 \\ 30 & 20 & 0 & 263.59 & 0.09 & -0.01 & -0.09 & 0.3 \\ 40 & 30 & 0.03 & 264.12 & 0.09 & -0.01 & -0.09 & 0.3 \\ 50 & 40 & 0.06 & 264.05 & 0.1 & -0.01 & -0.1 & 0.4 \\ 60 & 50 & 0.06 & 263.41 & 0.11 & -0.01 & -0.11 & 0.1 \\ 70 & 60 & 0.03 & 262.3 & 0.12 & -0.02 & -0.12 & 0.5 \\ 73 & 70 & 0.14 & 258.35 & 0.11 & -0.02 & -0.11 & 1.5 \\ & 73 & 0.46 & 252.14 & 0.1 & -0.03 & -0.1 & 10.8\end{array}$


DTS-RPT-090, Rev. 0

\section{D1.2 COLOG COMPENSATED DENSITY LOGS}

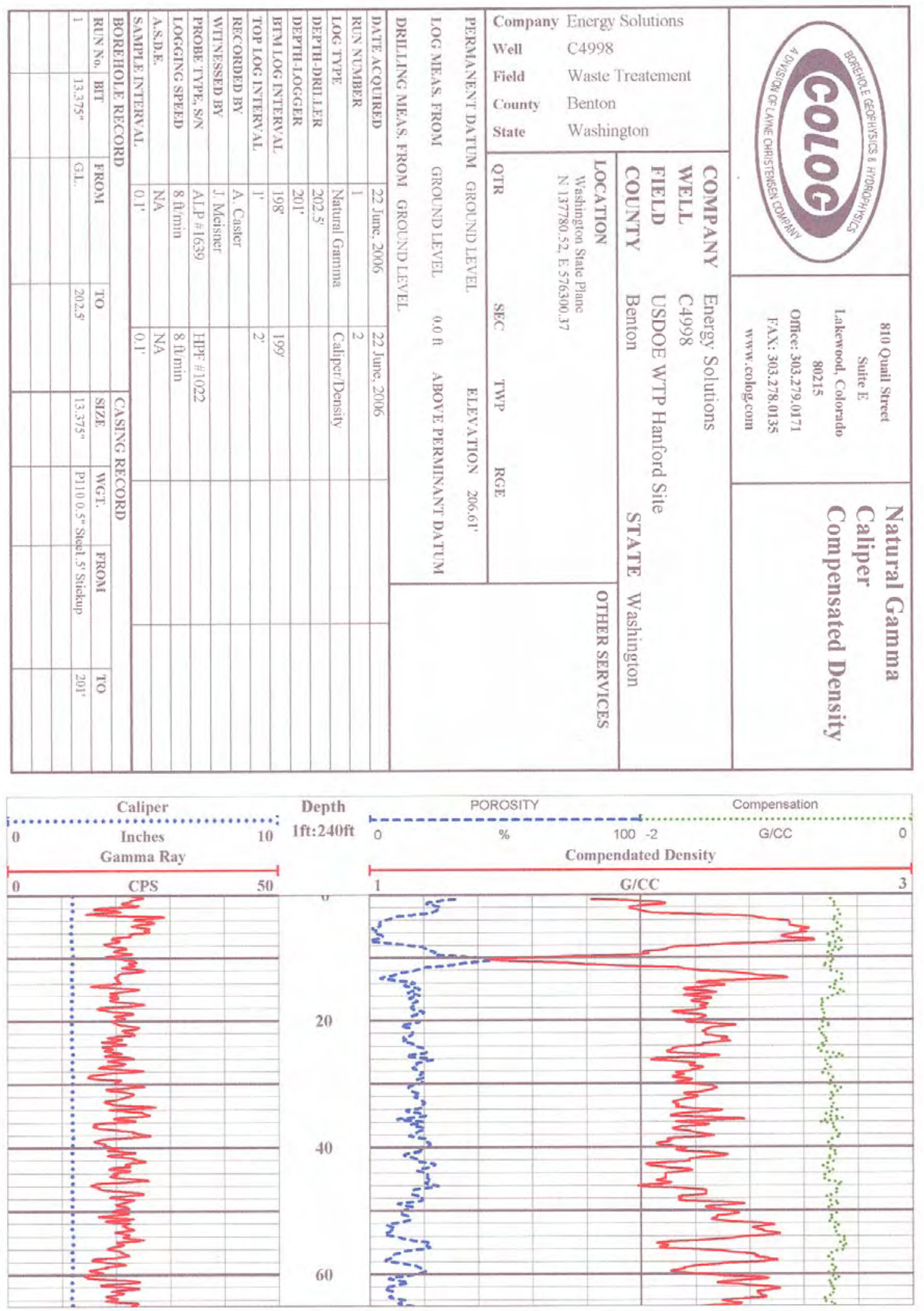


DTS-RPT-090, Rev. 0

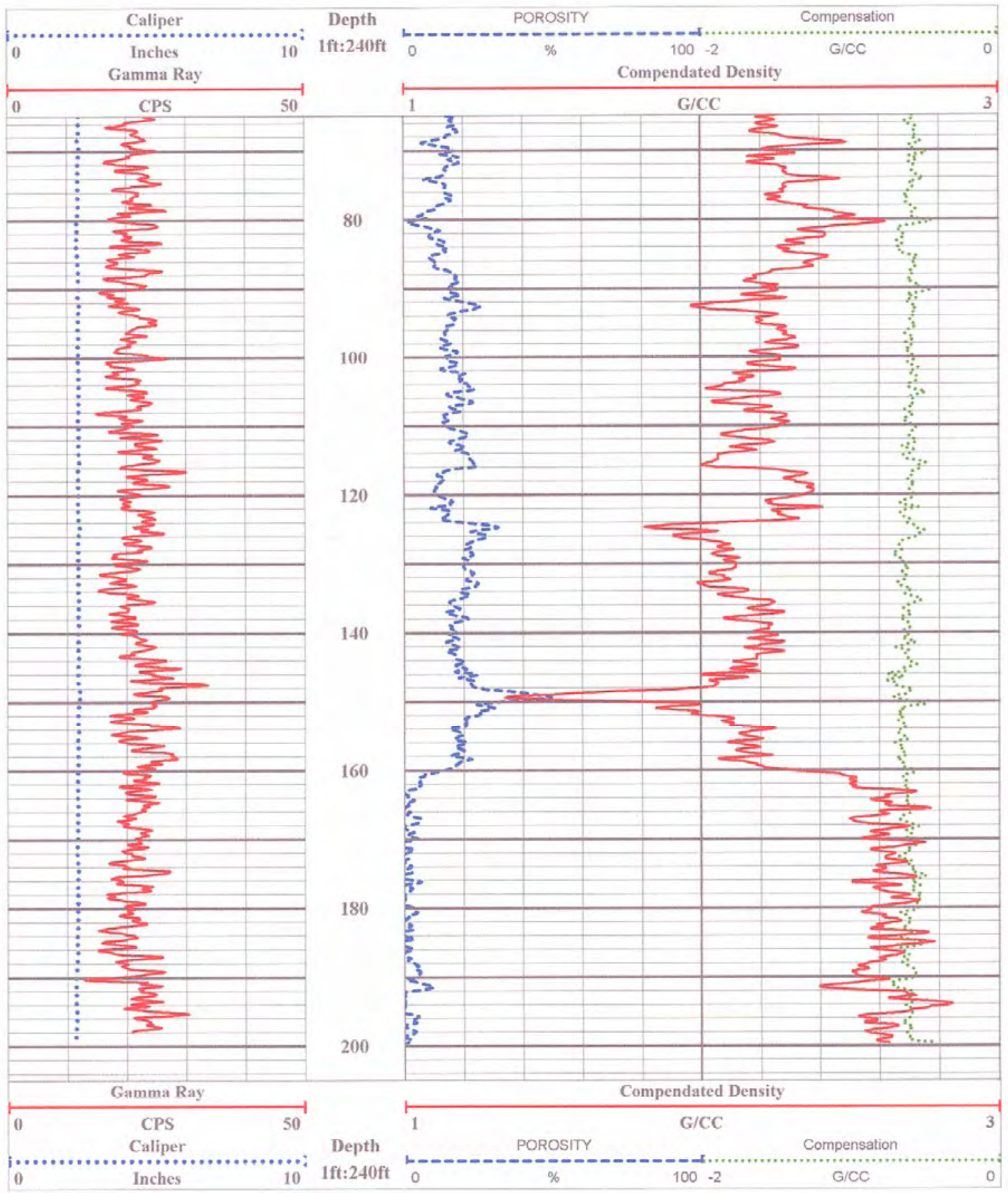


DTS-RPT-090, Rev. 0

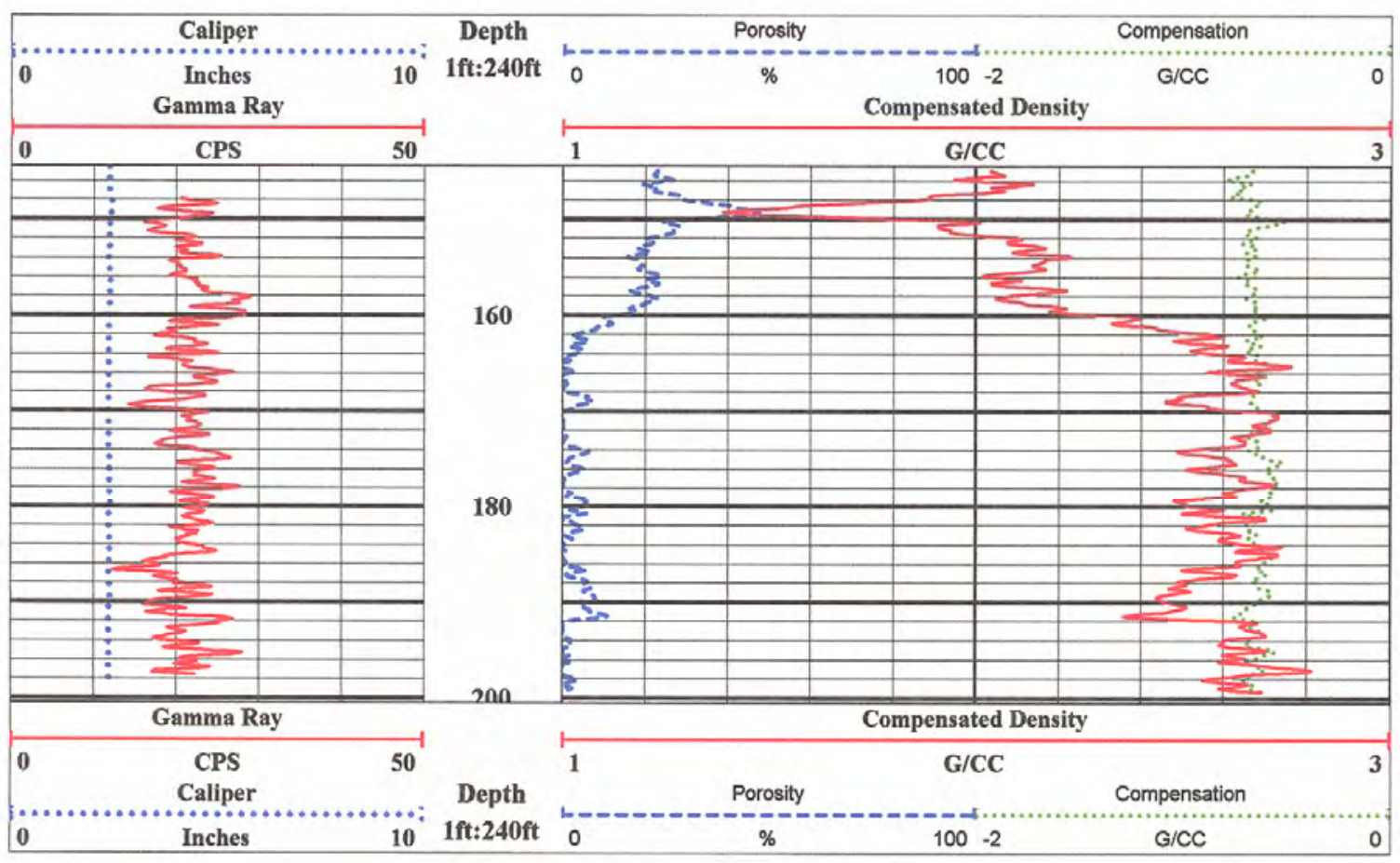


DTS-RPT-090, Rev. 0
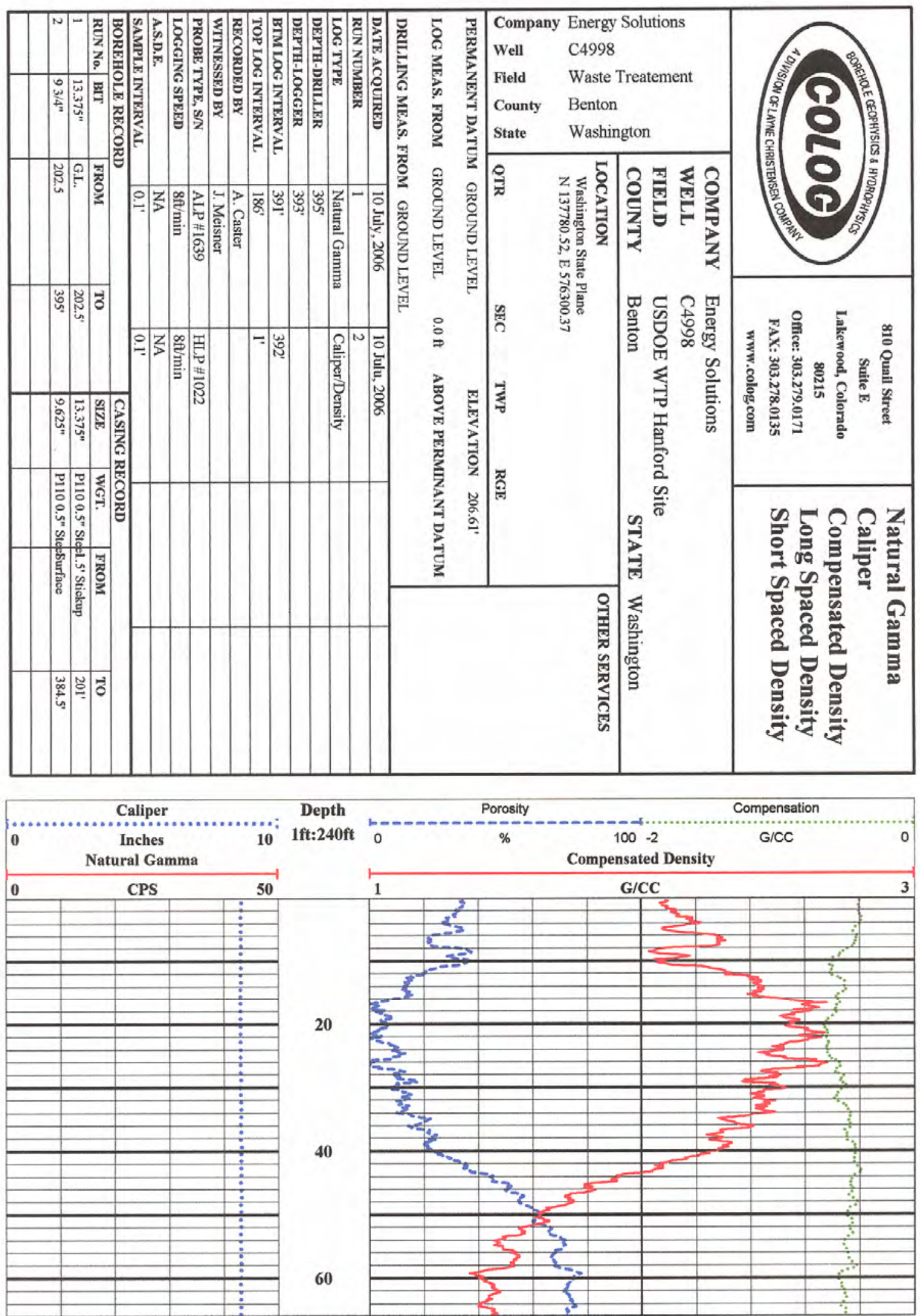
DTS-RPT-090, Rev. 0

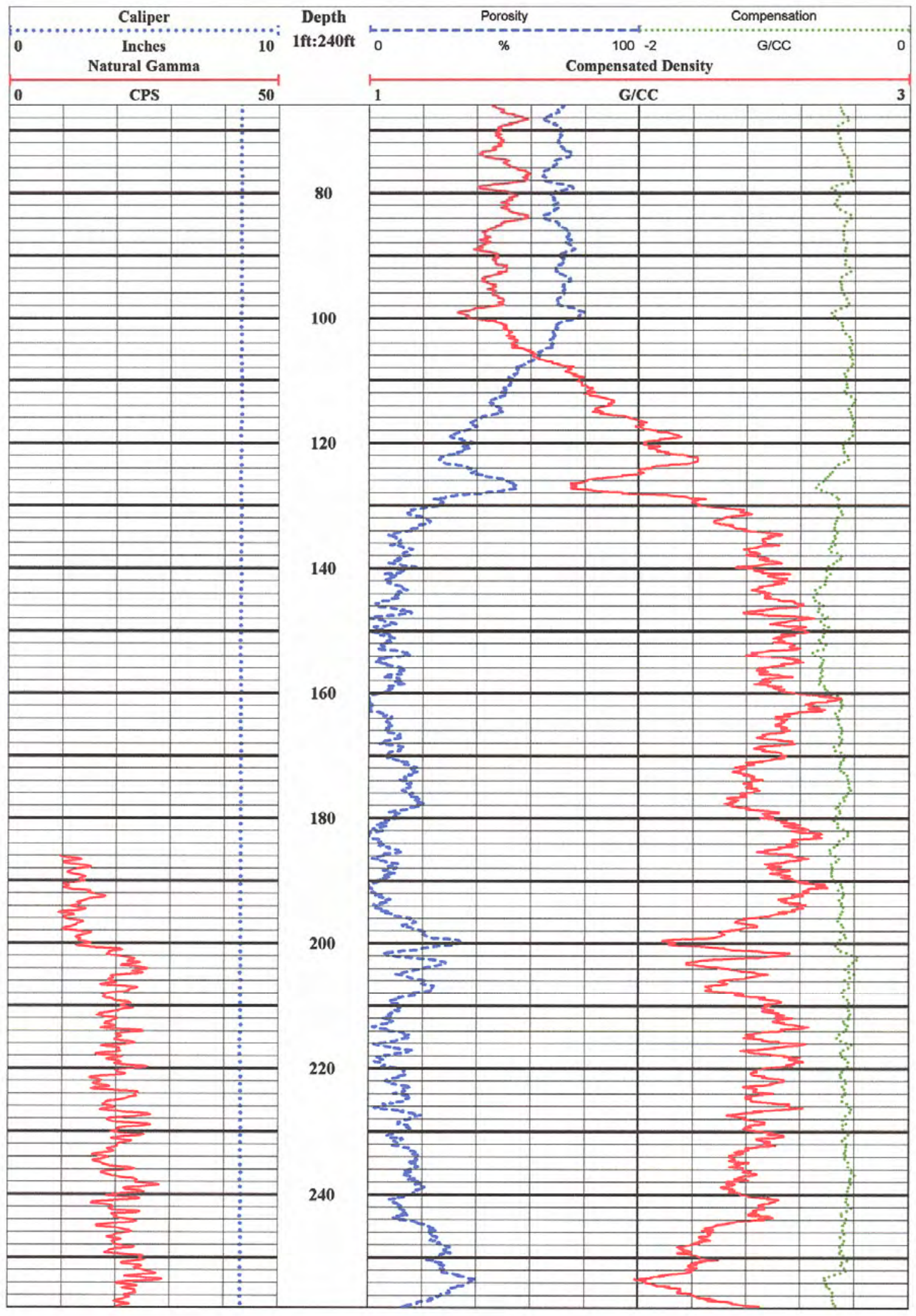


DTS-RPT-090, Rev. 0

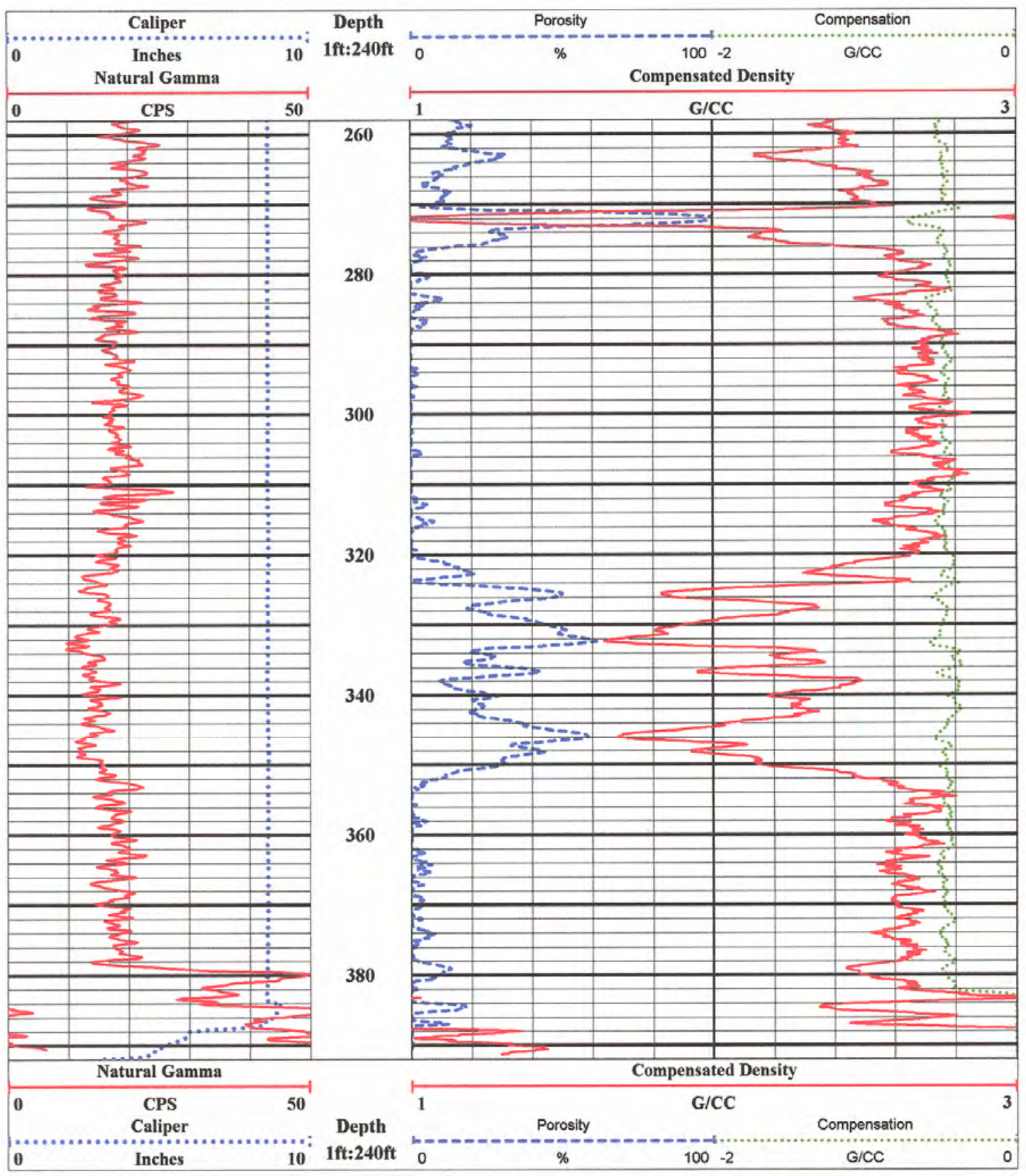


DTS-RPT-090, Rev. 0

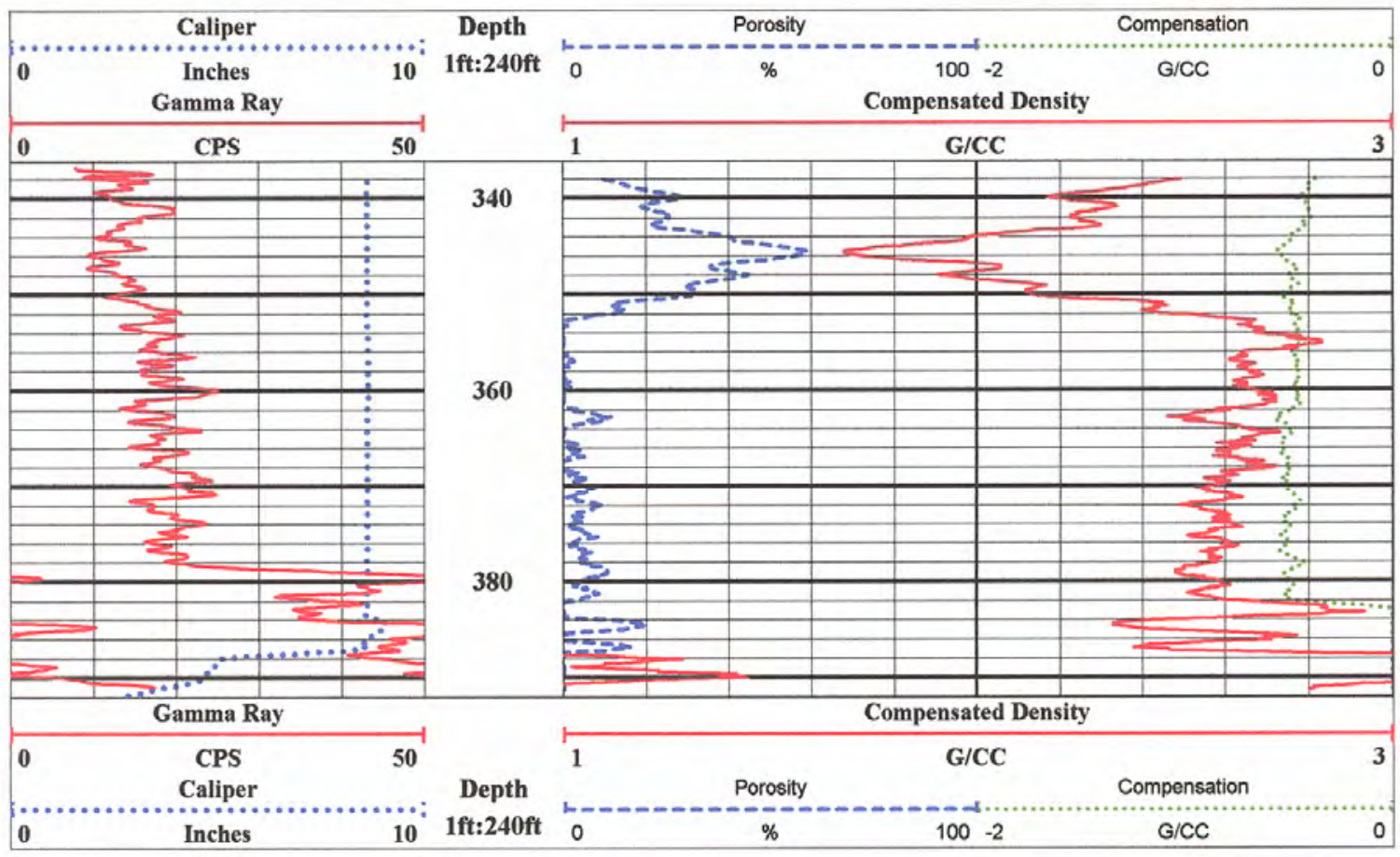


DTS-RPT-090, Rev. 0

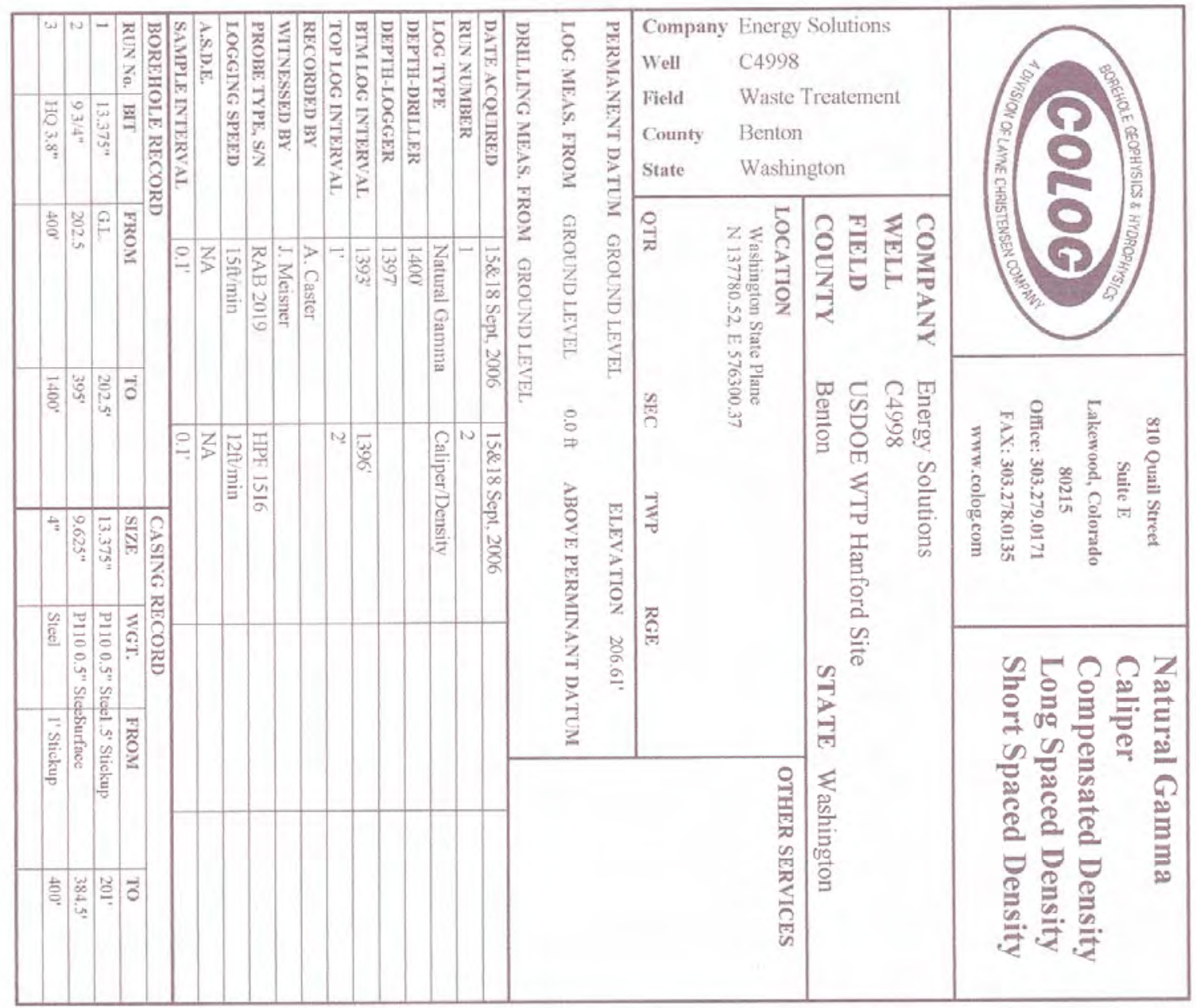

COMMENTS

NA - Not Available, N/A - Not Applicable

Bottom $\log$ is repeat section, middle $\log$ was ran through $\mathrm{HQ}$ from $1215^{\prime}$ to $1100^{\prime}$ and openhole from $1396^{\prime}$ tol215',

top log was ran openhole from $1170^{\prime}$ to $400^{\prime}$. 
DTS-RPT-090, Rev. 0

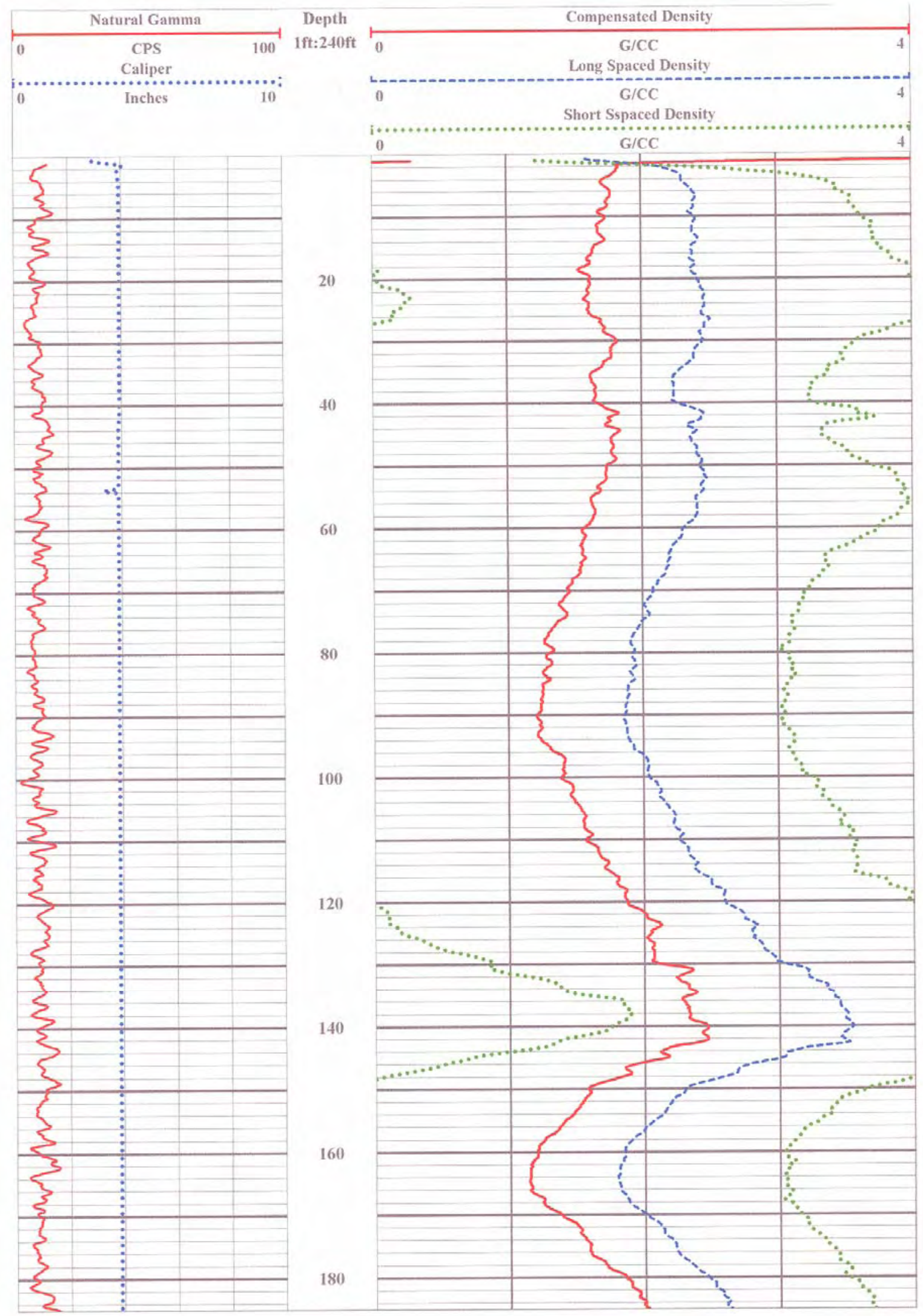


DTS-RPT-090, Rev. 0

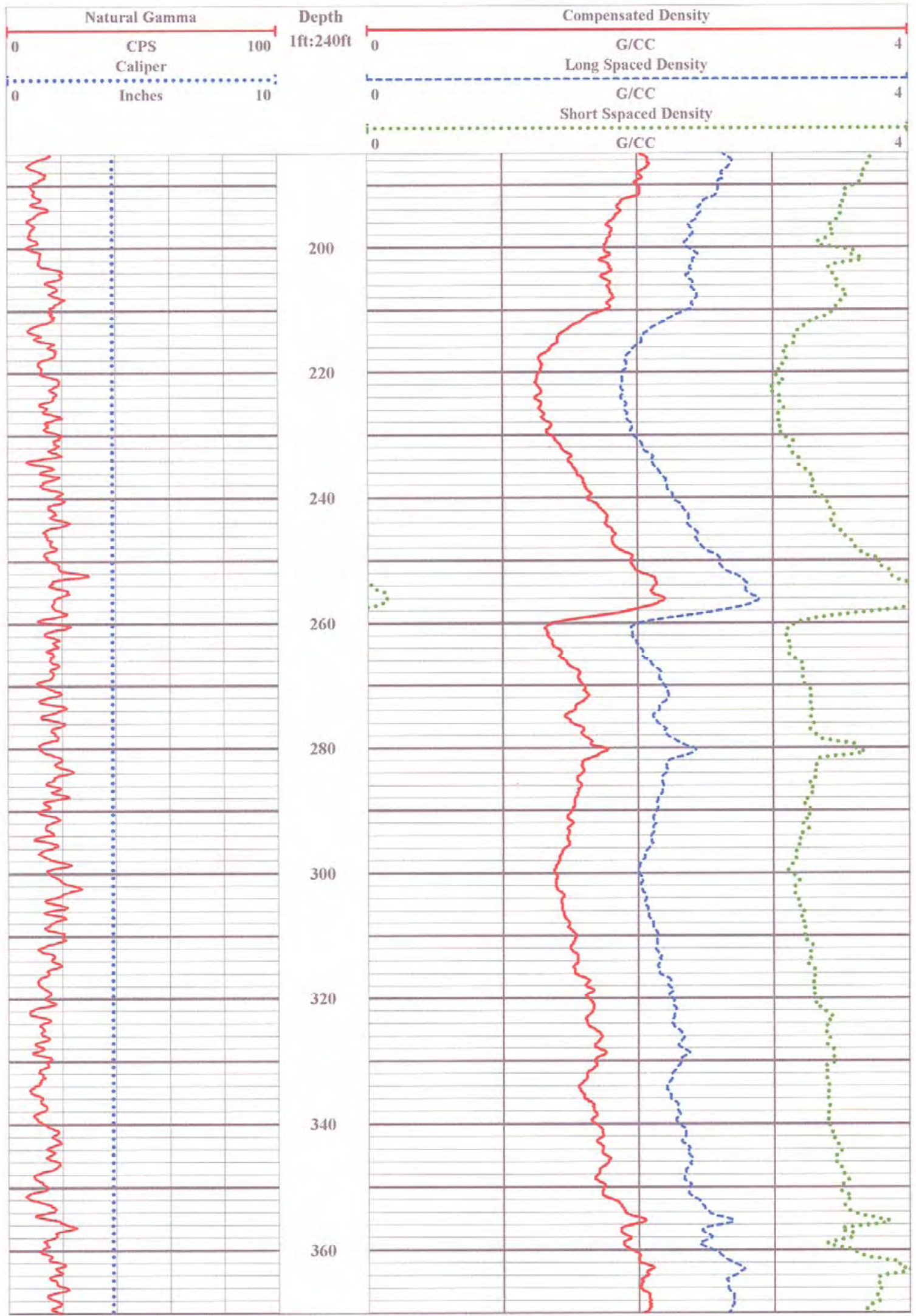


DTS-RPT-090, Rev. 0

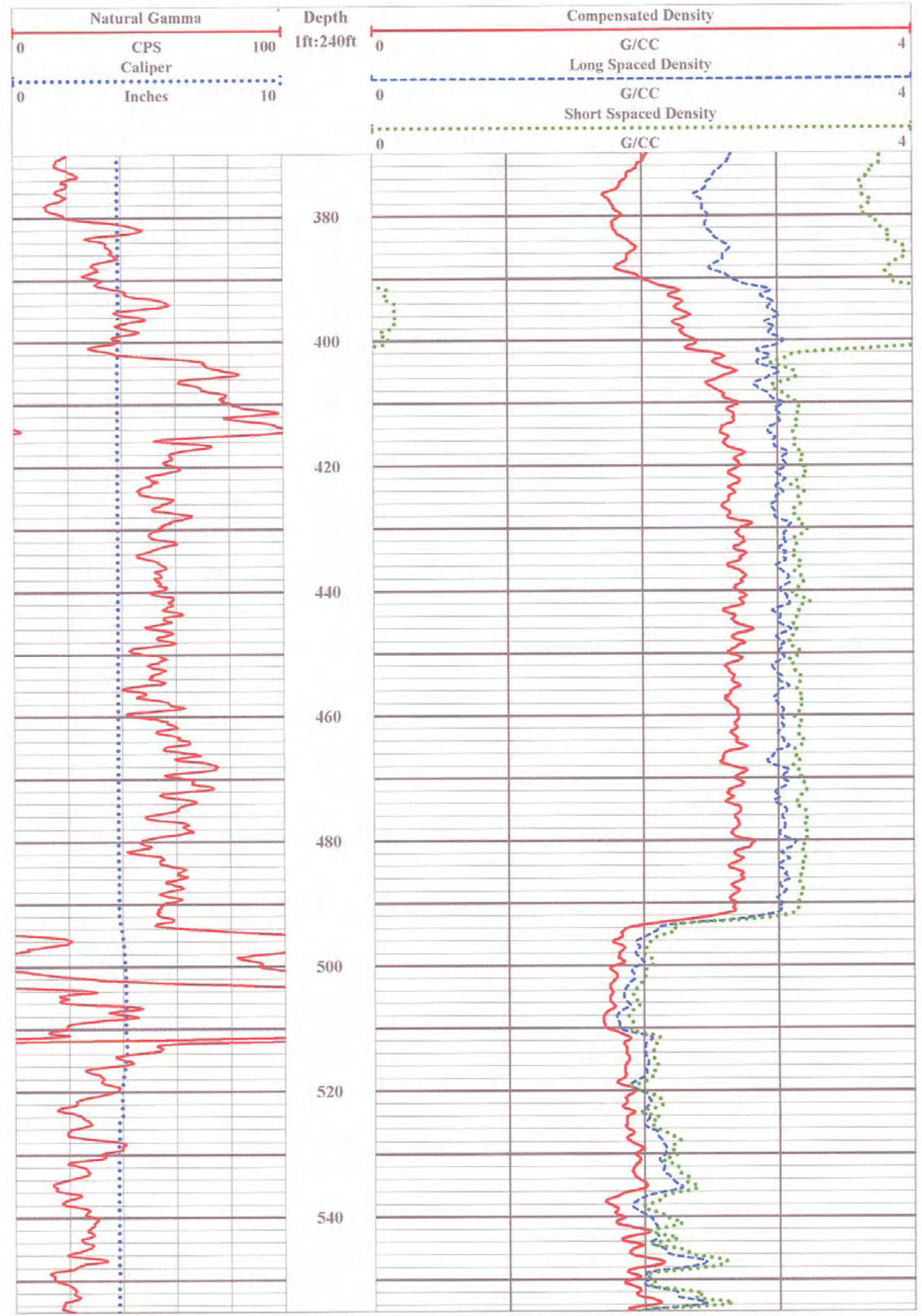


DTS-RPT-090, Rev. 0

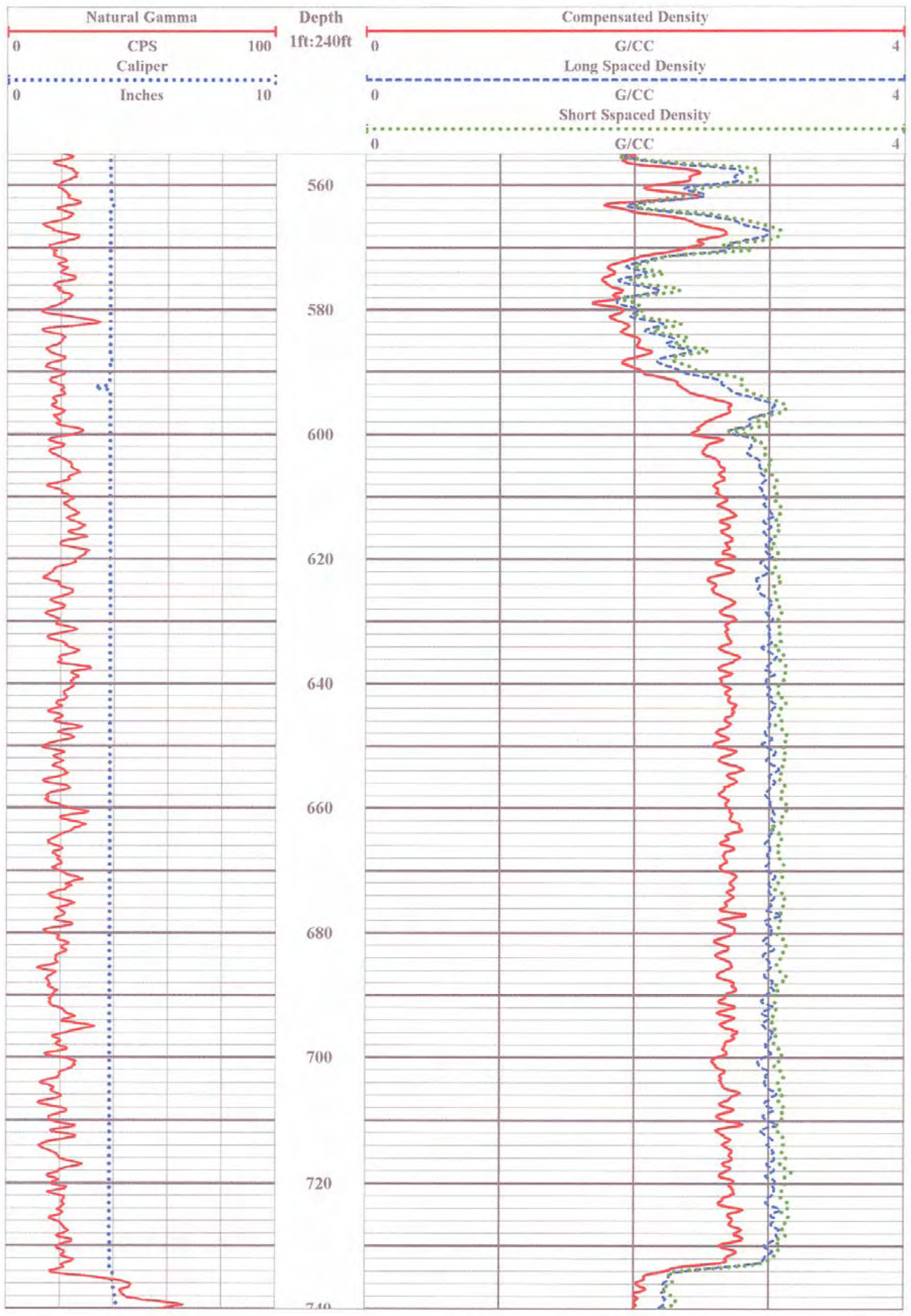


DTS-RPT-090, Rev. 0

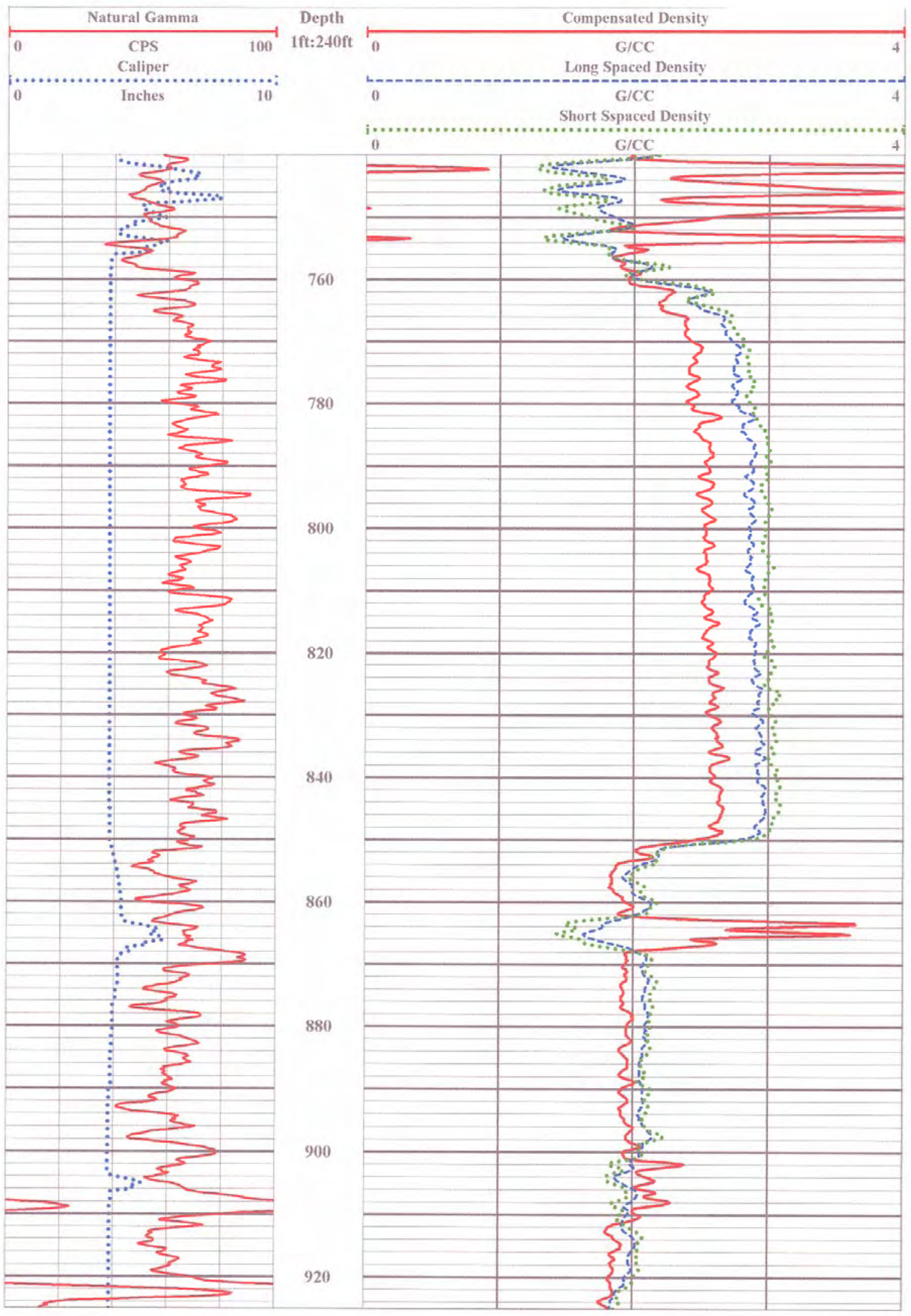


DTS-RPT-090, Rev. 0

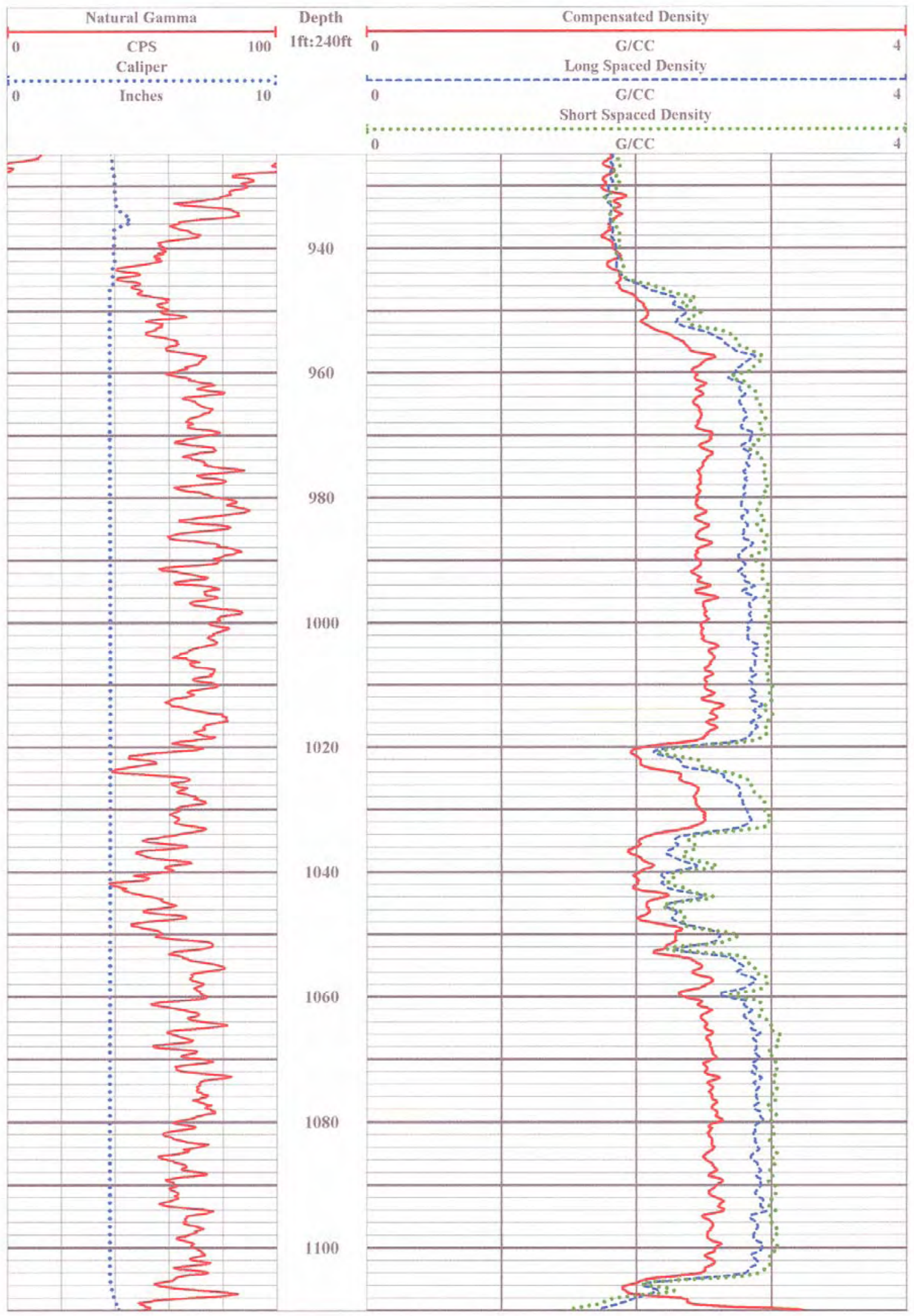




\section{DTS-RPT-090, Rev. 0}

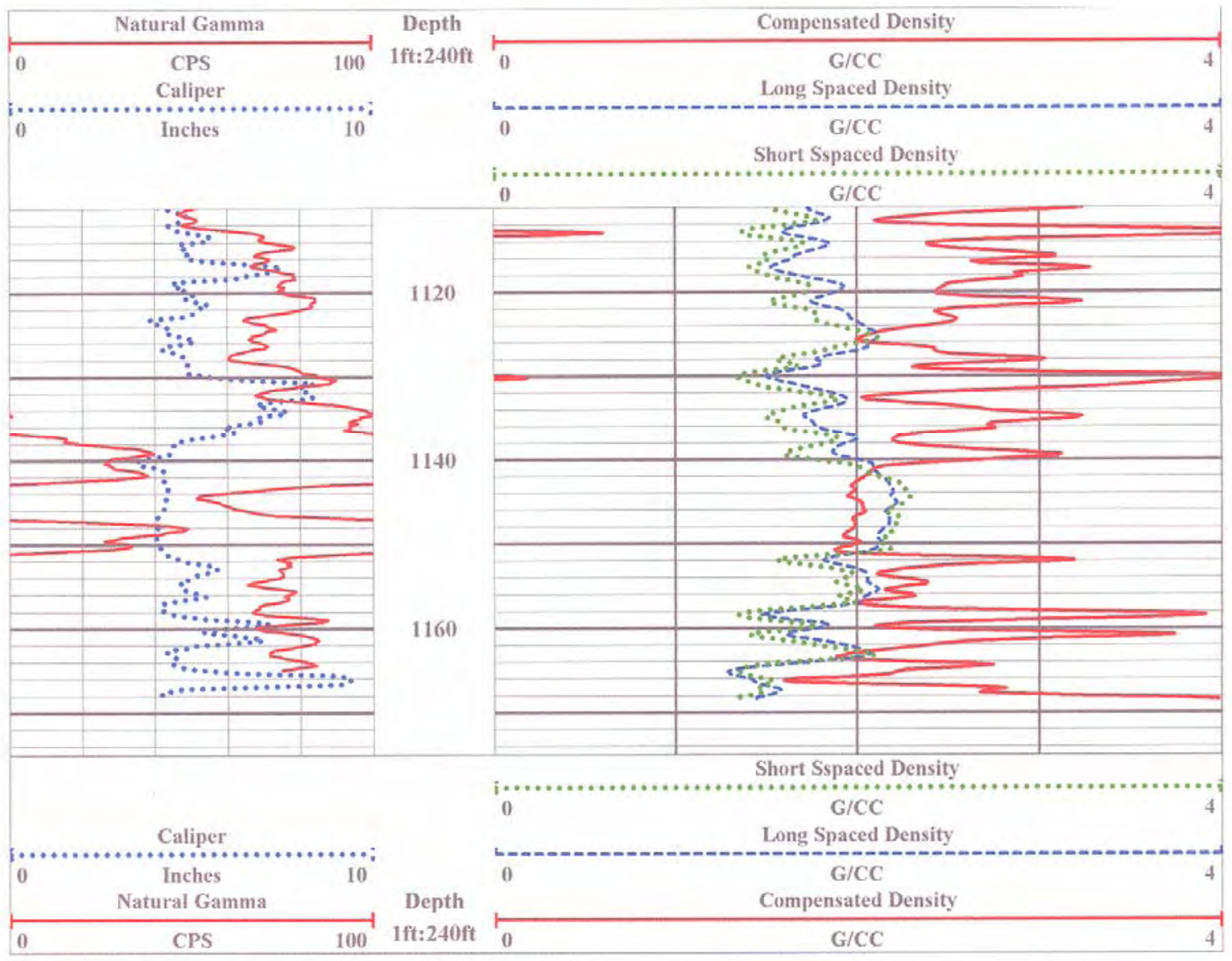


DTS-RPT-090, Rev. 0

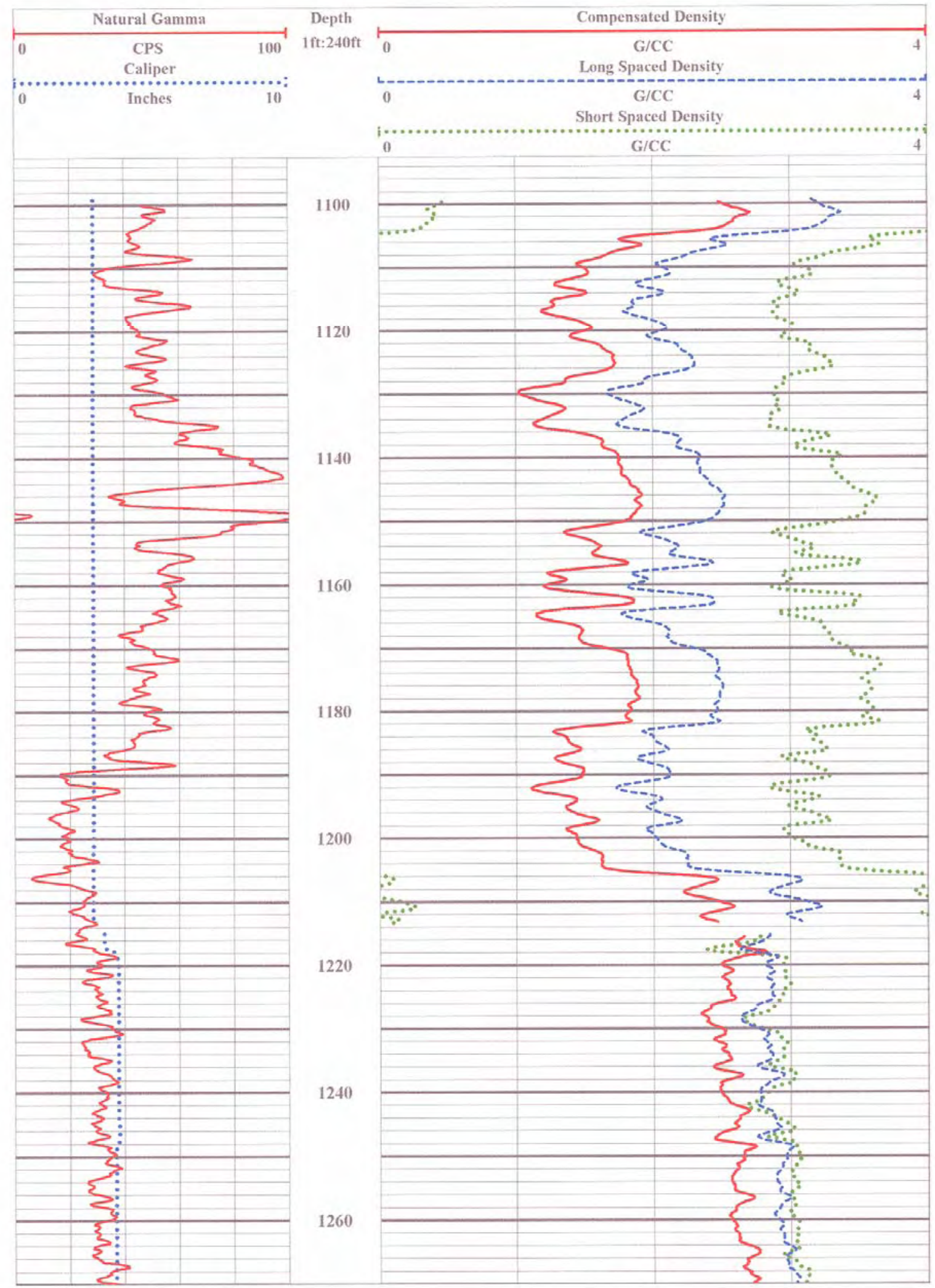


DTS-RPT-090, Rev. 0

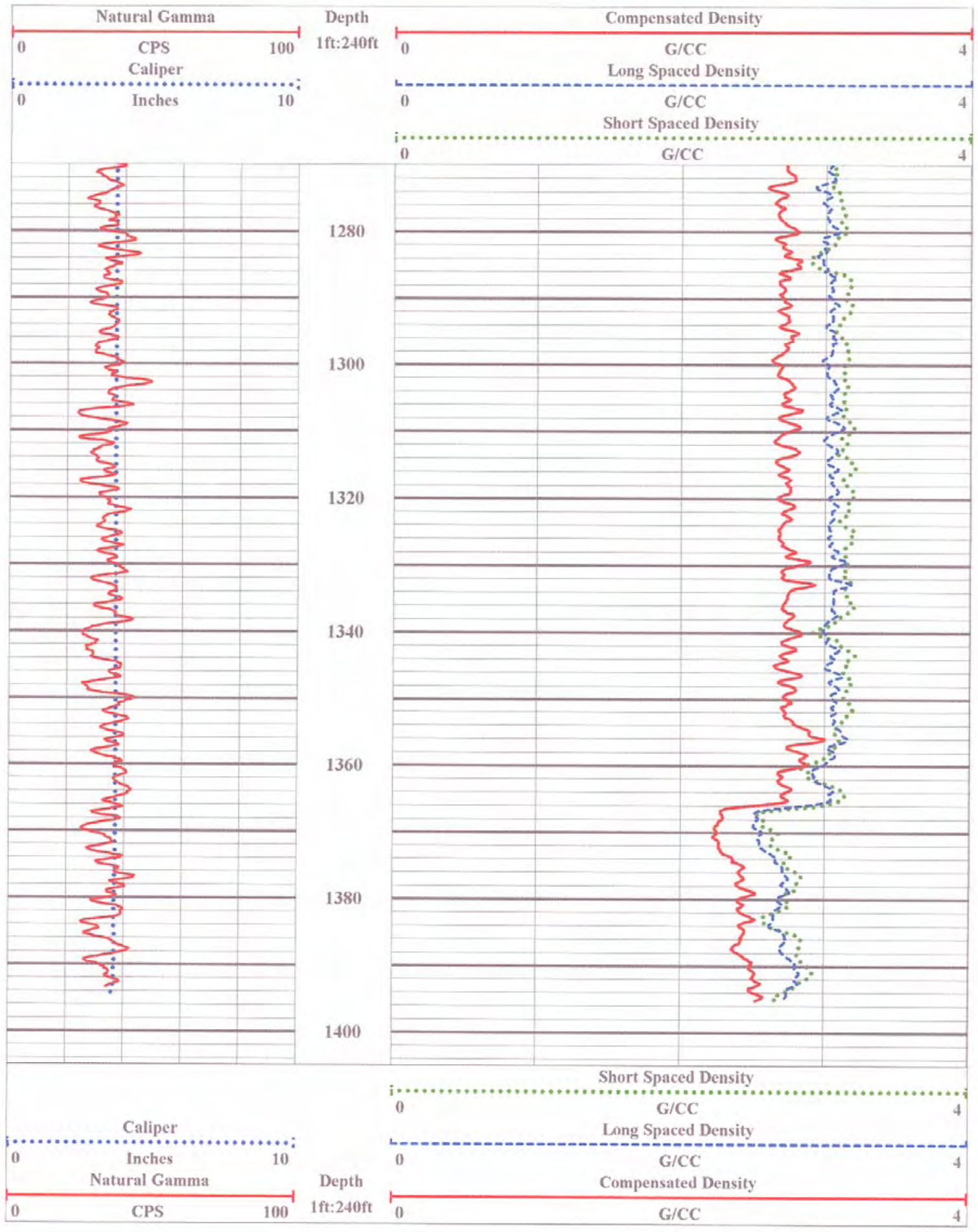


DTS-RPT-090, Rev. 0

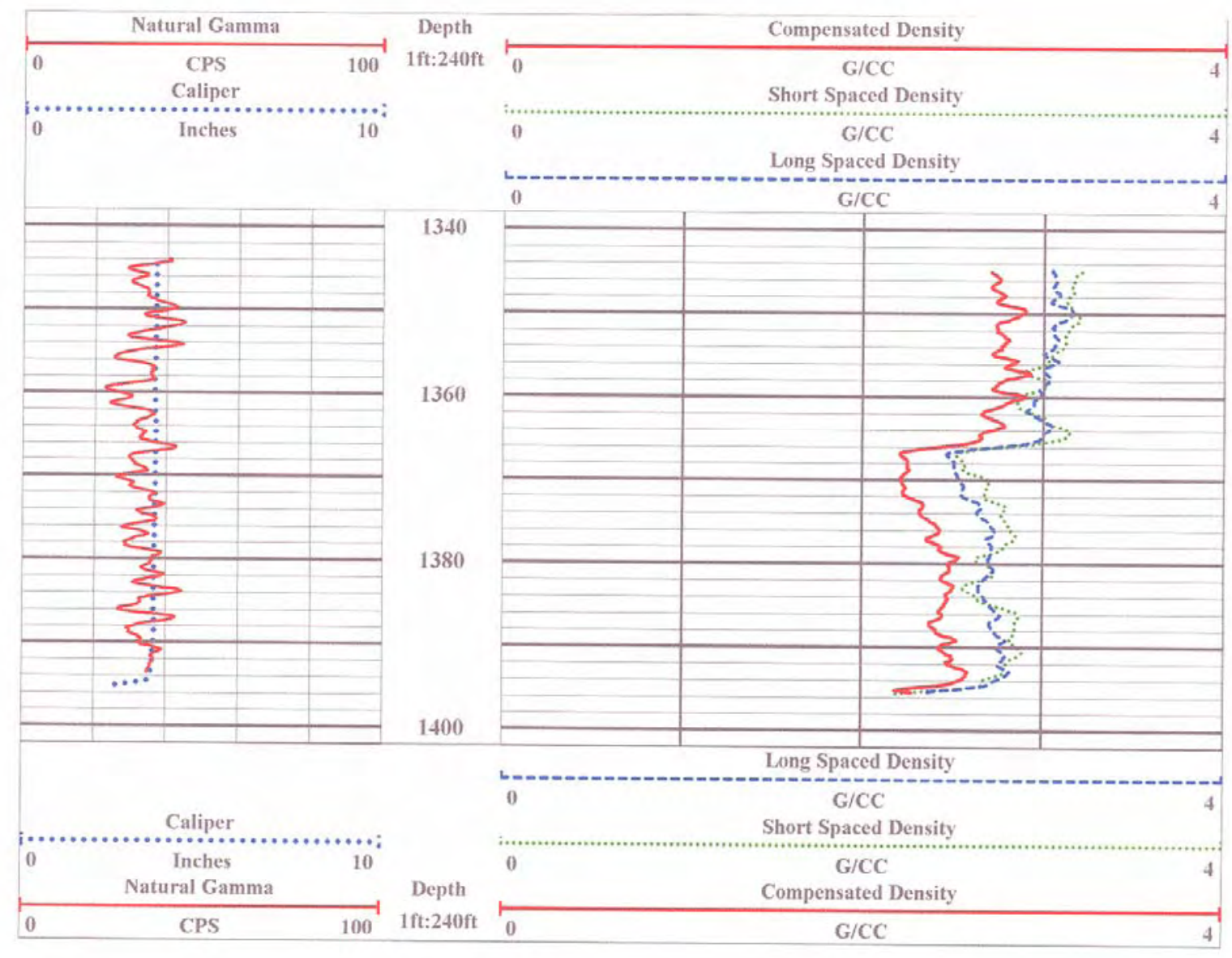


DTS-RPT-090, Rev. 0

This page intentionally left blank. 